
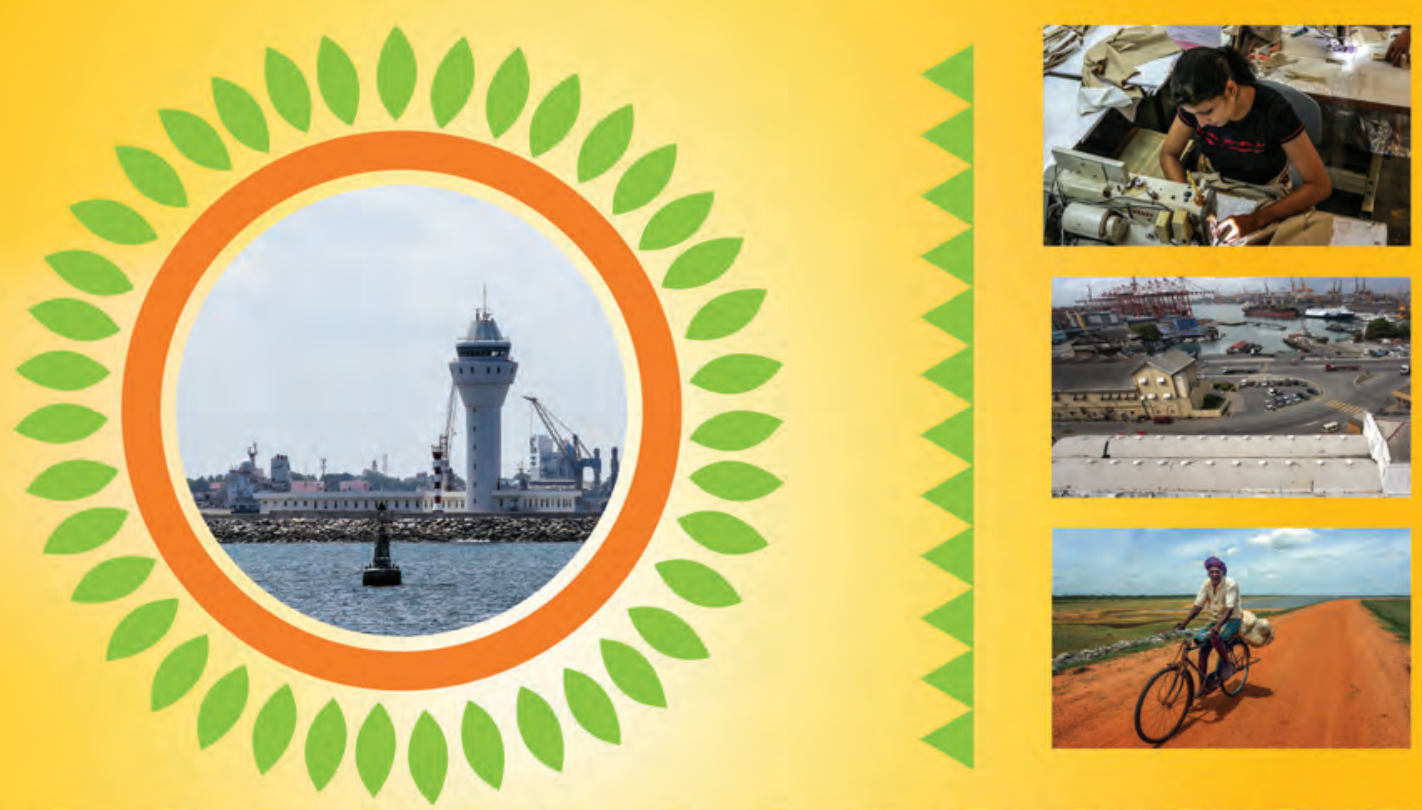

THE SRI LANKAN

ECONOMY

CHARTING A NEW COURSE

Edited by Prema-chandra Athukorala, Edimon Ginting, Hal Hill, and Utsav Kumar 



\section{THE SRI LANKAN ECONOMY \\ CHARTING A NEW COURSE}

Edited by Prema-chandra Athukorala, Edimon Ginting, Hal Hill, and Utsav Kumar 
(C) 2017 Asian Development Bank

6 ADB Avenue, Mandaluyong City, 1550 Metro Manila, Philippines

Tel +632632 4444; Fax +6326362444

www.adb.org

Some rights reserved. Published in 2017.

Printed in the Philippines.

ISBN 978-92-9257-973-9 (Print), 978-92-9257-974-6 (e-ISBN)

Publication Stock No. TCS178786-2

DOI: http://dx.doi.org/10.22617/TCS178786-2

The views expressed in this publication are those of the authors and do not necessarily reflect the views and policies of the Asian Development Bank (ADB) or its Board of Governors or the governments they represent.

ADB does not guarantee the accuracy of the data included in this publication and accepts no responsibility for any consequence of their use. The mention of specific companies or products of manufacturers does not imply that they are endorsed or recommended by ADB in preference to others of a similar nature that are not mentioned.

By making any designation of or reference to a particular territory or geographic area, or by using the term "country" in this document, $\mathrm{ADB}$ does not intend to make any judgments as to the legal or other status of any territory or area.

This work is available under the Creative Commons Attribution 3.0 IGO license (CC BY 3.0 IGO)

https://creativecommons.org/licenses/by/3.o/igo/. By using the content of this publication, you agree to be bound by the terms of this license. For attribution, translations, adaptations, and permissions, please read the provisions and terms of use at https://www.adb.org/terms-use\#openaccess

This CC license does not apply to non-ADB copyright materials in this publication. If the material is attributed to another source, please contact the copyright owner or publisher of that source for permission to reproduce it. $A D B$ cannot be held liable for any claims that arise as a result of your use of the material.

Please contact pubsmarketing@adb.org if you have questions or comments with respect to content, or if you wish to obtain copyright permission for your intended use that does not fall within these terms, or for permission to use the ADB logo.

Photos in this publication are the property of ADB.

Notes:

In this publication, "\$" refers to US dollars.

ADB recognizes "Ceylon" as Sri Lanka and "United States of America” as the United States.

Corrigenda to ADB publications may be found at http://www.adb.org/publications/corrigenda 


\section{Contents}

Boxes, Figures, and Tables................................................................................................. vii

Foreword ............................................................................................................................ xiii

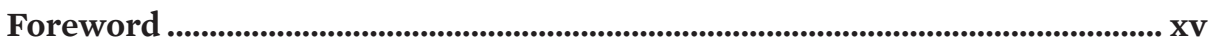

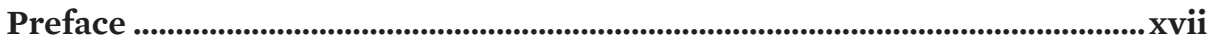

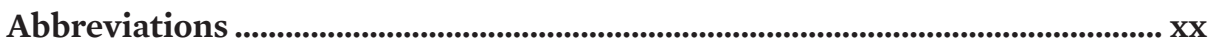

Author Profiles........................................................................................................................xxiii

The Sri Lankan Economy: Achievements, Prospects, and Policy Issues ............ 1

1.1. Introduction ............................................................................................... 1

1.2. Sri Lankan Economic Development: Some Stylized Facts.......................2

1.3. Sri Lanka: A Brief Policy History .................................................................6

1.3.1. Trade Policy Regime............................................................................. 9

1.3.2. Export Promotion and the Role of the Export Development Board ..................................................... 13

1.3.3 Foreign Investment Policy ………………………………………..... 14

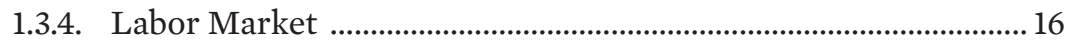

1.3.5. Macroeconomic Policy ....................................................................... 19

1.4. The Sri Lankan Development Record .................................................... 20

1.4.1. Economic Growth .........................................................................20

1.4.2. Structural Change ............................................................................22

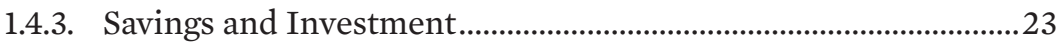

1.4.4. Inflation and Unemployment.........................................................24

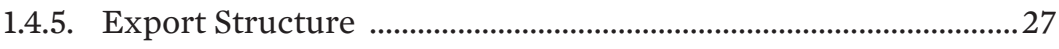

1.4.6. Poverty and Inequality........................................................................... 33

1.4.7. Comparative Dimensions ................................................................... 35

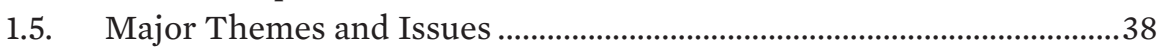

1.6. Policy Inferences .................................................................................... 44

Economic Performance and Macroeconomic Management................................. 51

2.1. Introduction ........................................................................................... 51

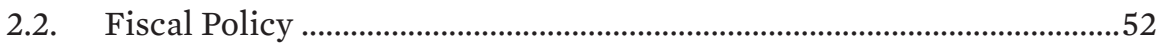

2.3. Monetary and Exchange Rate Policy ………….........................................67

2.4. Concluding Remarks ................................................................................. 72 
Logistics and Services in the Sri Lankan Economy .......................................................... 81

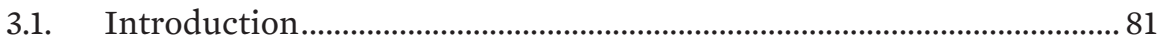

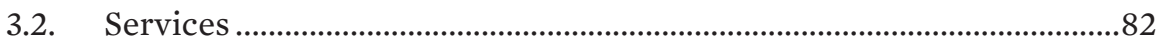

3.2.1. Sri Lanka's Changing Economic Structure ......................................82

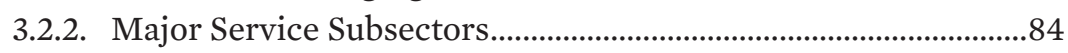

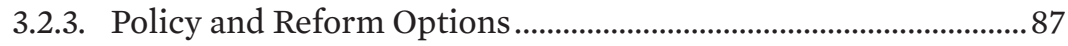

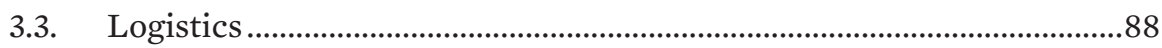

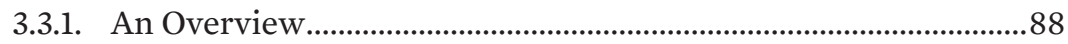

3.3.2. The Sri Lankan Logistics Subsector ................................................90

3.3.3. Transport Infrastructure.....................................................................94

3.3.4. The Policy, Regulatory, and Institutional Framework...................97

3.3.5. Regulatory, Policy, and Institutional Impediments ....................... 101

3.4. Recommendations for Logistics .............................................................103

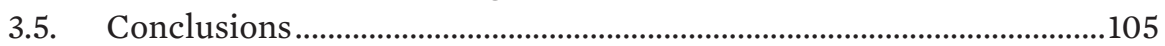

\section{Manufacturing Exports: Opportunities, Achievements,}

and Policy Options..................................................................................................................111

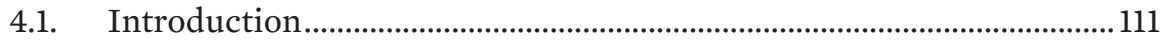

4.2. Analytical Framework .....................................................................113

4.3. Export Performance ..................................................................................... 116

4.4. The Role of Foreign Direct Investment

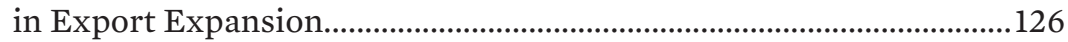

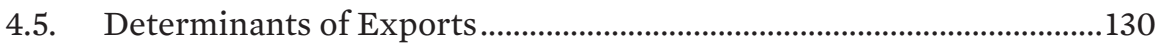

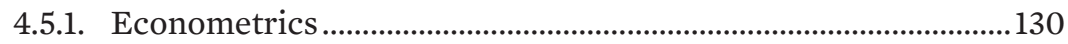

4.5.2. Evidence from Field Surveys............................................................134

4.6. Summary and Policy Inferences ................................................................ 137

Modernizing Agriculture in Sri Lanka-Status and Challenges.......................147

5.1. The Context .............................................................................................148

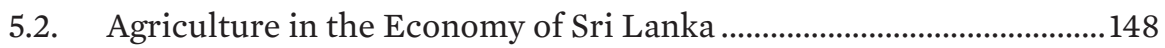

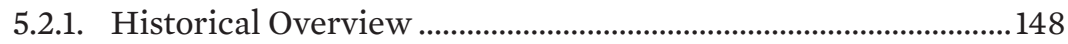

5.2.2. Contribution to Gross Domestic Product.......................................150

5.2.3. Labor Force Participation .................................................................151

5.2.4. Land-Use Patterns ............................................................................. 152

5.2.5. Food Consumption Pattern................................................................. 153

5.2.6. Agriculture and Food Trade ............................................................154

5.3. Sri Lankan Agriculture Compared

with Neighboring Countries....................................................................... 155

5.4. Agricultural Value Chains in Sri Lanka: Problematic Interfaces........157

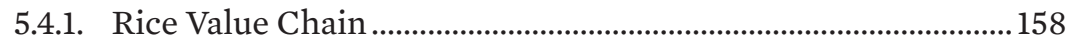

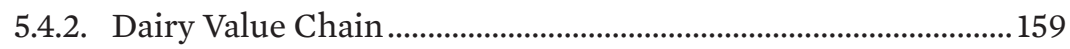




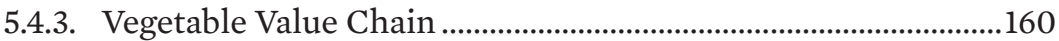

5.4.4. Coconut Value Chain .........................................................................162

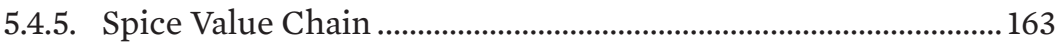

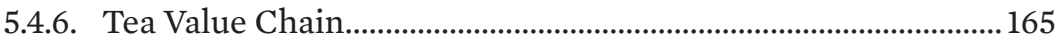

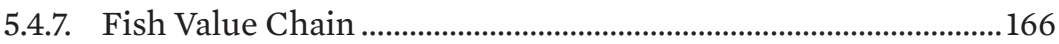

5.5. Agricultural Policy Framework Objectives

and Policy Instruments ............................................................................168

5.6. Policy Challenges Facing the Agriculture Sector .....................................169

5.6.1. Trade ..................................................................................................169

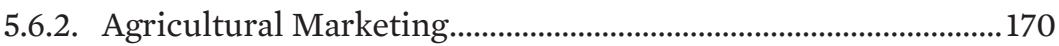

5.6.3. The Fertilizer Subsidy Policy .......................................................170

5.6.4. Agricultural Land Policy .................................................................. 172

5.6.5. Irrigation Water Policy ..................................................................... 173

5.6.6. Agricultural Credit Policy .............................................................. 174

5.6.7. Seed and Planting Material Policy ................................................... 176

5.6.8. Agricultural Research and Extension Policy ................................. 176

5.6.9. Agricultural Mechanization Policy ................................................. 177

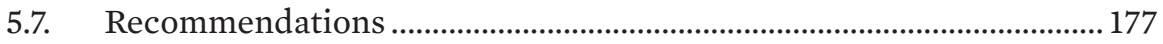

State-Owned Enterprise Reforms in Sri Lanka: The Way Forward ................182

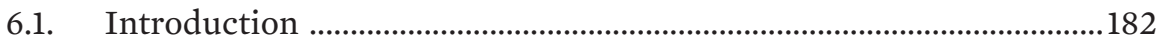

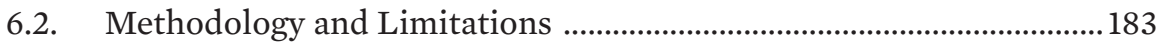

6.3. State-Owned Enterprise Reforms

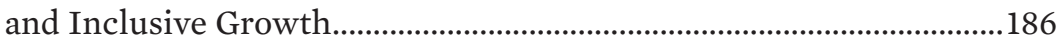

6.4. Historical Evolution: Learning from the Past.........................................189

6.5. State-Owned Enterprises: The Current Context .....................................195

6.6. Successful State-Owned Enterprise Reforms: International

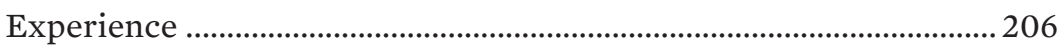

6.7. Types of State-Owned Enterprise Reforms............................................ 207

6.8. Potential Reform Pathways......................................................................210

Financing Sustainable Urbanization in Sri Lanka ............................................. 229

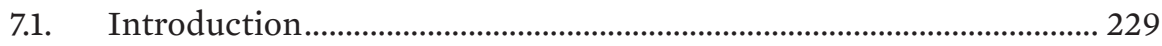

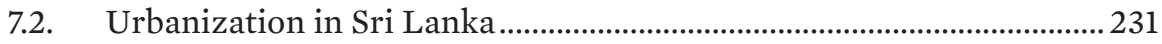

7.2.1. Urban Evolution, Form, and Structure .........................................232

7.2.2. Institutional Roles and Functions for Urban Development ....235

7.3. Urbanization Finance in Sri Lanka .........................................................237

7.3.1. Intergovernmental Fiscal Framework ……………………...........238

7.3.2. Local Government Revenues .........................................................239

7.3.3. Local Authority Expenditures ......................................................... 243

7.3.4. Considerations for the Way Forward .......................................... 247 
7.4. Funding Options for Urban Development

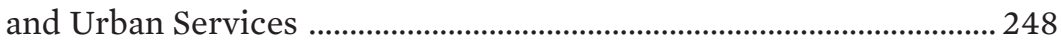

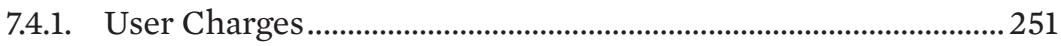

7.4.2. Property Taxes and Related Property Charges ............................. 251

7.5. Challenges and Opportunities for Urban Finance in Sri Lanka ........255

7.5.1. Realign Functions and Finance .....................................................25

7.5.2. Link Spatial and Sector Planning..................................................257

7.5.3. Improve Options for Private Participation ...................................257

7.6. Strategy for Establishing an Institutional Framework for Urban

Finance in Sri Lanka .............................................................................. 259

7.6.1. Strategic Element 1: Reset the Intergovernmental Fiscal Framework for Urban Service Delivery and Finance .............. 260

7.6.2. Strategic Element 2: Operationalize a Spatial Planning and Coordination Framework ......................................................2261

7.6.3. Strategic Element 3: Institutionalize a Governance Framework for Urbanization ....................................................... 262

Sri Lanka's Labor Market and Human Capital Formation .................................. 268

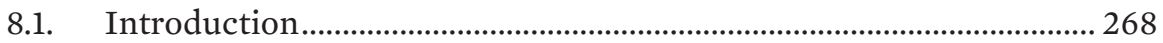

8.2. Employment Trends and Patterns........................................................... 269

8.2.1. Shifts of Sectoral Composition ....................................................... 269

8.2.2. Job Growth and Required Skills........................................................ 271

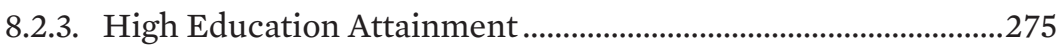

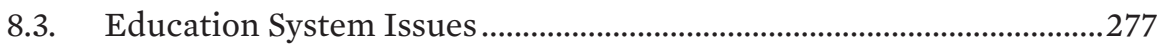

8.4. Demographic Changes.............................................................................279

8.5. Labor Force Trends and Participation .....................................................287

8.6. Increasing Trend of Working Abroad......................................................293

8.7. Conclusions and Policy Suggestions ...................................................... 294

Key Policy Recommendations.......................................................................299

9.1. Macroeconomic Management ………………...................................... 300

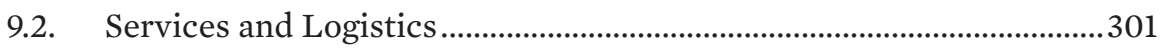

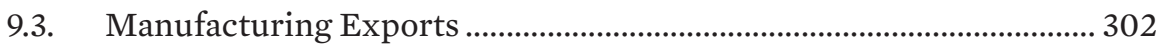

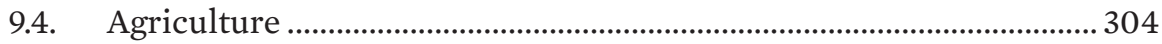

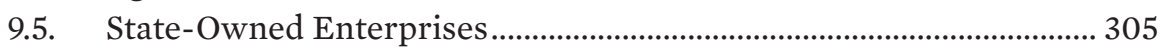

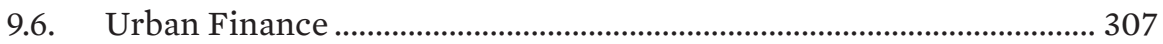

9.7. Labor and Education..................................................................................... 308

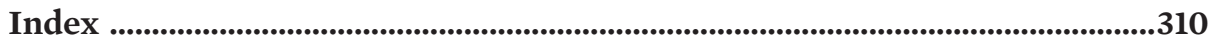




\section{Boxes, Figures, and Tables}

\section{Boxes}

6.1 Lanka Marine Services and Sri Lanka Insurance Corporation:

The Perils of Institutional Lapses.....

6.2 The Privatization of Sri Lanka Telecom and the Colombo

Gas Company.

6.3 International Monetary Fund Extended Fund Facility,

Pillar 4-State-Owned Enterprise Reform....................................................196

6.4 Lankaputhra Development Bank.................................................................... 203

6.5 Pioneer Service in the Transport Sector-Indonesia .................................. 209

6.6 Key Principles of the People's Republic of China's State-Owned

Enterprise Reform Strategy

\section{Figures}

1.1 Growth of Sri Lanka's Gross Domestic Product, 1960-2015, (\%)................ 21

1.2 Shares of Employment by Sector, 1981-2012, (\%) ..........................................23

1.3 Investment and Savings Rates, 1960-2015 (\% of GDP)................................24

1.4 Sri Lanka Annual Inflation Rate and Change in Exchange Rate,

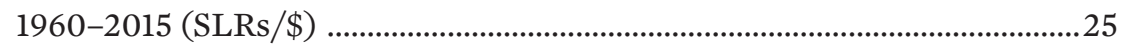

1.5 Sri Lanka's Unemployment Rate, 1990-2015 (\%) ..........................................26

1.6 Sri Lanka's Composition of Merchandise Exports, 1962-2015 (\%) ............27

1.7 Sri Lanka's Export Composition, 1962-2015 (\% of total exports)................28

1.8 Product Space Maps, 1980 and 2014 ............................................................30

1.9 Share of World Exports-Percent Change, 2000/2015 ..................................32

1.10 Poverty and Inequality Indicators, Sri Lanka ................................................34

2.1 Government Debt as a Share of GDP, 1990-2015 (\%) .....................................53

2.2 Global GDP Per Capita and General Government Revenue Ratio (\% of GDP)

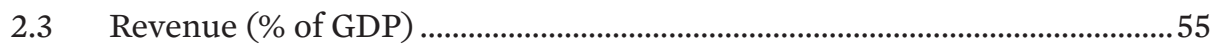

2.4 Buoyancy of Total Revenue (\% $\triangle$ Revenue/\% $\triangle$ GDP) ........................................55

2.5 Change in Revenue Composition (\% of total).................................................57

2.6 GDP per Capita (\$) and General Government Expenditure (\% of GDP) .....58

2.7 Government Interest Payments (\% of GDP) .................................................59

2.8 Bonds Spread and Foreign Ownership .........................................................60 
Figures, continued

2.9 General Government Expenditure by Major Category, 2015 (\% of GDP).... 61

2.10 Spending on Public Health and Education ......................................................62

2.11 Central Bank of Sri Lanka Budget Financing, 2000-2015 (\%).....................68

2.12 General Government Revenue-to-GDP (\%)

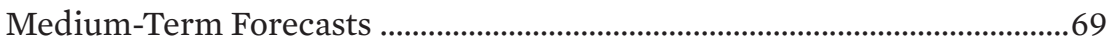

2.13 Inflation Rate of Sri Lanka, 1953-2015 (\%) ....................................................69

2.14 Sri Lanka: Real Exchange Rate and its Components

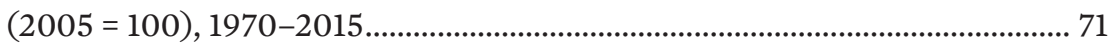

3.1 Structural Change in Output, Selected Years, 1980-2015 (\%)........................ 83

3.2 Structural Change in Employment, Selected Years, 1981-2015 (\%)............. 83

3.3 Share of Service Sector Value Added in GDP: Sri Lanka

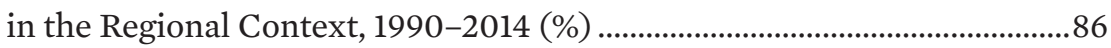

3.4 Departures for Foreign Employment, 1994-2014 …………………………..... 87

4.1 Sri Lanka's Merchandise Exports, 1965-2014 (\$ billion) ...............................116

4.2 Sri Lanka's Share of World Non-Oil Exports and Manufacturing Exports, 1988-2014 (\%).....................................................117

4.3 Foreign Direct Investment in Sri Lanka (\$ million)....................................... 127

4.4 Sectoral Composition of Approved Foreign Direct Investment, 2005-2015 (\$ million)

4.5 Industry Composition of Foreign Direct Investment in Manufacturing, 2005-2015 (\$ million)........................................................128

5.1 Household Expenditure on Food Items as a Share of Total Expenditure on Food and Drink, 1980-2013 (\%) ..............................................154

5.2 Value of Agricultural Exports (\$ million) .........................................................154

5.3 Land Productivity of Selected Crops in Selected South Asian

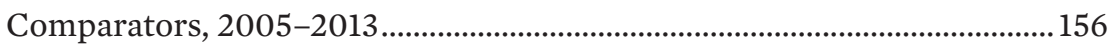

5.4 Structure of the Rice Value Chain ................................................................. 158

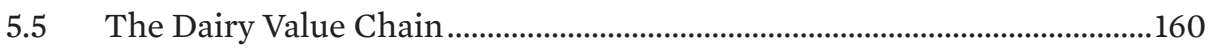

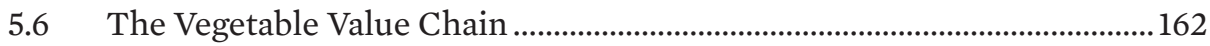

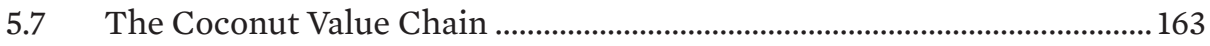

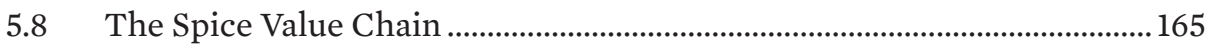

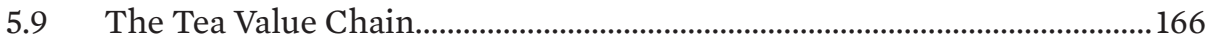

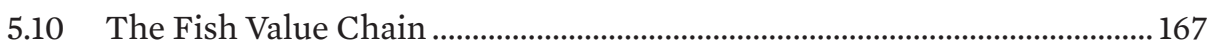

5.11 Average Total Import Taxes and Customs Duties by Commodity, 2003-2014 (\% of CIF)................................................................................... 170

6.1 Classification of State-Owned Enterprises ..................................................185

6.2 Investment in State-Owned Enterprises ........................................................197

6.3 Employment in State-Owned Enterprises ......................................................... 197

6.4 The Operational Efficiency of Sri Lanka Transport Board..........................198 


\section{Figures, continued}

6.5 Net Losses of Selected State-Owned Business Enterprises, 2011-2015 (SLRs million).

6.6 Five Biggest Winners and Five Biggest Losers, 2015 (SLRs million) ...... 200

6.7 Comparing the Annual Average Losses of Nonfinance and of All State-Owned Business Enterprises, 2011-2015

6.8 Annual Average Profits of Nonfinance and of All State-Owned Business Enterprises, 2011-2015 .............................................201

6.9 Circular Debt in 2015 (outstanding SLRs million) ...................................... 202

6.10 State-Owned Business Enterprise Reforms-Initiatives.............................204

6.11 State-Owned Business Enterprise Reforms-Institutional

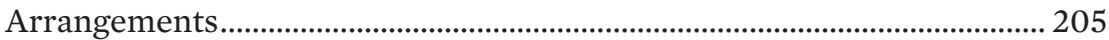

6.12 Framework for Assessing Public Enterprise Reform.................................. 206

8.1 Change in Value Added per Worker by Sector, 2006 and 2014 (\%) ......... 270

8.2 Sectoral Contribution to GDP by Economic Sector, 2006 and 2014 (\%)... 270

8.3 Sectoral Contribution to Employment, 2006-2014 (\%) ................................ 271

8.4 Contribution to the Difference in Job Growth, 2006 to 2014 (\%).............273

8.5 Distribution of Employment by Skills Level across Economic Sectors, 2006 and 2014

8.6 Boys (6-18 years) Attending School, by Age Group and Sector, School Year 2012/13 (\%)

8.7 Girls (6-18 years) Attending School, by Age Group and Sector, School Year 2012/13 (\%)

8.8 Sri Lanka's Demographic Pyramid ............................................................. 280

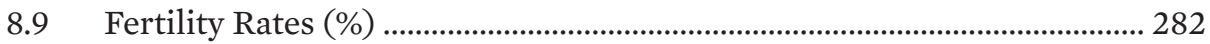

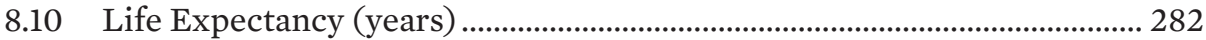

8.11 Forecast Fraction of Elderly Population, 65 years and above, 2015-2055 (\%)

8.12 Midline Forecast of Demographic Pyramids, 2020, 2030, 2040, 2050

8.13 Forecast Dependency Ratios Comparing Working Ages of 15-59 and 15-64, 2020-2050 (\%).

8.14 Total Labor Force Projections, 2014-2048 ('000) ......................................... 288

8.15 Working-Age Population Projections for Sri Lanka, by Age Category, 2014-2048 ('000)

8.16 Percentage Point Differences in Labor Force Participation Rates, 2014 Relative to 2006

8.17 Unemployment Rates, Males and Females 15 Years and Older, 2006-2015 (\%)

8.18 Labor Force Participation Rate, Males, by Age Group and Country, 2006 
Figures, continued

8.19 Labor Force Participation Rate, Females, by Age Group and Country, 2006

8.20 Average Hourly Wages Differences for Males and Females, 2006-2014 (\%)

8.21 Gender Difference in Average Hourly Wage, by Job Type, 2006-2014 (\%)

8.22 Departures for Foreign Employment, 2002-2013

A2.1 Stochastic Frontier and Peer Analysis Approaches to Revenue Potential.

A2.2 Correlation Between Tax Effort, Informality, Corruption, and Tax Gap

\section{Tables}

1.1 Sri Lanka: Nominal and Effective Rates of Protection Estimates, 2015......11

1.2 Sri Lanka: Sectoral Composition of Gross Domestic Product, 1960-2015, (\%)

1.3 Gross National Product per Capita of Sri Lanka and Selected Asian Countries as a Percent of that of the United States, 1950 and 1958

1.4 Comparative Economic Growth

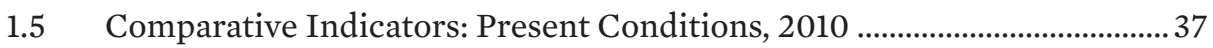

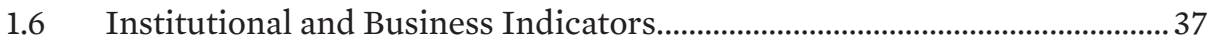

2.1 Revenue Reform Options for Narrowing the Policy Gap in the Medium-to-Long Term

2.2 Expenditure Reform Options for Narrowing the Policy Gap in the Medium-to-Long Term

3.1 Average Annual Rate of Real GDP Growth (\%).

3.2 Value Added by Industry and Service Sectors, Selected Asian Economies

3.3 Employment Share in Industry and Service Sectors, Selected Asian Economies (\% of total employment)

3.4 Distance from Feeder Ports to Colombo and Other Major Hub Competitors (nautical miles).

3.5 Logistics Performance Index: Selected Countries, Country Rank .............92

3.6 Logistics Performance, Subindexes, Selected Countries’ Rank, 2014 ........92

3.7 Quality of Infrastructure, Selected Countries’ Rank Among 138 Countries

3.8 Trading Across Borders: Performance of Selected Asian Countries .98

4.1 Sri Lanka: Commodity Composition of Manufacturing Exports (\%, 2-year averages) 


\section{Tables, continued}

4.2 Share of Global Production Network Products

in Manufacturing Exports, 2012-2013 (\%).

4.3 Parts and Components of Industrial Electronics and Electrical

Goods Exported from Sri Lanka, 2000-2014 (\$ million)

4.4 Sri Lankan Clothing Exports-Top 20 SITC-5 Digit Products, 2000-2001 and 2012-2014

4.5 Foreign Direct Investment Inflow as a Share of Gross Domestic Capital Formation, 1980-2013 (\%, period averages)

4.6 Implementation Status of the Investment Projects Approved by the Board of Investment (May 2016)

4.7 Summary Statistics of the Variables Used in Estimating the Export Equation

4.8 Determinants of Manufacturing Exports ..................................................... 133

4.9 Business Sentiment Indexes, 2014Q1-2016Q3 ............................................. 135

5.1 Growth and Average Share of Gross Domestic Product in Agriculture, 1970-2014

5.2 Employment in Major Sectors, 2015 (\%)

5.3 Labor Force Participation in Agriculture, Forestry, and Fishing.................151

5.4 Land Area under Crops

5.5 Average Monthly Household Consumption of Selected Food, 1980-2013

5.6 Average Yields of Selected Crops, 1977-2014 (t/ha).

5.7 Distribution of Paddy Land by System of Tenure, Maha, 2014-2015 (\%)

5.8 Total Cultivation Loans from Lending Banks.

5.9 Loans and Advances of Commercial Banks (\$)

7.1 Urban Population by Districts, 2001 and 2012.

7.2 Central, Provincial, and Local Authority Revenue and Expenditure, 2014 (SLRs million and \%)

7.3 Revenue and Expenditures for Local Authorities, 2014 (SLRs '000 and \%).

7.4 Recurrent and Capital Revenue Structure for Local Authorities, 2014 (SLRs '000 and \%)

7.5 Recurrent and Capital Revenue Per Capita Collections, 2014 (SLRs '000)

7.6 Comparative Local Authority Own Source Revenue

Contribution, 2004 and 2014 (\% of total collection)

7.7 Local Authority Recurrent and Capital Expenditures, 2014 (SLRs '000) 


\section{Tables, continued}

7.8 Recurrent and Capital Per Capita Expenditures, 2014 (SLRs '000)........ 245

7.9 Contribution of Recurrent and Capital Expenditures by Local

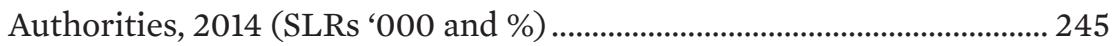

7.10 Per Capita Municipal and Urban Council Revenues

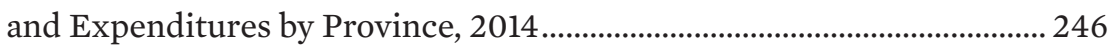

7.11 Funding Sources for Urban Infrastructure ................................................. 249

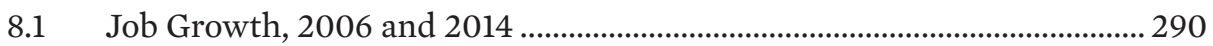




\section{Foreword}

he initiative taken by the Asian Development Bank (ADB) to conduct the Country Diagnostic Study is timely in the wake of the Government of

Sri Lanka announcing its "Vision 2025." Vision 2025 envisages making Sri Lanka a rich country and a hub of the Indian Ocean, with a knowledge-based, highly competitive, social market economy by 2025 .

The structural transformation aims to generate growth with equity, which is necessary to achieve the government's vision. This transformation is currently under way in line with government policy framework: "Empowered Sri Lanka." Empowered Sri Lanka and Vision 2025 target achieving the following during the coming 3 years: raising per capita income to $\$ 5,000$ per year, creating 1 million new jobs, increasing foreign direct investment to $\$ 5$ billion per year, and doubling exports to $\$ 20$ billion per year.

The ADB Country Diagnostic Study provides in-depth discussions on the issues and challenges that Sri Lanka faces in achieving inclusive and sustained growth. Accordingly, the government will have to address issues such as fiscal challenges to reduce short-term vulnerabilities and create space to support sustainable improvement of productivity over time. This is needed to develop new sources of growth, upgrade traditional well-performing sectors, unlock sources of productivity growth, unlock the potential of cities as new engines of growth to reap benefits from agglomeration, and address skill shortages to match market requirements and challenges associated with aging population as the country seeks to upgrade its production base.

The government has taken several measures to strengthen the macroeconomic framework and has reemphasized its commitment to medium-term fiscal consolidation and to achieve the targets under the program supported by the International Monetary Fund (IMF). The government is planning to reduce the country's ratio of debt to gross domestic product to $70 \%$ by 2020 under the Medium Term Debt Management Strategy. A clear policy will be formulated to encourage public-private partnerships, in order to reduce reliance on sovereign loans for development projects in health care, leisure, 
tourism, education, ports, and aviation sectors. The government is coordinating with the private sector to (1) improve its productive participation in economic activities, and (2) encourage the sector to play a key role in making the economy competitive and successful in the global environment. In this light, we are confident of meeting the twin challenges of physical and financial resilience in moving toward upper middle-income country status.

We welcome the findings of this study, which we believe will stimulate dialogue among key development stakeholders on the country's major medium-term challenges. The study will serve as a useful reference for policy makers as they grapple with some of the critical issues facing Sri Lanka today.

\section{Priyantha Rathnayake}

Director General

Department of External Resources

Ministry of National Policies and Economic Affairs

Government of Sri Lanka 


\section{Foreword}

n recent decades Sri Lanka has recorded respectable economic growth by international standards. Because of its good potential, the Sri Lankan economy continued to grow quite strongly during the internal conflict that lasted for nearly 26 years. After the conflict ended in 2009, economic growth recovered well, assisted by good commodity prices. With continued growth, the poverty incidence has declined significantly. Economic progress also produced a reasonable improvement in social indicators, such as education and health. Sri Lanka outperforms other countries in South Asia on many other development indicators.

Considering Sri Lanka's strategic geographical location, its welleducated labor force, and its earlier success in implementing progressive economic reforms, there is no doubt that the country's historical growth performance has been significantly below its potential. After the return of peace, the government has geared its policies to reignite the country's growth. However, the task has proven challenging in the current global economic uncertainties. With the country's narrow export base, an indifferent export performance has resulted in external imbalances and slower growth. The gradual erosion of the tax base, coupled with increased nondiscretionary spending, has also resulted in continuing fiscal imbalances.

This book, The Sri Lankan Economy: Charting a New Course, presents findings of thematic studies on current development challenges and selected drivers of growth that could help Sri Lanka plan to achieve its growth potential and accelerate its progress toward upper-middle-income status. To learn from the past, the book starts with a policy-oriented analytical survey of Sri Lanka's development issues and outcomes. Sri Lankan economic history clearly demonstrates that well-designed international economic integration has resulted in dividends for the country. To reduce the country's external imbalance and diversify its export structure, the book makes a strong case for renewing the emphasis on trade, investment, and commercial policy reforms. The reforms will be more effective if they are accompanied by greater investments in infrastructure, enhancing logistics and the services sector and 
sustainably facilitating new urban growth centers. In addition, the agriculture sector continues to be the largest employer of labor with over $27 \%$ of the workforce, and measures to improve agriculture's productivity will facilitate equity objectives. Finally, while continued investment in human resources is imperative to maintain the country's historic strengths, macroeconomic reform is needed, based on more prudent fiscal management as well as monetary policy that contains inflation and ensures that exchange rate settings support international competitiveness.

I believe that The Sri Lankan Economy: Charting a New Course will be of value to a wide spectrum of development stakeholders, especially those who care deeply about Sri Lanka's continued economic progress and prosperity.

\section{Yasuyuki Sawada}

Chief Economist and Director General

Economic Research and Regional Cooperation Department

Asian Development Bank 


\section{Preface}

$\mathrm{S}$ ri Lanka's overall economic performance has been relatively strong but economic growth has been episodic, reflecting the impact of an array of domestic factors and international conditions. The period following the economic liberalization reforms initiated in 1977 saw moderately high but volatile economic growth. Economic growth dipped in the early years of the civil conflict before recovering in the early 1990s. Sri Lanka was little affected by the 1997-1998 Asian financial crisis, but was adversely affected by the surge in world oil and food prices during 2007-2008 and the global financial crisis that followed. Despite these external shocks and the intensification of the civil war in its final stages, the economy expanded by an annual average rate of $6.1 \%$ during the second half of that decade. During the 3 years immediately following the end of the civil conflict, the country's economy experienced one of its strongest periods of growth during the entire post-independence period. In the last 3 years, however, the growth has weakened significantly due to the global economic slowdown.

This book, The Sri Lankan Economy: Charting a New Course, has been prepared during a pivotal period in Sri Lanka's history. On the one hand, the return of peace provides the country with a historic opportunity. The peace dividend can be very large. On the other hand, the country faces daunting, but not insurmountable, challenges ahead. On the back of the global economic slowdown, economic growth in Sri Lanka has weakened and the country has experienced both external and fiscal imbalances.

This country diagnostic study, which aims to contribute to Sri Lanka's way forward, is a result of collaboration between an Asian Development Bank (ADB) team with government counterparts and a panel of external and national experts.

ADB Chief Economist Yasuyuki Sawada, Economic Research and Regional Cooperation Department (ERCD), and Deputy Chief Economist Juzhong Zhuang provided oversight and valuable guidance to the study team. Former ERCD Chief Economist Shang-Jin Wei, Cyn-Young Park, Abdul D. Abiad, and 
Sakiko Tanaka provided useful advice in conceptualizing the study. Kee-Yung Nam initiated the study; Utsav Kumar led the next stage before moving to ADB's South Asia Department; and Maria Rowena Cham took it to completion. Edimon Ginting, Director, Economic Analysis and Operations Support Division of ERCD, provided overall supervision of the study. Major contributors to the volume include Sirimal Abeyratne, Subhashini Abeysinghe, Prema-chandra Athukorala, Maria Rowena Cham, Edimon Ginting, Asoka Gunawardena, Aneesha Guruge, Hal Hill, Roy Kelly, Yougesh Khatri, Malathy Knight, Utsav Kumar, Kiyoshi Taniguchi, and Jeevika Weerahewa. Maricor Muzones, Lilibeth Poot, and Lotis Quiao also contributed to the book. Regina Salve Baroma, Marie Ann Cagas, and Amador Foronda provided research assistance. The book also summarizes the findings from a parallel study: Enhancing Workforce Skills for a Competitive Economy: Sri Lanka, which was led by Kiyoshi Taniguchi.

The study team expresses its gratitude to the Government of Sri Lanka for the strong support provided throughout the conduct of the study. We thank Dr. Indrajith Coomaswamy, Governor of Central Bank of Sri Lanka and Dr. Sarath Rajapatirana, Chief Economic Advisor to the President of Sri Lanka, for their keen interest in the study. We also thank Mr. Sanjaya Mudalige, Director General, National Planning Department, Ministry of National Policies and Economic Affairs for valuable guidance throughout the study; and the senior government officials from across government ministries and agencies who provided useful insights during consultation meetings and workshops. The study benefited from extensive consultations with the Government of Sri Lanka, academe, development partners, and private sector stakeholders. Feedback received from various stakeholders during consultations and national workshops was valuable in finalizing the volume.

Our special thanks to colleagues at ADB's Sri Lanka Resident Mission, who helped us understand the country context, gave timely and critical feedback, and tirelessly supported the conduct of this study, particularly Country Director Sri Widowati, Tadateru Hayashi, Nimali Hasitha Wickremasinghe, Savindi Jayakody, and Anouk Tyagarajah. We are also grateful to our colleagues in the South Asia Department for the extensive comments provided during internal discussions and reviews. Those who provided comments include Manjula Amerasinghe, Palitha Bandara, Kamal Dahanayake, Tadateru Hayashi, Sudharshana Jayasundara, Herath Jayasundera, and Aruna Nanayakkara. 
The book was edited by Jill Gale de Villa. Joe Mark Ganaban did the layout and typesetting, and Edith Creus designed the cover. Gee Ann Carol Burac, Ricasol Cruz-Calaluan and Roslyn Perez provided administrative and secretarial support.

We hope readers will enjoy the book as much as we have enjoyed preparing it and that it will prove beneficial to those guiding Sri Lanka's road forward.

$\begin{array}{llll}\text { Prema-chandra } & \text { Edimon Ginting } & \text { Hal Hill } & \text { Utsav Kumar } \\ \text { Athukorala } & \text { Director } & \text { Professor } & \text { Economist } \\ \text { Professor } & \text { Economic Research and } & \text { Australian } & \text { South Asia } \\ \text { Australian } & \text { Regional Cooperation } & \text { National } & \text { Department, Asian } \\ \text { National } & \text { Department, Asian } & \text { University } & \text { Development Bank } \\ \text { University } & \text { Development Bank } & & \end{array}$




\section{Abbreviations}

\begin{tabular}{|c|c|c|}
\hline $\mathrm{ADB}$ & - & Asian Development Bank \\
\hline ASEAN & - & Association of Southeast Asian Nations \\
\hline BIA & - & Bandaranaike International Airport \\
\hline BOI & - & Board of Investment \\
\hline CBSL & - & Central Bank of Sri Lanka \\
\hline $\mathrm{CCC}$ & - & Ceylon Chamber of Commerce \\
\hline CEB & - & Ceylon Electricity Board \\
\hline CIF & - & cost, insurance, and freight \\
\hline CMR & - & Colombo Metropolitan Region \\
\hline COPE & - & Committee on Public Enterprises \\
\hline CPI & - & consumer price index \\
\hline DCS & - & Department of Census and Statistics \\
\hline DPE & - & Department of Public Enterprises \\
\hline EBI & - & export bias index \\
\hline EDB & - & Export Development Board \\
\hline EPL & - & Elkaduwa Plantations, Ltd. \\
\hline ERP & - & effective rate of protection \\
\hline ESCAP & - & Economic and Social Commission for Asia and the Pacific \\
\hline FAO & - & Food and Agriculture Organization of the United Nations \\
\hline FDI & - & foreign direct investment \\
\hline FTZ & - & free trade zone \\
\hline GAP & - & Government Accountability Project \\
\hline GCEC & - & Greater Colombo Economic Commission \\
\hline GDP & - & gross domestic product \\
\hline GPN & - & global production network \\
\hline GSL & - & Government of Sri Lanka \\
\hline ILO & - & International Labour Organization \\
\hline IMF & - & International Monetary Fund \\
\hline IPS & - & Institute of Policy Studies \\
\hline ISIC & - & international standard industrial classification \\
\hline JAAF & - & Joint Apparel Association Forum \\
\hline
\end{tabular}




\begin{tabular}{|c|c|c|}
\hline JEDB & - & Janatha Estates Development Board \\
\hline KPI & - & key person interview \\
\hline LFPR & - & labor force participation rate \\
\hline MDR & - & Massachusetts Department of Revenue \\
\hline MFA & - & Multi Fiber Agreement \\
\hline MOE & - & Ministry of Education \\
\hline MOF & - & Ministry of Finance \\
\hline MPI & - & Ministry of Plantation Industries \\
\hline MPRD & - & Ministry of Petroleum Resources Development \\
\hline NHRDC & - & National Human Resource Development Council \\
\hline NPVP & - & $\begin{array}{l}\text { Newport Partners, LLC, and Virginia Polytechnic Institute } \\
\text { and State University }\end{array}$ \\
\hline OLS & - & ordinary least squares \\
\hline OSR & - & own-source revenue \\
\hline PEB & - & Public Enterprise Board \\
\hline PMB & - & Paddy Marketing Board \\
\hline PPP & - & public-private partnership \\
\hline PRC & - & People's Republic of China \\
\hline PUCSL & - & Public Utilities Commission of Sri Lanka \\
\hline SITC & - & Standard International Trade Classification \\
\hline SLBFE & - & Sri Lanka Bureau of Foreign Employment \\
\hline SLEDB & - & Sri Lanka Export Development Board \\
\hline SLFP & - & Sri Lanka Freedom Party \\
\hline SLPA & - & Sri Lanka Port Authority \\
\hline SLRe/SLRs & - & Sri Lanka rupee(s) \\
\hline SLSPC & - & Sri Lanka State Plantations Corporation \\
\hline SLTB & - & Sri Lanka Transport Board \\
\hline SOBE & - & state-owned business enterprise \\
\hline SOE & - & state-owned enterprise \\
\hline UKDCLG & - & $\begin{array}{l}\text { United Kingdom Department for Communities } \\
\text { and Local Government }\end{array}$ \\
\hline UN & - & United Nations \\
\hline UNCTAD & - & United Nations Conference on Trade and Development \\
\hline UNDP & - & United Nations Development Programme \\
\hline UNFPA & - & United Nations Population Fund \\
\hline UNP & - & United National Party \\
\hline US & - & United States \\
\hline USAID & - & United States Agency for International Development \\
\hline VAT & - & value-added tax \\
\hline WDI & - & World Development Indicators \\
\hline
\end{tabular}




$\begin{array}{lll}\text { WEF } & - & \text { World Economic Forum } \\ \text { WEO } & - & \text { World Economic Outlook } \\ \text { WHO } & - & \text { World Health Organization } \\ \text { WTO } & - & \text { World Trade Organization }\end{array}$

\section{Weights and Measures}

$\begin{array}{lll}\mathrm{ha} & - & \text { hectare } \\ \mathrm{kg} & - & \text { kilogram } \\ \mathrm{km} & - & \text { kilometer } \\ \mathrm{km} / \mathrm{h} & - & \text { kilometer per hour } \\ \text { teu } & - & \text { twenty-foot equivalent unit }\end{array}$




\section{Author Profiles}

Sirimal Abeyratne is a Professor of Economics at the University of Colombo, Sri Lanka. His research interests cover the areas of international trade and finance, policy reforms in developing countries, and issues of economic development, including economic dimensions of political conflicts. His current research is on regional integration in South Asia (with emphasis on global product sharing). His latest publication, together with coauthor N.S. Cooray, is Trade and Spatial Growth: Sharing Images from Japan and Sri Lanka. He holds a PhD in Economics from the Free University, Amsterdam; Master's degree from the International Institute of Social Studies, The Hague; and Bachelor's degree from the University of Colombo.

Subhashini Abeysinghe is a Research Director at Verité Research, a think tank based in Colombo, Sri Lanka. Her research interests cover areas of international trade policy, trade facilitation, trade agreements, and trade logistics. Her current research topics include the economic impact of para-tariffs, impact of domestic barriers on agricultural export competitiveness, and impact of bureaucratic resistance on measures taken to facilitate trade. She holds a Master's degree in International Law and Economics from the World Trade Institute attached to the University of Bern in Switzerland.

Prema-chandra Athukorala is a Professor of Economics at the Australian National University, fellow of the Academy of Social Sciences in Australia, and Honorary Professorial Research Fellow at the University of Manchester. His publications include Trade Policy Issues in Asian Development; Labour Migration and Structural Adjustment in East Asia; Liberalization and Industrial Adjustment: Sri Lanka in International Perspective; Saving; Investment and Growth in India; Multinational Enterprises in Asian Development; six other books; and numerous contributions to scholarly journals and multi-author volumes. At various times, has served as a consultant to the Asian Development Bank (ADB), several United Nations agencies, and the World Bank. 
Maria Rowena Cham is a senior economics officer in the Economic Analysis and Operational Support Division (EREA), Economic Research and Regional Cooperation Department (ERCD) at ADB and has worked at the Philippines' National Economic and Development Authority and the Power Sector Assets and Liabilities Management Corporation. She has contributed to a number of country diagnostic studies that ADB has published. She has coauthored chapters in Diagnosing the Philippine Economy: Toward Inclusive Growth and Diagnosing the Indonesian Economy: Toward Inclusive and Green Growth and has published journal articles on the Philippine economy. She has a Master's degree in economics from the University of the Philippines and is currently pursuing her $\mathrm{PhD}$ in economics from the same university.

Edimon Ginting is Director of EREA, ERCD, ADB. In his current capacity, he leads the preparation of the country diagnostic studies for ADB developing member countries (DMCs). The studies inform ADB operations and facilitate dialogue with DMC officials on key structural reforms. In his first 6 years in ADB, he led nine large $\mathrm{ADB}$ operations to support economic reforms and countries' response to the global financial crisis. As Deputy Country Director of ADB in Indonesia, he supervised the delivery of ADB programs for the country, including a number of loans to support structural reforms in the capital market, transport, and energy sectors. Prior to joining ADB, he had extensive international experience, including as an economist at the International Monetary Fund (IMF); advisor at the Indonesian Parliament; research economist at the Productivity Commission, Australia; researcher and lecturer at the University of Indonesia; postdoctoral fellow at Monash University; and research economist at Gadjah Mada University. He received his $\mathrm{PhD}$ in economics from Monash University.

Asoka Gunawardena is the Chair at Marga Institute, a Sri Lankan development think tank. Formerly of the Sri Lanka Administrative Service, he was the Chairman of the Finance Commission. His professional experience covers public policy, governance, and decentralization and he was closely associated with the Sri Lankan devolution initiative from its inception in 1988. His current study engagements include urbanization, sustainable development, and governance. He holds a Bachelor's degree from the University of Ceylon; a Master's degree in Social Science from the University of New England, Armidale, Australia; and a PG Diploma in Development Administration, from the University of Leeds, UK.

Aneesha Guruge, Economist, is a Research Assistant at Verité Research, Colombo, Sri Lanka. Her research interests include public economics, development economics, and econometrics. She holds a Bachelor of Arts degree in economics with a minor in mathematics from the State University of New York at Oswego. 
Hal Hill is the H.W. Arndt Professor Emeritus of Southeast Asian Economies at the Australian National University. His general research interests are the ASEAN economies, including country case studies and thematic, comparative work; industrialization and foreign investment in East Asia; regional (subnational) development; and the political economy of development. $\mathrm{He}$ is the author or editor of 18 books and has written about 150 academic papers and book chapters. He is an occasional contributor to Australian and Asian newspapers, magazines, and websites, and a radio and television commentator. He has worked as a consultant for ADB, the Australian Government, the Indonesian Government, several United Nations agencies, and the World Bank. He has held visiting appointments at Gadjah Mada University, the University of the Philippines, the Institute of Southeast Asian Studies, University of Oxford, International University of Japan, Tinbergen Institute, Columbia University, University of Freiburg, and National University of Malaysia. He serves on the editorial board of 14 academic journals, and for several years edited the Bulletin of Indonesian Economic Studies. He is a Fellow of the Academy of Social Sciences of Australia and has been an official guest of Indonesia as a "Presidential Friend of Indonesia."

Roy Kelly is a Professor of the Practice of Public Policy and Director of the Program on Fiscal Decentralization and Local Government Financial Management at the Sanford School of Public Policy, Duke University, United States. His research and policy experience focuses on fiscal decentralization, local government finance, and revenue mobilization. He has served as resident advisor in Cambodia, Indonesia, Kenya, and Tanzania and has worked throughout Asia, Eastern Europe, and Latin America. He received his Master of City and Regional Planning degree and $\mathrm{PhD}$ in Urban Planning from Harvard University.

Yougesh Khatri is the Managing Director of Alphanomiks Pte. Ltd. (a Singaporebased consultancy), a Senior International Advisor to the Australia-Indonesia Partnership for Economic Governance, a visiting lecturer at Imperial College Business School, and a consultant to ADB. Until July 2015, he was a Senior Economic Advisor to The Government of Singapore Investment Corporation (GIC) in London, advising on a range of areas including Europe, emerging markets, and frontier markets. Before returning to London, he headed GIC's economics team (and co-headed Economics and Capital Markets) in Singapore. During 2010-2011, he led macroeconomic research on Southeast Asia with Nomura Singapore Ltd. Between 1998 and 2009, he was an economist with the IMF, including 2 years at the IMF Regional Office for Asia and the Pacific in Tokyo (working on Japan and regional issues), and 3 years as an IMF Resident Representative in Jakarta. Prior to joining the IMF, he held various academic 
positions, including at Birkbeck College, Cambridge University, and the London School of Economics. He completed his $\mathrm{PhD}$ at the University of Reading and a Bachelor of Science degree at the London School of Economics. He has published journal articles, book chapters, and working papers in a wide range of areas.

Malathy Knight is a Research Director at Verité Research, Colombo, Sri Lanka, and former head of industry, public enterprise reform, and regulatory research at the Institute of Policy Studies Sri Lanka. She has written leading studies in these areas and has served on many government commissions. Her specific areas of expertise also include privatization and state-owned enterprise reform, telecommunications policy and regulation, competition policy, regulatory governance, and new institutional economics. She sits on the Ceylon Chamber of Commerce's Economic Planning Committee and is a Fellow at the Centre for Competition, Investment and Economic Regulation in India. She has published in international and local journals and has a PhD from Manchester, a Master of Arts degree from Colombo, and a Bachelor of Arts degree from Swarthmore.

Utsav Kumar is an economist in ADB's South Asia Department. Before that, he was an economist in EREA, ERCD, ADB. Earlier, he was an ADB consultant, an economist at The Conference Board, and a research analyst at the IMF. He has published in leading peer-reviewed journals such as the Cambridge Journal of Economics, Japan and the World Economy, Journal of the Asia Pacific Economy, Journal of Comparative Economics, Journal of Monetary Economics, and Structural Change and Economic Dynamics. He was a member of the core team that produced the ADB Guidelines for the Economic Analysis of Projects in 2017. He obtained his PhD in Economics from the University of Maryland; Master's degrees in Economics from the University of Maryland, and the Delhi School of Economics, University of Delhi; and Bachelor's degree in Economics from the University of Delhi.

Kiyoshi Taniguchi is senior economist at EREA, ERCD, ADB. His research interests include agriculture economics, international trade, applied microeconometrics, and impact evaluation. At ADB, he has worked for the Pacific Department and Private Sector Operations Department and was stationed in Tashkent, Uzbekistan. He has also worked for the Indonesia Country Office of the World Bank. He received his $\mathrm{PhD}$ and Master of Arts degree in economics from Ohio State University. 
Jeevika Weerahewa is the Professor of Agricultural Economics at the Department of Agricultural Economics and Business Management, Faculty of Agriculture, University of Peradeniya, Sri Lanka. She served as Coordinator of the Faculty of Agriculture Undergraduate Research Symposium in 2016 at the University of Peradeniya, Head of the Department during 2013-2016, and Chairperson of the Board of Study in Agricultural Economics at the Postgraduate Institute of Agriculture during 2011-2015. She is a Collaborator of the International Food Policy Research Institute, a Hewlett Fellow of the International Agricultural Trade Research Consortium, a Fellow of the Canadian Agricultural Trade Policy Research Network, and a recipient of an Endeavour Fellowship awarded by the Government of Australia. She obtained her Master of Philosophy and Bachelor of Science degrees from the University of Peradeniya and $\mathrm{PhD}$ from the University of Guleph, Canada. 



\section{Chapter 1. \\ The Sri Lankan Economy: Achievements, Prospects, and Policy Issues}

Prema-chandra Athukorala, Edimon Ginting, Hal Hill, and Utsav Kumar

\subsection{Introduction}

his book is prepared during a pivotal period in Sri Lanka's history-one of historic opportunity but also of daunting challenges. The country is now at peace. The peace dividend can be very large. Defense expenditure can be wound back, as it has been in recent years, and the funds so released invested in badly needed education, health, infrastructure, and rural development projects. Investors, domestic and foreign alike, can look to the future with greater optimism. Intercommunal harmony and trust can be restored. Sri Lanka can reenter the regional and international mainstream, politically and commercially. Moreover, although global economic growth is sluggish, Sri Lanka is favorably located in the most dynamic region of the world. India is now the world's fastest growing major economy. Growth in the People's Republic of China is slowing, but the annual increment to its gross domestic product (GDP) is as large as it was a decade ago during the period of hypergrowth. Several medium-sized economies of the Association of Southeast Asian Nations (ASEAN) continue to grow strongly.

Sri Lanka's reform process can be reignited, confident in the knowledge that past reform efforts produced tangible and broad-based benefits for the country and its populace. Great accumulated wisdom on the analytics and the practicalities of how to reform is available from the decades of growth in the dynamic East Asian region, from India for the last quarter century, and from Sri Lanka itself. 
But the risks and challenges are just as large. If broad-based growth is not maintained, destructive ethnic tensions of the past could resurface. Public finances have yet to be reestablished on a sound footing. Public debt, which has risen rapidly in this century, poses serious macroeconomic challenges. And the global outlook continues to be clouded by a toxic combination of slow economic growth, financial volatility and uncertainty, sporadic outbreaks of terrorism, deep and protracted conflict in the Middle East, and unsettled relations between some of the great powers.

As a prelude to the thematic chapters that follow, this chapter provides a policy-oriented, analytical survey of Sri Lanka's development issues and outcomes. The chapter first develops what may be termed "stylized facts" that facilitate a deeper understanding of the country's development trajectory and that have been shaped by the country's distinctive historical, geographical, and political factors. These factors have shaped the country's development path, its policy making processes, and its socioeconomic outcomes.

The chapter is organized as follows. Section 1.2 provides a survey of the ebb and flow of Sri Lankan policy history, emphasizing both the successful reform episodes and the backtracking. Section 1.3 draws attention to some major stylized facts that have shaped the country's development trajectory. Section 1.4 reviews Sri Lanka's development record during the last half-century, comparing it with some of the dynamic ASEAN economies. Section 1.5 summarizes the contents of this book, and the last section draws out some key policy inferences. ${ }^{1}$

\subsection{Sri Lankan Economic Development: Some Stylized Facts}

The rich literature on Sri Lankan economic development highlights the sense of optimism at the time of independence in 1948 (Jennings 1948; World Bank 1953; Hicks 1958; Wriggins 1960, 2011; de Silva 1981). The country appeared to possess the essential ingredients for rapid economic development, ingredients that were not shared by most other Asian countries-a strategic location in the Indian Ocean, an open economy with a vibrant export sector, a high level of education, an absence of extreme poverty and inequality, a relatively well-developed physical infrastructure, and a broad-based and efficient administrative apparatus. Colombo had a legendary status as the major port on the shipping lanes from Africa, Europe, and the Middle East to the west, East Asia, Australasia, and the

Figures used in the chapter, unless otherwise stated, have been compiled from CBSL (various years). 
east. At the time of Sri Lanka's independence (and well into the 1950s) it ranked as one of the most prosperous Asian countries, with per capita income and other development indicators placing it not only well above its South Asian neighbors but also ahead of countries such as the Republic of Korea and Thailand. The domestic and external financial positions were sound, backed by large foreign exchange reserves and a solid budgetary position. ${ }^{2}$ The country appeared to have a settled and stable political system, including a strong, independent judiciary and an active civil society. Sri Lanka had undergone a fairly smooth transition to parliamentary democracy through a step-by-step transition from a colonial system through a succession of constitutional reforms since the turn of the century. The population had enjoyed universal suffrage since 1931, only 3 years after universal suffrage was implemented in the United Kingdom.

In contrast to the violent conflict and turmoil that gripped other portions of the Indian subcontinent at the time, Sri Lanka was "an oasis of stability, peace, and order" (de Silva 1981: 489). Importantly, though, the political and social tranquility masked deep underlying divisions among distinct and culturally separated ethnic groups, ${ }^{3}$ particularly between the Sinhalese (the major ethnic group) and the Tamils (the second-largest group). However, the political leaders of all ethnic groups were well educated, and they were part of the same "special class of Westernized Ceylonese" (Jennings 1948: 11). All main political parties were multiracial and included members of minority ethnic groups in their leadership. All ethnic groups were well represented in the first cabinet of independent Sri Lanka. Thus the indications were that the country was well placed to build on its highly favorable initial conditions while maintaining ethnic harmony and sociopolitical stability.

Together these initial conditions had provided the setting for the expectation that, of all post-colonial nations, Sri Lanka would prove "the best in Asia" (Jiggins 1976: 26). In the words of former Singapore Prime Minister Lee Kuan Yew, who had a close association with the country (Lee 2000: 461-2):

2 D.S. Senanayake, Sri Lanka's first Prime Minister, in an interview with Newsweek in 1948 stated that Sri Lanka "wanted neither grants nor loans from the United States or any other country" (Wijesinghe 1976).

3 The major ethnic group, Sinhalese (about $70 \%$ of the population in 1946), trace their ancestry to a group of North Indian "Aryan" settlers believed to have arrived in the country around $500 \mathrm{BC}$. The second-largest ethnic group, the "Sri Lankan Tamils" (11.0\%), claim to have lived in the country for at least 2 millennia. The "Indian Tamils" (11.7\%) are (mostly) descendants of migrant workers brought from South India by the British colonialists to work on the tea and rubber plantations. The "Muslims," also termed Moors, (6.4\%) trace their ancestry to Arab traders involved in the millennia-old seaborne trade between the Middle East and South and Southeast Asia. A smaller group, the "Ceylon Burghers," are descendants of various European settlers (Athukorala and Jayasuriya 1994, Table 3.1). 
Ceylon was Britain's model Commonwealth country. It had been carefully prepared for independence. After the war, it was a good middle-size country with fewer than 10 million people. It had a relatively good standard of education, with 2 universities of high quality, ... a civil service largely of locals, and experience in representative government starting with city council elections in the 1930s. When Ceylon gained independence in 1948, it was the classic model of gradual evolution to independence.

However, this early promise proved misplaced. During the 2 decades from about the early 1960s, the growth of Sri Lanka's per capita income fell behind the fast-growing East Asian economies and instead converged to the levels of its South Asian neighbors (Athukorala and Rajapatirana 2000; Snodgrass 1998). Sri Lanka's standards of living, measured by the usual indicators such as adult literacy, life expectancy, and infant mortality had remained well above those of many other Asian countries until the mid-1960s, but were no longer such an outlier.

Periods of quite rapid economic growth followed the crucial liberalization reforms initiated in 1977. By international benchmarks, Sri Lanka's economic performance has been relatively strong, and its long-term average growth rate has not been far short of the slower growing members of the East Asian "miracle" club. But this progress has often been nipped in the bud by incomplete reforms, by political unrest and war, by external shocks, and sometimes by a combination of all three factors.

These observations are central to the main theme of this book, that of unrealized potential. Sri Lanka could and should grow faster than its historical average. As its incomplete liberalization experience illustrates, with the "right" policies, the country can grow considerably faster, and achieve greatly improved living standards. This in turn creates a "virtuous circle" of progressive reforms that strengthen the political constituency for improved policy and alleviate the social tensions that are an inevitable feature of a multiethnic community. The fact that the economy has continued to grow even during periods of the most severe conflict underscores the potential for accelerated growth.

The following stylized facts are useful to guide an understanding of the Sri Lankan economy looking both backward and forward. They are not of course immutable to change. Countries can and do break out of "path dependence" trajectories through bold and far-reaching reform. 
Economic Performance. First, as shown below, during the last halfcentury, Sri Lanka's economic performance has been moderately strong. Sri Lanka has not quite been in the Asian Miracle group, but has performed better than the developing (and South Asian) country average, although somewhat overshadowed by India during the last quarter century.

Episodic Performance. Second, Sri Lanka's performance has been episodic, reflecting the impact of an array of (1) domestic factors-principally reform propensities and regress, and periods of conflict; and (2) international conditions, including the country's terms of trade. But notwithstanding the latter, Sri Lanka has been master of its own destiny: by far the most important determinant of economic success has been domestic policies.

Location. Third, geography has not played a major role in Sri Lanka's development outcomes. The country inherited a commercial advantage from its crossroads location, but arguably was also influenced by India's 4 decades of increasing economic isolation. However, on balance, neither of these nor related factors played a decisive role.

Trade Policy. Fourth, like many developing countries, Sri Lanka has experimented with all manner of trade policy regimes, from one major liberalization episode to a comprehensive socialist experiment. The liberalization program of 1977 was a striking success in terms of growth and employment. In this respect, Sri Lanka was well ahead of its neighbors, particularly India. The country has had periods of trade and investment liberalization, but has not persisted with them. Thus, the liberalization efforts have not developed the durable and influential constituency that could be used as a stepping stone to further and deeper reform. ${ }^{4}$

Macroeconomic Management. Fifth, Sri Lanka has had a mixed record of macroeconomic management, generally avoiding macroeconomic crises, at least of a recurrent nature. But it has not consistently pursued prudent macroeconomic management. Substantial fiscal deficits have been a common feature, triggered by domestic conflict (and the necessity to increase defense expenditure); a large (and largely uneconomic) state-owned enterprise (SOE) sector; and other domestic political factors. As these deficits have been monetized, the result has been periods of high inflation that, combined with a reluctance to depreciate, have resulted in periods of quite severe exchange rate misalignment. Interestingly, unlike other countries, including India, a macroeconomic crisis was not the trigger for trade policy reform.

4 It is perhaps just of symbolic significance, but the country is still referred to as the "Democratic Socialist Republic of Sri Lanka" (italics added). 
Egalitarianism. Sixth, the country has maintained a strong commitment to egalitarian ideals and, even though inequality has been rising, Sri Lanka's polity has rarely if ever deviated from the ideals. In particular, its educational achievements have been among the best in the developing world. Gender inequality is less of an issue than in most developing countries, especially compared with South Asian neighbors.

Conflict. Seventh, its post-independence history has been overshadowed by conflict, at times serious and costly. Durable peace has proved elusive. The conflict has had its roots in ethnic tensions and outbursts of ethnic chauvinism, and a failure to forge a genuine sense of national unity. Ethnic considerations continue to dominate political and policy calculations, on occasion arguably to an unhealthy degree.

Institutions. Finally, Sri Lanka's institutional record is a mixed one. Sri Lanka is one of the few developing countries to remain a functioning democracy for almost its entire post-independent history. It inherited a well-functioning bureaucracy, a highly regarded judiciary, and a vibrant civil society. Over time, however, these strengths have tended to erode, particularly during periods of conflict and authoritarian rule. There has been a trend toward overstaffing in the public sector, buttressed by powerful trade unions. Conditions of employment in the public sector have generally declined, resulting in an exodus of talent from the public sector and the country as a whole. ${ }^{5}$

\subsection{Sri Lanka: A Brief Policy History}

The reasons for Sri Lanka's failure to fulfill its early promise of strong economic growth have been the subject of much debate. ${ }^{6}$ Many analysts, particularly those associated with international funding agencies, argued during the 1960 s and $1970 \mathrm{~s}$ that government expenditures on health, nutrition, and education were primarily responsible for the slowdown, by diverting government resources away from direct growth-oriented investments. Of course there would have been some room for redressing the investment-redistribution trade-off through better targeting of social welfare services, which were provided free of charge irrespective of the income status of the recipients. However, there are strong reasons to argue that the primary cause of the slide to slow growth and stagnation was that successive administrations turned away from a private-sector led, outward-oriented

5 These observations extend to universities, which remain in the state sector and have slipped significantly in international rankings. This has had important implications more generally, for the quality of governance, policy advice, and civil society.

6 For a comprehensive review of this debate, see Osmani (1994). 
development strategy in favor of state-led inward-looking policies. As illustrated by the East Asian experience (Perkins 2013), government expenditure on human capital development could have played a vital complementary role in economic growth and structural transformation of the country under a market-friendly, outward-oriented development strategy.

During the first decade after independence in 1948, Sri Lanka continued with a liberal trade and foreign direct investment (FDI) policy regime. Most of the import restrictions imposed by the colonial government were removed in the early 1950s, aided by an improved balance-of-payments position due to the commodity price boom during the Korean War. Unlike in many other newly independent countries, state intervention to help development of manufacturing was not a policy priority. A number of industries that had been set up during the war years were closed down. The main item on the government's development agenda was reviving domestic food crop agriculture, predominantly rice, based on irrigation-cum-land development schemes in the sparsely populated dry zone of the country.

From the late 1950s, a combination of changes in political leadership and growing balance-of-payments problems induced a policy shift toward a stateled import-substitution strategy. In 1957, the Parliament passed the Scheme of Industrialization that established a state monopoly over basic and strategic industries. This was accompanied by the State Industrial Corporation Act, which provided the legal framework for setting up SOEs in these industries. With a modest start in the early 1960s, the number of SOEs multiplied in the first half of the 1970s. The Paddy Marketing Board was established in 1971 as the sole buyer of paddy (unhulled rice) from farmers. Most of the plantation sector, the dynamo of the export economy inherited from the colonial era, came under government ownership through the Land Reform Act of 1972. Import restrictions, initially imposed to address payment difficulties, became increasingly tight as the development strategy shifted to import-substitution policies and led to pervasive state interventions in the economy. By the mid-1970s, the Sri Lankan economy had become one of the most inward-oriented in the world outside the Communist Bloc. As a result of the marginalization of the private sector in the economy under the dirigiste policy regime, coupled with rampant inefficiency of public enterprises, the annual average growth rate of per capita gross national product declined from $2.8 \%$ in the 1960 s to a mere 0.7\% during 1970-1977 (Athukorala and Jayasuriya 1994: 28).

As a reaction to the dismal economic outcome of the inward-looking policy, in 1977 Sri Lanka embarked on an extensive economic liberalization process that marked a decisive break with decades of protectionist policies 
(Snodgrass 1998; Rajapatirana 1988; Athukorala and Rajapatirana 2000). The first round of reforms, carried out during 1977-1979, included (1) significant trade policy reforms; (2) opening up of the economy to FDI, with new incentives for export-oriented FDI under an attractive free trade zone (FTZ) scheme and a constitutional guarantee against nationalization of foreign assets without compensation; (3) abolition of the multiple exchange rates followed by a sharp devaluation of the unified exchange rate; and (4) the introduction of limits on direct public-sector participation in the economy.

Sri Lanka's ability to reap benefits from this remarkable policy transition was seriously hampered by the escalation of the ethnic conflict in the early 1980s. ${ }^{7}$ It virtually cut off the Northern Province and large parts of the Eastern Province (which together account for one-third of Sri Lanka's total land area and almost $12 \%$ of the population) from the national economy. Even in the rest of the country, the prospects for attracting foreign investment, particularly in long-term ventures, were seriously hampered by the lingering fear of sporadic attacks by the rebels. The government's preoccupation with the civil war also hampered capturing the full benefits of economic opening through delays and inconsistencies in the implementation of the reform processes.

There was, however, no retreat to the old control regime. In a decisive move to infuse momentum into the unfinished reform process, a significant "second wave" liberalization package was implemented in 1990, followed by notable privatization and deregulatory reforms (including privatizing telecommunication and reverting large plantations to private-sector management under a 100-year leasing arrangement). By the mid-1990s, Sri Lanka appeared to be "at the point of moving into an important policy phase marked by shifting the agenda away from protection and toward achieving a stable and predictable economic policy environment" (Cuthbertson 1997: 637).

There were early signs of back-sliding from liberalization reforms in the last 2 decades (Rajapatirana 2004; Pursell 2011; Kaminski and Ng 2013). As early as the late 1990s, the trade liberalization process suffered a setback because of the pressure for raising additional revenue from import tariffs to finance the ballooning war budget. The planned reduction of tariffs into a single band was abandoned, and from then on tariffs were adjusted frequently in an ad hoc manner. The protectionist tendencies soon received added impetus from growing

7 The causes of the ethnic conflict in Sri Lanka are beyond the scope of this chapter. While the conflict had deep and complex political and historical roots, evidence suggests that sluggish economic growth during the first 3 decades of the post-independence period is an integral part of the explanation (Wilson 1988; Athukorala and Jayasuriya 2015; Abeyratne 2004). 
discontent among the electorate, which was propelled by the crisis economic conditions as the civil war accelerated.

The backlash against liberalization reforms gained added impetus as the country returned to a state of normalcy at the end of the 3-decade-old civil war in May 2009. The government emphasized the role of the state in guiding the markets with a view to redressing untoward effects of economic globalization. Privatization of key state enterprises (banking, power, energy, transport, and ports) was explicitly ruled out, while the government conspicuously avoided any reference to trade policy reforms (GSL 2010). Rapid infrastructure development of rural and conflict-affected parts of the country and the promotion of small and medium-sized enterprises were the key priorities under the new policy. However, overall there was no retreat to the old dirigisme regime.

\subsubsection{Trade Policy Regime}

Liberalizing trade was the key element of the liberalization reforms initiated in 1977. Quantitative restrictions, which covered virtually all imports during the previous 2 decades, were replaced by tariffs. Only a few items remained exempt (less than $5 \%$ of total import value), for health and security reasons. As part of second-wave reforms initiated in the late 1980s, import tariffs were further rationalized, and in 1993 a three-band tariff structure was adopted involving rates of $10 \%, 20 \%$, and $35 \%$. In 1997, all textile tariffs were abolished and tariffs on clothing imports were substantially reduced, with a view to providing a freetrade regime for the booming garment industry. In 1994 Sri Lanka achieved Article VIII status of the International Monetary Fund (IMF) after abolishing foreign exchange restrictions on current account transactions, including the foreign exchange surrender requirement on export transactions.

On the export side, duties on all plantation products were removed in December 1992, correcting a long-standing anomaly in the taxation of traditional exports. ${ }^{8}$ The share of export taxes (duties, cesses, and other surcharges) in total government revenue, which was as high as $25.2 \%$ in the early 1980 s, declined to $0.05 \%$ in 1993.

Between 1995 and 2002, Sri Lanka's average (unweighted) applied import tariff rate halved, from $20.0 \%$ to $9.4 \%$. During the same period, the duty collection rate (duties as a percentage of import value including cost, insurance, and

8 However, some moderate surcharges and taxes (cesses) on exports were retained. These were plowed back into the export sector in the form of selective incentives, replanting subsidies, and start-up subsidies for new exporters. 
freight) fell from $7.5 \%$ to $4.6 \%$. By this time, the average tariff rate in Sri Lanka was comparable with those of Indonesia, Malaysia, and the Philippines and somewhat lower than that of the People's Republic of China, Thailand, and Viet Nam. Estimates indicate that the effective rate of protection (ERP) ${ }^{9}$ for import-competing manufacturing declined from $70 \%$ in 1991 to $56 \%$ in 2002, and there was a significant reduction in the incentive bias against exporting in the tariff structure (World Bank 2005).

However, the reform process began to lose momentum from about the late 1990s because of additional fiscal pressures following the escalation of the civil war and economic downturn during the early 2000s, which infused a new lease on life into domestic protectionist lobbies (Athukorala 2012). By 2009, the Sri Lankan tariff schedule included nine import taxes in addition to the standard customs duty. Of the nine taxes, five were para tariffs: taxes that are only applied to imports of products for which there is no domestic equivalent, and hence add to whatever protection that customs duties provide to domestic production. The total nominal protection rate (customs duty plus para tariff) went up slightly between late 2002 and early 2004, but then more than doubled, from $13.4 \%$ in 2004 to $27.9 \%$ in 2009 (Pursell 2011). During the ensuing years, there were also numerous ad hoc duty exceptions and case-by-case adjustments of duties on manufacturing imports that directly compete with domestic production.

When Sri Lanka embarked on liberalization reforms in the late 1970s, the ERP for import-competing manufacturing was as high as 137\% (Cuthbertson and Athukorala 1991). This declined to $70 \%$ by the early 1990 s and to $56 \%$ by the dawn of the New Millennium (World Bank 2005). The latest estimates prepared by the Department of Census and Statistics indicate that this trend has reversed in the subsequent years, resulting in a weighted-average ERP of $63.2 \%$ in 2015 (Table 1.1). For total tradable production (manufacturing, agriculture, fishing, and mining) the ERP in 2005 was $46.7 \%$. The estimates reveal a clear incentive bias against agriculture and in favor of manufacturing embodied in the tariff structure. Product-level estimates for both years suggest that in several agricultural products (sugarcane, rubber, livestock, milk, and eggs), tariffs on intermediate inputs exceeded tariffs on the final products, leading to negative effective protection.

9 The ERP measures the proportionate increase in per unit value added of a product due to the complete system of tariffs and thus captures the resource allocation effect of tariffs on both final goods and intermediate inputs. 
Table 1.1: Sri Lanka: Nominal and Effective Rates of Protection Estimates, 2015

\begin{tabular}{|c|c|c|c|c|c|c|}
\hline & \multicolumn{3}{|c|}{ Nominal Rate of Protection } & \multicolumn{3}{|c|}{ Effective Rate of Protection } \\
\hline & $\begin{array}{c}\text { All } \\
\text { Tariffs }\end{array}$ & $\begin{array}{l}\text { Customs } \\
\text { Tariffs }\end{array}$ & $\begin{array}{l}\text { Para } \\
\text { Tariffs }\end{array}$ & All Tariffs & $\begin{array}{l}\text { Customs } \\
\text { Tariffs }\end{array}$ & $\begin{array}{c}\text { Para } \\
\text { Tariffs }\end{array}$ \\
\hline \multicolumn{7}{|c|}{ Weighted Averages ${ }^{a}$} \\
\hline $\begin{array}{l}\text { Agriculture, } \\
\text { Forestry, and } \\
\text { Fishing }\end{array}$ & 23.5 & 3.4 & 20.1 & 31.4 & 4.1 & 27.3 \\
\hline $\begin{array}{l}\text { Mining and } \\
\text { Quarrying }\end{array}$ & 2.7 & 0.0 & 2.7 & -1.7 & -1.4 & -0.3 \\
\hline Manufacturing & 34.3 & 7.8 & 26.4 & 63.2 & 14.5 & 48.7 \\
\hline $\begin{array}{l}\text { All Tradable } \\
\text { Production }\end{array}$ & 28.0 & 5.6 & 22.4 & 46.7 & 9.5 & 37.2 \\
\hline \multicolumn{7}{|c|}{ Simple Averages (mean) and Dispersion } \\
\hline Agriculture: Mean & 23.8 & 4.5 & 19.2 & 26.6 & 5.0 & 21.6 \\
\hline Range & 0 to 110.5 & 0 to 27.8 & 0 to 85.5 & -8.3 to 137.9 & -4.8 to 31.6 & 7.7 to 106.3 \\
\hline $\mathrm{CV}^{2}$ & 129.6 & 178.5 & 121.2 & 149.3 & 197.9 & 141.5 \\
\hline $\begin{array}{l}\text { Manufacturing: } \\
\text { Mean }\end{array}$ & 35.9 & 6.9 & 28.9 & 68.3 & 12.9 & 55.4 \\
\hline Range & 0 to 206.7 & 0 to 89.0 & 0 to 145.1 & 26.2 to 523.8 & -5.8 to 120.9 & 20.9 to 443.2 \\
\hline $\mathrm{CV}^{2}$ & 110.6 & 179.8 & 103.3 & 161.2 & 205.0 & 160.0 \\
\hline $\begin{array}{l}\text { All Tradable } \\
\text { Products: } \\
\text { Mean }\end{array}$ & 33.1 & 6.4 & 26.7 & 58.8 & 11.1 & 47.7 \\
\hline Range & 0 to 206.7 & 0 to 89.0 & 0 to 145.1 & -26.2 to 523.8 & -5.8 to 120.9 & 20.9 to 443.2 \\
\hline $\mathrm{CV}^{2}$ & 114.9 & 182.0 & 107.4 & 170.0 & 215.2 & 168.5 \\
\hline
\end{tabular}

$\mathrm{CV}=$ coefficient of variation.

Notes: The staff of the National Accounts Division of the Department of Census and Statistics, in particular Manjula Ekanayake and Anuruddha Weeratunga, prepared the estimates for this table. The original estimates are for 101 tradable production sectors identified in the 2010 input-output table. Weighted averages were estimated using output (value-added) data obtained from the same input-output table. Coefficient of variation $=(\text { standard deviation } / \text { mean })^{*} 100$.

a Weighted by value added.

Source: Compiled using nominal and effective rates of protection estimates provided by the Department of Census and Statistics.

The disaggregated estimates of ERP for traditional customs duties and para tariffs reported in Table 1.1 clearly indicate the dominant role para tariffs played in determining the effective protection embodied in the structure of trade protection in Sri Lanka. The disaggregated (product-level) estimates indicate that this pattern of para tariff dominance in the structure of protection is observable across most of the 101 products covered in this analysis. All three measures of ERP indicate a high degree of variability among products: the estimates for the 101 sectors (based on the 2010 input-output table) ranged from $26.6 \%$ to $523.5 \%$, a coefficient of variation of $181.9 \%$. 
Let us denote ERP for production for domestic market and production for export in a given industry (j) by $E R P_{d j}$ and $E R P_{e j}$ respectively. Combining the two measures gives a useful summary measure of the export bias embodied in the overall incentive structure, dubbed here the export bias index $\left(E B I_{j}\right) .^{10}$ Given the paucity of data relating to incentives for export production, the authors constructed three alternative export bias indexes (EBIs) based on three alternative measures of $E R P_{x^{*}}$. The first index (EBI1) is directly estimated based on the Lerner Symmetry theorem: the proposition that a tax on imports has the same effect as an equal tax on exports. EBIl captures only the negative effect of import tariffs on the relative profitability of producing for the export market, while ignoring import duty and income tax concessions applicable specifically to exporters. The second index (EBI2) represents the case in which the export producers, unlike their import-substituting counterparts, are partly cushioned against the anti-export bias of the trade regime by a fully functional duty exemption scheme (duty rebates and FTZ provisions) for imported intermediate goods while the income taxation is equally applied to all firms. The third index (EBI3) is constructed under the assumption that exporting firms are eligible for full exemption from import duties on intermediate inputs and from income tax. ${ }^{11}$ The assumption of import duty exemptions, on which the EBI2 estimation is based, holds well in the Sri Lankan case. ${ }^{12}$ However, not all export producers were benefiting from tax holidays offered under the Board of Investment (BOI) incentive package in the 2 years for which the authors have made EBI estimates. ${ }^{13}$ Thus, the relative incentive pertaining to the average exporting firm lies between the EBI2 and EBI3 estimates.

The estimates suggest that, on average, production for the domestic market is over $70 \%$ more profitable than production for exporting. The few industries with a positive or near zero export bias in terms of both EBI2 and EBI3 are observable only for eight products (grain mill products, spinning and weaving textiles, finishing textiles, wearing apparel, medical and botanical products, miscellaneous chemical products, sporting goods, and textile machinery). Estimates for individual industries show a notable similarity in the

10

$E B I_{j}=\left[\frac{\left(1+E R P_{d j}\right)}{\left(1+E R P_{x j}\right)}-1\right] * 100$

A positive $E B I$ implies an incentive bias in favor of exporting and a negative $E B I$ implies an incentive bias against exporting, compared to production for the domestic market.

11 The price wedge created for export producers under this assumption was estimated by multiplying the before-tax operation merging (available in the Sri Lanka Department of Census and Statistics database, used as a proxy for before tax profit) by the company tax rate of $14 \%$. Intermediate imports directly embodied in export products are not subject to para tariffs.

13 According to BOI data, tax holiday periods of over a third of BOI approved firms had expired by 2015 . 
industry ranking in terms of the three alternative export bias indexes: the rank correlation coefficients between the three alternative export bias indexes are both about 0.9 . This indicates the dominant role played by import tariffs, which are effectively a tax on export production, in determining the relative incentives faced by export-oriented production in the economy. A comparison of the three indexes across industries clearly suggests that, while various indirect measures to counterbalance the anti-export bias of the protectionist regime seem to have had some effect, they are unlikely to achieve the desired neutrality in the incentive structure even if the efficiency of their implementation is substantially improved.

Progress has been made, and more still needs to be done. The current government has promised a renewed policy focus on an outward-oriented development strategy. Some of the measures include simplifying the tariff structure by introducing a 3-band system, removing several para tariffs and planning to remove the remaining para tariffs, negotiating trade agreements, introducing a National Trade Policy, and drafting a National Export Strategy. However, driven by fiscal exigencies, some import surcharges were added to the list of para tariffs in the 2015 budget. The taxes (termed "cesses" in Sri Lanka and some other countries) on tea, rubber, coconut, and cinnamon in primary form are maintained, ostensibly for promoting domestic value added through further local processing. The foreign exchange surrender requirements for exporters, which was introduced as part of the country's commitment to achieve Article VIII Status of the IMF in 1994, was reintroduced. Exporting firms consider this requirement to be a significant constraint on the financial flexibility needed for successful export operations.

\subsubsection{Export Promotion and the Role of the Export Development Board}

A wide range of export promotion schemes, including a duty rebate scheme, direct cash subsidies, manufacturing-in-bond, provision of equity and working capital to firms with export potential, and measures aimed at product and market development, were introduced under the Sri Lanka Export Development Board (EDB), established in 1979. In 1980, the operation of the duty rebate scheme (originally introduced in 1964 but largely inactive because of various administrative rigidities) was transferred from the Ministry of Industries to the EDB. The EDB completely reformulated the scheme and instituted a more flexible implementation procedure to cover all nontraditional exports using imported inputs. The coverage of the duty rebate scheme was expanded in 1982 to include sales to FTZs. Manufacturing-in-bonds for exporters importing material for reexport as part of a finished good, a cash grant scheme based on annual export increments, and concessionary credit for exporters were among the other EDB incentives. 
Over time, the use of the duty rebate scheme (and other arrangements for exempting exporters from duties on imported inputs) has declined, reflecting lower tariffs on intermediate goods (including free trade in textiles) under the liberalization process. Extension of BOI privileges to export-oriented firms located outside the FTZs also contributed to the decline. Starting in January 1997, the duty rebate and bonded warehouse schemes came under the Treasury and the Department of Customs. (Approval of duty rebate claims was the responsibility of the Customs while reimbursement was done by the Treasury.) From 2001, implementation of the schemes has become the sole responsibility of the Department of Customs. The EDB has scaled down its operation in the last decade and currently its role is limited to some export facilitating services.

\subsubsection{Foreign Investment Policy}

Concurrent liberalization of the trade and foreign investment regimes was a hallmark of the Sri Lankan liberalization reforms. The most important aspect of the new FDI policy was setting up the Greater Colombo Economic Commission (GCEC) in 1978 with wide-ranging power to establish and operate FTZs. ${ }^{14}$ The investment promotion policy package offered to FTZ investors was comparable to, or more attractive than, incentive packages of FTZs in most other countries. It included (1) permitting complete foreign ownership of investment projects; (2) a tax holiday for up to 10 years with complete tax exemption for remuneration of foreign personnel employed, royalties, and dividends of shareholders during that period; (3) duty exemption for the import of inputs, and assistance with customs clearances; and (4) industrial services at subsidized rates and unlimited access to foreign-currency credit. ${ }^{15}$

A guarantee against nationalization of foreign assets without compensation was provided under Article 157 of the Constitution of Sri Lanka adopted in 1978. Following the nationalization of the foreign-owned gas and petroleum outlets during 1962-1964, Sri Lanka became the first country against which the United States (US) government invoked the Hickenlooper Amendment requiring the suspension of US aid to countries expropriating US property without

14 The first FTZ, at Katunayaka near the Colombo International Airport was opened in 1978. The remarkable success of the Katunayaka FTZ paved the way for setting up a second FTZ in Biyagama (a northern suburb of Colombo) in 1982 and a third in Koggala on the southern coast in June 1991. Five other (mini) FTZs were opened in regional cities (Hambantota, Mirigama, Pallekele, Seethawaka, and Wathupitiwala) during the ensuing years. Katunayaka and Biayagama zones have remained fully occupied for the last 19 years.

15 "I don't see what more an investor could want than Sri Lanka has to offer" noted G.W. Bell, Managing Director of Lehman Brothers (Bell 1980). 
compensation (Olson 1977). The constitutional guarantee was, therefore, vital to restore investor confidence. As an important part of the FDI policy, steps were also taken to enter into investment protection agreements and double taxation relief agreements with the major investing countries.

Until 1990, there was no major change in the policy toward domesticmarket oriented FDI. Such projects had to go through the normal approval procedure of the Foreign Investment Advisory Committee, and majority local ownership continued to be the general rule for approving such projects. In 1990, the activities of the Foreign Investment Advisory Committee and GCEC were consolidated under a new BOI in order to facilitate and speed up investment approval within a unified policy framework applicable to import-substituting and export-oriented investors. As part of this institutional reform, restrictions on the ownership structures of joint-venture projects outside FTZs were abolished, export-oriented foreign ventures in all parts of the country were given free-trade status (in addition to the area demarcated by the original GCEC Act), and a new system of automatic approval of projects was introduced in 1990 in place of the case-by-case approval procedure.

In November 1991, BOI status was extended to local investors who establish new export-oriented projects outside the FTZs. This provision, which was initially applicable only to investors who were prepared to implement their projects prior to 30 September 1991, was extended in February 1993 to local investors starting new export ventures as well as existing companies that set up production facilities outside the Western Province. This has become a permanent feature of the BOI approval procedure.

Developments in the last decade have, however, begun to send mixed signals to foreign investors. In 2008 the parliament passed the Strategic Development Projects Act, empowering the minister in charge of the BOI to grant exemptions to "strategic development projects" from all taxes for a period of up to 25 years. In the Act, a strategic development project means "a project which is in the national interest and likely to bring economic and social benefits to the country and which is also likely to change the landscape of the country, primarily through provision of goods and services which will be of benefit to the public, substantial inflow of foreign exchange, substantial employment, and technology transfer" (GSL 2008). This definition leaves a great deal of room for the minister's discretion in the investment approval process, thus undermining the BOI's role. 
The Revival of Underperforming Enterprises and Underutilized Assets Act was passed in November 2011, empowering the government to acquire and manage 37 "underperforming" or "underutilized" private enterprises. These enterprises (some of which are said to be profit making, according to media commentaries) included seven enterprises with foreign capital participation including the Colombo Hilton (of which Mitsui of Japan was a significant shareholder) and Sri Lanka Airlines. Both the Fitch Group and Moody Corporation, two major credit rating agencies, warned that the bill would erode investor confidence and affect Sri Lanka's investment rating (Goodhand 2012).

The perennial issue of whether the government should give tax incentives (tax holidays) to foreign investors figures prominently in the contemporary FDI policy debate in Sri Lanka. Tax incentives given by the BOI have become highly politicized in the last 2 decades. As against the original BOI policy of giving time-bound tax holidays, many BOI-approved firms have continued to enjoy this privilege for over 3 decades. This has raised concerns about the rationale for giving tax concession, particularly in light of the challenge the government faces in meeting the conditions of the recently negotiated extended fund facility with the IMF. Consequently, the BOI has suspended giving tax holidays to new investors.

\subsubsection{Labor Market}

Sri Lanka has a long history of trade union organization and worker militancy. The country's trade union movement has evolved since the 1930s in close association with the emergence of Marxist-influenced left-wing politics (Jayawardena 1972). Professor Joan Robinson, who visited Sri Lanka in 1958 as an advisor to the newly formed National Planning Council, commented on the constraining effect of the system of labor relations on the country's effort to design a national development strategy to absorb a rapidly growing labor force:

Ceylon has imported from the advanced capitalist counties the ideals of the welfare state, and her trade union movement has imported the conception that belongs to unions in a developed economy, whose business is to keep profits in check and secure an acceptable share of national output for the workers.... Ceylon has tasted the fruit before she has planted the tree. Her Trade Unions are anxious to share in profits but the energetic, enterprising and thrifty capitalists for them to share with have not yet appeared (Robinson 1958: 40-51, emphasis added). 
Ironically, despite significant policy reforms over the years, Robinson's characterization remains a valid depiction of Sri Lanka's labor market situation.

Under the Termination of Employment of Workmen Act of 1953 (as amended in 1971), the employer of a firm with more than 15 employees has to obtain prior written consent of the employee, or the permission of the Commissioner of Labor, to terminate an employee on nondisciplinary grounds (e.g., closure and/or rationalization of business, ill health and/or incompetence of the employee). Interestingly, this legal provision goes beyond the International Labour Convention No. 158, which recognizes the right of an employer to terminate an employee's service on account of economic, technological, and structural changes and similar developments, subject to the provision of sufficient notice and the timeframe for recognition. Under the Industrial Dispute Act of 1950, the employee has the right to appeal against a dismissal to a labor tribunal. Failure of the employer to justify its decisions results in an order for reinstatement with compensation, even if the worker was in its employment for only a few days. The Act stipulates that the labor commissioner is required to complete the inquiries within 3 months, but the Supreme Court has held that such a requirement is only discretionary and not mandatory. In practice some dispute settlements have gone on for many years (Rodrigo 1983; Rama 1994).

As part of the liberalization reforms initiated in 1977, the government made some attempts to reform the labor legislation to achieve greater labor market flexibility in general and in particular to exempt firms set up under the GCEC from labor legislations applicable to workers in the rest of the country. However, in the face of widespread opposition by the trade unions, the government quickly abandoned the already published (gazetted) bills. The only significant change achieved was the abolition under the GCEC Act of the ban on night work for women in FTZ enterprises.

Following these failed attempts, the government adopted "informal" strategies to resolve the contradiction between the existing rigid labor law and the need to provide GCEC enterprises with greater flexibility in labor management. First, greater care was taken in recruiting employees into the enterprises in the FTZs; employees were recruited from applicants who were registered with the GCEC after prior police screening for trade union involvement. Second, a tight inspection process was introduced for monitoring daily entry of workers to FTZs. The labor market in the rest of the economy also remained peaceful until about the mid-1990s, because of the special political circumstances of the country at the time. Following the defeat of the center-left parties in 1977, the trade union movement was in disarray and membership became increasingly associated with the ruling party. The government was, therefore, able to control labor relations. 
The extrajudicial approaches to achieving labor market flexibility proved less effective following the change of political leadership in 1994. Apparently, several foreign firms left the country during this period because of prolonged labor market disputes. The government's promulgation of the National Workers Charter in 1995 and attempts to "sell" the Charter "as a victory to the working class" exacerbated the industrial relations atmosphere.

Collective bargaining is not a common system of wage setting in the private sector in Sri Lanka, except in the banking and urban mercantile sectors. Two laws govern formal private-sector wage setting. The first is the Wages Board Ordinance of 1941, which was enacted to regulate wages and other conditions of employment in "trades" (defined to include any industry or business undertaking, other than shops and offices). At present there are 44 wages boards that determine wages and employment conditions of more than 1.3 million workers. The second is the Shops and Office Employees Act of 1954, which covers persons employed in shops and offices. In industries not covered by the wages boards, the labor commissioner has the power to fix minimum wages. The wage-setting process under the two ordinances is supposed to be tripartite, giving equal representation to the unions, the employer, and members nominated by the government. But, in practice the labor commissioner often takes decisions in compliance with directives given by the government (Rodrigo 1983). However, the minimum wages are no longer a source of labor market rigidity in Sri Lanka's manufacturing sector. In most industries, in export-oriented manufacturing in particular, market-determined wages have been well above the minimum wages for the last 2 decades.

An important positive facet of Sri Lanka's otherwise costly labor market regime relates to child labor. Since the colonial era, employment of children has been curbed in the country, and the minimum statutory age for employment is 18, with some conditional exemptions for those over 16. Subsequently, Sri Lanka became an early signatory to the International Labour Organization's 39 Core Conventions covering workplace practices, prohibition of forced labor and child labor, and ensuring of better working conditions, and is still the only Asian signatory. Compliance with these regulations is rigorously enforced and monitored by the labor department and other bodies (Perry 2012). These labor market regulations were instrumental in preparing the apparel industry to effectively meet the "ethical trade" norms that international buyers have started to emphasize as an important part of their procurement practices. 


\subsubsection{Macroeconomic Policy}

The 1977 liberalization reform package was formulated with emphasis on the complementarity between macroeconomic management and trade liberalization. The dual exchange rate system, which had been operating since 1968, was abolished and the new unified exchange rate was to be adjusted to reflect foreign exchange market conditions. The other elements of the declared macroeconomic policy aimed at addressing the real exchange misalignment. They included significant interest rate reforms and a number of measures to ensure fiscal prudence, including privatization of loss-making SOEs and a broadening of the domestic tax base.

However, from the first half of 1981, the Central Bank of Sri Lanka (CBSL) gradually deviated from the original plan and started using the nominal exchange rate as an "anchor" to contain inflation. During the ensuing years, the exchange rate regime remained a quite tightly managed float. The policy emphasis on fiscal prudence was short-lived. The main source of macroeconomic instability and pressure on the real exchange rate in the 1980s was a massive public-sector program that included the Mahaweli River basin development scheme (a billiondollar multipurpose irrigation and hydroelectricity project), a large public housing program, and an urban development program (Athukorala and Jayasuriya 1994). Also, while a few loss-making public enterprises were either shifted to the private sector or closed down, most continued to operate with heavy dependence on budgetary transfers. The domestic macroeconomic environment deteriorated further in the second half of the 1990s because of the civil war's escalating costs. In the face of increased domestic inflationary pressure originating largely from the widening budget deficit, in most years the real exchange rate tended to appreciate. Given the massive domestic macroeconomic imbalances, attempts to redress real exchange rate appreciation through nominal exchange rate adjustment as part of the second-wave liberalization during 1989-1990, and under the standby agreement signed with the IMF in 2001 and 2008, had only a passing impact. Overall, the international competitiveness gained during 1977-1980 through macroeconomic policy reforms as part of the liberalization program in 1977 was never regained during the ensuing 3 decades. During the 5 -year period after the ending of the civil war, there was a massive appreciation of the real exchange rate. During this period, large-scale foreign borrowings to finance infrastructure projects helped the CBSL to maintain the stability of the nominal exchange rate, but these capital inflows invariably contributed to real exchange appreciation through domestic nontradable inflation fueled by the infrastructure projects (see Chapter 2 for details). 
In early September 2015, the CBSL allowed greater flexibility in the determination of the exchange rate (CBSL 2016a). Consequently, between the third quarter of 2015 and the second quarter of 2016, the CBSL's 24-currency nominal effective exchange rate index declined by $6.0 \%$. This rate of nominal depreciation, however, translated into a real depreciation of only $4.2 \%$ as the nominal depreciation was partly counterbalanced by higher domestic inflation than that of the trading-partner countries. ${ }^{16}$

\subsection{The Sri Lankan Development Record}

This section provides an empirical assessment of the Sri Lankan development record during the last half century, based on indicators of economic growth, structural change, export composition, macroeconomic management, and poverty and inequality. The focus is on this extended time period because economic development is a long-term process. Restricting the analysis to a short time period obscures the longer-term dynamics as well as the impact of key events such as policy reforms and intensified conflict. Where relevant, the record is compared with some of the small and medium-sized high-growth Southeast Asian economies, which are relevant benchmarks given initial conditions and geographic proximity. Malaysia in particular is a very suitable comparator, due to its somewhat similar colonial experience and the challenge it has faced in dealing with ethnic diversity and tension. ${ }^{17}$

\subsubsection{Economic Growth}

The annual growth rate of the Sri Lankan economy, with "markers" to draw attention to some of the key factors influencing the growth trajectory, is plotted in Figure 1.1. Following an average annual growth rate of about 5\% during 1965-1969, growth slowed to $2.8 \%$ during the first half of the 1970s. The economy contracted by $0.8 \%$ in 1971, mainly because of the turmoil following a youth uprising in southern Sri Lanka, and the economy continued to experience slower growth than in the previous decade mainly because of shortages of imported inputs (Athukorala and Jayasuriya 1994, Chapter 4). The period following economic liberalization reforms initiated in 1977 saw moderately high but volatile economic growth. A cycle of growth and conflict followed over the last 3 decades, with only

16 The figures are calculated from the data reported in CBSL (2016b).

17 See Bruton, Abeysekera, and Saderatne (1992) for a comparative study of Malaysia and Sri Lanka. 
1 year of negative growth, in $2001 .^{18}$ Sri Lanka was little affected by the 1997-1998 Asian financial crisis, while growth remained positive, albeit slower, during the global financial crisis a decade later. The devastating Indian Ocean Tsunami of 2004, while deeply traumatic for those directly affected, caused only a minor blip in aggregate economic activity.

\section{Figure 1.1: Growth of Sri Lanka’s Gross Domestic Product, 1960-2015 (\%)}

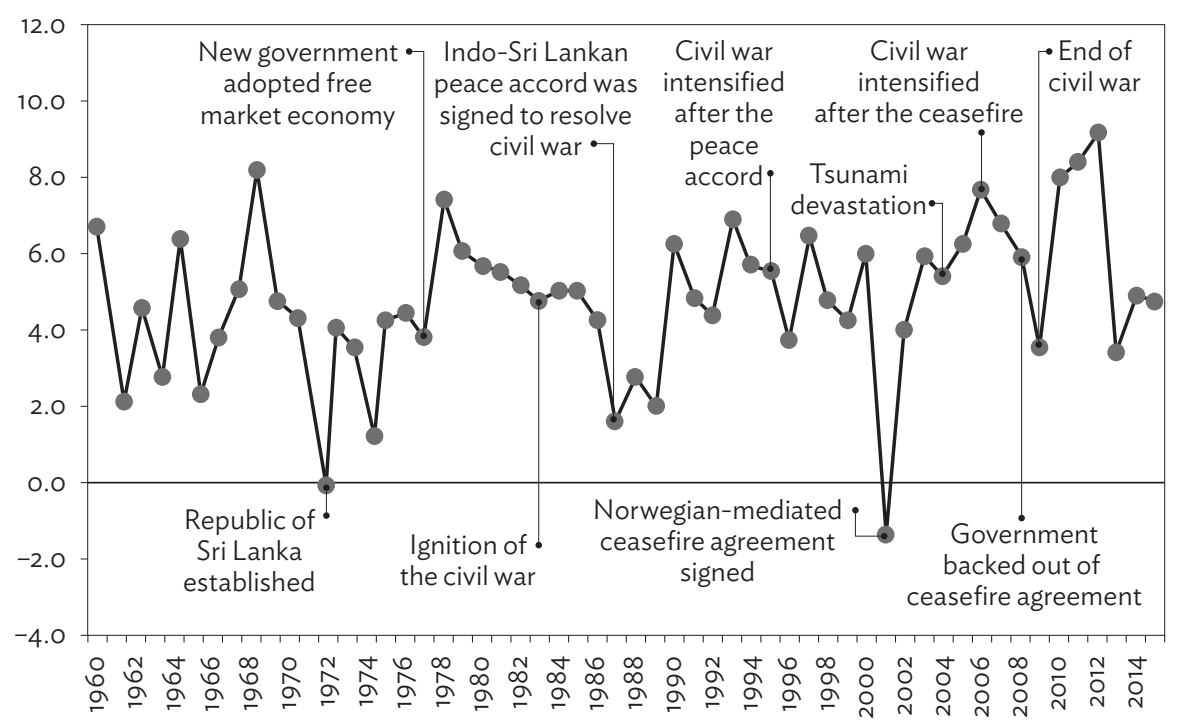

Source: Estimates based on data from CBSL (2016a).

The Sri Lankan economy was adversely affected by the surge in world oil and food prices during 2007-2008 and the global financial crisis that followed. Despite these external shocks, and the intensification of the civil war in its final stage, the economy expanded by an annual average rate of $6.1 \%$ during the second half of that decade. The first 3 years following the end of the civil conflict recorded one of the economy's strongest growth rates (8.7\% during 2010-2012) during the entire post-independence period. However, the growth was driven largely by massive infrastructure development projects funded by foreign borrowing (mainly from the

18 In 2001 the economy was hit by a series of adverse external shocks resulting in the negative real GDP growth. The prolonged drought that started in 2000 and continued in 2001 reduced domestic agricultural output and hampered hydroelectricity generation. The terrorist attack on the Katunayake International Airport in July sharply curtailed tourist arrivals, weakened business confidence, and reduced external trade as a result of the imposition of a high war-risk insurance premium on ships and airlines following the attacks. Intensification of the ethnic conflict further lowered investor confidence (CBSL 2002). 
People's Republic of China), while recovery of economic activities in the war-affected Northern and Eastern provinces also played a role. The main drivers of growth have been the nontradable sectors (construction, transport, utilities, trade, and other services), reflecting the role of the major public-sector infrastructure development projects. During the next 2 years, the average growth rate dropped to $4.1 \%$, attesting to the unsustainability of the debt-driven growth (Athukorala and Jayasuriya 2015; Kelegama 2016; Rajapatirana 2016).

\subsubsection{Structural Change}

The process of structural change accompanying Sri Lanka's economic development has been largely conventional (Table 1.2 and Figure 1.2). Since 1960, the share of agriculture has shrunk quite rapidly, from about $30 \%$ of GDP to a little over 10\%. Industry has expanded from about $20 \%$ of GDP in 1960 to over $30 \%$ by 2015 . The growth of industry following the liberalization reforms in 1977 is particularly noticeable. Meanwhile, the share of services has continued to increase. During this period until about 2005, the major contributor to the increase of industry's share was manufacturing. The share of manufacturing in GDP increased from about $3 \%$ in the 1970 s to $19 \%$ in $2005-2009$. Since then, the share has declined, while industry's share continued to increase because the share of utilities and construction increased at a much faster rate, reflecting the impact of the debt-fueled construction boom.

Table 1.2: Sri Lanka: Sectoral Composition of Gross Domestic Product, 1960-2015 (\%)

\begin{tabular}{|c|c|c|c|c|c|c|c|c|}
\hline & $\begin{array}{c}1960- \\
1969\end{array}$ & $\begin{array}{c}1970- \\
1979\end{array}$ & $\begin{array}{c}1980- \\
1999\end{array}$ & $\begin{array}{c}2000- \\
2004\end{array}$ & $\begin{array}{c}2000- \\
2004\end{array}$ & $\begin{array}{c}2005- \\
2009\end{array}$ & $\begin{array}{c}2010- \\
2014\end{array}$ & 2015 \\
\hline Agriculture & 36.2 & 29.0 & 27.1 & 23.7 & 17.2 & 12.2 & 8.8 & 8.2 \\
\hline Industry & 17.2 & 26.1 & 27.0 & 26.4 & 27.5 & 30.0 & 30.8 & 29.6 \\
\hline Manufacturing & 9.7 & 12.8 & 14.3 & 15.7 & 16.9 & 18.9 & 19.7 & 16.9 \\
\hline Utilities $^{\mathrm{a}}$ and construction & 7.5 & 13.3 & 12.7 & 10.6 & 10.6 & 11.1 & 9.4 & 9.7 \\
\hline Services & 46.6 & 45.0 & 45.8 & 50.0 & 55.3 & 57.9 & 60.8 & 62.2 \\
\hline \multicolumn{9}{|l|}{ Memo Item } \\
\hline Nontradable Sectors ${ }^{\mathrm{b}}$ & 54.1 & 58.3 & 58.5 & 60.6 & 65.9 & 69.0 & 70.2 & 71.9 \\
\hline $\begin{array}{l}\text { Notes: } \\
\text { a Electricity, telecommunica } \\
\text { b Utilities and construction } \\
\text { Source: CBSL (various years). }\end{array}$ & $\begin{array}{l}\text { n, wate } \\
\text { s servic }\end{array}$ & and sem & erage. & & & & & \\
\hline
\end{tabular}


Figure 1.2: Shares of Employment by Sector, 1981-2012 (\%)

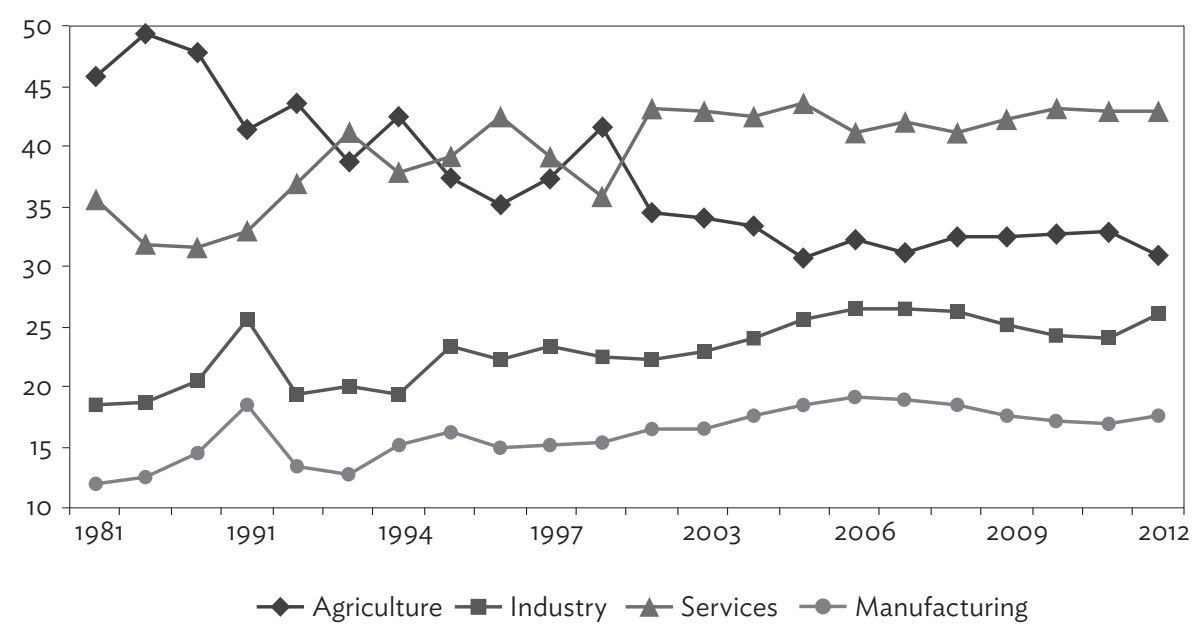

Note: Reference age-group for working-age population is ages 10 and above.

Source: CBSL (various years).

The share of services increased from about $47 \%$ in the early 1960 s to over $63 \%$ in 2015 . As with other developing countries where this pattern is evidentfor example, India, Indonesia, and the Philippines-it reflects a mix of both modern sector activities, including tourism, finance, and telecommunications, and traditional "last-resort" activities. The large international remittance flows also created additional commercial opportunities in trade and construction. But in the Sri Lankan case, owing to Dutch Disease effects (the real exchange rate appreciation), debt-financed massive infrastructure projects that directly fueled nontradable sector growth and indirectly hampered the growth of the tradable sectors (in particular manufacturing) played a much more important role, over and above the influence of the "autonomous factors." The impact of the infrastructure boom is visible in the increased share of nontradable sectors increased (services, construction, and utilities) to 69.7\% during 2005-2014 from about $60 \%$ in the previous decade (Table 1.2). The composition of employment across sectors followed these trends with the usual lag, resulting in a continuing high share of agriculture (Figure 1.2).

\subsubsection{Savings and Investment}

Sri Lanka's national savings rate varied in the narrow range of $10 \%-15 \%$ in the 1960s and 1970s (Figure 1.3). The savings rate has increased remarkably during the reform era since the late 1970s, reaching about $30 \%$ during the last 5 years. 
In most of the years during 1960-2015, the rate of domestic investment exceeded the savings rate by a significant margin, reflecting the economy's heavy reliance on foreign savings (capital inflows) to finance domestic investment.

Figure 1.3: Investment and Savings Rates, ${ }^{a}$ 1960-2015 (\% of GDP)

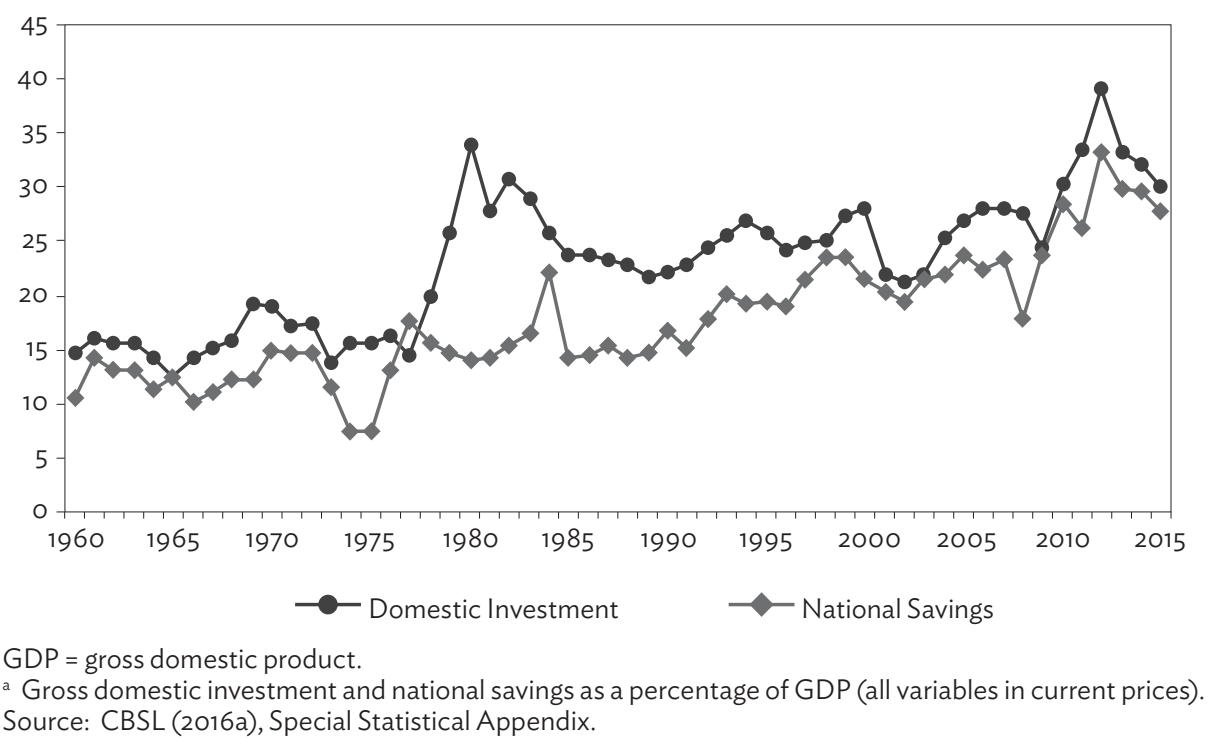

\subsubsection{Inflation and Unemployment}

Sri Lanka had very low inflation until about the early 1970s, with the annual rate measured by the consumer price index (CPI) varying in the range of $1 \%$ to $4 \%$ (Athukorala and Jayasuriya 1994). This pattern has since changed notably, with an annual average rate of $8.5 \%$ during $1980-2015$ and greater year-to-year variability. Interestingly, contrary to popular perception, there is no close relationship between the rate of inflation and the change in the nominal exchange rate. ${ }^{19}$ This is because, following the significant opening of the economy to external trade, changes in nontradable prices began to exert a much greater impact on the inflation trajectory of the economy. As demonstrated in Chapter 2, the inflation rate of nontradables has implications for understanding the determinants of the economy's international competitiveness (as measured by the real exchange rate) and the role of overall macroeconomic policy-and not just the exchange rate policy-for averting real exchange rate misalignment.

19 The fixed exchange rate was certainly one factor explaining the low inflation before the early 1970s. 
The inflation figures shown in Figure 1.4 need to be treated with caution because of well-known limitations of the available CPI series. During the prereform era, pervasive price controls were instrumental in keeping inflation at artificially low levels. Even after the liberalization reforms, prices of a number of items covered in the CPI commodity basket (in particular house rent, public transport, education, and liquor) have remained under price controls. There is also the problem of the poor representativeness of the data. For example, the Colombo CPI used to measure inflation until 2004 (see notes to Figure 1.4) was based on a 1949-1950 family budget survey covering 455 working-class households in Colombo. The basket of goods and the set of weights used in 1952 continued in use despite major changes in expenditure patterns and weights. The subsequent revisions to the CPI have extended the coverage only to urban households in Colombo district. The new CPI compiled by the Department of Census and Statistics since 2008 excludes alcohol, a commodity that accounts for a substantial share of household expenditure, particularly in working class households, from the commodity basket. ${ }^{20}$ However, the exclusion of alcohol from the CPI basket was rectified later on during the rebasing exercise conducted.

Figure 1.4: Sri Lanka Annual Inflation Rate ${ }^{\mathrm{a}}$ and Change in Exchange Rate, 1960-2015 (SLRs/\$) ${ }^{b}$

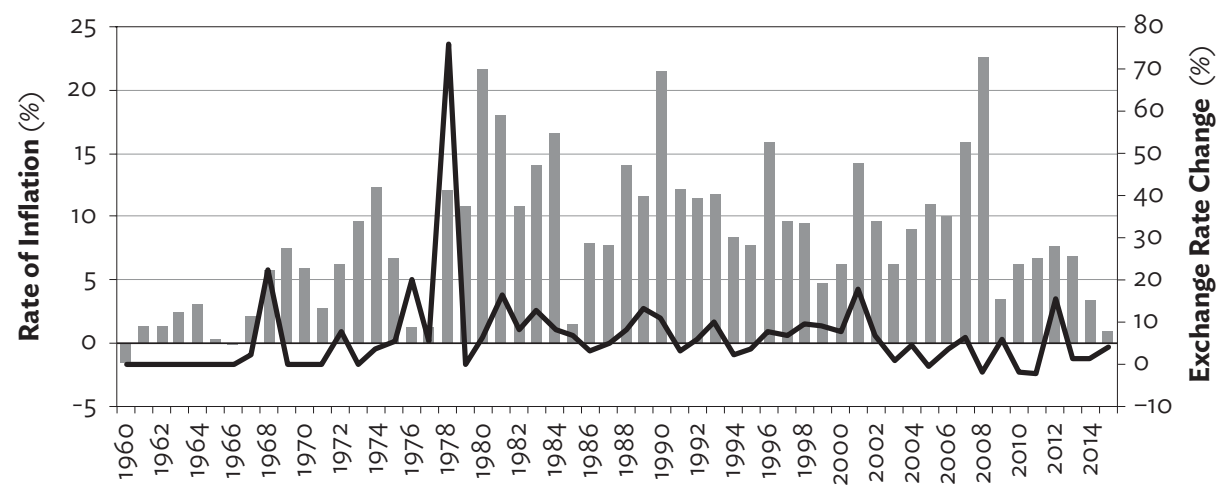

Inflation (left scale) _ Exchange Rate Change (right scale)

SLRs = Sri Lanka rupees.

a Based on the consumer price index, 1960-2003: covers low-income households in Colombo Municipality; 2004-2007 covers urban households within the Colombo district; 2008-2015 covers urban households in Colombo district (revised consumption bracket).

b Calculated from the annual average $\$ / S L R e$ exchange rate; an increase (decrease) indicates nominal depreciation (appreciation) of the rupee against the United States dollar.

Source: Based on data compiled from CBSL (2016a), Special Statistical Appendix.

20 Possible underestimation of the CPI-based inflation is at least partly reflected in a comparison of it with an alternative figure based on the CBSL's wholesale price index: for the period 1975-2015, the two alternative inflation rates were $10.0 \%$ and $11.5 \%$. But the degree of underestimation of the actual rate could be much larger because the wholesale price index does not fully capture nontradable prices that, for the reasons already mentioned, could have increased at a much faster rate than tradable prices during this period. 
In the early 1990s, the rate of unemployment was about $15 \%$. The incidence of unemployment among women, at $21 \%$, was almost twice that among men, at $11 \%$ (Figure 1.5). Since the 1990s, the unemployment rate has declined, with the gap between the rates for men and women narrowing considerably. The observed trend is likely to overstate the decline in unemployment because the data do not cover the two war-affected Northern and Eastern provinces during 1990-2007 and the Northern Province for the remaining years. ${ }^{21}$ According to estimates by Sarvananthan (2016), which are not directly comparable with the official estimates because of methodological differences, the rate of unemployment in the Northern and Eastern provinces in 2012 was as high as $32 \%$.

Figure 1.5: Sri Lanka's Unemployment Rate, 1990-2015 (\%)

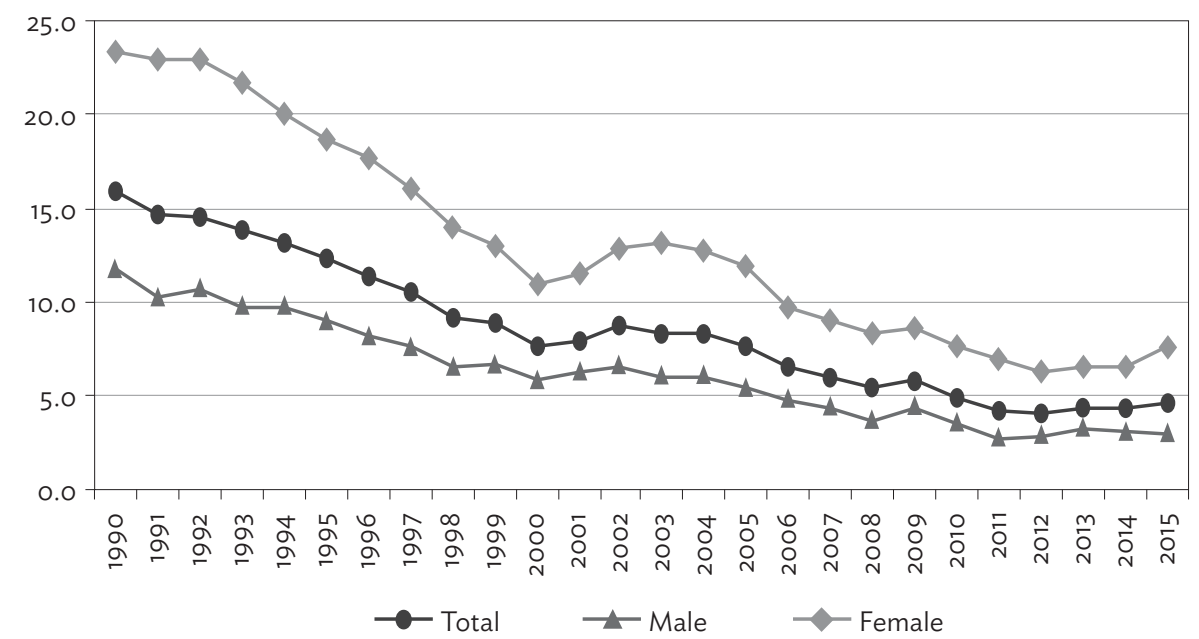

Note: Data for 1990-2007 do not cover Northern and Eastern provinces, and the Northern Province is not covered from 2007 on.

Source: CBSL (2016a), Special Statistical Appendix.

Other than economic growth, two important factors would have contributed to the decline in official estimates of unemployment in recent years: an increase in public-sector recruitments and a surge in overseas employment of Sri Lankans. In a dramatic reversal of the contraction in the size of the publicsector workforce maintained during the previous decade, total employment in the public sector increased from about 900,000 persons $(9.4 \%$ of the total labor force) in 2005 to over 1.3 million (11.4\%) in 2014. During 2002-2015, on average, a quarter of a million Sri Lankans left annually for overseas employment,

21 Labor force data from 2011 covers the entire island. 
with the number increasing every year. A tentative estimate suggests that the total stock of Sri Lankan overseas contract migrant workers reached 2 million by 2011 , amounting to over $17 \%$ of the country's total working-age population (Arunatilake, Jayawardena, and Weerakoon 2011).

\subsubsection{Export Structure}

The changing export composition in this period is even more pronounced (Figures 1.6-1.7). In the early 1960s, Sri Lanka's merchandise exports were overwhelmingly agricultural (tea, rubber, and coconut products), accounting for over $95 \%$ of the total. The share began to fall very sharply from the late 1970 s as manufactured exports took off after liberalization, so that by 1990 the share was less than one-third of that in 1970. Reflecting the country's resource endowments, mineral exports have never been significant, in most years less than $5 \%$. Thus, manufactures now dominate the country's merchandise exports, typically accounting for a reasonably stable share, at about three-quarters of the total, for the last quarter century.

Figure 1.6: Sri Lanka's Composition of Merchandise Exports, 1962-2015 (\%)

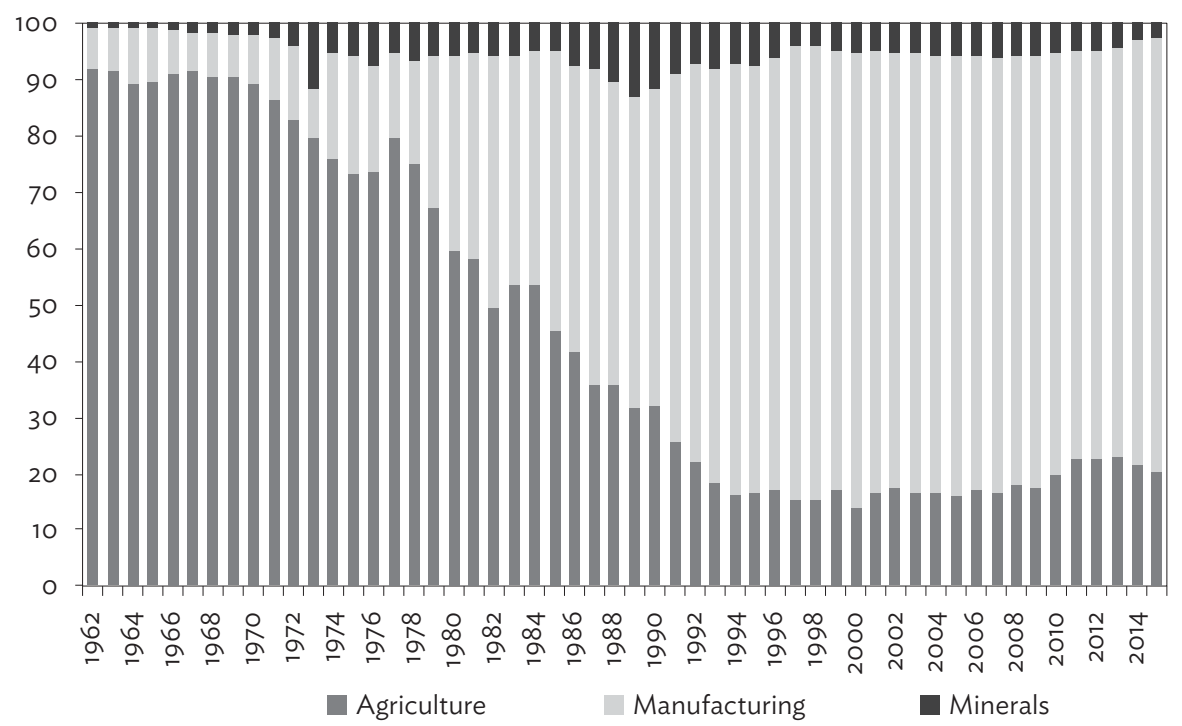

Source: Estimates based on UN Commodity Trade statistics and Observatory of Economic Complexity data, accessed October 2016. 
Figure 1.7: Sri Lanka's Export Composition, 1962-2015

(\% of total exports)

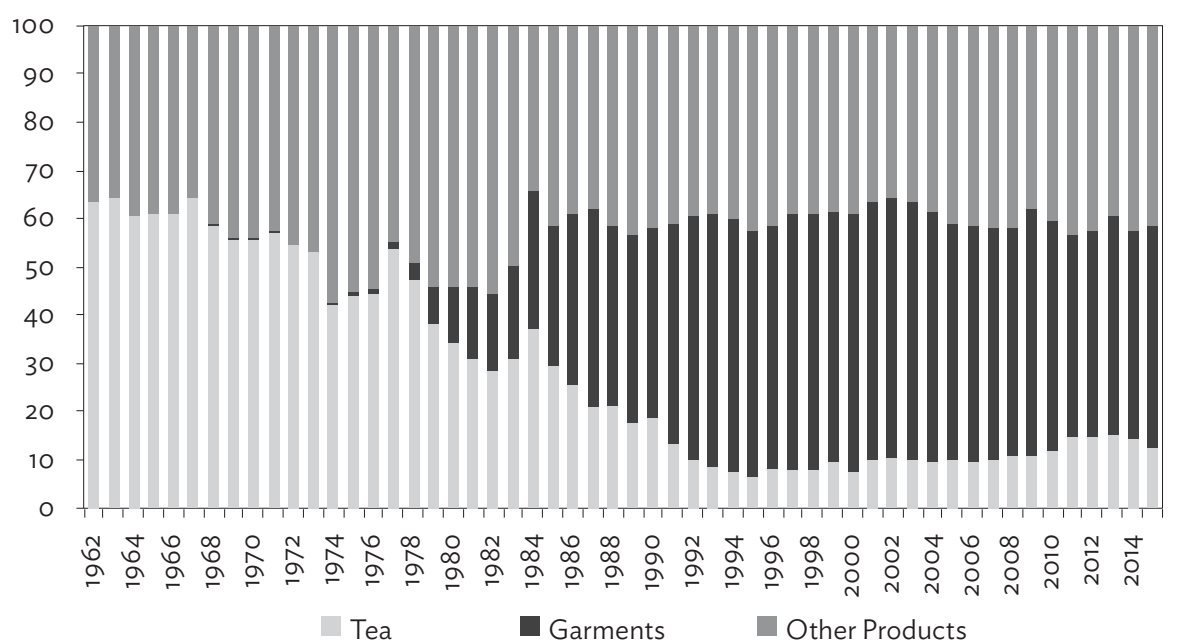

Source: Estimates based on UN Commodity Trade statistics and Observatory of Economic Complexity data, accessed October 2016.

It is useful to dig below these aggregates because two products dominate the flows (Figure 1.7). Historically, tea was the dominant commodity, and still accounted for over $60 \%$ of the total in the early 1960s. Tea was a classic colonial export that accorded with the country's topographical and climatic conditions. Although criticized in some quarters to the extent that it diverted resources from food production, tea export was an efficient, labor-intensive activity (see Chapter 5). The major contemporary export is garments, which accounts for about $45 \%$ of the total, and in some years over $50 \%$. Although sewing was historically a well-established household activity-as illustrated by the ubiquitous presence of Singer sewing machine outlets throughout the country-the export-oriented factory subsector grew dramatically after the 1977 reform. As a result, the share of garments in total exports rose from less than $2 \%$ to almost $40 \%$ within a decade. Sri Lanka has quickly emerged as a significant player in the international garment trade, not only as an exporter of increasingly high-fashion products, but also informally as a technology exporter, as illustrated by the prominence of Sri Lankan nationals in middle and senior managerial roles in neighboring countries (see Chapter 4).

The garment export success story has important implications for policy and development analytics. First, and most important, the liberalization was a success story, for largely conventional reasons. As explained above, the reform package was comprehensive and credible enough to ensure that the trade, foreign 
exchange, and foreign investment regimes quickly attracted major investors and buyers, foreign and domestic alike. Second, the liberalization built on the country's latent comparative advantage in labor-intensive activities, based on the country's near universal literacy and an easily trainable workforce. The one puzzling feature of the country's reform success is that considerable skepticism persists in influential quarters about the merits of continued liberalization.

Overall, the Sri Lankan experience with manufacturing exports provided further evidence that a prolonged period of import substitution is not a necessary prerequisite for export success. That is, countries that undertake credible and reasonably comprehensive reform, and have the requisite resources-particularly labor and infrastructure-are able to quickly connect to international markets. No doubt fortuitous timing played a role, as Sri Lanka was the first South Asian economy to open up. But the East Asian experience is replete with similar successful reform episodes (Perkins 2013).

Two additional comments on the country's export performance and structure are relevant. First, it is arguably of some concern that the export base has not diversified over the years. In some respects, Sri Lanka has merely transitioned from heavy dependence on one historical export, tea, to a modern one, garments. Such heavy reliance on just one industry, albeit a dynamic and diverse one, can be a source of vulnerability, especially as the international trade in garments has historically-though less so now-been the subject of intense regulation. There have been spillovers from the garments industry to other labor-intensive activities, for example footwear (see Chapter 4), and it is not uncommon for small economies to exhibit high levels of export concentration. The obvious gap in Sri Lanka's exports has been its failure to penetrate the East Asian global production networks concentrated on the electronics industry. This has been the fastest growing segment of global and East Asian trade, and it is one that reforming latecomers, such as Viet Nam and even Cambodia, have been able to penetrate. The important policy lesson is that Sri Lanka had the potential to achieve the "garment successes" in other export-oriented industries such as electronics and electrical goods but for the adverse investment climate during the period of prolonged ethnic conflict (see Chapter 4). ${ }^{22}$ This failure to broaden the export base is reflected in Sri Lanka's comparatively narrow product space map, compared for example to Malaysia and Thailand (Figure 1.8).

22 While sharing common features in their labor intensity and export orientation, international buying groups are just as important as equity investors in garment exports. By contrast, the electronics parts and components firms are typically $100 \%$ foreign owned. High-quality internationally oriented logistics are also crucial for just-in-time delivery to other factories in the complex web of international production centers. The intensification of conflict in Sri Lanka appears to have had a very limited negative impact on garment exports, which are buyer driven but it would have deterred potential foreign investors. 
Figure 1.8: Product Space Maps, 1980 and 2014

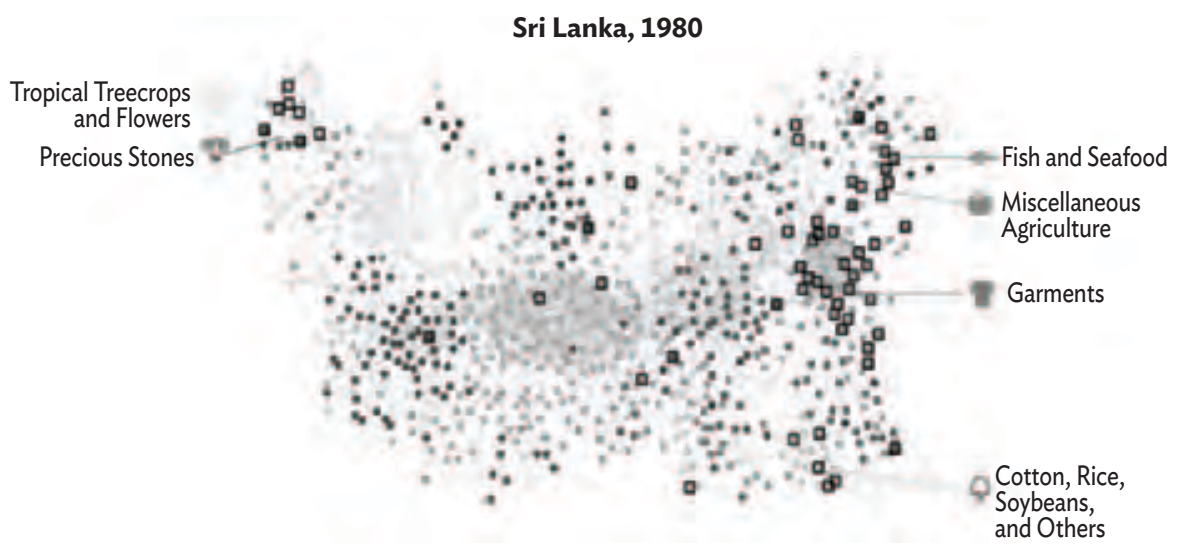

Thailand, 1980
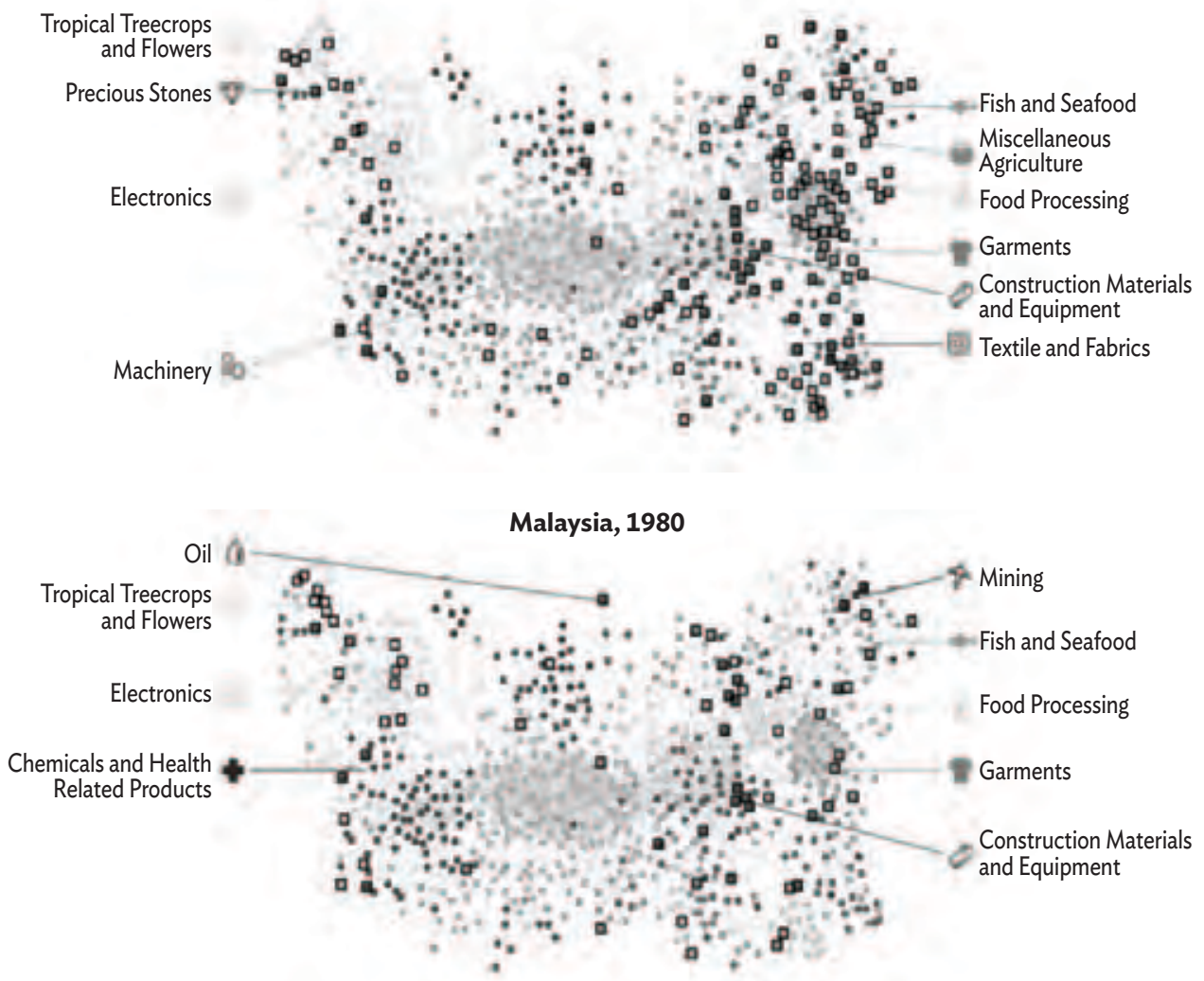
Figure 1.8 continued

Sri Lanka, 2014
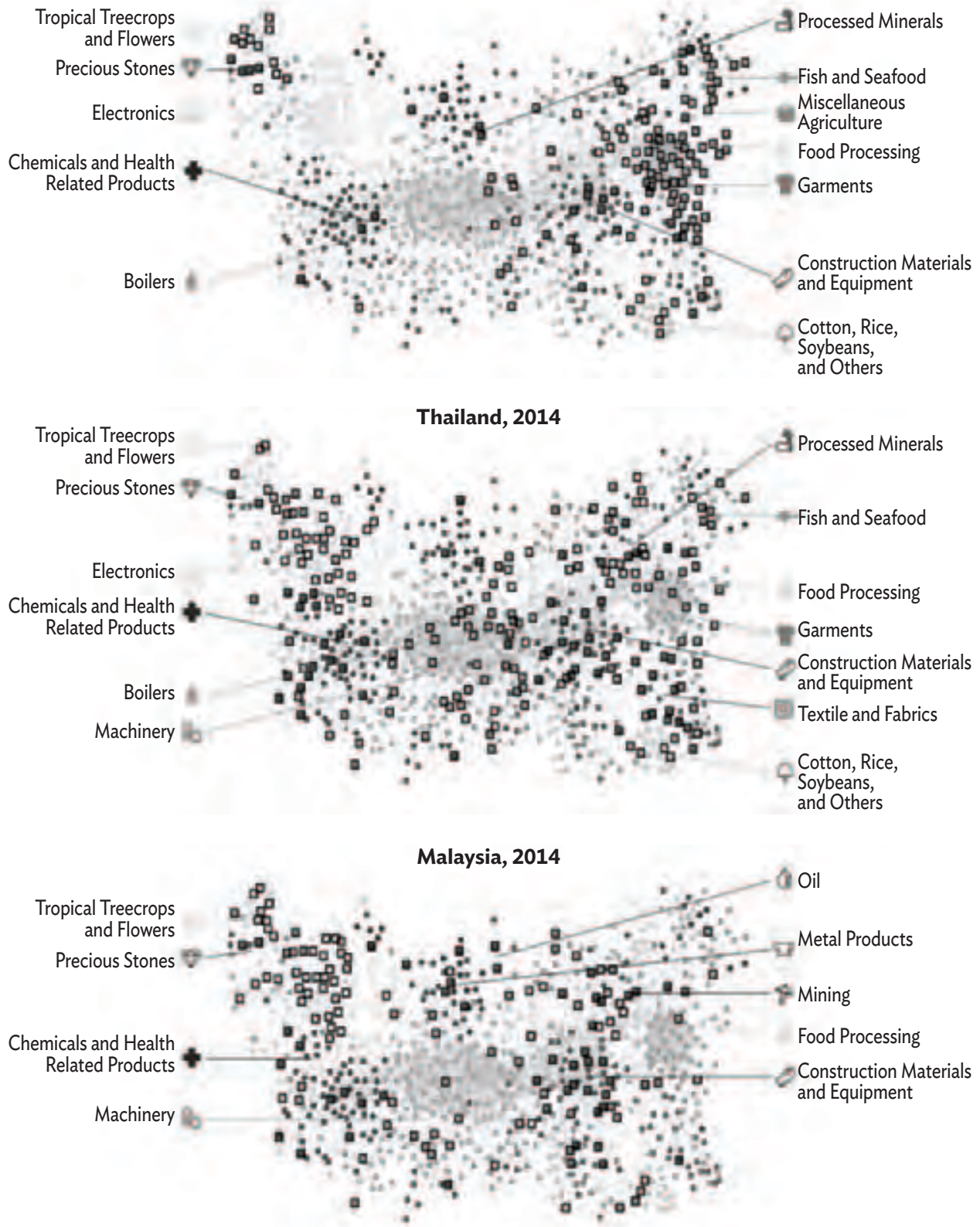

Note: Commodities are grouped into "communities" as proposed by Hausmann et al. (2011). Black squares show the products exported with real competitive advantage.

Source: Computations based on UN Commodity Trade statistics, accessed October 2016. 
Second, the discussion thus far refers only to merchandise exports, which (as of 2015) account for only $44 \%$ of total current account receipts (goods, services, and factor payments). Migrant worker remittances have been the fastest growing item of total current account receipts since the early 1980s. The share of remittances in total foreign exchange earnings increased from $41 / 2 \%$ in 1985 to $143 / 4 \%$ in 2000 , and was about $22 \%$ during $2005-2015$. Sri Lanka's potential as a tourist destination remained in the doldrums during the period of prolonged civil conflict. Following an increase from 20,000 to 400,000 tourist arrivals in 1982, annual numbers varied around that figure until 2009. Since then the numbers have increased dramatically, reaching 1.8 million in 2015. Earnings from tourism surged from $\$ 349$ million in 2009 to $\$ 2.981$ billion in 2015 , becoming the third-largest contributor to current account receipts (12\%) after migrant worker remittances (29\%) and garment exports (19\%). Recent years have also seen an impressive increase in exports of computer software and information technology services (IPS 2016). These developments explain the otherwise puzzling trends reported in Figure 1.9, that show Sri Lanka's share of global merchandise goods exports has been declining marginally, while its share of service exports has been rising quickly.

Figure 1.9: Share of World Exports-Percent Change, 2000/2015

Figure 1.9a: Goods

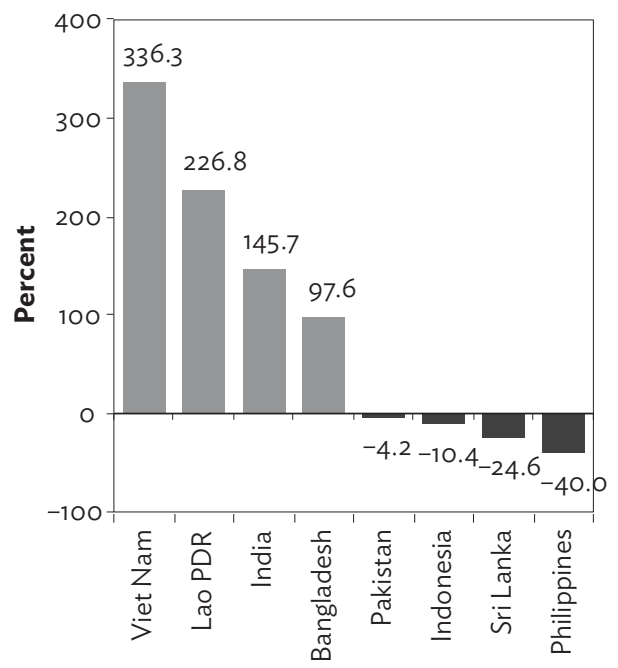

Figure 1.9b: Services

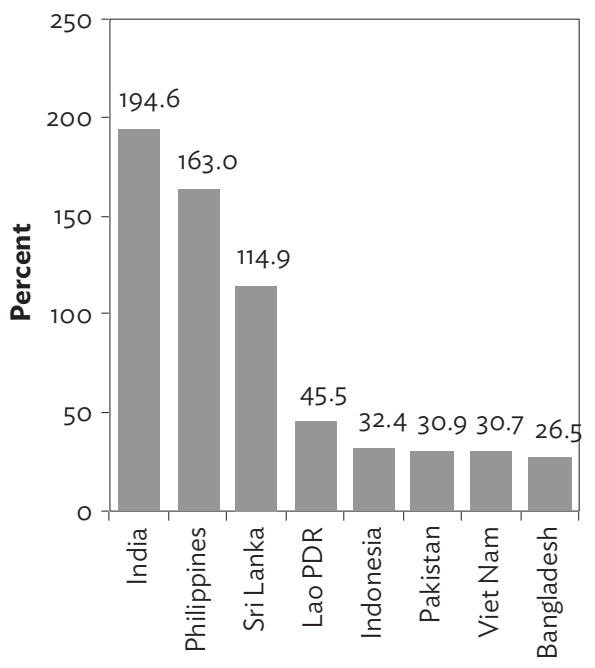

Lao PDR = Lao People's Democratic Republic.

Source: Based on UNCTAD database, accessed February 2017. 


\subsubsection{Poverty and Inequality}

In the 1960s and 1970s, Sri Lanka was highlighted in the development literature as a country that had impressively achieved growth with equity. At the time, both the poverty head-count and income inequality (measured by the Gini ratio and the other standard indicators) were remarkably low compared with almost all countries at a similar stage of development (Sen 1981; Pyatt and Roe 1977; Marga Institute 1974). Sri Lanka also had "the best social indicators, compared to its income, of any country for which data are available" (Isenman 1980: 237). This record was underpinned by massive government social welfare expenditures, including universal food subsidies, free education, and health care. In the early 1970s, social welfare expenditure accounted for over $40 \%$ of government expenditure and amounted to over 12\% of GDP (Athukorala and Jayasuriya 1994, Table 3.16). However, there were growing concerns about the growth-equity trade-off in the context of the poor performance of the economy and rapid population growth (Isenman 1980; Bhalla and Glewwe 1986).

Changes in the level of poverty and inequality in Sri Lanka following the liberalization reforms initiated in 1977 have been the subject of heated debate. In the 1980s, Bhalla and Glewwe argued in a series of papers that accelerating growth under market-oriented reforms contributed to a reduction in both poverty and the degree of income inequality (Bhalla and Glewwe 1986; Glewwe 1986, 1988a, 1988b). Their studies, however, came under criticism on the grounds of methodological issues and data limitations, focusing specifically on income inequality (Ravallion and Jayasuriya 1988; Sen 1988; Dunham and Jayasuriya 2000). The latter studies indicated a deepening of income inequality, with particularly adverse effects on households in the lowest income brackets. More recent data are consistent with the alternative view that Sri Lanka's egalitarian legacies have been gradually eroding, and the country now displays moderately high inequality. The Gini ratio rose by almost 10 percentage points during the 1990s, and for the first time in its history it exceeded 40 (Figure 1.10).

Nevertheless, poverty has been falling quite quickly. All three headcount ratios in Figure 1.10 display a broadly similar declining trend. Destitution has virtually disappeared, with less than $2 \%$ of households falling below the revised (\$1.90) threshold. Poverty incidence at the higher level (\$3.10) is now about onethird that of 1985. According to the national poverty line that falls between the two international thresholds, the rate of decline has been fairly similar. Clearly, in spite of the rising inequality, poverty reduction has responded strongly to growth. Assuming that the household enumeration was complete in the northern and other conflict-affected regions, this is a creditable record in view of the serious conflict episodes during this period. 
Figure 1.10: Poverty and Inequality Indicators, Sri Lanka

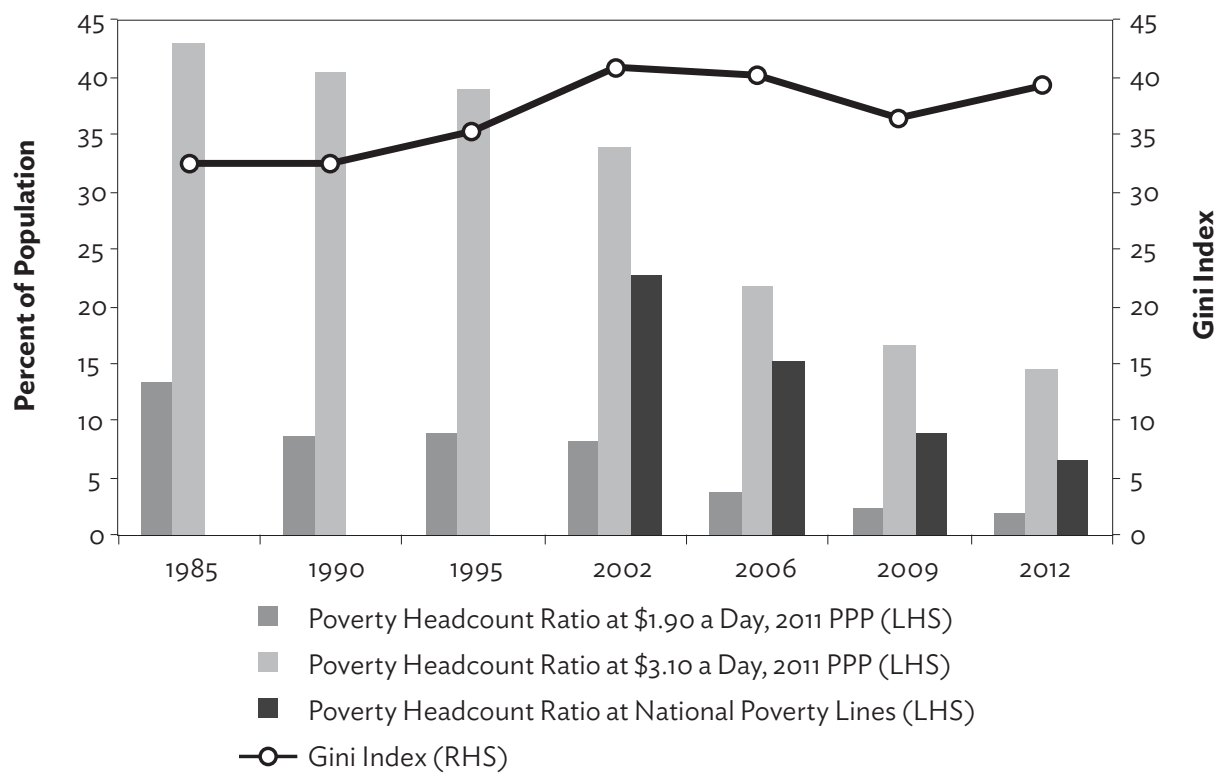

LHS = left-hand side axis, RHS= right-hand side axis, $\mathrm{PPP}=$ purchasing power parity.

Source: World Bank, WDI, accessed December 2016.

There are no systematic studies of the source of poverty reduction. But circumstantial evidence suggests that, in addition to overall growth of the economy, the growth of export-oriented manufacturing (particularly apparel) and migrant worker remittances would have played a pivotal role. Total employment in organized manufacturing increased from about 110,000 during 1970-1977 to over 500,000 by 2014, with firms in FTZs contributing over $65 \%$ of the increment. More than two-thirds of the workers in export-oriented firms belong to unskilled and semi-skilled categories (Athukorala and Rajapatirana 2000; CBSL 2016a). Remittances by migrant workers as a percentage of gross national income increased from about $7 \%$ in the late 1980 s to $8.5 \%$ in 2015 . Direct government transfers under poverty alleviation programs and war-related employment (recruitment to the armed forces and compensation payment to the families of fallen soldiers) also contributed to poverty reduction (Dunham and Jayasuriya 2000; Dunham and Edwards 1997). ${ }^{23}$

23 The overwhelming majority of new recruits to armed forces during the period of ethnic conflict were from low-income rural families. The personnel in the armed forces (including reserve personnel and national guardsmen) increased from about 15,000 in the early 1980s to nearly 250,000 at final stage of the war in 2009. 


\subsubsection{Comparative Dimensions}

How does the Sri Lankan record compare internationally? The choice of comparators is obviously arbitrary and selective: it could be based on country size, geography, resource endowments, colonial heritage, or other factors. Although Sri Lanka is in South Asia, the other regional economies are so different that the authors have selected a group of small and medium-sized Southeast Asian economies, some of which share similar structural features with Sri Lanka and all of which could be regarded as aspirational models for an outward-looking neighboring economy. The closest comparator among the three was Thailand. Malaysia and (especially) Singapore were historically richer and more exportoriented than Sri Lanka, but Sri Lanka's educational attainments were at least comparable to Singapore's and its health indicators were close to Malaysia's.

At the time of independence and well into the 1950s, Sri Lanka's per capita income was much higher than those of Thailand and the Republic of Korea (and presumably Indonesia), and it was just below Malaysia's (Table 1.3). However, from the early 1960s, Sri Lanka continued to slip below these countries for the next quarter century. By the mid-1990s, Sri Lanka's real per capita income amounted to $65 \%$ of Indonesia's, $41 \%$ of Thailand's, $23 \%$ of Malaysia's, $12 \%$ of the Republic of Korea's, and just $5 \%$ of Singapore's. Since then Sri Lanka's relative performance has reversed somewhat. By 2015, Sri Lanka had regained some lost ground but differences remain very large, other than for the comparison with Indonesia. Interestingly, even 4 decades after Sri Lankan policy makers embarked on liberalization reforms aspiring to emulate Singapore, Sri Lanka's per capita income remains only $7 \%$ of that of Singapore.

Table 1.3: Gross National Product per Capita of Sri Lanka and Selected Asian Countries as a Percent of that of the United States, 1950 and 1958

\begin{tabular}{lcc}
\hline Country & 1950 & $\mathbf{1 9 5 8}$ \\
India & 7.1 & 7.3 \\
\hline Indonesia & - & $5.8^{\mathrm{b}}$ \\
\hline Korea, Republic of & 7.6 & 8.5 \\
\hline Malaysia & 14.6 & 15.3 \\
\hline Pakistan & 9.0 & 6.4 \\
\hline Philippines & 10.3 & 11.5 \\
\hline Sri Lanka & 11.4 & $\mathbf{1 2 . 6}$ \\
\hline Thailand & 9.6 & 9.5 \\
\hline
\end{tabular}

$-=$ not available.

Purchasing power parity adjusted.

Figure is for 1960.

Source: Kravis, Heston, and Summers (1982). 
Sri Lanka's comparative economic performance can also be judged with reference to the multiple by which real per capita income has risen during various subperiods (Table 1.4). For illustration, the multiples of the current period (2015) are compared with those of 1961; 1980 (that is, just after the major Sri Lankan reforms); and 2000 (after the Asian financial crisis). Sri Lanka compares increasingly favorably moving forward. Since 1961, GDP per capita has risen over sixfold, is now not much less than in Malaysia and Thailand, and is well above the developing country average. In the comparison, Sri Lanka is held back by the slower growth in the 1960s and 1970s. Since 1980, Sri Lanka compares favorably and is similar to Singapore, ahead of Malaysia, and only marginally behind front-ranked Thailand. One factor in the comparison is that Sri Lanka was much less affected by the Asian and global financial crises. In fact, in the 21st century it has grown faster than the other three. Again, the effect of the global financial crisis was a differentiating factor. In addition, Malaysia and Thailand have been beset by homegrown difficulties, while Singapore is already at the frontiers of global income and therefore growing more slowly.

Table 1.4: Comparative Economic Growth

\begin{tabular}{l|cc|c|c} 
& $\begin{array}{c}\text { 2015 GDP } \\
\text { per Capita }\end{array}$ & \multicolumn{3}{c}{ GDP per Capita Ratio Between } \\
Country & $\begin{array}{c}\text { (constant 2010 \$) } \\
\text { Malaysia }\end{array}$ & $\mathbf{2 0 1 5}$ and 2000 & $\mathbf{2 0 1 5}$ and 1980 & $\mathbf{2 0 1 5}$ and 1961 \\
\hline Singapore & 10,877 & 1.57 & 3.29 & 7.42 \\
\hline Sri Lanka & 51,855 & 1.55 & 3.90 & 14.63 \\
\hline Thailand & 3,638 & 1.98 & 3.92 & 6.24 \\
\hline
\end{tabular}

GDP = gross domestic product.

Source: World Bank, WDI, accessed 22 December 2016.

In key social indicators, too, Sri Lanka has slipped behind Singapore, but has remained similar to indicators in Malaysia and Thailand (Table 1.5). As noted, this is a distinctive feature of Sri Lankan development; despite slipping behind on monetary indicators, the country's strong social performance remained more or less intact. This finding is noteworthy also because Sri Lanka experienced far more severe conflict than its ASEAN neighbors which, with the partial exception of Thailand, were virtually free of conflict. 
Table 1.5: Comparative Indicators: Present Conditions, 2010

\begin{tabular}{|c|c|c|c|c|}
\hline Country & $\begin{array}{l}\text { Years of Schooling, } \\
\text { (for aged } 15 \text { and } \\
\text { older) }\end{array}$ & $\begin{array}{c}\text { Years of Schooling, } \\
\text { (for aged } 25 \text { and } \\
\text { older) }\end{array}$ & $\begin{array}{l}\text { Life Expectancy } \\
\text { at Birth } \\
\text { (years) }\end{array}$ & $\begin{array}{c}\text { Infant Mortality } \\
\text { (deaths per } 1,000 \\
\text { lives) }\end{array}$ \\
\hline Malaysia & 10.4 & 9.8 & 82.6 & 6.8 \\
\hline Singapore & 10.8 & 10.6 & 74.5 & 2.2 \\
\hline Sri Lanka & 10.1 & 9.8 & 74.6 & 9.4 \\
\hline Thailand & 8.0 & 7.3 & 74.1 & 12.5 \\
\hline
\end{tabular}

Sources: For years of schooling, Barro and Lee (2013): 184-98; for life expectancy and infant mortality: United Nations Department of Economic and Social Affairs, Population Division (2015), downloaded 15 December 2016.

Finally, it is helpful to compare Sri Lanka against some widely used business and governance quality indicators. Some of these indicators are subjective. Many indicators are available. Three that are plausible, in wide use, and frequently employed by governments as aspirational benchmarks are (1) the World Bank's Ease of Doing Business ranking across 190 economies, (2) the corruption perceptions index of 191 economies prepared by Transparency International, and (3) the World Bank's Logistics Performance Index ranking across 160 economies. The data, presented in Table 1.6, are for 2014 or 2015.

Table 1.6: Institutional and Business Indicators

\begin{tabular}{l|c|c|c} 
Economy & $\begin{array}{c}\text { Ease of Doing } \\
\text { Business, 2016 } \\
\text { (rankings: 1-190) }\end{array}$ & $\begin{array}{c}\text { Corruption Perceptions } \\
\text { Index, 2015 } \\
\text { (rankings: 1-91) }\end{array}$ & $\begin{array}{c}\text { Logistics Performance } \\
\text { Index, 2014 } \\
\text { (rankings: 1-160) }\end{array}$ \\
\hline Malaysia & 23 & 54 & 25 \\
\hline Singapore & 2 & 8 & 5 \\
\hline Sri Lanka & 110 & 83 & 89 \\
\hline Thailand & 46 & 76 & 35 \\
\hline
\end{tabular}

Sources: For ease of doing business: World Bank, Doing Business, accessed 22 December 2016; for the corruption perception index: Transparency International, accessed 22 December 2016; and for the logistics performance index: World Bank Logistics Performance Index Dataset, accessed 22 December 2016.

The picture that emerges is reasonably clear; is consistent with the major literature on Sri Lanka, as cited in this book; and provides the basis for some policy recommendations. First, Sri Lanka's business climate lags behind that of its neighbors. A major implication is the need to simplify regulatory and licensing procedures. Second, although less distant from Sri Lanka's comparators, the business community clearly regards corruption as a serious problem. Third, Sri Lanka has adopted a rather restrictive approach to foreign investment, which has limited its access to international markets and technology. The country has 
attracted much smaller FDI flows than neighboring economies, including even India, during 2005-2015. ${ }^{24}$ Finally, Sri Lanka lags well behind its neighbors in the provision of high-quality, internationally oriented logistics. Taken together, these variables clearly indicate the magnitude of the reform effort needed for the country to develop a business environment comparable to that in its more efficient neighbors.

\subsection{Major Themes and Issues}

A brief summary of the contents of this book follows, drawing out also the major links to the issues discussed above.

In Chapter 2, on macroeconomic management, Yougesh Khatri, Edimon Ginting, and Prema-chandra Athukorala examine Sri Lanka's macroeconomic policy and outcomes. With regard to fiscal policy, they note the large and persistent budget deficit averaging over 7.7\% of GDP since 1990, while public debt to GDP has averaged $89.1 \%$ during the same period. One explanation for this outcome is that the revenue-to-GDP ratio has been on a secular decline, from $20 \%$ in 1990 to about $13 \%$ in 2015 . Fiscal deficits have complicated the conduct of monetary policy, resulting in frequent double-digit inflation rates.

The authors argue that there is a broad consensus on the need for fiscal consolidation, creating fiscal space by boosting revenues to address the fiscal risks and expenditure pressures ahead. This will require the introduction of robust tax measures, sustained improvement of tax administration, and other institutional changes. Past fiscal reform efforts to increase the revenue ratio, however, have not given expected results. Furthermore, the authors maintain, fiscal and structural reform is hard to achieve under the best economic and political circumstances, but with growth below trend and under a coalition government, reform may be much more difficult to deliver. Nevertheless, there are reasons for cautious optimism, including the end of the civil war and some recent progress with expenditure reduction.

With regard to monetary policy, the deterioration of Sri Lanka's international competitiveness, as reflected in the persistent appreciation in the real exchange rate, has been an important factor behind Sri Lanka's indifferent performance in manufacturing exports, a point also emphasized by Athukorala in Chapter 4. Therefore, macroeconomic adjustments are needed to restore

24 Of course other factors affect the stock of foreign investment: conflict is an obvious variable in assessing the Sri Lankan record. 
international competitiveness by depreciating the real exchange rate. This will, of course, require a substantial nominal depreciation of the rupee. However, given the massive build-up of foreign-currency-denominated government debt, exchange rate depreciation alone may worsen the budgetary problems. Therefore, a comprehensive policy package is needed, encompassing greater exchange rate flexibility and fiscal consolidation through both rationalization of expenditure and a widening of the revenue base.

\section{In Chapter 3, Subhashini Abeysinghe and Sirimal Abeyratne examine the growth, performance, and policy issues of the Sri Lankan service and logistics sectors. The government has clear priorities for these} sectors, building on the country's locational advantage. The policy documents of successive governments have emphasized the strategy of creating a globally integrated and competitive service hub. The authors observe that services and logistics are mainly, but not exclusively, nontraded activities. As in many countries, reform has proceeded relatively slowly in Sri Lanka. First, as nontraded activities, services and logistics have not faced the direct competition that liberalization has imposed upon the traded goods sectors. Second, the international benchmarking of productivity and efficiency exercises-such as ease of doing business, competitiveness, and logistics-that are now used to indicate a country's performance are of relatively recent origin (i.e., within the last 15 years). Third, much of the sizable Sri Lankan SOE sector is concentrated in services. As discussed in Chapter 6, political constraint and unionization have slowed the pace of SOE reform, and by extension that of services and logistics.

The authors also argue that efficiency in logistics services is an important determinant of a country's international competitiveness. Logistics and services can catalyze unleashing the economic benefits of Sri Lanka's strategic location in the Indian Ocean. Some of the key challenges facing the sector include uncoordinated development of transport infrastructure, lack of synergy between city and port development, bureaucratic red tape, failure to attract global third party logistics firms, and a lack of a unified and holistic policy approach. Developing a master plan and establishing a national committee on logistics is important to address issues arising from weaker coordination and communication, and greater use of information and communication technology will help cut red tape. In addition, reforms that aim to introduce better regulation, encourage greater private-sector participation, and enhance competition will help the country improve the performance of its logistics sector and unlock its location potential. 
In Chapter 4, Prema-chandra Athukorala provides a comprehensive examination of Sri Lanka's experience with expanding manufacturing exports. The chapter emphasizes policy priorities for exploiting the country's export potential in a rapidly changing global context in which global production sharing has become the prime mover of cross-border production and trade. There is compelling evidence that the liberalization reforms initiated in 1977 helped transform the classical export economy inherited from the colonial era into one in which manufacturing plays a significant role. Were it not for the civil strife and inconsistent macroeconomic policies that adversely affected the investment climate, export performance would have been much more impressive. Econometric analysis of the determinants of exports reported in Chapter 4 suggests that that international competitiveness (measured by the real exchange rate) and FDI participation in export-oriented production, which together capture the state of the domestic economic environment, are much more important determinants of exports than world demand.

Athukorala argues that Sri Lankan policy makers' ambivalence about the role of the apparel industry (often called a "traditional industry") seems puzzling. The remarkable resilience of Sri Lanka's apparel exports to the termination of the Multi Fiber Arrangement in 2004 has been underpinned by a clear pattern of compositional shift in exports within the apparel value chain, from basic apparel to apparel with significant fashion content. After the Multi Fiber Arrangement expired, the Sri Lankan apparel industry has also settled into a smaller core of firms, which are presumably well prepared to take advantage of changing future demand. A number of Sri Lankan apparel firms are now global players with production bases in several countries, and Colombo is now considered South Asia's apparel technology hub. Moreover, the dominance of apparel in the composition of manufacturing exports mirrors the country's lackluster achievement in attracting major global players in vertically integrated producer-driven production (particularly in electronics) because of political and policy uncertainly, notwithstanding the country's intrinsic comparative advantage in this area of international production. However, a sizable number of mediumscale foreign-invested firms have been successfully operating in Sri Lanka within these production networks.

Athukorala asserts that his findings make a strong case for redressing policy backsliding and for continuing with the market-oriented reforms agenda that was left incomplete in the late 1990s, and for setting up institutional safeguards to avert further backsliding. The chapter also contains a preliminary analysis of the issue of labor shortages that has received much emphasis in recent policy debates as 
a constraint to further export expansion. The findings suggest that the reported labor shortages are at least partly due to structural impediments that hinder the operation of free market incentives. Providing facilities and incentives for factories to locate where labor is available and requiring firms to provide workers with dormitories (as is widely done in many other successful exporting countries) as part of the BOI investment approval and monitoring procedures and infrastructure development could redress these structural impediments to labor mobility.

In Chapter 5, Jeevika Weerahewa argues that the agriculture sector occupies a special place in the Sri Lankan economy despite its relatively small contribution to GDP and its slow growth rate. Directly or indirectly, agricultural activities provide employment to approximately one-third of the labor force and most of the rural population (which comprises $80 \%$ of the country's total population). The growth rates of food manufacturing and food services, classified under industry and services, respectively, are primarily determined by the performance of agriculture.

She points out that agricultural value chains in Sri Lanka are characterized by a large number of scattered small-scale producers, a concentrated food processing sector, inadequate linkages with the global value chains (despite the unique characteristics of certain agricultural products), and inadequate diversification at the farm and export levels (despite the diversification of diet). Some of the factors that slowed the modernization of agriculture are vagaries of weather; increased wage rates; out-migration of labor and the agricultural labor force's increased share of women, with lack of access to production opportunities and with low wages; and a policy environment that incentivized selected sectors.

With regard to policy priorities, successive governments have implemented several programs aimed at achieving multiple objectives, including selfsufficiency, poverty alleviation, safe and nutritious food, and enhanced export competitiveness. However, a focused and consolidated effort with clear policy directives is required to speed up the modernization of agriculture. Modernization should help producers acquire economies of scale; encourage private investment in food processing (by minimizing policy uncertainties); increase productivity (through reforms in mechanization policy, seed and planting material policy, and land policy); increase investments in public goods such as agricultural research, extension, and irrigation (by diverting resources from public procurement and price subsidies); improve access to agricultural insurance and finance; and promote entrepreneurship. 
In Chapter 6, Malathy Knight, Aneesha Guruge, and Maria Rowena Cham provide a comprehensive analysis of Sri Lanka's extensive SOE sector. The sector has witnessed episodes of nationalization and privatization and has been subject to varied degrees of competition. Yet, despite the rich knowledge base resulting from years of reform experience, much more needs to be done. The chapter emphasizes the fact that a sustainable SOE reform process must go beyond technical solutions and must unpack and resolve the more controversial political elements to secure broad-based stakeholder buy-in.

The authors examine SOE reforms through the lens of inclusive growth and look at the performance of public enterprises from three dimensions: efficiency, fiscal, and distributional. They maintain that four factors are critical to a sustainable SOE reform process: (1) efficient state provision of public goods and public service obligations, with the cost of these obligations being explicitly estimated and taken into consideration when evaluating the performance of public enterprises; (2) a competitive business environment with competitive pricing; (3) independent regulation; and (4) full transparency of SOE finances, including the various implicit subsidies and payments, combined with the functioning of public enterprises under a hard budget constraint. Given Sri Lanka's political economy context, the authors suggest that management and accountabilityoriented reforms and public-private partnerships may prove useful. In particular, for Sri Lanka, performance contracts and government holding company models have potential; indeed, Sri Lanka is currently in the process of establishing a government holding company, designed as a hybrid of Singapore's Temasek and Malaysia's Khazanah structures.

In a broader context, Sri Lanka has an opportunity today to undertake meaningful reform of public enterprises. There are, as always, significant sociopolitical, institutional, and technocratic challenges. However, looking to international good practice and to Sri Lanka's own experience with these reforms can contribute to sensible policy conversations. A crucial element in all of this is mobilizing public opinion by effective communication strategies that clearly indicate the reform objectives. What is required therefore is a political economy strategy with the capacity to address opposition to SOE reforms in a rational, transparent, and systematic manner. Dramatic reform is unlikely and expectations need to be managed, but incremental progress is certainly achievable.

In Chapter 7, Asoka Gunawardena and Roy Kelly examine the challenge of urbanization and its financing. They point out that urbanization and cities are expected to play an important role in Sri Lanka's ongoing transition to become an upper middle-income country. Theory and international experience 
have long recognized urban areas as important engines of economic growthproviding the benefits of urban agglomeration efficiencies; stimulating gains in productivity and competitiveness; providing markets for goods and services; and generating opportunities for knowledge creation, innovation, and specialization of production and services.

The authors argue that mobilizing financial resources is critical to ensuring sustainable urbanization. Financing instruments are needed to raise the upfront costs to build urban infrastructure, and the underlying funding instruments are critical to provide (1) the stream of revenues needed to deliver current urban services, and (2) the funding leverage needed to mobilize the upfront infrastructure financing while protecting environmental amenities. Mobilizing these funding and financing resources requires a coordinated approach involving central and local-level governments, development partners, and the private sector.

Specifically, the Sri Lankan government has an ambitious urbanization plan. Major challenges are to be expected in planning, financing, and governance of economic agglomerations and creating city-region linkages that will be socially and environmentally sustainable. The Western Region Megapolis Project alone, for example, is estimated to cost over $\$ 40$ billion, roughly $50 \%$ of Sri Lanka's GDP in 2015. To date, Sri Lanka has relied on central government investment, often with the assistance of international financial institutions, to finance large-scale urban infrastructure. As these traditional approaches may not generate sufficient funds, the authors argue that the government will need to build long-term partnerships with the private sector, while recognizing the need to enhance the capacities of provincial and local level authorities to play a stronger partnership role in urban development planning and service delivery.

Such changes call for (1) resetting the intergovernmental fiscal framework to enable the plans, (2) operationalizing a spatial planning and coordination framework, and (3) institutionalizing a governance framework for urbanization. The authors then provide a detailed set of specific policy recommendations under each broad grouping, with particular focus on the enhancing policy capacity.

\footnotetext{
Finally, in Chapter 8 Kiyoshi Taniguchi examines a broad set of analytical and policy considerations affecting outcomes in the Sri Lankan labor markets and education system. He starts with the observation that Sri Lanka is transitioning from a rural-based agriculture economy into a more urbanized high-value-adding economy, and thus the country faces new labor and skills match challenges. The transformation means, for example, that labor
} 
demand will be more job-specific. At the same time, the population is gradually aging, and the dependency ratio is increasing. The education system therefore needs to adapt to these ongoing changes. Substantial mismatches persist between labor demand and supply of workers, especially high-skilled workers.

With regard to education, the author argues that policy reforms are warranted in order to equip a skilled labor force appropriately. Female labor force participation needs to be increased, while greater competition and diversity is needed in the higher education sector, including a stronger orientation to the needs of the private sector.

Focusing on both the quality and quantity of labor, the author notes that the declining labor force growth can be addressed by a combination of increasing labor force participation, decreasing unemployment, and increasing the return of migrant workers from abroad. He argues that the largest source of additional labor is likely to be from increasing female labor force participation. This would entail a broader set of enabling reforms, recognizing that women remain the principle caregivers for the elderly, and thus the aging of the population will itself provide an additional barrier to female labor force participation. The author then provides a detailed set of recommendations to achieve the goal of increased female workforce participation.

The author also argues that Sri Lanka needs to increase the proportion of science and technology workers. Reform in this area requires both demand- and supply-side adjustments, including more flexible labor markets, a more responsive higher education system, and more innovative public-sector hiring practices.

\subsection{Policy Inferences}

The analysis in this introduction and the detailed studies that follow provide a clear road map for developing a policy framework that will enable the Sri Lankan government and its people to achieve the articulated goals of stronger and more inclusive growth, and faster graduation into the ranks of upper middle-income economies. As argued here, Sri Lanka's economic performance has been quite respectable by international standards. But it could easily have been stronger, resulting in a much faster reduction in poverty and an easing of the ethnic tensions that have occasionally beset the country.

Four sets of policy reforms are central to the objective of accelerated development. 
First, significant macroeconomic reform is needed, based on more prudent fiscal management and monetary policy that contains inflation and ensures that exchange rate settings support the goal of international competitiveness. There is great scope for public-sector fiscal consolidation, through attention to the provision of subsidies (while maintaining targeted support for low-income groups), more vigorous and broad-based revenue efforts, and major reform of the SOE sector. Combined with the peace dividend from ending the civil war, these measures could create the fiscal space for the government to strengthen infrastructure and social expenditures while also reducing fiscal deficits. Greater central bank independence with explicit inflation targeting would reduce the problem of exchange rate misalignment and support ongoing trade and microeconomic reforms.

Second, there is a strong case for renewing the emphasis on trade and commercial policy liberalization. Sri Lankan economic history clearly demonstrates that well-designed international economic integration has resulted in dividends for the country. The supply-side response to the effective 1977 liberalization reforms resulted in faster economic growth and significant employment creation. Despite the evident success, Sri Lanka has had a mixed reform history, with periodic backtracking undermining the many positive achievements. The ambivalence toward foreign investment, exacerbated by periods of political turbulence, has denied the country the opportunity to participate extensively in the fast-growing, East Asiancentered, global production networks in electronics, automobiles, machinery and related products, and service activities. As a first step, the country would be well advised to develop a comprehensive reform package, including the "tariffication" of nontariff barriers, the unification and gradual reduction of the tariff structure, and government revenue compensation measures through an increased value-added tax. The current FTZs, many of which are operating successfully, should be retained pending broader and deeper trade and investment reform.

Third, the country can achieve macroeconomic and trade reform without compromising its historic strengths in education and health. Sri Lanka has maintained its educational advantages, but the margin is eroding as other countries catch up. Greater public and private investments in education are required at all levels. The public investments also need to be carefully targeted to ensure that all socioeconomic groups benefit from them. 
Fourth, reforms will be more effective if they are accompanied by greater investments in infrastructure, combined with a regulatory environment that encourages public and private investment and ensures that the increased investment addresses both efficiency and equity objectives. Sri Lanka lags behind its more outward-looking East Asian neighbors in infrastructure. More efficient logistics would enable the country to regain its important historical status as a hub for international air transport and shipping. A stronger domestic transport network, including both road and rail, would enable broad-based participation in the benefits of trade reform. The equity objectives could be met by extending this network into previously marginalized communities, in the process alleviating any concerns about the so-called "labor scarcity" that is primarily due to geographic concentration of much of the new job creation in Sri Lanka's industrialized and urbanized regions. 


\section{References}

Abeyratne, S. 2004. Economic Roots of Political Conflict: The Case of Sri Lanka. World Economy. 27(8): 1295-314.

Arunatilake, N., P. Jayawardena, and D. Weerakoon. 2011. Sri Lanka. In S. Kelegama (ed). Migration, Remittances and Development in South Asia. New Delhi: Sage.

Athukorala, P. 2012. Sri Lanka's Trade Policy: Reverting to Dirigisme? The World Economy. 35(12): 1662-86.

Athukorala, P., and S. Jayasuriya. 1994. Macroeconomic Policies, Crises and Growth in Sri Lanka, 1969-1990, Washington, D.C.: World Bank.

. 2015. Victory in War and Defeat in Peace: Politics and Economics of Post-Conflict Sri Lanka. Asian Economic Papers. 14(3): 22-54.

Athukorala, P., and S. Rajapatirana. 2000. Liberalization and Industrial Transformation: Sri Lanka in International Perspective. New Delhi: Oxford University Press.

Barro, R., and Jong-Wha Lee. 2013. A New Data Set of Educational Attainment in the World, 1950-2010. Journal of Development Economics. 104.

Bell, G. 1980. Asian Wall Street Journal, 23 September.

Bhalla, S., and P. Glewwe. 1986. Growth and Equity in Developing Countries: A Reinterpretation of the Sri Lankan Experience. World Bank Economic Review. 1(1): 35-64.

Bruton, H., G. Abeysekera, and N. Sanderatne et al. 1992. Sri Lanka and Malaysia. Oxford University Press.

Central Bank of Sri Lanka (CBSL). 2002. Annual Report 2001. Colombo: CBSL. . 2016a. Annual Report 2015. Colombo: CBSL. . 2016b. Monthly Bulletin of Statistics: July. Colombo: CBSL . various years. Annual Report. Colombo: CBSL. Statistics. http://www.cbsl.gov.lk/htm/english/08_stat/stat.html

Cuthbertson, A. 1997. The Trade Policy Review of Sri Lanka. World Economy. 20(5): 633-48.

Cuthbertson, A., and P. Athukorala. 1991. Sri Lanka. In Papageorgiou, Michaely, and Choksi (eds.). Liberalizing Foreign Trade. Vol. 5. Oxford: Basil Blackwell.

De Silva, K. 1981. A History of Ceylon. Delhi: Oxford University Press.

Department of Census and Statistics (DCS). Input-Output Tables. http://www. statistics.gov.lk/national_accounts/dcsna_r2/iot.php

Dunham, D., and C. Edwards. 1997. Rural Poverty and Agrarian Crisis in Sri Lanka, 1985-93: Making Sense of the Picture. Poverty and Income Distribution, Series No. 1. Colombo: Institute of Policy Studies.

Dunham, D., and S. Jayasuriya. 2000. Equity, Growth and Insurrection: Liberalization and the Welfare Debate in Contemporary Sri Lanka. Oxford Development Studies. 28(1): 97-110. 
Glewwe, P. 1986. The Distribution of Income in Sri Lanka in 1969-1970 and 1980-1981: A Decomposition Analysis. Journal of Development Economics. 24(2): 255-74.

.1988a. Economic Liberalization and Income Inequality: Further Evidence on the Sri Lankan Experience. Journal of Development Economics. 28(2): 233-46.

. 1988b. Response to Ravallion and Jayasuriya. Journal of Development Economics. 28(2): 257-60.

Goodhand, J. 2012. Sri Lanka in 2011: Consolidation and Militarization of the Post-War Regime. Asian Survey. 52(1): 130-37.

Government of Sri Lanka (GSL). 2008. Strategic Development Projects Act, No. 14 of 2008. Sri Lanka: Government Publication Bureau.

. 2010. Sri Lanka: The Emerging Wonder of Asia: Mahinda Chintana Vision for the Future. Colombo: Department of National Planning.

Hicks, J. 1958. Reflections on the Economic Problems of Ceylon. In Papers by Visiting Economists. Colombo: Planning Secretariat.

Institute of Policy Studies (IPS). 2016. State of the Economy. Colombo: IPS.

Isenman, P. 1980. Basic Needs: the Case of Sri Lanka. World Development. 8(3), 237-58.

Jayawardena, V. 1972. The Rise of the Labor Movement in Ceylon. Durham, NC: Duke University Press.

Jennings, I. 1948. The Economy of Ceylon. Oxford: Oxford University Press.

Jiggins, J. 1976. Dismantling Welfarism in Sri Lanka. Overseas Development Institute Review. 9(2): 84-104.

Kaminski, B. and F. Ng. 2013. Revival of Inward-Orientation and Its Impact on Sri Lanka's Performance in Global Markets. WSiZ Policy Research Working Papers 2. Washington, D.C.: World Bank.

Kelegama, S. 2016. The Political Economy of the Rajapaksa Decade in Sri Lanka, 2005-14: Policy Contradictions and Mal-Governance. In Hill and Menon (eds.). Managing Globalization in the Asian Century: Essays in Honor of Prema-chandra Athukorala. Singapore: Institute of Southeast Asian Studies.

Kravis, I., B. Heston, and R. Summers. 1982. World Production and Income: International Comparison of Real Gross Product. Baltimore: Johns Hopkins University Press.

Lee Kuan Yew. 2000. From Third World To First: The Singapore Story: 1965-2000. Singapore: Singapore Press Holdings.

Marga Institute. 1974. Welfare and Growth in Sri Lanka. Colombo: Marga Institute. Observatory of Economic Complexity. Data. atlas.media.mit.edu

Olson, R. 1977. Expropriation and International Economic Coercion: Ceylon and the West, 1961-65. Journal of Developing Areas. 11(2): 205-26. 
Osmani, S. 1994. Is there a Conflict between Growth and Welfarism? The Significance of the Sri Lanka Debate. Development and Change. 25(3): 387-421.

Perkins, D. 2013. East Asian Development: Foundations and Strategies. Cambridge, MA: Harvard University Press.

Perry, P. 2012. Exploring the Influence of National Cultural Context on CSR Implementation. Journal of Fashion Marketing and Management. 16(2): 141-60.

Pursell, G. 2011. Para Tariffs and Sri Lanka's New Protectionism. Economic and Political Weekly. 76(25): 31-4.

Pyatt, G., and A. Roe. 1977. Social Accounting for Development Planning with Special Reference to Sri Lanka. Cambridge: Cambridge University Press.

Rajapatirana, S. 1988. Foreign Trade and Economic Development: Sri Lanka's Experience. World Development. 16(10): 1143-57

. 2004. Industry Policy. In Kelegama (ed.). Economic Policy in Sri Lanka: Issues and Debates. New Delhi: Sage.

. 2016. Policies towards Globalization in Sri Lanka, 1960-2012: Change and Continuity. In H. Hill and J. Menon (eds.). Managing Globalization in the Asian Century: Essays in Honor of Prema-chandra Athukorala. Singapore: Institute of Southeast Asian Studies.

Rama, M. 1994. Flexibility in Sri Lanka's Labor Market. Policy Research Working Paper No. 1262. Washington, D.C.: World Bank.

Ravallion, M., and S. Jayasuriya. 1988. Liberalization and Inequality in Sri Lanka: A Comment. Journal of Development Economics. 28(2): 247-55.

Robinson, J. 1958. Economic Possibilities of Ceylon. In Planning Secretariat, Papers by Visiting Economists, Colombo: Government Publication Unit, 39-45. (reproduced in Athukorala [ed.]. The Economic Development of South Asia, V1, Cheltenham, UK: Edward Elgar.)

Rodrigo, C. 1983. A National Wage Policy for Sri Lanka. Colombo: Sri Lanka Institute of Development Administration.

Sarvananthan, M. 2016. Elusive Economic Peace Dividend in Sri Lanka: All that Glitter is not Gold, Geojournal. 81(4): 571-96.

Sen, A. 1981. Public Action and the Quality of Life in Developing Countries. Oxford Bulletin of Economics and Statistics. 43, no. 4(1981): 287-319. . 1988. Sri Lanka's Achievements: How and When? In T.N. Srinivasan and Pranab K. Bardhan (eds.). Rural Poverty in South Asia. New York: Columbia University Press.

Snodgrass, D. 1998. The Economic Development of Sri Lanka: A Tale of Missed Opportunities. In R. Rotberg (ed.). Creating Peace in Sri Lanka: Civil War and Reconciliation. Washington D.C.: Brookings Institution Press.

Transparency International. Corruption Perceptions Index 2015. http://www. transparency.org/ cpi2015\#downloads 
UN Comtrade Database. International Trade Statistics Database. https:// comtrade.un.org/

United Nations Conference on Trade and Development. UNCTAD Stat. http:// unctadstat.unctad.org/wds/TableViewer/tableView.aspx

United Nations Department of Economic and Social Affairs, Population Division. 2015. World Population Prospects: The 2015 Revision. https://esa.un.org/ unpd/wpp/

Wijesinghe, M. 1976. The Economy of Sri Lanka, 1948-1975. Colombo: Ranco Printers.

Wilson, A. 1998. The Break-up of Sri Lanka: The Sinhalese-Tamil Conflict. New York: C. Hurst \& Co.

World Bank. 1953. The Economic Development of Ceylon. Baltimore: John Hopkins University Press.

. 2005. Sri Lanka Development Policy Review 2014. Washington, D.C.: World Bank.

. Doing Business. http://www.doingbusiness.org

. Logistics Performance Index Dataset. http://lpi.worldbank.org/

. World Development Indicators (WDI). http://data.worldbank.org/ data-catalog/world-development-indicators

Wriggins, W. 1960 (republished 2015). Ceylon: Dilemmas of a New Nation. Princeton, NJ: Princeton University Press.

. 2011. After Forty Years. In Hold (ed.) The Sri Lanka Reader: History, Culture, Politics. Durham: Duke University Press. 


\section{Chapter 2.}

\section{Economic Performance and Macroeconomic}

\section{Management}

Yougesh Khatri, Edimon Ginting, and Prema-chandra Athukorala

\subsection{Introduction}

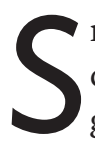

ri Lanka's economic growth in the last 3 decades was relatively strong, considering that it took place during a 26-year civil conflict. Economic growth averaged 5\% during 1971-2015. Sri Lanka also made major strides in reducing poverty, with the poverty rate declining from $28.8 \%$ in $1995 / 96$ to $6.7 \%$ in 2012. Sri Lanka's growth experience, as in many economies at its stage of development, was underpinned by structural transformation that boosted productivity. The share of the less-productive agriculture sector declined steadily from an average of $29.8 \%$ in the 1970 s to an average of $8.5 \%$ in $2013-2015$.

Notwithstanding its relatively strong growth performance and poverty reduction record, Sri Lanka missed an opportunity to deepen its industrial base. A shift from an inward-oriented, import-substitution-based industrialization to an export-oriented development strategy and proactive policy to attract foreign investors in the 1980s supported a rapid growth of manufacturing exports for 2 decades, particularly garments. Since the late 1990s, Sri Lanka's trade in goods to gross domestic product (GDP) ratio has shown a secular decline. This is partly due to successful episodes of trade and investment liberalization. However, they were not continued and built on with deeper reforms, and in many cases there was a reversal of the policies. Since the late 1990s, the trade liberalization process has suffered a setback because of the pressure for raising additional revenue from import tariffs to finance the ballooning war budget. New para tariffs were introduced and the protectionist measures together created an anti-export 
bias. Uncertainty and reversals in investment policies have not helped either, and the foreign direct investment inflows that are greatly needed to attract new technology and help Sri Lanka integrate into global production networks has not materialized. As a result, Sri Lanka's manufacturing exports have not transitioned from garments to higher value-added segments. Over time, the lack of diversification in the manufacturing sector has reduced Sri Lanka's capacity to export.

With declining exports and relatively weak private investment, government spending (particularly infrastructure spending) played a major role in supporting growth. This resulted in a large and persistent budget deficit and debt-to-GDP ratio since 1990. At the same time, the revenue-to-GDP ratio has been declining. Fiscal dominance has also complicated the conduct of monetary policy, resulting in a frequent recurrence of double-digit inflation.

The next section discusses the cause of persistent fiscal deficits and potential medium-term fiscal reforms to gradually reduce the fiscal imbalance. Section 2.3 will discuss the linkage between monetary policy and fiscal policy (fiscal dominance) and its implication for past conduct of monetary policy and the country's competitiveness and trade performance. The chapter concludes with some remarks on fiscal consolidation and the macroeconomic policy coordination needed for more sustainable and broader-based growth in the medium-to-long term.

\subsection{Fiscal Policy}

Sri Lanka has experienced a large and persistent budget deficit, averaging over $7.7 \%$ of GDP since 1990, and the debt-to-GDP has averaged $89.1 \%$ during the same period (Figure 2.1). The revenue-to-GDP ratio has been on a secular decline from $20 \%$ in 1990 to about $13 \%$ in 2015. Sri Lanka's revenue-to-GDP ratio is one of the lowest in the world, and a declining ratio is very unusual for a fastgrowing emerging market economy. Despite clear expenditure needs (notably for infrastructure and social spending), expenditure has also been on a declining trend (constrained by revenue and financing). At the same time, the expenditure profile can be characterized as rigid-mainly nondiscretionary recurrent expenditure-with the single largest component being interest costs, at about $5 \%$ of GDP or $20 \%$ of total expenditure.

The fiscal challenges extend well beyond general government. The public sector plays a large and active role in various sectors through state-owned enterprises (SOEs), the balance sheets of which imply even larger contingent 
Figure 2.1: Government Debt as a Share of GDP, 1990-2015 (\%)

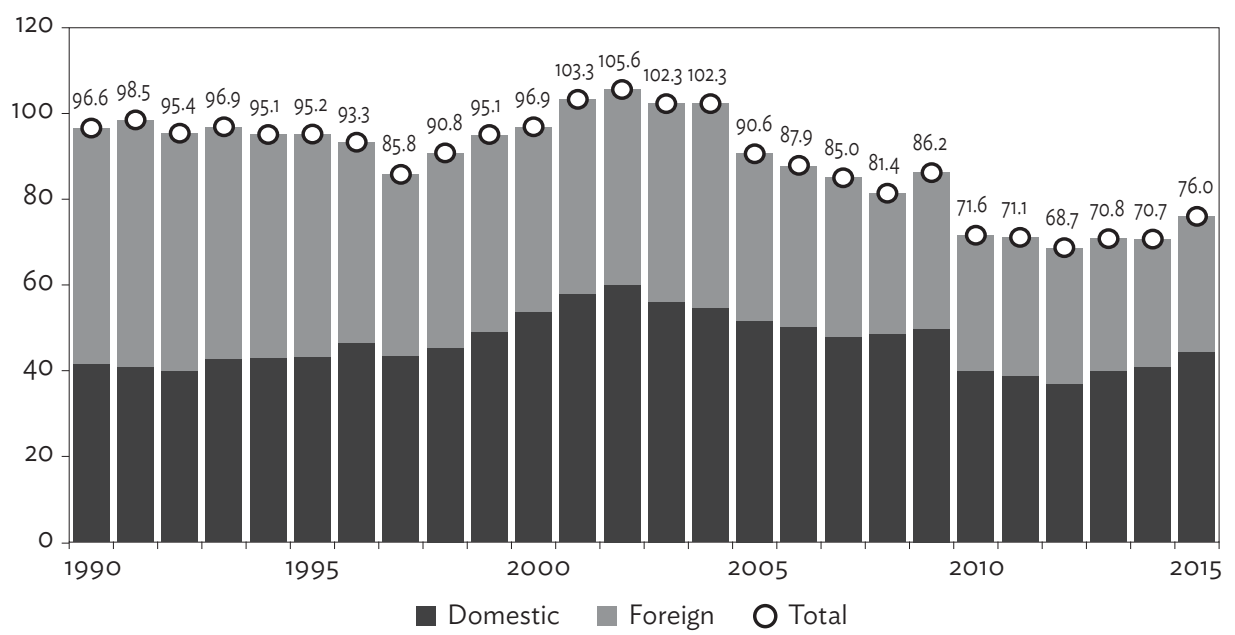

GDP = gross domestic product.

Source: CBSL, Statistics, accessed February 2017.

public sector liabilities. (The challenges stemming from a large SOE sector are discussed in Chapter 6.) Sri Lanka is also an aging economy and, as it approaches upper middle-income levels, is likely to face increasing pension and social expenditure pressures ahead.

Sri Lanka's fiscal situation reflects more than the usual "deficit bias" problem. Since the 1970s, fiscal policy globally has been characterized by a strong fiscal bias toward deficits. A large empirical and theoretical literature suggests this is related to weak public financial management and distorted political incentives (Beetsma and Debrun 2016). Sri Lanka's particularly unusual fiscal situation-a secular decline in revenues, despite robust growth, to one of the lowest revenue ratios in the world-suggests other factors are at play. Sri Lanka's civil war (1983-2009) likely exacerbated some of the drivers of deficit biases, including short-termism, the "common-pool" problem, the time-inconsistency problem, poor governance, and the high level of informality.

Because Sri Lanka's expenditure-to-GDP ratio (revenue ratio) is not high by international standards, the bulk of the challenge is on the revenue side. The secular decline in Sri Lanka's revenue ratio since 1990 is in stark contrast to the usual increasing revenue ratio associated with higher per capita income levels. Figure 2.2 starkly demonstrates the unusual decline and the current extremely low revenue ratio. The most commonly used explanatory variable for expenditure and revenue ratios is the level of development (proxied by per capita GDP), based on the hypothesis that a higher level of development brings more 
demand for public expenditure, and a higher level of tax capacity to pay for the higher expenditure (Tanzi 1987). Income growth associated with urbanization typically increases the formal sector share of the economy, increases demand for public services, and facilitates revenue collection (most revenue indeed stems from major cities). ${ }^{1}$ Sri Lanka's revenue ratio in the early 1990 s was in line with the trend line fitted to the global panel data (13\%), but the ratio has since declined substantially and is now less than half the level suggested by the trend line (28\%). ${ }^{2}$

\section{Figure 2.2: Global GDP per Capita and General Government Revenue Ratio} (\% of GDP)

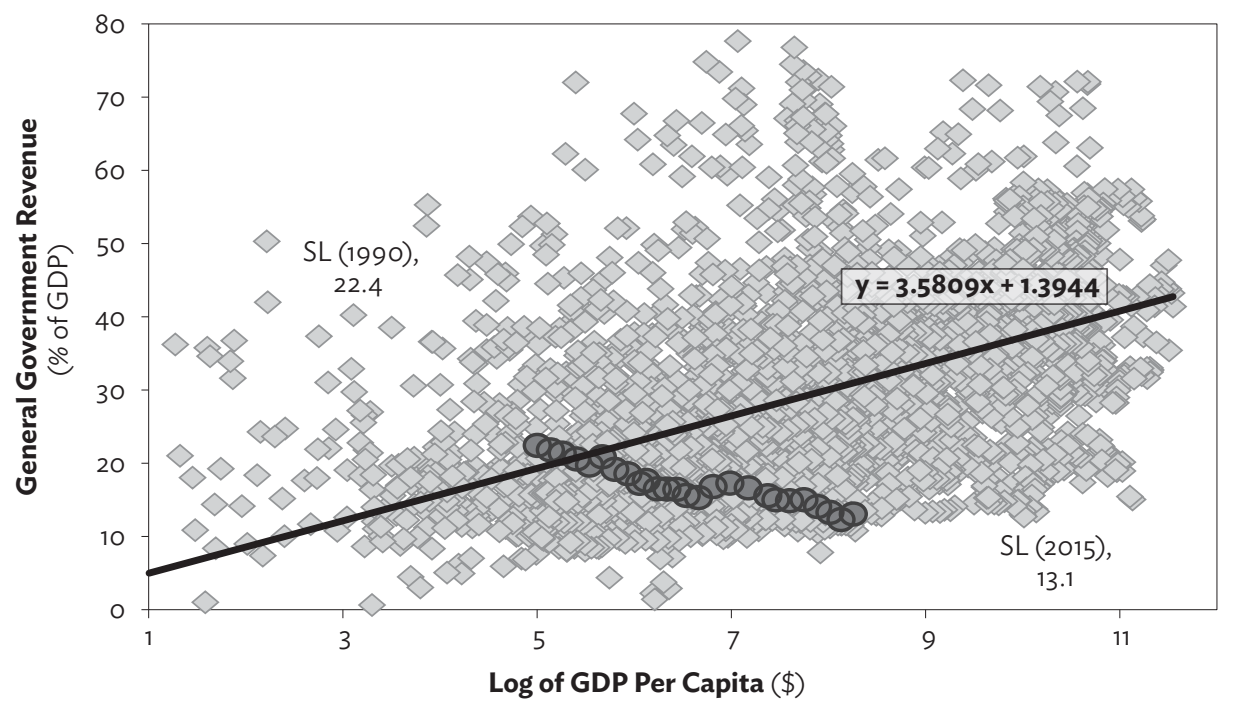

GDP = gross domestic product, $S L=$ Sri Lanka .

Source: IMF, WEO, accessed October 2016.

Revenue to GDP by major country groupings helps illustrate the extent to which Sri Lanka is an outlier-even among emerging market and Asian economies. Figure 2.3 shows that the average revenue ratio for all emerging and developing economies rose from $25 \%$ of GDP in 2000 to a peak of around $29 \%$ of GDP (and has fallen back somewhat since 2014 in the context of weaker commodity prices). The ratio for emerging Asia increased from $26 \%$ in 2000 to over $30 \%$ in recent years. Sri Lanka's revenue ratio has, in stark contrast, declined to less than half the emerging Asia average.

Appendix A2 discusses a more rigorous approach to comparing revenue ratios across countries. Sri Lanka's revenue-to-GDP ratio in this figure is from the IMF, WEO database for consistency with the other such data used and differs somewhat from the ratio calculated in this paper for the earlier years based on the new GDP series, interpolated back using the old GDP series. 
Figure 2.3: Revenue (\% of GDP)

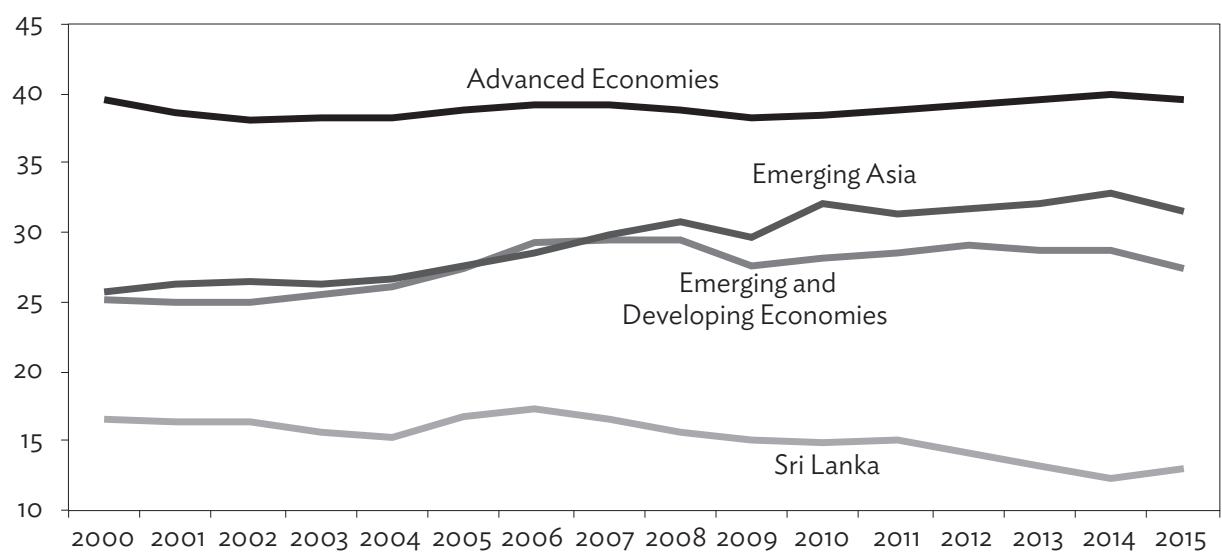

GDP = gross domestic product.

Source: IMF, WEO, accessed October 2016.

Sri Lanka's revenue buoyancy is low and has declined for major revenue sources. Another way of demonstrating the unusual evolution of Sri Lanka's revenue during recent decades is to look at the low and declining tax buoyancy ratio (Figure 2.4 shows the actual and trend tax buoyancy: buoyancy is defined as the percentage change in revenue relative to the percentage change in GDP).

Figure 2.4: Buoyancy of Total Revenue $(\% \triangle$ Revenue $/ \% \triangle G D P)$

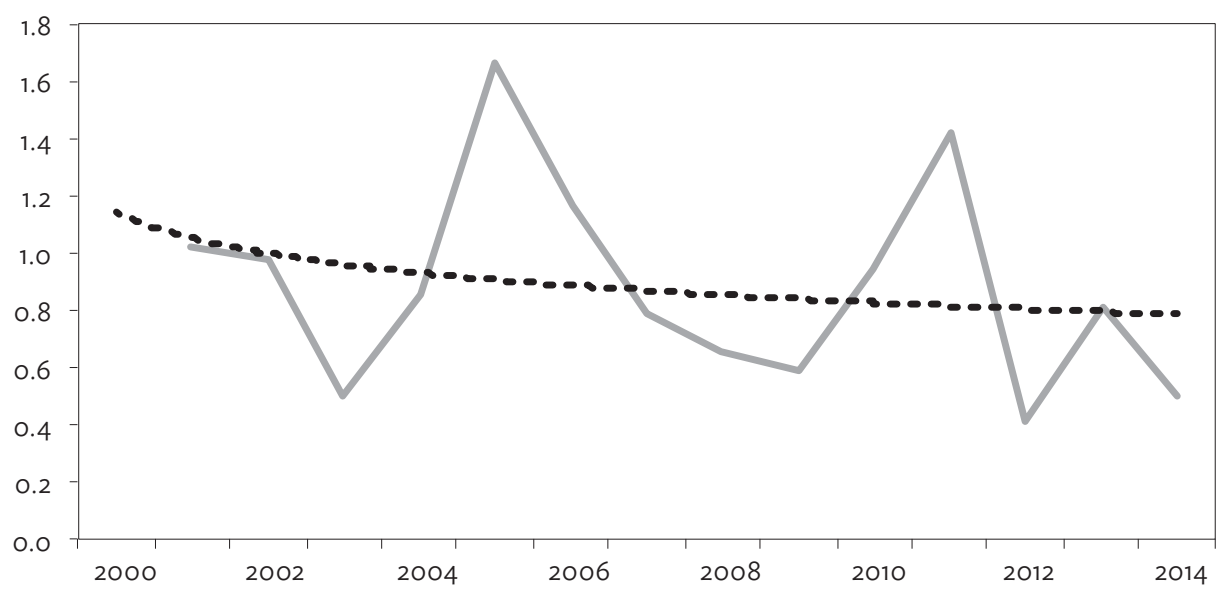

GDP $=$ gross domestic product.

$\% \triangle$ Revenue $/ \% \triangle G D P=$ the percentage change in revenue relative to the percentage change in GDP.

Source: Estimates based on IMF, WEO, accessed October 2016. 
With a trend of buoyancy for overall revenue below 1, revenue growth has fallen below nominal GDP growth, resulting in the declining revenue ratio. Developing countries typically have tax buoyancies greater than 1 (for reasons mentioned above) and hence the tax-to-GDP ratio typically increases with per capita income. Sri Lanka thus has some of the lowest tax productivities in the world (see comparisons in IMF WEO and World Bank [2016]). For example, the c-efficiency of value-added tax (VAT), at $25 \%$, is less than half that of lower middle-income countries. ${ }^{3}$

Underlying this low and declining revenue ratio are changes in tax policy and problems with tax administration. The chronology of contributing policy changes and tax administration problems is well documented elsewhere and not reproduced in detail here (see World Bank 2016; IMF 2016; IPS 2013). Some of the key interconnected problems include

- revenue losses related to reductions in statutory rates and to trade liberalization were not sufficiently offset by tax policy or administration measures elsewhere to boost revenue (such as through broadening the tax base);

- tax administration problems, including the lack of growth in the number of individual and corporate taxpayers, multiple institutions involved with tax administration, and a reliance on self-reporting; and

- an ever-growing list of concessions, exemptions, and incentives (and multiple incentives schemes)-for example, corporate tax expenditure is around the size of corporate tax revenue (IMF WEO); the VAT regime has evolved, since its introduction in 2002, to provide over 500 types of exemptions, and there are over 40 types of exemptions on corporate and personal income tax; and the Board of Investment also provided tax incentives to investors.

Deeper drivers of the low tax ratio and associated weak tax policy and administration likely include incentive distortions (resulting in deficit bias); the nexus of institutions, governance, and informality; and the civil war (IPS 2013). Addressing some of these deeper drivers will be fundamental to sustainably boosting revenue and meeting expenditure needs over the medium-long run. Tanzi and Davoodi (2000) find that income taxes may be more susceptible to tax inspectors' opportunistic behavior than VAT, which usually requires better bookkeeping and tax records. This may explain the predominant share of indirect taxes in total taxes in developing economies and in Sri Lanka.

3 Tax productivity is defined as tax collection relative to GDP over the tax rate. C-efficiency is similarly tax collection as a share of the relevant tax base divided by the tax rate. 
Consequently, revenue is very skewed toward indirect taxes and the decline in VAT accounts for much of the overall revenue decline (Figure 2.5). The share of excise, trade, and miscellaneous other taxes has increased to $60 \%$ of the total. The exemptions and administration issues mentioned above have contributed to the significant decline in VAT collection and thus overall revenues (the VAT contribution declined from a peak share of $39 \%$ in 2004 to $15 \%$ by 2015). Income tax accounts for an unusually small share of total revenue (at less than $20 \%$ of the total).

Figure 2.5: Change in Revenue Composition (\% of total)

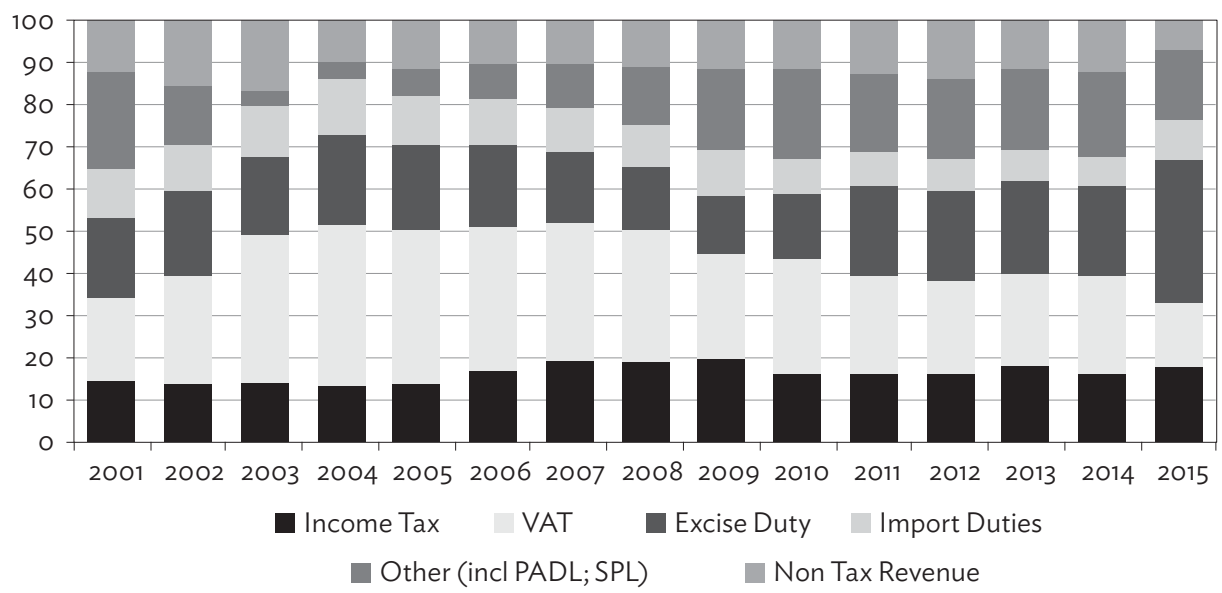

$\mathrm{PADL}=$ ports and airports development levy, $\mathrm{SPL}=$ social responsibility levy, VAT = value-added tax. Source: Based on CBSL, Statistics, accessed October 2016.

Drawing on cross-country-based assessments of revenue potential that take into consideration economic structure and fundaments, the revenue potential for Sri Lanka ranges from $20 \%$ to $26 \%$ of GDP (see the peer analysis and stochastic frontier approaches in Appendix A2). This suggests a revenue gap in the range of $9 \%-13 \%$ of GDP, i.e., revenue could feasibly be double the current ratio given Sri Lanka's current level of income per capita and other economic characteristics.

Sri Lanka's government expenditure-to-GDP ratio has declined since 1990 to a relatively low level. In the early 1990s, Sri Lanka's total government expenditure-to-GDP ratio (or expenditure ratio) of $30 \%$ of GDP was roughly in line with its income per capita (based on cross-section experience: Figure 2.6). Over time, the expenditure ratio has declined by a third to $20 \%$. This declinelike the decline in the revenue ratio-runs counter to the usual empirical trend 
and to prior expectations that the expenditure ratio increases with the level of development (as discussed above). Expenditure has been constrained by the poor revenue performance and a large deficit financing need. Much of the fiscal consolidation between 2008 and 2013 was through expenditure cuts.

Figure 2.6: GDP per Capita (\$) and General Government Expenditure (\% of GDP)

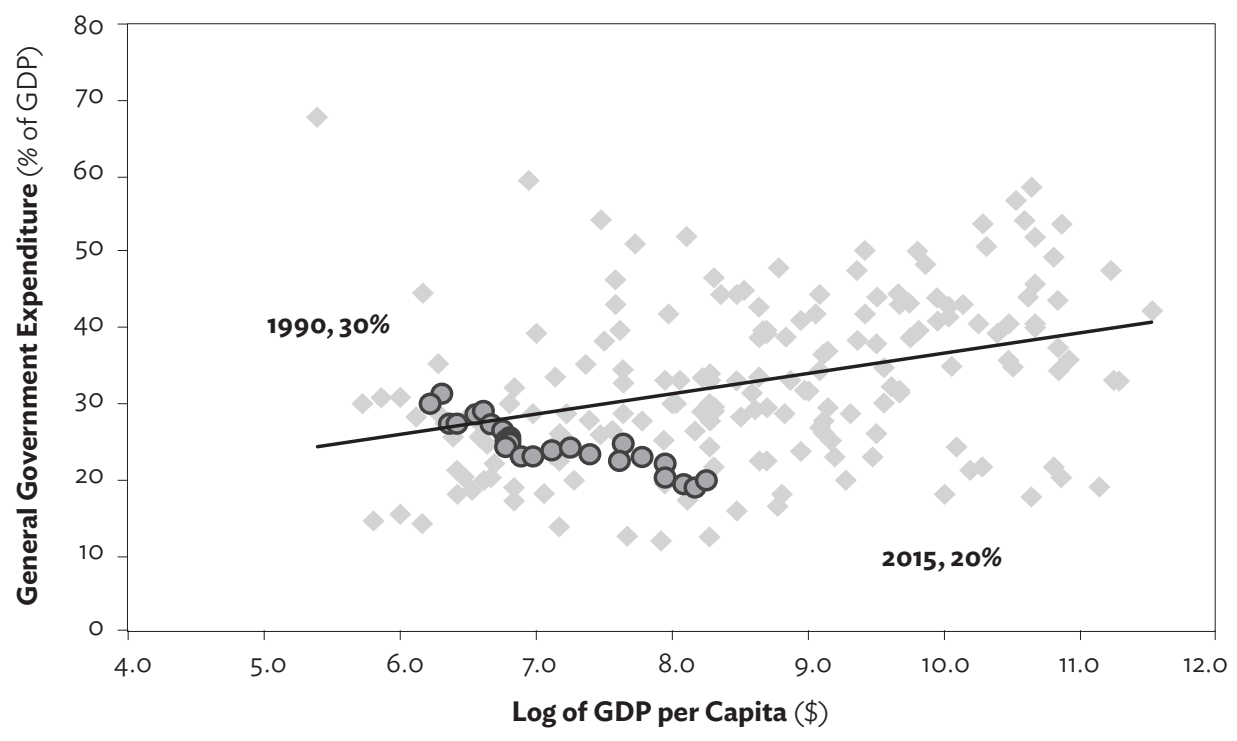

GDP = gross domestic product.

Source: Estimates based on IMF, WEO, accessed October 2016.

The composition of Sri Lanka's expenditure implies little short-term flexibility. More than half of overall expenditure and net lending (and over $70 \%$ of current expenditure) is for items that government has little scope to reduce in the near term, such as interest payments, transfer payments, subsidies, and salaries (transfers largely relate to civil service pension payments). The large increase in the number of civil servants (from 900,000 in 2004 to 1.3 million in 2014) and the hike in public sector salaries (which caused the spike in the expenditure ratio in 2015) has further increased the rigidity of expenditure and created a greater hurdle in terms of consolidation effort required. 
Interest payments are the largest single expenditure item at about onequarter of total expenditure and are well above the emerging market average (Figure 2.7). This is the legacy of large and persistent fiscal deficits and thus a high debt-to-GDP ratio and high bond yields. Interest expenditure fell from a peak of $6.2 \%$ of GDP in 2002 to $4.2 \%$ in 2014 but began to increase again, to $4.7 \%$ of GDP in 2015 . Over $40 \%$ of Sri Lanka's government debt is external and mostly concessional (the implied average interest rate on foreign debt in 2015 was about $2.5 \%$ versus about $10.5 \%$ for domestic debt). Sri Lanka's government bond spreads have already widened considerably in response to fiscal concerns (Figure 2.8). Over the medium term, as Sri Lanka moves to upper middle-income status and loses access to concessional financing, the share of foreign debt can be expected to decline and the effective interest rate and burden (all else equal) will increase.

Figure 2.7: Government Interest Payments ${ }^{\mathrm{a}}$ (\% of GDP)

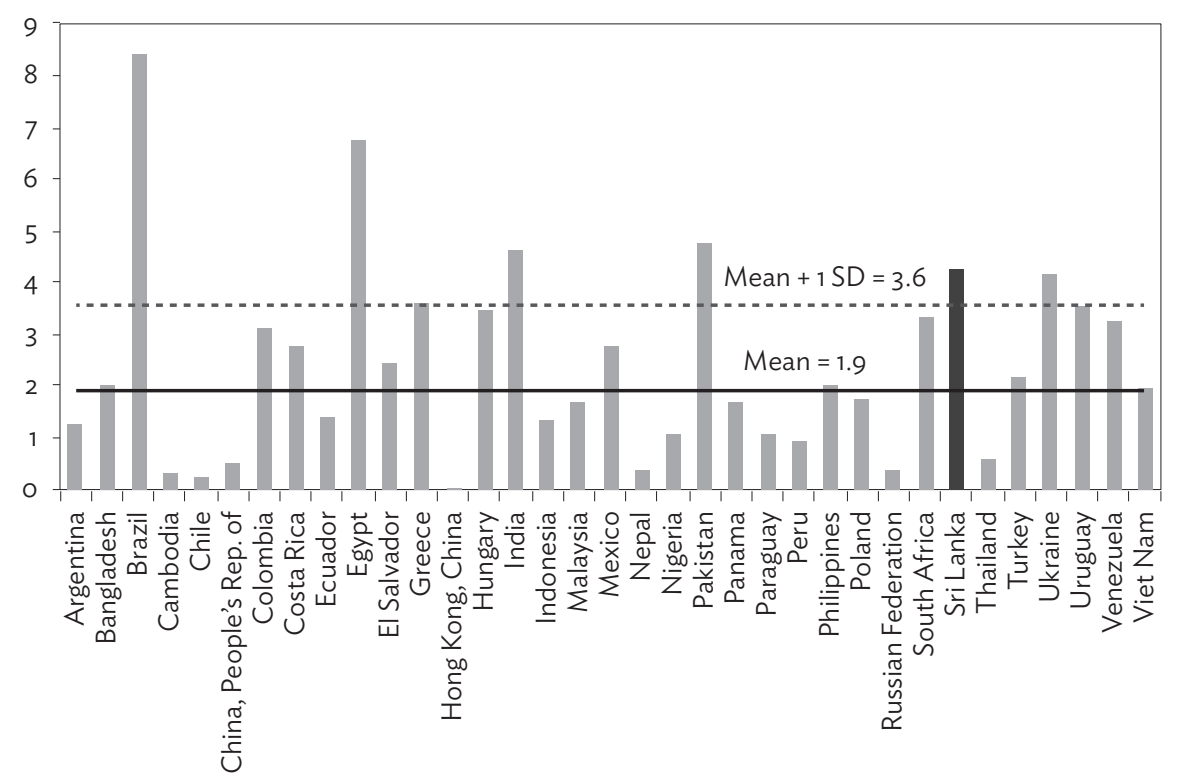

GDP = gross domestic product, SD = standard deviation.

a Derived from General Government Net Lending/Borrowing minus General Government Primary Deficit. Source: Estimates based on IMF, WEO, accessed October 2016. 
Figure 2.8: Bonds Spread and Foreign Ownership

Figure 2.8a: Bonds Spread, June 2008-December 2016

(5-year maturity, basis points)

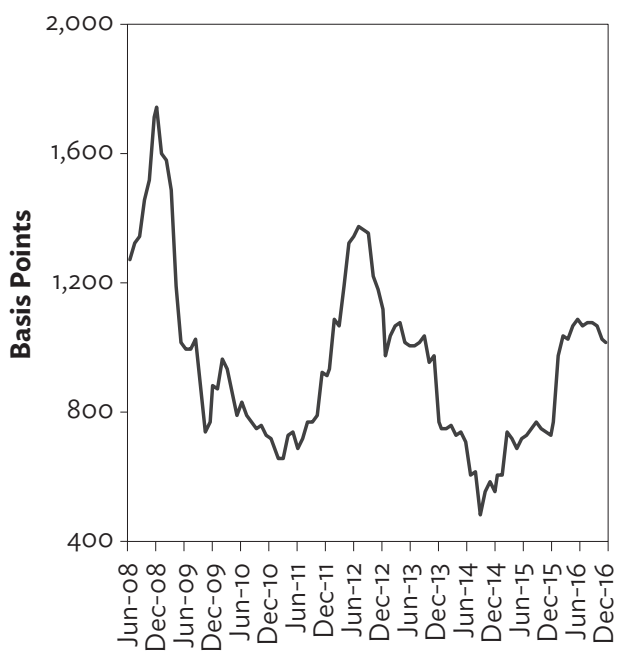

Figure 2.8b: Bonds Foreign Ownership, 2007-2014

(\% of total)

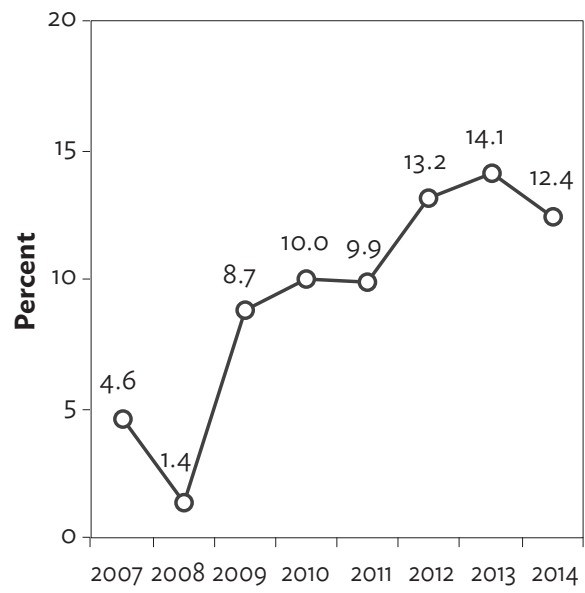

Sources: CBSL, Website, accessed October 2016, for bonds ownership; Bloomberg's bonds yield for Sri Lanka and United States of America for estimates of bond spreads, accessed October 2016.

As Sri Lanka becomes an upper middle-income country, its spending composition is also likely to change. Sri Lanka's per capita income is apt to reach $\$ 5,300$ by 2020 , within the upper middle-income range. International benchmarking can provide a guide not only for where one would expect the expenditure ratio to be for a given income level (as above), but also some idea of the "typical" composition of expenditure. Emerging market countries that report expenditure breakdowns by economic classification are considered by using the International Monetary Fund (IMF) Government Financial Statistics database.

The average expenditure ratios and average expenditure composition for emerging markets with per capita incomes about where Sri Lanka's is expected to be in 2020 are shown in the middle stacked bar of Figure 2.9. If these comparator expenditure compositions can be taken as broad indicators of the direction for Sri Lanka, then, consistent with the previous analysis, (1) the overall expenditure ratio would typically be much higher and trend upward, (2) personnel expenditure would typically increase relative to GDP but decline as a share of overall expenditure, (3) the ratio of capital expenditure to real assets is likely to be higher relative to GDP but remain around the same as a share of overall spending in the medium term and fall back as a share of GDP at even higher levels of development, and (4) social spending would increase but mainly at much higher levels of per capita income. 


\section{Figure 2.9: General Government Expenditure by Major Category, 2015 (\% of GDP)}

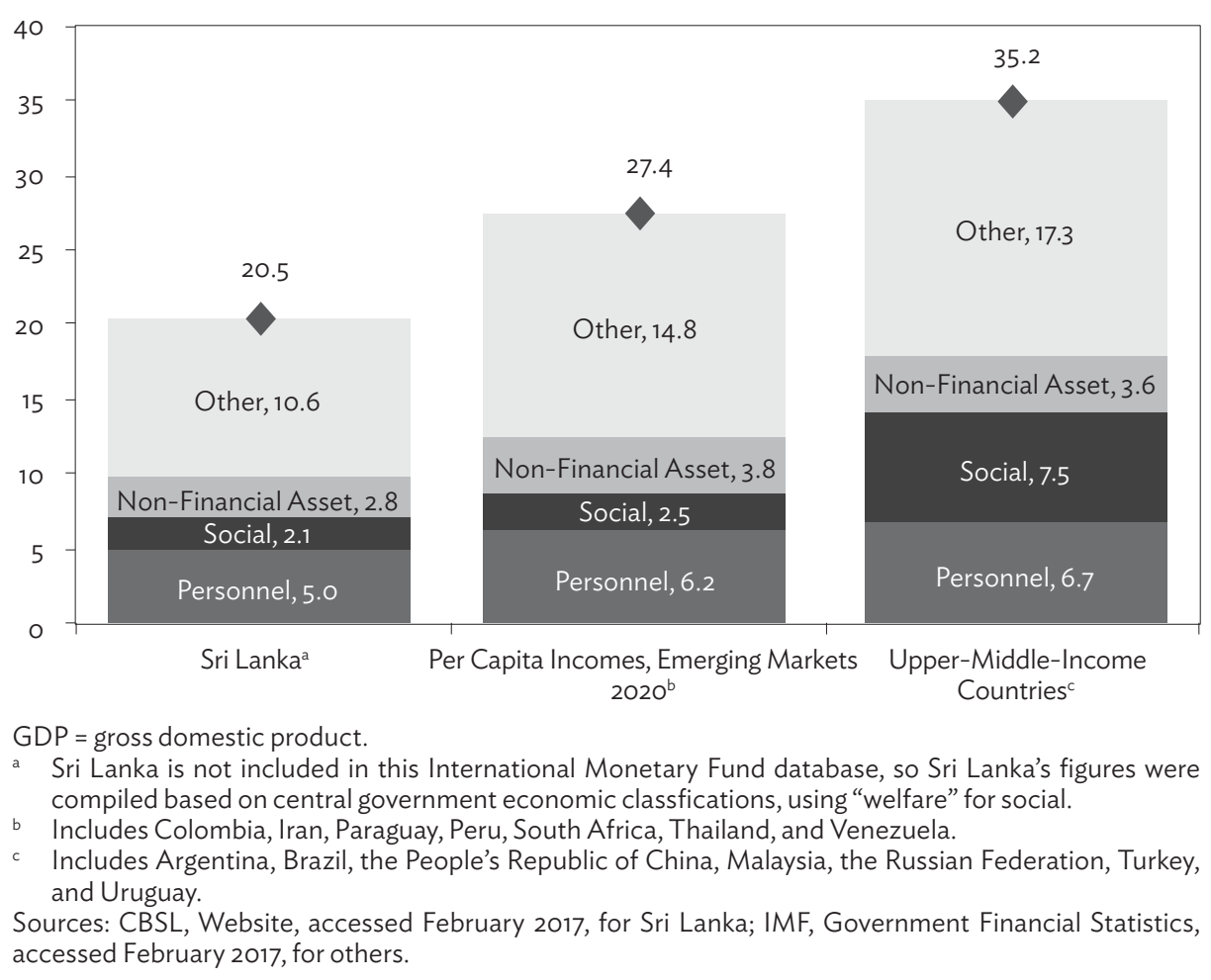

Sri Lanka is expected to face additional spending pressures ahead. The pressures include, most immediately, a need for more and better infrastructure, health, and education spending. There could also be spending pressures and contingent liabilities related to the extensive operations of SOEs unless they are successfully reformed and restructured. In the longer term, Sri Lanka's demographics represent a major fiscal and economic challenge.

Infrastructure needs to keep up with demand and support effective urbanization. Sri Lanka's infrastructure compares well with that of its South Asian neighbors. Progress has also been made on redressing post-war imbalances though a large ramp up of infrastructure spending in the Northern Province. As is well articulated in the Department of National Planning's Public Investment Programme 2017-2020, investment (particularly infrastructure) will need to meet growing demand in areas such as transport, energy, water and sanitation, and housing as a basis for effective urbanization. The Public Investment Programme has gross fixed capital formation increasing by about $1.5 \%$ of GDP to $31.5 \%$ of GDP by 2020 . 
Health and education spending relative to GDP have increased in recent years, but from a low base and remain among the lowest in the region and the world (Figure 2.10). ${ }^{4}$

\section{Figure 2.10: Spending on Public Health and Education}

\section{Figure 2.10a: Spending on Public Health and Education (\% of GDP)}

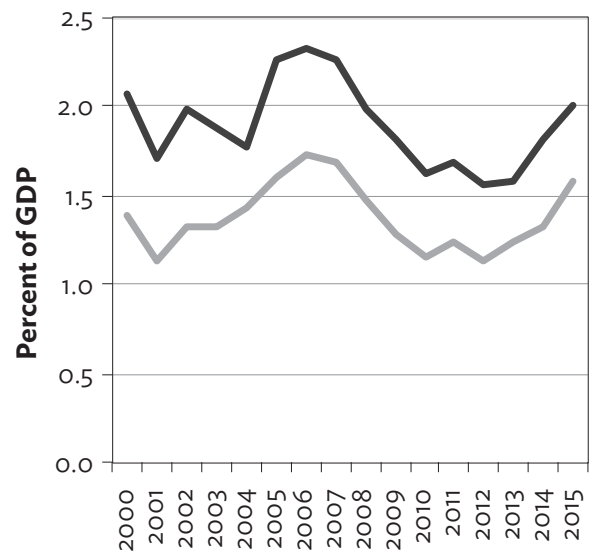

Figure 2.10b: Public Health/ Education Spending

(\% of GDP; average 2010-2014)

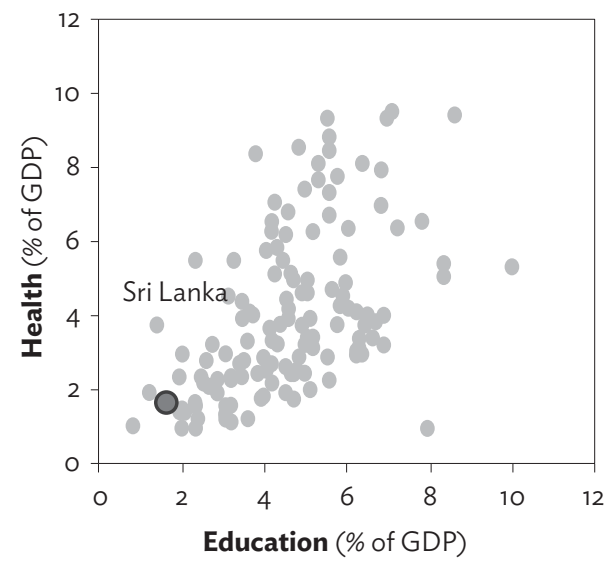

Health (\% of GDP) Education (\% of GDP)

$\mathrm{GDP}=$ gross domestic product.

Sources: For Figure 2.10a, CBSL, Statistics, accessed October 2016; for Figure 2.10b, World Bank, World Development Indicators database, accessed October 2016.

Government expenditures on health and education (as a share of GDP) have declined from their peaks in 2006, likely squeezed by overall fiscal consolidation and the post-conflict prioritization of infrastructure. Sri Lanka's past good record in human development is at risk if low levels of public spending on human capital persist (World Bank 2016). Indeed, as Sri Lanka moves toward upper middle-income levels, the quality of human capital will be increasingly important to maintaining growth and competitiveness.

SOEs are collectively a drain on public finances and a drag on the economy (IMF 2016: 28). While there is some ambiguity about the actual number of SOEs, they accounted for about $17 \%$ of economic activity in 2010 . Some are reasonably

4 World Bank World Development Indicators data are used, and include all countries for which both education and health spending was available during 2010-2014 (or for at least 1 year during that period). 
well run and profitable, but a small number of the largest SOEs account for the bulk of the fiscal and economic problems. Collectively, SOEs are a direct fiscal burden and are indirectly a burden through their funding by state banks and government guarantees. While measures are being taken to address the SOE problems, they are likely to remain a fiscal drain into the medium term. There are increasing fiscal risks related to contingent liabilities and guarantees extended by the government to SOEs. The outstanding amount of Treasury guarantees provided to SOEs and other entities has increased rapidly, from about $1.6 \%$ of GDP in 2006 to $5.7 \%$ in 2014; the share of guarantees related to institutions with stable revenues has declined while that of entities primarily reliant on government funds is on the rise (World Bank 2016). Chapter 6 provides more detailed assessment of the SOEs.

Aging will likely strain public finances in the long run. Sri Lanka is undergoing a demographic transition more akin to that of richer Asian economies than to neighbors in South Asia. Sri Lanka's working-age population as a share of the total population is already declining, the share of elderly is increasing, and the overall working-age population is expected to start to decline in a decade. Thus, Sri Lanka's population is expected to age quickly in the coming decades and the often-cited challenge is for Sri Lanka "to get rich before getting old." Aging will likely add to public expenditure (healthcare, pension, and long-term care); reduce private savings; reduce income tax collection (absent tax reforms); increase the overall deficit and debt servicing costs; and pull down trend growth (absent a productivity boost). The fiscal and broader implications of Sri Lanka's demographic challenge is a huge topic unto itself and beyond the scope of this study (see for example, IPS [2014] for a more detailed look at the implications of Sri Lanka's demographic prospects). Some implications are summarized in Chapter 8 and in World Bank (2016, Chapter 6), which undertakes an illustrative simulation of the long-term fiscal impact of aging. The simulation assumes no tax reform and a policy of bringing public health and education expenditure to levels closer to those in other middle-income countries. This would increase noninterest expenditure from $14 \%$ of GDP in 2013 to $20 \%$ by $2060 .{ }^{5}$ Long-term policy options include increasing the retirement age and broadening the tax base (only $4 \%$ of the working age population pay income tax).

The urgent fiscal challenge is to structurally and substantially boost the revenue ratio. The foregoing analysis clearly indicates policy should focus on boosting revenues to

5 Debt would balloon to $150 \%$ of GDP and interest payment would be a majority of public spending, which is clearly unsustainable. 
- reduce the structural fiscal deficit and create fiscal space for countercyclical fiscal policy in the near term;

- reduce the public debt ratio, fiscal risks, and debt servicing costs; and

- create space (including through lower interest costs/rates) for more and better public expenditure needed in the medium and long term.

Better spending efficiency and effectiveness will have an important role in creating fiscal space and nurturing a tax-paying culture. While overall expenditure is low, there is likely much room to improve expenditure efficiency (i.e., achieve the same outcomes for lower public expenditure) and effectiveness (how expenditure outcomes affect policy objectives such as growth, employment, and poverty reduction). Improved expenditure efficiency and associated more and better public services (together with an information and education campaign) could be expected to boost the willingness to pay taxes.

The government's fiscal reform commitments under the IMF program targets halving the deficit, to $3.5 \%$ of GDP by 2020 , with the revenue ratio increasing to approximately $16 \%$ of GDP (from $13 \%$ in 2015). However, considering the country's large medium- to longer-term fiscal needs to support sustainable growth, a more aggressive medium-term adjustment path is required for a longer adjustment period beyond 2025. The sequencing of reforms appropriately focuses on income tax first (the relatively weakest area); followed by VAT (which has had the biggest deterioration); and then customs and excise (IMF 2016, Box 3). What needs to be done is straightforward and includes the usual suspects of fiscal reforms:

(1) tax policy reform-legislative reform to create a simple, efficient, and fair tax regime focused squarely on raising revenue (requiring a broadening of the tax base and rationalization of the extensive tax expenditures and incentives);

(2) improved tax administration-including through building capacity in revenue administration, shifting to risk-based systems and performance benchmarking, and enhancing efficiency, including through the new information technology system and organizational reforms; and

(3) improving expenditure management-including through boosting expenditure efficiency and allocation, and enhancing expenditure management systems.

Tables 2.1 and 2.2 summarize some of the key measures on the revenue and expenditure side (consistent with the program recommendations) that could deliver the medium-term revenue and consolidation targets. 


\section{Table 2.1: Revenue Reform Options for Narrowing the Policy Gap in the Medium-to-Long Term}

\begin{tabular}{|c|c|}
\hline Revenue Item & Revenue Reform Options \\
\hline Revenue Measures & $\begin{array}{l}\text { Raising } 9 \%-13 \% \text { of GDP is possible based on cross-country analysis, and case studies suggest } \\
0.5 \%-1 \% / \text { year over } 5-10 \text { years is possible with comprehensive revenue reforms. }\end{array}$ \\
\hline $\begin{array}{l}\text { Personal and } \\
\text { Corporate } \\
\text { Income Tax }\end{array}$ & $\begin{array}{l}\text { - Prioritize appropriate new income tax legislation. } \\
\text { - Broaden the revenue base; use a simple tax rate scale. } \\
\text { - Improve tax administration (adopt risk-based administration, performance } \\
\text { indicators, new ICT system, web-based filings). } \\
\text { - Catalogue and remove tax expenditures. } \\
\text { - Rationalize tax incentives: the IMF estimates revenue losses of } 11 \frac{1}{3} \% \text { of GDP related } \\
\text { to corporate profit exemptions in } 2012-2013 \text { (roughly the size of tax collections). }\end{array}$ \\
\hline VAT & $\begin{array}{l}\text { - Target VAT c-efficiency at } 25 \% \text { (roughly half the MIC benchmark), so there } \\
\text { is substantial room to improve VAT collections by removing exemptions and } \\
\text { improving administration. } \\
\text { - Improve the VAT, e.g., repeal ineffective VAT facilities, reduce the threshold, } \\
\text { possibly increase the standard VAT rate after compliance improves, and fold the } \\
\text { National Buildings Tax into VAT. }\end{array}$ \\
\hline Property Taxes & - Strengthen property taxes, which are potentially the most "growth friendly" taxes. \\
\hline $\begin{array}{l}\text { Overall Tax } \\
\text { Administration } \\
\text { Measures }\end{array}$ & $\begin{array}{l}\text { - Use risk-based audit strategies, simplify tax laws, and improve the use of ICT } \\
\text { systems - this can go a long way to improving tax administration. Overall gains can } \\
\text { be large. The program assumes that base-broadening tax policy measures generate } \\
\text { additional revenues of about } 21 / 2 \% \text { during } 2017-2018 \text {; and revenue measures } \\
\text { overall are expected to deliver about } 3 \% \text { of GDP by } 2020 \text {. }\end{array}$ \\
\hline
\end{tabular}

$\mathrm{GDP}=$ gross domestic product, $\mathrm{IMF}=$ International Monetary Fund, ICT = information and communication technology, $\mathrm{MIC}=$ middle-income country, VAT = value-added tax.

Note: $c$-efficiency $=$ VAT revenue $/($ rate $x$ consumption $)$.

Sources: IMF (2015); World Bank (2016).

\section{Table 2.2: Expenditure Reform Options for Narrowing the Policy Gap in the Medium-to-Long Term}

\section{Expenditure Item}

Expenditure Reform Measures

Measures

Subsidies

Personnel Costs

Interest Savings

Defense Spending

\section{Expenditure Reform Options}

An IMF (2015) study finds average inefficiencies in public investment processes in emerging markets of $26 \%$. If this holds for overall government spending, then potential gains from removing one-third to one-half the inefficiency over a decade can be in the range of $2 \%-3 \%$ of GDP alone.

- Remove poorly targeted subsidies (one-third of social transfers go to the richest $60 \%$ of the population - see World Bank [2016]); use targeted transfers.

- Net reduction in public sector numbers by attrition (the 1 million public servants account for about $13 \%$ of the labor force).

- Control the wage bill (allowances are roughly equal to the formal wage bill).

- Fiscal consolidation, lower debt, and lower spreads could reduce the interest burden substantially (by $2 \%$ of GDP if the debt servicing moves to the emerging market average).

- Slow the growth in defense expenditure relative to GDP (toward the $2 \%$ regional average).

Capital Expenditure, - Target substantial efficiency and procurement dividends (including through Goods, and Services electronic government procurement, a commitment record system, and automated commitment control).

GDP = gross domestic product, IMF = International Monetary Fund.

Sources: IMF (2015); World Bank (2016). 
The government's reform priorities under the IMF program rightly couch fiscal adjustment within a broader set of mutually reinforcing reform areas (or "six pillars"). In addition to three fiscal reform areas (consolidation, revenue mobilization, and public financial management reform), the other three pillars are state enterprise reform, transition to inflation targeting under a flexible exchange rate regime, and reforms in the trade and investment regime. This broader set of structural reforms should improve macroeconomic stability, reduce the debt servicing burden and external financing needs (thus reducing overall macroeconomic risks and country risk premia), and boost competitiveness and growth. These would help increase the revenue buoyancies and support the consolidation effort.

A revenue-based consolidation that creates space for more and better spending and crowds in private investment can help offset growth consequences. A typical concern about aggressive fiscal consolidation is the implications for growth. If the consolidation is revenue based and creates space for more productive and growth-enhancing expenditure (such as on infrastructure, health, and education), and crowds in private investment through lower public funding needs and lower interest rates, then the growth consequences can be minimal. Indeed, Khatri and Kochhar (2002) provide some examples in Asia where substantial fiscal consolidation has been consistent with robust growth. When starting from a high debt level, the main channels include a reduction in the risk premia and thus debt servicing costs, and a reduction in unproductive expenditure and a switch toward productive infrastructure and social expenditure.

Addressing the deeper drivers of the anomalously low tax ratio-and associated weak tax policy and administration-will be important for successfully closing the policy gap in the long run. As discussed, the likely underlying factors include (1) incentive distortions resulting in the relatively extreme deficit bias; and (2) the nexus of institutions, governance, and informality. To the extent that the civil conflict accentuated these factors, the end of the civil war should enhance the prospects to improve in these dimensions.

Sri Lanka would be a good candidate for institutional frameworks that constrain discretion, such as fiscal rules and a fiscal council. Given the role of political-economy-related distortions underlying Sri Lanka's fiscal deficit bias, a revamped and effective fiscal rule together with an independent fiscal council could be effective (the Fiscal Responsibility Management Act was established but then amended in 2013 and has generally not bound fiscal excesses). These frameworks can help by acknowledging that a fiscal problem exists and signaling a commitment to address the problem, and by enhancing transparency and accountability. The frameworks' effectiveness will be commensurate to the extent that (1) they are tailored to addressing the main sources of deficit bias 
(independence will be important in Sri Lanka), and (2) escape clauses and penalties for breaching rules are well designed. Lessons on design and implementation of fiscal rules and councils can be found in Beetsma and Debrun (2016).

A micro (survey-based) empirical study could help to identify determinants of tax gaps in the informal sector and to design tailored policies to address the gaps. For example, the study by Danquah and Osei-Assibey (2016) investigates the determinants of the propensity to pay tax in informal enterprises in Ghana and the factors that explain the tax gap (Appendix A2). The study identifies targeted policies such as increasing financial inclusion (as savings in bank accounts increase the likelihood that the informal enterprise will pay tax) or the need to intensify public education on tax obligations. These findings are likely also relevant for Sri Lanka. Improving the quality and quantity of public services could also be important elements of increasing willingness to pay taxes and reducing informality. This again highlights the direct and broader benefits from improving public efficiency and effectiveness of expenditure.

Improvements in institutions and governance, in line with fiscal reform efforts, will likely be needed to successfully close the revenue gap in the long term. Sri Lanka may have difficulty achieving its long-term revenue potential without substantially reducing informality and, relatedly, improving governance and institutional quality and capacity. Thus, potential "missing links" in Sri Lanka's reform plans are broader institutional and governance reforms.

Successful fiscal reform will depend crucially on political will, ownership, and implementation. The idea that successful tax reforms are rooted in a strong political will to reform is established in several studies (Bird, MartinezVazquez, and Torgler 2004), and indeed a country's tax record likely mirrors its sociopolitical institutions (Davoodi and Grigorian 2007). The importance of political will and implementation to successful reforms were stressed by all key development stakeholders providing inputs to this study. The ability and willingness to undertake difficult reforms might require some shifts in "fundamentals"-which are considered in final section of this chapter.

\subsection{Monetary and Exchange Rate Policy}

Since its establishment in 1950, the Central Bank of Sri Lanka (CBSL) has had price stability as one of its core objectives. Monetary policy, however, also has broader development objectives-to promote growth, employment, and productive use of resources. The CBSL was required to balance both price stability and development objectives. The Monetary Law Act provides a wide range of instruments for monetary management, including reserve requirement, foreign exchange 
operation, interest rate management, and open market operations. To achieve its monetary policy objectives, the CBSL since the 1950s relied a lot on open market operations. Both the bank rate and statutory reserve requirement were used extensively. In the 1960s and 1970s, the CBSL relied on more direct controls (Perera 2016). On the other hand, fiscal policy from 1950s to the 1990s was expansionary, requiring monetary policy to be contractionary to reduce inflationary pressure emanating from fiscal deficit (CBSL 1998). In response to the changing economic environment, the Monetary Law Act was amended in 2002 to streamline the central bank objectives to focus on economic and price stability and financial system stability (CBSL 2005). In conducting monetary policy, the CBSL relies on monetary targeting framework using open market operations and interest rates management. More recently, Sri Lanka's monetary policy framework places greater reliance on market-based policy instruments and the use of market forces to achieve the desired objectives. Currently, the CBSL is progressing toward a flexible inflation targeting and exchange rate regime (IMF 2017).

With the persistent large fiscal deficits discussed above, it is important to understand the relationship between fiscal and monetary outcomes in Sri Lanka. Section 89 of the Monetary Law Act allows the CBSL to provide direct provisional advances to the government expenditure from the consolidated account, but the amount must not exceed $10 \%$ of estimated government revenue for the financial year. The limit aims to avoid excessive monetization of fiscal deficits. In practice, however, as shown in Figure 2.11, the CBSL credit to the government exceeded the $10 \%$ limit for many years. Continued deficit financing over the statutory limit for an extended period of time suggests that the CBSL has been subject to fiscal dominance in conducting its monetary policy (Abeygunawardana 2016). ${ }^{6}$

\section{Figure 2.11: Central Bank of Sri Lanka Budget Financing, 2000-2015 (\%)}

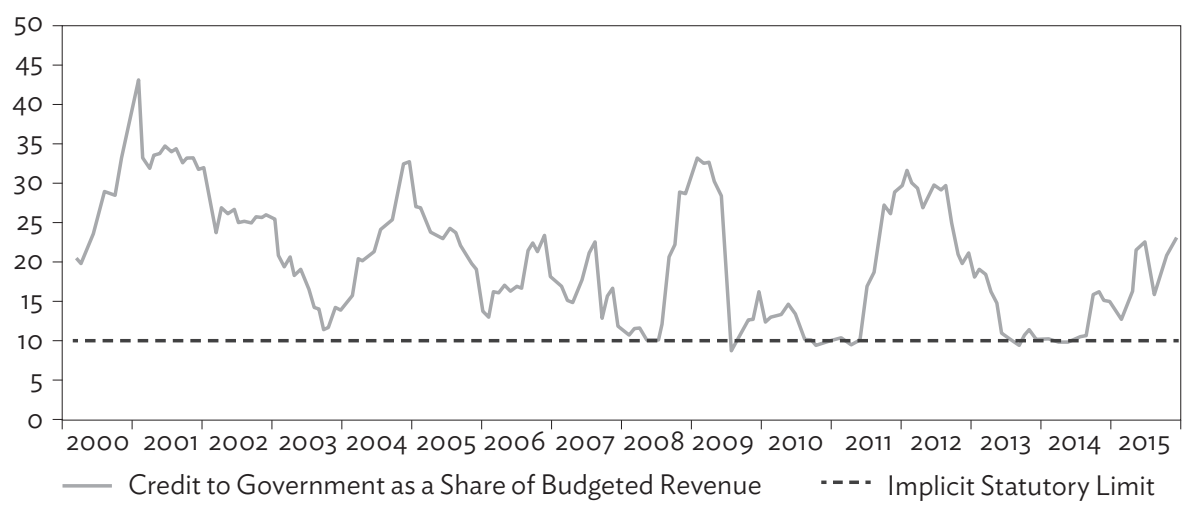

Note: International Monetary Fund disbursements were made in 2001-2003, 2005, and 2009-2012. Source: Based on Abeygunawardana (2016). in domestic monetary operations, whereas the statutory limit is only on provisional advances. 
By allowing the government to receive financing based on estimated revenue, the CBSL has to tolerate the burden of optimistic revenue estimates in the past budgets. As shown in Figure 2.12, revenue performance has been consistently below revenue forecasts in the budget, resulting in larger-thanplanned fiscal deficits. Sri Lanka's continued access to financing from multilateral organizations also may have contributed to the persistent fiscal deficits.

Figure 2.12: General Government Revenue-to-GDP (\%) Medium-Term Forecasts

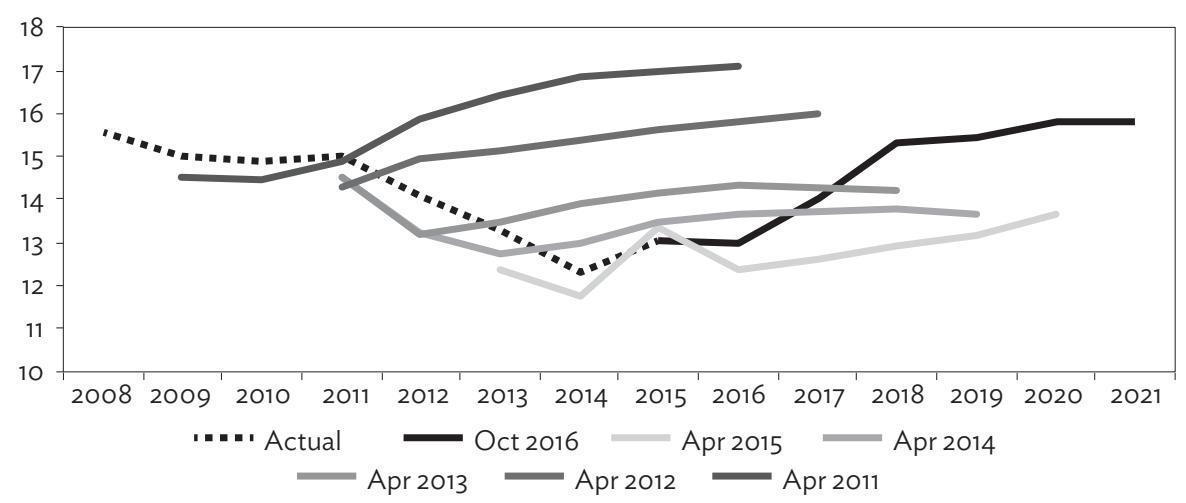

GDP = gross domestic product.

Source: Estimates based on IMF, WEO, accessed October 2016.

Success in managing inflation has been mixed. Inflation, which averaged double digits during the last 3 decades, has remained in single digits in recent years (Figure 2.13). While structural factors in both commodity and labor markets can also contribute to inflation, monetary policy would have a significant

Figure 2.13: Inflation Rate of Sri Lanka, 1953-2015 (\%)

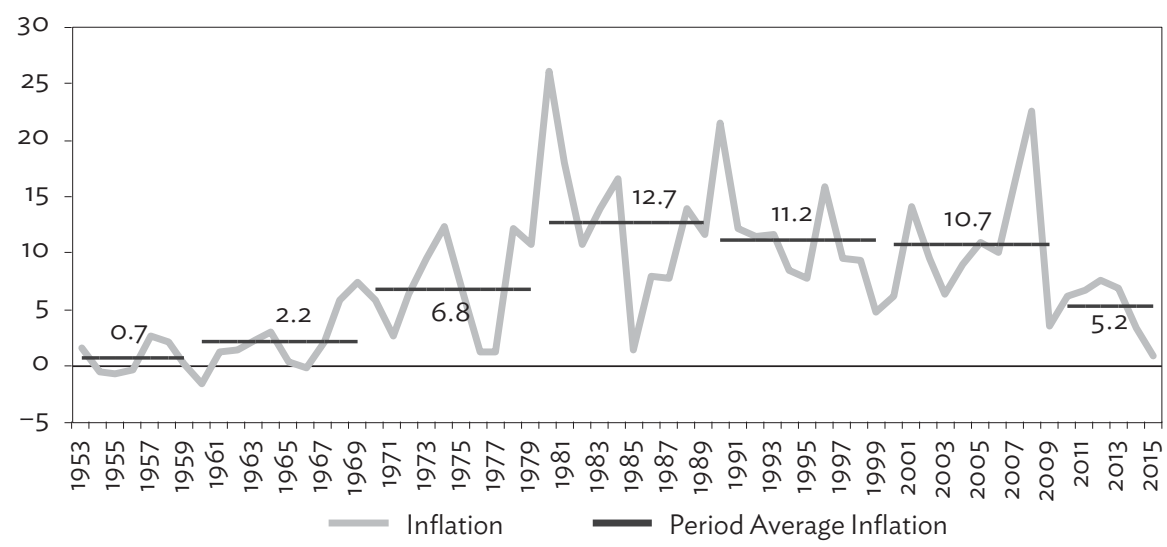

Source: CBSL, Statistics, accessed October 2016. 
contribution. In the context of Sri Lanka, considering the fiscal dominance, fiscal policy also plays an instrumental role in driving inflation. Compared with the neighboring countries, inflation in Sri Lanka was relatively high until recently, likely contributing to the appreciating real exchange rate and declining export competitiveness of key manufacturing exports and other tradable sectors discussed below.

On exchange rate policy, as part of the 1977 liberalization reform package, the dual exchange rate system (in operation since 1968) was abolished and the new unified exchange rate was to be adjusted to reflect foreign exchange market conditions. However, from the first half of 1981, the CBSL gradually deviated from the original plan and started using the nominal exchange rate as an "anchor" to contain inflation. In the face of increased domestic inflationary pressure, originated in a massive public-sector investment program, the CBSL intensified its intervention in the foreign exchange market and the float was eventually abandoned in November 1982. During the rest of the decade, the exchange rate regime remained a quite tightly managed float and the real exchange tended to appreciate, reflecting persistently high domestic inflation relative to that of Sri Lanka's main trading partners (Athukorala and Jayasuriya 1994).

Implementation of a more flexible exchange rate policy was a key element of the second-wave of liberalization reforms. After a sharp depreciation of the rupee against the United States (US) dollar (by 17.4\% in 1989, based on an endof-year comparison), the CBSL continued to adjust the exchange rate daily, responding to developments in the foreign exchange market and keeping an eye on the real exchange rate. During this period, the CBSL actually "leant against the wind" to achieve a greater degree of depreciation than would have been warranted solely by the foreign-exchange market fundamentals. The government had brought the budget deficit under control, backed by a ceasefire negotiated with the Liberation Tigers of Tamil Eelam, and this, together with the increased flexibility in exchange rate management, was successful in avoiding real exchange rate misalignment during the first half of the 1990s (Figure 2.14).

The domestic macroeconomic environment deteriorated in the second half of the 1990s due to the escalating costs of the war. The fiscal deficit rose to $9 \%-10 \%$ of GDP from $5 \%-6 \%$ during the first half, and official reserves dwindled to an alarmingly low level because of slower export growth and speculative capital outflows. In this volatile macroeconomic condition, discussion with the IMF led to the introduction of a floating exchange rate regime in January 2001 as a precursor to a stand-by arrangement signed in April 2001. Nominal exchange rate adjustment under the floating exchange rate regime during the next few years was instrumental in reversing the mild (albeit persistent) appreciation of the real 
Figure 2.14: Sri Lanka: Real Exchange Rate and its Components (2005 = 100), 1970-2015

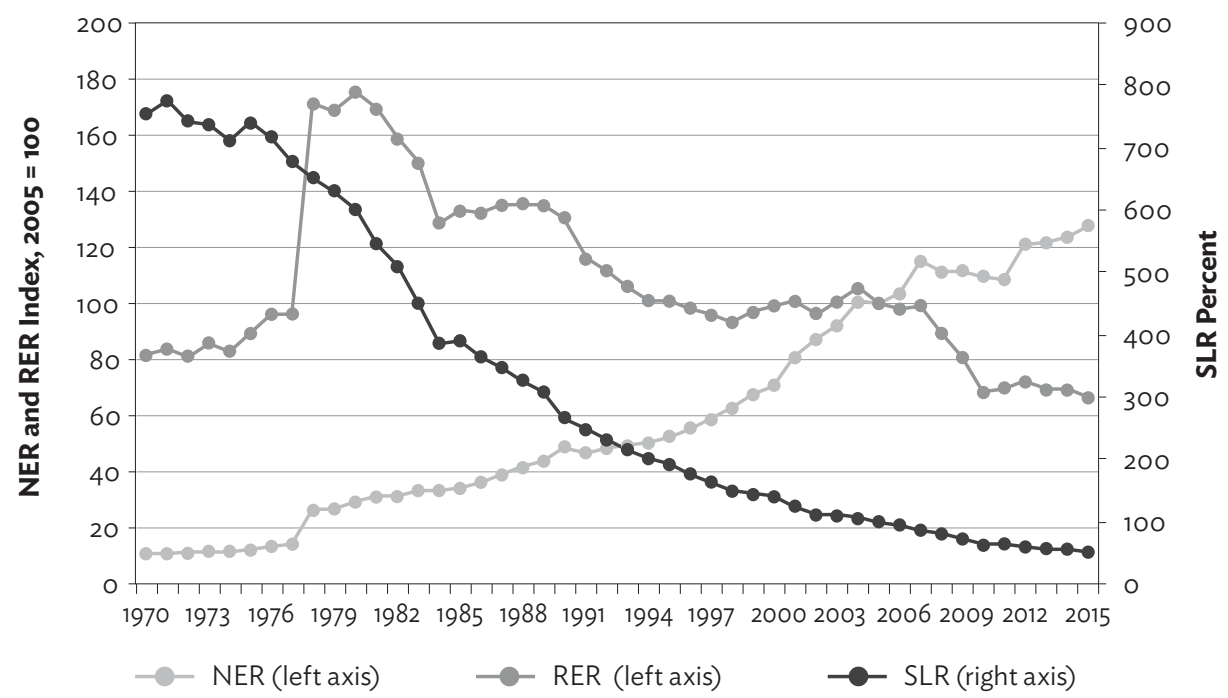

GDP = gross domestic product, NER = nominal exchange rate, $\mathrm{RER}=$ real exchange rate, $\mathrm{SLRe}=$ Sri Lanka rupees . Notes: NER is the export-weighted NER (measured as rupees per foreign currency unit) relating to Sri Lanka's top six manufacturing export destination countries (which together account for over $90 \%$ of the country's total manufacturing exports). RER is NER adjusted for the relative price level of Sri Lanka (measured by the GDP deflator) and the six destination countries (measured by the producer price index). An increase (decrease) in RER shows an improvement (a deterioration) in international competitiveness.

Sources: Compiled from data extracted from World Bank, World Development Indicator database, accessed October 2016; CBSL (various years).

exchange rate during the second half of the 1990s. By 2002, the real exchange rate had regained the levels that existed in 1992-1994. This was the outcome of sharp nominal depreciation that more than counterbalanced relatively high domestic inflation.

During the period from 2006 to 2008, the CBSL maintained a stable nominal exchange rate of the rupee vis-à-vis the US dollar by drawing on foreign reserves and foreign borrowing, including a $\$ 1$ billion sovereign bond issue, in a context where fiscal and monetary policy excesses continued to fuel domestic inflation. By late 2008, the country was on the brink of a balance-of-payments crisis: foreign reserves were approaching alarming levels, external debt was rising, and the CBSL was struggling to meet debt servicing commitments. The government had no alternative but to enter into a stand-by agreement with the IMF. The $\$ 2.5$ billion agreement helped Sri Lanka to avoid a balance-ofpayments crisis, improve investor confidence, and stabilize the exchange rate through further commercial borrowing. But the government failed to adhere to the promised fiscal consolidation under the stand-by agreement. 
In February 2012, in the face of a widening current account deficit and rapid depletion of foreign exchange reserves, the CBSL was forced to abandon foreign exchange market intervention to back up the exchange rate. However, from about the fourth quarter of 2013, the CBSL resumed stabilizing the exchange rate, drawing on foreign exchange reserves built up through sovereign bond issues. The persistent stability of the nominal exchange rate coupled with domestic inflation higher than that of the trading partner countries have resulted in the real exchange rate appreciating by about $22 \%$ during 2005-2014 compared with the previous 5 years, eroding the competitiveness of export-oriented and import-competing production in the economy (Figure 2.14).

In early September 2015, the CBSL allowed greater flexibility in the determination of the exchange rate. Consequently, between the third quarter of 2015 and the second quarter of 2016, the currency depreciated by $6.5 \%$ against the US dollar and $6.0 \%$ in terms of the CBSL 24-currency nominal effective exchange rate index. This translated into a $4.2 \%$ real depreciation (in terms of the 24-currency real exchange rate index) as the nominal depreciation was partly counterbalance by relatively higher domestic inflation. ${ }^{7}$

In 2016, the CBSL was transitioning to a flexible exchange rate regime and inflation targeting. This will require a sustained reform effort over the medium term. Studies suggest that monetary policy transmission in Sri Lanka is weak due to its shallow and developing financial market (Abeygunawardana 2016). Continued reform to deepen both financial and forex markets will be key to sustaining a flexible exchange rate and credible inflation targeting regime. Considering the historical fiscal dominance, a credible fiscal consolidation plan will be instrumental in achieving the CBSL's inflation target.

\subsection{Concluding Remarks}

There is broad consensus on the need for fiscal consolidation, creating fiscal space by boosting revenues to address the fiscal risks and expenditure pressures ahead. This will require introduction of robust tax measures, sustained improvement of tax administration, and other institutional changes. Past fiscal reform efforts to increase the revenue ratio, however, have disappointed. Sri Lanka's revenue ratio has been trending downward for 3 decades despite robust growth. Furthermore, fiscal and structural reform is typically difficult to achieve under the best economic and political circumstances.

7 Calculated from the data reported in CBSL (2016). 
So why will it be different this time? To be convinced that this time is different requires some fundamental changes in the factors underlying the past poor fiscal performance. But there are some reasons to be optimistic.

- The end of the civil war provides an unprecedented opportunity. The war likely exacerbated the factors underlying the declining and low revenue ratio (relating to the deficit bias and the institutionsgovernance-informality nexus). Thus, the end of the conflict should ease the influence of those factors.

- During 2009-2013, Sri Lanka made progress with debt reduction and fiscal consolidation. Although the progress was largely on the expenditure side, the experience will be useful going forward.

- Sri Lanka has no alternative to pursuing fiscal consolidation given its fiscal position. As the country is moving to upper middle-income status, budget financing will come increasingly from market and commercial borrowing. In the face of ratings downgrades, rising fiscal risks, increasing interest rates, and spreads on long-term debt, the business-as-usual option is not sustainable.

- Macroeconomic management has improved considerably as demonstrated by the early positive result of the revenue-based fiscal consolidation effort, more flexible market determined exchange rate, and progress toward flexible inflation targeting.

The progress in cutting unproductive expenditure needs to continue given the requirement for more infrastructure spending and the potential fiscal pressure arising from the country's aging population in the long term. Increased private participation in financing viable urban infrastructure could potentially create fiscal space for other productive spending in the medium term. Improvement in the overall performance of SOEs would reduce the fiscal burden and the government's contingent liabilities.

Considering the fiscal dominance, successful fiscal consolidation is key to managing inflation. But with an increased proportion of government debt coming from the market and interest payment being the largest item of government spending, lower domestic inflation will also directly benefit the government budget through declining interest payments.

Reducing inflation is also key for attracting the significant amount of private investment needed to support higher growth. Empirical evidence has identified a negative relationship between the inflation level and its volatility with GDP growth (Judson and Orphanides 1999). One important channel is through a higher cost of capital. The government's domestic and international borrowing costs are often used as benchmarks for the cost of private sector lending. 
Finally, the economy's deteriorating international competitiveness, as reflected in persistent appreciation in the real exchange rate, has been a key factor behind Sri Lanka's poor performance in manufacturing export (Chapter 4). Even under an optimistic scenario of external financing being available from alternative sources, eventually export expansion is a sine qua non for sustaining robust growth. To expand exports requires macroeconomic adjustments to restore the international competitiveness of the economy by depreciating the real exchange rate. This will, of course, require a substantial nominal depreciation of the rupee. However, given the massive build-up of foreign-currency-denominated government debt, relying solely on exchange rate depreciation would naturally worsen budgetary woes. Also, given the increased exposure of the economy to global capital markets, a large abrupt change in the exchange rate could also shatter investor confidence, triggering capital outflows. Therefore, what is required is a comprehensive policy package encompassing greater exchange rate flexibility and fiscal consolidation through both rationalization of expenditure and widening of the revenue base. 


\section{Appendix A2: Estimating Sri Lanka's Revenue Potential}

Revenue potential can be broadly thought of as the maximum revenue a country can collect. This can be derived based on the country's economic fundamentals (intrinsic economic structure and strength) or based on what is specified by the country's legal framework and thus in tax policy variables (see Khwaja and Iyer 2014).

The tax gap is the difference between the actual revenue and the potential revenue. To the extent that the ambit of the informal economy is an important determinant of the tax potential/gap, estimating its size can be an important input for estimating the tax gap. There are two approaches in the literature to estimating the size of the informal sector as a basis for estimating the tax gap-top down (macro approaches) and bottom up (micro approaches). They are nicely summarized by Danquah and Osei-Assibey (2016). This appendix focuses on direct estimation of the revenue potential rather than via estimates of the informal economy.

Two macro approaches are employed here to estimate the revenue potential/gap based on economic fundamentals in a cross-country framework (see IMF [2013]).

(1) Peer Analysis typically uses a model: $r_{i}=\alpha+\beta^{\prime} x_{i}+\varepsilon_{i}$, where revenue to gross domestic product (GDP) in country $i$ depends on a set of characteristics (typically per capita income plus a wide range of other variable identified in the literature). ${ }^{1}$ The total potential revenue for country $i$ from the fitted equation would then be the fitted value of $r_{i}$ and the difference between the actual and fitted value $\left(\varepsilon_{i}\right)$ would be the estimated additional possible revenue. (This can be done for overall revenue or subcategories of revenues). This approach is represented by the black (fitted) trend line in Figure A2.1. One drawback of the approach is it provides the "average" fit for a given set of country characteristics and not the upper bound of what is possible in terms of the revenue ratio (so some countries are substantially above their "potential" if the fitted line is taken as potential revenue).

(2) The stochastic frontier approach models potential revenue directly using: $\mathrm{ri}=\mathrm{U}\left(\mathrm{z}_{\mathrm{i}}\right) \mathrm{M}\left(\mathrm{x}_{\mathrm{i}}\right) \mathrm{e}^{\mathrm{vi}}$, where $M$ denotes maximum revenue (the gray curved line in Figure A2.1) and $U$ denotes "effort" (actual revenue as a

1 Other potential control variables include old-age dependency, political participation, trade share of GDP, and share of agriculture in GDP. 
share of the maximum revenue, so in the range $0-1$ ), and depends on a set of variables, $z$, which are thought to be largely choice variables and social preferences (e.g., preference for big versus small government). So, while peer analysis finds the best fit (not the maximum revenue), the stochastic frontier approach aims to identify a frontier (maximum) for a given set of fundamentals.

Figure A2.1: Stochastic Frontier and Peer Analysis Approaches to Revenue Potential

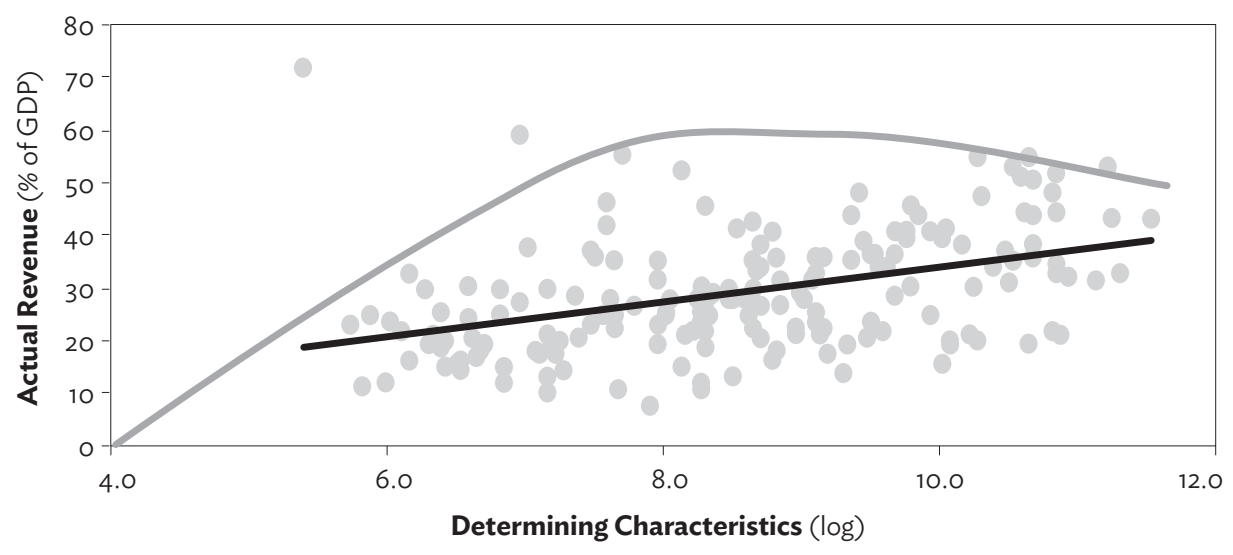

GDP = gross domestic product.

Source: IMF (2013).

The International Monetary Fund provides estimates of tax potential using both the peer analysis and stochastic frontier approaches (IMF 2013). Both approaches are found to yield highly correlated results, and the results are in line with priors and previous studies.

The simple peer analysis in this appendix suggests the potential revenue ratio is at least twice as large as the current actual revenue ratio. The IMF (2013) peer analysis does not report fitted revenue estimates for Sri Lanka so a very simple cross-sessional estimate was generated here based on the equation: $\mathrm{r}_{\mathrm{i}}=\alpha+\beta 1 * \mathrm{x}_{\mathrm{i}}+\beta 2 * \mathrm{x}_{\mathrm{i}}{ }_{\mathrm{i}}+\varepsilon_{\mathrm{i}}$, where $r_{i}=$ revenue-to-GDP ratio for country $i$ in 2015, and $x_{i}=$ per capita income in dollars for country $i$ in 2015 and $x^{2}{ }_{i}=$ square of per capita income in dollars for country $i$ in $2015 .^{2}$ The fitted revenue (revenue adjusted for per capita income) for Sri Lanka is found to be $26.6 \%$ of GDP versus the actual level of $13 \%$ of GDP, suggesting a huge revenue gap of over $13 \%$ of GDP. ${ }^{3}$

All the countries in the IMF WEO database are used, accessed October 2016.

Using just the per capita income variable with the squared term gives an even higher "fitted" revenue ratio of $28.2 \%$ of GDP. 
Using the stochastic frontier approach, Fenochietto and Pessino (2013) report Sri Lanka's tax effort to be around $0.6 \%$ and tax capacity in the range of $20 \%-22 \%$ of GDP versus actual revenue of $12.5 \%$ of GDP (a gap of 9\%-11\%). Fenochietto and Pessino use "tax and pension contributions revenue collected by central and subnational governments as percent of GDP" as the dependent variable and the data are for the year 2011; therefore, the results for Sri Lanka are not strictly comparable to our simple peer analysis above. Given that the revenue ratio has drifted down since 2011 and the economic fundamentals (such as per capita income) that drive the tax capacity estimate have continued to strengthen, the overall tax gap has likely grown since that estimated for 2011. Thus, both the simple peer approach and the stochastic frontier approach suggest Sri Lanka's tax capacity is about double its current revenue ratio.

Informality and corruption (or broader institutional quality) are intuitively linked to the tax effort. The literature finds evidence for this link and flags potential simultaneity and nonlinearity between tax effort, corruption, and the size of the shadow economy (see the discussion and papers cited in Davoodi and Grigorian 2007). Given the complexity, simultaneity, and nonlinearity of these links and the plethora of other variables likely affecting tax effort, it is not surprising that the simple scatter plots in Figure A2.2 find only weak correlations between tax effort (or tax gaps) and corruption and informality indicators. Simple cross-sectional ordinary least squares regressions of tax effort (or tax gaps) from the stochastic frontier and peer analysis on measures of corruption and informality find only the former has any statistical significance. A far more rigorous empirical study (beyond the scope of this chapter) would be needed to properly investigate these relationships.

A micro (bottom up) approach could also be very valuable for understanding the drivers of Sri Lanka's large tax gap and thus which targeted policies could best help boost the revenue ratio. Again, such a study is beyond the scope of this chapter. Danquah and Osei-Assibey (2016) undertake just such a micro (bottom up) study to investigate the implications of informality on the tax gap in Ghana. They use the Ghana Living Standards Survey to (1) identify the determinants of individuals and small (nonfarm) enterprises' propensity to pay tax (using a logit model), and (2) identify the factors that explain the gap using a simple ordinary least squares panel regression. They find the following characteristics significantly increase the propensity to pay tax: male firm owners with at least primary education; and firm-level variables such as sales, bank savings, type of business, urban location, and experience of the firm. The study was thus able to identify targeted policy prescriptions such as the need to intensify public education-particularly for women micro entrepreneurs-on tax responsibilities, and the importance of promoting financial inclusion as a basis for reducing the tax gap. 
Figure A2.2: Correlation Between Tax Effort, Informality, Corruption, and Tax Gap

Figure A2.2a: Tax Effort

(Stochastic Frontier) and

Corruption Perception Index, 2011

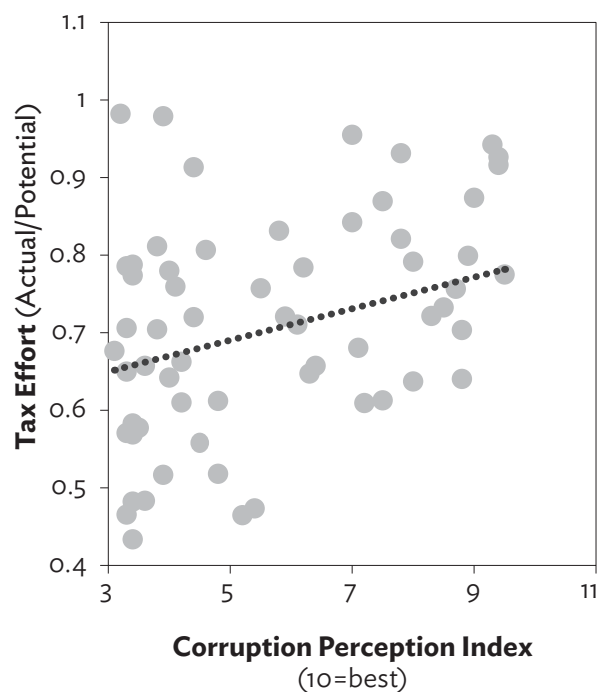

Figure A2.2c: Size of Informal Economy and Tax Gap (Stochastic Frontier)

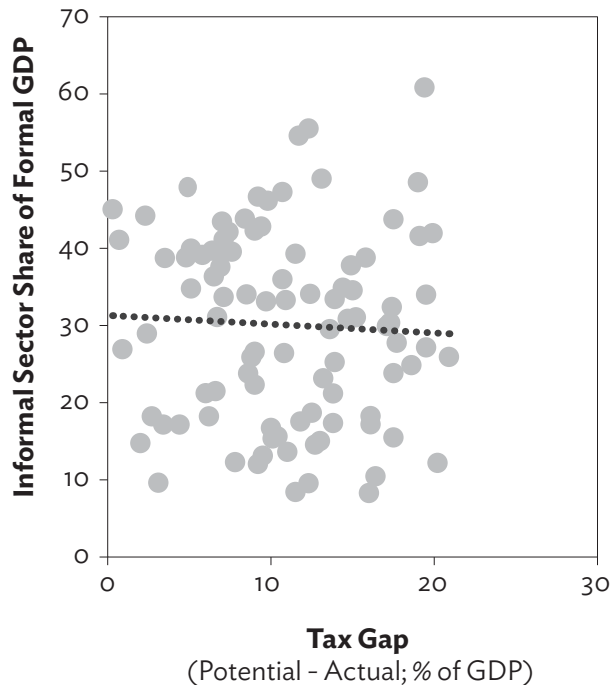

Figure A2.2b: Actual/Fitted Revenue (Peer Analysis) and

Corruption Perception Index 2015

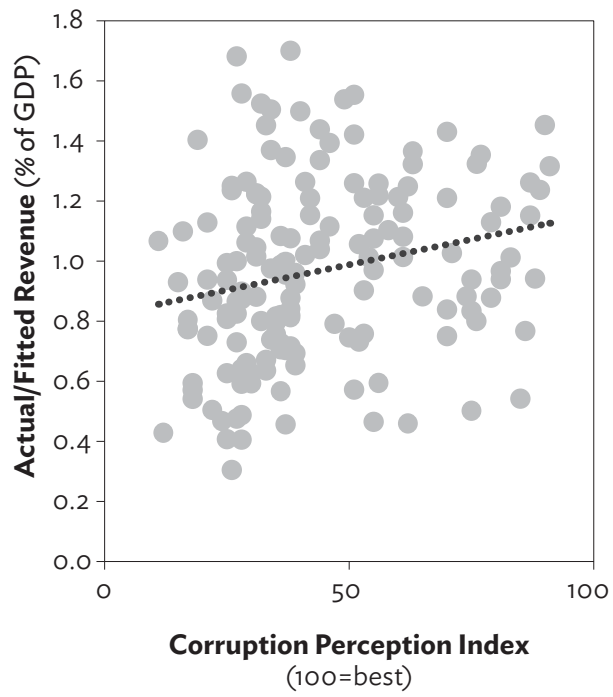

Figure A2.2d: Size of Informal Economy and Tax Gap (Peer Analysis)

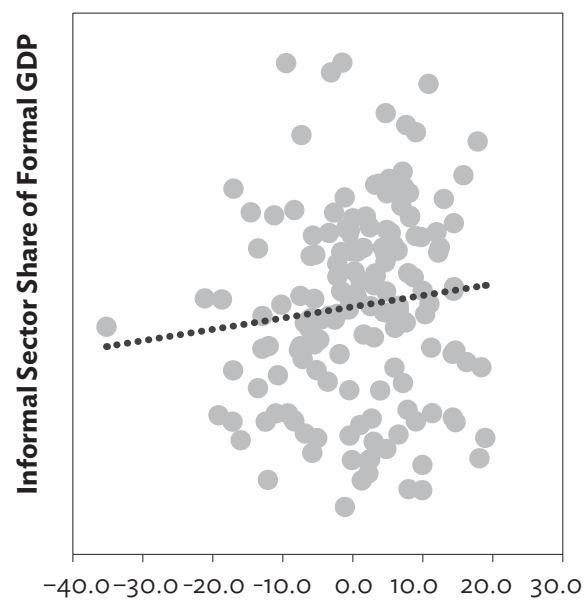

Tax Gap

(Fitted - Actual Revenue; \% of GDP)

Sources: IMF, WEO, accessed October 2016; Transparency International for the Corruption Perception Index, accessed October 2016; Schneider, Buehn, and Montenegro (2010) for estimates of the size of the informal economy. 


\section{References}

Abeygunawardana, K. 2016. Implementing Inflation Targeting in Sri Lanka: The Fiscal Challenge. World Bank Working Paper. October. Washington, D.C.: World Bank. Athukorala, P., and S. Jayasuriya. 1994. Macroeconomic Policies, Crises, and Growth in Sri Lanka, 1969-90. Washington, D.C.: World Bank.

Beetsma, R., and X. Debrun. 2016. Fiscal Rules, Fiscal Councils and All That: Commitment Devices, Signaling Tools or Smokescreens? IMF Working Paper WP/16/86. Washington, D.C.: International Monetary Fund.

Bird, R., J. Martinez-Vazquez, and B. Torgler. 2004. Societal Institutions and Tax Effort in Developing Countries. International Studies Program, Andrew Young School of Policy Studies. Working Paper 04-06: Atlanta: Georgia State University.

Bloomberg. Markets, Rates and Bonds. https://www.bloomberg.com/markets/ratesbonds

Central Bank of Sri Lanka (CBSL). 2016. Monthly Bulletin of Statistics. July. Colombo: CBSL.

1998. Economic Progress of Independent Sri Lanka. Central Bank of Sri Lanka, Colombo.

2005. Objectives, Functions and Organization. Central Bank of Sri Lanka, Colombo.

. various years. Annual Report. Colombo: CBSL. website. http://www.cbsl.gov.lk/index.asp

. Statistics webpage. http://www.cbsl.gov.lk/htm/english/08_stat/s_3.html.

Danquah, M., and E. Osei-Assibey. 2016. Informality and the Tax Gap: A Case of NonFarm Enterprises in Ghana. International Growth Centre Report No: S-33206GHA-1, August. London: International Growth Centre.

Davoodi, H., and D. Grigorian. 2007. Tax Potential vs. Tax Effort: A Cross-Country Analysis of Armenia's Stubbornly Low Tax Collection. IMF Working Paper WP/07/106. Washington, D.C.: International Monetary Fund.

Fenochietto, R., and C. Pessino. 2013. Understanding Countries' Tax Effort. IMF Working Paper 13/244, November. Washington, D.C.: International Monetary Fund.

International Monetary Fund (IMF). 2013. Taxing Times. Fiscal Monitor, October. Washington,D.C.:IMF.https://www.google.com/search?q=IMF,+2013,+\%E2\% 80\%9CTaxing+Times\%E2\%80\%9D,+Fiscal+Monitor,+IMF,+October+2013\&s ourceid=ie7\&rls=com.microsoft:en-US:IE-Address\&ie $=\& o e=\& s a f e=o n \& g w s_{-}$ $\mathrm{rd}=\mathrm{ssl} \# \mathrm{spf}=1$

. 2015. Making Public Investment More Efficient. IMF Staff Report, June. Washington, D.C.: IMF.

2016. Sri Lanka: Staff Report for the 2016 Article IV Consultation and Request for a Three-Year Extended Fund Facility. IMF Country Report No. 16/150. Washington, D.C.: IMF. 
. World Economic Outlook (WEO) database. http://www.imf.org/external/ pubs/ft/weo/2016/02/weodata/index.aspx

. Government Financial Statistics. http://data.imf.org/?sk=388DFA60-1D264ADE-B505-A05A558D9A42, accessed February 2017.

2017. Second Review Under the Extended Arrangement Under the Extended Fund Facility, Request for Waivers of Applicability and Nonobservance of Perfomance Criterion, and Request for Modification of Performance Criterion. WashingtonDC.http://www.imf.org/en/Publications/CR/Issues/2017/08/10/ Sri-Lanka-Second-Review-under-the-Extended-Arrangement-under-theExtended-Fund-Facility-45178

Institute of Policy Studies (IPS). 2013. Sri Lanka: State of the Economy 2012 Report (Theme: Keeping Sri Lanka on the Growth Expressway) October 2013. Colombo: IPS.

. 2014. Economic Impacts of Demographic Ageing with Special Emphasis on Sri Lanka and Old-Age Income Security. Colombo: IPS.

Judson, R. and A. Orphanides. 1999. Inflation, Volatility and Growth. International Finance. 2(1): 117-38.

Khatri, Y., and K. Kochhar. 2002. India: The Fiscal Situation in International Perspective. IMF Country Report No. 02/193, September. Washington, D.C.: IMF.

Khwaja, M., and I. Iyer. (2014). Revenue Potential, Tax Space and Tax Gap, A Comparative Analysis. World Bank Policy Research Working Paper 6868. Washington, D.C.: World Bank. https://openknowledge.worldbank.org/ bitstream/handle/10986/18806/WPS6868.pdf?sequence=1\&isAllowed=y

Perera, A. 2016. Monetary Transmission Mechanism in Sri Lanka: A Comprehensive Assessment with New Evidence. Staff Studies. Volume 43 Numbers 1 and 2. Colombo. Central Bank of Sri Lanka.

Schneider, F., A. Buehn, and C. Montenegro. 2010. Shadow Economies All over the World New Estimates for 162 Countries from 1999 to 2007. World Bank Policy Research Working Paper 5356, July. Washington, D.C.: World Bank.

Tanzi, V. 1987. Quantitative Characteristics of the Tax Systems of Developing Countries. In Newbury and Stern (eds). The Theory of Taxation in Developing Countries. Oxford: Oxford University Press.

Tanzi V., and H. Davoodi. 2000. Corruption, Growth and Public Finances. IMF Working Paper WP/00/182. Washington, D.C.: IMF.

Transparency International. Corruption Perceptions Index 2016. http://www. transparency.org/news/feature/corruption_perceptions_index_2016\#table

World Bank. 2016. Sri Lanka Development Update Fall 2016. Washington, D.C.: World

Bank. http://documents.worldbank.org/curated/en/622841476967944601/ pdf/109372-REVISED-PUBLIC-SLDU-fv9.pdf

. World Development Indicators database. http://databank.worldbank.org/ data/reports.aspx?source=world-development-indicators 


\section{Chapter 3.}

\section{Logistics and Services \\ in the Sri Lankan Economy}

Subhashini Abeysinghe and Sirimal Abeyratne

\subsection{Introduction}

his chapter examines the growth and performance of Sri Lankan services and logistics, and highlights the policy reforms needed to raise their productivity. The chapter commences with a broad overview of the services sector, which is followed by an investigation of one of its most important components, the logistics subsector.

The government has clear priorities for the sector, building on Sri Lanka's locational advantage. The policy documents of successive governments have emphasized the strategy of creating a globally integrated and competitive service hub. The creation of 1 million jobs was a target of the new government elected in 2015. The Economic Policy Statement by Prime Minister Ranil Wickremesinghe in Parliament on 27 October 2016 states that the government plans to make Sri Lanka a logistical and business center in the Indian Ocean (Wickremesinghe 2016: 3). Under the previous policy regime too, the government's main policy document-Mahinda Chintana 2010-envisaged positioning Sri Lanka as a "naval, aviation, commercial, energy and knowledge hub, serving as a key link between the East and West" (Rajapaksa 2010: 9).

Services and logistics are mainly, but not exclusively, nontraded activities. Reform of services and logistics has proceeded relatively slowly in Sri Lanka, as in many countries. First, as nontraded activities, they have not faced the direct competition that liberalization has imposed on the traded goods sectors. Second, the international benchmarking of productivity and efficiency exercises-such 
as ease of doing business, competitiveness, and logistics-that are now used to indicate a country's performance are of relative recent origin. Third, much of the sizable Sri Lankan state-owned enterprise (SOE) sector is concentrated in services. As discussed in Chapter 6, political constraints and unionization have slowed the pace of SOE reform, and by extension that of services and logistics.

The traditional view of the services sector was that it would expand relative to the agriculture and industry sectors as a country's per capita income rose. However, many developing countries, Sri Lanka included, have service sectors that, relative to their gross domestic product (GDP), are approaching the size more commonly found in advanced countries. Moreover, crucially, in contrast to the earlier "stages" approach to economic development, modern thinking emphasizes the synergies between the goods sectors and services. Not only are services increasingly traded across international borders, but also what is now termed "service link costs" is a key determinant of the efficiency of the goods sectors. In addition, the distinction between goods and services is increasingly blurred as many goods embody services as part of the final product.

The chapter is organized as follows. Section 3.2 provides a sketch of the services sector, drawing attention to its size, dynamics, international orientation, and major subsectors. Section 3.3, the major part of the chapter, examines the logistics subsector, including its components, international dimensions, and government policies. Section 3.4 outlines an agenda for reforming the logistics subsector, and section 3.5 concludes. The major interrelated themes, as in other chapters, are missed opportunities and the urgency of reform to maintain the recent growth momentum.

\subsection{Services}

\subsubsection{Sri Lanka's Changing Economic Structure}

Sri Lanka has experienced the conventional process of structural change, resulting in a declining share of agriculture and rising shares of both industry and services. The share of the services sector has risen quickly, and since around 2005 it has generated almost $60 \%$ of GDP (Figure 3.1 and Table 3.1). A similar transformation has occurred in the labor market, with services employing over $45 \%$ of the workforce in 2015 (Figure 3.2). The data also indicate that labor productivity in services is about $25 \%$ higher than the economy-wide average. 
Figure 3.1: Structural Change in Output, Selected Years, 1980-2015 (\%)

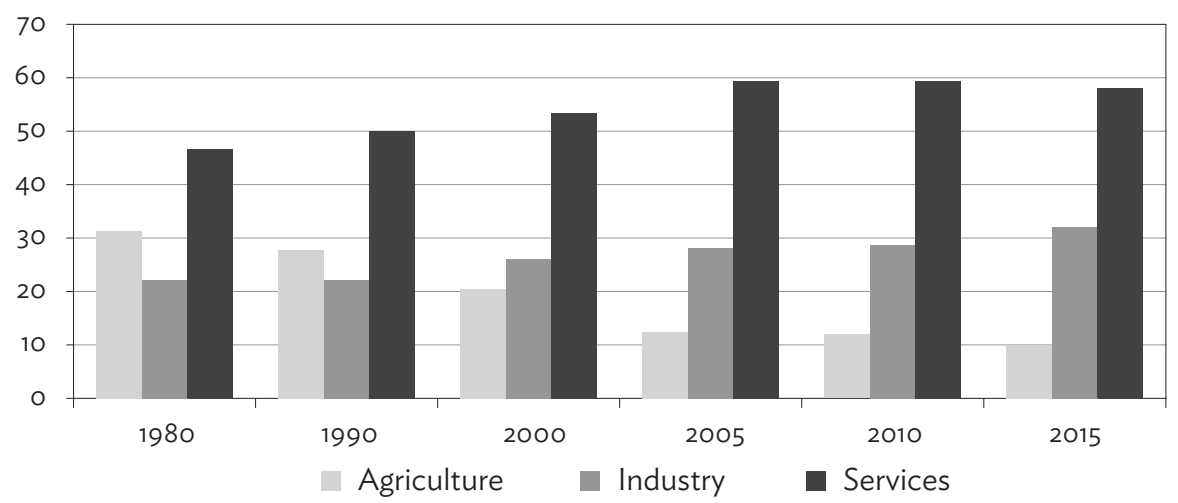

Source: Data from CBSL website.

Table 3.1: Average Annual Rate of Real GDP Growth (\%)

\begin{tabular}{lccccc} 
Years & Agriculture & Industry & Services & GDP \\
\hline $1981-1985$ & 4.6 & 2.9 & 6.2 & 5.2 \\
\hline $1986-1990$ & 1.2 & 5.3 & 3.3 & 3.4 \\
\hline $1991-1995$ & 2.3 & 7.2 & 5.6 & 5.4 \\
\hline $1996-2000$ & 1.4 & 6.3 & 5.8 & 5.0 \\
\hline $2001-2005$ & 0.5 & 3.4 & 5.2 & 4.0 \\
\hline $2006-2010$ & 5.5 & 6.9 & 6.4 & 6.4 \\
\hline $2011-2015$ & 3.3 & 9.3 & 6.5 & 7.0 \\
\hline
\end{tabular}

GDP = gross domestic product.

Source: Data from CBSL website.

Figure 3.2: Structural Change in Employment, Selected Years, 1981-2015 (\%)

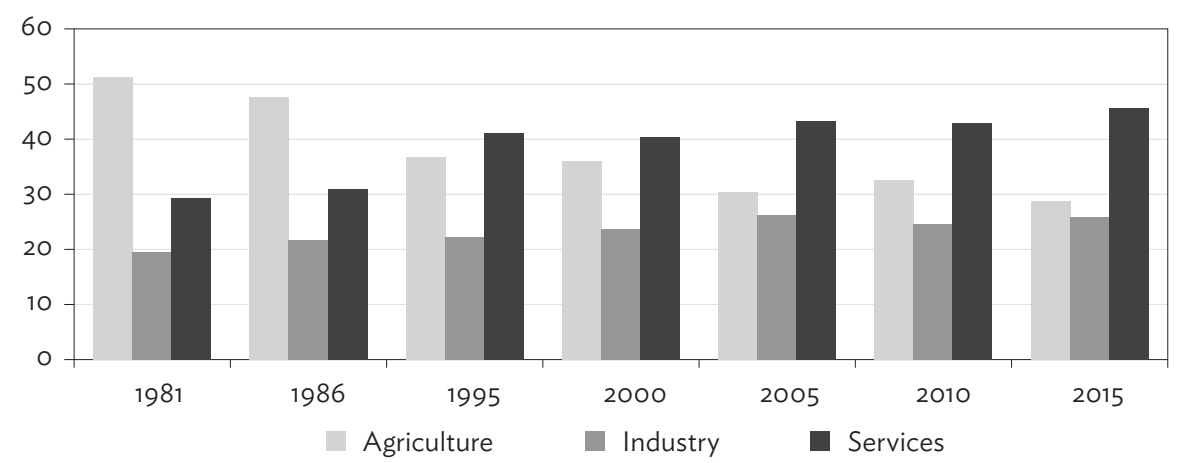

Source: DCS website. 
In fact, the share of services in the Sri Lankan economy is high by regional standards. In 2014, for example, the Sri Lankan share was 7 percentage points higher than the South Asian average and 13 percentage points higher than that for East Asia and the Pacific, excluding high-income economies (Table 3.2).

\section{Table 3.2: Value Added by Industry and Service Sectors, Selected Asian Economies}

\begin{tabular}{|c|c|c|c|c|c|}
\hline \multirow[b]{2}{*}{ Economy } & \multicolumn{2}{|c|}{$\begin{array}{l}\text { Value Added Share of } \\
\text { GDP, } 2014(\%)\end{array}$} & \multicolumn{3}{|c|}{$\begin{array}{l}\text { Average Annual Growth Rate, } \\
\text { 2005-2014 (\%) }\end{array}$} \\
\hline & Industry & Services & Industry & Services & GDP \\
\hline Bangladesh & 27.6 & 56.3 & 8.4 & 6.0 & 6.2 \\
\hline India & 30.0 & 52.6 & 7.2 & 9.4 & 7.6 \\
\hline Nepal & 15.6 & 50.7 & 3.3 & 5.3 & 4.3 \\
\hline Pakistan & 20.9 & 54.1 & 4.3 & 4.8 & 4.0 \\
\hline Sri Lanka & 30.6 & 60.8 & 6.8 & 6.7 & 6.4 \\
\hline South Asia & 28.8 & 53.2 & 7.0 & 8.7 & 7.1 \\
\hline China, People's Republic of & 42.7 & 48.1 & 10.7 & 10.6 & 10.0 \\
\hline Malaysia & 40.0 & 51.2 & 3.0 & 7.2 & 4.9 \\
\hline Thailand & 36.9 & 52.7 & 3.2 & 4.1 & 3.5 \\
\hline Singapore & 24.9 & 75.0 & 6.5 & 6.0 & 6.0 \\
\hline $\begin{array}{l}\text { East Asia and the Pacific } \\
\text { (excluding high-income } \\
\text { countries) }\end{array}$ & 41.7 & 48.1 & 9.2 & 9.5 & 8.8 \\
\hline
\end{tabular}

$\mathrm{GDP}=$ gross domestic product.

Source: Data from World Bank, World Development Indicators.

\subsubsection{Major Service Subsectors}

The major service subsectors are domestic trade; passenger and goods transport; and banking, insurance, and real estate (Table 3.3). ${ }^{1}$ Wholesale and retail trade is the largest single subsector, contributing $18 \%$ of GDP in 2015 , about $60 \%$ of it originating in domestic trade. Transport (passenger and goods) is the secondlargest subsector, contributing $12 \%$ of GDP. This is a diverse subsector, but it is dominated by land transport (95\% of the total), reflecting the unimportance of air and sea transport in Sri Lanka's domestic economy. The third-largest subsector is banking, insurance, and real estate, with less than $12 \%$ of GDP. The major subsectors have all grown strongly during the last decade, by at least $6 \%$ per annum.

Table 3.3 includes utilities and construction. However, these subsectors are conventionally included as industrial sector activities, together with mining and manufacturing. 
Table 3.3: Employment Share in Industry and Service Sectors, Selected Asian Economies (\% of total employment)

\begin{tabular}{lccc} 
Economy & Industry & Services & Year \\
\hline Bangladesh & 17.7 & 35.3 & 2010 \\
\hline India & 21.5 & 28.7 & 2013 \\
\hline Nepal & 11.2 & 22.4 & 2013 \\
\hline Pakistan & 22.5 & 34.0 & 2014 \\
\hline Sri Lanka & 25.5 & 43.4 & 2014 \\
\hline South Asia & $\mathbf{2 1 . 4}$ & $\mathbf{2 9 . 3}$ & $\mathbf{2 0 1 3}$ \\
\hline China, People's Republic of & 46.9 & 47.0 & 2011 \\
\hline Malaysia & 27.4 & 60.3 & 2014 \\
\hline Thailand & 20.3 & 37.5 & 2013 \\
\hline Singapore & 28.3 & 70.6 & 2014 \\
\hline East Asia and Pacific & $\mathbf{4 1 . 2}$ & $\mathbf{4 6 . 6}$ & $\mathbf{2 0 1 1}$ \\
\hline (excluding high-income countries) & & & \\
\hline
\end{tabular}

Source: Data from World Bank, World Development Indicators.

In addition, some of the smaller subsectors have been growing very quickly. Notable among these are hotels and restaurants, and post and telecommunications, both accounting for less than $1 \%$ of GDP but both growing at about $13 \%$ per annum. The revival of tourism as the security situation has improved after 2009 is a key driver of growth in hotels and restaurants. Tourist arrivals have increased fourfold from less than half a million in 2009 to nearly 1.8 million by 2015, while tourism's earnings have increased twelvefold in the same period, from $\$ 252$ million to $\$ 2.98$ billion. (Figure 3.3 compares Sri Lanka's share of service sector value added in GDP with that of South Asia and of East Asia and the Pacific.) The rapid growth of telecommunication has been driven by a combination of policy liberalizations and technological innovations, and by a decrease of disruptions caused by security problems. Nevertheless, telecommunication usage remains modest: cellular phone penetration was 116 per 1,000 persons in 2015, and only an estimated $12 \%$ of households use the internet.

Government and private services have grown at about the same rate as the economy, somewhat slower in the case of government services, which make up $7.5 \%$ of GDP. Much of the increase is explained by the growth in public sector employment rather than wage growth. The historically strong commitment to public education and health has been constrained for much of the recent period by the tight fiscal situation. 
Figure 3.3: Share of Service Sector Value Added in GDP: Sri Lanka in the Regional Context, 1990-2014 (\%)

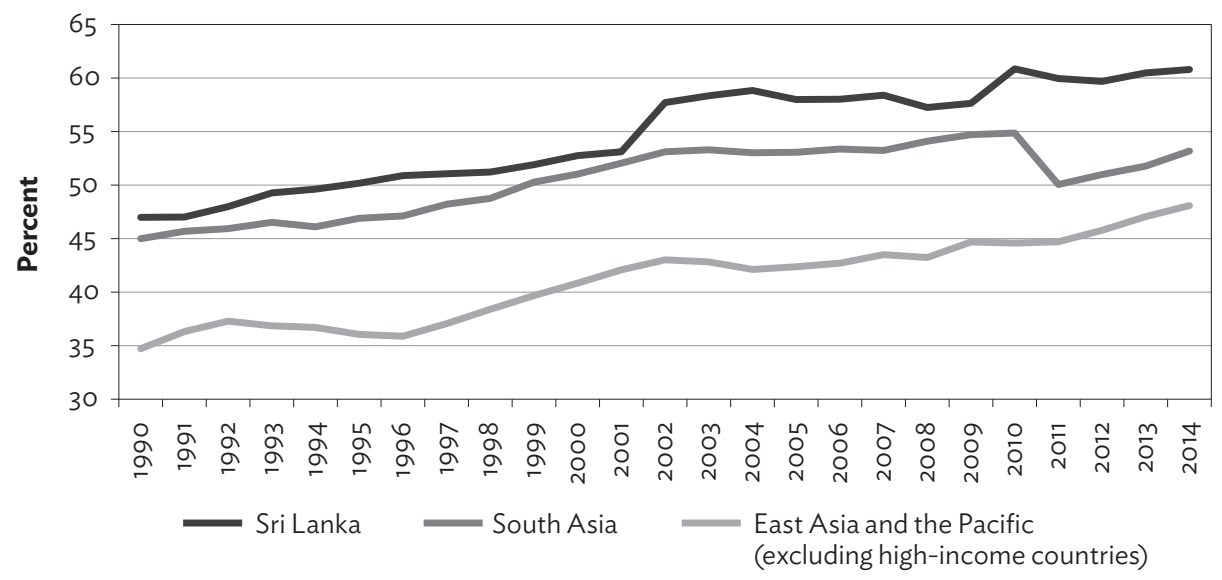

$\mathrm{GDP}=$ gross domestic product.

Source: Data from World Bank, World Development Indicators.

Meanwhile, service exports have been growing strongly in recent years, faster than merchandise exports. Services now account for one-third of total exports, up from about $20 \%$ a decade ago. Travel accounts for almost half of service exports, with tourism a key factor, as noted.

With regard to employment, of 8.5 million people employed in the fourth quarter of 2015, wholesale and retail trade, and repair of vehicles accounted for the largest share (14.1\%). The next largest subsectors, employing in the range of $6.0 \%$ to $7.5 \%$, were transport, construction, utilities, and public administration. Education and health, which are primarily delivered by the government, employed a further $6.4 \%$.

Although service sector employment has been growing quite strongly and open unemployment is a relatively low $4.3 \%$ of the workforce, unemployment is typically higher among the better-educated people. For example, unemployment is $8.1 \%$ for those with the Advanced Level General Certificate of Education and higher qualifications, but only $2.7 \%$ for those with educational attainment below the Ordinary Level General Certificate of Education. This is one factor behind continuing high levels of foreign employment. The number of people 
gaining foreign employment remains buoyant (Figure 3.4). An interesting feature of recent trends is the decline in the unskilled and housemaid category, from about $80 \%$ of the total in the mid-1990s to less than $60 \%$ currently. The numbers of professional, skilled, and clerical workers have been rising, reflecting limited employment opportunities at home and opening labor markets abroad. Correspondingly, remittances have been growing strongly and are now equivalent to about two-thirds of merchandise exports.

Figure 3.4: Departures for Foreign Employment, 1994-2014

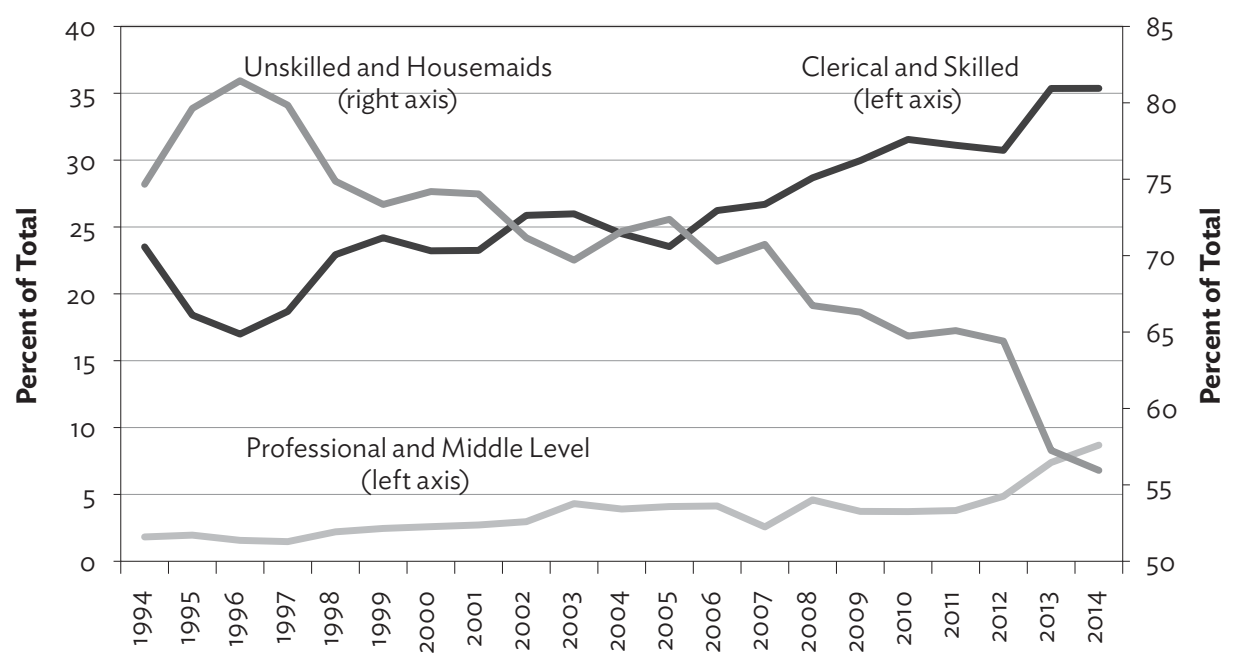

Note: "Percent of Total" = Percent of total departures for foreign employment.

Source: Data from Sri Lanka Bureau of Foreign Employment.

\subsubsection{Policy and Reform Options}

Given the country's strong educational foundations and strategic location, there is much scope for the service sector to be more dynamic, enabled by ongoing policy reform similar to reforms that have been successfully adopted in some of the goods sectors. Three key elements are overall trade liberalization, adjustments of the regulatory arrangements, and decreased government involvement.

First, continue the overall trade liberalization. The reforms of the late 1970s need to be extended and intensified, as discussed in Chapter 4. In turn, an internationally oriented goods sector requires an efficient services sector, so that its service links' costs are competitive. 
Second, liberalize the services sector further. Loosen regulatory barriers and strengthen certain regulatory arrangements, particularly those that ensure competitive and efficient services. Unlike trade barriers, tradable services are typically subject to regulatory barriers both at and behind the borders. This constrains the tradable services' global integration and competition. Moreover, there are often discriminatory regulations between domestic and foreign investments in the same services, thus affecting their costs and market structures.

Third, reduce government involvement in the economy by scaling back public ownership in competitive industries and by reforming SOEs more generally. The private sector needs to face fewer regulatory constraints. Government involvement in service supply increases the market risks of, and imposes additional costs on, the private sector, discouraging both domestic private and foreign investment. Often, government service providers are inefficient, thus imposing additional costs on the private sector. The government role needs to shift from service supplier to facilitator, enabling the private sector to play a more effective role in service supply.

\subsection{Logistics}

The chapter now turns to a detailed examination of the logistics subsector. As noted above, logistics is a significant and diverse component of the services sector, and one where reform is vital to increase Sri Lanka's growth rate and improve its international competitiveness.

\subsubsection{An Overview}

"Logistics management is a supply chain management component that is used to meet customer demands through the planning, control, and implementation of the effective movement and storage of related information, goods, and services from origin to destination. Logistics management helps companies reduce expenses and enhance customer service" (Techopedia website). The services rendered by logistics providers extend beyond the point of consumption. These services, sometimes referred to as "reverse logistics," include after-sale services provided to customers (e.g., repair); waste management; recycling; and transfer to other parties or to the original manufacturer for reuse, remanufacturing, or resale. Logistics services therefore embrace a wide range of interrelated services and providers, across and within borders. 
Logistics efficiency is a critical factor that determines the international competitiveness of a country. As formal trade barriers decline in most countries, the efficiency of logistics provision is often a key determinant of the wedge between international and domestic prices. In many countries, including Sri Lanka, trade liberalization has proceeded more quickly than the regulatory reform that is necessary to ensure that logistics services are comparable to the best international standards. Indeed, the slow reform of logistics services often explains the disappointing outcomes from trade liberalization, and may in turn undermine the reform process.

Technological innovation in the international transport and communication subsectors and in the international organization of production activities, both goods and services, emphasizes the need for efficient logistics services. Global production networks, entailing the fragmentation of production across international borders based on principles of comparative advantage, have developed rapidly in recent decades. Electronic commerce ("e-commerce") is growing rapidly, changing the nature of many internationally traded services.

East Asia has been at the forefront of these changes, while South Asia, including Sri Lanka, has been a relatively minor participant in the goods trade, for reasons discussed in Chapter 4. The international trade in services, facilitated by the rapid growth in e-commerce, has undergone a similar revolution with the advent of business process outsourcing. Here, South Asia has been a major player, led by India. Sri Lanka has also participated in this process, although it could have played a much more significant role given its locational and educational advantages.

The following subsections assess the current status of Sri Lanka's logistics subsector and the impediments to its growth. In turn, this involves examining the components of the logistics value chain, including transport and logistics infrastructure, and the policy, regulatory, and institutional framework. Sri Lanka is compared in a regional and international perspective. This is crucial to the country's reform agenda. Trade liberalization immediately exposes domestic producers to the discipline of import competition. Many of the logistics service providers are in nontraded activities. Therefore, benchmarking against international "best practice" is important. Such an exercise is particularly apposite given the country's proximity to some of the world's most efficient, internationally oriented logistics providers, such as Dubai, Malaysia, and Singapore.

Over time, the types of activities that fall under the ambit of logistics have increased. Traditionally, logistics simply entailed facilitating domestic and international transport and warehousing, which are still the main services 
provided by most of the world's logistics companies (60\%). Now, logistics providers also furnish services such as labeling, packing, quality checking, and managing orders and inventories.

As noted, changes in technology and managerial processes have transformed and elevated the importance of logistics provision. In response to intense competition and to meet increasing consumer demand for lower prices and faster delivery times, global firms have outsourced noncore functions. Such functions include managing inventories, packing, labeling, checking quality, and simple assembly operations, which are now often outsourced to logistics providers (Yang 2014). As noted, the rise of global production networks has accelerated these trends, placing a premium on the efficient transfer of parts and components across international borders. The internet revolution has also spawned the rapid growth of e-commerce.

Logistics services have therefore become an integral and important part of manufacturing globally and a critical determinant of manufacturing and trade competitiveness. The global outsourced logistics market was valued at over $\$ 760$ billion in 2015. The largest region in terms of outsourced logistics market size is Asia and the Pacific, followed by Europe and North America (PRNewswire 2016).

\subsubsection{The Sri Lankan Logistics Subsector}

Sri Lanka enjoys a strategic geographical advantage, given its proximity to the main East-West shipping route, linking East Asia with Africa, Europe, and the East Coast of the United States. Colombo has been a major seaport in Asia since the 14th century, and historically was widely used by merchants from what is now the People's Republic of China as well as India, Persia, and elsewhere. Colombo was ranked the 30th busiest port in the world by the Journal of Commerce in 2014. As India has opened up since the early 1990s, Sri Lanka's locational advantage has been further enhanced.

Colombo is the largest transshipment hub for Indian Subcontinent traffic in the region and handles about $35 \%$ of the subcontinent's total transshipment traffic (Government of Kerala 2015). The distance to key regional ports from Colombo is less than that from other hub ports in the region and thus the time and cost taken to transport goods via Colombo is lower except for Kandla and Karachi from Dubai (Table 3.4). For example, sailing time from Colombo to Chennai is 1-2 days compared with $4-5$ days from Singapore, 6-7 days from 
Salalah, and 7-8 days from Aden (Premaratne 2005). Sri Lanka has untapped potential to expand beyond the Indian Subcontinent, to cater to transshipment traffic from Myanmar as well as East Africa (Espina 2016).

Table 3.4: Distance from Feeder Ports to Colombo and Other Major Hub Competitors (nautical miles)

\begin{tabular}{l|r|r|r|r|c} 
& \multicolumn{5}{c}{ Hub Port } \\
Feeder Port & Aden & Colombo & Dubai & Salalah & Singapore \\
\hline Kolkata & 3,304 & 1,245 & 3,134 & 2,500 & 1,650 \\
\hline Chennai & 2,650 & 590 & 2,359 & 1,840 & 1,586 \\
\hline Chittagong & 3,340 & 1,292 & 3,155 & 2,550 & 1,517 \\
\hline Cochin & 1,850 & 310 & 1,483 & 1,180 & 1,853 \\
\hline Kandla & 1,700 & 1,255 & 907 & 900 & 2,801 \\
\hline Karachi & 1,720 & 1,340 & 453 & 890 & 2,887 \\
\hline Mumbai & 1,657 & 890 & 898 & 950 & 2,435 \\
\hline Tuticorin & 1,925 & 175 & 1,598 & 1,300 & 1,617 \\
\hline Source: & & &
\end{tabular}

Sources: Data from the Colombo Port South Harbor Development Project, Int. Report, Vol. 1, and the Ships Atlas, cited in Premaratne (2005).

Nevertheless, the country's importance as an international logistics hub has declined since the 1950s. More efficient infrastructure providers in the Middle East and Southeast Asia have emerged. A range of factors in Sri Lanka has held back development, including the 30-year conflict lasting until 2009, inward-oriented trade policies, infrastructure bottlenecks, and the regulatory regime. A key policy priority for the government is to regain its earlier advantage as an international logistics hub.

As will be discussed below, Sri Lanka now lags behind the more efficient regional logistics providers. According to the Chartered Institute of Transport and Logistics of Sri Lanka, the country's cost of logistics is as high as $23 \%$ of GDP, compared with the global benchmark of 10\% (Hathiramani 2010). The Sri Lankan figure is higher than most regional economies, including the People's Republic of China at $21 \%$, Malaysia at $13 \%$, Singapore at $8 \%$, the Republic of Korea at 16\%, and Thailand at 20\% (Indonesia Investments 2013; Arumugam 2012). Such high logistics costs undermine the competitiveness of Sri Lanka's trade and industry, a point frequently emphasized by the efficient Sri Lankan textile and garment industry, especially as it strives to position the country as a destination for high-end fashion apparel (Lopez-Azevado and Robertson 2016). 
International Comparisons. A widely used source is the World Bank's Logistics Performance Index. Although the country ranking improved significantly with the end of civil war in 2009, Sri Lanka consistently lags behind all relevant regional comparators (Table 3.5). Furthermore, the Logistics Performance Index comprises six subindexes, each measuring different factors that affect the efficiency of a country's logistics services. Sri Lanka fared poorly in comparison to key competitors in almost all indicators (Table 3.6). The country fares better only in logistics quality competence against Oman and Pakistan, and in tracking and tracing, against Pakistan. Clearly, the reform agenda is a very large one.

Table 3.5: Logistics Performance Index: Selected Countries, Country Rank ${ }^{a}$

\begin{tabular}{lcccccccc} 
Year & India & Malaysia & Oman & Pakistan & Singapore & Sri Lanka & UAE \\
\hline 2010 & 47 & 29 & 60 & 110 & 2 & 137 & 24 \\
\hline 2012 & 46 & 29 & 62 & 71 & 1 & 81 & 17 \\
\hline 2014 & 54 & 25 & 59 & 72 & 5 & 89 & 27 \\
\hline
\end{tabular}

$\mathrm{UAE}=$ United Arab Emirates.

a Sri Lanka was not ranked in the 2016 Logistics Performance Index.

Source: World Bank (2014b), accessed 10 September 2016.

Table 3.6: Logistics Performance, Subindexes, Selected Countries' Rank, 2014

\begin{tabular}{lcccccccc} 
Index & India & Malaysia & Oman & Pakistan & Singapore & Sri Lanka & UAE \\
\hline Customs & 65 & 27 & 74 & 58 & 3 & 84 & 25 \\
\hline Infrastructure & 58 & 26 & 57 & 69 & 2 & 126 & 21 \\
\hline $\begin{array}{l}\text { International } \\
\quad \text { Shipments }\end{array}$ & 44 & 10 & 31 & 56 & 6 & 115 & 43 \\
\hline $\begin{array}{l}\text { Logistics Quality } \\
\quad \text { Competence }\end{array}$ & 52 & 32 & 73 & 75 & 8 & 66 & 31 \\
\hline Tracking and Tracing & 57 & 23 & 80 & 86 & 11 & 85 & 24 \\
\hline Timeliness & 51 & 31 & 67 & 123 & 9 & 85 & 32 \\
\hline
\end{tabular}

$\mathrm{UAE}=$ United Arab Emirates.

Source: World Bank (2014b), accessed 10 September 2016.

The analysis reported in the Global Competitiveness Index 2016 largely confirms the logistics rankings, although Sri Lanka does compare somewhat more favorably (Table 3.7). It lags well behind Malaysia and Singapore, but compares more favorably with South Asian neighbors. For Sri Lanka to reemerge as a major South Asian logistics hub, it needs to significantly outperform its neighbors, especially India, as Singapore has done in the Southeast Asian context. 


\section{Table 3.7: Quality of Infrastructure, Selected Countries' Rank Among 138 Countries}

\begin{tabular}{|c|c|c|c|c|c|c|c|}
\hline Infrastructure & Bangladesh & India & Malaysia & Singapore & $\begin{array}{c}\text { Sri } \\
\text { Lanka }\end{array}$ & Thailand & $\begin{array}{l}\text { Viet } \\
\text { Nam }\end{array}$ \\
\hline $\begin{array}{l}\text { 1. Quality } \\
\text { of Overall } \\
\text { Infrastructure }\end{array}$ & 120 & 51 & 19 & 2 & 55 & 72 & 85 \\
\hline 2. Quality of Roads & 113 & 51 & 20 & 2 & 43 & 60 & 89 \\
\hline $\begin{array}{l}\text { 3. Quality of } \\
\text { Railroad } \\
\text { Infrastructure }\end{array}$ & 72 & 23 & 15 & 5 & 43 & 77 & 52 \\
\hline $\begin{array}{l}\text { 4. Quality of Port } \\
\text { Infrastructure }\end{array}$ & 89 & 48 & 17 & 2 & 60 & 65 & 77 \\
\hline $\begin{array}{l}\text { 5. Quality of } \\
\text { Air Transport } \\
\text { Infrastructure }\end{array}$ & 115 & 63 & 20 & 1 & 58 & 42 & 86 \\
\hline $\begin{array}{l}\text { 6. Available Airline } \\
\text { Seat-Kilometers, } \\
\text { (million/week) }\end{array}$ & 58 & 8 & 23 & 20 & 54 & 15 & 29 \\
\hline
\end{tabular}

Source: WEF (2016) accessed 10 October 2016.

Output. The closest sectoral classification in the national accounts that can be taken as representative of logistics is transport of goods and passengers, including warehousing, ${ }^{2}$ and postal and courier services. In 2015, transport of goods and passengers was valued at $\$ 2.1$ billion and accounted for $10.8 \%$ of GDP, while postal and courier services were valued at just $0.04 \%$ of GDP. In recent years, the transport sector has been growing at about $6 \%$ annually, in line with the economy. About 528,000 people were employed in transport and storage, ${ }^{3}$ or $6 \%$ of the total employed workforce. With regard to exports, in 2015 the value of transport services was $\$ 2$ billion, about half of which was sea and air freight, which generated about $12 \%$ of total service exports.

\subsubsection{Transport Infrastructure}

Transport infrastructure includes seaports, airports, railroads, and roads. They all play a vital role in determining the efficiency and competitiveness of a country's logistics services. They have somewhat different institutional and regulatory characteristics and are therefore reviewed separately. ${ }^{4}$

2 The current published data do not provide data separately for transport of goods and transport of passengers.

3 The International Standard Industrial Classification (ISIC) classification is used when calculating employment. The national account classification measures contribution to GDP. Thus, the two measures are different.

4 Much of the data in this subsection comes from the CBSL (2015), Annual Report, particularly Chapter 3, Economic and Social Infrastructure. 
Seaports. Sri Lanka has four main commercial ports: Colombo on the western coast, Hambantota and Galle on the southern coast, and Trincomalee on the eastern coast. The Port of Colombo is the main international gateway, accounting for over $95 \%$ of the total cargo by volume, and is thus the main focus of this subsection.

As noted, the Port of Colombo's location makes it a natural transshipment hub port for the Indian Subcontinent region. About $75 \%$ of the cargo the port handles is being transshipped in that region. Until 2013, the port's growth was constrained by capacity limits-its two terminals could together handle only 4.7 million twenty-foot equivalent unit (teu) per annum, and its depth could not accommodate new generation mega vessels. Three new terminals are being provided, including with Asian Development Bank funding. The Colombo South Terminal-Colombo's first deep water terminal-has been completed and operational since 2013. The terminal can handle 2.4 million teu. By the end of 2016, the terminal had handled 2 million teu. The terminal operator noted that $70 \%$ of the cargo handled by the port was generated by ultra large and very large container carriers (Colombo International Container Terminals website). The three new terminals are expected to more than double the port's capacity by 2023, to 11.7 million teu per annum.

The facilities of Hambantota Port in Sri Lanka's southern region, are currently underutilized, but its use could increase in the future. It is strategically located within 10 nautical miles of the East-West shipping lane and has received very large People's Republic of China-funded investments.

Airports. Sri Lanka has 2 international and 18 domestic airports. Most of the domestic airports are operated by the Sri Lankan Air Force. Bandaranaike International Airport (BIA) is the main airport serving international passenger and cargo movements. A second international airport, Mattala Airport, commenced operations in 2013 but remains hugely underutilized.

BIA is relatively small by international standards. It is designed to handle 6 million passengers and 250,000 tons of cargo annually. Passenger numbers are growing quickly in response to the dynamism of the tourism sector. The airport reached its designated passenger capacity in 2011. In 2016, BIA handled over 9 million passengers (Rafeek and Hemachandra 2017). Expansion of the airport commenced in 2014, planning to increase BIA's passenger capacity to 15 million per annum by 2019; however, the plan does not include increasing cargo capacity. Discussions to address this were ongoing at the time of writing this chapter.

Land Transport. Sri Lanka's road network density is one of the highest 
in Asia. The present network comprises about 11,700 kilometers $(\mathrm{km})$ of national highways, $15,500 \mathrm{~km}$ of provincial roads, $65,000 \mathrm{~km}$ of local authority roads, and $24,000 \mathrm{~km}$ of roads owned or controlled by irrigation, wildlife, and other authorities (GSL 2007). Work has commenced on a major expressway connecting Colombo to the northern regions through the Central Province (Kandy). Nearly $98 \%$ of total domestic freight is carried by road.

During the last 5 years, the road network has been upgraded by introducing expressways. Three are operating. The Southern Expressway, covering $126 \mathrm{~km}$ from Colombo to Galle, commenced operations in 2011. In 2014 it was extended to Matara, connecting the south of Sri Lanka to Colombo. The Katunayake Expressway (26 km) opened in 2013 and connects Colombo with BIA. The Outer Circular Highway $(19 \mathrm{~km}$ ) is in the Colombo Metropolitan Region. It opened in 2015, and passes through Colombo and Gampaha administrative districts connecting to the Southern Expressway. Work has commenced on a major northern expressway connecting Colombo to the northern regions through the Central Province and Kandy (MOHEH n.d.).

The rail network is underdeveloped. About $90 \%$ of the $1,500 \mathrm{~km}$ of rail is single track, resulting in very slow average speeds of $18-33 \mathrm{~km}$ per hour. Much of the track network needs maintenance. As a result, rail accounts for just $2 \%$ of total freight movements. Plans are slowly proceeding for railway electrification and modernization under the Western Region Megapolis Project. The expansion of the rail network and the Port of Colombo is hampered by land acquisition issues.

In addition to inland container depots, the Western Region Megapolis Project plans to build an "Aero City," a "Logistics City," and a "Logistics Corridor." Multimodal connectivity such as dedicated roads, expressways, and railway links are proposed for freight handling and transport. Industrial clusters are to be developed to accommodate facilities such as transshipment, dry port, warehousing, cold storage, vehicle repair, and cargo distribution. The facilities will also be integrated with the 13 industrial parks and export processing zones managed by the Board of Investment; six of the industrial parks and export processing zones are in the Western Province.

Impediments to Transport. Congestion within and beyond the Port of Colombo continues to be a major problem. "During the peak city hours, it is usual to find about 40 container-laden semi-trailers queuing to leave the port via Gate 6. This is due to police giving priority to city traffic outside the gate and the long time taken by Sri Lanka Customs to clear [fully loaded] containers" (ADB 2012: 24). Approximately 2,300 containers enter and leave the Port of 
Colombo daily (Ministry of Megapolis and Western Region Development n.d.). A similar line of semi-trailers awaits entry to the port at the same time. Congestion is a key problem in transporting cargo between factories and the Port of Colombo and BIA. Currently, only one access road connects the Port of Colombo and Colombo City. The Road Development Authority is planning to alleviate this bottleneck by constructing an elevated port access highway that will run through the port and beyond the current road.

The number of passenger vehicles within Colombo City area is also increasing rapidly, resulting in a significant reduction of vehicular travel speed. A Ministry of Transport survey found that the average speed of vehicles entering Colombo is 13 kilometers per hour $(\mathrm{km} / \mathrm{h})$ from Galle, $16 \mathrm{~km} / \mathrm{h}$ from Negombo, $14 \mathrm{~km} / \mathrm{h}$ from Malabe, and $16 \mathrm{~km} / \mathrm{h}$ from the High Level Road (Lankacnews.com 2014 and MOT 2014). In response to the rising congestion and lower average speeds, transport operators are increasing their charges.

Compounding these problems on the freight side is the absence of central collection or distribution centers for access by rail. The result is double handling of cargo, with cargo being trucked from different locations to the train station at the point of origin and again trucked from the train station to a port or vessel at the point of departure, thereby increasing the cost of transporting cargo via rail. Another significant drawback is the lack of rail linkages to new port terminals in the Port of Colombo. Further, because trucks do not pay road user charges, trucking by road is effectively subsidized. This also makes rail freight a less attractive alternative at present (Kumarage 2004). Stakeholder interviews revealed that the utilization of expressways for trucking remains low; one reason is that truckers consider that the highway toll is too high. Powerful trucking interests are also holding back the transition from road to rail.

Underlying these problems is the absence of long-term network planning. As stated in the National Road Master Plan 2007-2017, the development of roads (and other transport infrastructure) has been mostly reactive to emerging land use and transport patterns (GSL 2007: 3). Two major infrastructure development projects-the Colombo South Harbour Expansion project and the BIA expansion project-demonstrate the impact of weak long-term planning and lack of an integrated approach to transport. For example, the port expansion plan has failed to make the necessary provisions to connect the new terminals at the Port of Colombo via rail to the rest of the country, and the airport passenger expansion plans originally made no provision for increased cargo capacity. 
Interministerial and interagency cooperation and coordination need strengthening. Four ministries are working separately and in parallel in planning the development of transport infrastructure:

- for the Road Master Plan-the Ministry of Transport and Civil Aviation;

- for the Western Region Megapolis Master Plan-the Ministry of Megapolis and Western Region Development;

- for the Port Master Plan-the Ministry of Ports and Shipping; and

- for the Northern Expressway-the Ministry of Higher Education and Highways.

\subsubsection{The Policy, Regulatory, and Institutional Framework}

As noted, policies affecting the logistics subsector's performance are set by several government agencies that are separately responsible for transport, investment, commerce, industry, and customs and border management. The lack of a unified approach to logistics policy can lead to inefficiencies, duplication, and inconsistencies. In other countries, success at coordinating the logistics subsector has been based on developing a national logistics master plan and strategy. For example, the Republic of Korea has been developing comprehensive logistics plans and regulations since the 1990s (ESCAP 2013). The country's performance in terms of cost and time taken to engage in international trade (Table 3.8) demonstrates the success of good planning and execution. The Republic of Korea enacted the Framework Act on Logistics Policies in 2007. The country formulates a National Logistics Master Plan every 5 years, based on the guidelines set by the Act (ESCAP 2013). The other high-performing logistics economies of East Asia have broadly similar approaches. By contrast, Sri Lanka does not have a logistics or a maritime sector policy or strategy in place at present. 
Table 3.8: Trading Across Borders: Performance of Selected Asian Countries

\begin{tabular}{|c|c|c|c|c|c|c|c|c|}
\hline Indicator & India & Indonesia & $\begin{array}{l}\text { Korea, } \\
\text { Rep. of }\end{array}$ & Malaysia & Philippines & Singapore & $\begin{array}{c}\text { Sri } \\
\text { Lanka }\end{array}$ & Thailand \\
\hline \multicolumn{9}{|c|}{$\begin{array}{l}\text { Border } \\
\text { Compliance } \\
\text { Cost }(\$)\end{array}$} \\
\hline Export & 416 & 254 & 185 & 321 & 456 & 335 & 366 & 223 \\
\hline Import & 574 & 383 & 315 & 321 & 580 & 220 & 300 & 233 \\
\hline \multicolumn{9}{|c|}{$\begin{array}{l}\text { Border } \\
\text { Compliance } \\
\text { Time } \\
\text { (hours) }\end{array}$} \\
\hline Export & 109 & 39 & 14 & 20 & 42 & 12 & 43 & 51 \\
\hline Import & 287 & 99 & 6 & 24 & 72 & 35 & 72 & 50 \\
\hline \multicolumn{9}{|c|}{$\begin{array}{l}\text { Documentary } \\
\text { Compliance } \\
\text { Cost }(\$)\end{array}$} \\
\hline Export & 102 & 170 & 11 & 45 & 53 & 37 & 58 & 97 \\
\hline Import & 145 & 160 & 27 & 60 & 50 & 37 & 283 & 43 \\
\hline \multicolumn{9}{|c|}{$\begin{array}{l}\text { Documentary } \\
\text { Compliance } \\
\text { Time } \\
\text { (hours) }\end{array}$} \\
\hline Export & 41 & 72 & 1 & 10 & 72 & 4 & 76 & 11 \\
\hline Import & 63 & 144 & 1 & 10 & 96 & 1 & 58 & 4 \\
\hline
\end{tabular}

Source: World Bank (2014b).

Given the wide scope of activities covered in the logistics subsector, countries usually do not have a dedicated ministry or agency overlooking the subsector. The more common approach has been to create an inclusive publicprivate framework in a national-level committee or council comprising key public and private stakeholders and academics to design and implement logistics policy for the country. Sri Lanka does not have such a council or committee. However, the chambers of commerce have recently initiated committees to address impediments faced by the subsector and propose policies and strategies to the government. An example is the National Agenda Committee on Logistics and Transport set up by the Ceylon Chamber of Commerce. The Committee includes the private sector, public sector officials from relevant organizations, and academics specializing in transport and logistics (CCC 2016a).

Regulations and administrative procedures governing logistics activities have a significant impact on the performance of the logistics subsector. Overly complex administrative procedures and red tape are often obstacles to developing logistics centers. Ad hoc and frequent changes to the import tax regime during the last decade also impact logistics performance. The revisions have resulted in 
the introduction of multiple para tariffs including, for example the Import Cess, the Port and Airport Development Levy, and the Special Commodities Levy, which have increased the level of protection and reduced the transparency and predictability of the import tax regime.

Facilitating trade by enhancing efficiency in the administration and procedures associated with cross-border trade can help improve the efficiency of logistics services. Hence, reducing red tape can significantly enhance the overall performance of the logistics subsector and facilitate value-added logistics services.

Sri Lanka ratified the Trade Facilitation Agreement in May 2016, which was concluded at the World Trade Organization's 2013 Bali Ministerial Conference. The Trade Facilitation Agreement contains provisions for expediting the movement, release, and clearance of goods, including goods in transit. It also sets out measures for effective cooperation between customs and other authorities on trade facilitation and customs compliance issues. The Agreement contains provisions for related technical assistance and capacity building (WTO 2016). Sri Lanka's government is in the process of compiling the commitments it will make as part of this protocol.

Returning to the World Bank's Doing Business Index (Table 3.8), Sri Lanka has consistently fared well compared with India, except for documentary compliance (World Bank 2014a). This creates scope for Sri Lanka to develop as a business-friendly bridge to India and the rest of South Asia. However, as noted the country still lags well behind the most efficient Southeast Asian comparators.

Stakeholder consultations also revealed that the logistics subsector suffers from the lack of regulation in some areas and overregulation in some other areas. For example, most stakeholders interviewed were of the view that trucking and ports and terminal operations are not adequately regulated, impeding the growth and efficiency of the logistics subsector. Trucking in Sri Lanka is fully deregulated. There is no rate regulation and restrictions on vehicle sizes are not adhered to. One assessment noted that, while at the organized corporate level the trucking industry's efficiency is reported to be acceptable, the industry has numerous individually owned trucks that have a multitude of problems, including unroadworthy vehicles and high accident rates (Kumarage 2004: 2).

While proposals have been made to reduce the age limit of imported container trucks to improve the quality of the vehicles and thereby the quality of the services (GSL 2004), the proposals have not yet been implemented. Increasing private sector participation in port terminals has highlighted the need 
for an independent regulator for Sri Lanka's ports. At present, the Sri Lanka Port Authority (SLPA) functions both as a regulator and an operator; this conflict of interest highlights the need for an independent regulator (CCC 2016b).

Sri Lanka Customs suffers from overregulation. Its regulations need to be updated to reflect modern trade practices and use of technology. A key proposal to facilitate modern trade and logistics practices is to amend the Sri Lanka Customs Ordinance, originally enacted in 1869. The Ordinance has been amended several times, but stakeholders note that the current law still fails to address a number of areas. At present, the government is taking measures to amend the existing act (Lanka Business Online 2016).

Sri Lanka introduced Commercial Hub Regulation No. 1 of 2013 to facilitate and encourage value-added logistics activities and to reduce red tape. According to the regulation, companies engaging in entrepot trade, off-shore businesses, front-end services to clients abroad, operations of headquarters, and value-added logistics services are exempted from exchange control, customs, and import and export control regulations. However, the companies have to secure $65 \%$ of their funding from foreign sources and obtain minimum investments ranging from $\$ 3$ million for companies engaging in value-added logistics services to $\$ 5$ million for companies engaging in entrepot trade. Additionally, the activities have to be carried out in areas designated by the regulation as free ports and bonded areas.

Another regulatory barrier highlighted as preventing growth in the logistics subsector and greater participation by global firms is the restriction of foreign ownership in ship agency and freight forwarding services. Per the Gazette Notification issued in 2002 under the Exchange Control Act No. 24 of 1953, foreign ownership of shipping agencies and freight forwarding is restricted to $40 \%$ (Gazette 2002). The commercial hub regulations introduced in 2013, however, remove foreign ownership restrictions on investments in logistics services (such as freight forwarding) provided the firms meet the conditions outlined (such as minimum capital requirements) and operate within designated free ports and bonded areas (Gazette 2013). The associations representing freight forwarding companies have resisted unconditional liberalization of the sector. Ship agency services are still limited to $40 \%$ foreign ownership and the industry is opposing further liberalization of the sector (Daily Financial Times 2015).

Information and communication technology is frequently used to improve the efficiency of border regulations, enhance transparency and accountability, and thereby reduce the time and cost of compliance. Sri Lanka's initiatives in this field date back to the 1990s. The country also started to automate customs functions in the early 1990s. However the results have been mixed. In 2012, Sri Lanka 
Customs launched an initiative to introduce the "Single Window," a facility that enables all parties involved in trade and transport to lodge all necessary trade-related documents and information to be submitted at once at a single entry point to fulfill all trade and regulatory requirements. However, the current Single Window's operations do not meet the criteria of a single window because (1) it has only partly automated the trading process; (2) traders still have to produce hard copies of documents to clear goods; and (3) only a few border agencies are linked to the electronic system, with a majority still being outside it. The stakeholders linked are the traders, customs brokers, transport operators, port operators (e.g., terminals), some banks, and a few border agencies such as the Sri Lanka Tea Board (Lankadeva 2016).

The SLPA started to move toward electronic communications in the mid1980s, much earlier than Sri Lanka Customs. The SLPA commenced developing electronic data interchange activities in 1986 with the maritime information network-MARINET-which came into effect in 1989/1990. All shipping agents involved in container handling were connected electronically with the SLPA through the MARINET system (UN 2003). In 2009, the SLPA purchased a new terminal management system called NAVIS (Wijayasiri and Jayaratne 2009). The new system is web based and several electronic data interchange modules are available to exchange information between the SLPA and agents (Navis.com 2017).

\subsubsection{Regulatory, Policy, and Institutional Impediments}

The current Sri Lankan logistics regulatory arrangements lack harmonization. For example, transport policy and infrastructure development plans for airport, road, and rail connectivity are largely focused on facilitating passenger movement and provide little recognition of the needs of freight movement. Further, because transport infrastructure related to road, rail, sea, and air is developed with little or no communication and coordination between their agencies, the networks fail to facilitate the flow of cargo and passengers. Another example is that trade facilitation initiatives are not recognized as a vital component of better logistics services.

Private sector respondents surveyed complained about the inefficient administration of regulations, fees, and levies imposed and the lack of transparency and accountability. For example, although Sri Lanka generally has the potential to develop entrepot trade with the broader South Asian region and beyond, to do so requires minimal red tape. Cargo that is brought in for entrepot trade and is for re-export should be processed fast with minimum intervention by Customs and should not be subject to duties or levies. However, interviewees noted that the current government procedures and resulting red tape hinder development of the entrepot trade (a view supported by media, e.g., Sunday Times 2013). 
Exporters of perishable goods find the process of checking for regulatory and security compliance time consuming and inefficient. Interviews with the exporters of perishable goods revealed that the goods are checked separately by four different authorities before loading onto aircraft-the Air Force, the National Plant Quarantine Service, Customs, and Sri Lankan cargo. The process of checking, from quarantine until the goods are handed over to the Sri Lankan cargo officials, can take 10-12 hours. Other grievances include inadequate training of agency officials on how to handle perishable cargo, frequent pilferage of items packed for export, lack of surveillance cameras in inspection areas, and lack of temperature controlled areas for inspecting perishable items.

Sri Lanka's potential for increasing value-added logistics services through multi country consolidation (MCC) is considered to be high. MCC is a cost-effective solution that consolidates cargo from different countries of origin to build full container loads. MCC helps companies that import small volumes of goods from multiple countries to take advantage of the more economic freight rates for full container loads (OOCL Logistics website). The Port of Colombo is only in the primary stage of MCC activities, compared with ports in Dubai, Salalah, and Singapore (Gajanayake and Mudunkotuwa 2015). A key competitive disadvantage highlighted by stakeholders and confirmed by research is the relatively high cost of operating MCC operations in Sri Lanka compared to other major MCC hubs in the region, owing to the high levies imposed (Gajanayake and Mudunkotuwa 2015). Moreover, MCC operations are only permitted within the Port of Colombo premises. The space limitations and bureaucratic red tape within the port hinder the development of MCC (Whybrow 2008).

The time and cost taken to demonstrate compliance with border regulations have led to traders increasingly outsourcing this section of the supply chain to logistics companies and clearing and forwarding agents. In effect, the complexity has created a business opportunity. Companies with good access to information and networks offer to assist clients to comply with government regulations. The downside is that the costs of trading are increased by the payments to the clearing agents, which may include "unofficial" payments.

Respondents also complained about the slow progress in introducing paperless trade and the Single Window facility. Evidently, the absence of political will and bureaucratic resistance has stymied progress. International evidence, for example from Malaysia, has demonstrated that the success of a single window facility depends on having an effective mechanism to monitor and evaluate its progress. Sri Lanka currently has no such mechanism. 
Finally, stakeholders interviewed in both the public and private sectors stated that successive governments have introduced policies and regulations that affect the logistics subsector, but have done so with limited or no consultations with stakeholders, including the government agencies delivering the services, while formulating the policies and regulations or before their implementation.

\subsection{Recommendations for Logistics}

Nine recommendations follow from the foregoing analysis.

Devise a master plan and a strategy to develop the logistics subsector. The private sector highlights the lack of a clear policy on maritime and logistics as a key impediment to their development (Kotalwela 2016). A national-level logistics plan and/or strategy will help create synergy between different policies and plans governing aspects of logistics activities. This will help prevent duplication and inconsistencies in the current policy-making process. The overarching purposes of a national logistics plan/strategy are to (1) set out the national priorities and goals for logistics in the short, medium, or long term; and (2) bring together all the key stakeholders, both private and the public, to ensure synergy between different plans and strategies.

Establish a national-level committee on logistics. Logistics-related activities fall under the ambit of several government and private sector stakeholders. The development of a logistics strategy and policy requires continuing dialogue among stakeholders, and their active involvement is important for effective implementation of the strategy. Therefore, a formal national coordination mechanism-a national-level committee or council comprising senior representatives from all key agencies as well as academics-is highly desirable. The committee's or council's objective would be to coordinate and serve as a focal point for policy matters relating to logistics.

Ensure that objectives of city development are integrated into logistics development. To position Colombo to be a key maritime logistics hub in the region, urban plans (e.g., the Western Region Megapolis Plan) aimed at developing a hub need to take measures to integrate the objectives of city development into logistics development and to ensure harmony between city functions and port functions, including logistics centers. This is of particular concern as the Port of Colombo is facing challenges due to unplanned infrastructure development around the port (e.g., congestion within and outside port gates, and scarcity of land to develop into logistics parks). 
Introduce a central data exchange to facilitate seamless flow of information. It is important to fast-track implementation of the Single Window facility. For Sri Lanka to compete with other logistics hubs in the region, the Single Window must ultimately be a central data exchange facility similar to the Republic of Korea's KTNET and Singapore's TradeNet. The experience of other countries clearly demonstrates the benefit of such a system in improving the efficiency of logistics services and reducing the time and cost of conducting cross-border trade. Having a paperless trading environment is important to achieve the government's economic policy objectives.

Introduce regulations to ensure fair competition and standards for service quality. The quality of logistics services can be improved by setting up minimum requirements for entry and regulating the standards of operation. An example is introducing voluntary certification schemes. Many authorities in the region have introduced certification schemes that encourage companies to improve their operations (ESCAP 2013). Such certification signals to the customer that the service provider has been vetted by government authorities and recognized as a company of good standing. To encourage certification, the company is given special benefits such as decreased frequency of inspection; facilitation measures, such as expedited clearance or "green lane" treatment-forgoing physical inspection; high priority when entering public facilities; dedicated officials to work with the company; and high-priority status for participating in other government schemes, such as financial support (ESCAP 2013).

\section{Facilitate greater participation of global leading third-party logistics} providers. The presence of internationally competitive logistics companies is critical in developing a logistics hub. Therefore, logistics policy should encourage and support domestic logistics firms to expand internationally and encourage global logistics firms to expand locally. The experiences of advanced international ports demonstrates that the increased use of third-party logistics service providers is closely related to the successful operation of logistics centers in ports (ESCAP 2002). The presence of global firms in the Port of Colombo's logistics provision would help to enhance its credibility as a logistics hub and encourage global manufacturing firms and retailers to use the Port of Colombo as a center for value-added logistics activities. Removing foreign ownership restrictions alone will not suffice to encourage investments by global third-party logistics providers. Other regulatory and procedural bottlenecks that undermine the ability of private companies to provide high-quality logistics services at a reasonable cost and speed must also be addressed, such as improving the functioning of the public sector apparatus. 
Increase the focus of transport infrastructure development plans on the logistics subsector's needs. Logistics have not been given sufficient attention in plans to develop modes of transport infrastructure, specifically for air, roads, and rail. Plans for the logistics subsector have been largely limited to seaport development. That the planned expansion of BIA's facilities originally failed to take into account and integrate the expansion of cargo facilitates is a serious drawback that needs to be redressed as a matter of priority.

Fast-track implementation of logistics infrastructure. Sri Lanka has several plans in place to develop state-of-the-art logistics parks, cargo villages, dry ports, and inland container depots with good connectivity to seaports and airports. It is important to fast-track the development of these logistics facilities. The world's leading logistics hubs have succeeded because they have up-to-date infrastructure to facilitate value-added logistics services.

Implement far-reaching SOE reform. SOE logistics providers play a very large role in Sri Lanka's logistics subsector. There is nothing wrong in principle with a large SOE presence, as the Singapore experience has demonstrated. However, as shown in Chapter 6 of this book, parts of the Sri Lankan SOE sector are inefficient and resistant to reforms of the sectors in which they operate. The reform of SOEs in logistics will therefore need to be part of a broader SOE reform agenda.

\subsection{Conclusions}

Consistent with the narratives developed in the other chapters of this book, there is great scope for productivity-enhancing reforms in services and logistics, reforms that will both accelerate economic growth and generate improved distributional outcomes. With its well-educated population, Sri Lanka has a latent and thus far underexploited comparative advantage in most service subsectors. The country's strategic location gives it great opportunities to regain its historic status as a key regional and international hub for transport and associated services.

Improved logistics services link directly to, and underpin, the performance of the other sectors and issues examined in this book. More efficient logistics will boost the performance of manufactured exports and of agriculture. Some SOEs are major logistics providers, and reforming them is central to better logistics. Greater efficiency of the state-owned logistics providers will have beneficial fiscal policy effects by reducing their claims on the budget. Efficient mass transit and other key services are essential for efficient and livable cities. 
Better infrastructure is needed for labor markets to operate more effectively, including connecting geographically marginalized workers to the country's commercial mainstream.

More investment is needed in all services subsectors, especially in logistics. Most of this investment will have to come from the private sector, both domestic and international, because many services are better operated by the private sector and to relieve the government's constrained fiscal position. But the government will need to be the key driver of this growth. A clear, credible, and transparent business climate is needed for investors to be comfortable with placing their resources in infrastructure projects, which usually have long gestation periods. Regulatory reform is critical to open up all sectors to the private sector and to ensure that SOEs compete with the private sector on an equal footing. SOE reform will result in increased efficiency and relieve their drain on the government budget.

Some major infrastructure projects-for example, ports, airports, major highways, and telecommunication facilities-have natural monopoly characteristics. In such cases, the government's role is to create arms-length regulatory agencies that protect the national interest. 


\section{References}

Arumugam, M. 2012. The Role and Contribution of the Logistics Sector as a Trade Facilitator. Seminar on Assessing the Contribution of the Maritime Industry to Malaysia's Economy. Kuala Lumpur. 20 July.

Asian Development Bank (ADB). 2012. Sri Lanka Multimodal Transport Report. V1. Mandaluyong City: ADB. https://www.adb.org/sites/default/files/ project-document/81062/41249-022-tacr-01.pdf

Central Bank of Sri Lanka (CBSL). 2015. Annual Report 2015. Colombo: Central Bank of Sri Lanka.

Website. Data. http://www.cbsl.gov.lk

Ceylon Chamber of Commerce (CCC). 2016a. Ceylon Chamber Launches 'National Agenda Committees' to Spur New Thinking on Strategic Economic Issues. Media release.

2016b. Sri Lanka Economic Summit-Insights from Audience Survey. Colombo: CCC.

Colombo International Container Terminals. Website. http://www.cict.lk/ CICT\%20surpasses $\% 202 \% 20 \mathrm{~m} \% 20 \mathrm{TEU} \% 20$ milestone $\% 20$ in $\% 20$ second\%20full\%20year\%20of\%20operation.php

Council of Logistics Management, United States. 1991. Cited in Encyclopedia Britannica. https://global.britannica.com/topic/Council-of-LogisticsManagement

Daily Financial Times. 2015. Outgoing SLFFA Chairman Outlines Challenges Facing Freight Forwarders. 15 July.

Department of Census and Statistics (DCS). http://www.statistics.gov.lk

Espina, K. 2016. Colombo International Container Terminals Seeks 10\% Volume Growth in 2016. Lloyd's List. 20 April.

Gajanayake, H., and M. Mudunkotuwa. 2015. A Study of Developing Colombo Port as a Major Multicountry Consolidation (MCC) Hub in South East Asia Region with the Help of Improving the Effectiveness of the MCC Activities. Proceedings of 8th International Research Conference, 27-28 August, Kotalawela Defense University. p 218.

Gazette of the Democratic Socialist Republic of Sri Lanka (Extraordinary) (Gazette). 2002. Notices under the Exchange Control Act (Chapter 423 of the CLE). No. 1232/14, 19 April. Section 3.

2013. The Finance Act No. 12 of 2012. No. 1818/30. 11 July. Section 7.

Government of Kerala. 2015. Feasibility Report-Development of Vizhinjam International Deepwater Multipurpose Port through PPP. Thiruvananthapuram: Government of Kerala.

Government of Sri Lanka (GSL). 2004. National Ports and Shipping Policy. Colombo: GSL. 
(Ministry of Highways and Road Development). 2007. National Road Master Plan 2007-2017, Executive Summary and Investment Plan. Colombo: GSL. http://www.rda.gov.lk/supported/noticeboard/publications/nrmp_ executiveSummary.pdf

Hathiramani, J. 2010. 23\% of GDP Logistics Costs Resulting in Too-High Cost of Living. Sunday Times. 18 July.

Indonesia Investments. 2013. World Bank: Logistics Costs Reduces Economic Potential of Indonesia. 10 September. http://www.indonesia-investments. com/news/news-columns/world-bank-report-logistic-costs-reduceeconomic-potential-of-indonesia/item1079

Journal of Commerce (JOC). 2014. Top 50 Global Container Ports. http://www. joc.com/port-news/international-ports/joc-top-50-world-containerports_20150820.html

Kotalwela, H. 2016. To Become Logistics Hub, SL Needs to Develop Human Capital: Maritime Professionals. Daily Mirror. 22 August.

Kumarage, A. 2004. Regulatory Impediments to Land Transport Sector in Sri Lanka, Workshop on Regulatory Impact Assessment. Sri Lanka Institute of Policy Studies. Colombo. 22-23 June.

Lanka Business Online. 2015. Full text of Economic Policy Statement made by PM in Parliament. Lanka Business Online, 5 November. http://www. lankabusinessonline.com/full-text-economic-policy-statement-made-bypm-in-parliament

2016. CCC Proposes Amendments to Sri Lanka's Customs Ordinance. 12 September. https://www.wto.org/english/news_e/newsl6_e/ fac_31mayl6_e.htm

Lankacnews.com. 2014. The Speed a Vehicle enters Colombo is $10 \mathrm{KMPH} . .$. Now it's $16 \mathrm{KMPH}$. In VivaLanka.com, 20 March. http://www.vivalanka.com/ newspage/627373ai-the-speed-vehicle-enters-colombo-10-kmph-now-its-16-kmph

Lankadeva, A. 2016. Sri Lanka Customs Single Window. Seminar on Sri Lanka Customs Single Window, Current Status and Future Outlook, National Chamber of Exporters, Colombo, 10 June.

Lopez-Azevado, G., and R. Robertson, eds. 2016. Stitches to Riches? Apparel Employment, Trade and Economic Development in South Asia. Washington D.C.: World Bank.

Ministry of Megapolis and Western Development. n.d. Western Region Megapolis Planning Project, Infrastructure needs, Draft Report, Working Group 03, p. 56.

Ministry of Transport (MOT). 2014. Urban Transport System Development Project for Colombo Metropolitan Region and Suburbs. Technical Report No. 2 Present Road Network and Traffic Condition. Colombo: MOT. http://open jicareport.jica.go.jp/pdf/12176681_02.pdf 
Navis.com. 2017. navis.com/news/in-news/sri-lankas-sagt-goes-live-navisterminal-system (accessed 19 August 2017).

OOCL Logistics. Multi Country Consolidation. http://www.oocllogistics.com/ eng/internationallogistics/multicountryconsolidation/Pages/default.aspx (accessed March 2017).

Premaratne, H. 2005. Can Colombo Port Emerge as Mega Hub of South Asia. 25 February. http://www.skyscrapercity.com/showthread.php?t=184331

PRNewswire. 2016. World Logistics Market 2016 Analysis: Outsourcing, E-Commerce Driving Growth. http://www.prnewswire.com/newsreleases/world-logistics-market-2016-analysis-outsourcing-e-commercedriving-growth-571059941.html

Rajapaksa, M. 2010. Mahinda Chintana: Vision for the Future, Presidential Election 2010. Colombo.

Sri Lanka Bureau of Foreign Employment. http://www.slbfe.lk

Sri Lanka Ports Authority. n.d. Colombo Port Location. http://www.slpa.lk/portcolombo/location

Sunday Times. 2013. Sri Lanka Blows Away Millions of Rupees Owing to Lack of Support for 'Entrepot' Trade. 15 September.

United Nations Economic and Social Commission for Asia and the Pacific (ESCAP). 2002. Commercial Development of Regional Ports as Logistics Centers. Bangkok: ESCAP. p. 61.

2013. Guide to Key Issues in Development of a Logistics Policy. Bangkok: ESCAP.

United Nations (UN). 2003. Initiatives for E-Commerce Capacity-Building of Small and Medium Enterprises, Proceedings and Papers Presented at the Regional Consultative Meeting on Initiatives for E-Commerce Capacity-Building of Small and Medium Enterprises. Seoul. 13-15 November 2002.

Whybrow, S. 2008. We Have the Ingredients, Lack Focus to be Logistics Hub: Ruwan Waidyaratne. The Nation. 27 July.

Wickremesinghe, R. 2016. Hon. Prime Minister's Economic Statement in Parliament on 27th October 2016. Colombo. http://www.pmoffice.gov.lk/ download/press/D00000000053_EN.pdf?p=7

Wijayasiri, J., and S. Jayaratne. 2009. The Impact of Information Technology (IT) in Trade Facilitation on Small and Medium Enterprises (SMEs) in Sri Lanka. Asia Pacific Research and Training Network on Trade. p. 28. https://www.google.de/search?q=Wijayasiri\%2C+J.\%2C+and+S.+Jayaratn e.+2009.+The+Impact+of+Information+Technology+(IT)+in+Trade+Facil itation+on+Small+and+Medium+Enterprises+(SMEs)+in+Sri+Lanka\&trac kid=sp-006

World Bank. 2014a. Doing Business 2015. http://www.doingbusiness.org/reports/ global-reports/doing-business-2015 
2014b. Logistics Performance Index. http://lpi.worldbank.org/ (accessed 10 September 2016).

. World Development Indicators. http://databank.worldbank.org/data/ reports.aspx? source=world-development-indicators

World Economic Forum (WEF). 2016. Global Competitiveness Report 20162017. https://www.weforum.org/reports/the-global-competitivenessreport-2016-2017-1

World Trade Organization (WTO). 2016. News Items. Sri Lanka Ratifies Trade Facilitation Agreement. https://www.wto.org/english/news_e/news16_e/ fac_31mayl6_e.htm

Yang, Xu. 2014. Status of Third Party Logistics, A Comprehensive Review. Journal of Logistics Management. 


\section{Chapter 4.}

\section{Manufacturing}

\section{Exports: Opportunities,}

\section{Achievements,}

and Policy Options

Prema-chandra Athukorala

\subsection{Introduction}

he economic liberalization reforms initiated in 1977 and sustained for the ensuing 3 decades dramatically transformed the economic landscape of

Sri Lanka. The export structure of the economy underwent a remarkable shift from land-intensive, plantation exports to labor-intensive manufacturing, ending the economy's historic dependence on three primary commodities (tea, rubber, and coconut products). Export-oriented manufacturing emerged as the major generator of employment opportunities in the economy, accounting for over half of total employment growth. The Sri Lanka Development Policy Review 2004 noted that "It would be hard to find a more convincing case of trade and industrial transformation of a small island economy through marketfriendly policy reforms" (World Bank 2005: 6).

Notwithstanding the notable economic achievements, backsliding from liberalization reforms commenced in about 2005, and especially following the end of the ethnic conflict in May 2009 (Pursell and Ahsan 2011; Athukorala 2012; Kaminski and Ng 2013). In spite of the official commitment to "moving toward further integrating Sri Lanka into the world economy" (GSL 2010: 53), 
in practice the development strategy began to reemphasize the role of the state in "guiding the markets" with a view to redressing perceived untoward effects of economic globalization. Public enterprise reform was explicitly ruled out, while conspicuously avoiding any reference to trade policy reforms. The policy backsliding, coupled with real exchange rate appreciation underpinned by the emphasis on debt-financed infrastructure development, was reflected in a massive contraction of exports as a share of gross domestic product. Sri Lanka's share in world exports and in exports from developing countries declined sharply. Largely due to the sluggish export performance, the current account deficit widened and the total outstanding external debt almost doubled.

The policy dilemma of Sri Lanka's new regime is how to redirect policy changes to restore the economy's international competitiveness and to contain debt dependency. The purpose of this chapter is to inform the policy debate by specifically focusing on trade and investment policy reforms needed to improve the overall investment climate for promoting manufacturing exports and assessing the potential for export expansion. The chapter aims to identify policy priorities for fully exploiting the country's export potential in a rapidly changing global context in which global production sharing has become the prime mover of cross-border production and trade.

The study is based on data pieced together from secondary sources and information gathered from field research. The secondary sources include unpublished investment approval and monitoring records of the Sri Lanka Board of Investment (BOI); unpublished exporter-level Customs data disaggregated by commodity, destination, and the mode of shipment; the United Nations (UN) Comtrade database; the news clipping collection at the Institute of Policy Studies, Colombo; and company websites. As part of the field research, face-to-face interviews were conducted from 20 June to 7 July in 2016 with top executives of six exporting firms of varying sizes, the Ceylon Chamber of Commerce, the Sri Lanka Export Development Board, the Institute of Policy Studies, and the Ministry of Industry and Commerce. The study also draws on information from interviews with top executives of exporting firms and senior officials of the Joint Apparel Association Forum, conducted in November 2012 and July-August 2013 for an apparel study for the Asian Development Bank.

The chapter is structured in four sections. Section 4.2 provides a typology of the emerging patterns of manufacturing exports from developing countries against the backdrop of the ongoing process of global production sharing and 
the resultant expansion of trade within global production networks, in order to set the stage for the ensuing analysis. Section 4.3 examines trends and compositional changes in exports using disaggregated trade data in order to identify Sri Lanka's achievements in and prospects for integrating into global manufacturing production networks. The role of foreign direct investment (FDI) in the expansion of manufacturing exports is the subject of section 4.4. Section 4.5 presents the results of an econometric analysis of the determinants of manufacturing exports and findings of field research on constraints faced by exporting firms. The final section summarizes the key findings and makes policy recommendations by analyzing the findings in the context of the wider literature on export performance of developing countries.

\subsection{Analytical Framework}

Cross-border dispersion of production processes within vertically integrated global industries, with each country specializing in a particular stage of the production sequence, has been an increasingly important structural feature of economic globalization in recent decades. This phenomenon, termed "global production sharing" in this chapter, ${ }^{1}$ opens up opportunities for countries to participate in a finer international division of labor within given products, instead of producing the product from beginning to end within its national boundaries. Consequently, for the last 4 decades, parts and components, and final assembly traded within global production networks-"interwork trade" or "vertical trade"-have been growing at a much faster rate in world trade than have goods wholly produced within countries-"horizontal trade" (Yeats 2001; Helpman 2011; Athukorala 2014a; Antras 2016). Global production sharing has been the prime mover of a notable structural shift in world manufacturing trade from developed countries to developing countries during the last 4 decades (Krugman 2008).

With the rapid expansion of global production sharing, the conventional approaches to trade pattern analysis, which are based on the conventional trade theoretical assumption that international trade takes place in goods produced entirely (from start to finish) in just one country, have become increasingly irrelevant for understanding emerging export opportunities for developing

Other terms used in the recent international trade literature include international production fragmentation, intraprocess trade, vertical specialization, slicing the value chain, and offshoring. 
countries. ${ }^{2}$ When it comes to analyzing trade patterns of developing countries, this approach is basically relevant only for domestic-resource-based manufacturing and standard consumer goods that are made to local specifications (such as handicrafts), which together account for a shrinking share of total world trade.

In the case of resource-based manufacturing, a country's potential for export expansion is obviously limited by its resource endowment. There are also other constraints on export success in this arena. For example, world demand growth for resource-based manufactures has proved to be much slower than that for the other two product categories. Some processing activities, particularly in the mineral and chemical industries, are characterized by high physical and/or human capital intensity and may not therefore be suitable for location in a low-income country. A further major deterrent is cascading tariff structures in industrialized countries, which still provide heavy effective protection to domestic processing industries. Insecure property rights in resource-rich developing countries also may act as a deterrent to investors in large, capitalintensive projects.

The market potential for goods that are made to local specifications accounts for only a small share of manufactured exports from developing countries. With the rapid expansion of buyer-driven production networks for made-to-order goods, opportunities for traditional labor-intensive products of this nature (e.g., clothing, toys, shoes, and sporting goods) have been rapidly disappearing.

Production sharing enables countries to specialize in a given slice of the production process because parts and components, capital, and production technology are mobile within global production networks. Workers in a given country may tend to have different skills from those in another country, or the skills required in each production block differ (as in the Ricardian model). Alternatively, the production blocks may differ from each other in the proportion of factors required, enabling firms to locate labor-intensive production blocks in countries where productivity-adjusted labor cost is relatively low (as in the Heckscher-Ohlin model). But the ability of a given country to link the value chain does not depend on the availability of labor and relatively low wages alone. Crossborder spread of production activities involves new fixed costs of establishing "services links"-arrangements for connecting and coordinating activities into

2 The most widely used conventional approach to trade flow analysis is the "factor-intensity based" product classification, which divides exports into resource-intensive, skill- and capital-intensive, and labor-intensive categories. In the presence of global production sharing, this classification results in misleading characterization of the export structure, because factor proportions naturally vary among different slices (tasks) of a given product and countries specialize in different slices depending on their relative cost advantage. 
a smooth sequence resulting in the production of the final good. Thus, a whole range of factors impacting the business climate are important in attracting FDI and other mobile inputs (Jones and Kierzkowski 2004; Helpman 2011).

Trade based on global production sharing is, however, not a homogenous phenomenon. In terms of the organizational structure, production networks based on global production sharing take two major forms: buyer-driven production networks and producer-driven production networks. Understanding the difference in the governance structure of the two forms of production networks is vital for formulating policies for linking a country's manufacturing industry into global production networks.

Buyer-driven networks are generally common in diffused-technology based consumer goods industries such as clothing, footwear, travel goods, toys, and handicrafts. In these networks, the "lead firms" in the value chain are international buyers (large retailers such as H\&M, Marks \& Spencer, and WalMart) or brand manufactures (such as Gap, Nike, Victoria's Secret, and Zara). Global production sharing in these networks takes place predominantly through arm's length relationships, with global sourcing companies playing a key role in linking producers and the lead firms. (Global sourcing companies are value chain intermediaries such as the Hong Kong, China-based Li \& Fung, and Mast Industries Far East.) Therefore, there is room for local firms to engage directly in exporting through links established with foreign buyers (Gereffi 1999; Schmitz and Knorringa 2000).

Producer-driven production networks are common in vertically integrated global industries such as electronics, electrical goods, automobiles, and scientific and medical devices. In a producer-driven production network, the "lead firm" is a multinational manufacturing enterprise (such as Apple, Intel, or Motorola). Global production sharing takes place predominantly through the lead firms' global branch network and/or its close operational links with established contract manufacturers. In these high-tech industries, production technology is specific to the lead firm and is closely protected in order to prevent imitations. Also the production of final goods in these industries requires highly customized and specialized parts and components whose quality cannot be verified or assured by a third party; it is not possible to write a contract between the final producer and input supplier that would adequately specify product quality. The bulk of global production sharing, therefore, takes place through intrafirm linkages rather than in an arm's-length manner. However, as the production unit (affiliated company) becomes well established in a given country and forges business links with private- and public-sector agents, arm's length subcontracting arrangements with local firms can develop, leading to upgrading the local firms' technology and management capabilities. 
Mindful of the considerations in this section (and the subsequent section on the role of FDI in export expansion), a classification system is employed that explicitly focuses on export opportunities opened up by global production sharing. For the purpose of the analysis, export data based on this classification system were compiled using trade data at the 5-digit level of the Standard International Trade Classification (SITC). The classification system is discussed in Appendix A4.

\subsection{Export Performance}

During the colonial era, Sri Lanka's export structure relied heavily on a limited range of primary commodities (Snodgrass 1966). The colonial export structure remained virtually unchanged during the first 3 decades of the post-independence period. By 1977, the share of manufacturing (excluding petroleum products) in total exports was only $4 \%$, while the rest came from the traditional tea, rubber, and coconut, and other primary products.

Following the 1977 policy reforms, the export composition shifted from primary products toward manufactured goods. Exports of manufactured goods, in current United States dollar terms, grew at an annual compound rate of over $30 \%$ during $1978-2005$, lifting their share in total exports to over $70 \%$. However, since then the rate of expansion of manufacturing exports has lagged behind that of primary commodity exports, with the share of total exports varying in the range of $70 \%$ to $68 \%$ (Figure 4.1 ).

Figure 4.1: Sri Lanka’s Merchandise Exports, 1965-2014 (\$ billion)

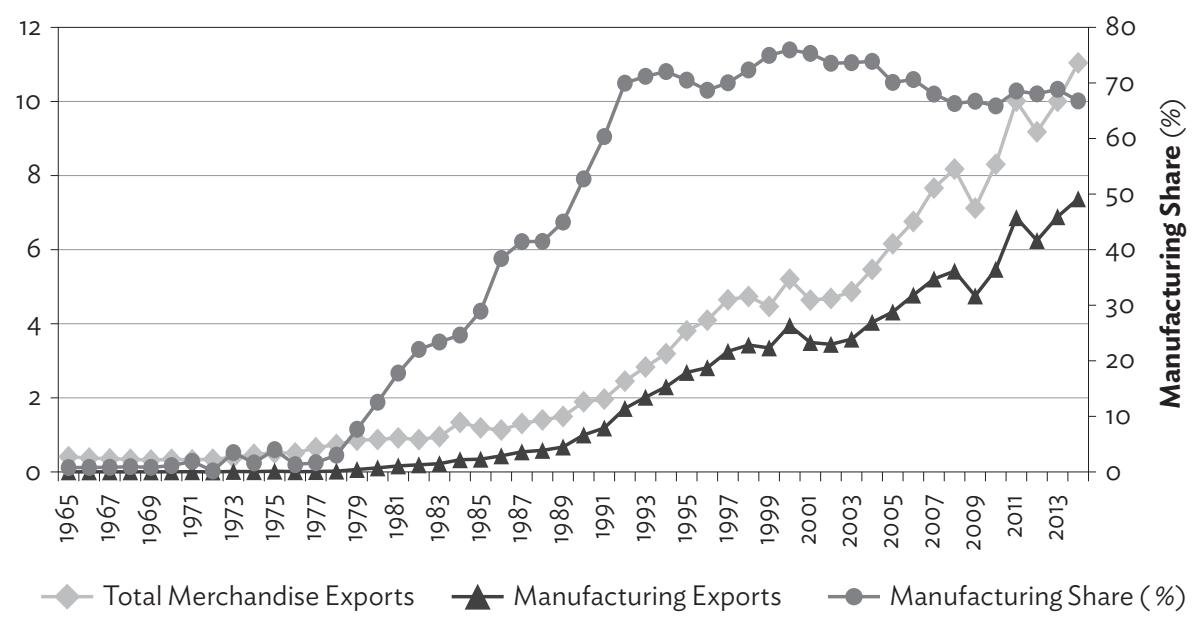

Source: Data compiled from UCTAD World Investment Report database. 
Sri Lanka's share of world manufacturing exports increased from $0.03 \%$ in the mid-1980s to about $0.09 \%$ in 1999 (Figure 4.2), then declined, reverting to the level in the 1980s. This overall pattern suggests that slowing of the export growth during the last 2 decades has been driven primarily by domestic supplyside factors.

Figure 4.2: Sri Lanka's Share of World Non-Oil Exports and Manufacturing Exports, 1988-2014 (\%)

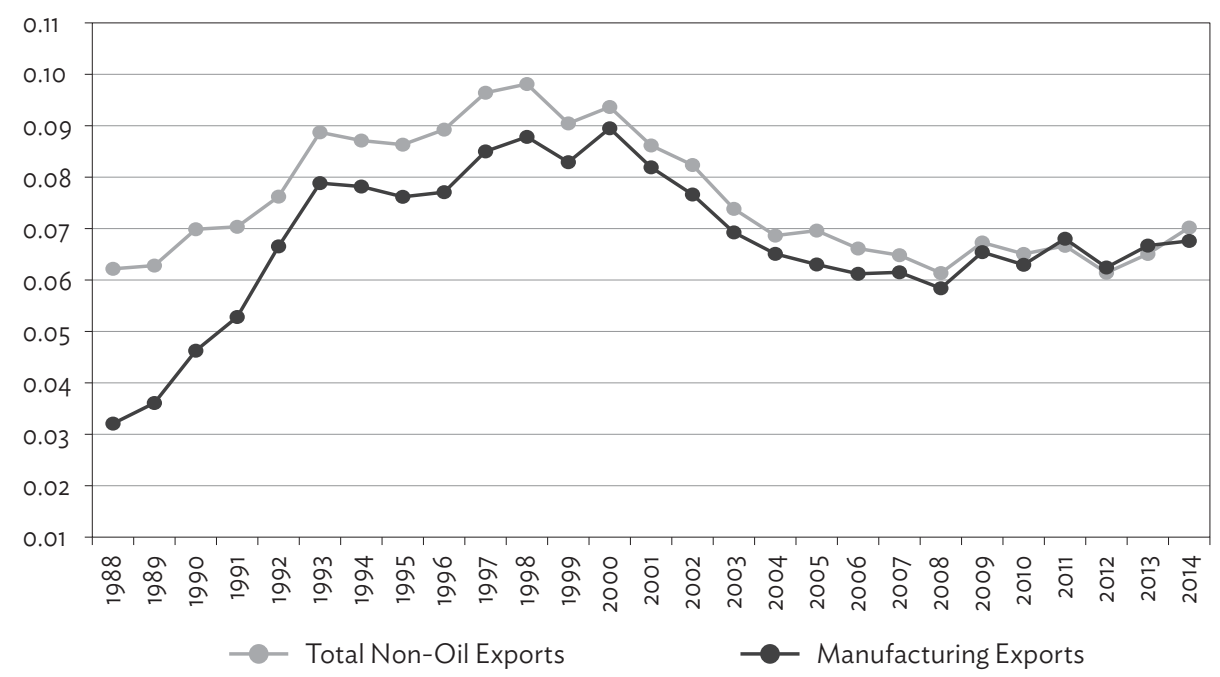

Source: Data compiled from UN Comtrade database.

The percentage composition of manufacturing exports based on this classification is summarized in Table 4.1. Products exported within global production networks (GPNs) account for over three-fourths of total manufacturing exports from Sri Lanka, a figure comparable to the East Asian average (Table 4.2). But, unlike the dynamic exporting countries in East Asia, Sri Lankan GPN exports are heavily concentrated with buyer-driven networks. Within this product category, apparel accounts for the lion's share. There was some diversification since the late 1980s into other labor-intensive products, such as leather goods, footwear, toys, plastic goods, and diamond cutting and jewelry. 
Table 4.1: Sri Lanka: Commodity Composition of Manufacturing Exports (\%, 2-year averages)

\begin{tabular}{|c|c|c|c|c|c|}
\hline \multirow[b]{2}{*}{$\begin{array}{l}\text { Product Group/Product } \\
\text { (SITC coded in brackets) }\end{array}$} & \multicolumn{5}{|c|}{ Year } \\
\hline & $\begin{array}{c}1990- \\
1991\end{array}$ & $\begin{array}{l}2000- \\
2001\end{array}$ & $\begin{array}{c}2005- \\
2006\end{array}$ & $\begin{array}{c}2010- \\
2011\end{array}$ & $\begin{array}{c}2013- \\
2014\end{array}$ \\
\hline GPN Products (buyer-driven + producer-driven) & 70.87 & 81.12 & 74.30 & 73.00 & 75.66 \\
\hline Buyer-Driven & 66.35 & 74.33 & 66.13 & 63.06 & 67.18 \\
\hline Garments & 64.99 & 70.03 & 65.20 & 62.47 & 66.08 \\
\hline Footwear & 0.93 & 1.16 & 0.35 & 0.30 & 0.80 \\
\hline Producer-Driven & 4.52 & 6.79 & 8.17 & 9.93 & 8.48 \\
\hline $\begin{array}{l}\text { Electronics and Electrical Goods } \\
\text { (SITC } 75,76 \text {, and } 77 \text { ) }\end{array}$ & 1.62 & 4.37 & 3.90 & 3.36 & 2.83 \\
\hline Transport Equipment (SITC 78 and 79) & 1.14 & 1.28 & 2.58 & 3.24 & 1.98 \\
\hline $\begin{array}{l}\text { Traditional (horizontal) Products } \\
\quad \text { (largely domestic resource based) }\end{array}$ & 29.13 & 18.88 & 25.70 & 27.00 & 24.34 \\
\hline Essential Oil (SITC 551) & 0.27 & 0.10 & 0.10 & 0.22 & 0.35 \\
\hline Activated Carbon (SITC 59864) & 1.16 & 0.44 & 0.45 & 0.99 & 1.16 \\
\hline Tires (SITC 625) & 1.19 & 2.46 & 6.08 & 7.34 & 7.88 \\
\hline $\begin{array}{l}\text { Other Rubber-Based Products } \\
\text { (SITC 62-625) }\end{array}$ & 0.74 & 0.74 & 1.02 & 1.70 & 1.97 \\
\hline Porcelain (SITC 666) & 1.17 & 0.97 & 0.80 & 0.52 & 0.45 \\
\hline Diamonds, Gems, and Jewelry (667) & 13.26 & 4.32 & 7.59 & 7.39 & 5.30 \\
\hline Total Exports & 100 & 100 & 100 & 100 & 100 \\
\hline$\$$ million & 1,093 & 3,723 & 4,546 & 6,167 & 7,131 \\
\hline \multicolumn{6}{|l|}{$\begin{array}{l}\text { Memo Items: Share of Parts and Components in } \\
\text { GPN Exports }\end{array}$} \\
\hline Total & 4.99 & 8.35 & 9.93 & 8.37 & 7.79 \\
\hline Buyer-Driven & 0.67 & 0.57 & 0.51 & 0.59 & 0.63 \\
\hline Producer-Driven & 68.32 & 93.51 & 86.10 & 57.77 & 64.52 \\
\hline
\end{tabular}

GPN = global production network, SITC = Standard International Trade Classification, UN = United Nations. Source: Compiled from UN Comtrade database using the classification system described in Appendix 4A.

As discussed in the next section, Sri Lanka's lopsided engagement in global production sharing mirrors a lackluster performance with attracting foreign investors into assembly production in high-tech industries (particularly electronics), despite the country's intrinsic comparative advantage in this area of international production. However, a sizable number (over 30, according to BOI records) of fully export-oriented medium-scale foreign-invested enterprises are currently successfully operating in electronics, electrical, and automotive industries. A recent study by the Sri Lanka Export Development Board (SLEDB 2015) indicates that these firms currently employ over 20,000 workers. The firms' 


\section{Table 4.2: Share of Global Production Network Products} in Manufacturing Exports, 2012-2013 (\%)

\begin{tabular}{lrrr}
\hline Economy & Buyer-Driven GPN & Producer-Driven GPN & Total \\
\hline Developing East Asia & 19.2 & 57.2 & 76.4 \\
\hline China, People's Rep. of & 20.5 & 57.3 & 77.8 \\
\hline Taipei,China & 7.2 & 72.6 & 79.8 \\
\hline Korea, Rep. of & 8.3 & 69.9 & 78.2 \\
\hline ASEAN & 14.0 & 61.2 & 75.2 \\
\hline Indonesia & 23.2 & 14.2 & 37.4 \\
\hline Malaysia & 6.3 & 69.3 & 75.6 \\
\hline Philippines & 13.2 & 64.1 & 76.3 \\
\hline Singapore & 2.3 & 92.3 & 94.6 \\
\hline Thailand & 12.4 & 59.4 & 72.3 \\
\hline Viet Nam & 23.5 & 34.3 & 57.8 \\
\hline South Asia & 12.2 & 21.2 & 23.5 \\
\hline India & 12.3 & 9.9 & 22.2 \\
\hline Sri Lanka & 67.2 & 8.5 & 75.7 \\
\hline ASEAN Assotian
\end{tabular}

ASEAN = Association of Southeast Asian Nations, GPN = global production network.

Source: Compiled from UN Comtrade database using the classification system described in Appendix A4.

exports account for only a small share (about 3\%) of total manufacturing exports, but data show a continued increase in the exports' value, from $\$ 247$ million in 2000 to over $\$ 470$ million in 2014 (Table 4.3 ).

Table 4.3: Parts and Components of Industrial Electronics and Electrical Goods Exported from Sri Lanka, 2000-2014 (\$ million)

\begin{tabular}{|c|c|c|c|c|c|c|c|c|}
\hline $\begin{array}{l}\text { SITC } \\
\text { Code }\end{array}$ & Product & 2000 & 2005 & 2010 & 2011 & 2012 & 2013 & 2014 \\
\hline 74492 & Lift Truck Parts & - & - & 15.0 & 34.1 & 31.2 & 43.6 & 57.1 \\
\hline 77313 & Vehicle Ignition Wire & - & - & 37.0 & 40.6 & 37.2 & 36.1 & 36.1 \\
\hline 77119 & Other Electrical Transforr & 13.1 & 16.4 & 50.0 & 36.7 & 28.4 & 28.4 & 4.5 \\
\hline 77282 & Switchgear Parts & 0.3 & 12.1 & 26.7 & 38.3 & 33.8 & 21.7 & 28.6 \\
\hline 77261 & Switchboards Etc. $<]$ & 0.7 & 6.1 & 11.1 & 13.2 & 6.9 & 20.0 & 27.3 \\
\hline 77281 & Switchboards Etc. Unequal & 8.1 & 14.2 & 12.4 & 17.3 & 11.8 & 12.6 & 17.2 \\
\hline 77220 & Printed Circuits & 14.8 & 5.9 & 22.7 & 28.6 & 26.6 & 16.7 & 10.9 \\
\hline \multirow[t]{3}{*}{77812} & Electric Accumulators & 0.3 & 0.4 & 0.2 & 0.3 & 0.8 & 6.0 & 18.4 \\
\hline & Other & 207.9 & 247.8 & 161.2 & 204.8 & 182.1 & 193.1 & 227.3 \\
\hline & Total Parts and Components & 246.8 & 307.5 & 346.4 & 429.2 & 377.1 & 399.4 & 472.1 \\
\hline
\end{tabular}

- = not available, SITC = Standard International Trade Classification, $\mathrm{V}=$ volt.

Source: Compiled from UN Comtrade database. 
For this study, in-depth interviews were conducted with the chief executive officers of three of the firms (Flintec Transducers, a fully owned Swedish firm; Lanka Harness, a Japan-Sri Lanka joint venture; and Variosystems, a fully owned Swiss firm). They assemble parts and components in high-tech industries (parts of weighing equipment, medical devices, and automobiles, respectively). The assembly processes are intrinsically labor intensive and unlikely to be affected by the "robotization" threat. While Sri Lankan policy indicates a human capital constraint on the country's potential for engaging in global production sharing, the prime reason these firms have located their production in the country is the availability of trainable labor, including supervisory manpower. The three firms have entirely local managers and all supervisors have been trained on the job within the firms. The success of Lanka Harness was featured in the Nikkei Asia Review (Markan-Marker 2016). All three firms plan to expand their production.

Among the non-GPN products (horizontal exports), rubber-based products, in particular pneumatic (airless and solid) tires, have shown impressive growth. Sri Lanka's share in world exports of pneumatic tires (SITC 62594) increased from $6.0 \%$ in $1990-1991$ to $22.3 \%$ in $2013-2014$ (CBSL n.d.). Two Sri Lankan joint ventures, with Camso (a Canadian multinational enterprise) and Tellobrog (a Swedish multinational enterprise), account for the country's entire production of pneumatic tires. The share of natural rubber (Sri Lanka's secondlargest traditional export) in total exports has declined sharply as a result of the rapid growth of rubber-based manufacturing industries. In 2014, more than $80 \%$ of the country's total natural rubber production was absorbed by the exportoriented industries.

An important issue in the contemporary trade and industrial policy debate is whether an import substitution phase is a precondition for an economy's successful transition to an export orientation. Related to this issue, the composition of the structure of manufacturing production at the time Sri Lanka embarked on liberalization reforms and the commodity composition of manufacturing exports during the subsequent years ${ }^{3}$ fail to suggest any direct link between emerging export patterns and the structure of production inherited from the importsubstitution era. On the contrary, the data suggest that most manufacturing exports commenced after the liberalization reforms. Most of the new exporting firms-those with FDI participation and purely local ones-emerged as exporting ventures independently of the industry-based exports established in the earlier period. In the apparel industry, a few firms established during the importsubstitution era have successfully ventured into export business. However, as shown in the next subsection, their new operations were based on knowhow and

3 The data are not presented here because of space constraint. 
management inputs obtained though foreign collaboration and/or marketing links established with foreign buyers.

The Special Case of Apparel (this section draws on Athukorala and Ekanayake [2017]). Sri Lanka began commercial production of apparel in the early 1960s (Kelegama 2009). However, expansion of the industry remained severely constrained during the ensuing 2 decades by a highly interventionist trade and industrial policy regime. The apparel industry started to grow only after the liberalization reforms were initiated in 1977. From 1992, apparel has been Sri Lanka's single largest export product. Over the years, the composition of manufactured exports has diversified into other labor- and resource-based products, but apparel still accounts for over $42 \%$ of total merchandise exports and over $62 \%$ of manufacturing exports.

In the lead up to the abolition of the Multi Fiber Agreement (MFA) quota, Sri Lanka was grouped with the countries expected to experience significant contraction after the termination (Nordås 2009). This gloomy prediction has not materialized: the average annual Sri Lankan apparel exports during 2005-2014 amounted to $\$ 3.564$ billion, up from $\$ 2.820$ billion during the preceding 5 years (2000-2004)-a 26\% increase. Sri Lanka's share in world apparel exports did decline, from about $1.10 \%$ during $2000-2004$ to $1.01 \%$ during $2005-2007$, but has increased since, reaching $1.17 \%$ in 2015 .

The performance of Sri Lanka's apparel industry after the MFA is particularly impressive considering two important impediments operating during this period. First, unlike many of its competitors, Sri Lanka does not enjoy preferential access to the major markets in Europe and North America. Second, Sri Lanka is no longer a low-wage production base when compared with many other apparel-producing countries in the region.

On 15 February 2010, the European Union suspended the Generalized Scheme of Preferences plus concessions to Sri Lanka (effective from 15 August) due to concerns about the violation of human rights. ${ }^{4}$ In addition to loosing preferential access to the European Union markets, the Sri Lankan apparel exporters had to compete in the United States market with exporting countries that enjoyed handsome tariff preferences under the African Growth Opportunity Act and regional trading agreements with countries in Latin America. The

4 Under the Generalized Scheme of Preferences, Sri Lanka was eligible for an average nonreciprocal preference margin of about $2.2 \%$ on clothing exports (the average Scheme rate of $9.0 \%$ compared with an average MFA tariff rate of $11.2 \%$ ). In July 2005, Sri Lanka became eligible for additional tariff concessions under the newly introduced "Generalized Scheme of Preferences plus" scheme, which offered duty free access for 7,200 products (including most clothing items). 
erosion of relative price competitiveness resulting from trade preferences has been compounded by wage increases in recent years. Sri Lanka's average hourly wage is now much higher than hourly wages in Bangladesh, Cambodia, and Viet Nam (and possibly in India and Indonesia), and is approaching the levels in the People's Republic of China and other East Asian countries that produce clothing (Athukorala and Ekanayake 2017, Table 2).

The remarkable resilience of Sri Lankan apparel exports to the MFA abolition under these constraints has been underpinned by a clear pattern of compositional shift in the exports, from "basic apparel" to "fashion-basic apparel" (Table 4.4). ${ }^{5}$ The degree of concentration of exports in the top 20 products has increased over time, from $79.8 \%$ in $2000 / 01$ to $90.2 \%$ in $2013 / 14$. Among these products, the share of women's apparel-which generally contains higher fashion content-increased from $44 \%$ to nearly $60 \%$. The two most rapidly expanding categories within this product group are brassieres (SITC 84551) and panties (SITC 84482). In 2013/14, Sri Lanka accounted for 9.2\% of total world exports of women's and girls' panties, up from $2.7 \%$ in $2000-2001$. Sri Lanka's world market share of brassieres increased from $3.2 \%$ to $7.4 \%$ in the same interval (Athukorala and Ekanayake 2017, Figure 1). Products that generally have no fashion content (such as men's business shirts and normal men's and women's trousers) have virtually disappeared from the export product mix.

In basic apparel products, labor cost is the major determinant of international competitiveness; thus, low-wage nations, especially those with access to inexpensive textiles, have the potential for major market share gains in the post-MFA era. By contrast, in fashion-basic products, exporting is more than a simple price-cost game; speed and flexibility are crucial capabilities for firms wrestling with product proliferation. What explains the Sri Lankan apparel industry's success at meeting these requirements?

The Sri Lankan apparel industry, as in the other second-tier exporting countries, started with "cut, make, and trim" operations: simple contract manufacturing for international buyers with designs and all intermediate inputs (fabrics and accessories) provided by the buyer. At the time, "quota-hopping"

5 This follows the three-way classification of apparel proposed by Abernathy et al. (1999): fashion products, basic products, and fashion-basic products. Fashion products are high-end products, such as dresses from Paris and Italian-made suits, the demand for which is largely driven by social status and deep-rooted cultural values. These products are not typically imported from developing countries. Basic apparel products remain in a retailer's or a manufacturer's collection for many seasons, such as men's shirts, trousers, and underwear. Fashion-basic products are variants of basic products that contain some fashion element (such as stone-washed jeans, pants with pleats or trim, and fashion lingerie and intimate wear). 


\section{Table 4.4: Sri Lankan Clothing Exports-Top 20 SITC-5 Digit Products, 2000-2001 and 2012-2014}

\begin{tabular}{|c|c|c|c|c|c|}
\hline \multicolumn{3}{|c|}{$2000-2001$} & \multicolumn{3}{|c|}{ 2013-2014 } \\
\hline $\begin{array}{l}\text { SITC } \\
\text { Code }\end{array}$ & Product & $\begin{array}{c}\text { Export } \\
\text { Share } \\
(\%)\end{array}$ & $\begin{array}{l}\text { SITC } \\
\text { Code }\end{array}$ & Product & $\begin{array}{c}\text { Export } \\
\text { Share } \\
(\%)\end{array}$ \\
\hline 84260 & Women's/Girls' Trousers, woven & 9.6 & 84551 & Brassieres & 9.9 \\
\hline 84140 & Men's/Boys' Trousers, woven & 8.9 & 84140 & Men's/Boys' Trousers, woven & 9.7 \\
\hline 84270 & Women's/Girls' Blouses, woven & 7.3 & 84260 & Women's/Girls' Trousers, woven & 9.8 \\
\hline 84540 & T-shirts/Singlets, knit & 5.6 & 84540 & T-Shirts/Singlets, knit & 9.4 \\
\hline 84530 & Jerseys/Pullovers & 5.4 & 84482 & Women's/Girls' Panties, knit & 9.2 \\
\hline 84130 & Men's/Boys' Jackets, woven & 5.2 & 84691 & Gloves, knit & 4.7 \\
\hline 84551 & Brassieres & 4.8 & 84426 & Women's/Girls' Trousers, knit & 4.6 \\
\hline 84151 & Men's/Boys' Trousers, cotton woven & 4.7 & 84822 & Women's Nightwear, woven & 4.4 \\
\hline 84230 & Women's/Girls' Jackets, woven & 3.4 & 84151 & Men's/Boys' Trousers, cotton & 3.5 \\
\hline 84371 & Men's/Boys' Trousers, cotton knit & 3.2 & 84530 & Jerseys/Pullovers & 3.2 \\
\hline 84250 & Women's/Girls' Skirts, woven & 3.2 & 84270 & Women's/Girls' Blouses, woven & 3.2 \\
\hline 84240 & Women's/Girls' Dresses, woven & 3.0 & 84240 & Women's/Girls' Dresses, woven & 3.0 \\
\hline 84482 & Women's/Girls' Panties, knit & 2.7 & 84381 & Men's/Boys' Underwear, knit & 2.8 \\
\hline 84282 & Women's Nightwear, woven & 2.6 & 84512 & Baby Clothes, knit & 2.3 \\
\hline 84512 & Baby Clothes, knit & 2.4 & 84564 & Women's/Girls' Swimwear, knit & 2.2 \\
\hline 84470 & Women's/Girls' Blouses, knit & 2.0 & 84424 & Women's/Girls' Dresses, knit & 2.3 \\
\hline 84691 & Gloves, knit & 1.9 & 84250 & Women's/Girls' Skirts, woven & 1.7 \\
\hline 84511 & Baby Clothes, woven & 1.7 & 84483 & Women's/Girls' Skirts, woven & 1.5 \\
\hline 84423 & Women's/Girls' Jackets, knit & 1.1 & 84371 & Men's/Boys' Trousers, cotton & 1.5 \\
\hline \multirow[t]{2}{*}{84159} & Men's/Boys' Trousers, woven & 1.1 & 84423 & Women's/Girls' Jackets, knit & 1.2 \\
\hline & Total & 79.8 & & Total & 90.2 \\
\hline
\end{tabular}

SITC = Standard International Trade Classification.

Note: Two-year averages.

Source: Compiled from UCTAD World Investment Report database, accessed 27 September 2016.

apparel producing firms in East Asia (especially Hong Kong, China) that had set up production plants dominated the industry. However, from about the late 1990s, an increasing number of firms with expanded local capital participation embarked on package contracting ("original equipment manufacturing"): producing according to customer specifications by sourcing fabrics and other inputs from foreign suppliers designated by the buyers. Several such firms have become full package manufacturers (or "original design manufacturers"). They offer a full range of services to customers, encompassing product development, pattern making, finishing, sourcing, manufacturing, and delivering. Such firms now account for about $60 \%$ of total exports (by value), with the rest coming from package contractors. "Cut, make, and trim" activity has virtually 
become a relic of the past. A few Sri Lankan firms have gained "original brand manufacturing" status (JAAF 2012). By the late 1990s, the industry had a well-developed customer base including well-known brand names such as Abercrombie and Fitch, Gap, Hunkemoller, Liz Claiborne, Marks \& Spencer, Nike, Pierre Cardin, Ralph Lauren, Sainsbury's, Tesco, Tommy Hilfiger, and Victoria's Secret. Large apparel firms (at least the top 10 companies) had established their own design centers that worked closely with design teams of brand owners. Most large companies (in particular the top 10) have invested in computer-aided design and manufacturing, and in electronic fitting, which enables design decisions by visualizing the garment digitally, skipping fit-on sessions with models.

In the post-MFA era, the Sri Lankan apparel industry has settled into a smaller core of firms, which are presumably well prepared to take advantage of changing future demand. Customs records indicate that Sri Lanka had 817 exporting firms in 2004 (using an export value of $\$ 10,000$ as the minimum cutoff point). The number declined to 671 in 2008 and to 450 in 2011, and the size distribution of the surviving firms has become increasingly skewed, with larger farms accounting for the bulk of exports. At the upper end, the three largest firms accounted for over 35\% of total exports in 2011, up from over $13 \%$ in 2004 . In 2011, more than two-thirds of exports originated from the top 20 firms, compared with $39 \%$ in 2004 . Some of the large firms are now multinational enterprises in their own right with subsidiary companies in other apparel exporting countries, such as Bangladesh, India, Jordan, Kenya, Madagascar, and Viet Nam. These firms have the ability to coordinate production within their global production networks to meet orders from their strategic buyers, reminiscent of the triangular manufacturing practices of the East Asian firms during the MFA era.

A key determinant of a firm's success in manufacturing flexibly is the domestic availability of high-quality inputs, which reduces the transport costs of inputs, delays, and the management time needed to coordinate a fragmented supply chain. Until about the mid-1990s, the domestic content of apparel exports from Sri Lanka was basically equivalent to the labor content: about 20\% (Kelegama and Foley 1999). Since then, the three largest firms (Brandix, Hidramani, and MAS Holding) have set up plants to produce textiles (mostly knitted fabric and elastic) and ancillary inputs (hangers, brassier molding, packaging material, labels, and buttons) to be used mostly in their own apparel plants, but also to meet the requirements of other apparel producers in the country. Currently, about $60 \%$ of fabric used in apparel production (about $80 \%$ of fabrics used in knitted apparel and about $20 \%$ of woven apparel) and the bulk of the ancillary inputs are produced domestically. 
Given the country's long-standing commitment to providing universal free education, the labor force also had a much higher level of formal education (on average 10.3 years of schooling) than in most other apparel exporting countries (Savachenko and Acevedo 2012). Therefore, a worker who joined the labor force as a "helper" in an apparel factory takes only 2-3 months to become a machine operator, versus 3-6 months taken by a Bangladeshi counterpart. ${ }^{6}$ In addition, the managerial and technical capability of Sri Lanka's apparel industry has improved notably during the last 4 decades, with public-private partnerships playing a pivotal role. Initially, the Sri Lankan apparel industry was heavily dependent on textile technicians from Hong Kong, China. The dependence on foreign textile technicians had virtually disappeared by the dawn of the new millennium. Sri Lanka has also become a supplier of textile technicians and managers to other apparel-producing countries in the region and beyond (Jacob 2013; Staritz 2011).

As the Sri Lankan apparel industry expanded, the country's major apparel producing firms placed greater emphasis on ethical employment practices than is the case in many of its Asian competitors (Fernando and Almeida 2012; Ruwanpura and Wrigley 2011; Friedman 2000). The "Garment without Guilt" campaign launched by the Joint Apparel Association Forum played a pivotal role in strengthening corporate social responsibility commitments among apparel exporting firms and promoting Sri Lanka as an ethical clothing manufacturer destination (JAAF 2012; Amalean 2001). Most large firms provide workers with transport facilities, free breakfast, subsidized meals, and medical care, and engage in community services in rural areas where the factories are located. Some firms produce "fair trade" clothing and invest in building "green" factories. The impressive record of compliance with ethical employment practices and internationally agreed environmental standards have enhanced Sri Lanka's attractiveness as a source of procurement for the leading brand marketers and specialty stores.

Finally, the data suggest that production disruption resulting from trade union action is much less of an issue in the clothing industry than in other industries. ${ }^{7}$ Employment conditions, particularly in large firms, had improved significantly, leaving little room for trade union action. Moreover, the predominance of women in the workforce is an important source of industrial

6 Based on an interview with a Sri Lankan firm that has a large branch plant in Bangladesh. See also Savachenko and Acevedo (2012).

7 According to the data on number of strikes and lost person days reported in various issues of (Department of Labour 2010). 
peace. ${ }^{8}$ The macho orientation of political trade unionism in Sri Lanka has deterred women from participating in trade unions. And female workers do not have a compelling reason for joining unions because of the short-term nature of their employment; they typically remain in the labor force for about 5 years before returning to their villages to other forms of employment and marriage (Gunawardana 2007).

\subsection{The Role of Foreign Direct Investment in Export Expansion}

The initial response of foreign direct investors to the liberalization reforms in Sri Lanka was impressive. During 1970-1976, net FDI inflows increased rapidly, from half a million dollars a year to $\$ 64$ million in 1982 . The outbreak of the war in 1983, however, severely disrupted this impressive trend and annual flows during the rest of the decade varied in the range of $\$ 17$ million to $\$ 58$ million. The second-wave reforms and the temporary cessation of hostilities during the first half of the 1990s witnessed a notable surge in FDI, which increased to an all-time high of $\$ 184$ million in 1993. The growth rate of FDI inflows slowed during the next decade, with a mild increase in 2000 , mostly reflecting increased inflows related to the privatization program. ${ }^{9}$ Sri Lanka's performance in attracting FDI was impressive during the post-reform period until about the mid-1990s, but has since deteriorated slightly (Table 4.5).

FDI increased noticeably during the 5 years following the end of the civil conflict (Figure 4.3), although the increase is less dramatic if judged by the standard definition of FDI rather than the new definition of the Central Bank of Sri Lanka (CBSL). The inflows have been heavily concentrated in tourist hotels and nontradable sectors (mostly real estate); FDI in export-oriented manufacturing accounted for less than $30 \%$ of total approved investment during 2010-2015 (Figures 4.4 and 4.5).

8 Young, poor women from the rural areas make up approximately $85 \%$ of all workers in the garment industry.

9 During 1999-2002, inflows relating to acquisitions accounted for over 30\% of net annual FDI inflows to Sri Lanka (calculations based on data reported in CBSL [various years]). 
Table 4.5: Foreign Direct Investment Inflow as a Share of Gross Domestic Capital Formation, 1980-2013 (\%, period averages)

\begin{tabular}{|c|c|c|c|c|c|c|c|}
\hline Economy & $\begin{array}{c}1980- \\
1984\end{array}$ & $\begin{array}{c}1985- \\
1989\end{array}$ & $\begin{array}{c}1990- \\
1994\end{array}$ & $\begin{array}{c}1995- \\
1999\end{array}$ & $\begin{array}{c}2000- \\
2004\end{array}$ & $\begin{array}{c}2005- \\
2009\end{array}$ & $\begin{array}{c}2000- \\
2013\end{array}$ \\
\hline Developing Economies & 3.3 & 3.2 & 5.7 & 10.9 & 11.7 & 12.1 & 9.3 \\
\hline Asia & 2.7 & 3.9 & 6.7 & 10.2 & 9.7 & 10.3 & 7.2 \\
\hline Bangladesh & 0.1 & 0.1 & 0.1 & 1.2 & 3.0 & 3.9 & 3.4 \\
\hline Cambodia & - & - & - & - & 15.1 & 41.8 & 71.3 \\
\hline China, People's Rep. of & 0.6 & 2.2 & 9.8 & 13.6 & 9.3 & 6.1 & 3.5 \\
\hline India & 0.1 & 0.3 & 0.9 & 2.9 & 3.6 & 6.9 & 4.7 \\
\hline Indonesia & 0.9 & 1.8 & 0.9 & 2.7 & -5.5 & 6.8 & 6.7 \\
\hline Lao PDR & - & - & - & 12.5 & 10.5 & 13.6 & 15.3 \\
\hline Malaysia & 11.5 & 9.3 & 19.4 & 16.6 & 10.5 & 13.6 & 15.3 \\
\hline Pakistan & 1.3 & 2.3 & 4.4 & 7.1 & 5.5 & 16.2 & 5.2 \\
\hline Philippines & 0.4 & 6.2 & 7.5 & 9.5 & 5.8 & 8.2 & 4.6 \\
\hline Singapore & 18.9 & 29.3 & 30.3 & 33.0 & 62.9 & 74.4 & 88.8 \\
\hline Sri Lanka & 3.1 & 2.5 & 4.3 & 5.2 & 5.2 & 6.1 & 5.0 \\
\hline Thailand & 2.6 & 4.5 & 4.4 & 13.4 & 14.2 & 13.3 & 11.4 \\
\hline Viet Nam & 0.2 & 0.1 & 33.5 & 27.9 & 12.5 & 20.4 & 21.7 \\
\hline
\end{tabular}

- = data not available, Lao PDR = Lao People's Democratic Republic.

Source: Compiled from UNCTAD World Investment Report database, accessed 27 September 2016.

Figure 4.3: Foreign Direct Investment in Sri Lanka (\$ million)

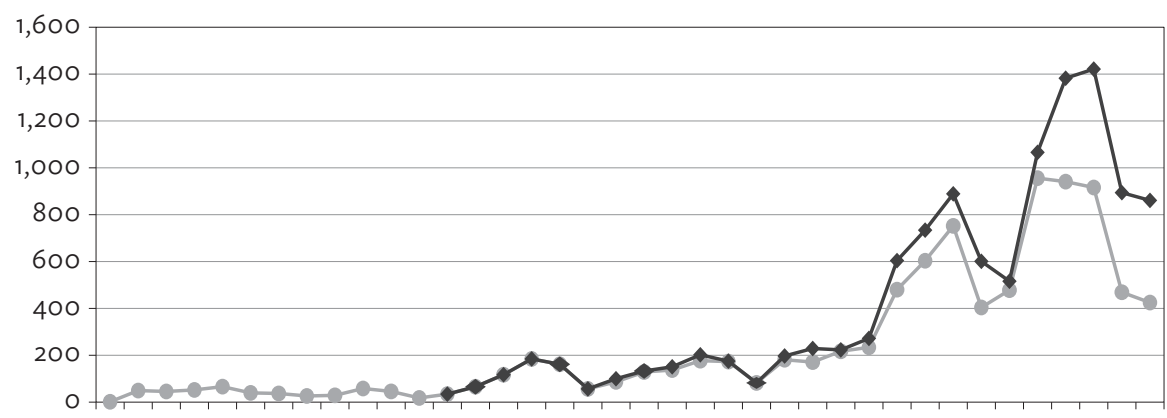

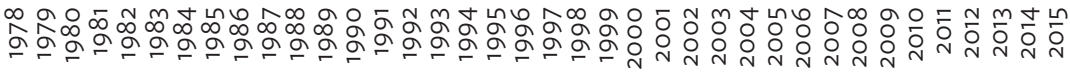

$\begin{array}{ll}\text { FDI(a): Standard definition (equity } & \text { FDI(b) + foreign loans to Board of } \\ \text { investment + retained earnings } & \text { Investment fims and other } \\ + \text { intra-company borrowing) } & \text { private sector firms }\end{array}$

$\mathrm{FDI}$ = foreign direct investment.

Source: CBSL (2015), Special Statistical Appendix. 


\section{Figure 4.4: Sectoral Composition of Approved Foreign Direct Investment, 2005-2015 (\$ million)}

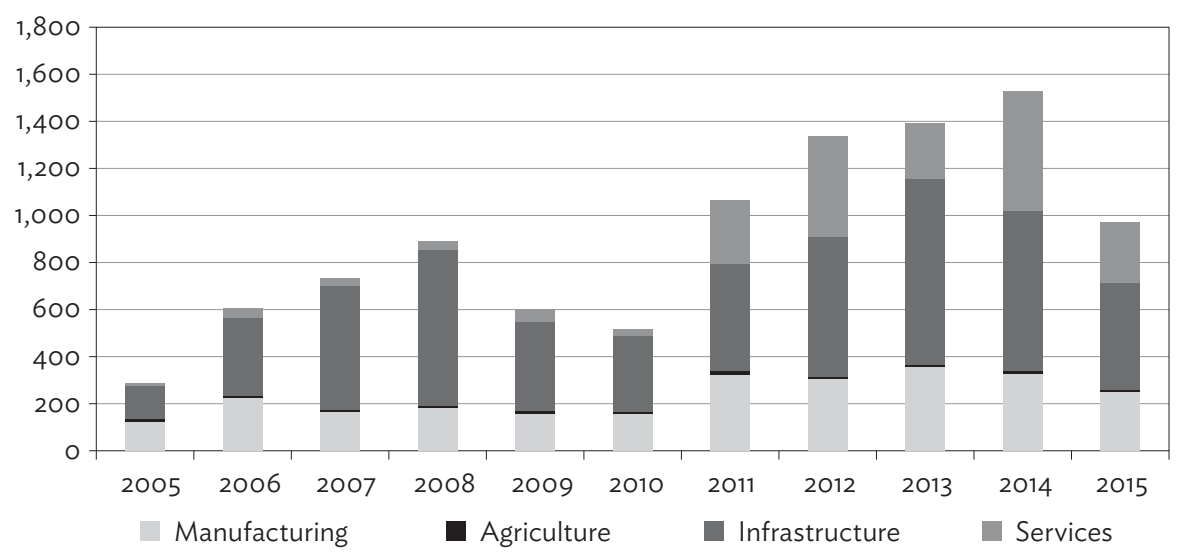

Source: Based on investment approvals, from unpublished Board of Investment records.

Figure 4.5: Industry Composition of Foreign Direct Investment in Manufacturing, 2005-2015 (\$ million)

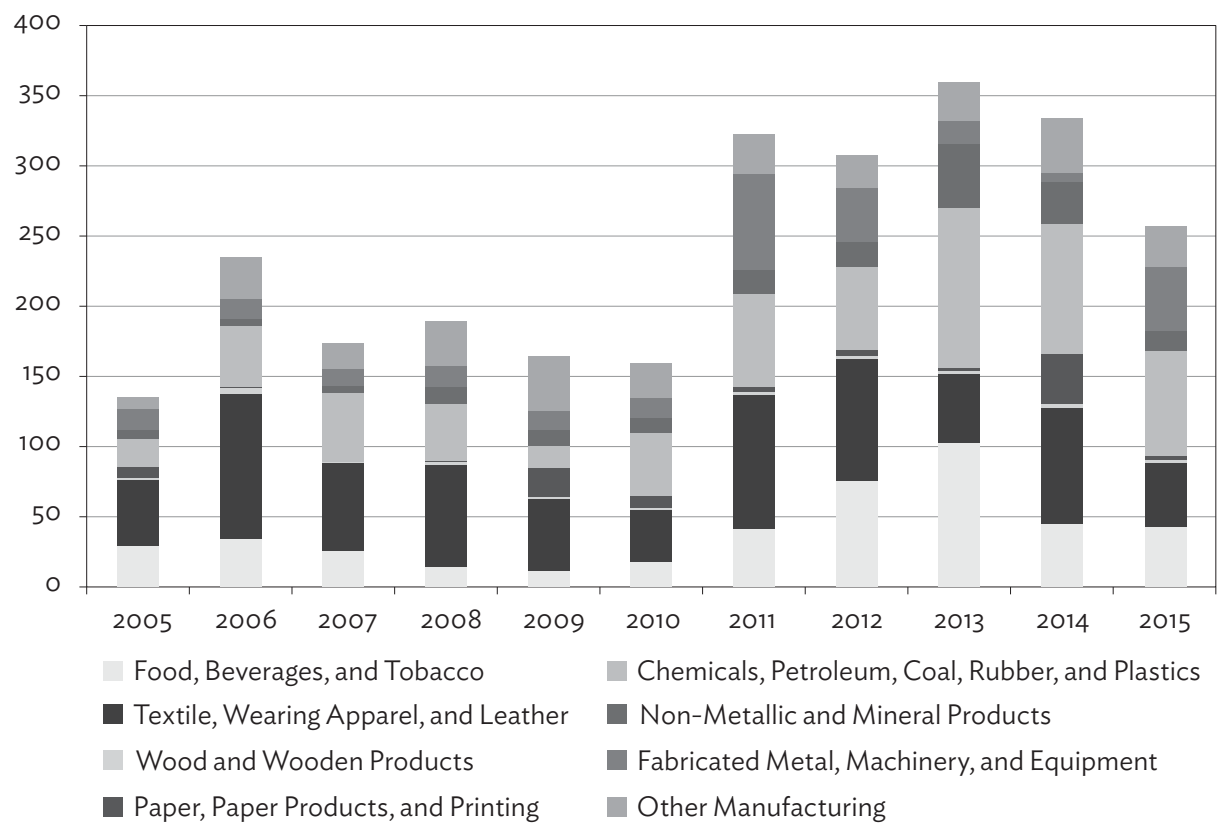

Source: Unpublished records of the Board of Investment. 
According to BOI records, several firms closed operations during this period: in 2015, 851 firms were operating, down from 1,040 in 2010 and 1,150 in 2005. FDI inflow in 2015 (about $\$ 400$ billion) was the lowest in the last 10 years. Currently, BOI investment approvals are dominated by totally locally owned firms: as of May 2016, foreign investment accounted for a mere $19.4 \%$ of approved investment, versus almost half of the firms in commercial production (Table 4.6).

\section{Table 4.6: Implementation Status of the Investment Projects Approved by the Board of Investment (May 2016)}

\begin{tabular}{|c|c|c|c|c|c|c|}
\hline \multirow[b]{2}{*}{ Project Status } & \multicolumn{3}{|c|}{ Project } & \multicolumn{3}{|c|}{ Planned Employment } \\
\hline & Total \# & \# of FIEs & FIE \% & Total \# & \# of FIEs & FIE $\%$ \\
\hline $\begin{array}{l}\text { Approved/Awaiting } \\
\text { Agreement }\end{array}$ & 114 & 32 & 28.1 & 21,676 & 4,207 & 19.4 \\
\hline Awaiting Implementation & 156 & 66 & 42.3 & 36,359 & 19,951 & 54.9 \\
\hline $\begin{array}{l}\text { Awaiting Commercial } \\
\text { Production }\end{array}$ & 190 & 85 & 44.7 & 37,604 & 16,096 & 42.8 \\
\hline In Commercial Operation & 1,700 & 747 & 43.9 & 347,072 & 167,104 & 48.1 \\
\hline Total & 2,160 & 930 & 43.1 & 442,711 & 207,358 & 46.8 \\
\hline
\end{tabular}

FIE = foreign-invested enterprise.

Note: Projects Approved under Sec 17 of Board of Investment Law. Foreign invested projects are fully foreign owned and joint-ventures.

Source: Compiled from unpublished data provided by the Board of Investment.

Standard labor-intensive manufacturing has been the main attraction for foreign investors in Sri Lanka, with a heavy concentration in the garment industry. The investment promotion campaign of the Greater Colombo Economic Commission aimed, during the early stage, at attracting FDI into electronics and electrical goods assembly. But Sri Lanka seems to have missed the opportunity to become an electronics hub because of the increase in political risk following the eruption of the ethnic conflict in the early 1980s (Snodgrass 1998). Foreign firms involved in vertically integrated assembly activities, unlike those in light consumer goods industries, view investment risk from a long-term perspective because output disruption in a given location can disturb production plans for the entire production chain. In fact, two electronics multinationals-Harris Corporation and Motorola-abandoned plans to set up assembly plants in Sri Lanka in the early 1980 s as the political climate begun to deteriorate. ${ }^{10}$ There is evidence of a "herd mentality" in site selection by multinational electronics firms, particularly if the "first-comer" is a major player in the industry. If the

10 On signing the investment agreement with the Greater Colombo Economic Commission in 1980, W.D. Douglas, a vice-president of Motorola stated: "Political stability is number one on our list wherever we go" (quoted in Wijesinghe 1976). 
Harris and Motorola projects had succeeded, other multinationals would have followed suit. Moreover, the entry of large players in vertically integrated global industries naturally sets the stage for the emergence of local small- and mediumscale firms supplying ancillary components and services (Athukorala 2014b).

FDI has undoubtedly been the engine of manufacturing export growth. Estimates made by matching the list of BOI-approved foreign-invested enterprises (FIEs) with export-level Customs records indicate that their share of total manufacturing exports increased from $24 \%$ in 1977 to over $80 \%$ in mid-1995 (Athukorala and Rajapatirana 2000, Table 6.8). Data compiled from BOI records show that the pattern of dominance by FIEs in manufacturing exports continued in the ensuing years: during 2002-2015, BOI-approved enterprises accounted for $82 \%-90 \%$ of total annual manufacturing exports.

\subsection{Determinants of Exports}

This section reports the results of an econometric analysis that aims to delineate the impact of international competitiveness (as measured by the real exchange rate) and the export-oriented FDI on export performance, while allowing for the impact of regime shifts and world demand. The econometric evidence is then supplemented by information gathered from field surveys.

\subsubsection{Econometrics}

The methodology involves estimating the following reduced form equation using data for the period 1970-2015:

$Q X=F(R E R, P C A P, F I E X, W D, T D P L B, D M F A, D N U R, D P W R, T I M E)$

where $Q X$ is real exports (export at 2005 prices). The explanatory variables are listed below with the expected sign of the regression coefficient in brackets.

\footnotetext{
RER (+) Real exchange rate.

FIEX $\quad(+)$ Real investment in FIEs.

PCAP (+) Production capacity, measured by real manufacturing output.

WEXD (+) Export demand, proxied by real manufacturing exports from developing countries.

$D P L B \quad(-) \quad$ Preliberalization dummy variable, which takes the value 1 for years $1970-77$ and 0 otherwise.
} 
DMFA (-) A dummy variable to capture the impact of MFA phase-out (1 for 2005-2015 and 0 for other years).

DNUR (-1) A dummy variable to capture production disruption caused by the youth uprising during 1987-1989.

DPWR (?) Post-civil war dummy that takes the value 1 for the period 1999-2015 and 0 otherwise.

TIME (+) Time trend.

Among the explanatory variables, $R E R$ is expected to capture the impact on export performance of changes over time in the relative profitability of exporting and selling domestically. $R E R$ is measured as the ratio of the rupee price of the export destination country currency adjusted for the foreign price to domestic price ratio. The role of FIEs in export expansion is presented by FIEX. This variable is measured as the total real investment in BOI-approved projects. ${ }^{11}$ PCAP is included to capture the impact of production capacity expansion in manufacturing on export performance. In the absence of a direct measure of production capacity, this variable is proxied by the average real manufacturing output during the 3 preceding years. WEXD is included to capture the impact of world demand on export performance. Foreign currency prices faced by Sri Lankan exporters are determined exogenously. However, the ongoing process of shifts in world demand toward developing countries driven by global production sharing in overall world demand is relevant for explaining export performance.

The export equation is estimated separately for total manufacturing goods (TMFX), textiles and garments (TGEX), and other manufacturing exports (OMEX). ${ }^{12}$ It is necessary to treat TGEX as a separate category to allow for the special market conditions faced by apparel exports until 2005, due to the market quota system under the MFA. The country-specific export quotas under the MFA, by segmenting the textile and garment market country-by-country, created market power for exporters, which would otherwise not have existed. In other words, the MFA quotas made the export demand schedules facing exporters less elastic than they would have otherwise been.

The RER series is related to Sri Lanka's six major export destination countries (France, Germany, India, Japan, the United Kingdom, and the United States). The data on producer price indexes for these countries are extracted from the World Development Indicators database of the World Bank. The data on

11 Total investment, rather than foreign investment, better captures the impact of FIEs on export performance because there has been a clear shift in the ownership structure of these firms from full foreign ownership to joint venture (with minority ownership in most cases).

12 It is preferable to separate the other manufacturing exports into GPN products and non-GPN products, but disaggregated price (unit value) data are not available. 
manufacturing exports from developing countries to construct the WEXD series were compiled from the UN Comtrade database. The data on all other variables are from various issues of the CBSL Annual Report. ${ }^{13}$

All data series (except dummy variables) were used in logarithmic form. ${ }^{14}$ The estimation was commenced by examining the time series properties of the data series using the Augmented Dicky-Fuller test. In terms of this test, all data series were found to be nonstationary (that is, the test did not reject the null hypothesis of unit-root nonstationary, $I[1])$. Thus, in order to guard against the possibility of estimating spurious relationships, it was necessary to estimate the export equation using an estimator that is appropriate for $I(1)$ variables. Of the alternative estimators, the Phillips-Hanses fully modified ordinary least squares (OLS) method was employed, which is applicable to data samples of the size typical in economics ( 47 in the current case). The fully modified OLS is an optimal-single equation technique, which is asymptotically equivalent to maximum-likelihood estimators. This estimator applies a semi-parametric correction to the OLS estimator to eliminate dependency on nuisance parameters, and give medium-unbiased t-statistics that follow a standard normal distribution asymptotically. ${ }^{15}$

The summary statistics of the variables are reported in Table 4.7. The results are reported in Table 4.8. PCAP was dropped because its coefficient turned out to be statistically insignificant (in some cases with the unexpected sign) in experimental rules. This is consistent with the fact that during the reform era, export-oriented manufacturing grew as an FDI-centered subsector side-by-side with the domestic-market-oriented sector. An interaction variable ( $\left.L R E R^{*} M F A\right)$ is also included in the export equation for textile and apparel to test whether the relative price effect textile and apparel exports has changed following the MFA abolition. All three equations pass the Augmented Dickey-Fuller test for residual stationarity. Hence the regression coefficients can be interpreted as long-run (steady state) elasticities.

13 The author is grateful to S.D. Nilanka for permitting him to use some of the data series from the database she constructed for the masters research essay (Nilanka 2016).

14 The log-linear specification of the model was tested against the simple liner specification using the standard functional form choice tests (Pesaran and Pesaran 2009, Section 11.9). None of these tests favored one over the other. The results are reported for the log-linear specification because it has the added advantage that the estimated coefficients can be directly interpreted as elasticities. These corrections work effectively for sample sizes as small as 50 (Philips and Hansen 1990; Pesaran and Shin 1999). 


\section{Table 4.7: Summary Statistics of the Variables Used in Estimating the Export Equation}

\begin{tabular}{lrrrr|r|r} 
& $\begin{array}{c}\text { Log } \\
\text { TMEX }\end{array}$ & $\begin{array}{c}\text { Log } \\
\text { TGEX }\end{array}$ & $\begin{array}{c}\text { Log } \\
\text { OMEX }\end{array}$ & $\begin{array}{c}\text { Log } \\
\text { RER }\end{array}$ & $\begin{array}{c}\text { Log } \\
\text { FIEX }\end{array}$ & $\begin{array}{c}\text { Log } \\
\text { WEXD }\end{array}$ \\
\hline Maximum & 13.27 & 12.99 & 12.35 & 5.17 & 12.39 & 15.40 \\
\hline Minimum & 6.68 & 6.00 & 5.98 & 4.20 & 1.10 & 10.74 \\
\hline Mean & 11.79 & 10.90 & 11.11 & 4.64 & 9.35 & 13.37 \\
\hline Standard Deviation & 1.69 & 2.13 & 1.48 & 0.27 & 3.63 & 1.54 \\
\hline Skewness & -1.39 & -1.08 & -1.78 & 0.35 & 1.36 & -0.24 \\
\hline Kurtosis & 1.29 & -0.11 & 2.97 & -0.62 & 0.36 & -1.44 \\
\hline Coefficient of Variation & 0.14 & 0.20 & 0.13 & 0.06 & 0.39 & 0.11 \\
\hline
\end{tabular}

FIEX = foreign-invested enterprises; OMEX = other manufacturing export; RER = real exchange rate; TGEX = textiles and garments export; TMEX = total manufacturing export; WEXD = world export demand, proxied by real manufacturing exports from developing countries.

Source: Author.

Table 4.8: Determinants of Manufacturing Exports

\begin{tabular}{|c|c|c|c|}
\hline & $\begin{array}{c}\text { Total } \\
\text { Manufacturing } \\
\text { Export (TMEX) }\end{array}$ & $\begin{array}{c}\text { Textiles and } \\
\text { Garments Export } \\
(\text { TGEX) }\end{array}$ & $\begin{array}{c}\text { Other } \\
\text { Manufacturing } \\
\text { Export (OMEX) }\end{array}$ \\
\hline Constant Term & $\begin{array}{l}-7.88 \\
(2.27)\end{array}$ & $\begin{array}{l}-3.33 \\
(1.21)\end{array}$ & $\begin{array}{l}-12.82 \\
(2.76)^{* *}\end{array}$ \\
\hline $\begin{array}{l}\text { Real Exchange Rate } \\
\text { (RER) }\end{array}$ & $\begin{array}{c}1.55 \\
(3.54)^{* * *}\end{array}$ & $\begin{array}{c}0.68 \\
(2.08)^{* *}\end{array}$ & $\begin{array}{c}1.58 \\
(2.78)^{* *}\end{array}$ \\
\hline $\begin{array}{l}\text { Investment in Foreign- } \\
\text { Invested Exporting } \\
\text { Firms (LFIEX) }\end{array}$ & $\begin{array}{l}0.16 \\
(3.76)^{* * *}\end{array}$ & $\begin{array}{c}0.30 \\
(9.58)^{* * *}\end{array}$ & $\begin{array}{c}0.20 \\
(3.78)^{* * *}\end{array}$ \\
\hline $\begin{array}{l}\text { World Export Demand } \\
\text { (WEXD) }\end{array}$ & $\begin{array}{c}0.83 \\
(5.15)^{* * *}\end{array}$ & $\begin{array}{c}0.61 \\
(5.07)^{* * *}\end{array}$ & $\begin{array}{c}1.26 \\
(6.01)^{* * *}\end{array}$ \\
\hline $\begin{array}{l}\text { Preliberalization } \\
\text { Dummy (DPLB) }\end{array}$ & $\begin{array}{r}0.54 \\
(1.24)\end{array}$ & $\begin{array}{l}-0.21 \\
(0.71)\end{array}$ & $\begin{array}{r}0.73 \\
(1.31)\end{array}$ \\
\hline $\begin{array}{l}\text { Post-MFA Dummy } \\
\text { (DPMFA) }\end{array}$ & $\begin{array}{l}-0.40 \\
(2.68)^{* *}\end{array}$ & $\begin{array}{l}-0.27 \\
(2.56)^{* *}\end{array}$ & \\
\hline $\begin{array}{l}\text { Post-Civil War Dummy } \\
\text { (DPWAR) }\end{array}$ & $\begin{array}{r}0.24 \\
(1.25)\end{array}$ & $\begin{array}{r}0.04 \\
(0.16)\end{array}$ & $\begin{array}{r}0.15 \\
(0.61)\end{array}$ \\
\hline $\begin{array}{l}\text { Southern Youth } \\
\text { Uprising Dummy } \\
\text { (DUPR) }\end{array}$ & $\begin{array}{l}-0.30 \\
(2.44)^{* *}\end{array}$ & $\begin{array}{l}-0.03 \\
(0.34)\end{array}$ & $\begin{array}{l}-0.64 \\
(3.90)^{* * *}\end{array}$ \\
\hline Trend & $\begin{array}{r}0.67 \\
(0.00)\end{array}$ & $\begin{array}{r}0.01 \\
(0.39)\end{array}$ & $\begin{array}{l}-0.09 \\
(3.46)^{* * *}\end{array}$ \\
\hline LRER*DPMFA & & $\begin{array}{l}-0.51 \\
(0.61)\end{array}$ & \\
\hline R-Bar Squared & 0.93 & 0.98 & 0.84 \\
\hline ADF & $-4.09^{* * *}$ & $-6.52^{* * *}$ & $-3.53^{* *}$ \\
\hline
\end{tabular}

$\mathrm{ADF}=$ Augmented Dickey-Fuller unit root test, MFA $=$ Multi Fiber Arrangement, OMEX $=$ other manufacturing export, RER = real exchange rate, TGEX = textiles and garments export, TMEX = total manufacturing export.

Source: Author. 
The "real exchange rate" variable (RER) is by far the most important determinant of expert performance in all three equations. For total manufacturing exports and nontextile and apparel exports, the results suggest a statistically significant real exchange rate elasticity of 1.50 and 1.56 , respectively. The magnitude of the real exchange rate elasticity of textiles and apparel is much smaller (0.68), although statistically significant at the $5 \%$ level. This result is consistent with the analytical prior relating to the impact of the market segmentation effect of MFA quotas. Interestingly, the coefficient of $L R E R^{*} M F A$ is not statistically significant. This result is consistent with the earlier inference that, as part of the adjustment process in the post-MFA era, the Sri Lankan exporting firms have carved out niches at the upper end of the apparel value chain.

The coefficient of FIEX is statistically significant at the $1 \%$ level in all equations, supporting the hypothesis that FDI played a vital role in the expansion of manufacturing exports. Interestingly, in the equation for textiles and apparel, the coefficient of FIEX is much larger than that of RER. This is consistent with the analytical narrative of the evolution of the pivotal role FIEs played in the expansion of Sri Lanka's textile and apparel exports.

The coefficient of the "world demand" variable is statistically significant with the expected positive sign in all three equations. This result is consistent with the analytical prior that world demand is important even for small countries in a context where the ongoing structural shifts in world export demand toward developing countries is not determined only by relative price competition. However, the coefficient of the variable $l$ is much smaller in all equations than that of $R E R$. The important inference is that, while world demand shifts toward developing countries play a role, "international competitiveness," which captures supply-side developments, is far more important in determining export success.

\subsubsection{Evidence from Field Surveys}

An interviewee commented that the lack of clear policy signals had adversely affected the business environment for export-oriented production in general and for export-oriented FDI in particular. Several interviewees noted the sudden suspension of tax concessions for export-oriented firms and the reintroduction of the requirement to surrender export proceeds were knee-jerk responses to the broader macroeconomic crisis of the country, and were not consistent with the government's declared commitment to restore incentives for export production. The concerns are also consistent with the assessment of the business climate in the country in the Global Competitiveness Report (WEF 2016) and the findings of the Business Outlook Survey (CBSL n.d.). The Global Competitiveness Report identified policy instability as the single most important factor that is problematic 
for doing business in the country. The CBSL Business Outlook Survey indicates that overall business conditions have deteriorated from the third quarter of 2015 through the second quarter of 2016 (Table 4.9).

Table 4.9: Business Sentiment Indexes, 2014Q1-2016Q3

\begin{tabular}{l|c|c|r|r|r|r|r|r}
$\begin{array}{l}\text { Business Sentiment } \\
\text { Index }\end{array}$ & $\begin{array}{c}\mathbf{2 0 1 4} \\
\mathbf{Q 3}\end{array}$ & $\begin{array}{c}\mathbf{2 0 1 4} \\
\mathbf{Q 4}\end{array}$ & $\begin{array}{c}\mathbf{2 0 1 5} \\
\mathbf{Q 1}\end{array}$ & $\begin{array}{c}\mathbf{2 0 1 5} \\
\mathbf{Q 2}\end{array}$ & $\begin{array}{c}\mathbf{2 0 1 5} \\
\mathbf{Q 3}\end{array}$ & $\begin{array}{c}\mathbf{2 0 1 5} \\
\mathbf{Q 4}\end{array}$ & $\begin{array}{c}\mathbf{2 0 1 6} \\
\mathbf{Q 1}\end{array}$ & $\begin{array}{c}\mathbf{2 0 1 6} \\
\mathbf{Q 2}\end{array}$ \\
\hline Business Conditions & 136 & 126 & 107 & 111 & 111 & 122 & 105 & 86 \\
\hline Profitability & 120 & 117 & 97 & 97 & 106 & 112 & 79 & 68 \\
\hline Skilled Labor Availability & 101 & 90 & 102 & 84 & 100 & 76 & 98 & 87 \\
\hline Demand & 137 & 136 & 122 & 139 & 129 & 146 & 116 & 105 \\
\hline Sales & 127 & 140 & 123 & 145 & 142 & 142 & 118 & 117 \\
\hline Capacity Utilization & 122 & 130 & 131 & 134 & 138 & 124 & 121 & 119 \\
\hline
\end{tabular}

Source: CBSL (n.d.), Business Outlook Survey, accessed 22 September 2016.

Regarding infrastructure-related trade costs, a common complaint was the periodic power cuts and high cost of electricity. Contrary to popular perception, there were no complaints about cargo transport and cargo handling at the Port of Colombo and the airport. The managers of exporting firms interviewed spoke favorably about the customs clearance procedures.

Manufacturing exporting firms do not seem to consider unviability of managerial and supervisory manpower as a significant impediment to their operations. All the firms visited for the study are managed by Sri Lankans, following the involvement of foreign managers for a limited period of time during the formative stage. The firms seem to successfully train supervisors on the job. Sri Lanka's track record of technical and tertiary education is not as impressive as its long-standing success with primary and secondary education, but the country's human capital base is capable of acquiring technical and managerial skills within a short period.

A major concern in Sri Lankan policy circles relating to the viability of manufacturing exports from Sri Lanka is labor shortages (mostly of unskilled factory workers). During the field work for this study, news reports placed the number of unfilled vacancies in export-producing factories at 30,000100,000 . However, the reported labor shortages may be mostly due to structural characteristics of the economy that hinder the operation of free market incentives.

First, the reported labor scarcity is predominantly concentrated in urban centers in the Western Province, and in the two free-trade zones (FTZs) in the province. The relatively higher cost of living in this region and poor accommodation facilities seem to hinder movement of labor from the rest of the 
country. Also, as the chief executive officer of a major electronics firm operating in the Katunayaka FTZ noted, the lingering bad image (created by the poor working conditions of apparel factories as initially set up in Katunayaka FTZ and failure to provide accommodation dormitories for factory workers) continue to deter workers from going to that FTZ. Firms in rural areas closer to their labor force do not seem to experience labor shortages. For example the just-mentioned electronics firm experiences labor shortages only in its Katunayaka FTZ factory; its factory in the Koggala FTZ has a waiting list for vacancies. Variosystems, an electronics firm employing 600 workers and situated in a rural area (in Badalgama, about 35 kilometers from the Katunayaka FTZ), has not faced labor shortages since starting operations in 1998. The firm has built dormitories for workers, but these are not fully occupied because most of the workers commute from their homes.

Second, because of job security, pension entitlement, and social status, workers prefer public sector jobs. Therefore, the massive, politically motivated increase in public sector employment in the last 10 years seems to have compounded labor shortages faced by private sector firms. In a dramatic reversal of the contraction in the size of the public-sector workforce that had been maintained for the previous decade, total employment in the public sector increased from about 900,000 (11.1\% of the total labor force) in 2005 to over 1.3 million $(14.0 \%)$ in 2014. Some workers employed in the private sector, even at much higher salaries, moved to the public sector during this period. Moreover, and perhaps more importantly, the expectations created by the public sector employment boom seem to have encouraged potential labor market entrants to remain unemployed until job openings arise in the public sector.

Third, there is no systematic island-wide institutional mechanism for disseminating information on available job openings. Many interviewees complained that the BOI's "job bank," the stated role of which is to introduce potential job seekers to BOI-approved firms, had remained virtually inactive. Most firms seem to rely on their current employees to fill vacancies, often paying a finders' fee for bringing in new recruits.

Labor scarcity in the apparel industry seems anomalous given the massive labor outmigration. A tentative estimate suggests that the total stock of Sri Lankan overseas contract migrant workers had reach 2 million by 2011, equal to over $14 \%$ of the country's total working-age population (Arunatilake et al. 2011). For $2000-2014$, about $53 \%$ of migrant workers were female and over $80 \%$ of them were engaged in household services at a wage that is comparable to or even lower than the average factory worker's wage in Sri Lanka (SLFEB 2015). There are two possible reasons for Sri Lankans to migrate for work. First, foreign employment 
provides an opportunity for accumulating more savings because the cost of living (which is increasing rapidly in Sri Lanka) is covered as part of the overseas employment contract. Second, and perhaps more importantly, in a country where white-collar employment is highly valued as a result of universal free education, there is a stigma attached to working in a factory. The long working hours are an additional reason for aversion to apparel industry jobs.

Finally, relating to the labor market regime, the interviewees did not consider the existing minimum wage legislation as a constraint on their performance. They were also strongly sympathetic to the prohibition of child labor, which the apparel exporters consider as part of their competitive edge in the upper-end fashion-basic apparel market. Interviewees' main (perhaps the only) concern related to the cumbersome and long-drawn-out legal procedures for terminating employment and settling industrial disputes.

\subsection{Summary and Policy Inferences}

Trade and investment policy reforms initiated in the late 1970s have brought about far-reaching changes in the structure and performance of the Sri Lankan manufacturing sector. The achievements are all the more remarkable when allowing for the fact that the country failed to capture the full benefits of reforms because of the protracted civil war that damaged the investment climate and undermined macroeconomic stability.

The Sri Lankan experience highlights the complementary role of investment liberalization for exploiting the potential gains from trade liberalization: trade liberalization increased the potential returns to investment by capitalizing on the country's comparative advantage, while liberalization of foreign investments permitted international firms to take advantage of such profit opportunities. There is compelling evidence that the entry of foreign firms is virtually essential for a "latecomer" to export successfully. In addition to FIEs' direct contribution to export expansion, their positive spillovers have contributed to the success of local firms at exporting.

The Sri Lankan experience supports the view that trade-cum-investment policy reforms can set the stage for new exporting firms to emerge. In a global context in which factors of production-capital, technology, and marketing and managerial knowhow-are mobile across national boundaries, the nature of the existing manufacturing base is not a prerequisite for export diversification in the ongoing process of economic globalization. Developing human capital and building the country's innovative capabilities should of course be among 
the government's long-term policy priorities, but there is no need to wait to achieve these objectives in order to link domestic manufacturing into global production networks.

The findings make a strong case for redressing backsliding in policy, continuing the market-oriented reforms agenda that was left incomplete in the late 1990s, and setting up institutional safeguards to avert further backsliding.

Unification of para tariffs and the standard customs duties and rationalization of the resultant tariff structure with the aim of achieving greater uniformity of rates is an important policy goal based on sound economic reasoning. In addition to economic efficiency gains, this would help to improve the efficiency of customs administration. Customs revenue could increase under a more uniform tariff structure, through achieving greater transparency of the tariff administration and reducing incentives for smuggling (Roy and Pattnaik 2004; Subramanian 1994).

Restoring the BOI's role to its original status as the apex institute for FDI promotion is vital for linking the economy to rapidly evolving global production networks. This requires repealing, or superseding by new legislation, the Revival of Underperforming Enterprise and Underutilized Assets Act and the Strategic Development Project Act, and a firm commitment at the highest political level to promote FDI.

There is, of course, a strong case for rationalizing the fiscal incentives offered by the BOI. The very objective of giving incentives for promoting FDI is nullified if they are not made strictly time-bound and transparent. However, whether the government should go ahead with abolishing or phasing out tax incentives for export-oriented foreign firms is highly debatable. The evidence often cited against tax incentives in the recent policy debate in Sri Lanka comes from studies that have not made a distinction between import-substituting and export-oriented FDI (see for example World Bank 2016). Several studies (Wells 1986; Morisset and Prinia 2001; Guisinger and Associates 1985; Weigand 1983) that have systematically examined the issue though firm-level surveys and have made a clear distinction between the two types of investors have found that tax incentives play an important role in influencing location decisions of export-oriented foreign investment. (This assumes, of course, that the other preconditions-political stability, favorable geographic location, infrastructure provision, etc.-are reasonably met.) In any case, if all other countries in the region are using tax incentives as an integral part of their strategy for attracting export-oriented FDI, it would be counterproductive for Sri Lanka to "swim against the tide" purely on revenue considerations. 
The usual characterization of FTZs as "enclave arrangements" is not applicable to FTZs in Sri Lanka. Many other countries have implemented exportprocessing zone schemes as a an appendage to a highly restrictive trade regime, whereas in Sri Lanka BOI privileges are available to foreign and local investors that meet the approval criteria (the prime criterion being "export orientation"), and BOI-approved firms can operate anywhere in the country. The number of BOI firms operating outside the FTZs has increased significantly and would have been more rapidly geographically spread but for binding infrastructure constraints. Moreover there is clear evidence that many local firms have become successful exporters in their own right through experience gained from joint ventures with foreign partners.

Restoring the international competitiveness of the economy by depreciating the real exchange rate is essential for sustaining robust exporting. This requires a substantial nominal depreciation of the rupee. The CBSL's recent move to achieve greater flexibility in determining the exchange rate is therefore a step in the right direction. However, under the current economic conditions, relying on nominal exchange rate depreciation alone for restoring international competitiveness could be counterproductive. Given the massive build-up of foreign-currency-denominated government debt, exchange rate depreciation naturally worsens budgetary woes. And given the increased exposure of the economy to global capital markets, a large abrupt change in the exchange rate could shatter investor confidence, triggering capital outflows. Therefore, to improve the overall investment climate in the country requires (1) a comprehensive policy package encompassing greater exchange rate flexibility and fiscal consolidation (which requires both rationalization of expenditure and widening of the revenue base) to achieve a durable reduction in the public debt; and (2) complementary measures, including trade and investment policy reforms.

The labor shortages reported, which have received much emphasis in recent policy debates, seem to be at least partly due to structural impediments that hinder the operation of free market incentives. The structural impediments to labor mobility could be redressed by (1) providing facilities and incentives for firms to locate factories where labor is available, and (2) requiring them to provide workers with dormitories (as is widely done in many other successful exporting countries) as part of the BOI investment approval and monitoring procedures and infrastructure development.

There is a clear need for reforms to achieve labor market flexibility by repealing restrictions set by the Industrial Dispute Act and the Termination of Employment of Workers Act on retrenchment of workers for economic reasons, and shifting from centralized wage fixing toward work-place bargaining. The 
central question here is how to design a mechanism to gain the support of the workers whose cooperation is crucial for these policies to work. Immediate beneficiaries (at least in the eyes of the workers) are the employers and the gains for the workers and the populace at large (in terms of higher market-determined wages, better job prospects, etc.) come with a significant time lag. Thus, from the workers' point of view, "gains from proposed policy reforms are largely promissory" (Campos and Root 1986: 121). Making the policy work, therefore, requires designing a mechanism to guarantee that both parties-workers and employers-have a reasonable chance to share in the benefits.

People who favor a single-handed approach to labor market reforms in Sri Lanka point to draconian labor control measures implemented in the highperforming East Asian countries. But they often ignore the important fact that restrictive labor market policies in these countries were always combined with policies that ensured explicit sharing of the benefits by both parties: "although labor was politically disabled, its economic needs were largely met" (Campos and Root 1986: 19). Moreover, the restrictive approach to labor relations in these countries was part of a package of durable and credible growth-promoting policies. Broad-based social support gained through economic success brought about by these policies allowed the political leadership to ignore radical labor union demands without the risk of regime failure. 


\section{Appendix A4: Trade Data Compilation}

A prerequisite for analyzing patterns and determinants of trade within global production networks (GPNs) is the systematic delineation of parts and components and final assembly from the standard (customs-records-based) trade data. Following the seminal paper by Yeats (2001), it has become common practice to use data on parts and components to measure GPN trade. However, there has been a remarkable expansion of production sharing from parts and components to encompass final assembly. Moreover, the relative importance of these two tasks within production networks varies among countries and over time in a given country, making it problematic to use data on the parts and components trade as a general indicator of the trends and patterns of GPN trade over time and across countries. In this study network trade is defined to incorporate both components and final (assembled) goods exchanged within the production networks.

The data used in this study are compiled from the United Nations Comtrade database (5-digit Standard International Trade Classification [SITC] data). Parts and components are delineated from the reported trade data using a list compiled by mapping parts and components in the intermediate products subcategory of the United Nations Broad Economic Classification with the SITC. The list of parts and components used in data compilation is available in Athukorala and Talgaswatta (2016).

There is no hard and fast rule for delineating final goods assembled within GPNs from the standard trade data. The only practical way of doing this is to focus on the specific product categories in which GPN trade is heavily concentrated. Once these product categories are identified, trade in final assembly can be estimated as the difference between parts and components, which are directly identified based on the list used for this study, and the total trade of these product categories.

Guided by the available literature on production sharing, 14 product categories are identified: power generating machinery (SITC 71), specialized industrial machines (SITC 72), metal working machines (SITC 73), general industrial machinery (SITC 74), office machines and automatic data processing machines (SITC 75), telecommunication and sound recording equipment (SITC 76), electrical machinery (SITC 77), road vehicles (SITC 78), other transport equipment (SITC 79), travel goods (SITC 83), clothing and clothing accessories (SITC 84), footwear and sport goods (SITC 85), professional and scientific equipment (SITC 87), and photographic apparatus (SITC 88). Of these, 
SITC 83 , SITC 84 , and SITC 85 can been classified as products predominantly traded with buyer-driven production networks and the rest as belonging to producer-driven production networks. It is quite reasonable to assume that these product categories contain virtually no products produced from start to finish in one country. The difference between the value of total exports of these categories and the value of total parts and components falling under these categories was treated as the value of final assembly. However, admittedly the estimates based on this list do not provide full coverage of final assembly in world trade. For example, outsourcing of final assembly takes place in various miscellaneous product categories such as clothing, furniture, sporting goods, and leather products. It is not possible to meaningfully delineate parts and components and assembled goods in reported trade in these product categories because they contain a significant (yet unknown) share of horizontal trade. 


\section{References}

Abernathy, F., J. Dunlop, J. Hammond, and D. Weil. 1999. A Stich in Time: Lean Retailing and the Transformation of Manufacturing: Lessons from the Apparel and Textile Industries. New York: Oxford University Press.

Amalean, M. 2001. The Apparel Industry of Sri Lanka: An Analysis of the Past Present and Future in a Global Context, Apparel Update (Colombo), May-July: 5-8.

Antras, P. 2016. Global Production: Firms, Contracts, and Trade Structure. Princeton: Princeton University Press.

Arunatilake, N., P. Jayawardena, and D. Weerakoon. 2011. Sri Lanka. In Kelegama (ed.), Migration, Remittances and Development in South Asia. New Delhi: Sage.

Athukorala, P. 2012. Sri Lanka's Trade Policy: Reverting to Dirigisme? The World Economy 35(12): 1662-86.

2014a. Growing with Global Production Sharing: The Tale of Penang Export Hub. Competition \& Change. 18(3): 221-45. 2014b. How India Fits into Global Production Sharing: Experience, Prospects and Policy Options. In Shah, Bosworth, and Panagariya (eds.). India Policy Forum 2013/14. New Delhi: Sage.

Athukorala, P., and R. Ekanayake. 2017. Repositioning in the Global Value Chain in the Post-MFA Era: Strategic Issues and Evidence from Sri Lanka. Development Policy Review. (forthcoming).

Athukorala, P., and S. Rajapatirana. 2000. Liberalization and Industrial Transformation: Sri Lanka in International Perspective. Delhi and Oxford: Oxford University Press.

Athukorala, P., and T. Talgaswatta. 2016. Global Production Sharing and Australian Manufacturing. Canberra: Department of Industry, Innovation and Science. http://www.industry.gov.au/Office-of-theChief-Economist/Publications/Pages/Global-production-sharing-andAustralian-manufacturing.aspx

Board of Investment. Unpublished records.

Campos, J., and H. Root. 1986. The Key to the Asian Miracle: Making Shared Growth Credible. Washington D.C.: Brookings Institution.

Central Bank of Sri Lanka (CBSL). 2016. Annual Report 2015. Colombo: CBSL. various years. Annual Report. Colombo: CBSL.

n.d. Statistics. Business Outlook Survey web page. Colombo: CBSL. http:// www.cbsl.gov.lk/htm/english/08_stat/s_8.html (accessed 22 September 2016).

Department of Labour. 2010. Sri Lanka Labour Gazette. Colombo: Department of Labour. 
Fernando, M., and S. Almeida. 2012. The Organizational Virtuousness of Strategic Corporate Social Responsibility: A Case Study of the Sri Lankan Family-Owned Enterprise MAS Holdings. European Management Journal. 30(6): 564-76.

Friedman, T. 2000. Lexus and the Olive Tree. New York: Anchor Books. Government of Sri Lanka (GSL). 2010. Sri Lanka: The Emerging Wonder of Asia: Mahinda Chintana Vision for the Future. Colombo: Department of National Planning.

Gereffi, G. 1999. International Trade and Industrial Upgrading in the Apparel Commodity Chain. Journal of International Economics. 48(1): 37-70.

Guisinger, S., and Associates. 1985. Investment Incentives and Performance, New York: Prager.

Gunawardena, S. 2007. Struggle, Perseverance, and Organization in Sri Lanka's Export Processing Zones. In Bronfenbrenuer (ed). Global Union: Challenging Transnational Capital Through Cross-Border Campaigns. Ithaca: Cornel University Press.

Helpman, E. 2011. Understanding Global Trade. Cambridge, MA: Harvard University Press.

Jacob, R. 2013. The Right Genes for Making Jeans. Financial Times, 23 January, p. 14. https://www.ft.com/content/d4191430-647b-11e2-934b00144feab49a

Joint Apparel Association Forum (JAAF). 2012. Chairman's Report to the Annual General Meeting, November, Colombo: JAAF (mimeo).

Jones, R., and H. Kierzkowski. 2004. Globalisation and the Consequences of International Fragmentation. In Dornbusch, Calvo, and Obstfeld (eds.). Money, Factor Mobility and Trade: Essays in Honor of Robert A. Mundell. Cambridge, MA: MIT Press.

Kaminski, B., and F. Ng. 2013. Revival of Inward-Orientation and its Impact on Sri Lanka's Performance in Global Markets. WSiZ Policy Research Working Papers 2. Washington, D.C.: World Bank.

Kelegama, S. 2009. Ready-Made Garment Exports from Sri Lanka. Journal of Contemporary Asia. 39(4): 579-96.

Kelegama, S., and F. Foley. 1999. Impediments to Promoting Backward Linkages from the Garment Industry in Sri Lanka. World Development 27.8. pp. 1445-60.

Krugman, P. 2008. Trade and Wages, Reconsidered. Brookings Papers on Economic Activity 1: Macroeconomics. pp. 103-38.

Marcan-Marker, M. 2016. Sri Lankan Auto-Parts Maker Rides Global Demand Wave. Nikkei Asia Review. 1 December. 
Morisset, J., and N. Prinia. 2001. How Tax Policy and Incentives Affect Foreign Direct Investment: A Review. Foreign Investment Advisory Service Occasional Paper 15. Washington D.C.: International Finance Corporation and World Bank.

Nilanka, S. 2016. Database for Real Exchange Rate and Manufacturing Exports from Sri Lanka. Canberra: Australian National University.

Nordås, H. 2009. The Global Textile and Clothing Industry Post the Agreement on Textiles and Clothing. Geneva: World Trade Organization.

Pesaran, B., and M. Pesaran. 2009. Time Series Econometrics Using Mirofit 5.0. Oxford: Oxford University Press.

Pesaran, M., and Y. Shin. 1999. An Autoregressive Distributed Lag Modelling Approach to Integration Analysis. In Strom (ed). Econometrics and Econometric Theory in the 20 $0^{\text {th }}$ Century: The Ragnar Frisch Centennial Symposium. Cambridge: Cambridge University Press.

Phillips, P., and B. Hansen. 1990. Statistical Inference in Instrumental Variables Regression with I (1) Processes. The Review of Economic Studies. 57(1): 99-125.

Pursell, G., and F. Ahsan. 2011. Sri Lanka's Trade Policies: Back to Protectionism. Australia South Asia Research Centre Working Paper 2011/03. Canberra: Australian National University

Roy, J., and R. Pattnaik. 2004. Uniform Import Duty: Next Step in Tariff Reform. Economic and Political Weekly. pp. 2483-9.

Ruwanpura, K., and N. Wrigley. 2011. The Costs of Compliance? Views of Sri Lankan Apparel Manufacturers in Times of Global Economic Crisis. Journal of Economic Geography. 11(6): 1031-49.

Savchenko, Y., and G. Acevedo. 2012. Female Wages in the Apparel Industry Post-MFA: The Case of Cambodia and Sri Lanka. Policy Research Working Paper 6061. Washington D.C.: World Bank.

Schmitz, H, and P. Knorringa. 2000. Learning from Global Buyers. Journal of Development Studies. 37(2): 177-205.

Snodgrass, D. 1966. Ceylon: An Export Economy in Transition. New Haven, CT: Yale University Press.

Snodgrass, D. 1998. The Economic Development of Sri Lanka: A Tale of Missed Opportunities. In Rotberg (ed). Creating Peace in Sri Lanka: Civil War and Reconciliation. Washington, D.C.: Brookings Institution Press.

Sri Lanka Export Development Board (SLEDB). 2015. Electronics Sector Baseline Survey. Colombo: SLEDB.

Sri Lanka Foreign Employment Bureau (SLFEB). 2015. Annual Statistical Report of Foreign Employment 2014. Colombo: SLBFE. http://www.slgfe. lk/page.phl?LID=1\&MIP=206 
Staritz, C. 2011. Making the Cut? Low-Income Countries and the Global Clothing Value Chain in a Post-Quota and Post-Crisis World. Washington, D.C.: World Bank.

Subramanian, A. 1994. The Case for Low Uniform Tariffs. Finance and Development. 31(2): 33-5.

United Nations Commission on Trade and Development (UNCTAD). World Investment Report database. http://unctad.org/en/pages/ PublicationWebflyer.aspx?publicationid=1555 (accessed 27 September 2016).

UN Comtrade database. https://comtrade.un.org

Weigand, R. 1983. International Investments: Weighing the Incentives. Harvard Business Review. 61(6): 146-52.

Wells, L. 1986. Investment Incentives: An Unnecessary Debate. The CTC Reporter. 22. pp. 58-60.

Wijesinghe, M. 1976. The Economy of Sri Lanka, 1948-1975. Colombo: Ranco Printers.

World Bank. 2005. Sri Lanka Development Policy Review. Washington, D.C.: World Bank. 2016. Sri Lanka: Ending Poverty and Promoting Shared Prosperity: A Systematic Country Diagnostic. Washington, D.C.: World Bank.

World Development Indicators database. Washington D.C.: World Bank. http://databank.worldbank.org/data/reports.aspx?source=worlddevelopment-indicators

World Economic Forum (WEF). 2016. The Global Competitiveness Report 20162017. https://www.weforum.org/reports/the-global-competitivenessreport-2016-2017-1

Yeats, A. 2001. Just How Big is Global Production Sharing? In Arndt and Kierzkowski (eds), Fragmentation: New Production Patterns in the World Economy. New York: Oxford University Press. 


\section{Chapter 5.}

\section{Modernizing Agriculture in Sri Lanka-Status and Challenges}

Jeevika Weerahewa

A griculture occupies a special place in the Sri Lankan economy despite its relatively small contribution to gross domestic product (GDP) and its slow growth rate. It provides employment to approximately one-third of the labor force and most of the rural population, which comprises $80 \%$ of the total population and either directly or indirectly engages in agriculture. The growth rates of the food manufacturing and food services subsectors, which are classified under industry and services respectively, are primarily determined by the performance of agriculture. Agricultural value chains in Sri Lanka are characterized by a large number of scattered small-scale producers, a food processing subsector that is concentrated by a few players, inadequate linkages with global value chains (despite the unique characteristics of certain agricultural products), and inadequate diversification at the farm and export levels (despite the diversification of the population's diet). Some of the factors that have held back the modernization of agriculture include vagaries of weather; increased wage rates; out-migration of labor and the increasing share of women in the agricultural labor force, with insufficient access to production opportunities and low wages; and a policy environment that incentivized selected sectors.

Successive Sri Lankan governments have implemented a number of programs with multiple objectives, e.g., achieving self-sufficiency in rice, alleviating poverty, producing safe and nutritious food, and enhancing export competitiveness. However, a focused and consolidated effort with clear policy directives will be required to speed up modernization of agriculture. Modernization should help producers to acquire economies of scale; encourage private investment in food processing (by minimizing policy uncertainties); 
increase productivities (through reforms in mechanization, seed and planting material, and land-use policies); increase investments in public goods such as agricultural research, extension, and irrigation (by diverting resources from public procurement and price subsidies); improve access to agricultural insurance and finance; and promote entrepreneurship.

\subsection{The Context}

The Government of Sri Lanka is keen to sustain the high growth rate experienced during the post-war period (from 2009 on) and to make the growth more inclusive. Plans are under way to revive the economy by improving its competitiveness and connecting it to the rest of the world through trade and investment, moving from public-sector-led to private-sector-led growth. This chapter addresses two questions:

(1) What is the relative position of agriculture in Sri Lanka's overall economy?

(2) What are the key institutional and policy challenges that the agriculture sector faces in supporting the structural transformation of the economy?

The chapter provides an account of the structure of (1) the agricultural economy, highlighting the changing role played by agriculture in Sri Lanka's economy; (2) agricultural land-use and employment changes in the domestic demand for agricultural produce; and (3) the connections with the rest of the world through exports and imports of agricultural produce. The chapter presents the key characteristics of selected agriculture value chains and assesses institutional challenges. Finally, the agricultural policy framework is chronicled, and policy challenges in land, fertilizer, seeds, research and extension, credit, mechanization, marketing, and trade are assessed.

\subsection{Agriculture in the Economy of Sri Lanka}

\subsubsection{Historical Overview}

Prior to British rule, which commenced in 1815, Sri Lanka had a self-sufficient economy comprising a peasant agriculture sector and a small amount of international trade in spices. Most agriculture land was used for growing rice.

The colonial rulers established large plantations to enable exporting. The British imposed restrictions on traditional land-use and ownership patterns. 
Farmers were allowed only cultivation rights, and vast areas of land were made available for European investors who established large plantations. This resulted in a steep rise in agriculture for export while domestic food production stagnated, producing mainly for household consumption with a little surplus for local markets (Samaratunga 2012). The role of domestic food production was further marginalized by the depressed prices in these markets following the widespread promotion of cheap imported food. The country's GDP grew rapidly with export earnings from the plantations, while the contribution of the domestic food production subsector gradually shrank until Sri Lanka achieved independence in 1948.

In the mid-1900s, nationalistic sentiment arose in the political movement. Large-scale irrigation projects were undertaken in the dry zone, and the irrigated lands were transferred to landless people from other areas in order to promote food production. This started a slight upward trend in domestic food production, which was reinforced by the scarcity and high prices of imported food from the early 1930s to the mid-1940s. Sri Lanka's independence in 1948 had a major impact on agriculture, particularly food production and consumption.

From 1948 on, domestic food production was given high priority, with selfsufficiency in rice the prime objective. With continued land development and support for rice prices, domestic food production picked up some momentum. This was further strengthened after 1960 by the increasing prices of imported food. The economic policy paradigm the Sri Lankan government adopted after the 1960s was clearly oriented to import substitution, and restrictions on imports and sporadic price support for domestic food crops further supported the growth of domestic food production. However, this change did not help the country alleviate its food import burden because the demand for food grew at a much faster rate than local food production increased.

The import substitution development strategy came to an end following the radical political change of 1977. The new government immediately liberalized trade and adopted an export promotion development strategy in the years that followed. Policy changes relevant to agriculture were less drastic than those introduced for industry. Rural wage rates rose, leaving agriculture an uncompetitive employer. This changed the price structure facing domestic agriculture, resulting in drastic changes in food production and consumption.

The plantation subsector continued to grow until the early 1970s, albeit more slowly than in earlier years. Land reforms the government brought into effect in 1973 limited the landownership to a maximum of 50 acres (about 20 hectares [ha]) of upland and 25 acres (about 10 ha) of lowland per individual. Larger plantations (termed "estates" in Sri Lanka) were nationalized and their management was brought under two government corporations. Despite the good intentions, this 
change did not improve the plantation subsector. Instead, mismanagement and pilferage led to a steady decline in production and productivity in the plantations (Athukorala and Jayasuriya 1994). This situation continued until the early 1990s, when plantation management was handed over to private companies. Although the change restored the plantation subsector to some extent, its relative contribution to the national economy declined vis-à-vis the nonagriculture subsectors.

\subsubsection{Contribution to Gross Domestic Product}

Agriculture's contribution to GDP has been declining over the years and was 7.8\% in 2015. This suggests that the sector provides a relatively small contribution to increasing Sri Lanka's economic growth rate. However, within agriculture, growth rates differ significantly across subsectors. The Department of Census and Statistics divides agriculture into 16 subsectors. Among them, fruits, vegetables, spices, and animal products have had relatively higher growth rates during 2011-2015. In addition, agriculture provides raw materials to the food, beverage, and tobacco manufacturing subsector, which is listed under industry. In 2015, the subsector contributed $6.3 \%$ to GDP and grew at a rate of $5.6 \%$, demonstrating agriculture's indirect contribution to Sri Lanka's economic growth. Bakery products, dairy, prepared meals, and sugar had higher growth rates in 2015 than other agriculture subsectors. In addition, the contribution made by accommodation, food, and beverage activities listed under services, which was $1.5 \%$ of GDP in 2015, should also be considered given agriculture's contribution to the subsector. Table 5.1 shows the growth rates of agriculture and GDP, and agriculture's contribution to GDP growth from 1970 to 2014.

Table 5.1: Growth and Average Share of Gross Domestic Product in Agriculture, 1970-2014

\begin{tabular}{l|ccc} 
Period & GDP Growth Rate & $\begin{array}{c}\text { Contribution } \\
\text { of Agriculture }\end{array}$ & $\begin{array}{c}\text { Agriculture Growth } \\
\text { Rates }\end{array}$ \\
\hline $1970-1974$ & 2.95 & 28.44 & 1.91 \\
\hline $1975-1979$ & 5.32 & 29.49 & 3.32 \\
\hline $1980-1984$ & 5.12 & 27.71 & 3.46 \\
\hline $1985-1989$ & 3.17 & 26.74 & 1.12 \\
\hline $1990-1994$ & 5.58 & 25.47 & 3.40 \\
\hline $1995-1999$ & 4.94 & 21.82 & 1.87 \\
\hline $2000-2004$ & 3.96 & 16.00 & 0.52 \\
\hline $2005-2009$ & 6.04 & 12.18 & 4.46 \\
\hline $\mathbf{2 0 1 0 - 2 0 1 4}$ & $\mathbf{7 . 4 4}$ & $\mathbf{1 1 . 3 1}$ & $\mathbf{3 . 7 2}$ \\
\hline
\end{tabular}

GDP = gross domestic product.

Sources: CBSL (various years), Annual Reports. 


\subsubsection{Labor Force Participation}

Table 5.2 shows the share of employment in major sectors in 2015. In Sri Lanka, $28.7 \%$ of the labor force was employed in the agriculture sector in 2015 . Thus, the sector's contribution to employment was more than three times its contribution to GDP, indicating agriculture's productivity is lower than that of other sectors. Poverty is a rural phenomenon in Sri Lanka and most of the rural poor rely on agriculture as a main source of income. Compared with the rich, the poor allocate a larger share of their income for food. An examination of the allocation of food expenditure across food items indicates that the general Sri Lankan diet has diversified over time toward proteins, fruits, and vegetables, and less starch.

Table 5.2: Employment in Major Sectors, 2015 (\%)

\begin{tabular}{l|c|c|c|c} 
Sector & Agriculture & Industry & Services & Total \\
\hline Sri Lanka & 28.7 & 25.8 & 45.6 & 100.0 \\
\hline Urban & 4.8 & 25.8 & 69.4 & 100.0 \\
\hline Rural & 30.6 & 26.6 & 42.8 & 100.0 \\
\hline Plantations & 72.6 & 12.5 & 14.8 & 100.0 \\
\hline
\end{tabular}

Plantations are termed "estates" in Sri Lanka.

Source: DCS (2014b).

The Labor Force Surveys (DCS various years) shows that women's participation rates in the agriculture sector have increased (Table 5.3).

Table 5.3: Labor Force Participation in Agriculture, Forestry, and Fishing

\begin{tabular}{l|c|c|c|c|c}
\hline & \multicolumn{3}{|c}{ Number } & \multicolumn{2}{c}{ Percent } \\
\hline Year & Male & Female & Total & Male (\%) & Female (\%) \\
\hline 1994 & $1,368,413$ & 717,582 & $2,085,995$ & 65.60 & 34.40 \\
\hline 2004 & $1,539,279$ & 935,446 & $2,474,725$ & 62.20 & 37.80 \\
\hline 2010 & $1,547,474$ & 972,431 & $2,519,905$ & 61.41 & 38.59 \\
\hline 2013 & $1,423,393$ & 897,822 & $2,321,215$ & 61.32 & 38.68 \\
\hline 2014 & $1,375,427$ & 847,432 & $2,222,859$ & 61.88 & 38.12 \\
\hline 2015 & $1,360,831$ & 883,716 & $2,244,547$ & 60.63 & 39.37 \\
\hline 2016 Q1 & $1,362,990$ & 911,732 & $2,274,722$ & 59.92 & 40.08 \\
\hline 2016 Q2 & $1,208,473$ & 753,344 & $1,961,817$ & 61.60 & 38.40 \\
\hline 2016 Q3 & $1,311,167$ & 857,815 & $2,168,982$ & 60.45 & 39.55 \\
\hline
\end{tabular}

Source: DCS (various years), accessed 13 March 2017. 
Among the employment categories, the percentages of own-account workers and contributing family workers are higher in the agriculture sector than in industry and services. In Sri Lanka, the contribution of informal sector employment to the total employment is about $59.8 \%$. The Labour Force Survey results reveal that $86.3 \%$ of agricultural employment comprises informal sector employment, and agriculture formal sector employment is only $13.7 \%$. Formal sector agricultural employment mainly comprises employment in the plantation subsector, owned by the government or corporate sectors.

The increasing share of women in the agriculture labor force is a worrying trend for two reasons. One is lower wellbeing of female workers due to the lower wages that prevail in agriculture. The other is the resulting lower labor productivity in agriculture due to the difficulties female workers face in accessing productive resources and various services.

Policies of the agriculture subsectors in Sri Lanka can be considered largely gender neutral, but gender-sensitive policies are required to increase women's participation in decision making and accessing resources in the agriculture sector.

\subsubsection{Land-Use Patterns}

Rice, coconut, and tea dominate the land-use pattern in Sri Lanka. Despite the low productivity of rice land in some geographical areas, farmers have not diversified significantly into other crops.

Table 5.4 clearly shows a strong bias in favor of rice. Although the areas under rice and fruit show a slight upward trend, the pattern of land allocation among crops has not changed appreciably from 1977 to 2014.

\section{Table 5.4: Land Area under Crops}

\begin{tabular}{l|c|c|c|c}
\hline & \multicolumn{4}{c}{ Land Area (hectares) } \\
Year & Rice & Other Food Crops & \multicolumn{1}{c}{ Fruit } & Vegetables \\
\hline 1977 & 828,000 & 195,426 & 48,842 & 91,906 \\
\hline 1980 & 845,000 & 161,418 & 49,773 & 80,971 \\
\hline 1985 & 882,000 & 176,125 & 54,980 & 81,850 \\
\hline 1990 & 857,000 & 230,520 & 61,367 & 83,408 \\
\hline 1995 & 915,000 & 160,552 & 84,497 & 90,973 \\
\hline 2000 & 878,000 & 111,167 & 92,330 & 98,611 \\
\hline 2005 & 937,000 & 118,135 & 97,720 & 80,778 \\
\hline 2010 & $1,065,000$ & 154,014 & 101,380 & 75,954 \\
\hline 2014 & 964,000 & 173,185 & - & - \\
\hline
\end{tabular}

— = not available

Sources: FAO, FAOSTAT database, accessed 13 March 2017; CBSL (various years), Annual Reports. 


\subsubsection{Food Consumption Pattern}

Table 5.5 shows that the quantity of rice, wheat flour, bread, and coconut consumed decreased from 1981 to 2013. Although the share of expenditure on sugar has declined, the quantity consumed increased during this period. Conversely, while the share of expenditure on milk and milk products rose, the consumption of fresh milk has declined from 2.7 liters per month per household to 0.4 liters. At the same time, the quantity of pulses, meat, fish, and eggs consumed continued to increase. Clearly, the diet has diversified considerably in the last 4 decades. Nevertheless, Sri Lanka's food production has continued to be concentrated in rice, with the objective of being self-sufficient in the grain. This indicates that local food production could not keep up with the changing demand for food that has accompanied the transformation in diet; consequently, the country has had to import most of its food needs.

\section{Table 5.5: Average Monthly Household Consumption of Selected Food, 1980-2013}

\begin{tabular}{|c|c|c|c|c|c|c|c|c|c|c|c|}
\hline & Rice & $\begin{array}{l}\text { Wheat } \\
\text { Flour }\end{array}$ & Bread & Pulses & Meat & Fish & $\begin{array}{l}\text { Dried } \\
\text { Fish }\end{array}$ & Sugar & Milk & Eggs & Coconuts \\
\hline & $\mathrm{kg}$ & $\mathrm{kg}$ & $\mathrm{kg}$ & $\mathrm{kg}$ & $\mathrm{kg}$ & $\mathrm{kg}$ & $\mathrm{kg}$ & $\mathrm{kg}$ & liter & \# & \# \\
\hline 1980-1981 & 46.7 & 3.6 & 7.8 & 1.4 & 0.8 & 3.5 & 1.4 & 3.8 & 2.7 & 7 & 37 \\
\hline $1985-1986$ & 45.2 & 4.0 & 9.3 & 1.7 & 1.1 & 3.4 & 1.4 & 6.0 & 2.4 & 7 & 38 \\
\hline 1990-1991 & 44.3 & 2.6 & 9.9 & 2.6 & 1.2 & 2.4 & 1.3 & 5.8 & 1.4 & 11 & 39 \\
\hline 1995-1996 & 38.0 & 3.0 & 12.5 & - & - & - & & 5.6 & 0.7 & 12 & 33 \\
\hline 2002 & 35.3 & 3.3 & 10.2 & 3.0 & 1.3 & 2.9 & 1.4 & 5.3 & 0.4 & 10 & 30 \\
\hline 2005 & 35.6 & 3.1 & 7.3 & 2.9 & 1.6 & 3.8 & 1.3 & 5.6 & 0.7 & 10 & 30 \\
\hline $2006-2007$ & 36.6 & 2.4 & 6.2 & 3.1 & 1.4 & 3.7 & 1.4 & 5.2 & 1.4 & 11 & 30 \\
\hline $2009-2010$ & 36.3 & 2.7 & 5.1 & 2.8 & 1.4 & 3.8 & 1.3 & 4.9 & 1.9 & 10 & 20 \\
\hline $2012-2013$ & 34.8 & 2.2 & 3.6 & 3.0 & 1.6 & 3.7 & 1.2 & 4.3 & 0.4 & 11 & 28 \\
\hline
\end{tabular}

$-=$ not available, $\mathrm{kg}=$ kilogram.

Source: DCS (2014a).

Diet diversification is described in terms of the share of expenditure on different food commodities and the quantities consumed over time. Figure 5.1 shows that the share of household expenditure on rice, wheat flour, bread, coconut, and sugar declined from 1981 to 2013. Conversely, the share of expenditure on fish, fruit, meat, pulses, and milk and milk products exhibit an increasing trend. Further, the share of expenditure on other food and drinks, such as other food crops (OFC-a category including black gram, green gram, chili, cowpea, sesame, groundnut, finger millet, and soybean), tea, and coffee, increased significantly during the last 4 decades. The share of expenditure on vegetables, condiments, dried fish, and eggs remained unchanged during this period. 
Figure 5.1: Household Expenditure on Food Items as a Share of Total Expenditure on Food and Drink, 1980-2013 (\%)

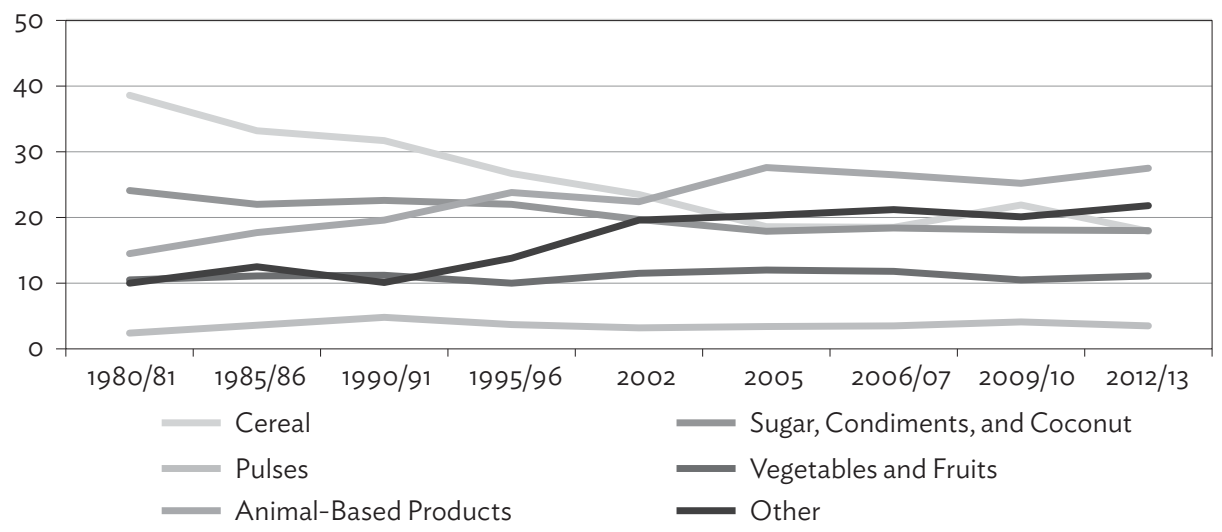

Source: DCS (2014a).

\subsubsection{Agriculture and Food Trade}

Trade in food and agricultural items constituted approximately $8 \%$ of total imports and $25 \%$ of total exports in 2015 . The major items in the export basket include tea, cinnamon, pepper, and desiccated coconut (Figure 5.2). The major food imports included wheat, sugar, and dairy. In order of importance, India, the United Arab Emirates, the Russian Federation, the United States, and Germany were the major export destinations during 2005-2014, and the People's Republic of China, India, Malaysia, the United States, Germany, and Pakistan were the major import sources. High dependence on imports to meet the domestic food requirement and inadequate diversification of the export basket are some key challenges that Sri Lanka faces.

Figure 5.2: Value of Agricultural Exports (\$ million)

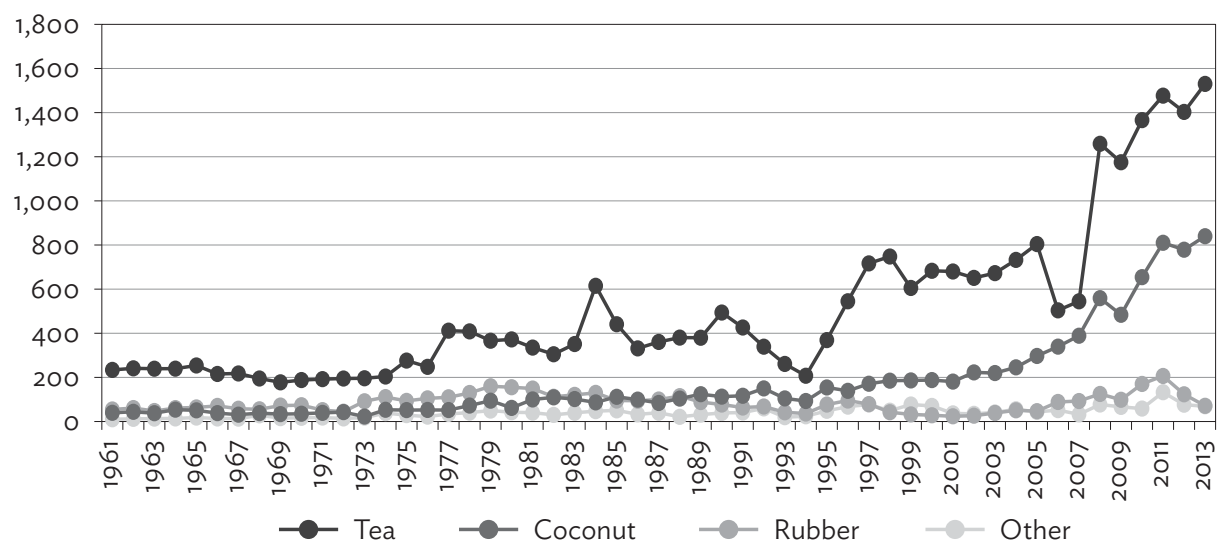

Source: FAO, FAOSTAT database, accessed 13 March 2017. 


\subsection{Sri Lankan Agriculture Compared with Neighboring Countries}

In this section, the productivity of land under selected crops in Sri Lanka is presented and then compared with the land productivity values in selected Asian countries. As depicted in Table 5.6, except for fruit, the productivity of all other croplands has increased from 1977 to 2014. The productivity of rice land continued to increase during this period with minimum fluctuations, and has doubled during the last 4 decades. In the case of sugar, average annual productivity decreased from 44.34 tons/ha to 37.30 tons/ha during 1977 to 1991 , increased from 1992 to 2007, then dropped after 2011.

The productivity of land under maize, potato, onion, and other food crops increased marginally during the period, with intermittent ups and downs, mainly due to the weather. Land productivity under vegetables after 2012 is double that in 1977, exhibiting a rapid increase. Fruit productivity, which was computed using total production and extent figures, has dropped significantly (Table 5.6).

Table 5.6: Average Yields of Selected Crops, 1977-2014 (t/ha)

\begin{tabular}{|c|c|c|c|c|c|c|c|c|}
\hline Crop & $\begin{array}{c}1977- \\
1981\end{array}$ & $\begin{array}{c}1982- \\
1986\end{array}$ & $\begin{array}{c}1987- \\
1991\end{array}$ & $\begin{array}{c}1992- \\
1996\end{array}$ & $\begin{array}{c}1997- \\
2001\end{array}$ & $\begin{array}{c}2002- \\
2006\end{array}$ & $\begin{array}{c}2007- \\
2011\end{array}$ & $\begin{array}{c}2012- \\
2014\end{array}$ \\
\hline Rice & 2.77 & 3.38 & 3.44 & 3.47 & 3.75 & 3.97 & 4.28 & 4.32 \\
\hline Sugar & 44.34 & 34.93 & 37.30 & 48.38 & 55.93 & 58.74 & 61.12 & 48.55 \\
\hline Maize & 1.23 & 1.00 & 1.22 & 1.14 & 1.06 & 1.32 & 2.40 & 3.47 \\
\hline Onion & 10.79 & 8.53 & 10.33 & 9.30 & 9.48 & 10.29 & 12.98 & 14.05 \\
\hline Potato & 13.83 & 12.46 & 12.24 & 11.62 & 12.10 & 13.76 & 14.32 & 15.40 \\
\hline OFC & 0.90 & 0.75 & 0.84 & 0.83 & 0.77 & 0.89 & 1.18 & 1.25 \\
\hline Fruits & 29.97 & 18.06 & 10.08 & 8.45 & 7.78 & 7.35 & 7.01 & 7.32 \\
\hline Vegetables & 4.26 & 6.47 & 7.41 & 6.69 & 7.10 & 7.73 & 9.45 & 10.73 \\
\hline
\end{tabular}

OFC = other food crops: including black gram, green gram, chili, cowpea, sesame, groundnut, finger millet, and soybeans; $\mathrm{t} / \mathrm{ha}=$ tons per hectare.

Sources: FAO, FAOSTAT database, accessed 13 March 2017; CBSL (various years), Annual Reports.

Sri Lanka ranks well among South Asian countries in terms of rice productivity (Figure 5.3), Bangladesh being the country with the highest land productivity. Sri Lanka ranked fourth with respect to land productivity in maize in 2005 and third in 2013. Compared with other countries in South Asia, land productivity of spices and soybean is by far the highest in Sri Lanka, while the land productivity of tea is ranked second among countries in the region. However, Sri Lanka's performance in vegetables such as potato production is well below that of other South Asian countries. 
Figure 5.3: Land Productivity of Selected Crops in Selected South Asian Comparators, 2005-2013
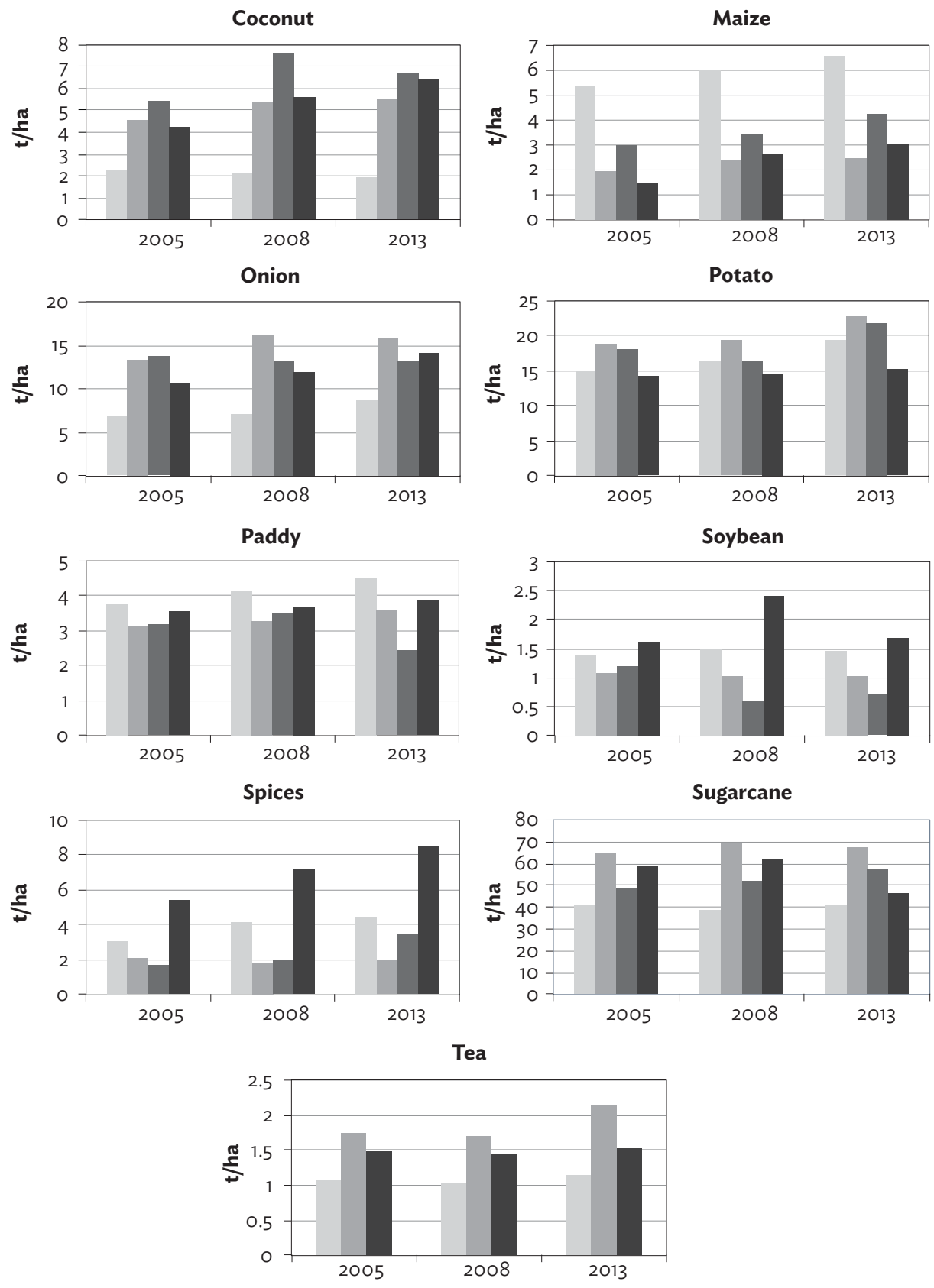

Bangladesh India Pakistan Sri Lanka

$\mathrm{t} / \mathrm{ha}=$ tons per hectare.

Source: FAO, FAOSTAT database, accessed 5 April 2017. 
Since its independence in 1948, Sri Lanka has been making substantial investment in irrigation and research and extension to increase its food crop production. However, the complementary institutional factors-such as water management mechanisms, input delivery systems, and efficient market mechanisms-were not developed in tandem and, consequently, the desired outcome was not adequately realized. This indicates the need for state intervention in providing modern technology, innovative institutions, improved infrastructure, and other assistance in order to enhance the productivity of the domestic food production subsector.

\subsection{Agricultural Value Chains in Sri Lanka: Problematic Interfaces}

Several institutional challenges have hampered the modernization of the agriculture value chains. Production in the value chains is generally scattered, making economies of scale and maintenance of quality assurance difficult to acquire. The value chains are also vulnerable to changes in weather and climate. Collective behavior among farmers is weak and hence their bargaining power is low. The increasing demand for labor by industry and services has reduced the availability of labor for agricultural production, increased wage rates, and thus reduced the competitiveness of farm production.

Agriculture value chains face a multitude of problems. Food processing is concentrated in a few enterprises, and private investment in food processing and value addition is insufficient. The inadequate investment could be due to uncertainties of policy and access to finance. Poor governance and a lack of social responsibility in the private sector may also have hindered vertical integration, and insufficient growth of contractual arrangements slowed the linking of smallholder farmers to markets.

Despite ample opportunities in the world market for the food and agriculture commodities that Sri Lanka could produce, domestic value chains have not been sufficiently connected to global value chains to take advantage of the opportunities. Causes include inadequate awareness of export demand and inadequate linkages among exporters with other players in the value chains. Low wages in neighboring countries could make their food and agricultural products more competitive in the world market if Sri Lanka does not connect to the global value chains.

A review of the value chains of rice, vegetables, coconut, spice, tea, dairy, broiler chickens, and fish reveals unique characteristics in each chain. 


\subsubsection{Rice Value Chain}

The rice value chain operates under a highly protected environment. The Paddy Marketing Board (PMB) was established in 1970 as the government-authorized body to purchase, sell, supply, and distribute paddy (unhulled rice) and to mill paddy and polish and prepare rice (PMB 2010). The PMB, a key actor in the value chain, was abolished in the early 1990s and reestablished in 2005. The PMB restarted purchasing paddy from farmers in 2008. The PMB also maintains a buffer stock of paddy (PMB 2010). ${ }^{1}$ However, the PMB is not as powerful in the rice value chain as it was in the 1970s and 1980s and large private rice millers now have more control over the rice stocks and prices than the PMB does (Figure 5.4). The rice value chain is characterized by a high concentration in rice milling.

\section{Figure 5.4: Structure of the Rice Value Chain}

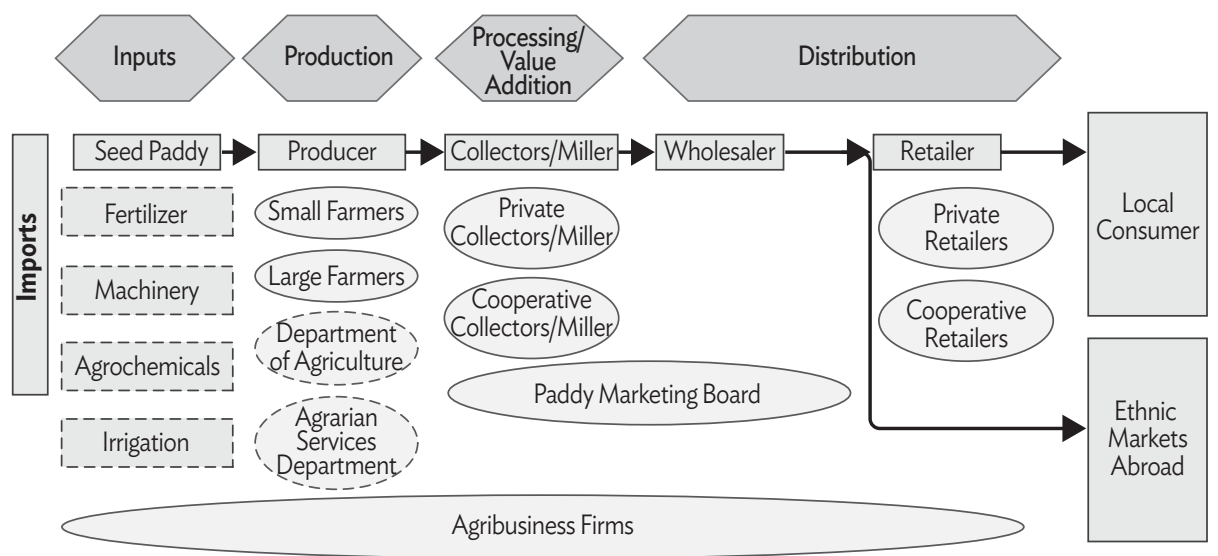

Note: $\bigcirc$ = stage of the value chain, $\square$ = main actor, $\bigcirc$ = other actor, $\mathbf{I}_{-}$= regulatory body, $\mathrm{I}_{-}^{-} \mathrm{l}=$ input other than seed paddy, $\longrightarrow$ = production flow.

Source: Adapted from Weerahewa et al (2015).

The government used to be the main producer and supplier of seed to rice growers, but large agribusiness companies such as CIC Agribusiness and farmers have moved into seed production. With the development of agribusiness firms in Sri Lanka, rice out-grower systems were introduced to the rice value chain. The agribusiness firms grow special varieties of good quality rice for niche markets.

1 The PMB is not expected to have a significant influence on the rice market as its market share is about $5 \%$ at present. However, Weerahewa (2004) concluded that, in the absence of government procurement, paddy prices would be further depressed, as private purchasers of paddy would exercise oligopsony power on paddy sellers/producers. This is due to two reasons. On the one hand, paddy sellers need to sell their produce immediately for cash to meet repayment obligations as they lack storage facilities. On the other hand, there are fewer millers of paddy than suppliers, allowing millers to exert oligopsony power. 
Sri Lanka is not competitive in the world rice market because of the high cost of production and lack of global consumer preference for the short-grain varieties preferred in Sri Lanka, although some traditional varieties of rice might find a niche abroad. Rice from Sri Lanka is exported to Sri Lankan communities living abroad.

\subsubsection{Dairy Value Chain}

The Sri Lankan government has a very ambitious target of becoming selfsufficient in milk. But at the rate the sector is growing ( $1 \%-2 \%$ per year), it will have difficulty meeting the increasing demand.

In 2015,374 million liters of milk were produced domestically. Of the total production, about $75 \%$ was channeled domestically via informal routes (Vernooij et al., 2015) and consumed as fresh milk or processed into products such as curd and yoghurt. According to Vernooij et al. (2015), MILCO Pvt. Ltd (a government-owned company) is the largest collector and accounts for $30 \%$ of the milk collected in Sri Lanka. Other collectors include Nestle Lanka Pvt. Ltd. (which collects about $23 \%$ of the milk that enters the formal milk market); Pelwatta companies, Rich Life, Kothmale, Cargills, Fontera, Ambewella, and CIC. Altogether, large-scale producers' collected 219 million liters of milk in 2015 (CBSL 2015), implying that approximately 60 million liters were channeled through small-scale collectors in the formal sector.

Domestic milk production is sufficient to meet only $40 \%$ of the requirement. In 2015, imports of milk and milk products increased. Sri Lankans are more used to drinking powdered milk than raw liquid milk, and 81,759 tons of milk powder were imported in 2015 (CBSL 2015).

Sri Lanka produces milk from dairy cattle and buffalo. In 2015, dairy cows produced 305 million liters of milk and buffalo produced 69 million liters. Sri Lanka had 392,710 milking cows and buffalo (91,570 were buffalo). Large-scale collectors accounted for 219 million liters. Government-owned farms produced 11 million liters in 2015. During 2012-2013, the government farms imported 2,000 cows from Australia; their output also helped meet the industrial demand for liquid milk.

Milk is produced in all Sri Lanka's districts. The largest cattle populations are in the dry and intermediate ecological zones. In terms of production, wet mid- and up-country areas are often perceived as the main dairy-producing areas. However, the dry and dry-intermediate zones produce $50 \%$ more milk than the wet and wet-intermediate zones. In the formal milk collecting network, 300,000 liters are channeled every day. However, the collecting network's capacity remains underutilized. 
Most milk is coming from smallholders who keep 1-2 cows. Cattle are raised mostly by smallholders as part of crop-livestock integration. The smallholder's milk production is low as the cattle are not fed high-quality grass and concentrates. Because the financial return for the farmers' labor is less than $50 \%$ of the casual wage rate, it is difficult to retain farmers in dairy production. Similar smallholder systems in Kenya and India are 50\%-70\% more productive than those in Sri Lanka, because the costs are lower than in Sri Lanka due to lower wage rates and cheaper feed. Milk production could be improved by attaching large-scale dairy farms and smallholders through an out-grower system, which has been successful in in Sri Lanka's poultry industry.

The efficiency of the dairy value chain (Figure 5.5) is hindered by the limited availability of good quality grass and limited awareness of good management practices.

Figure 5.5: The Dairy Value Chain

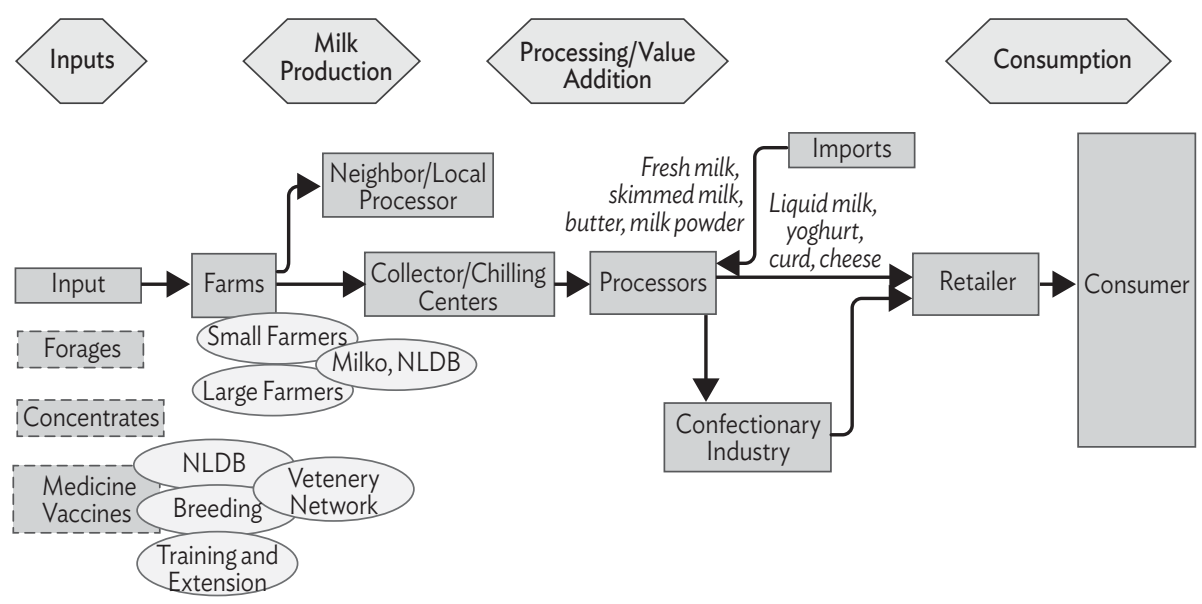

NLDB $=$ National Livestock Development Board.

Note: $\bigcirc$ = stage of the value chain, $\square$ = main actor, $\bigcirc=$ other actor, $\left.I_{-}^{-}\right]=$input, $\rightarrow=$ production flow. Source: Adapted from Weerahewa et al (2015).

\subsubsection{Vegetable Value Chain}

Vegetables are cultivated both in the uplands and in the plains, each with weather conditions suitable for different types of vegetables. Upland vegetable cultivation (mainly in Bandarawela, Nuwara-Eliya, and Welimada areas) is considered to be highly intensive with significant use of agrochemicals, whereas cultivation in the plains is less intensive and uses fewer chemicals. Vegetable farms sell their produce to village or town traders. The traders transport the produce to (1) large 
markets in Colombo, which distribute to the entire country; or (2) dedicated economic centers established in other parts of the country, which distribute vegetables grown near them.

Figure 5.6 depicts the vegetable supply chain. A new supply chain emerged with the spread of supermarkets, which sell produce for high-end, quality conscious customers. Small- and medium-scale supermarkets have become large buyers from wholesale vegetable suppliers in the traditional supply chain. Large supermarket chains have established procurement centers that buy directly from the farmers. This is more efficient than using the traditional supply chain because direct purchasing can reduce post-harvest losses due to improper harvesting practices and handling and to poor conditions during transport. Supermarket chains that buy directly from farmers promise to grade vegetables and pay a premium for high quality. However, this practice is not strictly implemented in all the procurement centers. Nevertheless, post-harvest losses are lower in the vegetables that pass through the supermarket procurement centers to the customers, as supermarkets are capable of adopting good handling practices.

The effects of supermarkets on consumer prices, producer prices, and food quality have been examined by a number of authors. Abeysekera and Abeysekera (undated) revealed that retail prices in supermarkets are 10\%-15\% lower than those in conventional marketing chains, contract growers supplying vegetables to the supermarkets receive prices that are $15 \%-25 \%$ higher than through the conventional marketing system, and most supermarkets have taken several steps to ensure the quality and improve the shelf life of fruits and vegetables. According to Kodithuwakku and Weerahewa (2013), supermarkets had created an alternative supply chain of vegetables that was more efficient and effective than traditional supply chains in terms of transparency, accountability, number and role of intermediaries, and prevalence of quality consciousness throughout the supply chain, as well as resulting in comparatively low post-harvest losses. However, only a minority of farmers had direct access to this supply chain.

Some supermarkets have developed contract grower systems for vegetables. The emergence of the supermarkets' supply chains has increased competition for supply and diverted some farmers' focus from traditional agriculture to alternative crops. However, the volume of vegetables flowing through the supermarket supply chain is smaller than through the traditional value chain, which remains the most assured market for farmers despite its weaknesses.

Vegetable value chains are impacted by farmers' inadequate awareness of good agricultural practices; a large number of intermediaries, which inhibits the efficiency of passing through quality signals; and inadequate links with foreign buyers. 
Figure 5.6: The Vegetable Value Chain

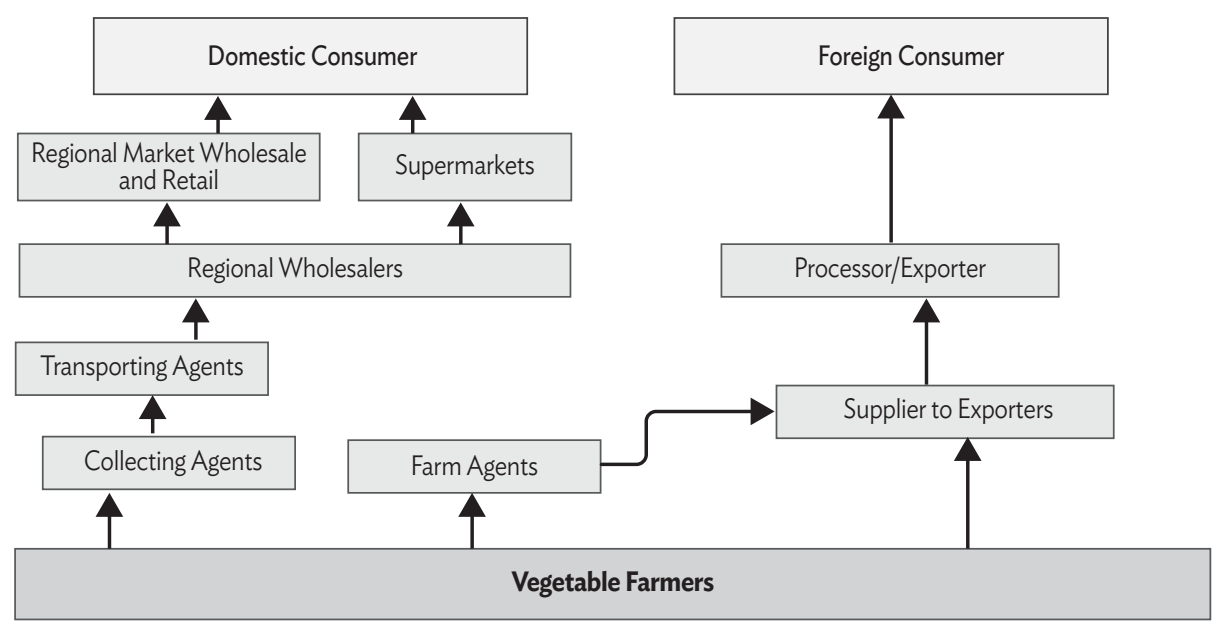

Note: $\longrightarrow$ = production flow.

Source: Adapted from Weerahewa et al (2015).

\subsubsection{Coconut Value Chain}

The coconut value chain (Figure 5.7) includes several types of items-food products, such as raw coconut, oil, and coconut milk; products from coconut waste, such as coconut fibers and shells; and crops that are intercropped with coconut, such as banana and rambutan. Stakeholders in the Sri Lankan coconut value chain are the growers, desiccated coconut millers, copra manufacturers, coconut oil manufacturers, fiber millers, shell charcoal manufacturers, valueadded fiber product manufacturers, activated carbon manufacturers, and exporters (EDB 2012). Producers generally have a poor understanding of the market (Romulo 2013). Infrastructure for manufacturing and transporting coconut products is insufficient. A major constraint that desiccated coconut exporters face is inadequate production to feed the mills. Additionally, the industry faces increasing energy costs and has not innovatively expanded its supply of products.

Coconut plantations are being fragmented and farmers practice intercropping with coconut to increase returns from the land. Links between smallholder farmers and processors are weak. 
Figure 5.7: The Coconut Value Chain

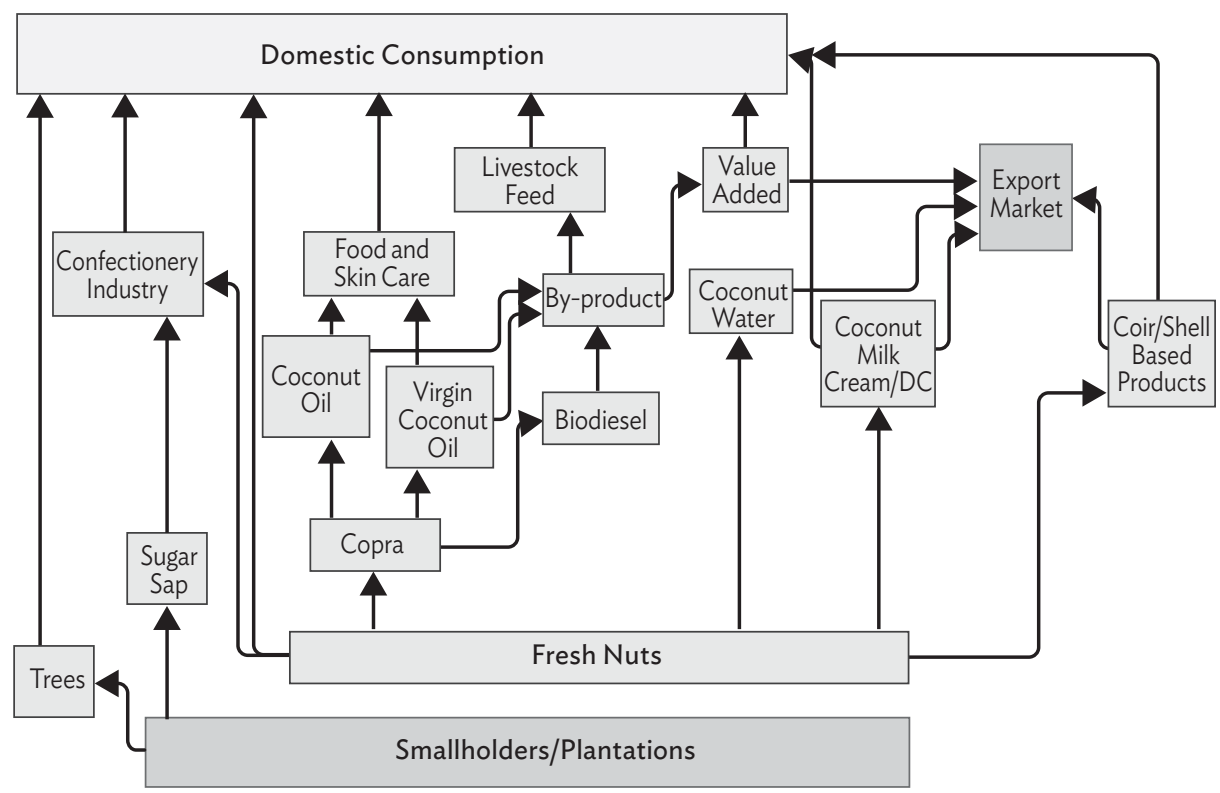

Note: $\longrightarrow$ = production flow.

Source: Adapted from Pathiraja and Weerahewa (2013).

\subsubsection{Spice Value Chain}

In Sri Lanka's traditional spice value chain, a travelling collector visits remote villages, collects the harvest, and sends it to a nearby wholesaler on the same day. Smallholders sell to the travelling collector to avoid transport cost. Or they may sell their produce to a village retail boutique. The boutique owner collects spices bought from farmers until a bulk is accumulated to sell to the wholesaler in the town. Smallholders may sell their spices to the boutique to compensate for debts owed to it. Usually, the travelling collectors pay higher prices than the boutiques.

From the local wholesaler, the produce goes to the wholesaler in town, then on to commission agents/brokers in Colombo. Spice exporters buy from the commission agents. The many intermediaries in the value chain add little value to the produce, but increase its prices. Benefits of the increased prices do not flow back to the farmers. The problem is poor market links between growers and exporters. 
Smallholder farmers have little or no understanding about the quality of the produce. They are not educated or trained in general agricultural or management practices. Because the produce is not graded and remunerated accordingly, smallholders are not motivated to be quality conscious. The result is high wastage as produce flows through the value chain and quality deteriorates with time. With continuing inflation and the rising cost of living, labor wages have increased and producers face higher production costs. Smallholders have difficulty attracting full-time labor (e.g., cinnamon peelers), as the wages offered are not attractive.

The spices subsector is facing several challenges and threats related to marketing. The value added in the value chain is very low, and produce deteriorates as it changes many hands from farmer to consumer. The international spice trade's export procurement systems are changing, and world trade agreements are increasing requirements for food quality and safety. These factors have created a new demand pattern with more focus on continuing supply of high-quality, safe, value-added products with improved processing technology and packaging. The impact of modem and restructured markets has several implications for farmers' efforts to keep up with emerging marketing trends. Innovative processing practices and appropriate technologies are needed to improve farmers' ability to handle restructured market conditions.

The global trend toward organic products is increasing. Since 1995, organic spice production has grown by $30 \%$ annually (Herath 2002). Sri Lanka will have to shift to organic farming practices and certification to keep up with the world's changing marketing conditions. According to the European Union's Centre for the Promotion of Imports from Developing Countries, the global spices market is growing at an annual growth rate of about $5 \%$ (by value) and is projected to exceed $\$ 10$ billion by 2020 (CBI 2017). The most recent report of Research and Markets states that the organic segment accounts for about $10 \%$ of the total seasonings and spices market (Businesswire 2016).

The spice value chain (Figure 5.8) is hampered by limited access to highquality planting materials, farmers' limited awareness of general agricultural practices, weak links between farmers and manufacturers, and limited awareness of the opportunities in the world market. However, Sri Lanka has a unique competitive advantage in the intrinsic good quality of its spices.

Sri Lanka's Spice Council, Department of Export Agriculture, and Export Development Board are the main government institutes facilitating the spice subsector. The Spice Council works with stakeholders to ensure that its industry segments can compete effectively and profitably in the spices and allied products markets at home and abroad. The Export Development Board, the state organization for promoting and developing exports, facilitates spice exports. 
Figure 5.8: The Spice Value Chain

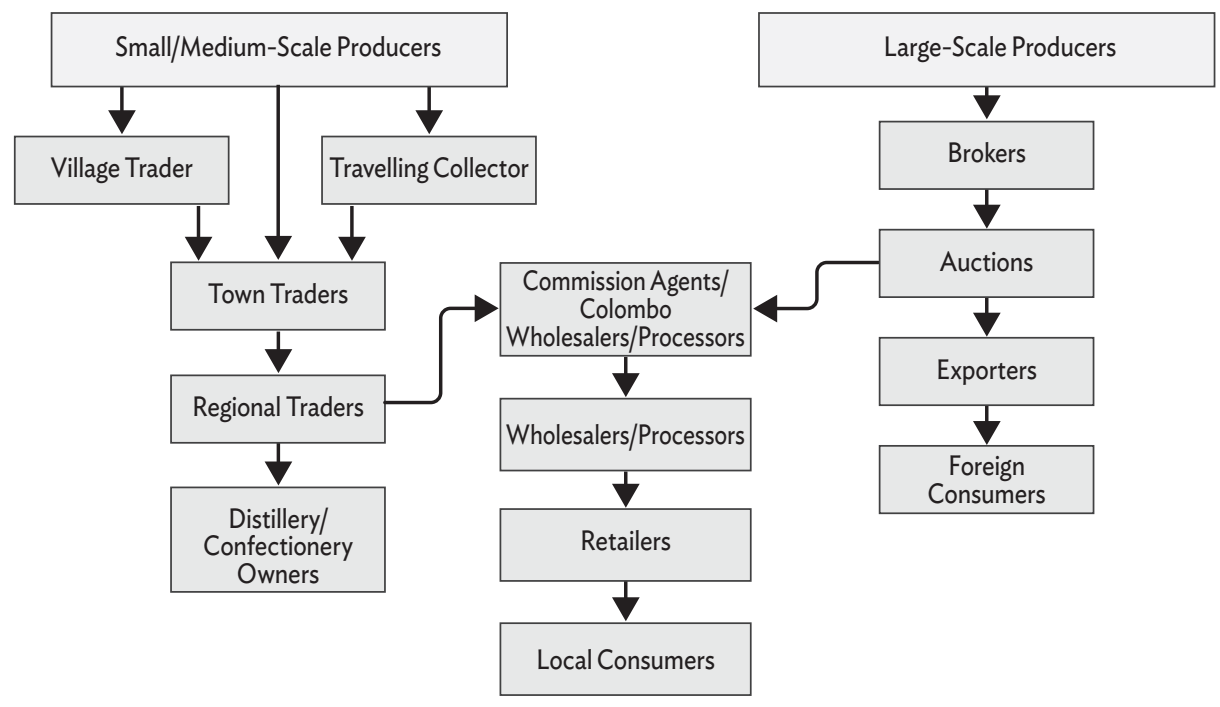

Note: $\longrightarrow$ = production flow.

Source: Adapted from Weerahewa et al (2015).

\subsubsection{Tea Value Chain}

Figure 5.9 illustrates Sri Lanka's tea value chain. Almost all tea (96\%) is marketed through public auction. Sri Lanka receives a higher price for its black tea in auctions in Colombo than other producers receive in their auctions (in Chittagong, Cochin, Guwahati, Jakarta, Kolkata, Malavi, and Mombasa). The main importers of bulk Sri Lankan black tea by import volume are Turkey, the Russian Federation, Iran, Iraq, the United Arab Emirates, and Syria.

Prices received for tea vary according to the elevation at which it is grown. The uplands were previously considered to produce the best quality tea and hence received the highest price. However, during the last decade, tea from the plains has received higher prices than that from the uplands, and in 2015 received the highest price followed by tea growing in Nuwara-Eliya (uplands).

In the plains, tea is mainly grown by smallholders, and smallholder production has increased while plantation production has stagnated. Upland tea plantations usually comprise a tea factory where green tea is fermented to black and then sent directly to auction. Smallholder tea growers collect and sell green tea leaves directly to the factories. Home-garden tea growers sell leaves to collectors or a nearby plantation. 
Sri Lankan tea exports have benefited vastly from the rapid and direct shipping connection to most of its large tea exporters. Because Sri Lanka has been exporting tea for centuries, its auction process and exporting have become very efficient. One reason for high auction prices in Colombo is the fast shipping connections. However, Sri Lanka's cost of producing tea has increased more than that of its competitors, mainly due to the labor cost for harvesting tea. Large plantations have difficulty hiring skilled harvesters at low wage rates. This is less of a problem for small-scale tea growers as they can use family labor. Sri Lanka's yield per harvester (18 kilograms [kg] per day) is below that of Kenya (46 kg per day) and India (25 kg per day).

\section{Figure 5.9: The Tea Value Chain}

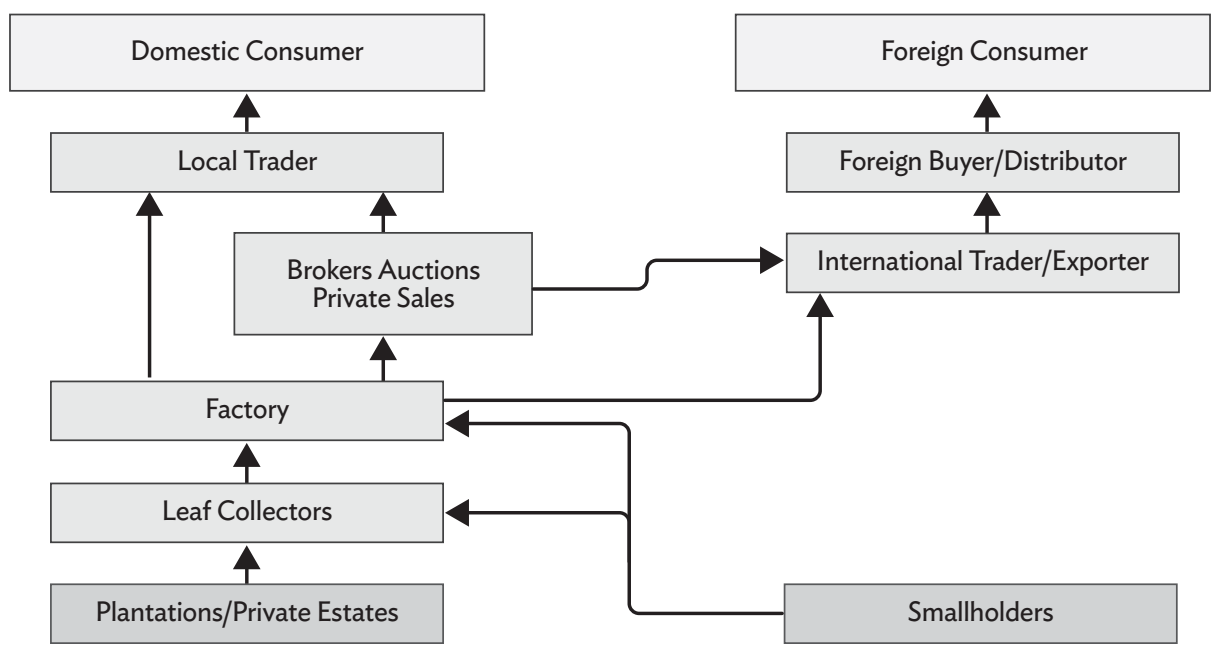

Note: $\longrightarrow$ = production flow.

Source: Adapted from Wijesinghe and Hirimuthugoda (2015).

On the one hand, tea production at the farm level is undergoing severe stress due to difficulties with labor retention. On the other hand, Sri Lanka is strategically located to develop a regional tea blending center with a gradual abolition of the auction system.

\subsubsection{Fish Value Chain}

Although marine fisheries have expanded and increased production substantially over the years, local fish prices remain high compared with peoples' average incomes, and the fishing communities' living standards have not improved much. One reason is that fisher families depend on local assemblers and commission agents, which hinders the fishers' independent growth and progress. The 
commission agents enjoy enormous power partly because they assume high risk with respect to the degradation of product quality (spoilage) and have access to market links and information. Commission agents invest fuel and food in fishing trips without assurance of a good fish catch. Therefore, fishers are highly dependent on the commission agents. Fishers could have a larger share of their catches if they directly interacted with exporting companies and large retailers. The United Nations Environment Programme (2009) showed that when fishers organize as groups for making collective decisions, the result can be more efficient and fairer value chains. To be effective, fisher cooperatives need guidance and monitoring by the government or another authority. The fish value chain is shown in Figure 5.10.

Most fish is exported whole or after minimal processing. If more fish can be exported as processed products with greater value added, more employment and foreign exchange would result. The fishers need education in proper fish handling and the importance of hygienic conditions to maintain the quality of fish along the supply chain, especially for the quality-conscious export market. The domestic consumer market responds more to price than quality. Consumer awareness of the importance of quality in fish needs to be improved. If the currently hierarchical value chain could be flattened, the intermediaries' exorbitant margins could be reduced and the benefits shared by fishers and consumers.

Figure 5.10: The Fish Value Chain

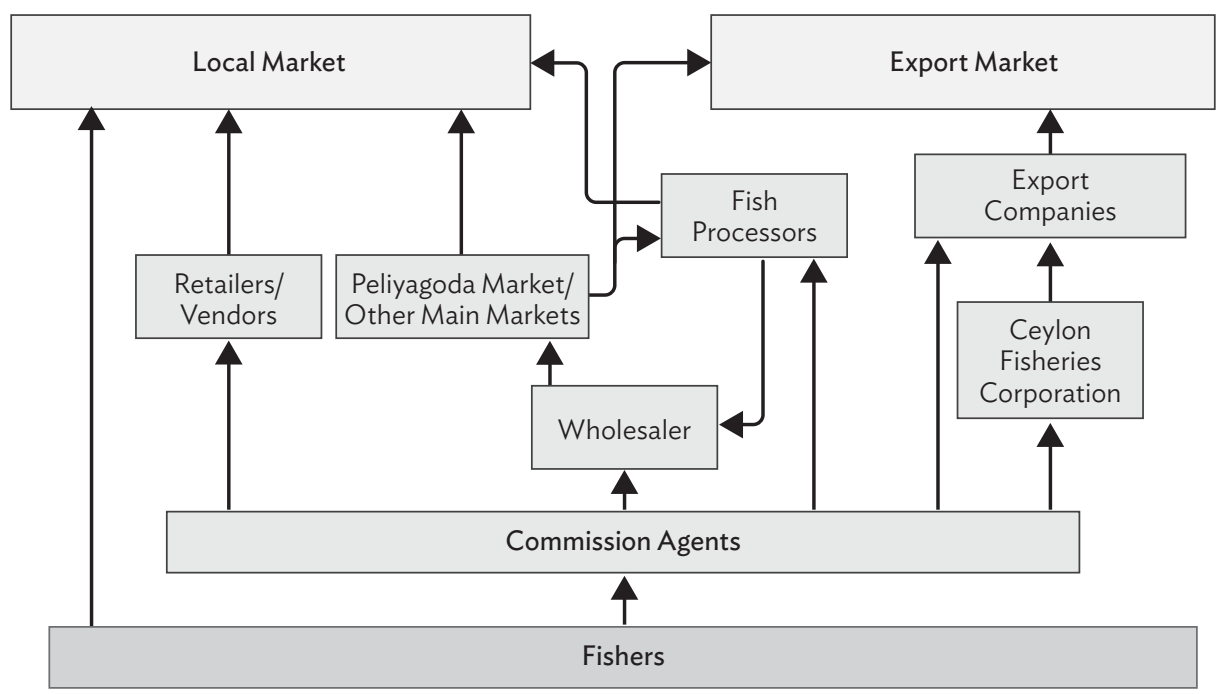

Note: $\rightarrow$ = production flow.

Source: Adapted from Arunatilake et al. (2008). 
The challenges that fish value chains face include limited transport and cold storage facilities, mechanisms to monitor the quality of fish sold in the local markets, access to finance, and awareness of opportunities in the global markets.

\subsection{Agricultural Policy Framework Objectives and Policy Instruments}

A new national agricultural policy document is being prepared. It will focus on achieving three main building blocks: food security, environmental sustainability, and economic opportunities. Recent economic policy statements by the Ministry of Finance place high priority on modernizing the agricultural practices and improving productivity and competitiveness while achieving food security (Karunanayake 2016, 2017). The focus is on introducing innovative technologies to achieve inclusive and sustainable economic growth with an assured food security for the nation. The Department of Agriculture's national food production program for 2016-2018 consists of promoting production of rice and other food crops, and a home-gardening program targeting 1 million home gardens. The main government thrusts are promoting production of liquid milk by developing the dairy industry, modernizing fisheries, developing agricultural "mega zones" and value chains, and modernizing irrigation.

A diverse range of policy instruments has been used to achieve the foregoing targets. To address the issues in agricultural marketing, the government has used price guarantees and ceilings, and the PMB has procured limited quantities of paddy. Fertilizer prices have been regulated and generously subsidized by the government. The price subsidy was converted to a cash transfer program in early 2016 to promote the use of organic fertilizers. The land market is highly regulated, and the government owns $80 \%$ of the arable land. Because increased security of tenure increases land productivity, a land titling program is in progress. The market for seeds and planting materials is highly regulated, as seed is produced in government farms and the import of seed is restricted. The government and producer organizations engage in research and development activities, but public expenditure allocated for research has been declining. To address capital constraints, state banks provide credit at concessionary rates.

To promote the mechanization of agriculture, the government has provided agricultural machinery to farmer organizations free of charge and duty concessions for items such as agricultural machinery.

\footnotetext{
2 The government intends to plan and develop the Western Province of Sri Lanka as a megacity with over 8 million people as a business, communications, and logistic hub.
} 


\subsection{Policy Challenges Facing the Agriculture Sector}

\subsubsection{Trade}

Exports are regulated to ensure the availability of raw materials, promote further domestic processing of local materials, finance export promotion activities, protect national security, and protect the environment. Export incentives include tax and various fiscal measures, a duty drawback scheme, the Temporary Importation for Export Processing Scheme, and a manufacturein-bond scheme. Export finance instruments have been introduced to mitigate the impact of financial crisis and provide financial assistance: these include the Export Development Reward Scheme, Simplified Value-Added Tax Scheme, and establishment of an export-import bank.

Sri Lanka has ratified the World Trade Organization's new Trade Facilitation Agreement, which came into force on 22 February 2017.

Although Sri Lanka's policy framework is conducive for exporting, exports remain limited. Export products and markets have not diversified and penetration of world markets by Sri Lankan trade names, trade promotion, and certification measures has been very slow.

Sri Lanka's system of trade taxes and tariffs on food import is complex, with a multiplicity of taxes, year-to-year and within-year variations, and lack of uniformity. To streamline the process, single specific customs duty rates were introduced for 10 food items, replacing the other charges, and the number of tariff bands was reduced.

Even though such efforts helped to alleviate the complex structure of import barriers to essential commodities, multiple and large taxes are levied on several agricultural commodities and are subjected to large fluctuations. Figure 5.11 demonstrates the total import taxes and custom duties charged on seven agricultural items during 2003-2014, as a percentage of cost, insurance, and freight. The fluctuations in tax levels have created an uncertain policy environment that was a disincentive for companies to invest in Sri Lanka.

Policy challenges for agricultural exports and imports primarily result from conflicting policy objectives. Sri Lanka attempts to use strategies for import substitution and export promotion and simultaneously to protect domestic producers and safeguard consumers. Achieving food self-sufficiency has been the primary strategy for achieving food security. Political ideologies that affect the design and prioritization of policies to address food needs result in setting targets without paying sufficient attention to the targets' economic feasibility. 


\section{Figure 5.11: Average Total Import Taxes and Customs Duties by Commodity, 2003-2014 (\% of CIF)}

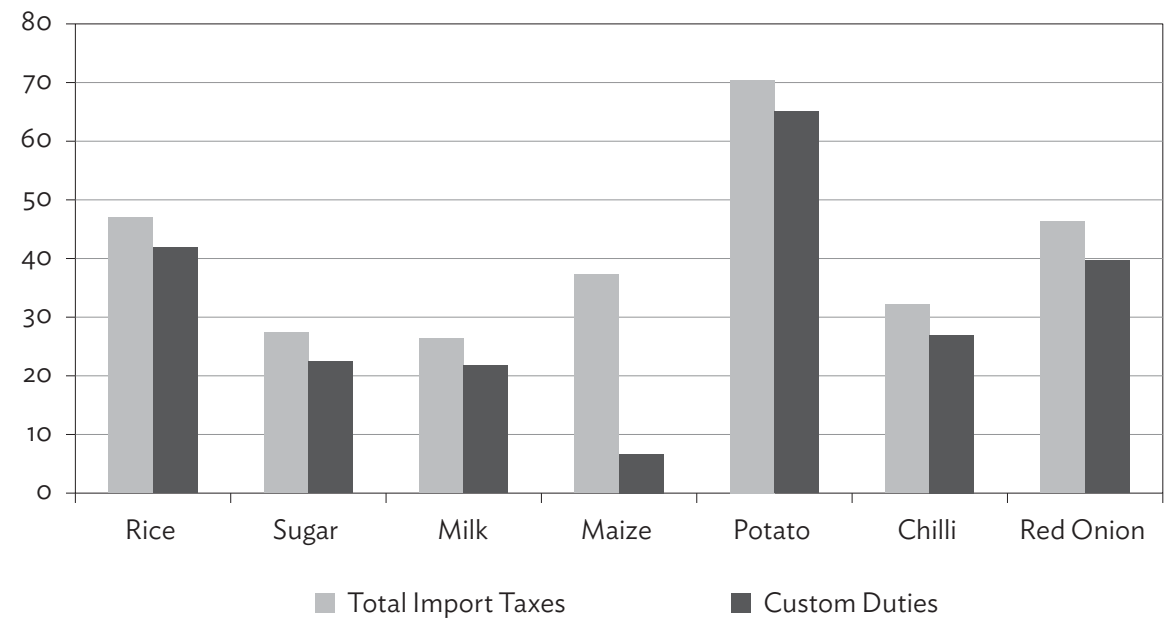

$\mathrm{ClF}=$ cost, insurance, and freight.

Note: "Total import taxes" exclude value-added tax and Nation Building Tax.

Source: Author's calculations based on data obtained from Sri Lanka Customs.

\subsubsection{Agricultural Marketing}

State interventions in agricultural marketing have been limited since the economy was liberalized in 1977. The PMB procures paddy at a guaranteed price and keeps a small buffer stock. The Cooperative Wholesale Establishment distributes rice through its Lak Sathosa system. Guaranteed prices for fresh milk, green tea leaves, and rubber, as well as measures to ensure better prices for chili, onion, and potato support producers. Ceiling prices for milk powder, broiler chickens, and other produce, and measures to control the prices of 10 essential goods are in place to safeguard consumers.

Nevertheless, marketing is the biggest issue that Sri Lankan agricultural producers face. There has been constant public pressure to create dedicated agencies for procuring agricultural produce at guaranteed prices. A great majority of the general public believes that government agencies should actively engage in providing marketing services to smallholders.

\subsubsection{The Fertilizer Subsidy Policy}

Among the policies and programs to increase food production, the fertilizer subsidy program is the longest lasting, most expensive, and most politically 
sensitive. It was initiated in 1962 at the onset of the Green Revolution, with the main objective of encouraging farmers to switch from traditional to highyielding rice varieties that are highly responsive to chemical fertilizers. Since then, the provision of the subsidy has become customary, and successive governments have been under tremendous pressure to continue the subsidy despite budgetary constraints.

The subsidy policy has evolved over time. During 1962-1989, a subsidy was provided for all three main types of chemical fertilizer-nitrogen, phosphorus, and potassium-targeted primarily at paddy. Subsidies were not provided during 1990-1994 but were reintroduced in 1995 for all three chemicals. In 1997-2004, the subsidy was limited to urea (nitrogen). Since 2005, the subsidy has again been expanded to cover all three chemicals. The price of a $50-\mathrm{kg}$ bag of fertilizer has been set at 350 Sri Lanka rupees (SLRs)/50-kg bag regardless of the world market price. This policy lasted until late 2015. In the inaugural Budget of November 2015, the government proposed to grant SLRs25,000/ha per year, for up to 2 ha, for procuring fertilizer. The selling price of fertilizer was initially supposed to be market determined, but was later regulated at SLRs2,500/50-kg bag. ${ }^{3}$

According to the World Bank (2013), the increase in a farmer's net income per acre is small relative to the subsidy cost per acre, an efficiency ratio ranging between 1.37 and 2.38. On average, the government spent SLRs1.40-SLRs2.40 per acre to increase a farmer's income by only SLRe1.00 per acre. Consequently, the price subsidy program was converted to a cash grant scheme. The intention of the grant was to allow the farmers greater flexibility in selecting their inputs, particularly organic fertilizers, and reduce the overuse of chemical fertilizers. A change in land-use pattern leading to diversification at the farm level was expected to result.

The cash grant system faces many challenges. The government is keen on producing the country's entire rice requirement in Sri Lanka, which could lead to productivity drops due to suboptimal application of inorganic fertilizers. A structural change in agricultural production cannot however be expected with the change in fertilizer policy alone. On the one hand, agricultural land transactions are restricted, locking paddy producers in rural areas into semisubsistence production. On the other hand, organic fertilizers are available in limited quantities, and without incentives to promote organic cultivation, recipients of the cash grant may switch to nonagricultural ventures.

3 The exchange rate was SLRe150/\$1 as of 13 March 2017. 


\subsubsection{Agricultural Land Policy}

The weak property rights that farmers face is a key factor in the country's agricultural productivity. Empirical evidence confirms that farmers with tenure rights are more productive and that subdividing land reduces farm productivity (Cornia 1985; Dealalikar 1981; Holden and Yohannes 2002; Otsuka 2002; Place 2009; Place and Otsuka 2002; Wickramarachchi 2016).

The Land Commission in 1927 and Land Development Ordinance in 1935 provide the regulatory framework for agricultural lands. Efforts have been made to lower the land restrictions-such as the Bim Saviya program and 99-year leases-by providing land rights. But converting paddy land for cultivation of perennial crops remains illegal.

Sri Lanka has four types of tenure for paddy-single ownership, joint ownership, share cropping (ande), and "other." Single ownership is the most widespread pattern, share-cropping is next, and joint tenure is the least frequent (Table 5.7).

\section{Table 5.7: Distribution of Paddy Land by System of Tenure, Maha, 2014-2015 (\%)}

\begin{tabular}{l|c|c|c|c|c|c|c|c|c|} 
& $\begin{array}{c}\text { Total Sown } \\
\text { Area }\end{array}$ & \multicolumn{2}{c|}{$\begin{array}{c}\text { Single } \\
\text { Ownership }\end{array}$} & \multicolumn{2}{c|}{$\begin{array}{c}\text { Joint } \\
\text { Ownership }\end{array}$} & \multicolumn{2}{c|}{ Share Crop } & \multicolumn{2}{c|}{ Other } \\
\hline Year $^{\mathrm{a}}$ & ha & ha & $\%$ & ha & $\%$ & ha & $\%$ & ha & $\%$ \\
\hline $2014-2015$ & 772,676 & 645,727 & 83.6 & 38,169 & 5.0 & 61,162 & 7.9 & 27,570 & 3.6 \\
\hline 2015 & 480,662 & 378,257 & 78.7 & 27,520 & 5.7 & 47,125 & 9.8 & 27,760 & 5.8 \\
\hline
\end{tabular}

ha $=$ hectare.

a 2014-2015 refers to the wet (monsoon) season, September-March, and 2015 is for the dry season, April-August 2015.

Sources: DCS (2015), accessed 13 March 2017.

The Paddy Lands Act of 1958 is intended to protect sharecroppers. Landowners have three specific rights according to Roman Dutch Law in Sri Lanka-to possess, use and enjoy, and alienate the land. The first two rights are transferred to a tenant who cultivates the land. In 1964, the Act was amended to accommodate settlements (groups of formerly landless people the government moved onto unused lands). Several amendments were introduced to protect tenants and the Agrarian Development Act No 46 of 2000 increased security for tenant cultivators. 
However, tenure problems may be difficult to fix through policy reforms. The identification of different tenure patterns and of issues such as informal transactions can guide the changes required in the regulations. Hence, periodic awareness programs are needed for officials who are responsible for endorsing land transactions and for the settlers. Such programs can help to increase the knowledge and understanding of those who draft policy, and hence make the institutional framework that is responsible for drafting policy more relevant to the settlers who are the policy's intended beneficiaries.

Legal reforms are necessary but not sufficient to improve security of tenure. Providing adequate security of tenure is hampered by the complicated nature of the operations in the settlements. Correct determination of the needy group is a priority. Farmers who operate land as original settlers or acquired land through inheritance with formal deeds do not need protection, whereas farmers who operate land with no legal document do. The latter form a large group, and attention to them is needed on a case-by-case basis. A countrywide survey is recommended to identify the group's detailed needs in order to provide them with the required land security.

\subsubsection{Irrigation Water Policy}

Investment in irrigation creates multiplier effects in the economy. The government is responsible for financing all new major irrigation development schemes. Until the early 1980 s, about $90 \%$ of investment in irrigation was to augment the supply and it accounted for $20 \%-40 \%$ of the total public investment in the country. In the mid-1970s, investments for rehabilitation were started and comprised $15 \%$ of the total irrigation investment by the mid-1980s (Aluwihare and Kikuchi 1991). Kikuchi et al. (2002) indicated that the total investment in irrigation declined drastically from the mid-1980s to the mid-1990s, to oneseventh of its peak level in the early 1980s, due to a drop in public investment in irrigation. The same authors noted that total irrigation investment showed a slight upward trend from its rock-bottom level in the early 1990s to 2002 . During 2015, the government invested SLRs19.23 billion ( $\$ 141.5$ million) and a large portion of funds i.e., SLRs8.45 billion ( $\$ 62$ million) was invested in major irrigation development projects (Ministry of Finance 2016). 


\subsubsection{Agricultural Credit Policy}

The history of government intervention to provide credit for the rural sector, including farmers, goes back to the enactment of the Co-operative Credit Societies Ordinance in 1911. Cultivation loans are provided at concessionary terms through state banks. Defaulting on agricultural credit has been common and steps have been taken to write off loans. Overdependence on the state for credit combined with low and uncertain returns to agricultural enterprises are common issues affecting agricultural credit.

The government's credit policy broadened in later stages, especially under the open economic policy after 1977. The conceptual changes in supplying credit to the rural economy are reflected in practices of the Central Bank of Sri Lanka (CBSL), which implements the government's credit policy. The CBSL has followed a two-way credit strategy after 1977. One is the nonplantation crops (rice and subsidiary food crops) agricultural credit system. Under this, credit advancement was liberalized for borrowers who had fully repaid previous loans on time. This improved the recovery rate. Under the other strategy, the CBSL's objective was to assure cost-effective and accessible credit facilities at low interest rates to lower-income farmers and rural families by providing microfinance. The approach was suitable and relevant for the poor who were unable to secure credit from formal commercial banks. Under this approach, Thrift and Credit Cooperative Societies in Sri Lanka (popularly known as SANASA), Sarvodaya Economic Enterprise Development Services, cooperative rural banks, Samurdhi banks (providing microfinance), and farmer banks were supported to provide credit to small borrowers. As a result of these microcredit initiatives, the farmers' ability to access credit at transaction costs that are lower than those experienced prior to the establishment of microcredit initiatives has increased considerably. However, the benefits are still not available to farmers in less-developed areas with poor infrastructure (Chandrasiri 2006).

Recently, the CBSL introduced concessionary investment credit schemes, with cooperation from commercial banks, including for agricultural production and processing and animal husbandry activities. Major instruments adopted for encouraging widespread credit are the provision of interest subsidies, refinance facilities, and credit guarantees to the lending banks or institutions. In most of the schemes, the interest rate is below the commercial banks' normal rate, which is about $16 \%$. However, the banking procedure requires producing collateral, which many poor families cannot do. Nevertheless, for the country as a whole, loans and advances of commercial banks to the agriculture sector have increased considerably, from SLRs13.08 billion ( $\$ 202.95$ million $^{4}$ ) in 1998 to SLRs130.4

$4 \quad 1998$ exchange rate $=$ SLRs $64.45 / \$ 1$. 
billion ( $\$ 998.74$ million $^{5}$ ) in 2014 (Table 5.8). Of the total advances during 2014, plantation crops accounted for $74.5 \%$, paddy for $12.9 \%$, and other crops for $12.6 \%$. Nevertheless, agriculture's share of commercial banks' total advances, which was already low at $5.4 \%$ in 1998 , had decreased to $3.7 \%$ in 2014 (Table 5.9). A strong government directive is needed to require the commercial banks to provide a minimum share of their total advances to the agriculture sector.

\section{Table 5.8: Total Cultivation Loans from Lending Banks}

\begin{tabular}{|c|c|c|c|c|c|c|c|c|c|}
\hline \multirow[b]{2}{*}{$\begin{array}{l}\text { Cultivation } \\
\text { Year }\end{array}$} & \multicolumn{3}{|c|}{$\begin{array}{l}\text { Loans Granted } \\
\text { (SLRs million) }\end{array}$} & \multicolumn{3}{|c|}{$\begin{array}{l}\text { Recoveries } \\
\text { (SLRs million) }\end{array}$} & \multicolumn{3}{|c|}{$\begin{array}{c}\text { Recoveries } \\
(\%)\end{array}$} \\
\hline & Rice & $\begin{array}{l}\text { Other } \\
\text { Crops }\end{array}$ & $\begin{array}{c}\text { All } \\
\text { Crops }\end{array}$ & Rice & $\begin{array}{l}\text { Other } \\
\text { Crops }\end{array}$ & $\begin{array}{l}\text { All } \\
\text { Crops }\end{array}$ & Rice & $\begin{array}{l}\text { Other } \\
\text { Crops }\end{array}$ & $\begin{array}{c}\text { All } \\
\text { Crops }\end{array}$ \\
\hline 1976-1977 & 102 & 58 & 160 & 54 & 31 & 84 & 52.8 & 52.5 & 52.7 \\
\hline 1986-1987 & 269 & 68 & 337 & 229 & 60 & 289 & 85.4 & 87.4 & 85.8 \\
\hline 1996-1997 & 412 & 178 & 590 & 314 & 134 & 449 & 76.4 & 75.3 & 76.1 \\
\hline $2006-2007$ & 1,030 & 984 & 2,013 & 961 & 874 & 1,834 & 93.3 & 88.8 & 91.1 \\
\hline $2013-2014$ & 5,074 & 3,306 & 8,380 & 4,528 & 2,982 & 7,508 & 89.2 & 90.2 & 89.6 \\
\hline
\end{tabular}

Note: "Other crops" include chili, onions, potato, and vegetables,

Source: CBSL (2015).

Table 5.9: Loans and Advances of Commercial Banks (\$)

\begin{tabular}{l|c|c|c}
\hline Item & $\mathbf{1 9 9 8}$ & $\mathbf{2 0 0 7}$ & $\mathbf{2 0 0 4}$ \\
\hline Plantation & 60.45 & 131.41 & 743.86 \\
\hline Paddy & 42.09 & 64.03 & 129.07 \\
\hline Other Crops & 100.33 & 187.38 & 125.93 \\
\hline Crop Total & $\mathbf{2 0 2 . 8 7}$ & $\mathbf{3 8 2 . 8 2}$ & $\mathbf{9 9 8 . 8 6}$ \\
\hline Agricultural Crops' Share of Total Loans and Advances & $5.42 \%$ & $4.30 \%$ & $3.66 \%$ \\
\hline Total Loans and Advances & $\mathbf{3 , 7 4 4 . 5 2}$ & $\mathbf{8 , 9 1 0 . 4 9}$ & $\mathbf{2 7 , 3 0 8 . 2 2}$ \\
\hline
\end{tabular}

Source: CBSL, Social and Economic Statistics of Sri Lanka, 1998-2014 (various years)

A number of changes in the provision of agricultural credit were introduced in 2015. State banks granted farmers a 50\% waiver on the capital of cultivation loans up to a maximum of SLRs100,000 ( $\left.\$ 736.07^{\circ}\right)$. The waived $50 \%$ was transferred to the nonperforming category on or before 31 January 2015. The rate of interest applicable for loans granted to borrowers by financial institutions participating under the Smallholder Plantation Entrepreneurship Development Programme was reduced to $7 \%$ per annum from $9 \%$ and the applicable interest rate for refinance facilities that the CBSL granted to participating financial institutions was reduced to $3 \%$ per annum from $4 \%$. 
Operating Instructions of the New Comprehensive Rural Credit Scheme were amended to incorporate the warehouse receipts financing system in order to provide short-term credit to small-scale farmer producers. Operating Instructions to implement the Working Capital Loan Scheme for Tea Factories were issued and the operating instructions of the Saubhagya Loan Scheme were amended to expand the scheme's grace period for loans for cultivating perennial crops up to a maximum of 12 months, depending on the nature of the project (CBSL 2015).

\subsubsection{Seed and Planting Material Policy}

The main objective of the national seed policy of 1996 and the Seed Act of 2003 was establishing a viable seed industry in Sri Lanka. The Plant Protection Ordinance provided the legal authority for regulating seed and planting material in the country. Rice breeder seed is produced by the Department of Agriculture and contract farmers.

The import of hybrid seeds is a source of concern, as the government encourages local production of seeds. The Department of Agriculture's Seed and Planting Material Development Center engages in local production of quality seed and planting materials and supplies them to farmers at the correct time and place, and at competitive prices. The Department of Agriculture produces breeders', foundation, and registered seeds. A contract grower system has been established to produce certified seeds for distribution among farmers.

Despite many efforts to increase the local availability of quality seed and planting materials, the local production has been insufficient to meet the requirement. The importation of seeds and planting materials is regulated considering sanitary and phytosanitary issues and farmers' rights.

\subsubsection{Agricultural Research and Extension Policy}

Investment in agricultural research trended upward during the Green Revolution starting in the early 1970s but began to decline in 1977 and settled at a low level thereafter. The cadre of agricultural extension workers was substantially reduced and agricultural productivity stagnated partly due to this policy change. Increased investment in research and extension is greatly needed. 


\subsubsection{Agricultural Mechanization Policy}

Policy documents show that the Government of Sri Lanka has tried to promote agricultural mechanization, e.g., the 2007 Sri Lanka National Agricultural Policy (n.d.). Tax rates on machinery and equipment used for agriculture and construction have always been low or nil. Loan schemes have been provided for purchasing equipment for developing agriculture and dairy farming, agricultural extension services, animal husbandry, domestic agriculture industries, and fisheries activities. However, agricultural productivity has not increased significantly and policy challenges for increasing mechanization include having small farm sizes, high initial capital costs, and inadequate willingness of farmers to purchase or use equipment collectively.

\subsection{Recommendations}

Sri Lanka's farm-level production and the processing and marketing of agriculture produce has been modernizing. The government has achieved its target of self-sufficiency in rice (and maize recently); however, domestic agriculture production is not sufficient to meet the now transformed dietary needs of the population. Diversification at the farm level has been limited and paddy plays a predominant role in agricultural land use.

The world market's demand for high-value agricultural products (e.g., processed, safe, and organically grown food, and food with functional properties) has increased significantly, but a large portion of Sri Lanka's exports are primary products. The export basket and destinations are not sufficiently diversified. Despite incentives for exporters, investment in food processing has been insufficient to produce what global markets need. The investment insufficiency is partly due to erratic policy measures and high rates of protection. Until land market imperfections are resolved or innovative cooperative farm management systems are evolved, economies of scale cannot be realized.

In addition, agriculture faces challenges associated with climate change and out-migration of labor.

The study points to six major policy recommendations to overcome critical constraints to the agriculture sector, and five recommendations to increase public investment. 
The policy recommendations are:

(1) Focus on commercializing agriculture by reducing regulatory barriers faced by agricultural enterprises with export potential and by reducing incentives provided to low-value agricultural commodities targeting the local food requirement.

(2) Enhance opportunities for land consolidation by reducing restrictions on land transactions and land use and speeding up the land titling program.

(3) Continue to promote appropriate technologies and enhance mechanization (e.g., drip irrigation and greenhouse technologies).

(4) Decrease inefficiencies in the seed market and take measures to increase the availability of quality seeds of high-yielding varieties.

(5) Gradually withdraw price and marketing interventions. Divert the expenditures to provision of agricultural extension, agricultural finances, irrigation infrastructure, and research and development.

(6) Support female agricultural workers by enhancing their knowledge and skills in agricultural production, processing, and marketing; increasing their access to agricultural inputs and services; and taking measures to increase their participation in community organizations.

To enhance returns from public investment:

(1) Increase government expenditure on productivity-enhancing infrastructure such as irrigation and rural roads.

(2) Increase allocations for productivity-enhancing agricultural research to produce safe and nutritious food for domestic and foreign markets.

(3) Establish linkages to connect smallholders to global value chains.

(4) Encourage foreign direct investment and public-private partnerships in agro-processing.

(5) Improve coordination across government agencies involved in designing and implementing policy pertaining to agriculture.

Most importantly, policy making based on scientific evidence should be institutionalized rather than based on responding to lobby groups and attending to short-term measures. In this connection, further research will be required to review agriculture expenditure and to assess the feasibility of private-public partnerships in agroprocessing and related areas, in order to provide an objective evaluation of alternative policy options and their trade-offs. Clear directions and directives will have to be provided to the implementing authorities. 


\section{References}

Abeysekera, T., and S. Abeysekera. undated. Alternative Supply Chain Management Practices and the Performance of Marketing Channels in Fresh Fruit and Vegetable Marketing in Sri Lanka. Market Analysis. Food and Agriculture Organization of the United Nations. http://www.fao.org/3/a-ah996e/ ah996e02.pdf

Aluwihare, P., and M. Kikuchi. 1991. Irrigation Investment Trends in Sri Lanka: New Construction and Beyond. Colombo: International Water Management Institute. XV. https://cgspace.cgiar.org/handle/10568/36341

Arunatilake, N., A. Gunawardena, D. Marawila, P. Samaratunga, A. Senaratne, and M. Thibbotuwawa. 2008. Analysis of the Fisheries Sector In Sri Lanka: Guided Case Studies for Value Chain Development In Conflict-Affected Environments. United States Agency for International Development (USAID). https://www.researchgate.net/profile/Manoj_Thibbotuwawa/ publication/247158760_ANALYSIS_OF_THE_FISHERIES_SECTOR_ IN_SRI_LANKA_GUIDED_CASE_STUDIES_FOR_VALUE_CHAIN_ DEVELOPMENT_IN_CONFLICT-AFFFECTED_ENVIRONMENTS/ links/Odeec51dbc4132884e000000/ANALYSIS-OF-THE-FISHERIESSEC TOR-IN - SR I - L A N KA - G U IDE D - C A S E - S T U D IE S - F ORVALUE-CHAIN-DEVELOPMENT-IN-CONFLICT-AFFFECTEDENVIRONMENTS.pdf

Athukorala, P., and S. Jayasuriya. 1994. Macroeconomic Policies, Crises and Growth in Sri Lanka, 1969-90. Washington, D.C.: World Bank.

Businesswire. 2016. Global Seasonings and Spices Market-Forecast to 2020Increasing Demand For Organic Seasonings. Research and Markets. http:/www.businesswire.com/news/home/20160413006478/en/GlobalSeasonings-Spices-Market-Forecast-2020

Central Bank of Sri Lanka (CBSL). 2015. Annual Report 2015. Colombo: CBSL. various years. Annual Report. Colombo: CBSL.

various years. Social and Economic Statistics of Sri Lanka: 1998-2014. Colombo: CBSL.

Centre for the Promotion of Imports from Developing Countries (CBI). 2017. Which Trends Offer Opportunities on the European Spices and Herbs Market? https://www.cbi.eu/market-information/spices-herbs/trends

Chandrasiri, J. 2006. The Recent Changes in Rural Credit Market in Relation to Paddy Cultivation in Sri Lanka: Findings of a Field Survey. Sri Lanka Journal of Agrarian Studies. ii(1).

Cornia, G. 1985. Farm Size, Land Yields and the Agricultural Production Function: An Analysis for Fifteen Developing Countries. Journal of World Development. 13(4): 513-34. 
Deolalikar, A. 1981. The Inverse Relationship between Productivity and Farm Size: A Test Using Regional Data from India. American Journal of Agricultural Economics. 63(2): 275-79.

Department of Census and Statistics (DCS). 2014a. Household Income and Expenditure Survey (HIES) Reports 1980/81-2012/2013. Colombo: DCS. 2014b. Labor Force Survey 2014. Colombo: DCS.

2015. Paddy Statistics 2014/15. www.statistics.gov.lk/agriculture/ Paddy\%20Statistics/PaddyStats.htm various years. Labour Force Survey. Colombo: DCS.

Export Development Board (EDB). 2012. Industry Capability Report: Coconut and Coconut Based Products. http://www.srilankabusiness.com/pdf/ coconut.pdf

Food and Agriculture Organization (FAO) of the United Nations. FAOSTAT database, 2005-14. http://www.fao.org/faostat/

Herath, A. 2002. Spice Sector of Sri Lanka: Issues, Challenges and Opportunities for the Next Decade. Economic Review. May/August 2002: 12-21.

Holden, S., and H. Yohannes. 2002. Land Redistribution, Tenure Insecurity and Intensity of Production: A Study of Farm Households in Southern Ethiopia. Journal of Land Economics. 78(04): 573-90.

Karunanayake, R. 2016. Budget Speech 2016, Budget Archives. Colombo: Ministry of Finance. http://www.treasury.gov.lk/ documents/10181/28027/Budget+Speech+2016/07f592ff-770f-4d71-8c26b06de595eab0?version $=1.0$

2017. Budget Speech 2017. Budget Archives. Colombo: Ministry of Finance.

Kikuchi, M., R. Barker, P. Weligamage, and M. Samad. 2002. Irrigation Sector in Sri Lanka: Recent Investment Trends and the Development Path Ahead. Research Report 62. Colombo: International Water Management Institute. Kodithuwakku, S., and J. Weerahewa. 2013. Supermarkets and their Effects on Smallholder Vegetable Farmers in Sri Lanka: An Exploratory Case Study. Journal of Agriculture Economics and Rural Development. 2(2) 2014: 62-71

Ministry of Finance. 2016. Annual Report 2015. Colombo: Ministry of Finance. http://www.treasury.gov.lk/documents/10181/12870/2015/68f51df3-54654805-ab6f-4a024ec672f6? version=1.1

Otsuka, K. 2002. Enhancing Land Access and Land rights for the Marginalized: Regional Overview in International Context, World Bank Regional Land Workshop in Phnom Penh, Cambodia.

Paddy Marketing Board (PMB). 2010. Annual Report: 2010. Colombo: PMB. Pathiraja, E., and J. Weerahewa. 2013. Coconut Sector in Sri Lankan Economy: An Overview under Different Regulatory Regimes. Lunuliwa: Coconut Research Institute. 
Place, F. 2009. Land Tenure and Agricultural Productivity in Africa: A Comparative Analysis of the Economics Literature and Recent Policy Strategies and Reforms. Journal of World Development. 37(08): 1326-36.

Place, F., and K. Otsuka. 2002. Land Tenure Systems and their Impacts on Agricultural Investment and Productivity in Uganda. Journal of Development Studies. 38(6): 105-28.

Romulo, N. 2013. Market and Trade of Coconut Products. Expert's Consultation for Coconut Sector Development in Asia and the Pacific. Bangkok, Thailand, 31 Oct-1 Nov.

Samaratunga, P. 2012. Achieving Economic Efficiency and Distribution of Land Use though Reforms and/or Market Discipline. Colombo: VijithaYapa Publication.

Sri Lanka National Agriculture Policy. n.d. Colombo: Ministry of Agriculture Development and Agrarian Services. http://www.agrimin.gov.lk/web/ images/docs/1252389643AgPolicy4.pdf

United Nations Environment Programme. 2009. Annual Report: United Nation Environmental Programme. Nairobi: United Nations.

Vernooij, A., H. Houwers, and J. Zijlstra. 2015. Old Friends-New Trends: Emerging Business Opportunities in the Dairy Sector of Sri Lanka. No. 831. Wageningen UR Livestock Research. https://www.rvo.nl/sites/default/files/2015/07/ Emerging\%20business\%20opportunities\%20in\%20the\%20dairy\%20 sector\%20of\%20Sri\%20Lanka.pdf

Weerahewa, J. 2004. Impacts of Trade Liberalization and Market Reforms on the Paddy/Rice Sector in Sri Lanka. MTID Discussion Paper, No. 70, Markets. Washington D.C.: Trade and Institutions Division, International Food Policy Research Institute.

Weerahewa, J., M. Thibbotuwawa, and P. Samaratunga. 2015. Dynamics of Transforming Agriculture in Sri Lanka: Trends, Challenges and Opportunities. Unpublished manuscript.

Wickramarachchi, N. 2016. Effects of Land Fragmentation and Tenure Security on Paddy Productivity: An Empirical Investigation in North Central Province of Sri Lanka. PhD thesis submitted to University of Colombo, Sri Lanka.

Wijesinghe, D., and D. Hirimuthugoda. 2015. Promoting Regional Value Chains in Tea in South Asia: Case of Sri Lankan Tea Sector. Colombo: Institute of Policy Studies of Sri Lanka.

World Bank. 2013. What is the Cost of a Bowl of Rice? The Impact of Sri Lanka's Current Trade and Price Policies on the Incentive Framework for Agriculture. Agriculture and Environmental Services Discussion Paper 2. October 2013. Washington, D.C.: World Bank. 


\section{Chapter 6.}

State-Owned Enterprise Reforms in Sri Lanka:

\section{The Way Forward}

Malathy Knight, Aneesha Guruge, and Maria Rowena Cham

\subsection{Introduction}

tate-owned enterprises (SOEs) in Sri Lanka, as in many other countries, have experienced episodes of nationalization and privatization and have

been exposed to varied degrees of competition. The conceptualization of reforms has largely, but not always, corresponded to the political ideology of the ruling party. ${ }^{1}$ Although the decades of experience with public enterprise reforms have provided stakeholders in the policy space with a rich knowledge base, the current state of these entities' affairs indicates that much more needs to be done. Importantly, sustainable SOE reforms need to go beyond technical solutions and unpack and resolve the more controversial political elements to secure broadbased stakeholder buy-in.

The primary research objectives underpinning this Chapter's analysis are to contextualize and to locate strategic reform pathways for SOEs to support more inclusive growth. The impetus for and trajectory of the current policies on public enterprise reforms are being shaped by a combination of internal and external factors including the bipolarity of the present political leadership ${ }^{2}$ and

1 The policies promulgated by President Chandrika Bandaranaike Kumaratunga (1994-2005) deviated from the traditional ideology of her party, the Sri Lanka Freedom Party (SLFP). While the SLFP has tended toward state-led economic policies, several complex privatization exercises were carried out during these years. 
the Extended Fund Facility arrangement granted to Sri Lanka by the International Monetary Fund (IMF) 3 in 2016 (IMF 2016b, c).

The rest of this chapter will address the following issues pertaining to SOE reforms in Sri Lanka: the next section sets out the methodology and limitations of this study. Section 6.3 considers public enterprise reforms in the context of inclusive growth, while section 6.4 provides a snapshot of the historical evolution of SOE reforms and important lessons learned. Section 6.5 takes stock of the current state of affairs and the need for reform, including the performance of SOEs in terms of efficiency, fiscal, and distributional dimensions; political economy realities; and the reform agenda. Section 6.6 looks at international experience with public enterprise reform and section 6.7 defines the types of SOE reform. Section 6.8 discusses potential reform pathways and sets out key building blocks for sustainable outcomes. The discussion in this chapter draws on the case studies on the areas or sectors identified as pivotal to an effective public enterprise reform strategy, such as state plantations (termed "estates" in Sri Lanka), electricity, and transport.

\subsection{Methodology and Limitations}

The analysis in this chapter is based on mixed methodology-a combination of quantitative and statistical methods using secondary data and qualitative methods such as content analyses of important literature and key person interviews (KPIs).

The KPIs, which were held with prominent decision makers and thought leaders in Sri Lanka's policy space, together with content analyses, provided for useful "triangulation," fine-tuning of research findings, and rich contextual details. However, gaps in trend data together with data discrepancies and the

2 The President and the Prime Minister come from two different political parties, each with differing ideologies. The President's SLFP has historically been more statist and welfare-oriented, while the Prime Minister's United National Party (UNP) has tended toward more open markets and trade. 2015 has also seen increased engagement by the Committee on Public Enterprises in terms of scrutinizing approximately 450 SOEs and coming up with recommendations for reform. The Committee on Public Enterprises is currently headed by a member of Parliament from the Janatha Vimukthi Peramuna, a political party with a socialist mindset. The party is allied with a number of trade unions across the public, private, and estate sectors and has traditionally been an instigator of contestation between the citizenry and the state. While this party has historically been vehemently ideologically opposed to privatization, it has modernized its outlook to some extent in the recent past.

3 In Sri Lanka, as in other countries, public opinion of the IMF has not always been positive. 
absence of publicly available data were major limitations encountered in the research process. As such, key unpublished data, including how much SOEs owe specific state banks and how much SOEs owe each other, could not be accessed for this study. Moreover, 2014 data had to be used in some instances, such as in the analysis of the efficiency dimensions of the state plantations sector and the Ceylon Electricity Board, in the absence of the 2015 numbers.

There is also no precise count of SOEs, with the figure cited varying among the multiple organizations that govern these enterprises. ${ }^{4}$ As mentioned during one of the KPIs, the number of SOEs may be more than even tentatively estimated given that some entities have $100 \%$ owned subsidiaries that are not formally classified or counted as SOEs. ${ }^{5}$ Per another KPI, the number of SOEs is estimated to be over 400 , with approximately 250 of them being categorized as commercial enterprises ${ }^{6}$ and just over a 100 entities coming under the purview of the new Ministry of Public Enterprise Development, which was set up to spearhead the SOE reform process.

Such discrepancies in classifying and counting SOEs undermine the formulation of an accurate understanding of the status quo and impede a comprehensive analysis of SOEs and possible pathways to reform. ${ }^{7}$ In view of the data limitations and practical realities pertaining to accessing data that are not in the public domain, this chapter will largely focus on a subset of SOEs referred to as state-owned business enterprises (SOBEs) with four case studies (Appendix A6). The working definition for SOEs used in this study is as follows (MOF 2015b: 1,2):

I. Entities deemed to be Regulatory Agencies, Promotional Institutions, Research and Development Agencies or Educational Institutions, which were established under an Act of Parliament.

4 SOEs come under the purview of the Ministry of Finance, the new Ministry of Public Enterprise Development, and the various line ministries.

5 For example, Sri Lanka Insurance Corporation (SLIC) is classified as an SOE. However, its fully owned subsidiary Litro Gas Lanka Ltd. is not counted as an SOE.

6 DPE (2015) gives the number as 257 while MOF (2015a) gives the number as 245.

7 This point of view was also reiterated at the Asian Development Bank's Consultation Workshop in August 2016, with participants pointing to the need for accurate data on public enterprises, from basic figures such as the number of SOEs and state-owned business enterprises (SOBEs), to precise numbers on outstanding debt liabilities. Moreover, participants highlighted that the numbers, when they are available, vary from organization to organization-for example, the Central Bank of Sri Lanka, the Treasury, the Ministry of Public Enterprise Development, and line ministries. 
II. Companies incorporated under the Companies Act No. 7 of 2007 in which the Government or a Public Corporation or local authority directly or indirectly hold fifty percent or more of the shares of that company.

III. Public Corporations (i.e., corporations, boards or bodies which were or are established by or under any written law, other than the Companies Act).

The working definition for SOBEs used in this chapter is (DPE 2015: 1):

SOEs that have been identified as Strategic State Owned Business Enterprises ... engaged in commercial activities (emphasis added).

Figure 6.1 illustrates the SOE and SOBE categories and relates them to the four case studies in the chapter's Appendix A6.

Figure 6.1: Classification of State-Owned Enterprises

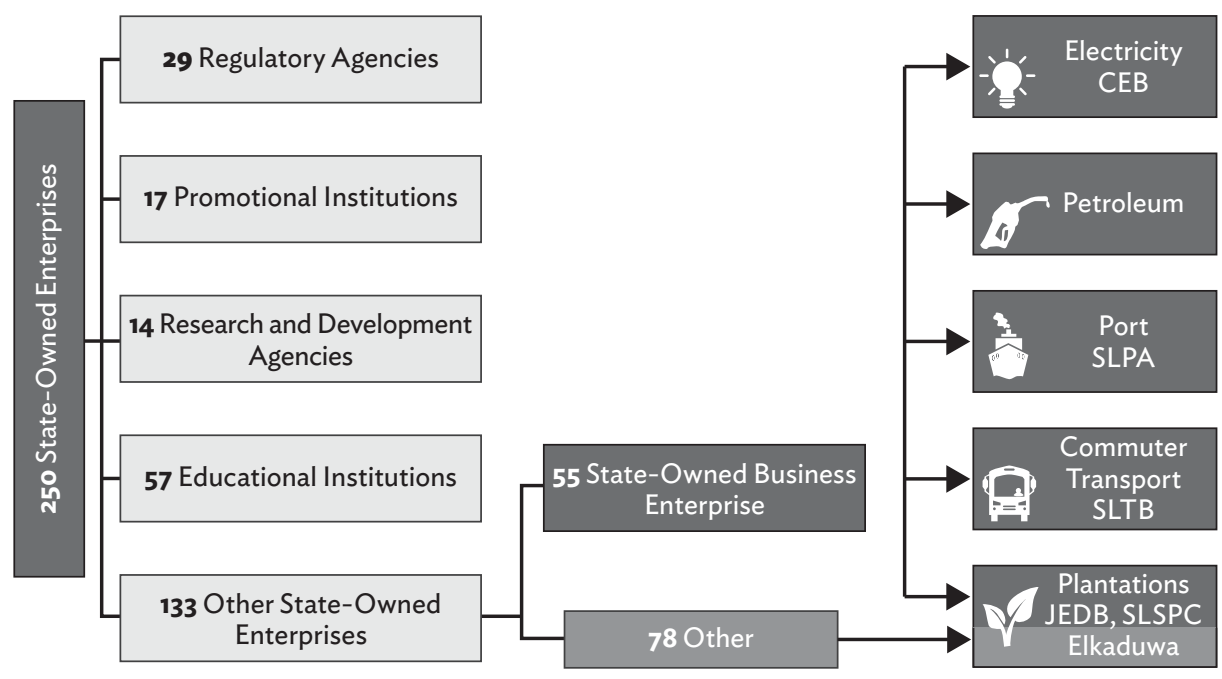

CEB $=$ Ceylon Electricity Board, JEDB = Janatha Estates Development Board, SLSPC = Sri Lanka State Plantations Corporation, SLPA = Sri Lanka Ports Authority, SLTB = Sri Lanka Transport Board.

Source: MOF (2015a, b). 


\subsection{State-Owned Enterprise Reforms and Inclusive Growth}

Despite the ebb and flow in the depth and breadth of SOE reforms in Sri Lanka and in the global arena, SOEs are likely to remain a crucial part of a country's socioeconomic and political landscape. ${ }^{8}$ For example, the proportion of public enterprises among the Fortune Global 500 grew from 9\% in 2005 to $23 \%$ in 2014 (PWC 2015). The pivotal role SOEs play in a country's development trajectory emphasizes the need to ensure that they deliver effectively on a range of outcomes-efficiency, fiscal, and distributional.

Given the research questions underpinning this study, the role of the state and of SOEs in the context of inclusive growth is central to this analysis. ${ }^{9}$ In Sri Lanka, the state has historically been viewed as a benefactor, with the economic policies of a welfare state. Private enterprise and privatization have traditionally been viewed with skepticism and as potentially exploitative-a perception that has also been nurtured by surreptitious SOE reform episodes that have fostered distrust between the government and the citizenry. The challenge therefore is to get to a middle ground in the SOE reform process where the objectives of inclusive growth are clearly set out, the need for reform is clearly communicated, the details of the reform process are made transparent, and stakeholder expectations are realistically appraised.

A very senior member of the present government noted in a KPI that the current reform process is being conceptualized as one of "improving operational efficiency, restructuring, increasing private participation to provide high quality goods and services at competitive prices."

Moreover, the Economic Policy Statement by Prime Minister Ranil Wickremesinghe in Parliament on 5 November 2015, set out the following:

We all agree that state enterprises must be more efficiently run. This can be achieved by ensuring that good economic management is practiced and efficient managers are put in place. Most of these ventures are loss-making due to various reasons. Those managing these ventures and politicians are

8 Examples of the need for public enterprises in an economy include natural monopolies, strategic industries such as defense and nuclear power, public service obligations (PSOs) and public goods, market failures, and provision of competition to the private sector.

9 Details of the political economy rationale for setting up and reforming SOEs over time are in section 6.4. 
benefiting while pretending that they are under public ownership. We will take steps to change this (News.lk 2015: 9).

The articulation of the concept of a competitive social market economy in the policy space is potentially relevant to the inclusive growth narrative. This concept, which promises to advance both economic competitiveness and social justice, was articulated by the United National Party (UNP) in its election manifesto and in the memorandum of understanding between the UNP and the Sri Lanka Freedom Party that forms the basis of the current coalition government (News First 2015a, b). However, there has been little visible policy discourse on a social market economy for Sri Lanka, except in a few writings by members of the academic community and isolated comments by members of the UNP.

Given the political economy milieu, four elements of the inclusive growth narrative are critical to a sustainable SOE reform process:

- efficient state provision of public goods and public service obligations (PSOs), with the cost being explicitly estimated and taken into consideration when evaluating the performance of public enterprises;

- a competitive business environment with competitive pricing;

- independent regulation; and

- full transparency of SOE finances, including the implicit subsidies and payments, combined with the functioning of public enterprises under a hard budget constraint.

Efficient state provision of PSOs is particularly critical in an ideological space that is tilted toward a welfare state. In Sri Lanka, a clear example of PSOs is given in Appendix A6 Case Study 4, on the Sri Lanka Transport Board (SLTB). Rural bus routes, less profitable routes, and transport to school and university students at subsidized fares are left to the SLTB to serve, while the private sector focuses on the more lucrative routes. The SLTB maintains 95 million kilometers of uneconomical routes, which is approximately $22 \%$ of its network routes. In 2015, the SLTB's cost of providing bus services on uneconomical routes was equivalent to $95 \%$ of its operating losses (MOF 2015a). For the provision of PSOs to be sustainable, the costs must be explicitly taken into account in the operations of SOEs that provide the services. 
A reform process that aims to realize inclusive growth must also ensure that competition is the driving force, whether it is within SOEs, ${ }^{10}$ across the public enterprise sector, or between SOEs and the private sector. Competition promotes efficiency, drives productivity and growth, and enhances the quality of service. State banks in Sri Lanka compete with private banks, and evidence shows that competition has benefited the banking sector, resulting in significant market efficiencies, rapid utilization of modern technology, and an expanded bank network coverage (Edirisuriya 2007). Another clear example of the benefits of competition and contestability is Sri Lanka's telecommunications sector (section 6.4). Competitive pricing is also a part of the competitive process.

While emphasizing the fundamental importance of competition in the reform process, it is also critical to acknowledge that competitive markets may take time to develop and that there is therefore no prima facie case against state intervention. The state has a critical role to play as regulator: balancing efficiency, fiscal, and distributional objectives and ensuring that the nature and extent of regulation is appropriate to the nature of the enterprise or industry. For example, the SOE reform process should be complemented by effective, independent ex-ante and ex-post regulators ${ }^{11}$ to achieve the inclusive growth objectives set out for the enterprises, to promote and sustain effective competition where possible, and to ensure that the interests of stakeholders such as consumers are safeguarded. Moreover, effective regulatory institutions are critical, particularly when ownership change is being considered as a modality for SOE reform. In a climate where rent seeking and crony capitalism may be rampant, privatization without effective regulation can further entrench rent-seeking interest groups and provide more or different opportunities for rent extraction. ${ }^{12}$

Finally, fiscal transparency and discipline must be maintained. Meaningful budget constraints coupled with public exposure of SOE finances (including otherwise hidden implicit subsidies) are critical in ensuring that reforms have a chance of succeeding. This is particularly important to avoid crony capitalism.

10 Anecdotal evidence suggests that there is some degree of competition between counters at Sri Lanka's Passport Office, which has speeded up processing times. This was also confirmed in some of the KPIs.

11 Sri Lanka does not have a comprehensive competition law (see for example, Knight-John [2004a] for an account of the issues impeding the enactment of this legislation, which persist to date).

12 Two examples (Lanka Marine Services Ltd. and Sri Lanka Insurance Corporation Ltd.) of privatization being reversed on such grounds by rulings of the Supreme Court of Sri Lanka will be discussed in section 6.4. 


\subsection{Historical Evolution: Learning from the Past}

Public policy on SOEs in Sri Lanka, as in other countries, has been interspersed with episodes of nationalization, privatization, and competition across the decades. In Sri Lanka, the policies have been influenced and shaped by various internal and external sociopolitical and economic factors: macroeconomic imperatives, welfare disbursement, political patronage, rent-seeking dynamics, and the international financing community. The years of experience with SOE reforms have endowed policy makers with a rich repository of knowledge on both the technical and the political economy aspects of the process. Prudent decision makers could build on the learning and extensive research on SOE reforms in Sri Lanka, rather than reinventing the wheel. This section describes SOE reform episodes from the liberalization of the economy in 1977, to acquire useful insights for the current reform process. The narrative on the evolution of public enterprise reforms will also highlight key successes and failures together with underlying sociopolitical and economic considerations.

Sri Lanka's development space prior to 1977 was marked by a heavy reliance on SOEs, with successive political regimes embarking on large-scale nationalization programs, creating new public enterprises, and fostering state monopolies. Support for the policies was secured by strategically catering to populist objectives such as employment creation and price controls, and cultivating perceptions of a welfare state. A large number of the SOEs were burdened with issues of overstaffing, mismanagement, corruption, and politicization (Kelegama 1997).

The UNP government that swept into power in 1977, securing a four-fifths parliamentary majority, had a strong political mandate for economic reform. However, while the regime carried out an extensive liberalization program, SOE reforms were placed on the back burner for over a decade. The absence of public enterprise reforms during this "first wave of liberalization" was, to a large extent, a rational policy response to the sociopolitical conditions prevalent during those years (Dunham and Kelegama 1997). The massive influx of concessionary aid that came in with the opening up of the economy eased resource constraints and made it possible for the government to carry on with its practices of political patronage. In addition, the first decade of liberalization was one of mounting political violence, where transforming what the public perceived as "sacred cows" was not a rational policy decision.

By 1989, at the start of the "second wave of liberalization" (Dunham and Kelegama 1995), the internal economic and external financing environment began to change. Budgetary transfers to SOEs averaged about $10 \%$ of gross 
domestic product, indicating that the macroeconomic fallout of wavering on public enterprise reform could not be ignored for much longer (Knight-John and Athukorala 2005). In addition, the multi- and bi-lateral financing community began to flag the need for macroeconomic stabilization, which included the need to address the massive fiscal costs imposed by SOEs (World Bank 1988). ${ }^{13}$ Privatization was announced as a state policy in 1988 (Ministry of Finance and Planning 1988), aiming to ease the fiscal burden and improve the efficiency of public enterprises, and the divestiture program commenced in 1989.

This "first wave of privatization" coincided with the election of a new UNP government led by President Premadasa, whose social background differed from the English-speaking urban elite that had traditionally dominated the political party in the past. The President cultivated strong ties with the urban underclass, the rural poor, and a new political business class to secure political support. An interesting and successful strategy the populist president used was dubbing the process "peoplization," to highlight the people-friendly aspects of the program and secure public buy-in for SOE reforms. Moreover, presidential directives were issued to the effect that retrenchment was not an option, in order to placate trade unions.

Extensive public sector reforms were carried out between 1989 and 1993 with the partial and full divestiture of about 43 commercial enterprises that yielded gross receipts of approximately $\$ 102$ million. However, the privatization proceeds were not transmitted to an ear-marked account and went instead into a fungible slush fund (Kelegama 1997). The entities that were sold during 19891993 could be typified as "easy picks" in contrast to the more complex utility and service sector divestitures that were carried out in the 1994-2000 reform episode that followed. The default modality for privatization was a "51:30:10" formula, where a majority shareholding of $51 \%-60 \%$ was sold to corporate investors, $30 \%$ was offered at par to the public, and $10 \%$ was given free of charge to workers under an employee share ownership plan. In some cases, the formula was not applied-examples are permitting employee buy-outs, such as the Buhari Hotel; giving $50 \%$ of shares to workers in the SLTB; selling assets of public corporations with the state assuming the liabilities (Ceylon Petroleum Corporation); and making management contracts (for the plantations).

Following the announcement of privatization as a state policy in 1987, several measures were undertaken to set up the legal and institutional structures

13 Privatization per se was not a conditionality imposed by the multi- and bi-lateral financing community. However, the political leadership strategically used the notion of external pressure to implement these reforms (Kelegama 1993). 
necessary for reform. Two pieces of legislation were enacted in 1987 to facilitate the commercialization of SOEs: Conversion of Government Owned Business Undertakings into Public Corporations Act No. 22 and Conversion of Public Corporations or Government Owned Business Undertakings into Public Companies Act No.23. In addition, several institutions, including the Presidential Commission on Privatization (renamed the Presidential Commission on Peoplization in 1989), Public Investment Management Board, and Commercialization of Public Enterprises Division of the Ministry of Finance were created to facilitate the privatization process. Specialized entities were also set up to oversee sectoral divestitures-for example, the Plantation Restructuring Unit to handle the privatization of the estate sector and a separate unit within the Ministry of Industries to handle the privatization of industrial enterprises. The involvement of these numerous organizations in the divestiture process and the inability to bring the program under one umbrella entity was largely because of the prevailing political climate at the time, when the President was facing impeachment proceedings and coalition building was critical for political survival.

Despite the positive elements in the 1989-1993 reform episode-in particular, the ability of the president to strategically steer the process amid potential political economy obstacles-this period is also viewed as one in which rent-seeking and asset-stripping were prevalent (Dunham 2004). Although several enterprises were divested, the process was mostly ad hoc and conducted behind closed doors. Moreover, the absence of sound regulatory governance structures-with the political leadership claiming that the speed of reform specified by multilateral financiers did not allow for setting up regulatory institutions prior to privatization-provided space for a policy process inimical to good governance (Salih 2000).

In late 1994, some elements of the public voiced dissatisfaction about spreading corruption, authoritarian rule, and political violence. This led to the end of 17 years of UNP rule and the election of a People's Alliance government, comprising a coalition of the Sri Lanka Freedom Party (SLFP), the traditional left parties, and splinter groups from the UNP. However, contrary to public expectations that the liberalization process would be reversed given the political economy ideology of this regime, it carried out complex privatization exercises in sectors such as telecommunications, airlines, and gas using the slogan "Free Market Economy with a Human Face" (Bandaranaike Kumaratunga 1995). This period also saw the divestiture of $51 \%$ of the shares of plantation companies, following the recognition that the 5-year management contract modality previously used in this sector was a disincentive to long-term capital investment. The gross privatization proceeds during the "second wave of privatization" (1994-2000) amounted to approximately $\$ 403$ million. 
Issues of alleged corruption in the previous UNP regime's privatization program had been highlighted as a major issue by the People's Alliance government in its election campaign. As such, the Public Enterprise Reform Commission was set up under an Act of Parliament in 1996 to be solely responsible for the privatization program and to ensure that the process was carried out in a structured and transparent manner. Although transparency and access to information about SOE reforms and divestitures did improve for a while with the establishment of this entity, allegations of questionable deals began to emerge in the policy space over time (Box 6.1). To protect the interests of workers in failed privatized entities and to limit industrial disputes, the government also enacted the Rehabilitation of Public Enterprises legislation in 1996.

\section{Box 6.1: Lanka Marine Services and Sri Lanka Insurance Corporation: The Perils of Institutional Lapses}

In 2002, a majority stake of Lanka Marine Services was sold through the Treasury and the Public Enterprise Reform Commission, with these same institutions selling a controlling interest in Sri Lanka Insurance Corporation in the following year. However, following a complaint by the Committee on Public Enterprises that the privatization process was carried out in a corrupt manner, these two transactions were investigated by the Supreme Court of Sri Lanka. Subsequently, between 2008 and 2009, the Supreme Court reversed both divestitures and ordered that the enterprises be reverted to state ownership.

On the privatization of Lanka Marine Services, the judgment stated that it was "done without lawful authority" for the benefit of a private holding company. On the divestiture of Sri Lanka Insurance Company, the Supreme Court determined that "the execution of the Share Sale and Purchase Agreement with parties not known and not approved by Cabinet was a wrongful executive act done without jurisdiction and as such was illegal and null and void ab initio" (GAP [n.d.]: 3).

Clearly, both these transactions point to the workings of rent-seeking, private interest groups, aiming to secure unlawful benefits from the privatization process. However, it is also important to understand that the incidents relate more to a failure in institutional and regulatory capacity than to the disposition of a particular political party.

Sources: Nanayakkara et al. (2008, 2009); GAP (n.d.).

However, this legislation was operational for only 6 months because the chambers of commerce began to voice concerns about renationalization and the government did not want to send erroneous signals to the investor community. The compensation packages drafted for retrenched workers also had inherent problems, including an inbuilt adverse selection bias where the relatively more skilled employees took the monies and quit the entity.

A significant feature of the divestiture structure during the "second wave of privatization" was the granting of exclusivity provisions without adequate regulatory arrangements in the sale of key entities such as telecommunications, 
gas, and airlines, and the underpricing of assets. The rationale for the policy decisions, according to KPIs conducted for this study, ranged from an absence of committed bidders for the transactions in the midst of a civil war and an unstable political climate, pressing budgetary constraints, and a dire need for investment. Two somewhat contrasting narratives on privatization episodes during this period are set out in Box 6.2.

\section{Box 6.2: The Privatization of Sri Lanka Telecom and the Colombo Gas Company}

In 1995, the shares of the state-owned Colombo Gas Company, which supplied the entire local market and dominated the market for liquefied petroleum gas were sold to Shell Gas, a large multinational. The privatization contract included exclusivity provisions for 5 years to the effect that Shell would be the only company to undertake liquefied petroleum gas business during this period. Moreover, in spite of the fact that the setting up of an independent regulator for this market had been a stated policy goal, this was not done, resulting in suboptimal distributional impacts, particularly post-privatization gas price hikes.

In contrast, the privatization of Sri Lanka Telecom (SLT) stands out as a success story in the reform narrative. In 1997, 35\% of the government's shareholdings in SLT was sold to Nippon Telegraph and Telephone Corporation through a competitive bidding process for the large sum of $\$ 225$ million. The government retained $61.5 \%$ share ownership and employees of SLT were given the balance 3.5\%. An Employee Share Ownership Plan was used to counter anticipated trade union resistance, members of these unions were sent to Latin American countries to study similar privatization processes, and letters were written to the wives and families of the members by the minister in charge of the subject area explaining the entire divestiture process.

Similar to the case of Shell, Nippon Telegraph and Telephone Corporation was granted exclusivity provisions such as the nonissuance of any other basic wireline and international licenses for 5 years and the nonimposition of universal service obligations on this entity. However, unlike in the case of the gas industry, competition was a major driver in the telecommunications sector. Competition in the fixed telephony segment existed prior to the privatization of SLT, due to the presence of two wireless loop operators. This structure also generated a dynamic of contestability in the fixed sector. Competition in the mobile segment was relatively higher than in its fixed counterpart-with Mobitel a fully owned subsidiary of SLT also in the mix. The privatization process was also accompanied by setting up an independent regulator-the Telecommunications Regulatory Commission-which at least in the early years was focused on pro-competitive reforms (in spite of the fact that the trifurcation of policy, operations, and regulation was not precisely separated).

Sri Lanka's telecommunications industry is viewed as one of the most progressive in the region, with the sector also being hailed as a key driver of socioeconomic growth. The reforms put an end to the high unmet demand for telecommunications services, long waiting periods, and poor transmission quality. Competition in the mobile telephony sector has also had beneficial impacts on users as reflected in low mobile prices and in the high rates of market penetration. This narrative on the telecommunications sector also shows that competition, contestability, and regulation oriented toward competition are as important as (and sometimes more important than) modalities that lean toward divestiture and that sequencing of reforms is crucial.

Sources: Knight-John and de Zoysa (2001); Jayasuriya and Knight-John (2002); Asia Foundation and Verite (2015). 
The election of a new political regime in 2001 saw the formation of a coalition government led by Prime Minister Ranil Wickremesinghe (UNP) and President Chandrika Bandaranaike Kumaratunga (SLFP). The national policy statement of this government, contained in a voluminous document-Regaining Sri Lanka-set out an acceleration of the privatization process as one of its three main themes (Wickremesinghe 2002a, b). Although this episode coincided with the signing of a stand-by arrangement with the IMF, privatization was not included as an aid conditionality. The locus of the reform process was centered in the Public Interest Program Unit, a sunset organization headed by technocrats. A major thrust of the work carried out by this entity was the framing of sound legislation and the setting up of strong, independent regulatory institutions for the SOE reform process. The Public Utilities Commission of Sri Lanka (PUCSL), an umbrella body set up to facilitate multisector regulation, was institutionalized under the purview of the Public Interest Program Unit. The PUCSL is generally considered to be an example of good regulatory governance, with its members appointed in concurrence with the Constitutional Council, to minimize the influence of partisan politics. ${ }^{14}$ Yet, despite these positive elements, the scope of the PUCSL is still limited to regulating the electricity industry.

In spite of all the progressive reform efforts undertaken by this UNP regime on the economic front, a robust strategy to secure the political capital required to sustain the reforms was lacking, resulting in the dissolution of Parliament in 2004. As a result, the United People's Freedom Alliance led by President Mahinda Rajapakse came into power in 2005. In view of public opposition and in response to the experience of its predecessor UNP regime, the election manifesto of the United People's Freedom Alliance declared that the privatization of national resources and public institutions would be stopped. In 2011, an expropriation law was also enacted under dubious principles to allow the government to acquire and manage 37 "underperforming" or "underutilized" private enterprises (GSL 2011). Moreover, the government reneged on competition-oriented electricity sector reforms, despite the enactment of supporting legislation, in the face of trade union opposition.

In line with the ideology that the sale of public assets will not be an option, President Rajapakse resurrected the Strategic Enterprise Management Agency created by ex-President Bandaranaike Kumaratunga to manage several strategic SOEs in various sectors, including banking, energy, transport, and plantations. The agency was given a clear mandate in terms of the strategic enterprises under its purview to improve the efficiency, fiscal, and distributional performance

\footnotetext{
14 However, as set out in the case study on Ceylon Electricity Board (Appendix A6), Cabinet approval is required for the revision of tariff methodology.
} 
of the entities without privatization. KPIs conducted for this study indicated that the Strategic Enterprise Management Agency had a systematic approach to the reform process: first looking at the SOEs in silos and then moving on to considering interrelations between the various entities (for example, the Ceylon Electricity Board and Ceylon Petroleum Corporation). At the time of writing, however, the Strategic Enterprise Management Agency is largely a passive entity in the current SOE reform space.

Another entity created during this period was the State Resources Management Corporation, set up under the Ministry of State Resources and Enterprise Development as a holding company with an aspiration to graduate into a Temasek-like model. KPIs indicated that the State Resources Management Corporation was intending to reform $100 \%$ government-owned companies. Private placements with other state companies were also being considered. However, the State Resources Management Corporation was shut down in what some of the stakeholders interviewed perceive as an attempt to create the space for the Public Enterprise Board (PEB)-the current regime's version of the Temasek model-which will be described later in this chapter.

At least three key political economy lessons emerge from the historical narrative on SOE reforms in Sri Lanka. First, strong political leadership with a focus on pragmatism and a strategy to win the public mind is critical for the success of the process. Second, as evidenced in Boxes 6.1 and 6.2, sound regulatory structures and institutional capacity are essential for an effective and sustainable reform process. While Sri Lanka has had some success stories-for example, the PUCSL and financial regulation-competition policy and law as well as sectoral regulation in areas such as transport are very much below par. As mentioned above, reforms in the absence of such institutional safeguards may well foster crony capitalism and entrench rent-seeking behavior. Third, as discussed in Box 6.2, competition and contestability combined with effective regulation are as important as or more important than ownership change in terms of reform outcomes.

\subsection{State-Owned Enterprises: The Current Context}

The public enterprise reforms that are important for Sri Lanka in the medium and long term are as highlighted in the historical evolution of this process. In addition, a key takeaway from the KPIs is the assertion that SOE reform is essential beyond the IMF's Extended Fund Facility (see Box 6.3 for the IMF's Pillar 4 objectives on public enterprise reform), given the efficiency, fiscal, and distributional issues 
that pervade this sector..$^{15}$ Moreover, the SOEs' underperformance is attributed to a range of factors, including the prevalence of a murky governance structure, the absence of systems of management and accountability amenable to enhanced efficiency, and additional burdens imposed by social and PSO objectives. ${ }^{16}$ This section aims to provide some context to these insights by presenting a flavor of the size and scope of the sector as well as its performance at the time of writing. The section will also briefly outline the current reform agenda together with the political economy backdrop to this reform process.

\section{Box 6.3: International Monetary Fund Extended Fund Facility, Pillar 4-State-Owned Enterprise Reform}

Objectives of the pillar are as follows:

- a resolution strategy for Sri Lankan Airlines to be completed by September 2016, effectively removing the enterprise from the government's accounts;

- recording of the fiscal cost of noncommercial obligations (such as utility subsidies) for state-owned enterprises in the central government budget, starting in 2017;

- Ministry of Finance, line ministries, and state-owned enterprises to sign and publish statements of corporate intent for the six largest state-owned enterprises (Ceylon Petroleum Corporation, Ceylon Electricity Board, Sri Lanka Airlines, National Water Supply and Drainage Board, Airport and Aviation Services, and Sri Lanka Port Authority) by December 2016, in order to enhance oversight and financial discipline;

- the Ministry of Finance to introduce an automatic fuel pricing mechanism that ensures retail prices above cost-recovery levels and a financial position of Ceylon Petroleum Corporation amenable to covering debt service, by December 2016; and

- the Cabinet to introduce an automatic electricity pricing mechanism that ensures retail prices above cost-recovery levels and a financial position of Ceylon Electricity Board amenable to covering debt service, by December 2016

Source: IMF (2016b).

15 Interestingly, a stakeholder interviewed for this study who had vehemently opposed SOE reforms on ideological grounds in the past, had this to say: "SOE reform is necessary not because of neoliberal prescriptions, but because we need to do so anyway in order to ensure productivity and sustenance. We must resolve to restructure existing SOEs, not for the IMF, but because we need to."

16 Examples cited in the KPIs were the subsidization of water and of public transport and the failure to adjust the prices of these services to reflect marginal costs. 
Although, as detailed in section 6.2, it was not possible to obtain comprehensive data on the SOE sector, the following numbers provide a useful snapshot of the enterprises. According to MOF (2015a), SOBE revenue was $12 \%$ of gross domestic product in $2015 .{ }^{17}$ In addition, the size of the SOE sector in terms of investment and employment is depicted in Figures 6.2 and 6.3. As evidenced by these statistics, public enterprises have a substantial presence in Sri Lanka's economy, underscoring the need to ensure that this sector performs at its full potential.

Figure 6.2: Investment in State-Owned Enterprises

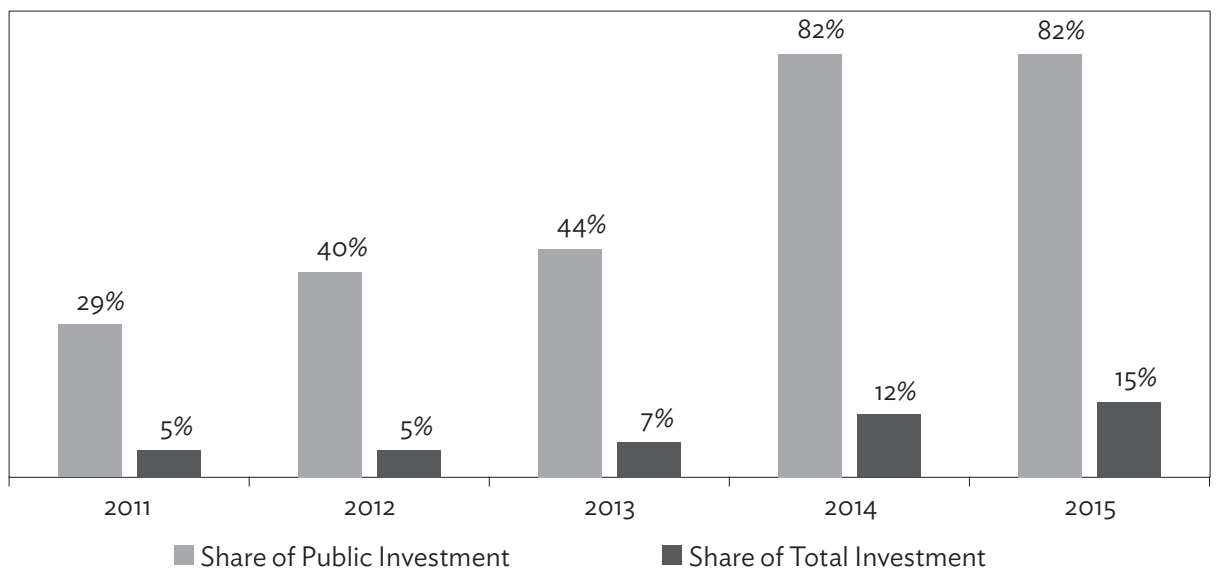

Sources: Calculated using MOF (various years), CBSL (various years).

Figure 6.3: Employment in State-Owned Enterprises

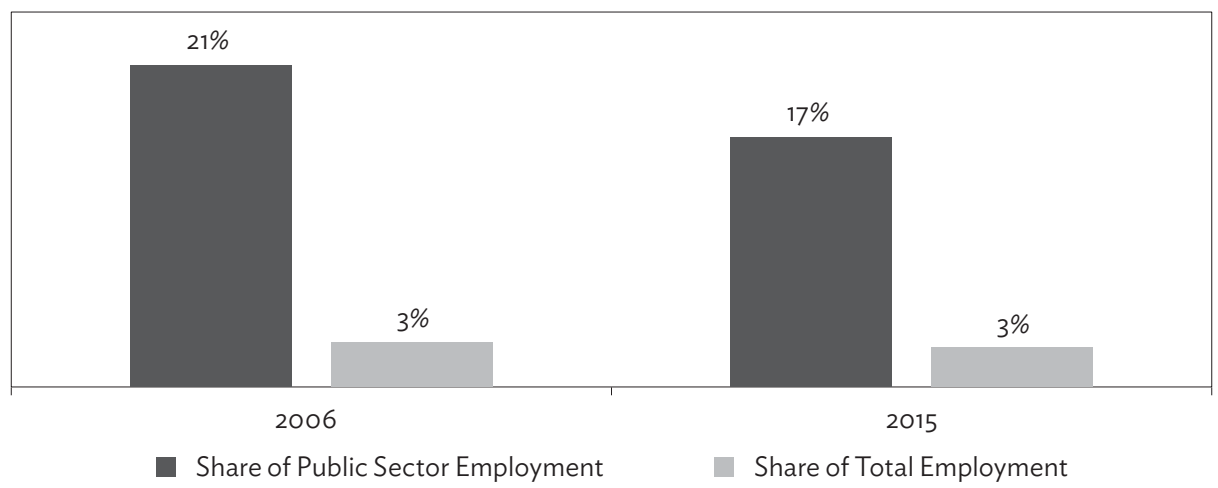

Sources: Calculated using MOF (various years); DCS (2014, 2015).

17 In the absence of complete data, this revenue calculation is used as a proxy for the size of the SOE sector in terms of gross domestic product. The calculation is based on the revenue data for the 55 SOBEs. 
The assessment of Sri Lanka's public enterprises for this analysis highlights the fact that the sector is underperforming at several levels, undermining its ability to effectively contribute to the country's socioeconomic development trajectory. As mentioned earlier and as will be set out below, there are significant efficiency, fiscal, and distributional dimensions ${ }^{18}$ to the problems afflicting the SOEs. Figure 6.4 illustrates the problems of operational efficiency in the SLTB, using the share of idle buses in the total fleet as an indicator. Although the utilization of buses has improved from 2013 to 2015, a significant proportion of the fleet is still idle. Inefficiencies are also prevalent in the energy sector due to excess capacity in Ceylon Petroleum Corporation's refinery, resulting from a fall in demand for fuel oil for the Ceylon Electricity Board's electricity generation, with the installation of the Norochcholai coal power plant (MPRD 2015). Additionally, the local retail prices of petroleum products are not revised based on fluctuations in world market prices or the taxes and levies imposed by the Treasury. As such, Ceylon Petroleum Corporation is, in most instances, compelled to sell petrol and diesel at prices that vary from the import cost (MPRD 2015).

Figure 6.4: The Operational Efficiency of Sri Lanka Transport Board

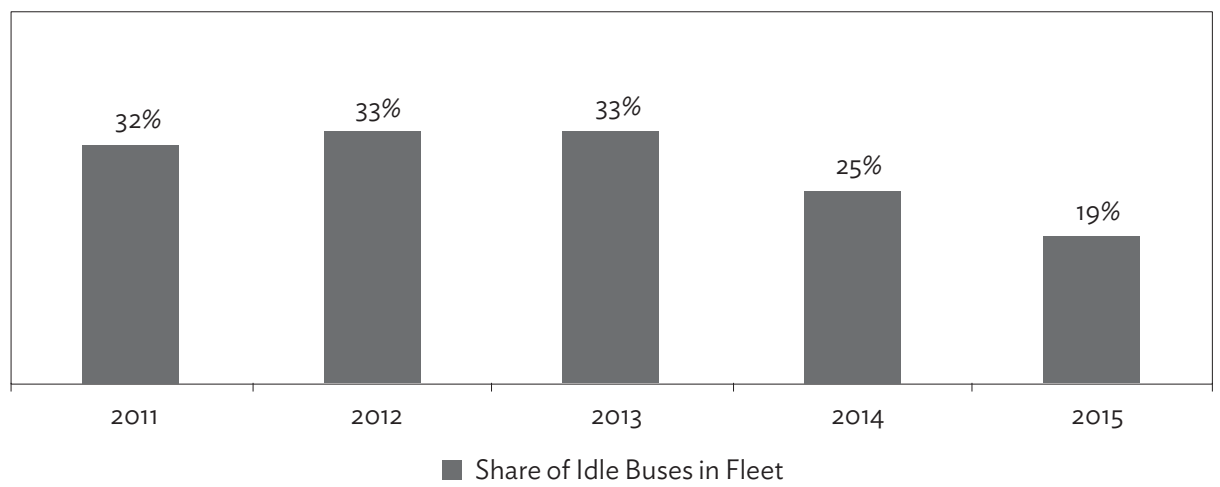

Source: Ministry of Transport and Civil Aviation (n.d.).

Fiscal considerations also provide a strong impetus for public enterprise reform, as illustrated in Figure 6.5. The figure shows the net accumulated losses for selected SOBEs during 2011-2015, and Figure 6.6 points to the five entities

18 Given the contextual variations pertaining to different SOEs, these dimensions are mostly illustrated in terms of the individual case studies analyzed later in this chapter. More detailed sectoral time-series data on operational efficiency, profits and losses, and quality of service are set out in the case studies. 
that performed the best and the five that performed the worst in 2015 alone. ${ }^{19}$ Financial sector public enterprises were not included in the calculations for the following reasons. First, it is more appropriate to evaluate public sector banking enterprises in relation to the private sector, given the level of competition in this market. Second, public sector banks that form a large part of the SOE sector have recorded profits for the last 10 years. By contrast, nonfinance sector public enterprises are a burden to their finance sector counterparts, and by extension to the entire financial system and to the economy.

\section{Figure 6.5: Net Losses of Selected State-Owned Business Enterprises, 2011-2015 (SLRs million)}

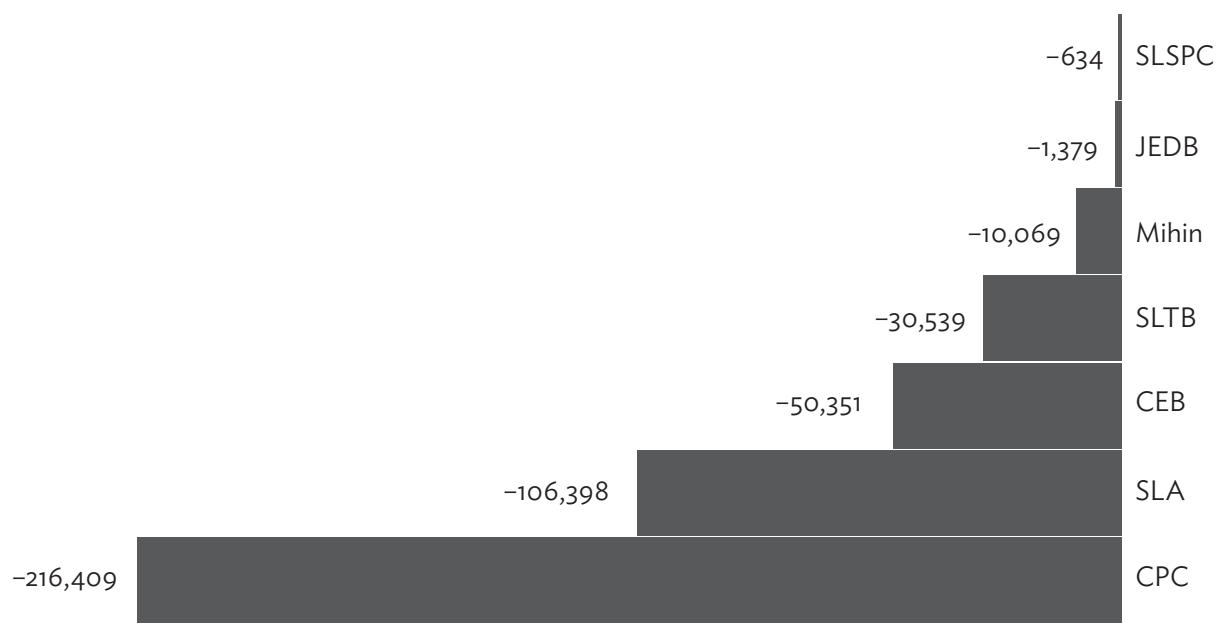

$\mathrm{CEB}=$ Ceylon Electricity Board, $\mathrm{CPC}=$ Ceylon Petroleum Corporation, JEDB = Janatha Estates Development Board, Mihin = Mihin Lanka , SLA = Sri Lanka Airlines, SLSPC = Sri Lanka State Plantations Corporation, SLTB = Sri Lanka Transport Board.

Source: MOF (various years).

19 Data in IMF (2016b) indicate that the financial obligations of selected SOEs amounted to approximately $11.5 \%$ of gross domestic product (Ceylon Petroleum Corporation [3.8\%], Sri Lanka Airport [2.8\%], Sri Lanka Ports Authority [2.2\%], Ceylon Electricity Board, [2.1\%]; Other [0.6\%]) and $15.1 \%$ of public debt in 2015 . 
Figure 6.6: Five Biggest Winners and Five Biggest Losers, 2015 (SLRs million)

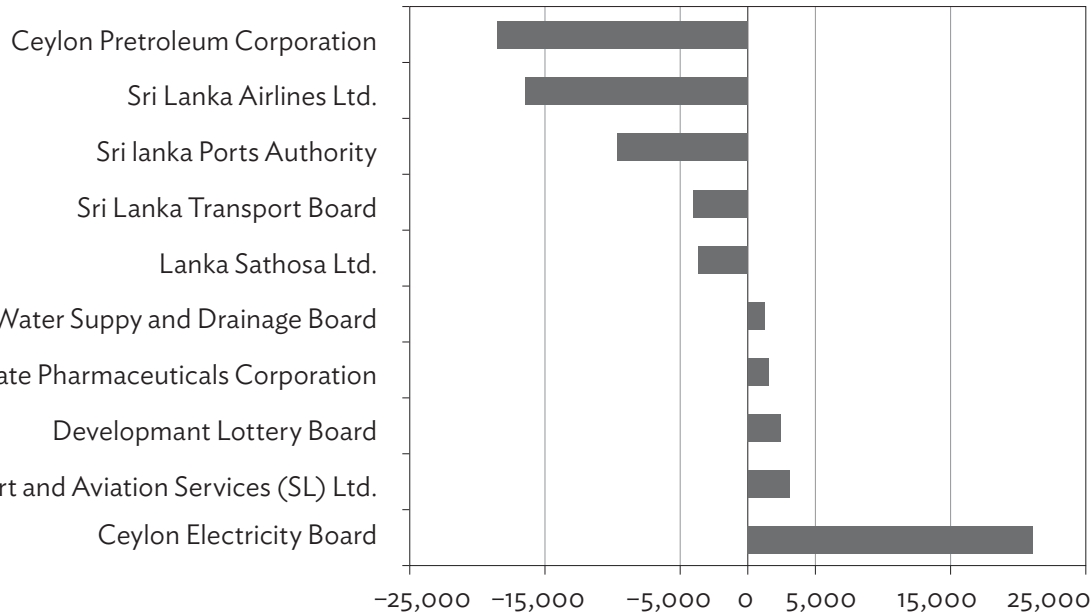

Notes: The losses of the five biggest losers were $185 \%$ of the profits of the five biggest winners in 2015 . Moreover, the operating losses of the five largest losers were approximately 30\% more than the 2015 budget of the Samurdhi program - a welfare payment system for low-income households.

Source: MOF (various years).

Figure 6.7 compares the annual average accumulated losses of all SOBEs and of nonfinance SOBEs from 2011 to 2015, and Figure 6.8 compares their annual average gross profits for the same period. As indicated in Figure 6.7, removing the effect of financial sector SOBEs only leads to an SLRs2 billion fall in the annual average losses of SOBEs. In contrast, as shown in Figure 6.8, removing the effect of financial sector SOBEs leads to a significant fall in profits, from SLRs94 billion to SLRs25 billion. It is therefore evident that SOBE profits for the last 5 years were largely generated by the financial sector, underscoring the necessity of treating the financial sector enterprises differently from the others in the reform process. 


\section{Figure 6.7: Comparing the Annual Average Losses of Nonfinance} and of All State-Owned Business Enterprises, 2011-2015

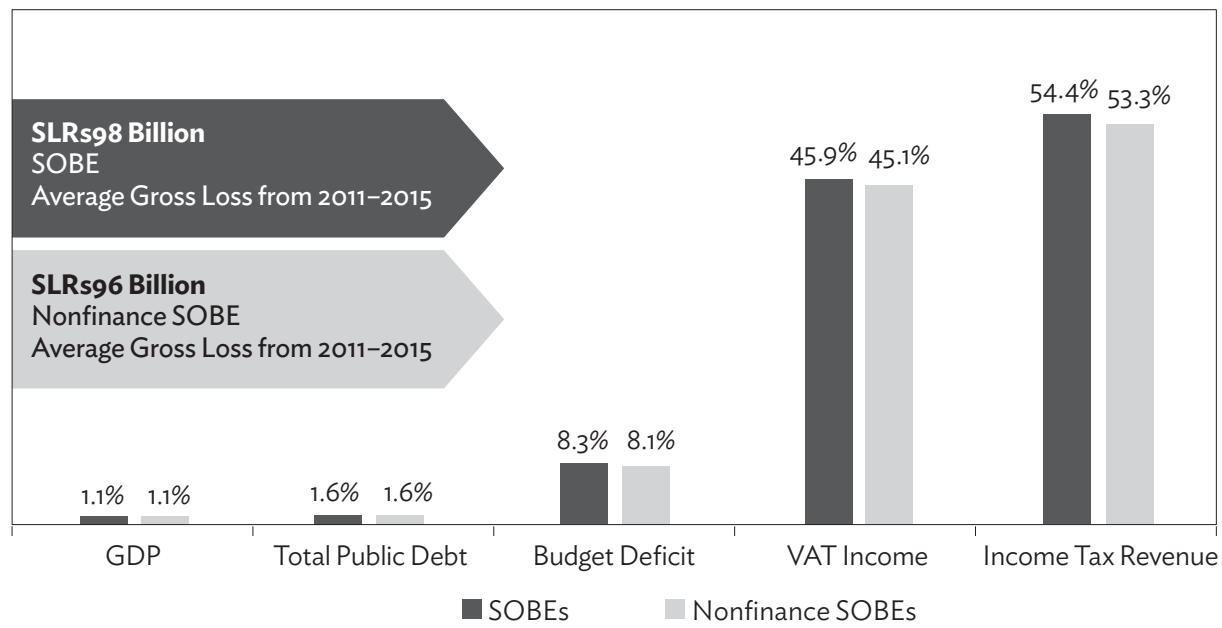

$\mathrm{GDP}=$ gross domestic product, $\mathrm{SOBE}=$ state-owned business enterprise, $\mathrm{VAT}=$ value-added tax . Source: MOF (various years); CBSL (various years).

Figure 6.8: Annual Average Profits of Nonfinance and of All State-Owned Business Enterprises, 2011-2015

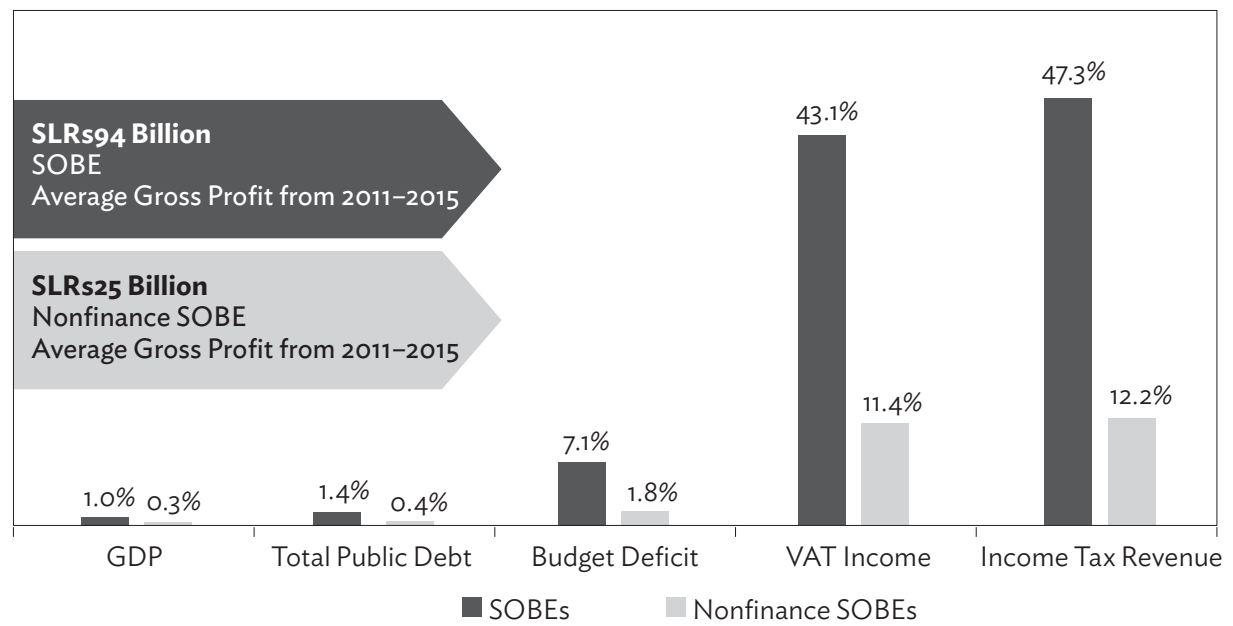

GDP = gross domestic product, $\mathrm{SOBE}=$ state-owned business enterprise, $\mathrm{VAT}=$ value-added tax. Source: MOF (various years); CBSL (various years). 
As illustrated in Figure 6.9, interlinking debts, obligations, and payments between many SOE entities further complicate their current state of affairs. ${ }^{20}$ As detailed in Appendix A6, the circular debt situation can impose unnecessary costs on the Treasury and is not conducive to the efficient functioning of the SOEs. An additional dimension to the fiscal burden, highlighted in KPIs with representatives from rating agencies, is the link between country ratings and the performance of SOEs. For example, in June 2016, Moody's changed the outlook on Sri Lanka's rating from stable to negative with weak financial performance of SOEs being a sizable contingent liability risk for the government and a potential source of fiscal and balance-of-payments pressure (Moody's 2016).

Figure 6.9: Circular Debt in 2015 (outstanding SLRs million)

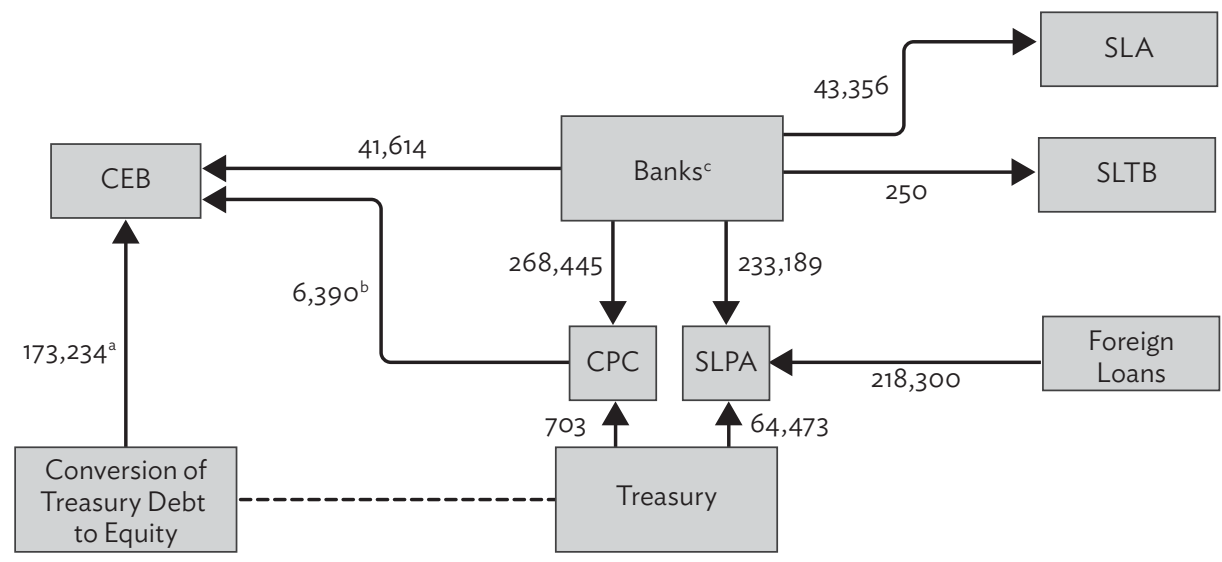

$\mathrm{CEB}=$ Ceylon Electricity Board, $\mathrm{CPC}=$ Ceylon Petroleum Corporation, SLA = Sri Lanka Airlines, SLPA = Sri Lanka Port Authority, SLTB = Sri Lanka Transport Board.

For 2014 and 2015 according to Ministry of Finance Annual Report 2015.

Outstanding debts to both CPC and independent power producers.

Includes state banks.

Sources: MOF (2015a, 2016b).

The underperformance of SOEs in terms of efficiency and fiscal dimensions also has adverse impacts on distributional outcomes. For example, as of 2014, the state plantations (estate) sector directly employed approximately 11,755 workers (COPE 2016), with significant indirect employment and a dependent plantations community. The plantations sector consists of a large, economically vulnerable, and socially marginalized population that depends on the performance of the state plantations. For example, the statutory dues of SLRs1.5 billion owed to employees of the Janatha Estates Development Board's Employment Provident Fund and

20 State banks have a large portfolio of lending to SOEs, which are effectively a captive market for state banks, given that most SOEs are only allowed to use state banks for their financial and banking needs. 
Employment Trust Fund benefits in 2015 have a particularly unfavorable impact on this community (MPI 2016). Similar distributional consequences are seen in the electricity sector where operational inefficiencies-including inadequate planning-have resulted in a tradeoff between cost and uninterrupted power supply to consumers (Case Study 2 in Appendix A6).

The inefficiencies and financial malaise in Sri Lanka's SOE sector are also associated with networks of political patronage that pervade the country's sociopolitical institutions. Historically, the government has used state organizations to disburse welfare in the form of employment opportunities or subsidized goods and services. Welfare disbursement in and of itself is not necessarily inappropriate; however, the hijacking of such objectives for narrow political gain is inimical to the public interest. Several such examples are documented in COPE (2016) and discussed in section 6.4. Box 6.4 provides one example: the Lankaputhra Development Bank.

The stance on SOE reform articulated by the Prime Minister and by high-ranking UNP politicians is set out in section 6.3. In addition, the following statement by the finance minister in the 2016 Budget Speech suggests that the government is cognizant of the political costs of hasty privatization and is exploring other means of public enterprise reform:

The government reiterates that no SOEs will be privatized simply as a means to increase revenue. Instead, the government is keen to follow a more strategic approach, where the SOEs will be strengthened and made independent (MOF 2016a: 86).

\section{Box 6.4: Lankaputhra Development Bank}

The performance of the Lankaputhra Development Bank contrasts starkly with that of other finance sector state-owned enterprises-in particular the Bank of Ceylon and the People's Bank, which have shown profits in the last decade.

The Lankaputhra Development Bank was established in 2006, following the 2005 elections, to assist local businesses. However, it was not run on a commercial basis or even managed effectively to provide development assistance. Instead, it was used to lend money as patronage and senior appointments to the bank were being made on a similar basis.

Unsurprisingly, early in 2007, the enterprise was declared unviable and merged with the SME Bank (which was also in financial distress due to questionable loans) as a means of rescue.

The Committee on Public Enterprises is scrutinizing the Lankaputhra Development Bank with a view to reform. Key elements the Committee is addressing include the need to follow stipulated procedures in terms of loans and interest rates on loans disbursed, and inconsistencies in recruitment procedures.

Source: COPE (2016). 
The mandate of the Ministry of Public Enterprise Development in the context of the current SOE reform process was also described by its minister in an interview with the Oxford Business Group (2016). The minister set out five key elements. First, a key mandate of the new ministry is to restructure SOEs and not merely to run them. Second, a major objective of the reform process is to reduce the fiscal burden imposed by the enterprises. Third, the restructuring process needs to balance PSOs with profitability. Fourth, a crucial element of reforms is to address the politicization of the SOEs and to provide increased scope for technocrats in managing these entities. Fifth, two modalities being carefully considered by the government are public-private partnerships (PPPs) and joint ventures.

The ongoing initiatives for SOBEs are set out in Figures 6.10 and 6.11. A more detailed discussion of some of these initiatives, such as for example the $\mathrm{PEB}$, is contained in the final section of this chapter.

Figure 6.10: State-Owned Business Enterprise Reforms-Initiatives

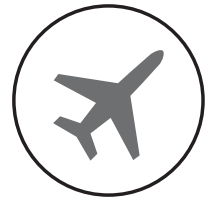

Sri Lankan Airlines and Mihin Lanka

- Seeking strategic investor and management partner

- Internal unbundling

- Wet lease of three airbus A330 aircrafts to PIA

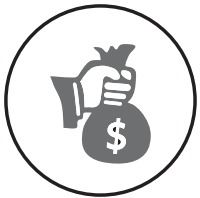

State Banks

- Consolidating banks (SMIB and HDFC)

- Strategizing future for Bank of Ceylon, People's Bank, and National Saving Bank

- Drawing up a plan for future capital requirements

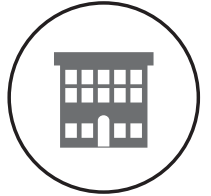

Nonstrategic Investment Divestiture

- CSE listing or request for proposals in 2016

- Entities to be included

- Lanka Hospitals

- Hotel Developers PLC

- Hyatt Residencies

- Waters Edge

- Grand Oriental Hotel

- Ceylinco Hospital

- Mobitel

$\mathrm{CSE}=$ Colombo Stock Exchange, $\mathrm{HDFC}=$ Housing Development Finance Corporation Bank, PIA = Pakistan International Airlines, SMIB = State Mortgage and Investment Bank.

Note: A "wet lease" is an arrangement covering the hire of an aircraft including the provision of a flight crew and sometimes fuel. PIA returned the airplanes in 2017.

Sources: Collated using MOF (2016a); News.lk (2015); interviews with key persons; various pieces in the English and vernacular press. 


\section{Figure 6.11: State-Owned Business Enterprise Reforms- Institutional Arrangements}

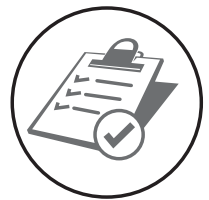

Strengthen Regulation

- Broaden PUCSL scope to include NWSDB and CPC

- Enhance PUCSL authority in setting tariffs

- Enable more cost reflective pricing mechanisms

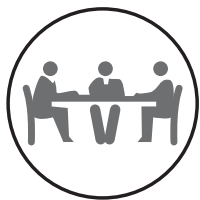

Public Enterprise Board

- Government holding company

- Temasek (and Khazanah) elements

- Public Enterprise Development Act (being drafted)

$\mathrm{CPC}=$ Ceylon Petroleum Corporation, NWSDB = National Water Supply and Drainage Board, PUCSL = Public Utilities Commission of Sri Lanka.

Sources: Collated using MOF (2016a); News.Ik (2015); interviews with key persons; various pieces in the English and vernacular press.

Despite statements by the government, the SOE reform initiatives, and the creation of a separate ministry to spearhead the reform process, the perception of a large number of stakeholders interviewed for this study is that policy for public enterprise reforms lacks coherence. Some stakeholders further expressed the view that reform initiatives were not aligned with practical realities and that public discourse is being driven by ideology rather than pragmatism.

The current political context highlights the potential opportunities and challenges that frame the public enterprise reform process. While the bipolar structure of the present government provides opportunities for cooperation, it also creates the opportunities for contradictions when consensus building is poorly managed. Given the differences in the political economy of the two main political parties that comprise the current government, political will for privatization is unlikely to be strong. Modalities of SOE reforms other than privatization are likely to be emphasized in the policy arena. Further, the need to secure mass consensus (including from key trade union actors) and legitimacy for public enterprise reforms also highlights the importance of the Janatha Vimukthi Peramuna, a socialist party, which has been traditionally averse to privatization. 


\subsection{Successful State-Owned Enterprise Reforms: International Experience}

SOE reforms implemented across countries vary significantly-there is no onesize-fits-all approach. Rondinelli (2005) posited that an SOE reform program should commence with a comprehensive performance review by a government commission or agency to list the SOE's resources and assets, determine the financial standing of the SOE, and evaluate its past performance in terms of meeting its financial and development objectives. The results should be used as inputs in designing an effective strategy for reform, which in turn should spell out a clear vision of the SOE's role in national development, mission, objectives, and performance targets (Figure 6.12).

Figure 6.12: Framework for Assessing Public Enterprise Reform

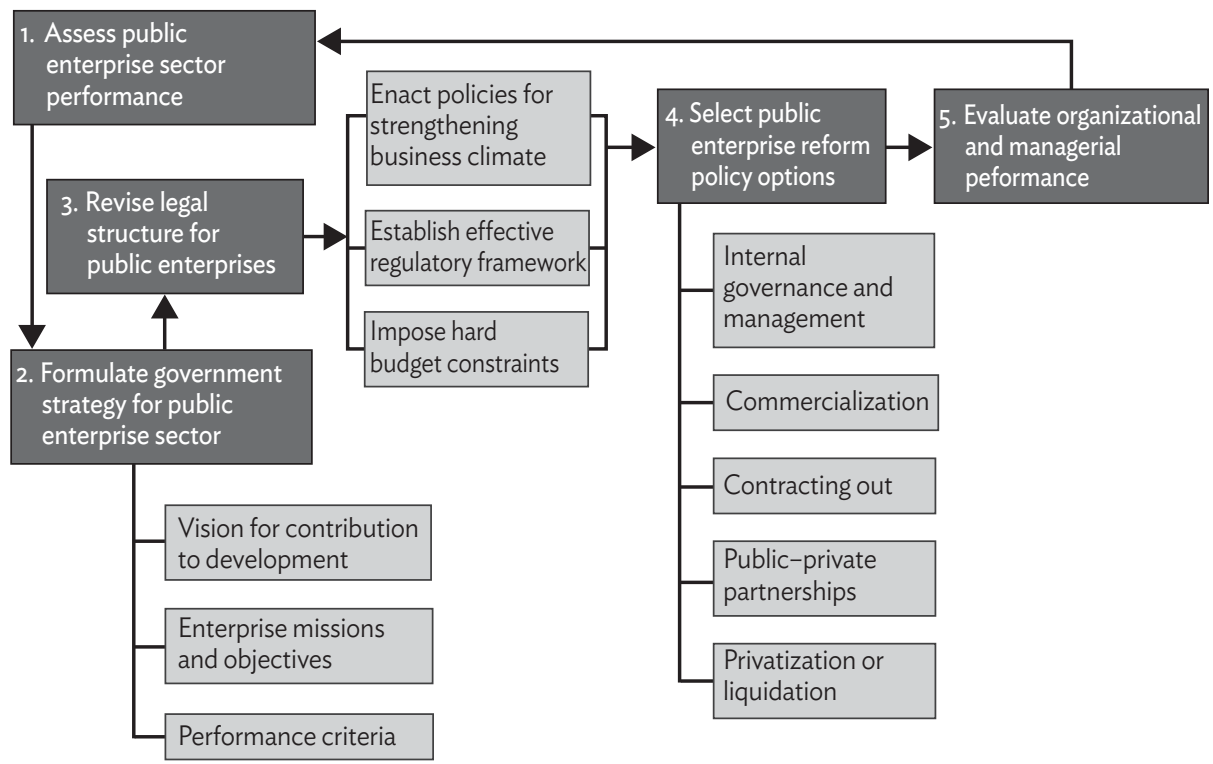

Source: Rondinelli (2005).

More often than not, the government must revise the legal structure of SOEs (Rondinelli 2005). The rights of parties within an SOE, their dynamics, and the ways by which an SOE transacts and behaves with external parties will basically be governed and guided by its legal structure. Therefore, diffusion and institutionalization of change in formal organization structure is importantly determined by the extent to which a measure is institutionalized-whether by law or any form of legitimation. For example, after embracing a socialist market economy as a national objective in 1992, the 1993 Company Law of the People's 
Republic of China (PRC) provided the legal basis for SOEs to be corporatized into shareholding companies with a modern corporate board structure, creating a variety of corporate SOE forms.

Because SOE laws and regulations define the legal structure, administration, oversight arrangement, and functions of each governing body of SOEs, the reform program needs to ensure a clear and robust legal framework. Often, SOEs are subjected to overlapping and contradictory provisions that may weaken accountability arrangements, limit profitability, and contribute to ineffective decision-making. The legal and regulatory framework should foster a level playing field for SOEs and private enterprises alike and protect the rights of businesses, consumers, workers, and citizens. It is important to establish a balanced regulatory framework that deters public and private enterprises from abusing market power but at the same time fosters an environment that encourages SOE managers to achieve the enterprise's objectives efficiently.

Moreover, policies should be enacted to provide an attractive business environment, which means improving the macroeconomic environment, financial system, and physical infrastructure. Lastly, the regulatory framework should include hard budget constraints to impose financial discipline among SOEs.

The literature on SOEs presents different types of SOE reforms that could lead to the financial and operational independence of SOEs. Figure 6.12 illustrates Rondinelli's proposed framework for assessing public enterprise reform.

In the Asia and Pacific region, different types and variants of SOE reforms have emerged over time. These include corporatization of public provision in sector networks and natural monopolies; corporate, including organizational and management, restructuring; financial restructuring and commercialization; PPP such as management of SOEs to transition toward contract-based private provision of important types of infrastructure services; and privatization to transition toward regulated private provision in selected sectors. The reforms implemented by SOEs reflect the nature of the infrastructure service taking into account the technological advances, their country's recent economic performance, and their level of institutional development (ADB n.d.).

\subsection{Types of State-Owned Enterprise Reforms}

Corporatization attempts to explicitly separate political considerations from economic considerations. Although the separation will not be total, the longterm economic and social objectives of the SOE are more likely to be achieved 
by instituting procedures that can help improve governance within the operating entity and strengthen accountability and transparency. Corporatization serves as the basis for commercialization.

Corporate restructuring is the act of reorganizing the legal, ownership, operational, or other structures of an entity to make it more profitable or better organized for its present needs. Corporate restructuring includes restructuring the organization and management with the aim of improving the entity's corporate governance through competitive recruitment, rationalization of staff compensation, and appointment of an independent board of directors to reduce political influence in the management.

Commercialization attempts to reorganize the SOE into a profit making commercial venture without financial support from the government (Zayyad n.d.). It is accompanied by financial restructuring to help improve the SOE's financial viability. Commercialization includes gradually withdrawing implicit guarantees or support from government, restructuring debts and/or assets, converting government loans into equity and writing off government loans (including accumulated interest), liquidating unviable SOEs, and reforming tariff to improve the SOE's financial viability.

Public-private partnership can be defined as a long-term contract between a private party and a government entity for providing a public asset or service, in which the private party bears significant risk and management responsibility and remuneration is linked to performance. PPPs can take many forms. The basics of an effective and strong PPP usually include (1) an agreement that allocates the tasks, obligations, and risks among the public and private partners in an optimal way; (2) a partnership structure that is designed to allocate risks to the partners that are best able to manage the risks and thus minimize costs while improving performance; and (3) an agreement that recognizes that the public and the private sectors each have advantages in performing specific tasks.

One form of PPP is outsourcing and contracting, where government retains ownership of the enterprise but contracts out some of the services, such as construction of infrastructure, management of operations, or provision of services. In Indonesia, this form of PPP was employed to provide transport services to economically lagging and geographically remote regions and enable Indonesians to have access to essential services (Box 6.5). 


\section{Box 6.5: Pioneer Service in the Transport Sector-Indonesia}

The Indonesian Constitution obligates the government to ensure that all Indonesians, regardless of their income level or location, have access to essential services. To help achieve the objective of regional economic development, a "pioneer services" scheme was implemented for providing infrastructure services. Pioneer services are provided in various transport modes (land, sea, and air) to promote the development of economically lagging and geographically remote regions and to develop national unity and stability. Private service providers are engaged on annual contracts through a bidding process. Tariffs for the services are set by the government, which compensates the service providers for the difference between the tariff and the cost of operations and maintenance plus pre-agreed profit margins.

One major pioneer service is the provision of shipping by private services that operate 56 routes and 30 ports throughout the country. Many of the routes serve intraprovincial shipping, with the time per round-trip voyage ranging from 10 to 27 days and the frequency ranging from 14 to 36 voyages per year. The average passenger load factor is low but the continuity of such services is essential.

Following implementation of the pioneer service scheme, a number of issues the providers faced have been identified. At the policy level, these include lack of clarity and consistency in applying the subsidy policy, decision making processes that are not transparent and prone to political influence, limited information available on market potential and target groups, the promotion of monopolistic behavior by current processes, and limited budget available to meet the increasing subsidy required to improve the quality of services. At the implementation level, pioneer services suffer from a lack of clear targets for the level and quality of service they should deliver, short-term service contracts that promote targeting of short-term goals and returns, payment delays, and difficulty in estimating the annual outlay for subsidies.

The Government of Indonesia has drawn up a comprehensive plan to overcome the issues to ensure more efficient and effective achievement of intended outcomes of providing the pioneer services. At the policy level, the scheme will promote fair competition among the service providers, with the gradual phasing out of direct contracting. Selection will be through an open bidding process with value for money as a key guiding principle. The contractual agreements will be based on an agreed level and quality of service, and will span multiple years to attract more private sector participation in the service provision. At the implementation level, the strategy will be agreed by relevant ministries (Bappenas, the Ministry of Transport, the Coordinating Ministry of Economic Affairs, and the Ministry of Finance) taking into account accountability and transparency in accordance with existing laws and regulations.

The initial step is for regional governments to prepare an "outline business case," which indicates (1) compliance of the proposal with the government definition of a pioneer service, (2) target beneficiaries, (3) economic benefits from the pioneer service, and (4) a budget strategy that clearly outlines the size of the subsidy. In step two, the regional government submits its outline business case to the Ministry of Transport for inclusion in the national planning process. Third, the Ministry of Transport prepares the final business case, including the proposed bidding and contracting arrangements as appropriate and the service delivery contract with performance measures indicated. This is submitted to Bappenas for conformity with the national planning process decision; to the Ministry of Finance to confirm if there is enough fiscal space for the required subsidy; and to the Ministry of State Owned Enterprises to confirm if the assigned state-owned enterprise can deliver the service without compromising is financial viability. Step four is the actual implementation during which Bappenas monitors the physical and financial performance of the pioneer services system based on established benchmarks, the Ministry of Finance allocates budget in accordance with Indonesia's law on financial management, and the Ministry of Transport manages and monitors the implementation of the pioneer services through annual performance reviews.

Source: Australian Agency for International Development (2010). 
Privatization refers to the act of transferring ownership of specified property or business operations from a government organization to a privately owned entity, and the transition of ownership from a publicly traded or owned company to a privately owned one. Chang (2007) and Welch and Fremond (1998) noted the key conditions of a successful SOE privatization as follows: (1) the SOEs operate in a competitive environment where competition cannot be enhanced without privatization; (2) the domestic capital market is well developed; (3) government has adequate regulatory capacity; (4) domestic firms are available that can value and arrange the sale of the $\mathrm{SOE}$ at an adequate price; (5) privatization is tailored to the circumstances of the country and the enterprisethere is no "right" approach; (6) strong political support and leadership, which is vital, are present; (7) transactions are well-prepared and attractive to private investors; (8) transparency, fairness, and a level playing field, which are essential, are in place; (9) outside expertise is sought; and (10) related structural reforms keep pace with privatization.

Governments of fast-growing economies have recognized the importance of pursuing SOE reforms because their successful implementation can help improve resource allocation, instill confidence in the economy, enable other important reforms to be implemented, and (more importantly) unlock new drivers of growth. This is why the PRC has included SOE reform as one of its main strategies for rebalancing its economy. The PRC's 5-year plan encourages various forms of ownership and private sector participation in SOEs and highlights the need to restructure enterprises that have been considered as "zombies" and at the same time strengthen the SOEs to be able to deliver the services while serving the national interest. Box 6.6 presents the key principles of the PRC's reform strategy.

\subsection{Potential Reform Pathways}

The preceding sections discussed the importance of SOEs in terms of inclusive growth, set out key lessons from the historical narrative on public enterprise reforms, and described the economic and sociopolitical context that frames the current reform episode. The objective of this section is to set out the broad contours of potential SOE reform pathways in Sri Lanka. Specific discussions on workable modalities are provided in the four case studies in Appendix A6.

When conceptualizing and operationalizing SOE reforms in the present context, one must consider at least three significant pitfalls: ideology, political realities, and a one-size-fits-all approach. First, there is a danger of the current discourse assuming an ideological slant, potentially missing out on the crucial lessons from the past. 


\section{Box 6.6: Key Principles of the People's Republic of China's State-Owned Enterprise Reform Strategy}

The People's Republic of China's reform strategy for state-owned enterprises (SOEs) has four key elements.

Transform the role of the state from an operator to investor. The role is being transformed to allow for greater private sector participation in SOEs. This entails allowing for a spectrum of ownership structures, including cross-share holdings, public listing, etc.).

Classify SOEs into broad categories with specific ownership structures, reform plans, and assessment criteria. The categories identified include (1) commercial strategic SOEs, such as telecommunication and energy, where the state will remain the major shareholder and the SOE will be tasked to support the country's national strategies such as "going global" and "creating champions"; (2) commercial nonstrategic SOEs that will compete directly with the market; and (3) SOEs with social obligations to improve the provision of public services.

Institutionalize the leadership role of the communist party by selecting a party member to serve as chairman of the board of the SOE.

Restructure or expedite the closure of nonviable SOEs, including their subsidiaries and local SOEs, to cut aggregate losses.

Source: IMF (2016a).

Second, the present political dynamics (section 6.5) are not amenable to privatization. ${ }^{21}$ Moreover, as evidenced in the international literature ${ }^{22}$ and as clearly demonstrated in the cases of the Lanka Marine Services and Sri Lanka Insurance Corporation privatizations, divestiture is not a panacea for the ills of underperforming SOEs. If the objective of privatization is to protect SOEs from political capture, there is no guarantee against the misuse of public benefits for private gain by crony capitalists when strong institutional and regulatory structures are not in place. Given this political context, policy makers must explore other means short of divestiture, at least for the strategic enterprises, to improve efficiency, reduce the fiscal burden, and ensure that distributional objectives are met. Additionally, the choice of reform modalities will hinge on the nature of institutional and regulatory arrangements.

Third, the unique circumstances that characterize individual SOEs require a case-by-case approach to the reform process. For example, Gunaruwan (2016) notes there are three types of public enterprises in Sri Lanka: departments (with inflexible rules and regulations, no space for risk taking, inadequate authority to

21 The follies of privatization in the Russian Federation and Latin America, for example, without sufficiently taking the sociopolitical context into consideration, are well documented (e.g., Birdsall and Nellis [2002]).

22

For example, Hodgson and Jiang (2007) and Rose-Ackermann (1999). 
meet responsibilities, and political interference); companies (with heavy political interference and lack of accountability); and body corporates such as authorities, boards, and corporations (with the negative features of both of the other types). The case studies in the appendix provide examples.

Two potential points of convergence with respect to reform modalities are management and accountability-oriented reforms and PPPs. There is no conclusive evidence from around the world that ownership change is a necessary or sufficient remedy for underperforming SOEs. ${ }^{23}$ Instead, examples of public enterprise reforms globally show that what matters for enhanced performance is the structuring of incentives in line with principal-agent dynamics. In the case of SOEs, the principal is by definition the public and the agent is the management of the enterprise, with politicians adding another layer to agency dynamics. Therefore, the challenge lies in institutionalizing incentives that firm up the line of accountability between the public and the management and in locating workable solutions that can do this on a sustainable basis.

According to the KPIs-and as further illustrated in the appendixpublic enterprises have significant management and accountability problems: lack of flexibility to hire and set wages, absence of corporate plans, absence of accountability mechanisms, and complex governance structures with no clear lines of accountability. PPPs, which are being actively explored by the present government, are likely to be viewed by the public with less suspicion than an outright sale of assets in the public mind. ${ }^{24}$ However, as documented in an audience survey (CCC 2016), while $85 \%$ of the participants endorsed PPPs as a viable modality for infrastructure projects, only $44 \%$ believed that Sri Lanka has the expertise to structure these complex deals, reiterating the point that institutional capacity is key to sustainable reforms and positive outcomes.

Experience with successive episodes of SOE reform demonstrates that certain key principles need to be in place if the process is to be sustainable with positive outcomes for inclusive growth. These principles, which are associated with the principal-agent and management dynamic, include governance aspects such as information, visibility, answerability, ${ }^{25}$ and

Consider for example, the failed privatization experiment of the British railways.

As set out in Knight-John (2009), while a survey in 2002 found that more than $80 \%$ of respondents viewed privatization as having a negative impact on poverty and living standards, even this group perceived PPPs as a feasible option for SOE reforms. For example, the KPIs with representatives of the Janatha Vimukthi Peramuna indicated that competition and PPP models could be introduced in nonstrategic entities such as dairy farming, with small-scale cooperative businesses being encouraged at the village level for sectors such as handicrafts and jewelry.

These aspects are also likely to improve with Sri Lanka's new Right to Information Act. 
internal operational (efficiency) aspects such as performance incentives and competition. ${ }^{26}$ Two reform options that work on these principles and that are likely to have considerable potential in Sri Lanka are performance contracts and the government holding company models. As mentioned earlier, Sri Lanka is currently in the process of establishing a government holding company that is a hybrid of Singapore's Temasek and Malaysia's Khazanah structures.

The essence of performance contracts is to institutionalize effective incentive structures and processes that reward managers and employees for improvements in efficiency, productivity, and consumer service. This approach is particularly useful when ownership change is not a workable option. Performance contracts may also be implemented as an incremental step in the process of eventual privatization. Performance contracts can be operationalized at all levels of public sector management, including for board members, directors, senior executives, and rank-and-file workers.

A typical performance contract sets out clear, transparent, and measurable targets and indicators, with a focus on three key areas: performance evaluation, performance information, and performance incentives. Performance evaluation deals with issues such as the selection of entities responsible for designing, implementing, monitoring, and evaluating a contract and the technical procedure pertaining to evaluation. Performance information focuses on providing timely and relevant information to the management and to rank-and-file workers on the chosen performance criteria. Performance incentives link the performance of the stakeholders to rewards and penalties, based on the outcome of the evaluation exercise. These incentives are designed to create and foster a competitive dynamic within the SOE-by providing, for example, additional compensation to managers who achieve a specific financial target or bonuses to workers who achieve a production output or service level or by institutionalizing profit sharing mechanisms (Knight-John 1997).

Although the performance contract modality has immense potential in the Sri Lankan context, it has not been sufficiently explored by policy makers, except for a few isolated experiments such as the Ceylon Leather Products Corporation and the Sri Lanka Tyre Corporation during the "first wave of privatization." Decision makers could conduct a more detailed review of this modality and its associated advantages and limitations in the current sociopolitical and economic context.

26 The beneficial impacts of competition are discussed in sections 6.3 and 6.4. 
An SOE management reform option that has gained significant traction internationally as well as in Sri Lanka's current public discourse is the Temasek model. Temasek is a state-owned holding company that owns and manages state assets in a wide range of sectors on behalf of the Singapore government. Temasek also takes investment decisions on behalf of the government, including on listing, divestment, and acquisition of shares. SOEs that function under Temasek make commercial decisions like private business entities and do not provide services below cost.

To implement the Temasek model requires certain political economy conditions such as a strong regulatory governance framework, accountability processes that are not muddied by political patronage, and access to an adequate pool of technocrats and professional civil servants. Without these essential prerequisites, adopting the Temasek model may not lead to improvements in management accountability and may, in fact, only add another layer of bureaucracy.

Nevertheless, some elements of the Temasek approach-specifically, listing shares of commercial SOEs on the stock exchange and institutionalizing performance contracts-could be considered in the Sri Lankan context. Listing even a modest percentage of SOE shares on the Colombo Stock Exchange could instill management discipline and make board members and senior executives accountable to shareholders. For the listing of shares to bring about effective improvements in management, however, regulatory institutions such as the Securities and Exchange Commission need to be robust. The 2017 Budget Speech (Paragraph 203) sets out the listing of non-strategic enterprises such as Grand Oriental Hotel, Hambanthota Salt, Hilton, Hyatt, Manthai Salt, Waters Edge, and West Coast during 2017.27

The precise structure and scope of Sri Lanka's version of this Temasek-the $\mathrm{PEB}$ - has not been made public. However, the KPIs provided some details. The legislation governing the PEB is currently at the Attorney General's department and is expected to be enacted in 2017. The PEB membership will likely be appointed by the Constitutional Council (Dissanayake 2017).

First, a key PEB objective is to address issues pertaining to the complex governance structure within which SOEs are currently embedded. As set out in sections 6.2 and 6.5, SOEs are governed by numerous organizations. The envisaged institutional strategy is to introduce the PEB as a central point of

27 In addition, this commitment is included as a policy action in the second tranche of ADB's Capital Market Development Program loan to Sri Lanka. 
contact to enhance operational efficiency and reduce political interference. Given this arrangement, the PEB will also have the following responsibilities for commercial SOEs: appointing board members and senior management; monitoring performance, including using key performance indicators to measure social and commercial returns; and restructuring the processes.

Second, the PEB's mission is to create wealth for the country rather than to draw resources from the public. As such, the following areas are high priority: securing public buy-in for restructuring, professionalizing boards and management to drive performance, rationalizing portfolio to maximize returns, transforming the organizational culture to be productive and competitive, and leveraging assets to enhance the entity's growth.

Third, the proposed strategy for SOE reforms under this approach is to be carried out in three stages: (1) make SOE operations profitable with positive cash flows (e.g., set performance incentives, professionalize boards and managements, and incorporate good governance practices); (2) make the SOEs comparable to the Sri Lankan private sector (e.g., restructure balance sheets, tie remuneration to performance, issue dividends, make an initial $15 \%$ public offering on the Colombo Stock Exchange); and (3) set examples for commercial enterprises in Sri Lanka (e.g., a strong balance sheet for sustained growth, have a return on investments, benchmark global players, and make a second float on the Colombo Stock Exchange). Based on performance indicators, private sector-level wages could be offered.

Fourth, the PEB is to be funded by a management fee of approximately $1 \%$ of the profits of SOEs. The feasibility of using the dividends of the restructured enterprises to reform other entities is to be discussed. As evidenced in the international literature and in Sri Lanka's regulatory governance context, such mechanisms are crucial to "ring fence" institutions from political interference (e.g., Knight-John 2004a).

The foregoing narrative indicates the PEB model's potential for SOE reforms. However, it is too early to estimate the extent of operational flexibility that the PEB will actually have. Predictability in implementation and the right people for the right jobs are key for the effective functioning of this organization. Given Sri Lanka's experience with public enterprise reforms (section 6.4), whether issues of institutional capacity and political indiscretion are handled better this time remains to be seen.

The management contract modality is also useful for addressing issues pertaining to SOE management inadequacies and is a form of PPP. Empirical 
evidence from around the world indicates that this modality is effective at infusing competition and improving productivity and the quality of service in situations where divestiture is not feasible. Similar to performance contracts, this modality can also be used as a step toward eventual privatization. In the plantation sector (Case Study 1, Appendix A6), 5-year management contracts were used as an interim step toward privatizing the estates. However, the short terms of the contracts proved to be a disincentive to long-term investment, and the government divested $51 \%$ of the shares of these enterprises in 1995 .

Sri Lanka's experience with management contracts points to some crucial ingredients that need to be in place to produce efficient and socially beneficial outcomes (Knight-John 2004b).

- First, management contracts must be drafted transparently, with all stakeholders able to access the content of the contracts.

- Second, management companies must be selected on a competitive basis using open bidding procedures.

- Third, the basis and calculation of management fees must be clearly set out in the contract.

- Fourth, conditions such as investment requirements and environmental and social obligations must be specifically delineated in the contract.

- Fifth, exit and termination clauses should be clearly laid out.

- Sixth, service standards and default triggers should be clearly defined.

- Finally, private management partners must have sufficient autonomy to respond to market forces and take decisions in line with principles of competition.

Sri Lanka has an opportunity to undertake meaningful reform of public enterprises. There are, as always, significant sociopolitical, institutional, and technocratic challenges. However, giving due consideration to international good practice and to Sri Lanka's own experience with reforms can contribute to sensible policy conversations.

As highlighted throughout this study, the SOE reform process must unpack and work around underpinning sociopolitical and economic realities. Policy makers must strategically work with the winners and losers of reforms to get to outcomes that are sustainable in terms of inclusive growth. Given that details of debt and losses in public enterprises have been in the limelight during the last 2 years more than ever before, there is political space for reform. However, because of the deep sociopolitical suspicion of privatization, reforms such as the sale of assets and retrenchment are unlikely to be feasible for strategic enterprises, even in the medium term. 
A crucial element in all of this is to mobilize public opinion through effective communication strategies, an area that the present government could ramp up. Facilitating an informed public dialogue is critical for greater stakeholder buy-in-communicating, for example, that the key objective of the reform process is to enhance the public benefit rather than narrow private or political interests. Therefore, a political economy strategy is needed that has the capacity to address opposition to SOE reforms in a rational, transparent, and systematic manner. Dramatic reform is unlikely and expectations need to be managed, but incremental progress is certainly achievable. 


\section{Appendix A6: Four Case Studies of State-Owned Business Enterprises}

\section{Case Study 1: State Plantation Sector \\ Elkaduwa Plantations Limited (EPL), Janatha Estates Development Board (JEDB), and Sri Lanka State Plantations Corporation (SLSPC)}

\section{Background and Context}

1. The plantations are primarily engaged in tea, rubber, and coconut production. The 3 state-owned plantations (EPL, JEDB, and SLSPC) only engage in tea and rubber production.

2. Although the sector has a large community, its labor accounts only for 2.3\% of Sri Lanka's total employment and its resident population is $4.4 \%$ of the total.

3. State plantations only account for a small share of the production of tea and rubber crops.

4. Labor unions are established and influential due to support from political parties such as the People's Liberation Front.

\section{Current Challenges}

A. Operational Inefficiencies

1. Low productivity

- JEDB and SLSPC have the lowest yield per hectare of tea estates.

- Yields per hectare in rubber are below the average of the 23 regional plantation companies.

- Land utilization is below $60 \%$ and is compounded by issues such as squatting.

2. EPL, JEDB, and SLSPC incurred huge loses, ranging from SLRs21/kilogram (kg) to SLRs142/kg of tea and SLRs50/ $\mathrm{kg}$ to SLRs166/kg of rubber in 2014. High cost of production and low profitability were exacerbated by the low productivity.

3. Labor issues contributed to the poor productivity resulting in poor financial performance in the last 5 years. Operational losses for the three entities combined during that period averaged SLRs435 million in 2015 prices.

\section{Reforms Undertaken}

1972-First wave

of plantation nationalization: private landownership capped at 50 acres (about 20 hectares); state acquired land in excess of that ceiling.

1975-government acquired plantation companies.

1976-1977-Majority of plantation lands vested under JEDB and SLSPC.

1992-Regional plantation companies formed from JEDB and SLSPC lands, and put under private management contracts.

\section{3-EPL formed} as the 23rd regional plantation company under a private management contract.

1995-1997-

Privatization of regional plantation companies started. Estate workers offered a $10 \%$ stake in the plantations; state retained the remaining "Golden Share," with power over the regional plantation companies' critical decisions.
Further Reform Options

1. Institutionalize worker retention policies, to include: providing labor and unions voice in the management decision making process, addressing health and dignity concerns of workers, and encouraging dialogue and transparency during management-labor discussions.

2. Introduce flexible labor cost structures to facilitate labor mobility from labor excess to labor shortage plantations.

3. Consider employing performance contracts, i.e., productivity-based, revenue sharing, out-grower model, or a mixed model, to incentivize workers and help increase productivity. 


\begin{tabular}{|c|c|c|c|}
\hline $\begin{array}{l}\text { Background } \\
\text { and Context }\end{array}$ & $\begin{array}{c}\text { Current } \\
\text { Challenges }\end{array}$ & $\begin{array}{c}\text { Reforms } \\
\text { Undertaken }\end{array}$ & $\begin{array}{c}\text { Further Reform } \\
\text { Options }\end{array}$ \\
\hline & $\begin{array}{l}\text { B. Persistent Fiscal } \\
\text { Burden } \\
\text { 1. Government has } \\
\text { been providing annual } \\
\text { subsidies to state } \\
\text { plantations of about } \\
\text { SLRs1.5 billion for their } \\
\text { continued operation. } \\
\text { 2. State plantations have } \\
\text { incurred arrears of } \\
\text { about SLRs3 billion on } \\
\text { their statutory dues. } \\
\text { C. Distributional Impacts } \\
\text { 1. People living in the } \\
\text { plantation communities } \\
\text { have the countries' } \\
\text { lowest human } \\
\text { development indicators } \\
\text { (least access to safe } \\
\text { drinking water, highest } \\
\text { poverty incidence, high } \\
\text { child under-nutrition } \\
\text { rates, and low access to } \\
\text { medical services). } \\
\text { 2. Access to opportunities } \\
\text { is affected by social } \\
\text { stigma associated with } \\
\text { being a plantation } \\
\text { worker and of Indian } \\
\text { Tamil ethnicity. } \\
\text { 3. Wage rates provided } \\
\text { to plantation workers } \\
\text { are below market } \\
\text { values and close to the } \\
\text { poverty line. }\end{array}$ & & $\begin{array}{l}\text { 4. Implement } \\
\text { management reforms, } \\
\text { such as allowing } \\
\text { unions to assume } \\
\text { management roles } \\
\text { and women to take } \\
\text { leadership roles to } \\
\text { address labor issues. } \\
\text { Allow longer-term } \\
\text { management } \\
\text { contracts and } \\
\text { tie them to } \\
\text { performance to help } \\
\text { improve plantation } \\
\text { productivity. } \\
\text { 5. Explore alternative } \\
\text { land utilization } \\
\text { options, such as dairy } \\
\text { farms, water bottling, } \\
\text { ecotourism, and mini } \\
\text { hydro power projects. } \\
\text { 6. Promote public- } \\
\text { private partnership }\end{array}$ \\
\hline
\end{tabular}

Source: Authors. 


\section{Case Study 2: Electricity Sector} Ceylon Electricity Board (CEB)

\section{Background and Context}

\section{Current Challenges}

\section{Reforms Undertaken}

1983-Lanka Electricity Company established to take over the distribution function from CEB in selected areas.

\section{7-Private sector} participation initiated in electricity generation and first independent power producer commissioned.

\section{2-Sri Lanka}

Electricity Act and Public Utilities Commission Act enacted. CEB internally unbundled into generation, transmission, and four distribution units, though no legal or financial separation occurred.

\section{9-Sri Lanka} Electricity Act enacted and CEB partially unbundled through PUCSL licensing requirement.

\section{0-CEB and other} operators required to obtain licenses from PUCSL. New tariff methodology approved, tariff filing conducted, and first public hearing regarding tariff adjustment held.

2013-Sri Lanka Electricity Act No. 31 amended and second public hearing on tariff held.
Further Reform Options

1. Pursue partial or complete unbundling, i.e., financial separation and independent reporting of all licensees under CEB.

2. Implement performance contracting through a results-based performance monitoring system to help increase efficiency and transparency within CEB.

3. Consider private sector participation through management contracting, marketization, and publicprivate partnerships to achieve sufficient and affordable supply of electricity without substantial subsidies from government. address effici

2. Poor management, system, and technical planning have threatened CEB's ability to provide a sufficient and reliable supply of electivity and resulted in total system failure in the past.

3. Electricity tariff is set to be affordable without due consideration for the cost of generation. 
Case Study 3: Ports Sector

Sri Lanka Ports Authority (SLPA)

\section{Background and Context}

1. $99 \%$ of Sri Lanka's trade is carried out via its ports.

2. Sea freight is the country's thirdlargest service export.

3. SLPA established in 1979 under the Sri Lanka Ports Authority Act No. 51 to function as owner, operator, and regulator of marine and cargo handling services at all ports.

4. SLPA has commercial ports operating in 7 locations including the Port of Colombo, one of the largest and busiest ports in South Asia.

5. SLPA owns $15 \%$ of South Asia Gateway Terminals, a private operator in the Port of Colombo.
Current Challenges

A. Operational Inefficiencies

1. SLPA is the least competitive port terminal operator and is losing market share to its competitors and the private sector due to antiquated container terminals and equipment, slow turn-around time, and berths that cannot accommodate mega ships.

2. SLPA's low capacity utilization and high nonoperational costs threaten the entity's financial sustainability. In 2015, SLPA incurred losses of SLRs9,575 million due to high administrative expenses, finance costs, and interest on foreign loans.

3. Competing interests (SLPA acting as regulator and operator), governance issues, and weak institutional capacity have undermined management and operational efficiency.

\section{B. Fiscal Burden}

\section{SLPA's financial} obligations are estimated at SLRs 240 billion or approximately $2.2 \%$ of gross domestic product.

2. SLPA's total liabilities increased due to the implementation of development projects. In 2015, SLPA's liabilities amounted to about $69 \%$ of its total assets.

\section{Reforms Undertaken}

1958-Port Cargo Corporation Act enacted, leading to establishment of the Port Cargo Corporation and nationalization of cargo handling services at the Port of Colombo.

\section{7-Port Tally and}

Protective Services

Corporation formed to perform on-board tallying and watchman services for agents.

1979-SLPA set up under an Act of Parliament, incorporating three entities aimed at creating a unified and autonomous entity under a single line of management control.

1980s-Modernization of the Port of Colombo.

1999-First private terminal operator entered the sector under a build-operate-transfer agreement.

2004-SLPA brought under the purview of the Strategic Enterprise Management Agency to improve the performance of ports.

2000-2013-Large scale port development projects and port modernization initiatives planned, i.e., Colombo Port expansion and Hambantota Port development.

2013-Entry of the second private sector operator in the Port of Colombo.

\section{Further Reform} Options

1. Implement management reforms such as institutionalizing merit-based management, recruitment systems, and performance contracting, and building of effective communication and consultation between management and labor.

2. Pursue public-private partnerships (PPPs). First step is to establish a PPP unit to handle PPP initiatives.

3. Unbundle SLPA into smaller business units that are legally and financially independent (e.g., separate units for terminal management, bunkering, stevedoring, etc.) and run as selfdriven cost-profit centers. 
Case Study 3 continued

\begin{tabular}{|c|c|c|c|}
\hline $\begin{array}{l}\text { Background } \\
\text { and Context }\end{array}$ & $\begin{array}{c}\text { Current } \\
\text { Challenges }\end{array}$ & $\begin{array}{c}\text { Reforms } \\
\text { Undertaken }\end{array}$ & $\begin{array}{c}\text { Further Reform } \\
\text { Options }\end{array}$ \\
\hline & $\begin{array}{l}\text { 3. SLPA's outstanding } \\
\text { debt is projected to } \\
\text { increase by } 141 \% \text { during } \\
2015-2018 \text {. } \\
\text { SLPA has not remitted } \\
\text { to the government any } \\
\text { dividends or levies, even } \\
\text { during SLPA's profitable } \\
\text { years (2011-2014). } \\
\text { C. Distributional Impact } \\
\text { 1. SLPA's workforce uses } \\
\text { a significant share of its } \\
\text { administrative costs, } \\
\text { which are mostly based } \\
\text { in Colombo. } \\
\text { 2. SLPA's ports are } \\
\text { overstaffed given low } \\
\text { utilization of port } \\
\text { services. }\end{array}$ & & $\begin{array}{l}\text { 4. Consider } \\
\text { diversifying } \\
\text { business } \\
\text { operations } \\
\text { beyond the Port } \\
\text { of Colombo to } \\
\text { realize full benefits } \\
\text { of SLPA's strategic } \\
\text { maritime location. } \\
\text { Logical extensions } \\
\text { are Galle (major } \\
\text { leisure and } \\
\text { marine tourism } \\
\text { destination), } \\
\text { Oluvil (center } \\
\text { for commercial } \\
\text { fisheries), and } \\
\text { Trincomalee (the } \\
\text { major shipping and } \\
\text { export hub). }\end{array}$ \\
\hline
\end{tabular}

Source: Authors.

\section{Case Study 4: Transport Sector Sri Lanka Transport Board (SLTB)}

\begin{tabular}{|c|c|c|c|}
\hline $\begin{array}{l}\text { Background } \\
\text { and Context }\end{array}$ & $\begin{array}{c}\text { Current } \\
\text { Challenges }\end{array}$ & $\begin{array}{c}\text { Reforms } \\
\text { Undertaken }\end{array}$ & $\begin{array}{c}\text { Further Reform } \\
\text { Options }\end{array}$ \\
\hline $\begin{array}{l}\text { 1. Demand for } \\
\text { bus services } \\
\text { accounted for } 47 \% \\
\text { of total motorized } \\
\text { transport services } \\
\text { in } 2014 \text {, but there } \\
\text { has been a shift } \\
\text { from public to } \\
\text { private modes of } \\
\text { travel. } \\
\text { 2. Only } 7 \% \text { of public } \\
\text { investments in the } \\
\text { transport sector } \\
\text { have gone to bus } \\
\text { transport. } \\
\text { 3. SLTB and private } \\
\text { operators provide } \\
\text { bus transport } \\
\text { services. }\end{array}$ & $\begin{array}{l}\text { 1. SLTB's average vehicle } \\
\text { utilization is below } \\
\text { the optimal level and } \\
\text { SLTB has a large idle, } \\
\text { unusable vehicle stock } \\
\text { of vehicles. } \\
\text { 2. The bus fleet } \\
\text { suffers from lack of } \\
\text { modernization, which } \\
\text { has affected quality } \\
\text { of service and led } \\
\text { passengers to shift to } \\
\text { private transport. } \\
\text { 3. Poor management } \\
\text { practices in recruitment } \\
\text { and allocation of human } \\
\text { resources resulted in } \\
\text { overstaffing. }\end{array}$ & $\begin{array}{l}\text { 1979-Liberalization } \\
\text { of bus transport; entry } \\
\text { of } 5,000 \text { private bus } \\
\text { operators. } \\
\text { 1991-National Transport } \\
\text { Commission established } \\
\text { to regulate interprovincial } \\
\text { private sector bus services } \\
\text { while provincial authorities } \\
\text { regulated intraprovincial } \\
\text { private bus operations. } \\
\text { The Commission is } \\
\text { criticized as being } \\
\text { ineffective. } \\
2002-\text { Coherent bus fares } \\
\text { introduced. }\end{array}$ & $\begin{array}{l}\text { 1. Create an } \\
\text { independent } \\
\text { regulator to } \\
\text { shield the sector } \\
\text { from political } \\
\text { interference } \\
\text { and improve the } \\
\text { sector's efficiency. } \\
\text { 2. Implement } \\
\text { organizational } \\
\text { and management } \\
\text { reforms to include } \\
\text { unbundling } \\
\text { SLTB operations; } \\
\text { reducing its } \\
\text { workforce; } \\
\text { implementing } \\
\text { an effective } \\
\text { incentives scheme } \\
\text { to address low } \\
\text { productivity; }\end{array}$ \\
\hline
\end{tabular}




\begin{tabular}{|l|l|l|l|}
\hline $\begin{array}{l}\text { Background } \\
\text { and Context }\end{array}$ & $\begin{array}{c}\text { Current } \\
\text { Challenges }\end{array}$ & $\begin{array}{c}\text { Reforms } \\
\text { Undertaken }\end{array}$ & $\begin{array}{c}\text { Further Reform } \\
\text { Options }\end{array}$ \\
\hline
\end{tabular}

4. SLTB is the single largest transport provider. It operates on approximately 1,500 routes island-wide, with 5,285 buses operating daily, covering 1.2 million kilometers.

5. SLTB has a social obligation to operate unprofitable routes.

6. SLTB is largely self-regulated.
4. Operating costs consistently exceeded operating revenues, resulting in losses.

B. Fiscal Burden

1. Costs for fulfilling SLTB's universal service obligation drastically increased in 20142015.

2. Government is obligated to subsidize SLTB operations to provide transport services on uneconomical or unprofitable routes.

3. Government at times had to provide interim support (salary and welfare adjustments) due to the time lag associated with recovery of universal service obligation costs from the Treasury.

\section{Distributional Impacts}

1. SLTB's large workforce is a result of political patronage.

2. Wage disputes, disproportionate wages among various job streams, and delayed wage payments have been sources of discontent.

3. An active labor union presence affiliated with major political parties at times increases tension in management-worker relations.

2004-Strategic Enterprise Management Agency established to oversee the (then) Sri Lanka Central Transport Board. The Agency played an advisory role and brought in sector expertise.

2005-Sri Lanka Central Transport Board reconstituted as SLTB.

(.)




\section{References}

Asia Foundation and Verite Research. 2015. Mobile Money in Sri Lanka: Key Lessons and Policy Insights. Colombo: Asia Foundation.

Asian Development Bank. n.d. Strengthening ADB's Engagement with StateOwned Enterprise. Unpublished.

Australian Agency for International Development (AusAID). 2010. Indonesia Infrastructure Initiative (financed by the AusAID). 2010. Public Service Obligation and Pioneer Service Policy in the Transport Sector. July. Jakarta. http://www.indii.co.id/publications-detail.php?id_news=128

Bandaranaike Kumaratunga, C. 1995. Policy Statement. Colombo: Government of Sri Lanka.

Birdsall, N., and J. Nellis. 2002. Winners and Losers: Assessing the Distributional Impact of Privatization. Working Paper No. 6. Washington DC: Center for Global Development.

Central Bank of Sri Lanka (CBSL). various years. Annual Report. Colombo: CBSL. Ceylon Chamber of Commerce (CCC). 2016. Sri Lanka Economic SummitInsights from Audience Survey. EIU, August 2016. Colombo: CCC.

Chang, Ha-Joon. 2007. State-Owned Enterprise Reform. National Development Strategies Policy Notes of the UN DESA. New York: United Nations. https:// esa.un.org/techcoop/documents/pn_soereformnote.pdf

Committee on Public Enterprises (COPE). 2016. First Report (For the Period from 26th of January 2016 to 08th of April 2016) from the Committee on Public Enterprises, Presented by Hon. Sunil Handunetti Chairman of the Committee, On 09 August 2016. Parliamentary Series No. 90 of the Eighth Parliament of the Democratic Socialist Republic of Sri Lanka (First Session). http://www.parliament.lk/uploads/comreports/1473324728009594. pdf\#page=1 (accessed 28 September 2016).

Department of Census and Statistics. 2014. Sri Lanka Labour Force Survey Annual Report - 2014. http://www.statistics.gov.lk/samplesurvey/LFS_Annual\%20 Report_2014.pdf (accessed 26 September 2016).

2015. Sri Lanka Labour Force Statistics Quarterly Bulletin: 4th Quarter 2015. http://www.statistics.gov.lk/samplesurvey/LFS_Q4_Bulletin_WEB_2015_ final.pdf (accessed 26 September 2016).

Department of Public Enterprises (DPE). 2015. Performance Report. Colombo: Ministry of Finance.

Dissanayake, C. 2017. New Public Enterprise Act in 1Q 2017. Daily FT. http://www. $\mathrm{ft} .1 \mathrm{k} /$ article/586132/ft (accessed 29 March 2017).

Dunham, D. 2004. Economic Liberalization and Institutional Reform. In Kelegama (ed.). Economic Policy in Sri Lanka: Issues and Debates. New Delhi: Sage, pp. 337-48. 
Dunham, D., and S. Kelegama. 1995. Economic Reform and Governance: The Second Wave of Liberalisation in Sri Lanka, 1989-93. Institute of Policy Studies, Research Studies, Governance Series No.2. Colombo: IPS

1997. A Second Look at the Sri Lankan Experience, 1977-93. Developing Economies. 35(2): 166-84.

Edirisuriya, P. 2007. Effects of Financial Sector Reforms in Sri Lanka: Evidence from the Banking Sector. Asia Pacific Journal of Finance and Banking Research. 1(1): 45-64.

Government Accountability Project (GAP). n.d.. Corrupt Privatization Does Not Deter IFI Lending to Sri Lanka. Washington DC: GAP https://www.whistleblower.org/sites/default/files/pictures/ CorruptPrivitizationDoesNotDeter.pdf (accessed 3 October, 2016).

Government of Sri Lanka. 2011. Revival of Underperforming Enterprises and Underutilized Assets Act No. 43 of 2011. Colombo: Government of Sri Lanka Gunaruwan, TL. 2016. Unsatisfactory Performance of Sri Lanka's State-Owned Enterprises: Causality Diagnostics in Management Autonomy and Accountability Mismatch. Proceedings of the Sri Lanka Economic Research Conference - 2016, University of Kelaniya, Sri Lanka, Dec 2016.

Hodgson, G., and S. Jiang. 2007. The Economics of Corruption and the Corruption of Economics. Journal of Economic Issues. 41 (4): 1043-61.

International Monetary Fund (IMF). 2016a. IMF Country Report No. 16/271. The People's Republic of China, Selected Issues. Washington D.C.: IMF. 2016b. Letter of Intent. Washington D.C.: IMF.

2016c. Staff Report for the 2016 Article IV Consultation and Request for a Three-Year Extended Arrangement under the Extended Fund Facility Press Release; Staff Report; Staff Statement, and Statement by the Executive Director for Sri Lanka. Washington D.C.: IMF

Jayasuriya, S., and M. Knight-John. 2002. Sri Lanka's Telecommunications Industry: From Privatization to Anti-Competition? Working Paper No. 14. Manchester: Centre on Regulation and Competition.

Kelegama, S. 1993. Privatization in Sri Lanka: The Experience During the Early Years of Implementation. Colombo: Sri Lanka Economic Association. 1997. Privatisation and the Public Exchequer. Asia Pacific Development Journal. 4(1): 14-25.

Knight-John, M. 1997. Performance Contracting: A Strategy for Public Enterprise Reform in Sri Lanka? Institute of Policy Studies, Research Studies, Public Enterprise Reform Series No. 2. Colombo: IPS. 2002. The Institutional Policy Framework for Regulation and Competition in Sri Lanka. Working Paper No. 40. Manchester: Centre on Regulation and Competition. 
2004a. Competition, Regulation and Regulatory Governance in Sri Lanka. In P. Cook, C. Kirkpatrick, M. Minogue, D. Parker (eds.). Leading Issues in Competition, Regulation and Development. Cheltenham: Edward Elgar. 2004b. Privatization and Regulation. In S. Kelegama (ed.). Economic Policy in Sri Lanka: Issues and Debates. New Delhi: Sage. 2009. Liberating the State Sector. LMD. August, 16. (1): 91.

Knight-John, M., and W. Athukorala. 2005. Assessing Privatization in Sri Lanka: Distribution and Governance. In J. Nellis and N. Birdsall (eds.). Reality Check: The Distributional Impact of Privatization in Developing Countries. Washington D.C.: Center for Global Development. p. 389-426.

Knight-John, M., and T. de Zoysa. 2001. World Bank Impact Study of Infrastructure Privatization in Sri Lanka. Colombo: SJ Associates.

Ministry of Finance (MOF). 2015a. Annual Report. Colombo: MOF. 2015b. Public Enterprises Circular No. PED 3/2015. Colombo: MOF. 2016a. Budget Speech - 2016. http://www.pmdnews.lk/wp-content/ uploads/2015/11/bgtspeech2016E.pdf (accessed 28 September 2016). 2016b. Mid-Year Fiscal Position Report. Colombo: MOF. various years. Annual Report. Colombo: MOF.

Ministry of Finance and Planning. 1988. Budget Speech. Colombo: Ministry of Finance and Planning.

Ministry of Petroleum Resources Development (MPRD). 2015. Progress Report-2015 and Action Plan-2016. Colombo: Ministry of Petroleum Resources Development.

Ministry of Plantation Industries (MPI). 2016. Statistical Information on Plantation Crops 2014. Colombo: MPI.

Ministry of Transport and Civil Aviation. n.d. Sri Lanka Transport Board. http:// www.transport.gov.lk/web/index.php?option=com_content\&view=article \&id=175\&Itemid=114\&lang=en (accessed 27 September 2016).

Moody's. 2016. Rating Action: Moody's Changes Outlook on Sri Lanka's Rating to Negative from Stable; Affirms Government Bond Rating at B1. https:// www.moodys.com/research/Moodys-changes-outlook-on-Sri-Lankasrating-to-negative-from--PR_348945 (accessed 30 September 2016).

Nanayakkara, V., K. Choksy, et al. 2008. SC FR Application No. 209/2007. Supreme Court of the Democratic Socialist Republic of Sri Lanka (2008).

SC FR Application No. 158/2007. 2009. Supreme Court of the Democratic Socialist Republic of Sri Lanka (2009).

News First. 2015a. United National Front for Good Governance Election Policy Manifesto. (http://newsfirst.lk/english/2015/07/united-national-frontfor-good-governance-election-policy-manifesto-unveiled/104831 (accessed 25 September 2016). 
2015b. UNP and SLFP reach a two-year agreement. http://newsfirst. lk/english/2015/08/unp-and-slfp-reach-a-two-year-agreement/107750 (accessed 25 September 2016).

News.lk. 2015. Economic Policy Statement made by Prime Minister, Ranil Wickremesinghe in Parliament on November 5, 2015. http://www.news.lk/ fetures/item/10674-economic-policy-statement-made-by-prime-ministerranil-wickremesinghe-in-parliament (accessed 25 September 2016).

Oxford Business Group. 2016. Kabir Hashim, Minister of Public Enterprise Development: Interview. https://www.oxfordbusinessgroup.com/ interview/key-changes-obg-talks-kabir-hashim-minister-publicenterprise-development (accessed 28 September 2016).

PricewaterhouseCoopers (PWC). 2015. State-Owned Enterprises: Catalysts for Public Value Creation? http://www.pwc.com/gx/en/psrc/publications/ assets/pwc-state-owned-enterprise-psrc.pdf (accessed 24 September 2016).

Researchgate.net https://www.researchgate.net/post/What_is_triangulation of_data_in_qualitative_research_Is_it_a_method_of_validating_the_ information_collected_through_various_methods

Rodinelli, D. 2005. Public Enterprises: Unresolved Challenges and New Opportunities. New York: United Nations Department of Economic and Social Affairs. https://publicadministration.un.org/publications/content/ PDFs/E-Library\%20Archives/2005\%20EGM\%20Public\%20Enterprises_ Unresolved\%20Challenges\%20and\%20New\%20Opportunities.pdf

Rose-Ackerman, S. 1999. Corruption and Government: Causes, Consequences and Reform. Cambridge: Cambridge University Press.

Salih, R. 2000. Privatization in Sri Lanka. In G. Joshi (ed.) Privatization in South Asia: Minimizing Negative Social Effects Through Restructuring: New Delhi: International Labour Organization.

Welch, D., and O. Fremond. 1998. The Case-by-Case Approach to Privatization. Washington D.C.: World Bank.

Wickremesinghe, R. 2002a. Regaining Sri Lanka: Part 1. Connecting to Growth: Sri Lanka's Poverty Reduction Strategy. http://www.erd.gov.lk/publicweb/ publications/regaining/Part\%20II\%20-\%20Regaining\%20Sri\%20 Lanka\%20-\%20Connecting\%20to\%20Growth\%20-\%20Text.pdf(accessed 3 October 2016).

(2002b). Regaining Sri Lanka: Part 1. Vision for Growth. http://www. erd.gov.lk/publicweb/publications/regaining/Part\%20I\%20\%20 Regaining\%20Sri\%20Lanka\%20-\%20Vision\%20For\%20Growth.pdf (accessed 3 October 2016). 
World Bank. 1988. Sri Lanka a Break with the Past: The 1987-90 Program of Economic Reforms and Adjustment. Confidential Report No. 7220-CE. Washington D.C.: World Bank.

2015. Sri Lanka-Ending Poverty and Promoting Shared Prosperity: A Systematic Country Diagnostic. Washington D.C.: World Bank.

Zayyad, H. n.d. Privatisation and Commercialisation in Nigeria. http://unpan1.un.org/intradoc/groups/public/documents/AAPAM/ UNPAN028228.pdf 


\section{Chapter 7.}

\section{Financing Sustainable}

Urbanization in Sri Lanka

Roy Kelly and Asoka S. Gunawardena

\subsection{Introduction}

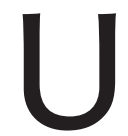
rbanization and cities are expected to play an important role in Sri Lanka's ongoing transition to an upper middle-income country. Theory and international experience have long recognized urban areas as important engines of economic growth, providing the benefits of urban agglomeration efficiencies, stimulating gains in productivity and competitiveness, providing markets for goods and services, and generating opportunities for knowledge creation, innovation, and specialization of production and services (World Bank 1999; Zhang 2011).

The central importance of cities in achieving sustainable development was recently reaffirmed by the international community (UN 2015). Sustainable Development Goal No. 11 states the need to "make cities inclusive, safe, resilient, and sustainable," with the focus on creating jobs and commerce, promoting social development and innovation, enabling people to advance socially and economically, and providing improved levels of urban and public services (typically, local transport, water, roads, security, libraries, etc.).

To facilitate the implementation of this Goal by 2030, the international community adopted the New Urban Agenda for sustainable urbanization at the Habitat III summit in Quito, Ecuador, in October 2016. Successful implementation of efficient, equitable, inclusive, and sustainable urbanization will require policies, institutions, and finance to enable the integration of urban planning, connectivity, and finance (Roberts and Kenaly 2006; World Bank 2012; Cities Alliance 2015; Kanuri et al. 2016; UN Habitat 2016b). 
Mobilizing financial resources is critical to ensure sustainable urbanization. While financing instruments are needed to raise the upfront costs to build urban infrastructure, the underlying funding instruments are critical to provide the stream of revenues needed to deliver current urban services and provide the funding leverage needed to mobilize upfront infrastructure financing while protecting environmental amenities (Slack 2009; Eichler et al. 2012; WEF 2014; Amirtahmasebi et al. 2016; Ardila-Gomez and Ortegon-Sanchez 2016; DuPuis and McFarland 2016; Kim 2016).

Mobilizing the resources requires a coordinated approach involving central and local governments, development partners, and the private sector. At the same time, countries must create an environment that enables effective planning, budgeting, and public investment management, and a coordinated central-local intergovernmental framework and partnership relationship between the government and the private sector.

In this regard, the central government must provide an intergovernmental fiscal environment that clarifies the roles and responsibilities of the central, provincial, and local governments regarding their assigned expenditure and revenue responsibilities, the system of intergovernmental transfers, and the subnational borrowing framework (Bahl 2008; Boex and Yilmaz 2010). This should be supported by a spatial-development planning environment that can integrate economic, social, and environmental outcomes, as well as encourage and regulate private sector participation in the funding and financing of urban infrastructure and urban service delivery (Bahl and Martinez-Vazquez 2006).

This multidimensional enabling environment should encourage inclusive, sustainable, better-planned, interconnected, and properly-financed urbanization, which can facilitate the economic growth and structural transformation needed to move Sri Lanka to an upper middle-income country, while spreading economic and social development throughout the country (GSL 2011).

Recognizing the important catalyzing role of urbanization for generating growth and development opportunities, Sri Lanka has launched the Western Region Megapolis Master Plan to transform the core western region into an urban megapolis by 2030 . The megapolis is expected to serve as the external economic hub that connects Sri Lanka to the world, and as the internal economic hub that can stimulate integrated spatial and economic development so as to promote efficient and balanced social and economic development while addressing important environmental concerns throughout Sri Lanka (GSL 2011; Ministry of Megapolis and Western Region Development 2016). 
These ambitious urbanization plans present a major challenge in planning, financing, and governance of economic agglomerations-city-region linkages that will be socially and environmentally sustainable. The Western Region Megapolis Project alone, for example, is estimated to cost over $\$ 40$ billion, roughly $50 \%$ of Sri Lanka's gross domestic product (GDP) in 2015 (World Bank 2016). To meet this challenge, Sri Lanka must mobilize significant capital financing for the initial urban infrastructure investment while simultaneously taking proactive steps to ensure a steady source of funding revenues to maintain and operate the investments and to ultimately repay their financing.

To date, Sri Lanka has relied on central government investment, often with the assistance of international financial institutions, to finance large-scale urban infrastructure. As these traditional approaches may not generate sufficient funds, the government is seeking to build long-term partnerships with the private sector, while recognizing the need to enable provincial and local authorities to play a stronger partnership role in urban development planning and service delivery.

This chapter focuses on the challenges and opportunities for financing and funding urbanization in Sri Lanka, looking specifically at issues of governance, institutions, and urban finance. Section 7.1 lays the background by discussing the Sri Lankan urban structure, institutions, roles, and responsibilities. Section 7.2 focuses on urban finance. Section 7.3 discusses urban funding and financing options. Section 7.4 focuses on the challenges and opportunities for urban finance in Sri Lanka, and section 7.5 concludes with a set of broad recommendations.

\subsection{Urbanization in Sri Lanka}

Sri Lanka's urbanization emerged in and around the Port of Colombo, built to service the modern plantation sector in the central hill country. Over time, the urban sprawl emanating from the City of Colombo concentrated economic activity in the Colombo Metropolitan Region (CMR). The CMR now dominates the urban scene in Sri Lanka, accounting for close to $50 \%$ of the urban population and nearly half of national GDP.

In addition to the dominant CMR, secondary urban centers are spread throughout Sri Lanka. They were established initially to deliver economic and social services to the rural areas and later developed into the regional-based capitals of territorial government administrations. Over time, these regional 
urban centers have shifted focus to trade, transport and communication, agroprocessing, agriculture, fishery, and tourism, while the CMR has shifted activity toward services (Indrasiri 2006; World Bank and UN Habitat 2012).

Sri Lanka's impressive economic growth largely concentrated in the urban core and led to a widening gap in social and economic integration across Sri Lanka. This development pattern generated perceptions of social injustice and regional inequality, and created conditions for conflict in the south and in the north, where it took the form of an armed war. This historic, political-economy background provides the context within which all growth and development policies, including those related to urbanization, must be designed and implemented to ensure inclusive, balanced, efficient, and equitable development.

\subsubsection{Urban Evolution, Form, and Structure}

Urbanization in Sri Lanka is largely a coastal phenomenon, with a significant urban population and commercial concentration in the CMR. The remaining urban population is spread throughout Sri Lanka in relatively small, low-density urban settlements immediately outside of the CMR, in the eastern and northern districts, and in the south and the central hill districts.

As Table 7.1 indicates, the urban population, defined as people living within the 23 municipal and 41 urban councils, has increased from $14.6 \%$ of total population in 2001 to $18.2 \%$ in 2012 . This level of urban population is very low in light of Sri Lanka's level on the Human Development Index. Countries with similar income per capita and long-term economic growth have urban population levels closer to $40 \%$ (Biller and Jabi 2013).

The CMR is geographically within the Western Province, covering approximately $6 \%$ of its land area, holding $28 \%$ of its population, and accounting for $45 \%$ of its GDP and $73 \%$ of its industrial value added. Eight cities with more than 100,000 people, including Colombo, account for nearly half of Sri Lanka's urban population. The rest of the urban population is spread throughout the remaining 56 municipal and urban councils. The Western Province alone, with 21 urban centers (7 municipal and 14 urban councils), accounts for $51 \%$ of Sri Lanka's total urban population (World Bank and UN Habitat 2012). 
Table 7.1: Urban Population by Districts, 2001 and 2012

\begin{tabular}{|c|c|c|c|c|c|c|}
\hline \multirow[b]{2}{*}{$\begin{array}{l}\text { Province } \\
\text { and District }\end{array}$} & \multicolumn{3}{|c|}{2001 Census } & \multicolumn{3}{|c|}{2012 Census } \\
\hline & $\begin{array}{l}\text { Total } \\
\left({ }^{\prime} 000\right)\end{array}$ & $\begin{array}{l}\text { Urban } \\
(' 000)\end{array}$ & $\%$ & $\begin{array}{l}\text { Total } \\
\left({ }^{\prime} 000\right)\end{array}$ & $\begin{array}{l}\text { Urban } \\
\left({ }^{\prime} 000\right)\end{array}$ & $\%$ \\
\hline \multicolumn{7}{|l|}{ Central Province } \\
\hline Kandy & $1,279.0$ & 156.0 & 12.2 & $1,375.4$ & 170.5 & 12.4 \\
\hline Matale & 441.3 & 36.1 & 8.2 & 484.5 & 60.3 & 12.4 \\
\hline Nuwara Eliya & 703.6 & 43.1 & 6.1 & 711.6 & 40.2 & 5.6 \\
\hline \multicolumn{7}{|l|}{ Eastern Province } \\
\hline Ampara & 593.0 & 112.5 & 19.0 & 649.4 & 153.3 & 23.6 \\
\hline Batticaloa & 486.4 & & & 526.6 & 151.2 & 28.7 \\
\hline Trincomalee & 340.2 & & & 379.5 & 85.1 & 22.4 \\
\hline \multicolumn{7}{|c|}{ North Central Province } \\
\hline Anuradhapura & 745.7 & 53.2 & 7.1 & 860.6 & 50.6 & 5.9 \\
\hline Polonnaruwa & 359.0 & & & 406.1 & & \\
\hline \multicolumn{7}{|c|}{ North Western Province } \\
\hline Kurunegala & $1,460.2$ & 34.7 & 2.4 & $1,618.5$ & 30.3 & 1.9 \\
\hline Puttalam & 709.7 & 65.3 & 9.2 & 762.4 & 67.0 & 8.8 \\
\hline \multicolumn{7}{|c|}{ Northern Province } \\
\hline Jaffna & 490.6 & & & 583.9 & 117.6 & 20.1 \\
\hline Kilinochchi & 127.3 & & & 113.5 & & \\
\hline Manner & 151.6 & & & 99.6 & 24.4 & 24.5 \\
\hline Mulativu & 121.7 & & & 92.2 & & \\
\hline Vavuniya & 149.8 & & & 172.1 & 34.8 & 20.2 \\
\hline \multicolumn{7}{|c|}{ Sabaragamuwa Province } \\
\hline Kegalle & 785.5 & 17.1 & 2.2 & 840.6 & 16.0 & 1.9 \\
\hline Ratnapura & $1,015.8$ & 58.2 & 5.7 & $1,088.0$ & 99.5 & 9.1 \\
\hline \multicolumn{7}{|c|}{ Southern Province } \\
\hline Galle & 990.5 & 109.9 & 11.1 & $1,063.3$ & 133.4 & 12.5 \\
\hline Hambantota & 526.4 & 21.6 & 4.1 & 599.9 & 31.7 & 5.3 \\
\hline Matara & 761.4 & 64.4 & 8.5 & 814 & 96.6 & 11.9 \\
\hline \multicolumn{7}{|l|}{ Uva Province } \\
\hline Badulla & 780.0 & 51.5 & 6.6 & 815.4 & 69.8 & 8.6 \\
\hline Monaragala & 397.4 & & & 451.1 & & \\
\hline \multicolumn{7}{|c|}{ Western Province } \\
\hline Colombo & $2,251.3$ & $1,229.6$ & 54.6 & $2,324.30$ & $1,802.9$ & 77.6 \\
\hline Gampaha & $2,063.7$ & 300.9 & 14.6 & $2,304.80$ & 360.2 & 15.6 \\
\hline Kalutara & $1,066.2$ & 113.2 & 10.6 & $1,221.90$ & 109.1 & 8.9 \\
\hline Total & $18,797.3$ & $2,467.3$ & 14.6 & $20,359.2$ & $3,704.5$ & 18.2 \\
\hline
\end{tabular}

Source: CBSL (2014). 
Sri Lanka's urbanization pattern is characterized by low-density sprawl and ribbon development, which results from regulatory and institutional constraints in land and housing markets and reflects responses to locationspecific issues related to land and housing costs, transport options, ecological situations, and inappropriate underpricing of urban services (World Bank and UN Habitat 2012). This pattern typically increases urban infrastructure and service delivery costs, congestion, and related environmental damage, while reducing the potential efficiency gains from agglomeration economies (Bird and Slack 2013; Howe 2005).

As noted earlier, the official urbanization rate is about $18 \%$, which is largely attributed to two major factors:

- First is the lack of rural-urban "push" migration due to government policies, which historically placed high priority on rural development, combined with resettlement of rural landless people in new agricultural settlement schemes (Kurukulasuriya 1979; Ellis and Roberts 2015).

- Second, the census policy defines only areas under municipal and urban council jurisdictions as containing urban population, implying that people living in the provincial councils (pradeshiya sabhas) are rural residents. Thus, in 1981, when Sri Lanka changed its local authority structure to absorb the extant town councils within the new district councils, the official share of urban population fell from $24.5 \%$ to $14.8 \%$-close to a $40 \%$ immediate reduction in the number of "urban" residents.

Urbanization studies have identified over 300 urban centers of various sizes with an estimated urban population of more than 9 million persons (Indrasiri 2006), suggesting an actual urbanization rate of over $40 \%$ and implying that sizable populations live in areas with urban characteristics and require urban services.

Following the end of the civil unrest, the government estimates the urbanization rate has been $3 \%-4 \%$ annually, meaning that about $60 \%$ of Sri Lanka will be living in urban centers by 2020 (World Bank and UN Habitat 2012). This increase in urbanization, if properly channeled and managed, could encourage urbanization agglomeration economies that can facilitate increased structural transformation and more efficient economic growth. 


\subsubsection{Institutional Roles and Functions for Urban Development}

Sri Lanka's government administration system dates back to British colonial rule and continues to operate in a very centralized manner. The central government largely operates through a system of deconcentrated (decentralized) central government offices spread across the territorial administrative districts and divisions, alongside a parallel system of rural and urban local authority governments. Over time, virtually all mainstream development services have been channeled through the deconcentrated territorial structures' units, bypassing the local authority government system.

This highly centralized state structure proved a challenge to addressing the economic, social, and political demands of the periphery in the north and the east. The growing social and political demands for greater sharing of government power and authority led to the passage of the Constitution's 13th Amendment (1987), which introduced a provincial tier of devolved government within the unitary and centralized state structure alongside the system of local authority. The 13th Amendment assigned subjects and functions between the center and the provinces, but with policies and programs continuing to be largely generic across all subjects and functions, and with every sector given deconcentrated and devolved delivery channels; this undermines the role of the province in service delivery. Thus, Sri Lanka, in effect, continues to operate in a highly centralized manner with the central government maintaining control over all policies and virtually all planning, financing, and project implementation (Gunawardena 2016).

Constitutionally, under the 13th Amendment, policy is reserved as a centrallevel function, determined by the Cabinet of Ministers. All development policies and plans continue to be approved by the Cabinet of Ministers. The responsibility for planning rests with central-level ministries and agencies. Overall, the result has separated sectoral planning, which is the responsibility of the Ministry for National Policy and Economic Affairs, through its National Planning Department, from spatial planning, which is under the National Physical Planning Department, and physical planning of "declared areas," which is under the Urban Development Authority. Both the National Physical Planning Department and the Urban Development Authority operate under the current Ministry of Megapolis and Western Development.

This fragmentation poses major challenges to the coherence of urban development, creating major obstacles to the coordinated planning, connectivity, and financing needed for efficient and sustainable urban development (Van Horen 
and Pennawala 2006; World Bank 2004, 2006; World Bank and UN Habitat 2012). Lack of coherence between sectoral and spatial planning is exacerbated by the planning roles and responsibilities at provincial and local levels.

At the provincial level, planning is limited to the allocation of spending on projects identified by the provincial sectoral departments-thus, provinciallevel plans are essentially annual implementation plans. Provincial planning does not extend to spatial planning. Local authority planning, on the other hand, is even more limited, only used as it relates to making budget estimates. However, local authorities do have powers to approve building plans. This implicitly takes into account notions of physical planning, which are prepared by the Urban Development Authority for areas declared as "development areas."

Table 7.2 reflects the dominant role of the central government. The clear majority $(87.3 \%)$ of public expenditures is channeled through the central government, with provincial governments accounting for $10.5 \%$ and the local rural and urban governments accounting for only $2.1 \%$ of all expenditures.

Table 7.2: Central, Provincial, and Local Authority Revenue and Expenditure, 2014 (SLRs million and \%)

\begin{tabular}{l|c|c|c|c|c|c} 
& Central & $\%$ & Provincial & $\%$ & Local & $\%$ \\
\hline Revenues & $1,195,206$ & 94.2 & 59,133 & 4.7 & 14,988 & 1.2 \\
\hline Expenditures & $1,795,865$ & 87.3 & 216,824 & 10.5 & 43,278 & 2.1 \\
\hline
\end{tabular}

Source: Ministry of Provincial Councils and Local Government (2014); CBSL (2015).

In addition to being highly centralized, the policy and administrative framework for urban service delivery in Sri Lanka is notable for its lack of partnership with the private and nongovernment sectors. Private participation and partnership remains confined at best to consultation, but the literature shows increasing recognition of the need to broaden this partnership approach, especially as Sri Lanka faces major challenges in mobilizing financial resources to fund its urban infrastructure requirements (ADB 2011; Biller and Jabi 2013; World Bank and UN Habitat 2012).

Since Sri Lanka's independence, urbanization policy and administration have been approached largely in a reactive manner, responding incrementally to development imperatives over time. Thus, different responses at different times through different institutions under different laws and regulations have created duplication and left horizontal and vertical domain gaps. 
This has led to a fragmentation of policy and administrative responsibility for the urban sector, and the noticeable absence of effective institutional arrangements for coordination. The Sri Lankan urbanization experience suggests that intra- and inter-urban dimensions have been approached dichotomously rather than in terms of their inherent linkages.

A further aspect of this fragmentation is the lack of clarity and coordination across central, provincial, and local authority levels. For example, over time, urban providers have been centralized-whether planning, regulation, or services-even though these functions have been written into local authority laws. The vertical dichotomy of responsibility for urban at the center and rural at the local level has created an urban lacuna in the decentralized coordination of development at the district and divisional levels. Urban is not a "subject" at the provincial level. Nor does a coherent urban development policy inform service delivery at the provincial level, although the provinces are responsible for social development services. Hence, provinces lack an urban development strategy that would enable them to address urban social welfare issues.

The central service providers are not accountable to any of the territorial planning and coordinating frameworks, but tend to function as sector-based agencies, implementing through centrally formulated development programs. Thus, spatial planning has had little influence over sector plans, with sector program planning coordinating weakly with spatial planning, usually implemented through specific projects rather than as sustained services.

Greater involvement of the provincial and local authority levels could improve governance, environmental management, conflict management and resolution, and urban service delivery. To realize this, the roles and responsibilities need to be realigned with capacity and resources. Prior to identifying a possible way forward, section 7.3 will explore the current financial situation at the local authority level in Sri Lanka.

\subsection{Urbanization Finance in Sri Lanka}

The local government system constitutes the basic structure for urban governance. The laws governing local government bodies-the Municipal Council Ordinance (1947), Urban Council Ordinance (1939), and Pradeshiya Sabhas Act (1987)-establish local government bodies as competent spending authorities with distinct financial and fiscal powers. Unfortunately, the scope of local government finance to support urbanization is severely constrained by 
the fragmented intergovernmental structure for urban service provision, and by fundamental weaknesses in the structure of local government finances.

Three aspects constrain the local authorities' ability to properly carry out their urban responsibilities. First, the central government is responsible for urban planning, regulation, and service delivery. Second, the central and provincial governments are also responsible for delivering development services within the jurisdictions of local government bodies, including virtually all urban capital infrastructure. Third, even the limited urban services responsibilities provided at the local government level are split across urban local bodies (municipal and urban councils) and rural local bodies (pradeshiya sabhas)-with the latter responsible for providing urban services in designated "built-up areas."

\subsubsection{Intergovernmental Fiscal Framework}

Urbanization finance is set within the framework of intergovernmental finance as defined by the 13th Amendment, which guarantees funds "adequate" to meet provincial expenditures. The Amendment also guarantees that local authorities retain their extant powers and hence their existing expenditure responsibilities and revenue assignment, but does not explicitly recognize their fiscal needs. Instead, local authorities are defined as a subject assigned to provincial councils. Thus, the fiscal needs of local authorities are incorporated within the framework of provincial fiscal needs, and central government financial transfers are channeled through provincial councils.

Accordingly, local authority finance constitutes a component of provincial finance. And, while provincial financial fiscal needs are defined to cover both recurrent and capital expenditures, local authority fiscal needs are defined only as those for meeting needs of their personnel costs. No specific provisions target the capital development needs of the local authorities.

The Finance Commission of Sri Lanka was established in 1987 under the 13th Amendment, to facilitate the process of resource transfers to the provinces. The Finance Commission is responsible for making recommendations and formulating principles for apportioning "adequate funds" between the nine provinces, and, by implication, some funds to the local authorities, in order to achieve balanced regional development in the country (Finance Commission of Sri Lanka 2014).

To identify the amount to be allocated from the central government to the subnational levels (the vertical share), the Finance Commission conducts an annual needs analysis to identify the gap between expected provincial revenues 
and required provincial expenditures. The Finance Commission's assessment is of a limited scope, focusing primarily on recurrent expenditures linked to personal emoluments and lacking a focus on delivering specific service outputs and performance.

The Constitution provides for an annual allocation of funds from the central government budget "in consultation with and on the advice of the Finance Commission." However, the Constitution does not compel the central government to allocate amounts recommended by the Finance Commission. To address the vertical imbalance, Sri Lanka could consider adopting the international practice of assigning to provinces and local authorities a fixed percentage, set at a minimum of $15 \%$ of government revenues, possibly being increased to $25 \%$ of government revenues during the ensuing 5 years in line with a restructuring of expenditure assignments.

Over time, the process of estimating expenditure needs and allocating the funds has become routine, essentially one of calculating the incremental need for personal emoluments of provincial and local personnel, under the control of the central government. The current "gap filling" approach of the Sri Lankan intergovernmental fiscal transfer system creates a perverse incentive against improving provincial and local government revenue mobilization and improving the efficiency of provincial and local government recurrent expenditures. As far as provincial and local governments are concerned, they are guaranteed to receive the personnel costs of the "approved cadre" and to have sufficient funds to meet the "gap" between their recurrent expenditures and revenues, providing no incentive to efficiently manage their personnel expenditures. To address the horizontal imbalances, the intergovernmental transfer system should shift from the current "gap filling grants" approach to a more transparent formula-based allocation approach predicated on client-based criteria.

The needs assessment for capital expenditure also continues to be ad hoc in the absence of well-developed provincial development frameworks. In fact, the actual allocation of capital expenditures between the central and provincial levels is largely based on the relative power of negotiation positions, rather than on a clear, comprehensive view of who does what and why.

\subsubsection{Local Government Revenues}

Local authorities have access to a mixture of financial resources that essentially include own-source revenues (OSRs), recurrent grants, capital grants, and loans. As indicated in Table 7.3, local authorities receive on average of $60 \%$ from OSRs for their recurrent revenue. The remaining $40 \%$ comes from the central 
government revenue grant, which is essentially a block grant to cover the costs of salaries, overtime, pensions, and travel, and is channeled to local authorities through the provincial governments.

Local authority collections of OSRs come mainly from property taxes, which are termed "rates" in Sri Lanka (35.6\%); other income, i.e., stamp duty on land transactions (30.4\%); rents (12.3\%); fees for service (11.9\%); and a little from licenses and warrants. Local authority capital revenues come virtually completely from central government capital grants (94.5\%), with only a small amount from loans (1.5\%) and sale of capital assets (1.1\%).

Table 7.3: Revenue and Expenditures for Local Authorities, 2014 (SLRs'000 and \%)

\begin{tabular}{|c|c|c|c|}
\hline Item & Details & $\begin{array}{l}\text { Local } \\
\text { Authority } \\
\text { Revenues }\end{array}$ & $\begin{array}{c}\text { Local } \\
\text { Government } \\
\%\end{array}$ \\
\hline $\begin{array}{l}\text { A. Own-Source } \\
\text { Revenue }\end{array}$ & & $20,113,999$ & 59.9 \\
\hline \multicolumn{4}{|l|}{ B. Recurrent Revenue } \\
\hline Taxes & $\begin{array}{l}\text { E.g., property taxes, acreage taxes, trade } \\
\text { licenses, entertainment taxes. }\end{array}$ & $7,154,315$ & 35.6 \\
\hline Rents & $\begin{array}{l}\text { E.g., market stalls and tendering of meat } \\
\text { and fish stalls; and license fees }{ }^{a}\end{array}$ & $2,480,354$ & 12.3 \\
\hline Licenses & Miscellaneous licenses. & 806,475 & 4.0 \\
\hline Fees for Services & $\begin{array}{l}\text { E.g., registration fees, statutory fees, } \\
\text { building applications. }\end{array}$ & $2,393,653$ & 11.9 \\
\hline Warrants & Warrant costs, fines, and penalties & $1,154,588$ & 5.7 \\
\hline Other Income & $\begin{array}{l}\text { Other Income, e.g., stamp duties and court } \\
\text { fines collected by provincial government. }\end{array}$ & $6,124,614$ & 30.4 \\
\hline Revenue Grants & $\begin{array}{l}\text { Block grants from central government } \\
\text { largely to cover local staff salaries }\end{array}$ & $13,480,266$ & 40.1 \\
\hline $\begin{array}{l}\text { Subtotal Recurrent } \\
\text { Revenue }\end{array}$ & & $33,594,265$ & 100.0 \\
\hline \multicolumn{4}{|l|}{ C. Capital Revenue } \\
\hline Capital Grants & $\begin{array}{l}\text { Central government allocations for capital } \\
\text { expenditure programs }\end{array}$ & $12,996,247$ & 94.5 \\
\hline Loans & $\begin{array}{l}\text { Loans, especially from the Local Loans and } \\
\text { Development Fund }\end{array}$ & 208,805 & 1.5 \\
\hline Sales of Capital Assets & & 149,978 & 1.1 \\
\hline Others & & 393,300 & 2.9 \\
\hline $\begin{array}{l}\text { Subtotal Capital } \\
\text { Revenue }\end{array}$ & & $13,748,330$ & 100.0 \\
\hline Total Revenue & & $47,342,595$ & \\
\hline
\end{tabular}

Includes "license fees" such as for bicycles, and "special license fees" such as for billboards, which in Sri Lanka are termed "hoardings."

Source: Derived from Table 7.4. 
Table 7.4 provides a disaggregated analysis of OSR for the different types of local authorities. While municipal councils rely on annual property taxes $(51.2 \%)$, urban councils have a mix of property taxes (32.9\%) and "other income" (31.3\%), pradeshiya sabhas rely on "other income" (38.2\%) with only $14.5 \%$ from property taxes. The OSR balance is raised from an amalgam of user charges mainly for regulatory services provided by local authorities.

Table 7.4: Recurrent and Capital Revenue Structure for Local Authorities, 2014 (SLRs '000 and \%)

\begin{tabular}{|c|c|c|c|c|c|c|c|c|}
\hline Item & $\begin{array}{l}\text { Municipal } \\
\text { Council }\end{array}$ & $\begin{array}{l}\text { Urban } \\
\text { Council }\end{array}$ & $\begin{array}{l}\text { Pradeshiya } \\
\text { Sabha }\end{array}$ & $\begin{array}{l}\text { Total } \\
\text { LGs }\end{array}$ & $\underset{\%}{\mathrm{MC}}$ & $\underset{\%}{\text { UC }}$ & $\begin{array}{l}\text { PS } \\
\%\end{array}$ & $\begin{array}{l}\text { LG } \\
\%\end{array}$ \\
\hline 2014 Population & $2,485,095$ & $1,498,718$ & $16,788,000$ & $20,771,813$ & & & & \\
\hline $\begin{array}{l}\text { A. Own-Source } \\
\text { Revenue }\end{array}$ & $10,298,091$ & $2,471,656$ & $7,344,252$ & $20,113,999$ & 65.4 & 61.8 & 53.0 & 59.9 \\
\hline \multicolumn{9}{|l|}{$\begin{array}{l}\text { B. Recurrent } \\
\text { Revenue }\end{array}$} \\
\hline Taxes & $5,273,494$ & 813,407 & $1,067,414$ & $7,154,315$ & 51.2 & 32.9 & 14.5 & 35.6 \\
\hline Rents & 812,540 & 461,442 & $1,206,372$ & $2,480,354$ & 7.9 & 18.7 & 16.4 & 12.3 \\
\hline Licenses & 349,948 & 89,730 & 366,797 & 806,475 & 3.4 & 3.6 & 5.0 & 4.0 \\
\hline Fees for Services & $1,118,107$ & 255,323 & $1,020,223$ & $2,393,653$ & 10.9 & 10.3 & 13.9 & 11.9 \\
\hline Warrants & 202,021 & 77,805 & 874,762 & $1,154,588$ & 2.0 & 3.1 & 11.9 & 5.7 \\
\hline Other Income & $2,541,981$ & 773,949 & $2,808,684$ & $6,124,614$ & 24.7 & 31.3 & 38.2 & 30.4 \\
\hline Revenue Grants & $5,445,453$ & $1,530,433$ & $6,504,380$ & $13,480,266$ & 34.6 & 38.2 & 47.0 & 40.1 \\
\hline $\begin{array}{l}\text { Subtotal } \\
\text { Recurrent } \\
\text { Revenue }(A+B)\end{array}$ & $15,743,544$ & $4,002,089$ & $13,848,632$ & $33,594,265$ & 100 & 100 & 100 & 100 \\
\hline \multicolumn{9}{|l|}{$\begin{array}{l}\text { C. Capital } \\
\text { Revenue }\end{array}$} \\
\hline Capital Grants & $1,851,724$ & $1,029,721$ & $10,114,802$ & $12,996,247$ & 86.5 & 91.6 & 96.5 & 94.5 \\
\hline Loans & 55,000 & - & 153,805 & 208,805 & 2.6 & - & 1.5 & 1.5 \\
\hline $\begin{array}{l}\text { Sales of Capital } \\
\text { Assets }\end{array}$ & 94,613 & 19,156 & 36,209 & 149,978 & 4.4 & 1.7 & 0.3 & 1.1 \\
\hline Others & 138,417 & 75,806 & 179,077 & 393,300 & 6.5 & 6.7 & 1.7 & 2.9 \\
\hline $\begin{array}{l}\text { Subtotal Capital } \\
\text { Revenue }\end{array}$ & $2,139,754$ & $1,124,683$ & $10,483,893$ & $13,748,330$ & 100 & 100 & 100 & 100 \\
\hline Total Revenue & $17,883,298$ & $5,126,772$ & $24,332,525$ & $47,342,595$ & & & & \\
\hline
\end{tabular}

$-=$ not available, $\mathrm{LG}=$ local government, $M C$ = municipal council, $\mathrm{PS}$ = pradeshiya sabha, $\mathrm{UC}=$ urban council. Sources: Ministry of Provincial Councils and Local Government (2014); CBSL (2015).

Apart from OSR, local authorities depend on revenue grants, which account for an average of $40 \%$ of total recurrent revenues. This contribution is higher for pradeshiya sabhas at $47 \%$, while it accounts for $34.6 \%$ in municipal councils and $38.2 \%$ in urban councils. These revenue grants are block grants allocated through the Finance Commission to local authorities for paying their salaries and other personnel costs. In addition, local authorities receive some smaller capital grants 
from the central government, which account for an average of $94.5 \%$ of their capital revenues.

Table 7.5 shows per capita revenues for different local authorities. These per capita amounts appear quite low in absolute terms and could be the focus for revenue enhancement activity through policy and administration reforms.

Table 7.5: Recurrent and Capital Revenue Per Capita Collections, 2014 (SLRs'000)

\begin{tabular}{|c|c|c|c|c|}
\hline Item & $\begin{array}{c}\text { Municipal } \\
\text { Council }\end{array}$ & $\begin{array}{l}\text { Urban } \\
\text { Council }\end{array}$ & $\begin{array}{c}\text { Pradeshiya } \\
\text { Sabha }\end{array}$ & All LGs \\
\hline A. Own-Source Revenue & 4,140 & 1,650 & 440 & 970 \\
\hline \multicolumn{5}{|l|}{ B. Recurrent Revenue } \\
\hline Taxes & 2,120 & 540 & 60 & 340 \\
\hline Rents & 330 & 310 & 70 & 120 \\
\hline Licenses & 140 & 60 & 20 & 40 \\
\hline Fees for Services & 450 & 170 & 60 & 120 \\
\hline Warrants & 80 & 50 & 50 & 60 \\
\hline Other Income & 1,020 & 520 & 170 & 290 \\
\hline Revenue Grants & 2,190 & 1,020 & 390 & 650 \\
\hline $\begin{array}{l}\text { Subtotal Recurrent } \\
\text { Revenue }\end{array}$ & 6,340 & 2,670 & 820 & 1,620 \\
\hline \multicolumn{5}{|l|}{ C. Capital Revenue } \\
\hline Capital Grants & 750 & 690 & 600 & 630 \\
\hline Loans & 20 & 0 & 10 & 10 \\
\hline Sales of Capital Assets & 40 & 10 & 0 & 10 \\
\hline Others & 60 & 50 & 10 & 20 \\
\hline $\begin{array}{l}\text { Subtotal Capital } \\
\text { Revenue }\end{array}$ & 860 & 750 & 620 & 660 \\
\hline Total Revenue & 7,200 & 3,400 & 1,400 & 2,300 \\
\hline
\end{tabular}

LG = local government, MC = municipal council, PS = pradeshiya sabha, UC = urban council. Source: Derived from Table 7.4

The composition of local authorities' OSR changed during 2004-2014, with a noticeable decline in the role of property taxes and rent, and a dramatic increase in the relative contribution of fees for service and, especially "other income." As Table 7.6 shows, the relative contribution of "other income" almost doubled everywhere, while the role of property taxes fell by $22 \%$ in municipal councils, $19 \%$ in urban councils, and less than $2 \%$ in pradeshiya sabhas, and the relative role of rents fell close to $33 \%$ in both pradeshiya sabhas and urban councils but only $19 \%$ in municipal councils. The exact reasons for this shift should be analyzed in designing an appropriate mix of policy and administrative reforms for the various local authorities. 
Table 7.6: Comparative Local Authority Own Source Revenue Contribution, 2004 and 2014 (\% of total collection)

\begin{tabular}{|c|c|c|c|c|c|c|c|c|c|c|c|c|}
\hline \multirow[b]{2}{*}{ Item } & \multicolumn{2}{|c|}{$\begin{array}{l}\text { Municipal } \\
\text { Council }\end{array}$} & \multicolumn{2}{|c|}{$\begin{array}{l}\text { Urban } \\
\text { Council }\end{array}$} & \multicolumn{2}{|c|}{$\begin{array}{c}\text { Pradeshiya } \\
\text { Sabha }\end{array}$} & \multicolumn{2}{|c|}{ Total LGs } & \multirow{2}{*}{$\begin{array}{c}\mathrm{MC} \\
\%\end{array}$} & \multirow{2}{*}{$\begin{array}{l}\text { UC } \\
\%\end{array}$} & \multirow{2}{*}{$\begin{array}{l}\text { PS } \\
\%\end{array}$} & \multirow{2}{*}{$\begin{array}{c}\text { LG } \\
\%\end{array}$} \\
\hline & 2004 & 2014 & 2004 & 2014 & 2004 & 2014 & 2004 & 2014 & & & & \\
\hline $\begin{array}{c}\text { Property } \\
\text { Taxes }\end{array}$ & 65.9 & 51.2 & 40.6 & 32.9 & 14.8 & 14.5 & 45.0 & 35.6 & -22 & -19 & -2 & -21 \\
\hline Rent & 9.8 & 7.9 & 27.7 & 18.7 & 24.8 & 16.4 & 16.9 & 12.3 & -19 & -33 & -34 & -27 \\
\hline Licenses & 2.9 & 3.4 & 4.3 & 3.6 & 8.8 & 5.0 & 5.2 & 4.0 & 17 & -16 & -43 & -23 \\
\hline $\begin{array}{l}\text { Fees for } \\
\text { Services }\end{array}$ & 7.3 & 10.9 & 9.3 & 10.3 & 13.6 & 13.9 & 9.8 & 11.9 & 49 & 11 & 2 & 21 \\
\hline Warrants & 1.9 & 2.0 & 2.5 & 3.1 & 11.5 & 11.9 & 5.4 & 5.7 & 3 & 26 & 4 & 6 \\
\hline Other & 12.2 & 24.7 & 15.6 & 31.3 & 26.5 & 38.2 & 17.7 & 30.4 & 102 & 101 & 44 & 72 \\
\hline Total & 100 & 100 & 100 & 100 & 100 & 100 & 100 & 100 & & & & \\
\hline
\end{tabular}

$\mathrm{LG}=$ local government, $\mathrm{MC}$ = municipal council, $\mathrm{PS}$ = pradeshiya sabha, $\mathrm{UC}=$ urban council. Source: 2004 data from Asia Foundation (2008: 8); 2014 data derived from Table 7.4.

\subsubsection{Local Authority Expenditures}

As Table 7.7 indicates, personal emoluments average $57.4 \%$ of total recurrent expenditures for all local authorities. Personal emoluments are $62.2 \%$ for urban councils, $59.1 \%$ for pradeshiya sabhas, and $54.7 \%$ for municipal councils. Other major recurrent expenses relate to supplies and requisites; transport, communication, utilities, and other services; and asset repairs and maintenance.

As a share of total expenditures (recurrent and capital), personal emoluments account for $45 \%$ in municipal councils, $42 \%$ in urban councils, and $30 \%$ in pradeshiya sabhas. The extent to which this spending level on personal emoluments is maintained by the reimbursement of salaries by government merits serious consideration, when compared with the share of the revenue grant in total revenue-approximately $30 \%$ for municipal councils, $30 \%$ for urban councils, and $26 \%$ for pradeshiya sabhas. 
Table 7.7: Local Authority Recurrent and Capital Expenditures, 2014 (SLRs '000)

\begin{tabular}{|c|c|c|c|c|c|c|c|c|}
\hline Item & $\begin{array}{l}\text { Municipal } \\
\text { Council }\end{array}$ & $\begin{array}{l}\text { Urban } \\
\text { Council }\end{array}$ & $\begin{array}{c}\text { Pradeshiya } \\
\text { Sabha }\end{array}$ & Total LGs & $\underset{\%}{M C}$ & $\underset{\%}{\text { UC }}$ & $\begin{array}{l}\text { PS } \\
\%\end{array}$ & $\underset{\%}{\mathbf{L G}}$ \\
\hline 2014 Population & $2,485,095$ & $1,498,718$ & $16,788,000$ & $20,771,813$ & & & & \\
\hline Personal Emoluments & $7,537,693$ & $2,178,953$ & $6,955,598$ & $16,672,244$ & 54.7 & 62.2 & 59.1 & 57.4 \\
\hline Travelling Expenses & 126,008 & 31,013 & 173,345 & 330,366 & 0.9 & 0.9 & 1.5 & 1.1 \\
\hline Supplies and Requisites & $1,902,034$ & 331,238 & $1,433,536$ & $3,666,808$ & 13.8 & 9.5 & 12.2 & 12.6 \\
\hline $\begin{array}{l}\text { Repairs, Capital Asset } \\
\text { Maintenance }\end{array}$ & $1,206,823$ & 519,324 & $1,581,375$ & $3,307,522$ & 8.8 & 14.8 & 13.4 & 11.4 \\
\hline $\begin{array}{l}\text { Transport, } \\
\text { Communication, } \\
\text { Utilities, and Other } \\
\text { Services }\end{array}$ & $2,264,692$ & 320,218 & $1,108,318$ & $3,693,228$ & 16.4 & 9.1 & 9.4 & 12.7 \\
\hline $\begin{array}{l}\text { Interest Payments, } \\
\text { Dividends, and } \\
\text { Subsidies }\end{array}$ & 175,823 & 41,742 & 138,168 & 355,733 & 1.3 & 1.2 & 1.2 & 1.2 \\
\hline Grants, Contributions & 435,569 & 43,339 & 258,526 & 737,434 & 3.2 & 1.2 & 2.2 & 2.5 \\
\hline $\begin{array}{l}\text { Pensions, Retirement } \\
\text { Benefits, and } \\
\text { Gratuities }\end{array}$ & 135,081 & 37,684 & 118,084 & 290,849 & 1.0 & 1.1 & 1.0 & 1.0 \\
\hline $\begin{array}{l}\text { Subtotal Recurrent } \\
\text { Expenditures }\end{array}$ & $13,783,723$ & $3,503,511$ & $11,766,950$ & $29,054,184$ & 100 & 100 & 100 & 100 \\
\hline $\begin{array}{l}\text { Equipment, Land, Land } \\
\text { Improvement, and } \\
\text { Structural Outlay }\end{array}$ & $2,636,421$ & $1,600,256$ & $10,976,678$ & $15,213,355$ & 94.6 & 97.5 & 97.7 & 97.1 \\
\hline Loan Repayments & 151,609 & 41,065 & 263,680 & 456,354 & 5.4 & 2.5 & 2.3 & 2.9 \\
\hline $\begin{array}{c}\text { Subtotal Capital } \\
\text { Expenditures }\end{array}$ & $2,788,030$ & $1,641,321$ & $11,240,358$ & $15,669,709$ & 100 & 100 & 100 & 100 \\
\hline Total Expenditures & $16,571,753$ & $5,144,832$ & $23,007,308$ & $44,723,893$ & & & & \\
\hline
\end{tabular}

$\mathrm{LG}=$ local government, $\mathrm{MC}=$ municipal council, $\mathrm{PS}=$ pradeshiya sabha, $\mathrm{UC}=$ urban council. Source: Ministry of Provincial Councils and Local Government (2014); CBSL (2015).

Table 7.8 breaks down the expenditures on a per capita basis, showing significantly higher expenditures per capita in the municipal councils than the pradeshiya sabhas. Urban local authorities are spending about $50 \%$ more per capita on capital projects than pradeshiya sabhas. The urban local authorities (municipal and urban councils) spent on average slightly more than SLRs1,070 per capita on capital expenditures compared with SLRs650 per capita being spent by pradeshiya sabhas. 
Table 7.8: Recurrent and Capital Per Capita Expenditures, 2014 (SLRs '000)

\begin{tabular}{|c|c|c|c|c|}
\hline Item & $\begin{array}{l}\text { Municipal } \\
\text { Council }\end{array}$ & $\begin{array}{l}\text { Urban } \\
\text { Council }\end{array}$ & $\begin{array}{l}\text { Pradeshiya } \\
\text { Sabha }\end{array}$ & Total LGs \\
\hline Personal Emoluments & $3,030,000$ & $1,450,000$ & 410,000 & 800,000 \\
\hline Travelling Expenses & 50,000 & 20,000 & 10,000 & 20,000 \\
\hline Supplies and Requisites & 770,000 & 220,000 & 90,000 & 180,000 \\
\hline $\begin{array}{l}\text { Repairs, Maintenance of Capital } \\
\text { Assets }\end{array}$ & 490,000 & 350,000 & 90,000 & 160,000 \\
\hline $\begin{array}{l}\text { Transportation, Communications, } \\
\text { Utilities, and Other Services }\end{array}$ & 910,000 & 210,000 & 70,000 & 180,000 \\
\hline $\begin{array}{l}\text { Interest Payments, Dividends, and } \\
\text { Subsidies }\end{array}$ & 70,000 & 30,000 & 10,000 & 20,000 \\
\hline $\begin{array}{l}\text { Grants, Contributions, and } \\
\text { Subsidies }\end{array}$ & 180,000 & 30,000 & 20,000 & 40,000 \\
\hline $\begin{array}{l}\text { Pensions, Retirement Benefits, } \\
\text { and Gratuities }\end{array}$ & 50,000 & 30,000 & 10,000 & 10,000 \\
\hline $\begin{array}{l}\text { Subtotal Recurrent } \\
\text { Expenditures }\end{array}$ & $5,550,000$ & $2,340,000$ & 700,000 & $1,400,000$ \\
\hline $\begin{array}{l}\text { Equipment, Land, Improvement, } \\
\text { and Structural Outlay }\end{array}$ & $1,060,000$ & $1,070,000$ & 650,000 & 730,000 \\
\hline Loan Repayments & 60,000 & 30,000 & 20,000 & 20,000 \\
\hline Subtotal Capital Expenditures & $1,120,000$ & $1,100,000$ & 670,000 & 750,000 \\
\hline Total Expenditures & $6,670,000$ & $3,430,000$ & $1,370,000$ & $2,150,000$ \\
\hline
\end{tabular}

LG = local government.

Source: Derived from Table 7.5.

Table 7.9 shows the comparative shares of recurrent and capital expenditures by local government type, with the share being highest in municipal councils and lowest in pradeshiya sabhas and vice versa for capital expenditure. This pattern of capital spending in pradeshiya sabhas reflects the relatively larger share of capital grants within these local authorities.

Table 7.9: Contribution of Recurrent and Capital Expenditures by Local Authorities, 2014 (SLRs '000 and \%)

\begin{tabular}{l|c|c|c|c|c|c|c|c|} 
Expenditure & $\begin{array}{c}\text { Municipal } \\
\text { Council }\end{array}$ & $\begin{array}{c}\text { Urban } \\
\text { Council }\end{array}$ & $\begin{array}{c}\text { Pradeshiya } \\
\text { Sabha }\end{array}$ & Total LG & $\begin{array}{c}\text { MC } \\
\%\end{array}$ & $\begin{array}{c}\text { UC } \\
\%\end{array}$ & $\begin{array}{c}\text { PS } \\
\%\end{array}$ & $\begin{array}{c}\text { LG } \\
\%\end{array}$ \\
\hline Recurrent & $13,783,723$ & $3,503,511$ & $11,766,950$ & $29,054,184$ & 83 & 68 & 51 & 65 \\
\hline Capital & $2,788,030$ & $1,641,321$ & $11,240,358$ & $15,669,709$ & 17 & 32 & 49 & 35 \\
\hline Total & $\mathbf{1 6 , 5 7 1 , 7 5 3}$ & $\mathbf{5 , 1 4 4 , 8 3 2}$ & $\mathbf{2 3 , 0 0 7 , 3 0 8}$ & $\mathbf{4 4 , 7 2 3 , 8 9 3}$ & $\mathbf{1 0 0}$ & $\mathbf{1 0 0}$ & $\mathbf{1 0 0}$ & $\mathbf{1 0 0}$ \\
\hline
\end{tabular}

LG = local government, MC = municipal council, PS = pradeshiya sabha, UC = urban council.

Source: Derived from Table 7.4. 
Table 7.10 provides a detailed provincial analysis of local government revenues and expenditures, which highlights significant observations.

The first is that per capita revenues of both municipal and urban councils vary widely across provinces. While the variations may have several economic and administrative reasons, they may also be related to property value differentials. The expenditure variations may result from different needs and service delivery costs arising from varying population densities and possible economic activities.

The second observation is the potential impact from the undercounting of urban population. As already noted, approximately $60 \%$ of the urban population lives in pradeshiya sabhas and built-up areas should be declared as urban for purposes of levying property and other taxes. However, according to the shares of taxes collected by the three types of local authorities, pradeshiya sabhas account for only $15 \%$ of total taxes while carrying $60 \%$ of the urban population (on the basis that $46.3 \%$ of the total is urban). The impact of not declaring urbanized rural areas as "built up" reduces the possible collection of property taxes.

\section{Table 7.10: Per Capita Municipal and Urban Council Revenues and Expenditures by Province, 2014}

\begin{tabular}{|c|c|c|c|c|c|c|c|c|c|c|c|c|}
\hline \multirow[b]{2}{*}{ Province } & \multicolumn{6}{|c|}{ Municipal Council } & \multicolumn{6}{|c|}{ Urban Council } \\
\hline & Pop. & $\begin{array}{l}\text { Rev. } \\
\left(000^{\prime}\right)\end{array}$ & $\begin{array}{l}\text { Per } \\
\text { Capita } \\
\text { SLRs }\end{array}$ & $\begin{array}{l}\text { Exp. } \\
\left(000^{\prime}\right)\end{array}$ & $\begin{array}{c}\text { Per } \\
\text { Capita } \\
\text { SLRs }\end{array}$ & $\begin{array}{c}\text { Exp./ } \\
\text { Rev. } \\
\text { Ratio } \\
(\%)\end{array}$ & Pop. & $\begin{array}{c}\text { Rev. } \\
\left(000^{\prime}\right)\end{array}$ & $\begin{array}{c}\text { Per } \\
\text { Capita } \\
\text { SLRs }\end{array}$ & $\begin{array}{l}\text { Exp. } \\
\left(000^{\prime}\right)\end{array}$ & $\begin{array}{l}\text { Per } \\
\text { Capita } \\
\text { SLRs }\end{array}$ & $\begin{array}{r}\text { Exp./ } \\
\text { Rev. } \\
\text { a Ratio, } \\
\text { (\%) }\end{array}$ \\
\hline Central & 208,976 & 2,527 & 12,092 & 2,391 & 111,442 & 95 & 108,925 & 474 & $4 \quad 4,352$ & 458 & $8 \quad 4,205$ & 97 \\
\hline Eastern & 234,744 & 354 & 1,508 & 409 & $9 \quad 1,742$ & 116 & 209,051 & 324 & $4 \quad 1,550$ & 342 & 21,636 & 106 \\
\hline North Central & 55,764 & 352 & 6,312 & 288 & 5,165 & 82 & - & - & - & - & - & - \\
\hline North West & 24,700 & 310 & 12,551 & 450 & 18,219 & 145 & 81,501 & 470 & $0 \quad 5,767$ & 242 & 2,969 & 51 \\
\hline Northern & 94,373 & 530 & 5,616 & 500 & 5,298 & 94 & 104,589 & 524 & $4 \quad 5,010$ & 415 & 53,968 & 79 \\
\hline Sabaragamuwa & 52,000 & 264 & 5,077 & 260 & 5,000 & 98 & 97,379 & 308 & $8 \quad 3,163$ & 271 & 12,783 & 88 \\
\hline Southern & 211,765 & 789 & 3,726 & 698 & $8 \quad 3,296$ & 88 & 85,097 & 361 & 14,242 & 332 & 23,901 & 92 \\
\hline Uva & 92,000 & 371 & 4,033 & 357 & $7 \quad 3,880$ & 96 & 5,742 & 32 & 25,573 & 31 & 15,399 & 97 \\
\hline Western & $1,510,773$ & 11,659 & 7,717 & 10,040 & 6,646 & 86 & 806,434 & 2,711 & 13,362 & $2 \quad 2,551$ & 13,163 & 94 \\
\hline Total & $2,485,095$ & 17,156 & 6,904 & 15,393 & $3 \quad 6,194$ & 90 & $1,498,718$ & 5,204 & $4 \quad 3,472$ & 24,642 & 23,097 & 89 \\
\hline
\end{tabular}

$-=$ not available, Exp. = expenditure, Pop. $=$ population, Rev. $=$ revenue.

Sources: DCS (2015); Ministry of Provincial Councils and Local Government (2014); CBSL (2015). 


\subsubsection{Considerations for the Way Forward}

This analysis identifies several key items to consider when attempting to design funding instruments and financing mechanisms of localized urban services.

(1) Local authority financial allocations and operations take place within an environment of strong central legal and regulatory controls related to local authority staffing and to the allocation of revenue and capital grants.

(2) Political resistance to raising local revenue levels and performance appears to be increasing.

(3) Increasing demand for urban services requires a combination of increased local OSRs and access to finance.

(4) The intergovernmental transfer system needs to ensure reliability, stability, and predictability to better address the vertical and horizontal imbalances.

(5) The current central transfers for financing the costs of salaries and wages in local authorities are creating perverse incentives that restrict choices in service delivery and adversely affect the efficiency of service delivery operations.

(6) Local authorities have tremendous potential for improving the efficiency and accountability of the growth and development process. Within a proper intergovernmental public-sector framework, local authorities will be able to plan, budget, implement, and monitor their assigned governance and development functions. To effectively contribute to improving the process, local authorities must be given clarity about their assigned roles and responsibilities, legitimacy, authority, and capacity, and the resources to implement their responsibilities in an efficient and accountable manner.

These challenges present an opportunity for a timely review and for developing an enabling urbanization framework and an appropriate urban development strategy, which can support the urbanization structure needed to stimulate economic growth and to equitably spread social and economic development across the country.

Prior to discussing the specific challenges and opportunities facing urban financing in Sri Lanka, section 7.4 will examine funding and financing options for urban development and urban services more generally. 


\subsection{Funding Options for Urban Development and Urban Services}

Urbanization, if properly harnessed, can generate the agglomeration economies needed to stimulate efficient economic growth. Well-planned, well-connected, and well-financed cities can provide the enabling environment to link economic factors to production, production to markets, and markets to consumers. These interactive synergies, combined with appropriate policies, systems, and procedures, are needed to guide the realization of sustainable economic and social development.

To function effectively, cities must have the requisite urban infrastructure and be able to provide key urban services such as water and sanitation facilities, roads and transport, school and health facilities, and waste disposal. Rapid urban growth combined with an infrastructure deficit is heightening the need to identify urban financing options and strengthen the underlying funding sources that can support those financing mechanisms (Dirie 2005; Bahl, Linn, and Wetzel 2013; Bahl and Bird 2008; Bird 2011; UN Habitat 2016a).

Countries require a combination of funding and financing mechanisms to address the challenges of urban development and urban service delivery. A strong underlying funding framework is essential to generate the monies needed to provide immediate urban services and, to the extent possible, to generate an operational surplus that can be used to leverage upfront investment financing for needed urban capital infrastructure.

As Table 7.11 indicates, a wide variety of taxes and other revenue sources can be used to provide the funding for urban infrastructure. They include revenues from (1) user charges (water, sewerage, transport), including utility surcharges (public benefit funds); (2) infrastructure-specific taxes and fees (motor fuel taxes, vehicle fees, vehicle-miles-traveled fees); (3) general taxes (income, sales, property); (4) developer-related charges (exactions, impact fees, linkage fees, tap fees); (5) land-value capture mechanisms (joint developments, development rights, betterment taxes, special assessments); and (6) lease or sale of land.

The detailed policy and administrative design for each option will need to reflect consideration of the revenue, efficiency, equity, administration, and political acceptability, and how they relate to leveraging upfront infrastructure financing from either debt- or equity-based methods. 
Table 7.11: Funding Sources for Urban Infrastructure

\begin{tabular}{|c|c|c|c|c|}
\hline $\begin{array}{l}\text { Funding } \\
\text { Category }\end{array}$ & $\begin{array}{c}\text { Funding } \\
\text { Instrument }\end{array}$ & $\begin{array}{l}\text { One Time } \\
\text { or Long- } \\
\text { Term }\end{array}$ & Description & $\begin{array}{l}\text { Sector } \\
\text { Application }\end{array}$ \\
\hline $\begin{array}{l}\text { Infrastructure- } \\
\text { Specific User } \\
\text { Charges }\end{array}$ & User charges & LT & $\begin{array}{l}\text { Funds collected through tariff, often } \\
\text { multi-part with fixed and marginal } \\
\text { costs, adjusted by location or } \\
\text { distance. }\end{array}$ & $\begin{array}{l}\text { Water, } \\
\text { sewerage, } \\
\text { transport }\end{array}$ \\
\hline $\begin{array}{l}\text { Utility } \\
\text { Surcharges }\end{array}$ & $\begin{array}{l}\text { Public benefit } \\
\text { funds }\end{array}$ & LT & $\begin{array}{l}\text { Funds collected either through a small } \\
\text { surcharge on electric bills or through } \\
\text { contributions from utilities (e.g., } \\
\text { public benefit funds in the United } \\
\text { States). }\end{array}$ & $\begin{array}{l}\text { Renewable } \\
\text { energy, } \\
\text { research and } \\
\text { development }\end{array}$ \\
\hline \multirow[t]{3}{*}{$\begin{array}{l}\text { Infrastructure- } \\
\text { Specific Taxes } \\
\text { and Fees }\end{array}$} & Motor fuel tax & LT & $\begin{array}{l}\text { Per gallon excise tax levied on } \\
\text { motor fuels collected at national, } \\
\text { state/provincial, and local levels; } \\
\text { administered through escrow } \\
\text { account. }\end{array}$ & Transport \\
\hline & Vehicle fees & LT & $\begin{array}{l}\text { Vehicle registration fee levied as a } \\
\text { flat fee, by weight, age, and/or value } \\
\text { generally collected at state/provincial } \\
\text { or local levels. }\end{array}$ & Transport \\
\hline & $\begin{array}{l}\text { Vehicle-mile- } \\
\text { traveled }\end{array}$ & LT & $\begin{array}{l}\text { Mileage-based fees levied either as a } \\
\text { flat or variable fee; tied more to wear } \\
\text { and tear compared to per gallon fuel } \\
\text { tax. }\end{array}$ & Transport \\
\hline \multirow[t]{3}{*}{ General Taxes } & Property tax & LT & $\begin{array}{l}\text { Property taxes are a cities' primary } \\
\text { tool for obtaining infrastructure-- } \\
\text { related tax revenue, including value } \\
\text { capture approaches (see below under } \\
\text { Land Value Capture Mechanisms). }\end{array}$ & Various \\
\hline & Income tax & LT & $\begin{array}{l}\text { National, state/provincial, and/or } \\
\text { local income taxes can be used by } \\
\text { cities as general fund appropriations } \\
\text { for infrastructure. }\end{array}$ & Various \\
\hline & Sales tax & LT & $\begin{array}{l}\text { Cities can be authorized to collect } \\
\text { local sales taxes dedicated to specific } \\
\text { infrastructure projects; requires voter } \\
\text { approval. }\end{array}$ & Various \\
\hline \multirow[t]{4}{*}{$\begin{array}{l}\text { Developer- } \\
\text { Related } \\
\text { Charges }\end{array}$} & Exactions & OT & $\begin{array}{l}\text { Developers donate land or build } \\
\text { facilities for public use as condition } \\
\text { for development approval. }\end{array}$ & $\begin{array}{l}\text { Sidewalks, } \\
\text { parks, open } \\
\text { space }\end{array}$ \\
\hline & Impact fees & OT & $\begin{array}{l}\text { Impact fees on developers to fund } \\
\text { additional service capacity; can be } \\
\text { conditioned on project approval } \\
\text { (e.g., the United Kingdom's } \\
\text { Community Development Levy). }\end{array}$ & $\begin{array}{l}\text { Roads, safety, } \\
\text { schools }\end{array}$ \\
\hline & Linkage fees & OT & $\begin{array}{l}\text { Fees on developers for secondary } \\
\text { effects, e.g., traffic increases. }\end{array}$ & Roads, housing \\
\hline & Tap fees & OT & $\begin{array}{l}\text { Utility connection fees levied } \\
\text { on developers to recover cost of } \\
\text { integrating new development with } \\
\text { existing infrastructure. }\end{array}$ & $\begin{array}{l}\text { Water, } \\
\text { sewerage }\end{array}$ \\
\hline
\end{tabular}


Table 7.11 continued

\begin{tabular}{|c|c|c|c|c|}
\hline $\begin{array}{l}\text { Funding } \\
\text { Category }\end{array}$ & $\begin{array}{c}\text { Funding } \\
\text { Instrument }\end{array}$ & $\begin{array}{l}\text { One Time } \\
\text { or Long- } \\
\text { Term }\end{array}$ & Description & $\begin{array}{c}\text { Sector } \\
\text { Application }\end{array}$ \\
\hline \multirow[t]{6}{*}{$\begin{array}{l}\text { Land Value } \\
\text { Capture } \\
\text { Mechanisms }\end{array}$} & $\begin{array}{l}\text { Joint } \\
\text { developments }\end{array}$ & LT & $\begin{array}{l}\text { Cost sharing between public operator } \\
\text { (e.g., rail transit) and private } \\
\text { developer; both benefit from property } \\
\text { value increases. }\end{array}$ & $\begin{array}{l}\text { Rail, public } \\
\text { transport }\end{array}$ \\
\hline & $\begin{array}{l}\text { Development } \\
\text { rights lease or } \\
\text { sale }\end{array}$ & OT/LT & $\begin{array}{l}\text { "Air rights" above/below the } \\
\text { permitted land use (e.g., increased } \\
\text { floor area ratios) can be leased or } \\
\text { sold as monetized development rights } \\
\text { (e.g., Brazil's CEPAC). }\end{array}$ & Various \\
\hline & $\begin{array}{l}\text { Betterment } \\
\text { tax }\end{array}$ & OT/LT & $\begin{array}{l}\text { Benefit assessment or betterment } \\
\text { levy imposed on beneficiaries of } \\
\text { infrastructure investments }\end{array}$ & $\begin{array}{l}\text { Water, } \\
\text { sewerage, } \\
\text { transport }\end{array}$ \\
\hline & $\begin{array}{l}\text { Special } \\
\text { assessments }\end{array}$ & LT & $\begin{array}{l}\text { Property tax increase applied to } \\
\text { specific districts that benefit from } \\
\text { infrastructure investments } \\
\text { (with increased tax rate). }\end{array}$ & $\begin{array}{l}\text { Roads, public } \\
\text { transport }\end{array}$ \\
\hline & $\begin{array}{l}\text { Tax increment } \\
\text { financing }\end{array}$ & LT & $\begin{array}{l}\text { Income, property, or sales tax } \\
\text { increments from infrastructure } \\
\text { improvements placed in a separate } \\
\text { escrow account to retire existing } \\
\text { debt, fund improvements, or use as a } \\
\text { pledge to secure new debt. }\end{array}$ & $\begin{array}{l}\text { Transport, } \\
\text { housing, urban } \\
\text { development }\end{array}$ \\
\hline & $\begin{array}{l}\text { Land-value } \\
\operatorname{tax}\end{array}$ & LT & $\begin{array}{l}\text { Tax assessed on land value rather } \\
\text { than property value (e.g., building); } \\
\text { better incentive for development } \\
\text { than property tax. }\end{array}$ & Various \\
\hline Lease or Sale & $\begin{array}{l}\text { Land lease or } \\
\text { sale }\end{array}$ & OT/LT & $\begin{array}{l}\text { Publicly owned land with enhanced } \\
\text { value can be leased or sold with } \\
\text { proceeds that can be reinvested into } \\
\text { infrastructure. }\end{array}$ & Various \\
\hline
\end{tabular}

CEPAC = certificate for additional construction potential, $\mathrm{LT}=$ long-term, $\mathrm{OT}=$ one time.

Sources: Adapted from WEF (2014) and Kim (2016).

There are five important considerations.

- The revenue potential should be predictable, stable, and/or buoyant over time. A stream of predictable funding resources can encourage investors to provide infrastructure debt or equity financing.

- Revenue instruments should encourage efficient and accountable use of individual services as well as more efficient wider land-use patterns.

- The "benefit" or "ability to pay" principle of public finance needs to be appropriately applied. Many revenue instruments (e.g., user charges, sales taxes) are regressive in nature, falling more heavily on the poor. Better targeted subsidization schemes are needed (e.g., lifeline water tariffs). 
- Effective administration requires clarifying where the authority and responsibility sits, what are the institutional systems and procedures, and what are the capacity and resources.

- Political acceptability is needed to ensure leadership, support, and buyin from policy decision makers, which must cut across government levels.

A few funding sources illustrate these policy and administration considerations, and how they may relate to challenges and opportunities for funding and financing urban infrastructure and services in Sri Lanka.

\subsubsection{User Charges}

User charges are universally recognized as an ideal funding source linked to urban infrastructure services such as water, sanitation, and transport, where most direct benefits are confined to individual consumers. And user charges based on the benefit principle could be designed and applied to all public services to the extent possible (Bird 2003; Australia Department of Treasury 2014).

User charges, at least at the local level in Sri Lanka, are not directly linked to urban infrastructure investment. These "fees for service," which are collected by the local authorities, are from registration certificates (inspection fees); emergency services; recoverable charges; and special, traffic, and parking fees (Asia Foundation 2016). Service fee collections increased from $9.8 \%$ in 2004 to $11.9 \%$ of local authority OSRs in 2014. User charges (such as for water tariffs) that can be used to leverage upfront infrastructure financing are currently under the central government, facing a variety of challenges (Fan 2015).

For other urban infrastructure needs, which do not have a clearly identifiable earmarked revenue flow from project-specific user charges, leveraging investment must rely on the "full faith and credit" (or full taxing capacity) of the government. In these cases, urban infrastructure investments, at least those leveraged at the local government level, will depend heavily on being serviced from property tax revenues.

\subsubsection{Property Taxes and Related Property Charges}

Property tax revenues are the most common tax base for local government throughout the world. Property-related taxes and charges include recurrent property taxes, property transfer taxes, betterment taxes and special assessments, and development charges and exactions. The most common, fundamental tax on property is the recurrent property tax. 


\subsubsection{Recurrent Property Taxes}

The recurrent property tax generates about $2 \%-3 \%$ of GDP in Canada, the United Kingdom, and the United States, and about $0.3 \%-0.5 \%$ of GDP in developing and emerging economies. Within Asian countries, Indonesia collects $0.25 \%$ of GDP, India collects $0.17 \%$ of GDP, and Viet Nam collects $0.06 \%$ of GDP from property tax (Kelly 2013; Mohanty 2016). The recurrent property tax in Sri Lanka currently generates $0.07 \%$ of GDP-very low by international standards. Through a combination of policy and administrative reforms, Sri Lanka should be able to double recurrent property tax revenues, say to $0.14 \%$ of GDP within 3-5 years, and double that again to $0.28 \%$ of GDP within $8-10$ years.

Property-related taxes have strong potential for revenue mobilization, especially in rapidly urbanizing areas (UN Habitat 2011):

- The tax base is immobile, maximizing economic efficiency, making it easier to identify and capture the tax base, and allowing the property to be the natural collateral if taxes are not paid.

- Property tax captures the value of location-specific capital investments and benefits from government programs and services not captured otherwise through fees, user charges, and other taxes.

- Property tax tends to be paid by people with an "ability to pay" rather than by the very poor.

- Such taxation encourages more responsive, efficient, and accountable governance and public service delivery.

Recurrent property taxes are justified primarily as a "benefit tax" or as a "quasi-user charge" paid by those benefiting from local public services received. Thus, there is a connection between local, location-related services and property values, and, when perceived as such, taxpayers' willingness to pay increases, improving the accountability between local-level governments and their residents.

To fully realize potential property tax revenues, policy and administration need to be adjusted to improve the coverage and accuracy of the property tax base; property valuation, revenue collection, and enforcement; and taxpayer services. Policy reforms could involve adjusting the tax base definitions and tax rate structures, and making appropriate decisions on assessment and valuation standards, appeals, collection and enforcement, and taxpayer service. Tax 
administration reforms could involve improving the coverage, valuation, and collection ratios; taxpayer services; and civic education. Such adjustments could significantly increase property tax revenues while simultaneously improving equity and economic efficiency, strengthening government accountability for public service delivery, and supporting improved land use allocation and housing decisions (Kelly 2013).

\subsubsection{Other Property-Related Taxes and Charges}

As Table 7.11 indicates, two major funding instruments are related to property, excluding the annual recurrent property tax-developer charges and land value capture mechanisms.

Developer-Related Charges. Developer charges (exactions, impact, and linkage fees) are applied to ensure that new developments contribute to pay their incremental costs to the city (NPVP 2008; UKDCLG 2011). Exactions require developers to provide land, public facilities, infrastructure, and community services within a development parcel. Impact fees are charged to cover the fiscal impact on the city, which may be required for area-wide new and expanded infrastructure needed off-site to accommodate the increase in population and economic activity. Linkage fees are applied to cover secondary impact such as social welfare needs. These fees are structured as one-time payments, ideally collected up-front from the developer.

Developer charges are very effective if applied in areas with good market demand for development, which provide a strong incentive for developers to be willing to pay the exactions and impact and linkage fees, in anticipation of recovering more than the costs through increased land values. Sri Lanka currently levies a one-time payment on parceling land diverted from permanent plantation agriculture to sale for building purposes. The payment could be reviewed and revised to better reflect the fiscal impact of local urban development.

Land Value Capture Mechanisms. Land value capture refers to a set of mechanisms designed to recover all or part of the increase in land values created through public infrastructure investment or from society more generally through urban and economic growth. The recaptured funding resources can then be channeled to pay for infrastructure investments and other public services (MDR 2001; Peterson 2009; Walters 2013; Kim 2016; Suzuki et al. 2015; Ardila-Gomez and Ortegon-Sanchez 2016; Siemens et al. 2016). 


\subsubsection{Sale of Development Rights}

One revenue instrument linked to changes in land use regulations relates to the sale or lease of development air rights (i.e., increases in floor area ratios) as monetized development rights.

Landownership is commonly seen as consisting of a bundle of rights. One is the "right to develop" in accordance with planning and land-use regulations, which affect the market value of individual parcels. Development restrictions can be changed by government modifications in land use policy, which can dramatically affect land market values. Land-value capture instruments relate to the sale of such development rights. One such technique, used famously in Brazil, is the sale, through auction, of development air rights known as "CEPAC"Certificates for Additional Construction Potential (Merk et al. 2012; Serva 2014; WEF 2014; Kim 2016; Siemens et al. 2016).

\subsubsection{Joint Development}

Another land value capture approach is through joint development projects, involving cooperation between the government and the private sector, but not necessarily through a public-private partnership (PPP) arrangement. Two successful examples of large-scale joint-development projects are found in Hong Kong, China and Tokyo, Japan (Floater and Rode 2014; Suzuki et al. 2015; ArdilaGomez and Ortegon-Sanchez 2016). As Table 7.11 indicates, a variety of taxes and charges that are related to increases in land values have been adapted and adopted across the urban world.

As with all funding and financing approaches, reformers must carefully consider revenue, efficiency, equity, and administrative aspects, while designing and implementing the various funding instruments and financial mechanisms before adapting and adopting them for use in Sri Lanka, both in the Megapolis and in other individual urban centers. The chapter now turns to the broader challenges and opportunities for urban finance in Sri Lanka. 


\subsection{Challenges and Opportunities for Urban Finance in Sri Lanka}

Financing urbanization and urban development requires a framework to bring together the governance, institutions, and finance to support inclusive and sustainable economic and social development. Such an enabling environment must holistically establish the political-administrative institutional framework, along with clearly assigned expenditure and revenue fiscal responsibilities for delivering efficient and accountable urban public services.

Countries typically deliver urban development and services through a combination of central and subnational government institutions. Based on the subsidiarity principle, the Constitution and enabling legislation typically define and allocate functional responsibilities across levels of government, along with a division of financial resources. The aim is to enable each level of government to deliver its mandated urban development and service delivery responsibilities. In addition, to ensure efficiency and accountability, systems and procedures must be established to promote multidimensional accountability. On top of this, intergovernmental coordination mechanisms must be put into place to guide and monitor effective implementation.

Within this context, a review of the current urbanization environment in Sri Lanka suggests the specific need to better realign functions and finance, link spatial and sector planning, and improve options for private participation.

\subsubsection{Realign Functions and Finance}

The intergovernmental context for urban service delivery and the enabling urban finance framework need to be reviewed and functions and finance reassigned across central, provincial, and local levels.

Responsibility for the provision and financing of urban development naturally must extend from central through provincial to local levels. At the national level, urban areas are expected to function as engines of economic growth and gateways to development. At the regional level, urban development is expected to promote regional growth clusters, enhancing economic connectivity with regional hinterlands. At the local level, urban centers are expected to provide urban services desired by local residents, while transforming the urban environment into engines of growth with active commercial and employment centers and efficient transport hubs. An economic corridor development approach is expected to facilitate this integration by strengthening the interconnectivity between residents, markets, employment, and services (Mitra et al. 2016; Brunner 
2013; De and Iyengar 2014; Jeong 2016). This will also require clear assignment of roles and responsibilities across central, provincial, and local levels within a broader intergovernmental fiscal framework analysis.

Functional assignment across government levels in Sri Lanka has been largely reactive, incremental, and not based on the principal of subsidiarity. Such expenditure assignments have resulted in contradictory assignment and/or duplication of responsibilities, leading to confusion, inadequate or excess public services, and/or inefficient use of scarce public resources.

To redesign the intergovernmental dimension of urban finance will require clarifying the functions to more efficiently allocate urban-related finance between the national, provincial, and local levels. The responsibility for providing public utility services currently lies with central providers, with very little coordination with provincial and local government levels. It is therefore imperative to redefine the roles and functions of local authorities in providing urban infrastructure and services. Such a framework, with an institutional design for vertical and horizontal linkages in urban governance and development, will enable the coordination of cost-effective service delivery across local authority jurisdictions, bringing them into the mainstream of urban development (Bird and Slack 2007; Andersson 2015).

The central government has provided financing (including project finance) to fund capital-intensive public utilities and service infrastructure, while local authorities have been expected to use their OSRs to take care of small-scale infrastructure and amenities. The use of private financing, either as direct private equity or through PPPs, is yet to become a serious financing option, due to statutory restrictions and the lack of the necessary institutional and regulatory framework.

The current financial environment presents several challenges. First, local government budgets, structured as balanced, often result in local governments managing within their income, which has compromised the quality and quantity of urban service delivered. Second, local government budgets are seldom structured in a multiyear medium-term perspective, making it difficult to guide the resource allocation process. Third, local authorities lack the ability to effectively link OSR generation with changes in their economic environmentfor example, not being able to effectively update their property tax rolls to reflect changes in property valuations. Fourth, local government budgets lack a strategic performance framework, making it difficult to effectively link income and expenditure to service provision goals and targets. 
In short, an enabling intergovernmental framework would improve the planning and delivery of urban infrastructure by making it more efficient and accountable. The result would be better urban service delivery outcomes.

\subsubsection{Link Spatial and Sector Planning}

An enabling urban framework must effectively link sector and spatial planning within and between urban areas. The responsibility for physical and sector planning is fragmented across agencies and departments, with very little interaction and coordination within individual urban areas and across the urban spatial systems. This fragmentation and lack of coordination creates major challenges to coordinating and implementing an effective urban financial framework.

At the level of urban policy, the government has tended to focus attention on specific urban locations rather than on the broader spatial dimensions of development change. Accordingly, urban finance has focused on intraurban situations rather than on the broader interurban (regional) perspective. Thus, the majority of urban infrastructure investment and urban service delivery planning and financing is being made by the central government. Although urbanization as a national growth and development strategy will remain a central government policy responsibility, urban financing must function within a coherent enabling framework to ensure efficient and accountable provision of urban infrastructure and services. The Megapolis Plan is designed to (1) involve the provision of enhanced economic and utility services to support the location and growth of competitive economic agglomerations, (2) increase urban-to-rural and urban-to-urban linkages for greater interurban convergence of benefits, and (3) ensure that urban growth and the multidimensional urban and rural linkages are environmentally and socially sustainable.

An urban framework with an appropriate assignment of functions and subfunctions would encourage greater efficiency and accountability for urban service provision.

\subsubsection{Improve Options for Private Participation}

Accountable urbanization governance is crucial to ensure effective planning, financing, and delivery of needed urban infrastructure and essential urban services. Such a governance framework requires an institutional, legal, and regulatory structure, along with strong leadership and administrative capacity, to enable open and transparent participation of all key stakeholders, including central, provincial, and local governments; the private sector; and civil society. 
To date, however, urban development in Sri Lanka has been approached as a purely public sector issue, with urban planning being implemented by the government on behalf of the public. Despite over 4 decades of economic liberalization, there has hardly been any flow of private capital funds, technology, or management expertise into the provision of urban infrastructure and urban services. Opportunities for partnerships with the private or nongovernment sector in the provision of development services are notably absent. The current intergovernmental fiscal structure also generates concern. An example previously noted is the full financing of local authority salaries by the central government, which creates a perverse incentive to discourage local outsourcing by local authorities to the private sector.

The government recognizes the need to open up partnership opportunities with the private sector in order to mobilize private capital flows to finance urban infrastructure investments. Mobilizing private sector capital flow, either directly from private equity financing or through PPPs, is now seen as critical to meeting the investment requirements for the Megapolis project and other future urban infrastructure projects (Biller and Jabi 2013; Ministry of Megapolis and Western Development 2016; President of Sri Lanka 2016). Putting these requisites in place in Sri Lanka will require changing laws to enable and encourage partnership arrangements between the government and the private sector (Carter and Florizone 2013; World Bank 2014).

Creating a legal and regulatory environment to enable private sector involvement is a first step. However, private sector investment requires urban development projects that are financially viable, able to provide a financial return for investment. Projects must generate their own steady source of revenues from user charges or be backed by creditworthy central or local governments that can make repayments from their general revenues. A credible, accountable governance structure is a major determinant of government credit worthiness.

Sri Lanka faces a number of urbanization challenges emerging from the historical, spatial, institutional, and financial structure of urban development and service delivery. The challenges provide opportunities for intentional, proactive government policy and administrative changes, which could encourage the sustainable, inclusive urbanization needed to promote greater economic growth and structural transformation in Sri Lanka. To accomplish this, a holistic enabling framework is needed to successfully integrate 
(1) an intergovernmental fiscal environment that would clarify the roles and responsibilities of the central, provincial, and local governments regarding assigned expenditure responsibilities and OSRs, and the role and structure of intergovernmental transfers and subnational borrowing for capital investment;

(2) an environment for developing special planning that can effectively incorporate economic, social, and environmental planning, budgeting, and implementation; and

(3) a PPP environment that can establish the legal and regulatory framework necessary to encourage private sector participation in long-term funding and financing of urban infrastructure and urban service delivery.

The next section considers how to institutionalize a framework for urban finance in Sri Lanka.

\subsection{Strategy for Establishing an Institutional Framework for Urban Finance in Sri Lanka}

Urban finance must be approached holistically and in an integrated manner. Indeed, gaps in urban finance policy and practice call for strategic interventions to enhance the institutional basis for urban engagement by (1) resetting the intergovernmental fiscal framework, (2) operationalizing a spatial planning and coordination framework, and (3) institutionalizing a governance framework for urbanization.

Each of three strategic elements will require enhanced capacity:

- Urban governance is about empowering local authority as provider of urban services. To accomplish this, the restricted role and functions of local authority in urban development need to be broadened.

- Urban institutions require enhanced local authority accountability in its service provision role, in both its external (intergovernmental) and internal (local stakeholders) contexts.

- Urban finance for funding urban development needs to be reconsidered (e.g., OSR mobilization, intergovernmental transfers) as does how to leverage this funding to finance the upfront costs of urban infrastructure through a combination of debt, private equity, and PPPs. 


\subsubsection{Strategic Element 1: Reset the Intergovernmental Fiscal Framework for Urban Service Delivery and Finance}

The first strategic requirement for transforming urban engagement is to reset the intergovernmental fiscal framework for urban service delivery and finance. This will entail a systematic review of the assignment of functions and finance between the central, provincial, and local governments on the subsidiarity principle.

The recommendations for resetting the intergovernmental framework for urban service delivery and finance, by capacity element, are as follows:

(1) for urban governance,

(a) review and redefine urban service delivery roles and responsibilities at central, provincial, and local levels;

(b) review the assignment of functions across central, provincial, and local governments; and

(c) eliminate the central control of local cadres;

(2) for urban institutions,

(a) design and introduce vertical and horizontal urban service delivery program partnerships; and

(b) establish urban-local jurisdictions as the primary tier of service delivery units for central providers of urban utilities; and

(3) for urban finance,

(a) restructure the intergovernmental fiscal arrangements to reflect service delivery roles and responsibilities;

(b) establish an urban development grant to finance provincial and local urban medium-term service delivery plans;

(c) redesign financial transfers to a needs-based, normative, and performance-linked system;

(d) formulate and introduce a realistic basis for demarcating urban areas in local authorities to enable efficient levy of property taxes; and

(e) introduce policy and administrative reforms to enable increased subnational OSR mobilization.

The current structure has evolved incrementally based primarily on historic institutional inertia, resulting in duplication and overlap, inefficiencies and inequalities, as well as gaps in the delivery of important urban services. Resetting the intergovernmental context for urban service delivery and finance on the basis of subsidiarity is necessary to establish a coherent institutional 
framework for urban engagement. At the same time, establishing a system of periodic review, implementation coordination, and support is critical to ensure sustainability, efficiency, and accountability.

\subsubsection{Strategic Element 2: Operationalize a Spatial Planning and Coordination Framework}

The second strategic element is to effectively link the broader enabling intergovernmental fiscal framework to space. That is, a spatial planning and coordination framework constitutes the basis for efficient intergovernmental relations in ordering service delivery between the national, provincial, and local levels as partners in urban development. Sri Lanka's development experience suggests that integrating sectoral into spatial planning has been the weakest link in moving toward distributing the benefits of growth and development throughout the country.

Recommendations for operationalizing a framework for spatial planning and coordination of urban Services, by capacity element, are as follows:

(1) for urban governance,

(a) effectively link spatial and sectoral aspects into the intergovernmental urban service delivery framework; and

(b) establish a system of central, provincial, and local government coordination;

(2) for urban institutions,

(a) establish the basis for defining urban areas to better reflect urbanization and urban service delivery needs, and

(b) formulate provincial- and local-authority-level urban results frameworks; and

(3) for urban finance, formulate a provincial- and local-authority-level, medium-term financing strategy for urban service delivery.

As outlined in the foregoing, the rational application of sectors to space will lead to better development outcomes when services are better aligned with spatial needs according to the realities of urban change. It is then imperative that the nature and scope of urban change can be captured by a realistic demarcation of urban areas. Engagement with urbanization is trapped within this sectoralspatial discontinuity. A spatial planning and coordinating framework to link sectors and spaces is a necessary condition for comprehensive engagement with urbanization. 


\subsubsection{Strategic Element 3: Institutionalize a Governance Framework for Urbanization}

The third strategic element in resetting the institutional basis for urban engagement is a governance framework comprised of structures and processes for bringing about the partnership of urban stakeholders. Such a framework would redefine vertical roles, responsibilities, and accountabilities at central, provincial, and local levels in terms of subsidiarity as proximate, middle, and upstream areas.

Recommendations for institutionalizing an urban governance partnership framework, by capacity element, are as follows:

(1) for urban governance, create subnational-level coordination for private sector and civil society participation;

(2) for urban institutions, establish guidelines for private sector and civil society participation in urban governance at central, provincial, and local levels; and

(3) for urban finance,

(a) mainstream participatory budgeting practices;

(b) explore PPP; and

(c) introduce effective central, provincial, and local urban development monitoring and reporting systems.

The framework would also create space for contextualizing partnership interventions and formulating performance frameworks comprised of urbanization outcomes at each level. The governance framework would also provide for horizontal partnerships in urban action especially at the central, provincial, and local levels. Such a framework is necessary to bring about complementarity in program actions of urban stakeholders, redefining accountabilities arising from the vertical and horizontal relations.

Further, the partnership approach would open up possible private sector engagement in the urban sector through debt finance, direct equity investments, or PPPs. 


\section{References}

Amirtahmasebi, R., M. Orloff, S. Wahba, and A. Altman. 2016. Regenerating Urban Land: A Practitioner's Guide to Leveraging Private Investment. Urban Development Series. Washington, D.C.: World Bank.

Andersson, M. 2015. Unpacking Metropolitan Governance for Sustainable Development. GIZ UN Habitat Discussion Paper. http:// metropolitangovernanceforum.org/node/217

Ardila-Gomez, A., and A. Ortegon-Sanchez. 2016. Sustainable Urban Transport Financing from the Sidewalk to the Subway: Capital, Operations, and Maintenance Financing. Washington, D.C.: World Bank.

Asia Foundation. 2008. Revenue Enhancement: Financial Management Training Module 2 of 4 . http://asiafoundation.org/publication/revenueenhancement-financial-management-training-module-2-of-4/ 2016. Local Government Finance Study-Sri Lanka: North East Local Services Improvement Project: Final Report. (Unpublished draft)

Asian Development Bank (ADB). 2011. Democratic Socialist Republic of Sri Lanka: Lagging Local Authorities Infrastructure Development. Technical Assistance Consultant's Report, Project Number 42459. Mandaluyong City: ADB

Australia Department of Treasury and Finance. 2014. Australian Government Cost Recovery Guidelines. Canberra: Commonwealth of Australia. https:// www.finance.gov.au/resource-management/charging-framework/

Bahl, R. 2008. The Pillars of Fiscal Decentralization. CAF Working Paper No. 2008/07 https://www.caf.com/media/3961/200807Bahl.pdf

Bahl, R., and R. Bird. 2008. Subnational Taxes in Developing Countries: The Way Forward. Public Budgeting \& Finance. (Winter 2008).

Bahl, R., and J. Martinez-Vazquez. 2006. Sequencing Decentralization. World Bank Policy Research Working Paper 3914. Washington, D.C.: World Bank.

Bahl, R., J. Linn, and D. Wetzel. 2013. Governing and Financing Metropolitan Areas in the Developing World. In Bahl, Linn, and Wetzel (eds). Financing Metropolitan Governments in Developing Countries. Cambridge, MA: Lincoln Institute of Land Policy. pp. 1-30.

Biller, D., and I. Jabi. 2013. Investing in Infrastructure: Harnessing its Potential for Growth in Sri Lanka. Washington, D.C.: World Bank.

Bird, R. 2003. User Charges in Local Government Finance. www1.worldbank.org/ publicsector/decentralization/June2003Seminar/Bird2.pdf 2011. Subnational Taxation in Developing Countries: A Review of the Literature. Journal of International Commerce, Economics and Policy.

Bird, R., and E. Slack. 2007. An Approach to Metropolitan Governance and Finance. Environment and Planning C: Government and Policy. 25(5): 729-55. 
2013. Metropolitan Public Finance: An Overview. In Bahl, Linn, and Wetzel (eds). Financing Metropolitan Governments in Developing Countries. Cambridge MA: Lincoln Institute of Land Policy. pp. 135-58.

Boex, J., and S. Yilmaz. 2010. An Analytical Framework for Assessing Decentralized Local Governance and the Local Public Sector. IDG Working Paper No. 2010-06, 2010. http://www.urban.org/research/publication/analyticalframework-assessing-decentralized-local-governance-and-local-publicsector

Brunner, H-P. 2013. What is Economic Corridor Development and What can it Achieve in Asia's Subregions? ADB Working Paper Series on Regional Economic Integration, No. 117. Mandaluyong City: ADB.

Carter, L., and R. Florizone. 2013. A Winning Framework for Public-Private Partnerships: Lessons from 60-Plus IFC Projects. Smart lessons Brief. Washington, D.C.: World Bank. https://openknowledge.worldbank.org/ handle/10986/18683

Central Bank of Sri Lanka (CBSL). 2014. Economic and Social Statistics of Sri Lanka 2014. Colombo: CBSL. www.cbsl.gov.lk/pics_n_docs/10_pub/_ docs/statistics/.../econ_\&_ss_2014_e.pdf 2015. Annual Report 2014. Colombo: CBSL.

Cities Alliance. 2015. Sustainable Development Goals and Habitat III: Opportunities for a Successful New Urban Agenda. www.citiesalliance. org/sites/citiesalliance.org/files/Opportunities $\% 20$ for $\% 20$ the $\% 20$ New\%20Urban\%20Agenda.pdf

De, P., and K. Iyengar. 2014. Developing Economic Corridors in South Asia. Mandaluyong City: ADB.

Department of Census and Statistics (DCS). 2015. Government Statistics 2015. Colombo: DCS.

Dirie, I. 2005. Municipal Finance: Innovative Resourcing for Municipal Infrastructure and Service Provision. Prepared for the Commonwealth Local Government Forum in cooperation with ComHabitat.

DuPuis, N., and C. McFarland. 2016. Paying for Local Infrastructure in a New Era of Federalism: A State-by-State Analysis. Washington, D.C.: National League of Cities http://www.nlc.org/resource/local-infrastructure-funding-report (accessed 26 October 2016).

Eichler, J., A. Wegener, and U. Zimmermann. 2012. Financing Local Infrastructure-Linking Local Governments and Financial Markets. Bonn: Deutsche Gesellschaft für Internationale Zusammenarbeit (GIZ). www.citiesalliance.org/.../ Financing\%20local\%20Infrastructure\%20 Finance\%20final.pdf

Ellis, P., and M. Roberts. 2015. Leveraging Urbanization in South Asia: Managing Spatial Transformation for Prosperity and Livability. South Asia Development Matters Series. Washington, D.C.: World Bank. 
Fan, Mingyuan. 2015. Sri Lanka's Water Supply and Sanitation Sector: Achievements and a Way Forward. ADB South Asia Working Paper Series, No. 35. Mandaluyong City: ADB.

Finance Commission of Sri Lanka. 2014. Annual Report 2014. Colombo: Finance Commission of Sri Lanka.

Floater, G., and P. Rode. 2014. Steering Urban Growth: Governance, Policy and Finance. New Climate Economy Cities, Paper 02. London: London School of Economics.

Government of Sri Lanka (GSL). 2011. National Physical Planning and Policy Plan 2011-2030. Colombo: GSL.

Gunawardena, A. 2016. Financing and Sustaining Sri Lanka's Urbanization and Urban Development. Prepared for the Sri Lanka Country and Employment Diagnostic Studies: Consultation Workshop, Colombo, Sri Lanka, 19 August.

Howe, C. 2005. The Functions, Impacts and Effectiveness of Water Pricing: Evidence from the United States and Canada. Water Resources Development. 21(1): 43-53.

Indrasiri, LH. 2006. Urbanization and Urban Redefinition-Sri Lanka 2005. Colombo: Urban Development Authority.

Jeong, Hoe Yun. 2016. Why Economic Corridor Development is the Way Forward for South Asia. Asian Development Blog published 26 July, https://blogs. adb.org/blog/why-economic-corridor-development-way-forward-southasia (accessed 29 October).

Kanuri, C., A. Revi, J. Espey, and H. Kuhle. 2016. Getting Started with the SDGs in Cities: A Guide for Stakeholders. A Report by the Sustainable Development Solutions Network: A Global Initiative for the United Nations. unsdsn.org/ wp-content/uploads/2016/07/9.1.8.-Cities-SDG-Guide.pdf

Kelly, R. 2013. Making the Property Tax Work. Working Paper. Atlanta, Georgia: Georgia State University.

Kim, J. 2016. Handbook on Urban Infrastructure Finance. Montreal: New Cities Foundation. https://gpc.stanford.edu/publications/handbook-urbaninfrastructure-finance

Kurukulasuriya, G. 1979. Poverty and the Urban-Rural Relationship in Sri Lanka. In Rural-Urban Relations in Sri Lanka: A Case Study. UNCRD Country Monograph. Nagoya: United Nations Centre for Regional Development.

Massachusetts Department of Revenue (MDR). 2001. Betterments and Special Assessments: Assessment and Collection Procedures. Boston, MA: MDR.

Merk, O., S. Saussier, C. Staropoli, E. Slack, and J-H Kim. 2012. Financing Green Urban Infrastructure. 2012/10. Paris: Organisation for Economic Co-operation and Development. 
Ministry of Megapolis and Western Development. 2016. Western Region Megapolis Plan-2030: From Island to Continent. Colombo: Ministry of Megapolis and Western Development.

Ministry of Provincial Councils and Local Government. 2014. Review of Financial

Performance of Local Authorities. Colombo: Ministry of Provincial Councils and Local Government. (Mimeo).

Mitra, S., R. Hasan, M. Sharma, H.Y. Jeong, M. Sharma, and A. Guha. 2016. Scaling New Heights: Vizag-Chennai Industrial Corridor, India's First Coastal Corridor. Mandaluyong City: ADB.

Mohanty, P. 2016. Financing Cities in India Municipal Reforms, Fiscal Accountability and Urban Infrastructure. New Delhi: Sage Publishing.

Munasinghe, J. 2013. Policies and Issues in Urban Development in Sri Lanka: An Examination of the Inter-Domain Gaps. Sri Lanka Journal of Social Sciences 2012/2013, 35/36 (1\&2): 9-17.

Newport Partners, LLC and Virginia Polytechnic Institute and State University (NPVP). 2008. Impact Fees and Housing Affordability: A Guide for Practitioners. Report prepared for the United States Department of Housing and Urban Development. https://www.huduser.gov/portal/ publications/affhsg/impactfees.html

Peterson, G. 2009. Unlocking Land Values to Finance Urban Infrastructure. Washington, D.C.: World Bank.

President of Sri Lanka. 2016. Western Province Megapolis Development Plan Launched. http://www.president.gov.lk/western-province-megapolisdevelopment-plan-launched/ (accessed 10 October 2016).

Roberts, B., and T. Kenaly. 2006. Lessons and Strategies for Sustainable Urban Futures. In Urbanization and Sustainability in Asia: Case Studies or Good Practice. Mandaluyong City: ADB.

Serva, L. 2014. How São Paulo Uses "Value Capture" to Raise Billions for Infrastructure. 22 May. http://citiscope.org/story/2014/how-sao-paulouses-value-capture-raise-billions-infrastructure

Siemens, PWC, and Berwin Leighton Paisner. 2014. Investor Ready Cities: How Cities can Create and Deliver Infrastructure Value. www.pwc.com/gx/en/ psrc/publications/assets/pwc-investor-ready-cities-vl.pdf

Slack, E. 2009. Guide to Municipal Finance. Nairobi: UN Habitat.

Suzuki, H., J. Murakami, YH Hong, and B. Tamayose. 2015. Financing TransitOriented Development with Land Values: Adapting Land Value Capture in Developing Countries. Urban Development Series. Washington, DC: World Bank.

United Kingdom Department for Communities and Local Government (UKDCLG). 2011. Community Infrastructure Levy: An Overview. London: DCLG Publications. www.gov.uk/government/uploads/system/uploads/ attachment.../1897278.pdf 
UN Habitat. 2011. Land and Property Tax: A Policy Guide. Nairobi: UN-Habitat. 2016a. HABITAT III Policy Paper 5-Municipal Finance and Local Fiscal Systems. 69 pp. Nairobi: UN-Habitat. 2016b. World Cities Report 2016. http://wcr.unhabitat.org/

United Nations (UN). 2015. Transforming our World: The 2030 Agenda for Sustainable Development. General Assembly Resolution, 70th Session, New York.

Van Horen, B., and S. Pennawala. 2006. Sri Lanka. In Roberts and Kenaly (eds). Urbanization and Sustainability in Asia: Case Studies or Good Practice. Mandaluyong City: ADB.

Walters, L. 2013. Land Value Capture in Policy and Practice. Journal of Property Tax Assessment \& Administration. 10(2): 5-21.

World Bank. 1999. Dynamic Cities as Engines of Growth. In World Development Report 1999/2000: Entering the 21st Century. New York: Oxford University Press.

2004. Sri Lanka: Reshaping Economic Geography: Connecting People to Prosperity. Washington D.C.: World Bank.

2006. Sri Lanka-Service Delivery and Decentralization: Assessment and Options. Washington D.C.: World Bank.

2012. Planning, Connecting, and Financing Cities-Now: Priorities for City Leaders. Washington D.C.: World Bank.

2014. Overcoming Constraints to the Financing of Infrastructure, Success Stories and Lessons Learned: Country, Sector and Project Examples of Overcoming Constraints to the Financing of Infrastructure. Prepared by the Staff of the World Bank Group for the G20 Investment and Infrastructure Working Group, February. 2016. World Bank Country Data: Sri Lanka. http://data.worldbank.org/ country/sri-lanka (accessed 15 October).

World Bank and UN Habitat. 2012. Turning Sri Lanka's Urban Vison into Policy Action. Washington D.C.: World Bank.

World Economic Forum (WEF). 2014. Global Agenda-Accelerating Infrastructure Delivery: New Evidence from International Financial Institutions. Geneva: WEF.

Zhang, Xing Quan. 2011. The Economic Role of Cities. Nairobi: UN Habitat. 


\section{Chapter 8.}

\section{Sri Lanka's Labor}

\section{Market and Human}

\section{Capital Formation*}

Kiyoshi Taniguchi

\subsection{Introduction}

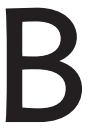

acked by strong growth, the government's development policy-entitled Empowered Sri Lanka (Balagath Sri Lanka) and launched in January 2017-aspires to make Sri Lanka a competitive, middle-income country. The policy's ambitious vision sees Sri Lanka as a logistics, commercial, energy, and knowledge hub for Asia.

Sri Lanka's economy has grown at an average of 6.4\% between 2010 and 2015 (World Bank, WDI database). The growth was accompanied by structural changes toward wider diversification and higher productivity. The share of agriculture in total gross domestic product (GDP) has been declining and will continue to do so, while the high-value-adding sectors such as manufacturing and services will gain the greater labor share. As Sri Lanka's economy has transitioned from a ruralbased agricultural economy into a more urbanized high-value-adding economy, the country is facing new labor and skills match challenges.

Along with being a more urbanized high value-adding economy, industry's shares of labor have been transformed from agriculture to services. As a result, labor demand will be more job-specific, which means that the employers are looking for workers with value-adding skills for their business (Dundar et al.

This chapter has benefited from the background papers prepared by the following researchers: Nisha Arunatilake, Sewin Chan, Ramani Gunatilaka, Tadateru Hayashi, Priyanka Jayawardena, Nomaan Majid, Ronald Miller, and Ravindra Rannan-Eliya. 
2014). At the same time, the population is gradually aging, and the dependency ratio will be deteriorating. In the middle of the demographic and economic shifts, the education system, which affects the pattern of human capital accumulation, needs to match ongoing changes. In particular, the higher education system needs to provide adequate learning and training for students and youth to acquire skill sets that fully meet the needs of labor demand. Unfortunately, substantial mismatches between labor demand and supply persist, especially among high-skilled workers.

This chapter intends to inform policy makers and researchers about the shortcomings in the education and skill training system in Sri Lanka that need to be addressed to catch up with the changing economic structure. Some policy reforms of the education system are warranted in order to appropriately equip the skilled labor force in the long run and for Sri Lanka to enhance its competitiveness as a middle-income country. In particular, the female labor force participation rate (LFPR) needs to be improved. Private sector participation in higher education should be encouraged to reduce dominance of the public sector. Past experience suggests that the public sector has insufficient capacity to produce engineering graduates to meet increasing demand for engineers in the job market. Considering the current dearth of teachers for science and mathematics, efforts need to be accelerated to close this gap. Government needs to encourage more private schools to enter the education market and to implement policies for females to participate in the labor market, especially in the high-value-adding sections of the labor market. Government needs to consider allowing more private schools to enter the education market and to implement policies for females to participate in the labor market, especially in the high-value-adding sections of the labor market.

\subsection{Employment Trends and Patterns}

\subsubsection{Shifts of Sectoral Composition}

Strong economic expansion has been brought about by an increase in value-added output across all economic sectors. Expansion in manufacturing appears to have been the principal driver. Productivity has also risen across industry, services, and construction, while remaining virtually unchanged in agriculture (Figure 8.1). The result has been a fairly balanced growth process where industrialization has not taken place at the expense of other sectors. This is evident in Figure 8.2, which shows that industry, including manufacturing, has experienced the greatest change in terms of value-added shares during the reference period. In contrast, contributions to GDP of construction and services have remained 
stable while agriculture's share has declined marginally. Employment shares by sector appear even more stable, as Figure 8.3 shows. While the total number of workers grew in each sector, and grew faster in agriculture than in the other sectors, employment shares of all sectors have remained remarkably stable.

Figure 8.1: Change in Value Added per Worker by Sector, 2006 and 2014 (\%)

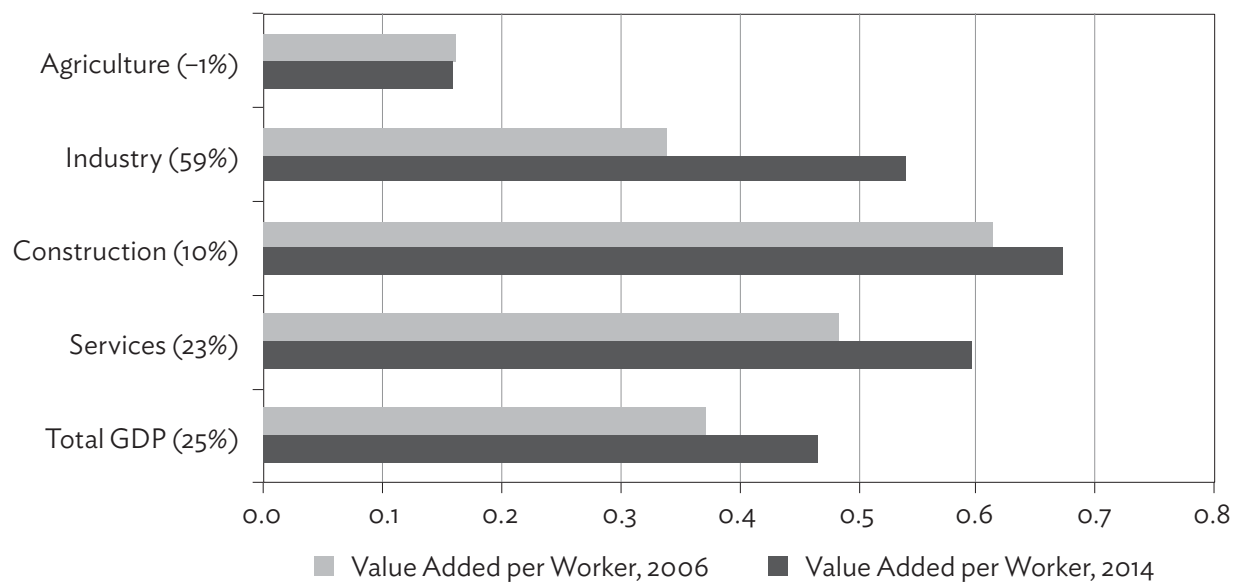

$\mathrm{GDP}=$ gross domestic product.

Note: Figures in parentheses are productivity growth rates experienced by the four sectors during the period, and productivity denotes value added per worker in the sector.

Source: Majid and Gunatilaka (forthcoming).

Figure 8.2: Sectoral Contribution to GDP by Economic Sector, 2006 and 2014 (\%)

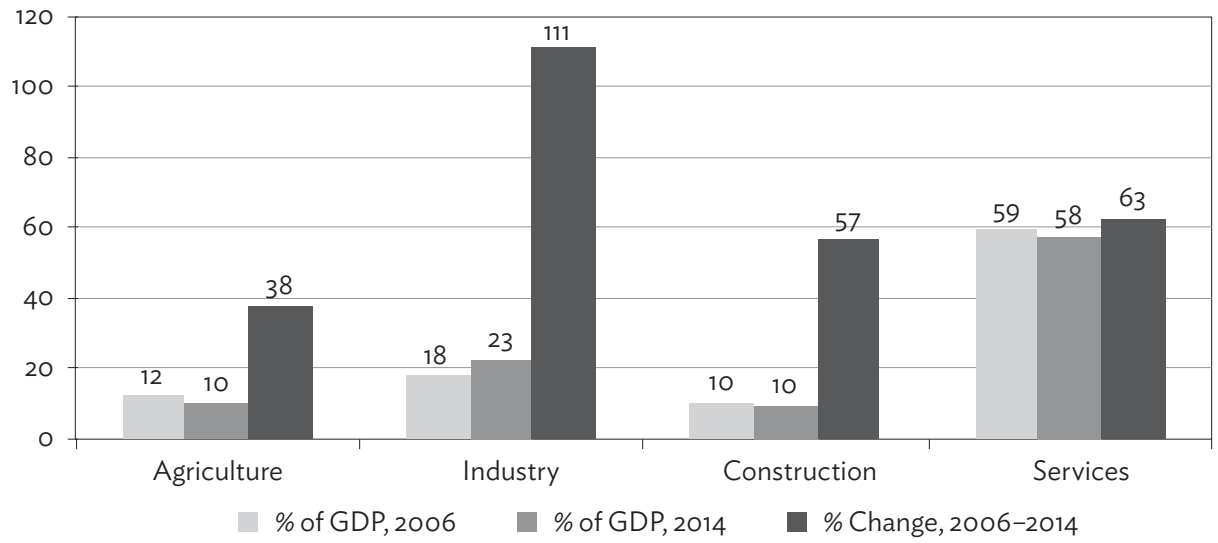

GDP = gross domestic product.

Source: Majid and Gunatilaka (forthcoming). 
Figure 8.3: Sectoral Contribution to Employment, 2006-2014 (\%)

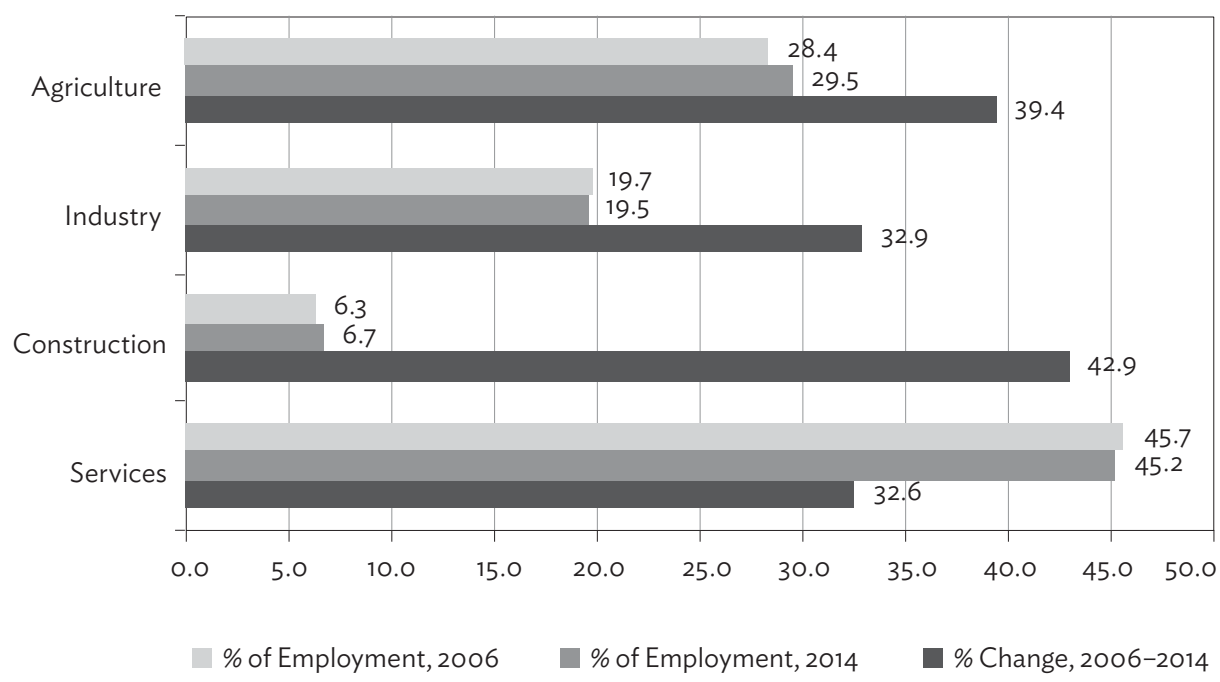

Sources: Majid and Gunatilaka (forthcoming).

\subsubsection{Job Growth and Required Skills}

The increase in employment has not kept pace with Sri Lanka's increase in working age population. From 2006 to 2014, the total jobs went up by almost 367,000 or $5.4 \%$. This is lower than the increase in the working age population of 764,000 and its growth of $6.4 \%$ during the same period. The employed population as a proportion of the total is often used as an indicator of an economy's need to create jobs. This ratio has decreased in Sri Lanka, from $57.1 \%$ in 2006 to $56.6 \%$ in 2014-a marginal deterioration in job creation.

Nonagricultural employment has grown at a faster pace than agricultural employment, indicating a shift in employment away from agriculture. Of total employment, the proportion of nonagricultural employment increased from $68.9 \%$ in 2006 to $70.3 \%$ in 2014 . However, a large proportion of the population still depends on agriculture for employment. As such, policies for improving productivity in the agriculture sector would help to improve living standards of the people employed in agriculture. 
The proportion of wage workers increased from $56.8 \%$ to $57.8 \%$ from 2006 to 2014. The uptick was greater for formal sector workers, indicating a marginal increase in better jobs. This increase in the wage worker proportion is mainly explained by the increase of nonagricultural wage workers, particularly in the public and formal private sectors (Figure 8.4). In 2014, 28.0\% of the total employment was in formal wage employment, with the public and formal private sectors contributing $14.7 \%$ and $13.3 \%$, respectively, to the total employment. The increase in formal sector employment is a positive development; however, a large proportion of workers remain informally employed and $39.4 \%$ are vulnerable workers (self-employed or unpaid family workers).

The increase in wage workers is mainly due to the increase of public sector employment (Figure 8.4). Of the total increase in employment, $51.8 \%$ or more than 190,000 jobs were public sector jobs. The number of formal private sector jobs also grew substantially, and the growth in informal sector jobs was relatively less. The increase in public sector employment is due to successive governments' policies to place graduates in jobs. Many public sector employment opportunities were created for recent graduates. The government is not likely to be able to continue to provide employment for so many graduates, and thus a more sustainable means of creating employment is needed. A recent survey by the National Human Resource Development Council suggests that public sector recruitment of unemployed graduates is not based on a strategic plan (NHRDC 2013). The survey reported that $48 \%$ of respondents were dissatisfied with the way graduates were recruited. The main reasons were political interference (43\%), unsystematic methods of recruitment (33\%), and recruitment not aligned with degree qualification (8\%). There is much room to increase productivity in the public sector by enhancing the avenues to recruit the graduates.

The increase in jobs included an increase in vulnerable employment. This is mainly due to the increase in self-employment. In 2014, almost $40 \%$ of employment in the economy was classified as vulnerable employment. This proportion declined marginally, from $40.1 \%$ in 2006 to $39.4 \%$ in 2014 . A high proportion of vulnerable workers indicates that many people have lower quality jobs, because social protection is mainly available to workers in the formal sector. Although employment trends are moving toward increased formal employment, the change is happening rather slowly. 
Figure 8.4: Contribution to the Difference in Job Growth, 2006 to 2014 (\%)

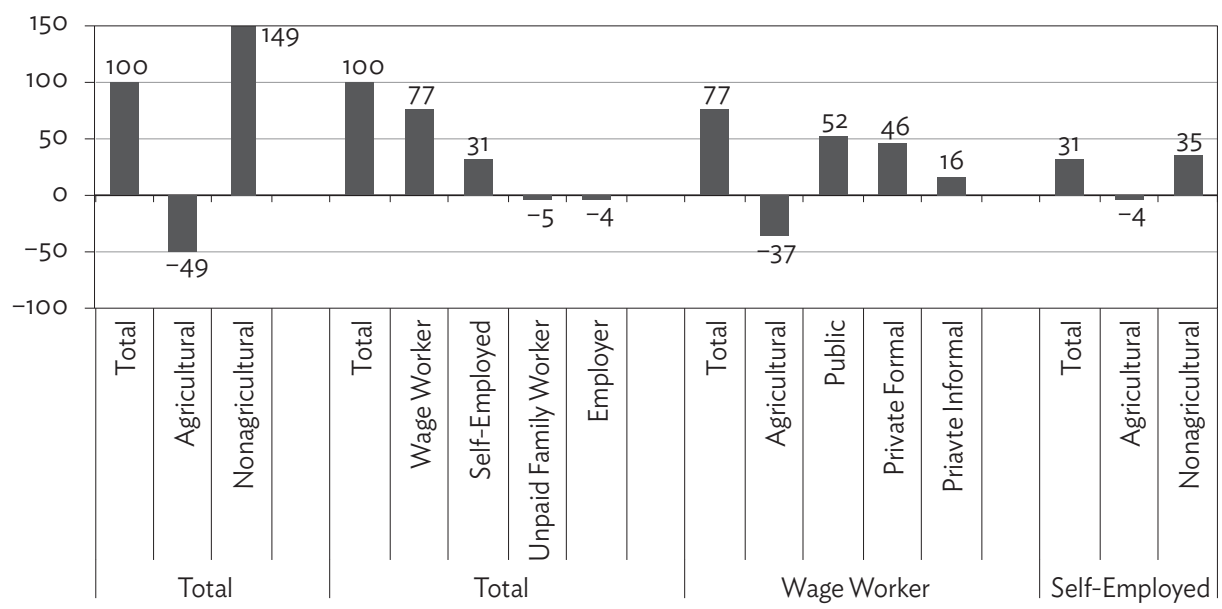

Note: From 2006 to 2014 the total number of jobs in Sri Lanka increased by almost 367,000. The figure shows the contribution of different types of jobs to this growth as a percent of the total increase. Source: Arunatilake (forthcoming).

As a result of the shifts in the sectoral composition of labor, the composition of skills required has changed across sectors. For this chapter, skills are defined according to occupation and the highest category of education attained. ${ }^{1}$ From the aspect of education-based skills levels, the share of highly-skilled workers increased from 2006 to 2014 in the economy at large and in each sector, while the share of low-skilled workers declined. The share of workers with middle levels of education has remained stable (Figure 8.5a). In occupation-based skill categories, the shares of highly-skilled workers have declined in the economy at large and in each sector. Even though the share of low-skilled workers has declined in the economy in general, there are key sectoral differences. The share of low-skilled workers has declined in agriculture and services, but has increased slightly in industry and construction. The shares of medium-skill-level occupations have expanded significantly (Figure 8.5b). The changes in the educational structure of employment appear to complement the consistently rising labor productivities across sectors, as observed earlier. Increasing skills underpinned by better education are likely to have pushed up productivity levels across the board.

1 "Highly-skilled" workers are defined in terms of occupation as those in the management, professional, and technician categories and in terms of education as those with the General Certificate of Education Advanced Level qualification or higher. "Medium-skilled" workers are in clerical, sales, and skilled agricultural and fisheries occupations, or have passed their General Certificate of Education Ordinary Level but not Advanced Level qualifications. "Low-skilled" workers are defined as craft workers, machine operators and assemblers, and elementary workers, or those who have not progressed beyond secondary education. 
At the same time, the composition of employment by occupation skill levels suggests that, because educational attainment at the lower end of the scale has risen from 2006 to 2014, the share of the medium-skill segments has increased. The expansion of the medium-skill segments was partly taken from the shares of highly-skilled occupations in the distribution.

Figure 8.5: Distribution of Employment by Skills Level across Economic Sectors, 2006 and 2014

Figure 8.5a: By Education Category

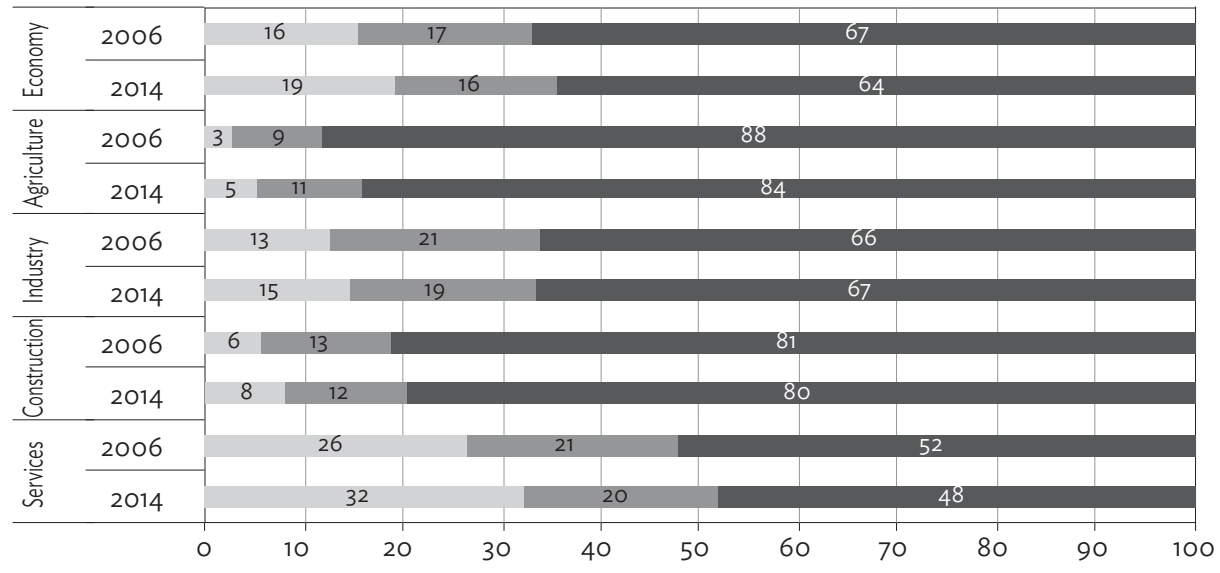

High Levels of Education $\quad$ Medium Levels of Education $\quad$ Low Levels of Education

Figure 8.5b: By Occupation Category

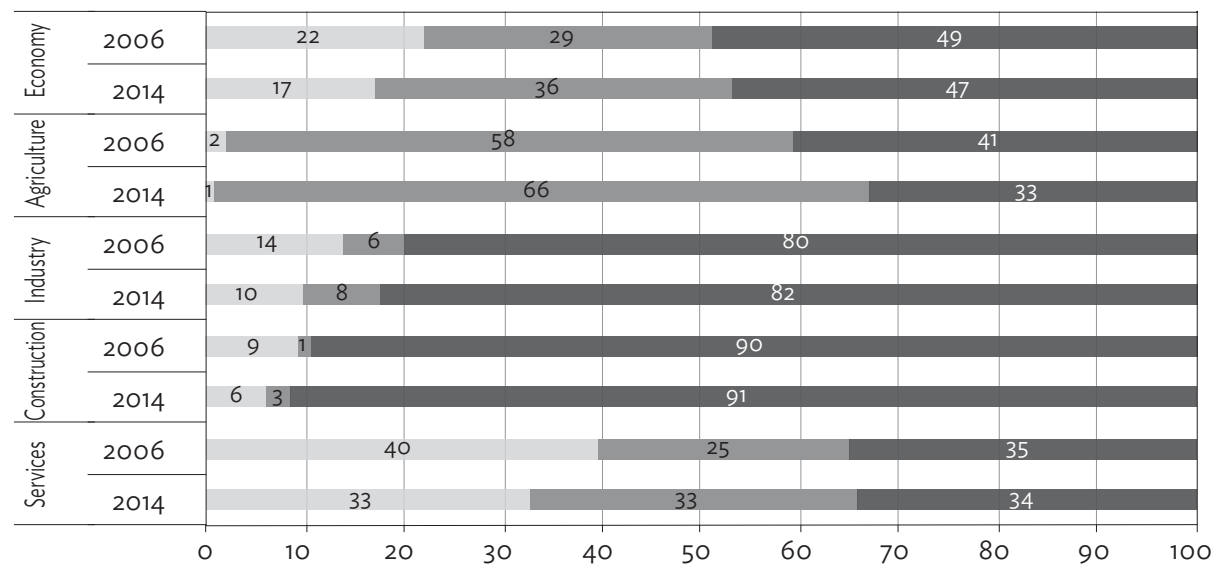

Highly-Skilled Occupations \Medium-Skilled Occupations $\square$ Lower-Skilled Occupations

Source: Majid and Gunatilaka (forthcoming). 
Labor shortage is one of the biggest concerns in the Sri Lanka labor market (Athukorala 2016). The labor scarcity is predominantly concentrated in urban areas in the Western Province and in the two free trade zones. The higher cost of living and relatively poor accommodation facilities in those areas are listed as a hindrance for domestic labor mobility. At the same time, due to Sri Lanka's open investment policy, its manufacturing sector is vertically integrated into the global supply chain through foreign direct investment. Foreign investors seek low-cost labor; therefore, rather than tapping the labor market in the urban areas, they set up factories in rural areas where the labor cost is lower. Workers from the rural areas generally do not go to urban areas to work, but they do tend to work abroad due to the vertical integration of industry. This structural issue creates a labor shortage in urban areas and provides opportunities to work abroad.

\subsubsection{High Education Attainment}

Sri Lanka has achieved universal primary education. Nearly $100 \%$ of pupils complete grade 5 (UNDP 2015). Nationwide, $98 \%$ of children aged $6-10$ years and $95 \%$ of children aged 11-14 years were attending school in 2012/13. This high rate of primary education attainment is largely due to the Universal Free Education Policy implemented in 1945. The Compulsory Education Policy implemented in 1998 applies to children aged through 14 years.

The share of children attending school declines sharply after the age of 14. At the national level, the percentages of children aged 15-16 years attending school have dropped to $85.5 \%$ for boys (Figure 8.6 ) and $86.7 \%$ for girls (Figure 8.7), indicating that about $15.0 \%$ of children in this age group drop out of school education. The percentage of children aged 15-16 living on plantations (the "estates") and not attending school is higher-at 31.4\% among the boys. Although the percentage of girls aged 15-16 years in the estates not attending school is higher than that in the urban and rural sectors, it is much lower than in the dropout rate of boys on the estates. The government's decision to raise the age of compulsory education to 16 years is expected to increase school attendance among children at least until they complete the General Certificate of Education Ordinary Level examination. Furthermore, the new government policy is to increase continuous schooling up to grade 13 (i.e., education up to 18 years) to enable all students to complete the Advance Level examination. 
Figure 8.6: Boys (6-18 years) Attending School, by Age Group and Sector, School Year 2012/13 (\%)

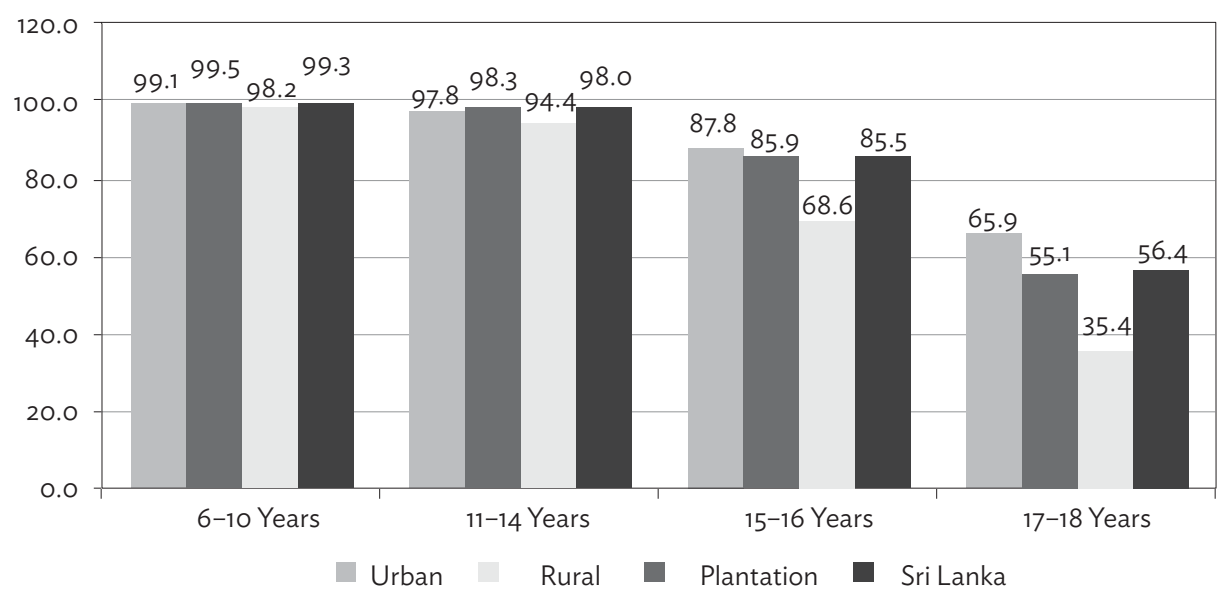

Source: Household Income and Expenditure Survey 2012-2013, cited in UNDP (2015).

Figure 8.7: Girls (6-18 years) Attending School, by Age Group and Sector, School Year 2012/13 (\%)

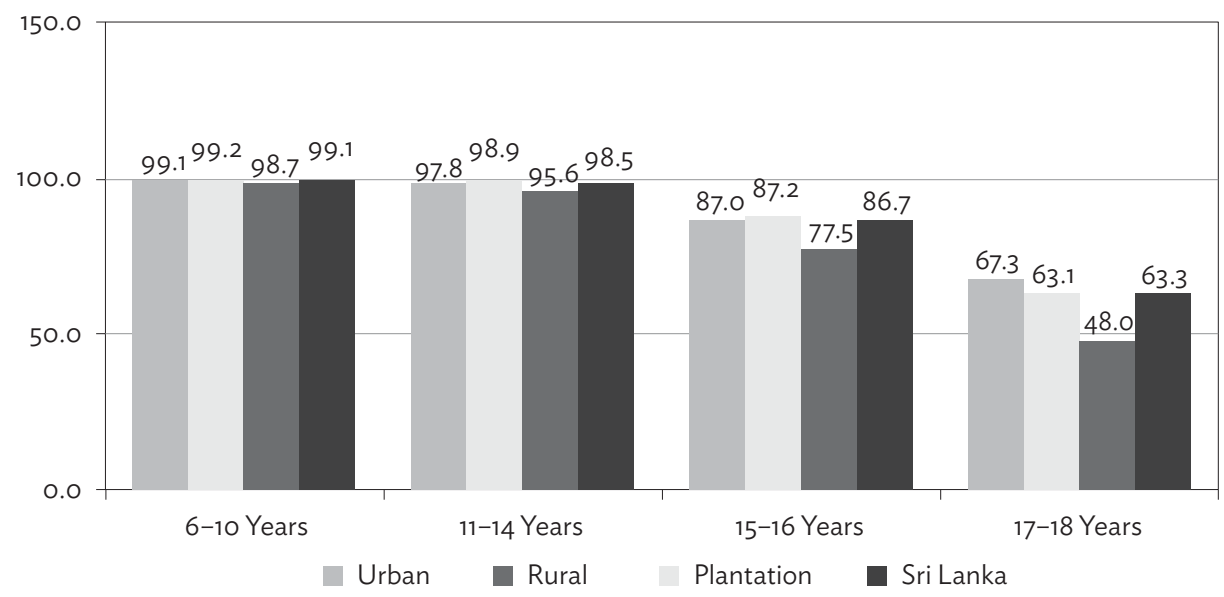

Source: Household Income and Expenditure Survey 2012-2013, cited in UNDP (2015). 


\subsection{Education System Issues}

Since the Universal Free Education Policy was implemented in 1945, Sri Lanka has been committed to providing free education from kindergarten through university. Public spending on education covers general education, higher education, and most vocational education programs. Successive governments implemented several welfare programs to improve access to general education, including the distribution of free textbooks, scholarships for disadvantaged students, free uniforms, and subsidized transport facilities. Consequently, Sri Lanka had little difficulty meeting the Millennium Development Goals related to education.

All private schools were nationalized in 1961, and were no longer allowed to provide general education. Private schools established before 1961 were taken over by the government; some were allowed to function under the supervision of the Ministry of Education. Given the restriction on private schools, international schools were established from the late 1970s under the Companies Act of Sri Lanka. International schools are not registered with the Ministry of Education and are not required to follow the national curriculum or implement the national examinations.

The Mahapola Higher Education Scholarship Trust Fund was established by the Act of Parliament No. 66 of 1981. The Fund's objectives include (1) to provide higher education facilities to the youth; (2) to assist deserving youth who have completed their secondary education satisfactorily, to enable them to complete their academic, industrial, or technical education at a university or technical or higher educational institute; (3) to set up and help to set up and manage vocational training institutes for enabling youth to develop vocational skills and competencies; (4) to set up and assist in the management and conduct of schools, institutes, foundations, and similar institutions engaged in the furtherance of education; and (5) to provide assistance for developing and improving the skills and competence of lecturers, teachers, and persons engaged in the furtherance of education. The Fund provides much needed scholarships and funding to higher education institutions; it also increases competition for places at state universities.

Since the effective nationalization of private schools, the role of private provision of higher education in Sri Lanka needs to be strengthened, supported by a sound mechanism for quality assurance and accreditation. The number of General Certificate of Education Advanced Level graduates exceeds the state universities' absorptive capacities. In response to the increasing number of students who want higher education, a parallel system of private higher 
education has emerged but the capacity of private sector providers should be strengthened. These institutions may be affiliated with foreign universities and operate independently (National Education Commission 2009). The private sector institutes are either (1) registered under the Ministry of Higher Education and Highways as degree-awarding institutes, or (2) unregistered higher education institutes that operate outside the purview of the University Grant Commission (CBSL 2016). There is no mechanism to assure the quality of degrees offered by the institutes affiliated with foreign universities. As of 2012, Sri Lanka had 9,931 government schools and 98 recognized private schools (MOE 2013). In addition there were 560 Buddhist centers of learning (pirivenas) and approximately 300 "international schools."

Given the Sri Lankan education system's legacy and institutional arrangements, it faces new challenges to improving the quality and relevance of education. This is necessary to equip workers with the evolving skills demanded in a globalized world. There are substantial skill mismatches between the demand for and supply of workers, especially in higher education and for highly skilled workers (Dundar et al. 2014). University education is beset with the challenge of meeting and improving the quality and relevance of courses to make them compatible with labor market requirements (ADB 2007). There is a wide gap between what students learn at school and what the employers require for business. The quality of the general education system, mainly provided by the public sector, does not equip students sufficiently with productive skills.

Because Sri Lanka's labor market now requires specific job skills, the education system needs to be substantially modernized accordingly. The economy needs workers who can think and act creatively, work industriously and productively, and innovate and adapt to available technologies. Attempts to improve the quality and relevance of general education have been made by introducing market-oriented subjects and a curriculum more oriented to practical needs, but the attempts were hampered by implementation issues, including financial and resource constraints. With constraints on public finance and limited private sector participation in education, meeting the emerging needs of Sri Lanka's labor market is a major challenge. A major education policy change is required. This chapter argues that allowing the private sector to reenter the education market is a feasible way to educate students who can afford to pay for it, and would contribute to evolving a modernized and creative economy with limited increase in fiscal outlays.

While there is no entry restriction, the limited number of private sector institutions in the higher education system has created at least three detrimental impacts. First is the public system's limited absorptive capacity. Many high 
school graduates who are fully capable of completing tertiary education cannot enter universities due to the limited places available. Second, public schools are heavily subsidized by the government and fiscal outlays for tertiary education are significant. Public education expenditures were slightly less than $2 \%$ of GDP in 2014, which is modest, and tertiary education absorbs a large share-about a quarter-of overall education expenditures. This is enormous considering that university enrollment is approximately $2 \%$ of the general education enrollment. Third, even though the quality of education is difficult to measure, indirect measures and anecdotal evidence indicate that substantial quality issues persist in the higher education system.

Some skills demanded by the market are in especially short supply. Two key ones are English language skills and information technology skills (Dundar et al. 2014). Teachers for subjects such as mathematics, science, English, and information technology are in short supply, especially in rural areas. The gap is partly because the qualifications of teachers being recruited under "unemployed graduate recruitment" schemes are not aligned with the subjects in demand.

\subsection{Demographic Changes}

The Sri Lankan population is aging as life expectancies have lengthened and birth rates have fallen. Sri Lanka has come to the end of its period of benefiting from the "demographic dividend." As a result, economic growth will be reduced because the working-age population will grow more slowly. This will be the case even if technology and capital accumulation continue to grow at a current high pace.

While Sri Lanka is not far along the demographic transition from high birth rates to lower ones accompanied with increased life expectancy, the country is further along in the transition than almost all other lower middle-income comparators. About $3.5 \%$ of Sri Lanka's population is classified as elderly (over 64 years). Some researchers claim that no other country has gone this far in the demographic transition at such an early stage of economic development (World Bank 2008).

An aging population has manifold effects on an economy. One key effect is slower growth in GDP per capita, resulting from slower growth of the working-age population. Challenges to the health care system will increase as the elderly population grows. People caring for the elderly may experience stress as higher old-age dependency rates will not be offset by a reduction in the burden of 
child care. The fiscal burden associated with increased costs for pensions, health care, and long-term care will also increase and be exacerbated by the relative loss in tax revenue from slower economic growth.

The last complete population census for Sri Lanka was conducted in 2012. A newly developed set of population forecasts has been prepared specifically for this chapter. In the absence of a complete census enumeration, the first piece of the forecast is the construction of a "nowcast"-an estimate of the current population and its composition. This is constructed by applying measured birth and death rates working from the base of the 2012 census. Figure 8.8 presents the demographic pyramid for Sri Lanka, estimated for 2015.

\section{Figure 8.8: Sri Lanka's Demographic Pyramid}

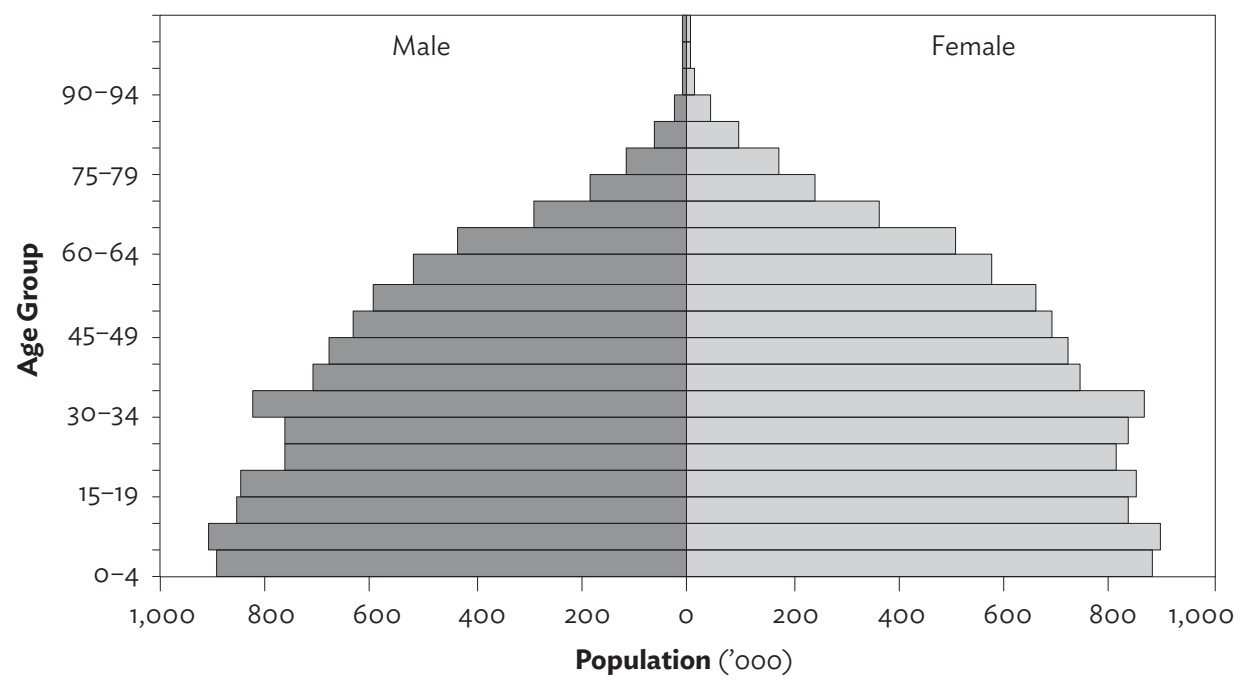

Source: Miller and Chan (forthcoming).

Several important facts are clear from the figure. First is that, although the figure is a standard rubric demographic pyramid, it is not particularly pyramidal, and has not been for some time. The 30-34 age group is one of the largest cohorts, with only the recent 0-4 and 5-9 cohorts being substantially larger. The recent bump is likely in part associated with the final achievement of peace. The other cohorts have been consistent with long-term zero population growth for 35 years. However, the cohorts of those in their 20s may well be somewhat under measured. The importance of migrant workers will be discussed in more detail below, but many of the Sri Lankans working abroad are likely to not have been captured in the census. The smaller cohorts, with people in their 20s, are at the prime age 
for worker migration. The census questionnaire asks about household members that have been abroad for more than 6 months, but is unlikely to fully capture migrant workers; indeed the census estimate, at approximately 605,000, is well below published estimates from the Sri Lanka Bureau of Foreign Employment. ${ }^{2}$

Another notable feature of the current demographic pyramid is that, at younger ages the numbers of males and females are approximately equal: for children under the age of 15 , the 2015 sex ratio is estimated at 1.02 males for 1.00 females. Globally, the natural biological sex ratio at birth is estimated at 1.04-1.06 (UNFPA 2012). In 2014, the sex ratio at birth for Sri Lanka was 1.04-at the natural level. Thus, Sri Lanka does not have any significant issues regarding gender balance at birth. This is a very different situation from most of South Asia and from the People's Republic of China (PRC), which also has pressing issues related to an aging population. In the PRC, the sex ratio at birth is 1.16; in South Asia as a whole, it is 1.10. These economies will, as their populations age, face additional issues related to their gender imbalance.

Many countries have experienced drops in fertility in recent decades. What makes Sri Lanka unusual is how early the process began vis-à-vis its income status-Sri Lanka exhibits a unique pattern of an aging population in a relatively poor country. Figure 8.9 includes fertility rates for Sri Lanka; the PRC, where population aging is a subject of much attention; and the middle-income countries as a whole. Sri Lanka has had a lower fertility rate than the average of middle-income countries since the 1960s, and the fertility rate has been steadily declining. In the PRC, fertility rates remained very high until the early 1970s, but then dropped extraordinarily rapidly due to the one-child policy implemented in 1979. For the middle-income countries as a whole, significant falls in fertility also did not begin until the 1970s, while Sri Lanka experienced falls in fertility earlier than the middle-income countries.

The other key element in a typical demographic transition is increasing life expectancy. Figure 8.10 displays data on life expectancy at birth for Sri Lanka, with the PRC and the overall levels for middle-income countries included for comparison. An important fact is that Sri Lanka has been leading middle-income countries in life expectancy since 1960, thanks to the early adoption of universal health care and education in the post-colonial period. Life expectancy increased rapidly during the 1960s and 1970s, the increase slowed during the 1980s and 1990 s, but then it surged again in the 2000s. As of 2016, life expectancy at birth

This issue is well understood by the Sri Lanka Department of Census and Statistics; it is inherently difficult to count individuals who are not actually present. Some discussion of the issue can be found in Final Report of the 2012 Census (DCS 2015a). For Sri Lanka Bureau of Foreign Employment figures, see SLBFE (2010). 
was 72.6 years for men and 78.9 years for women, with a population average of 75.8 years. In the United States, life expectancy was 78.4 years in 2015 , which is not too different from that of Sri Lanka. ${ }^{3}$

Figure 8.9: Fertility Rates (\%)

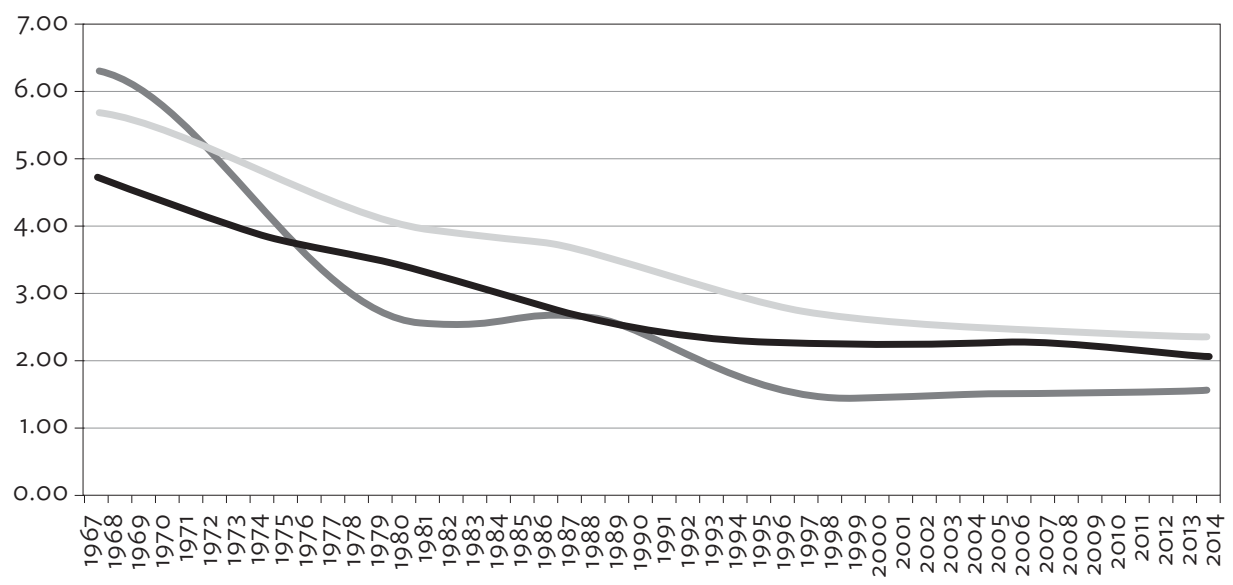

Middle-Income Countries $\quad$ People's Republic of China Sri Lanka

Source: Miller and Chan (forthcoming).

Figure 8.10: Life Expectancy (years)

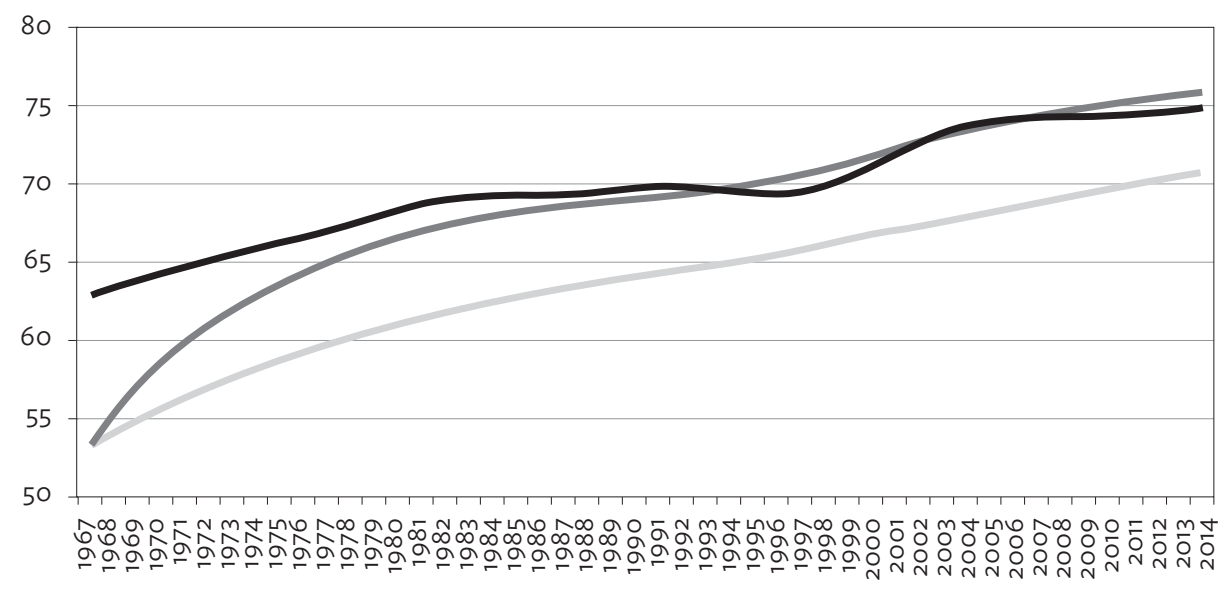

Middle-Income Countries People's Republic of China Sri Lanka

Source: Miller and Chan (forthcoming).

3 WHO. Countries. Sri Lanka. www.who.int/countries/lka/en/ (accessed 16 November 2016.). 
The three different forecast scenarios-low, middle, and high-are now considered. These scenarios reflect different assumptions concerning some of the key demographic variables, including total fertility rates (the theoretical fertility of an average women surviving throughout her reproductive life), life expectancies, and net immigration rates. For the three forecasts, the input values are picked based on their impact on population aging; for example the high-aging forecast assumes both a lower value for fertility and more rapid increases in life expectancy, while the low-aging forecast assumes the opposite. The three scenarios are not designed to bracket the possible rates of population growth, as is often the practice in demographic forecasts, but rather to bracket the potential impacts of population aging. While this chapter will largely focus on the midrange forecast, Figure 8.11 summarizes the three forecasts in terms of the fraction of elderly (age 65 and over) in the population over time.

Figure 8.11: Forecast Fraction of Elderly Population, 65 years and above, 2015-2055 (\%)

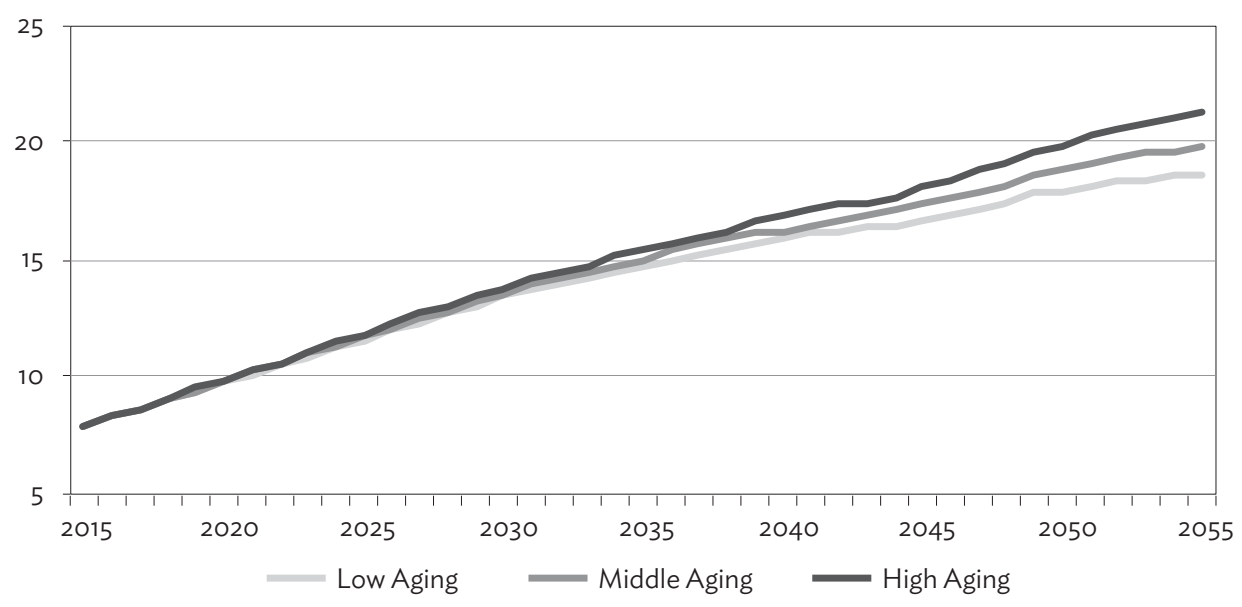

Source: Miller and Chan (forthcoming).

The differences between the three forecasts are modest until 2030, but they then diverge significantly. Demographic change moves slowly, but, over time, small differences in growth rates have large cumulative effects. In all three scenarios, the growth of the elderly population is dramatic. In the middle scenario, the fraction of elderly in the population will have doubled by 2038 relative to the 2015 baseline. Based on the middle forecast, by 2057 Sri Lanka will have the same proportion of elderly as the eurozone does today. The 
challenges for that late date may be not so great; although Europe is dealing with substantial issues related to an aging population today, the problems are not insurmountable. Based on figures for GDP per capita adjusted for purchasing power parity, from the World Bank WDI database, Sri Lanka could have GDP per capita equal to the eurozone in 2015 by achieving an average rate of real GDP growth of about 3\% a year. While economic forecasts so far into the future are always very uncertain, the $3 \%$ appears to be an eminently achievable figure. Well into the future, Sri Lanka is likely to face the same problems with aging that Europe does today, but it may face them with a similar level of economic resources. The most significant issues are likely to be faced in the next 10-20 years, in part because Sri Lanka has experienced decades of positive economic effects of the demographic transition.

The current official retirement age in Sri Lanka is 60; this applies to government workers and historically government workers were able to collect pensions at age 55 for men and age 50 for women (World Bank 2012). Because of such historically low retirement ages, for some economic projections, age 60 is a more relevant cutoff than the standard 65-and-over definition of the elderly. As of $2015,12.4 \%$ of Sri Lankans were 60 or older. Based on the midline forecast, this fraction will rise to $20.3 \%$ by 2035 . That is, the number of people past retirement age will increase by $64 \%$ in 20 years.

To get a better understanding, demographic pyramids are presented based on the midline forecasts for 2020, 2030, 2040, and 2050 in Figure 8.12. By 2030, the expansion of the elderly population, at the top of the pyramid, is visually clear. By 2040 , the sides are nearly straight from age 60 down, as a long series of cohorts is of near equal sizes. By 2050, the shrinkage of the younger generations has become clear, as the pyramid begins to taper at the bottom. One important feature of the demographic forecasts that may not be clear from the figure is the rapid increase of the older groups of the elderly. As of 2015, the fraction of the population 70 years or older was $4.8 \%$. This is forecast to rise to $10.4 \%$ by 2035 , more than doubling in 20 years. The increase may be significant as this older group is, on average, less healthy and may require additional care. 
Figure 8.12: Midline Forecast of Demographic Pyramids, 2020, 2030, 2040, 2050
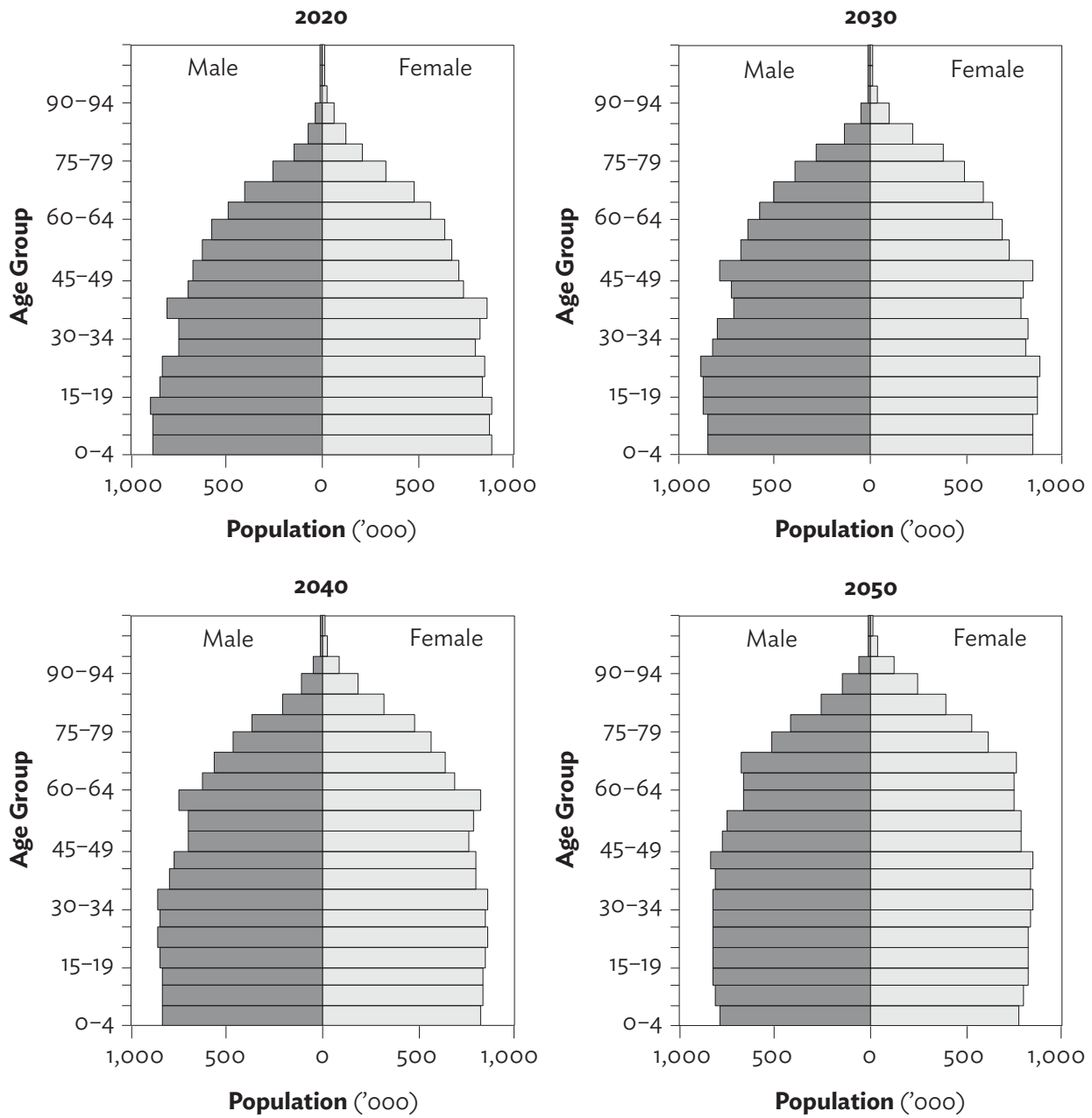

Source: Miller and Chan (forthcoming).

The "demographic dividend" is used to refer to a low overall dependency ratio (the share of children and elderly relative to the overall population), which is seen in the early stages of a demographic transition. The usual pattern starts with a lower fertility rate, so there are fewer children to support and a very small number of elderly people. As years progress, the share of the elderly population in the total increases. With a low overall dependency ratio, there are more potential workers relative to the total population, making it easier to increase income per capita. Some econometric studies find large growth impacts from the 
demographic dividend, significantly larger than could be accounted for by the abundant supply of labor; researchers have hypothesized that other advantages are associated with having a younger labor force, possibly including greater sectoral mobility and willingness to adapt new technologies. ${ }^{4}$

The dependency ratio is used to measure the pressure on the workingage population. The dependency ratio is expressed as the number of people age 65 and over and children age 14 and younger, taken together, as a share of the working age population, ages 15-64. In Sri Lanka, the ratio reached a minimum of $48.0 \%$ in 2005 (ILO 2016), with nearly a third of the population in the dependent category. This was a huge change-in 1960 the dependency ratio had been $87.5 \%$ (with nearly half of the population in the dependent category), was $67.4 \%$ in 1980, dropped to $48.0 \%$ in 2005 , and was $49.3 \%$ in $2015 .{ }^{5}$ Sri Lanka has cashed its demographic dividend.

Because of the traditionally low retirement age, the dependency ratio in Sri Lanka has often been calculated using a definition of working age as 15-59. Figure 8.13 presents forecast dependency ratios for the working age with the Sri Lankan definition and for the international standard definition of 15-64.

\section{Figure 8.13: Forecast Dependency Ratios Comparing Working Ages of 15-59 and 15-64, 2020-2050 (\%)}

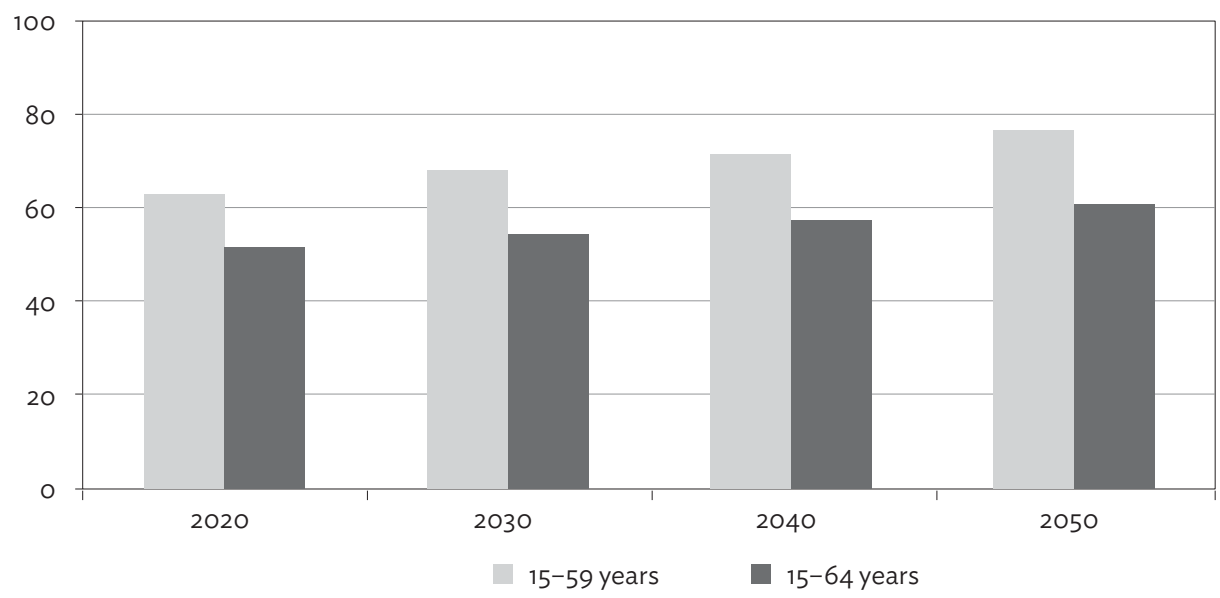

Source: Miller and Chan (forthcoming).

See, for example, Bloom, Canning, and Finlay (2010), and Bloom and Finlay (2009).

The 2015 figure is based on the new demographic forecast by the authors, which is slightly below the International Labour Organization figure. 
Based on the earlier retirement age, dependency ratios will rise very sharply, from $63 \%$ in 2020 to $76 \%$ in 2050 . Placing the retirement age at 65 improves the situation to some degree. With that measure, the dependency ratio rises from $51 \%$ in 2020 to $61 \%$ in 2050 . In the 1980 s, 1990 s, and 2000s, a falling dependency ratio almost certainly provided a major boost to the growth of output per capita. Since the mid-2000s, changing demographics have been close to neutral, with a very small increase in the dependency ratio. The forecast reveals a new dynamic: in the coming decades, the aging of the population in Sri Lanka is likely to create a significant drag on the growth of output per capita if there are no changes in other important factors.

In essence, the increase in the dependency ratio reflects the reduction of labor resources available for economic production, the result of an aging population. The dependency ratio only examines the working age population, whereas not all working age people are in the labor force and employed. The key economic question pertains to the number of productive workers; to take this better into account, the following section deals with labor force participation and unemployment rates.

\subsection{Labor Force Trends and Participation}

A steady and reliable labor supply is necessary for sustaining growth in the long term. Keeping a steady supply of workers will be a challenge for the economy. Projections show that Sri Lanka's labor force will increase very gradually until 2028, and then start to decline (Figure 8.14). The slow growth of the labor force will impede economic growth unless counteracted by stimulating growth or improving productivity. Analysis of labor force growth shows that the main reasons for its slowdown (Figures 8.15 and 8.16) are (1) slowing population growth, especially among the working age population; and (2) declining labor force participation rates (LFPRs).

Stimulating labor force growth requires promoting the LFPRs. A detailed look at the LFPRs shows that they have declined from 2006 to 2014 for all types of workers, with only a few notable exceptions. The decline is sharpest for youth and those with a secondary education, except for people with college degrees. The LFPR has also declined for females and people in rural and estate areas. As per capita income grows, some decline usually occurs in LFPRs. With a family's primary earner receiving higher income, secondary earners generally participate less in the economy. But a declining LFPR could also signal declining opportunities for employment. 
Figure 8.14: Total Labor Force Projections, 2014-2048 ('000)

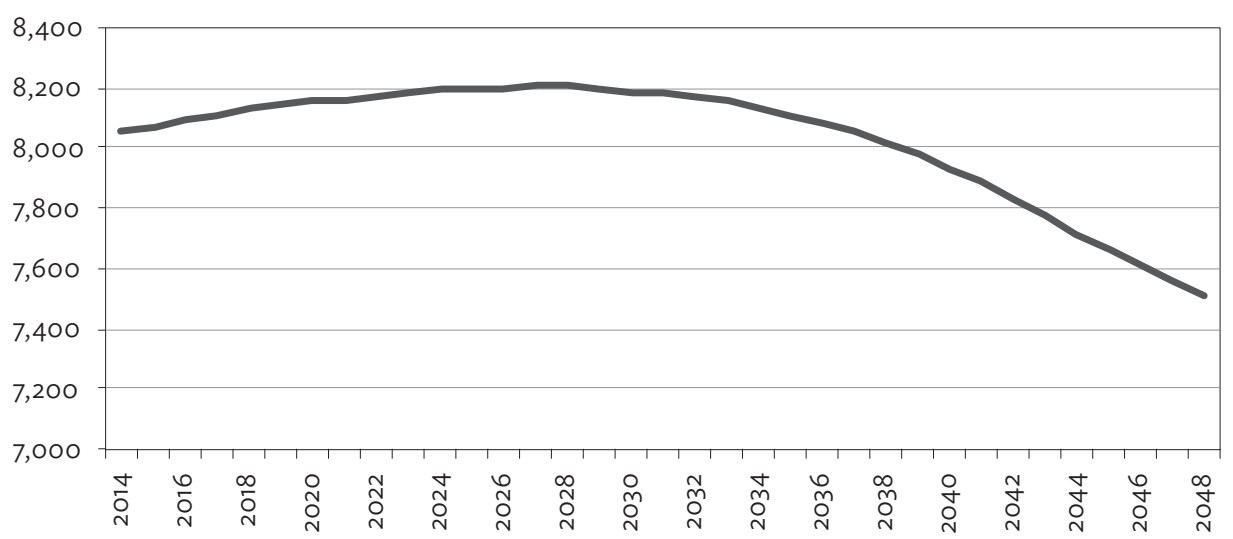

Note: Working age is $15-64$ years.

Sources: Arunatilake (forthcoming).

Figure 8.15: Working-Age Population Projections for Sri Lanka, by Age Category, 2014-2048 ('000)

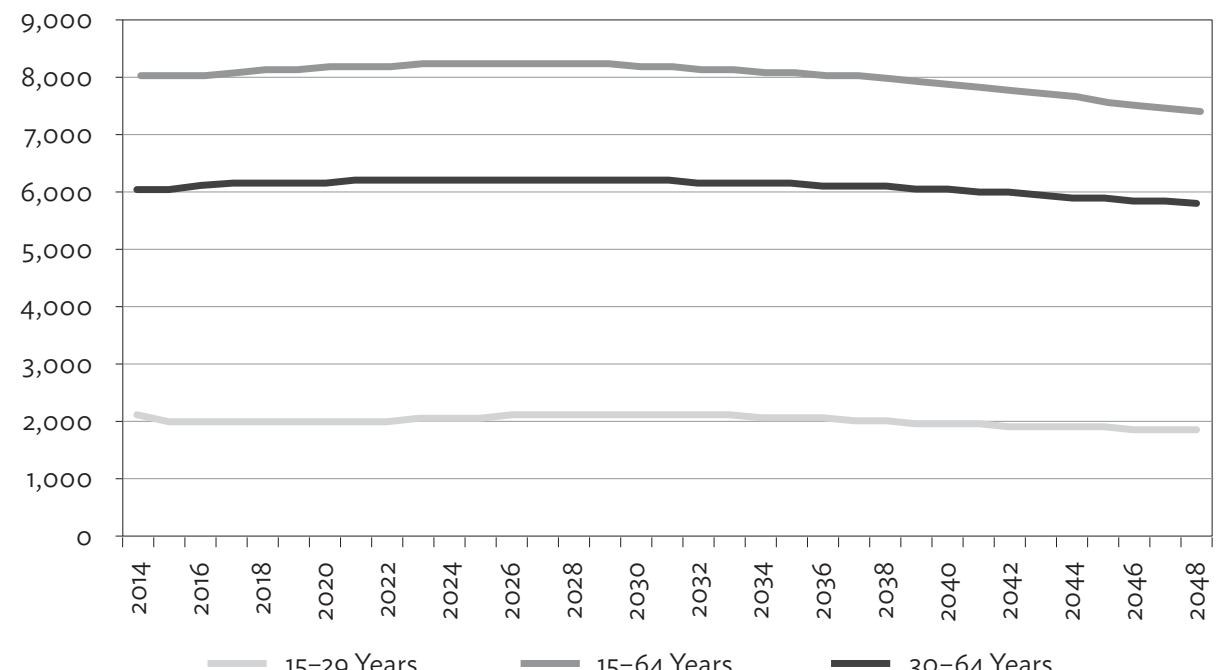

Source: Arunatilake (forthcoming). 
Figure 8.16: Percentage Point Differences in Labor Force Participation Rates, 2014 Relative to 2006

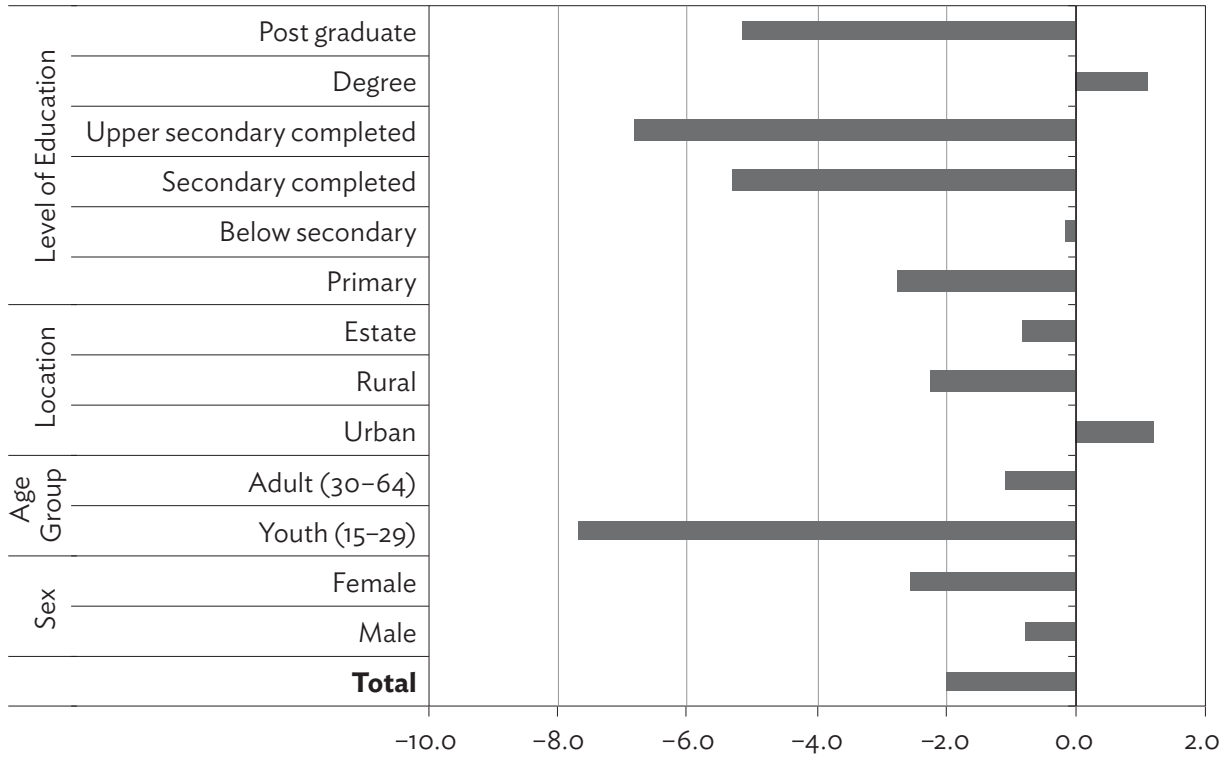

Note: Northern and Eastern provinces are excluded. "Estate" refers to individuals living on plantations. Source: Arunatilake (forthcoming).

Strong economic growth in an aging society transforms the overall pattern of job creation. Table 8.1 shows Sri Lanka's job growth from 2006 and 2014. It is obvious that more jobs were taken by male, older, and urban workers. The job growth rate of males is much faster than that of females, increasing the job gender gap. Given relatively stable labor force growth, the older groups took up more jobs than the younger groups, which is a worrying trend for future growth. Jobs are increasing in urban and rural areas, and decreasing in the estates. The job growth rate is fastest in the urban areas. Due to the lower population growth, unemployment has registered a decreasing trend in recent years (Figure 8.17). 
Table 8.1: Job Growth, 2006 and 2014

\begin{tabular}{|c|c|c|c|c|c|c|}
\hline & 2006 & $\begin{array}{l}\text { Share } \\
\text { in } 2006\end{array}$ & 2014 & $\begin{array}{l}\text { Share } \\
\text { in } 2014\end{array}$ & $\begin{array}{l}\text { Job Growth } \\
\text { Between } 2006 \\
\text { and } 2014\end{array}$ & $\begin{array}{c}\text { Contribution } \\
\text { to Total Job } \\
\text { Growth }\end{array}$ \\
\hline \multicolumn{7}{|l|}{ Gender } \\
\hline Male & $2,529,646$ & $65.3 \%$ & $2,728,248$ & $65.6 \%$ & 198,602 & $70.5 \%$ \\
\hline Female & $1,345,989$ & $34.7 \%$ & $1,428,963$ & $34.4 \%$ & 82,974 & $29.5 \%$ \\
\hline \multicolumn{7}{|l|}{ Age Group } \\
\hline $15-19$ & 187,119 & $4.8 \%$ & 118,666 & $2.9 \%$ & $-68,453$ & $-24.3 \%$ \\
\hline $20-24$ & 519,695 & $13.4 \%$ & 417,012 & $10.0 \%$ & $-102,683$ & $-36.5 \%$ \\
\hline $25-29$ & 564,277 & $14.6 \%$ & 516,479 & $12.4 \%$ & $-47,798$ & $-17.0 \%$ \\
\hline $30-39$ & 997,664 & $25.7 \%$ & $1,186,840$ & $28.5 \%$ & 189,176 & $67.2 \%$ \\
\hline $40-49$ & 908,814 & $23.4 \%$ & 989,468 & $23.8 \%$ & 80,654 & $28.6 \%$ \\
\hline $50-59$ & 609,231 & $15.7 \%$ & 779,534 & $18.8 \%$ & 170,303 & $60.5 \%$ \\
\hline $60-64$ & 88,837 & $2.3 \%$ & 149,213 & $3.6 \%$ & 60,376 & $21.4 \%$ \\
\hline \multicolumn{7}{|l|}{ Area } \\
\hline Urban & 515,034 & $13.3 \%$ & 772,450 & $18.6 \%$ & 257,416 & $91.4 \%$ \\
\hline Rural & $3,029,454$ & $78.2 \%$ & $3,116,354$ & $75.0 \%$ & 86,900 & $30.9 \%$ \\
\hline Estate & 331,146 & $8.5 \%$ & 268,409 & $6.5 \%$ & $-62,737$ & $-22.3 \%$ \\
\hline Total & $3,875,635$ & & $4,157,212$ & & 281,576 & \\
\hline
\end{tabular}

Note: "Estate" refers to the plantation areas.

Source: Arunatilake (forthcoming).

Figure 8.17: Unemployment Rates, Males and Females 15 Years and Older, 2006-2015 (\%)

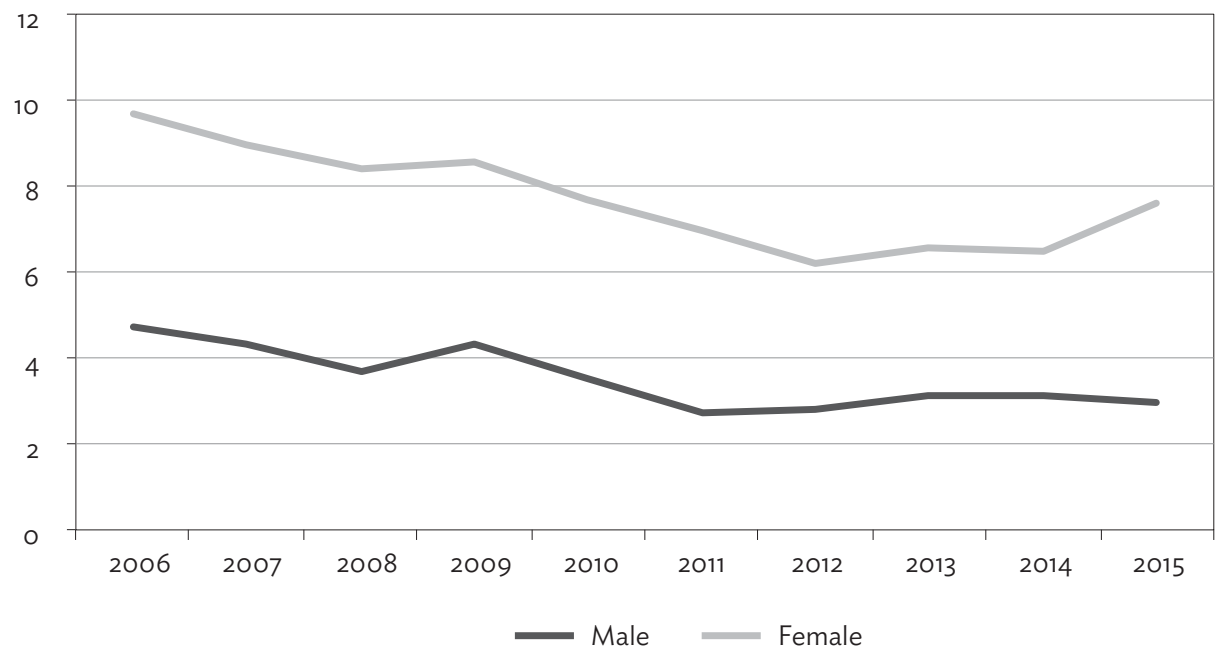

Note: The figures for 2006 and 2007 exclude the Northern and Eastern provinces; 2008-2010 excludes the Northern Province.

Source: Majid and Gunatilaka (forthcoming). 
Regarding the impacts of an aging population on the labor market, the most quantitatively important fact about labor force participation is the very low rate of female participation. In no age category is the female participation rate over $50 \%$ and overall it was $34.4 \%$ in 2014 (DCS 2016). This is a very low rate by the standards of most high-income countries, which averaged $52.1 \%$ in $2014 .^{6}$

Figures 8.18 and 8.19 compare age brackets' LFPRs in Sri Lanka with those in other countries. The comparison of Sri Lanka with more advanced countries (the Republic of Korea and Singapore) indicates that the lower LFPR in Sri Lanka is mainly due to the lower LFPR of females. The participation rate of females has declined from $43.0 \%$ in 2006 to $40.4 \%$ in $2014 .^{7}$ Hence, there is room for increasing the supply of labor through increasing the LFPR of females. Gunatilaka (2013) found a variety of reasons for the low female LFPR, including generally high reservation wages (the lowest wage acceptable for particular jobs). This results from the population's relatively high level of education and other cultural factors. Receipts of remittances from abroad as well as the earnings of the male household members also disincentivize married women from entering the labor market.

\section{Figure 8.18: Labor Force Participation \\ Rate, Males, by Age Group and Country, 2006}

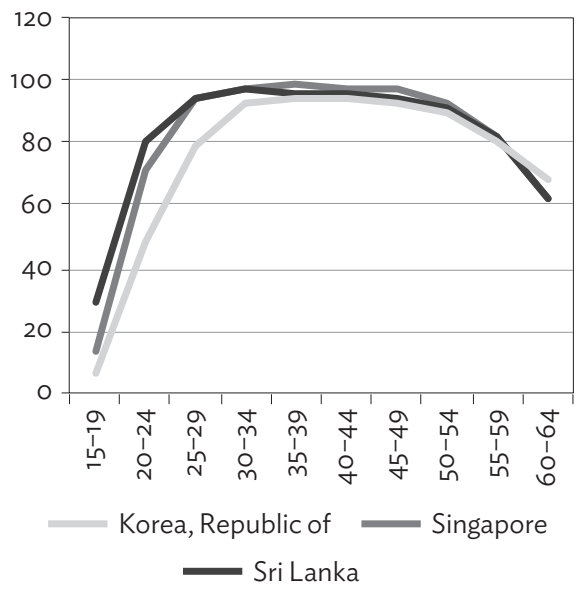

Source: Arunatilake (forthcoming).

\section{Figure 8.19: Labor Force Participation Rate, Females, by Age Group and Country, 2006}

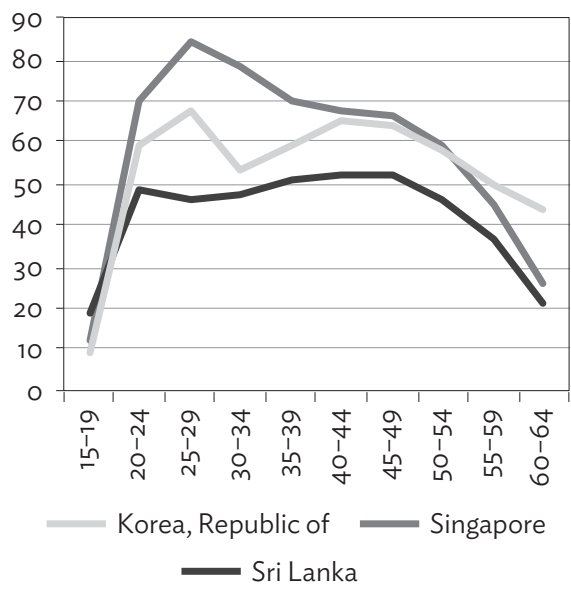

Source: Arunatilake (forthcoming).

World Bank, WDI (accessed 28 January 2017).

These rates are for ages 15-64 years; as such they are not directly comparable to the official statistics that are for the 15 and above population. 
Lower average wages for females than males could also explain females' lower labor force participation. Average hourly wages were $14 \%-25 \%$ higher for males than females during the 2006 to 2014 period (Figure 8.20). Further, this difference in wages was largely unexplained. For example, in 2014 average hourly wages were $25 \%$ higher for males than females, although, according to productive endowments, which determine the level of wages, the average hourly wages for females should actually be $10 \%$ higher than that for males. Close to $40 \%$ of the difference in wages is unexplained.

Figure 8.20: Average Hourly Wages Differences for Males and Females, 2006-2014 (\%)

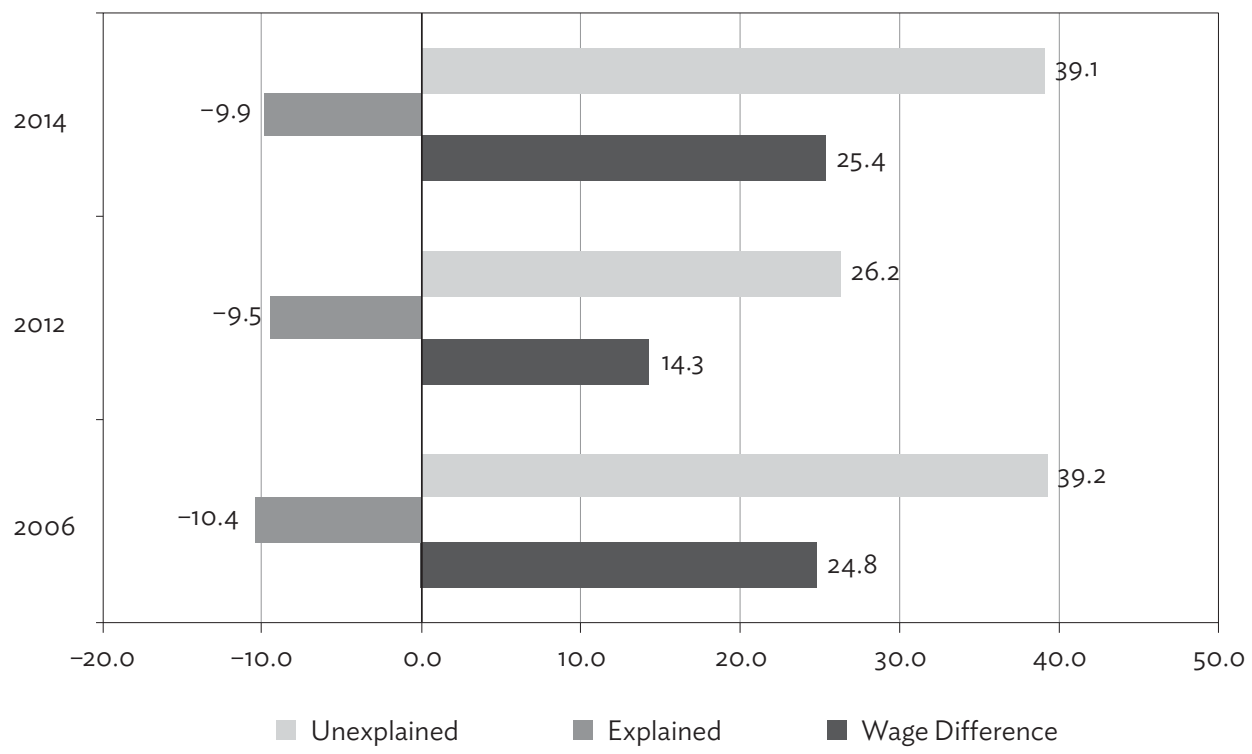

Source: Arunatilake (forthcoming).

The male-female difference in average hourly wages is greatest for the lowest-skilled workers (Figure 8.21), where the average hourly wage was $46.8 \%$ higher for males than that for females. In contrast, the corresponding difference was $3.0 \%$ lower for male senior officials, professionals, and technicians. This corroborates the authors' hypothesis that the lower LFPR of females is partly because they earn lower average hourly wages in general. Senior-level female workers receive slightly higher wages than males, but such jobs comprise a very small portion of the total. 
Figure 8.21: Gender Difference in Average Hourly Wage, by Job Type, 2006-2014 (\%)

Skilled Agricultural and Craft Workers, Machine Operators, Elementary Occupations

Clerks, Service, and Market Sales Workers

Senior Officials, Professionals, Technicians

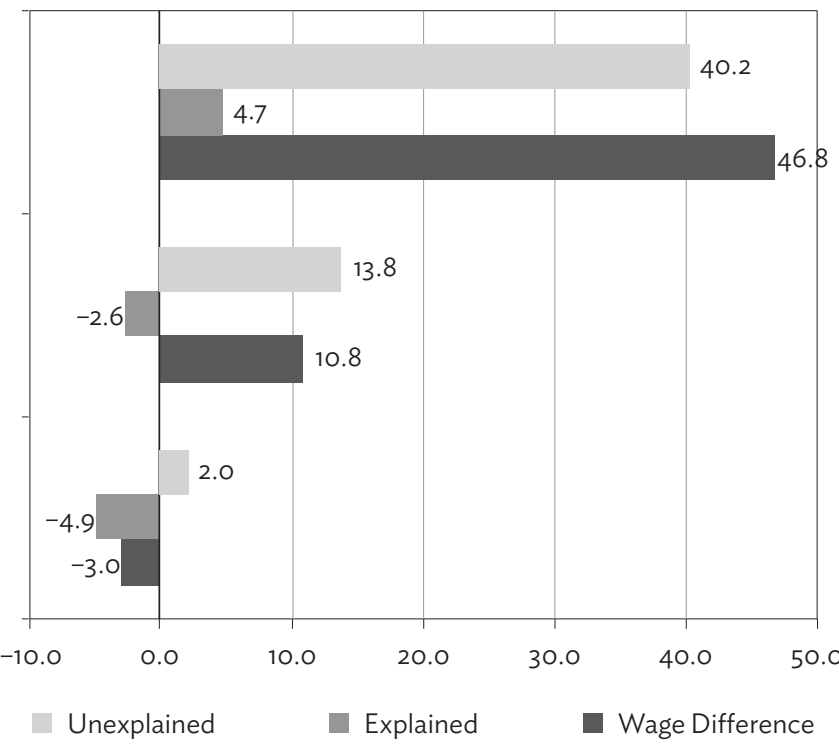

Notes: Northern and Eastern provinces are not included. The results are based on an Oaxaca decomposition analysis that included the following explanatory variables: years of education, experience, experience 2 , household head, marital status, formal occupation, occupation category (1), district, and sector.

Source: Arunatilake (forthcoming).

\subsection{Increasing Trend of Working Abroad}

Despite the declining labor force growth, Sri Lanka is losing a large proportion of its workers to foreign employment. In 2013, close to 300,000 persons left for employment abroad (Figure 8.22). The number has increased steadily from 2002. Census 2012 data show that $6.5 \%$ of the country's population aged 18 and over was temporarily residing abroad (Arunatilake 2016). The government's foreign employment policies need to take into account Sri Lanka's labor market requirements as well as its foreign exchange requirements. Despite a slowdown in the growth of the labor force, successive governments have promoted foreign employment, as foreign remittances are important for earning foreign exchange. To cater to the domestic labor market's needs, Sri Lanka will in future need to make employment more attractive within the country. This includes better compensation and a more conducive working environment. Further, the avenues for earning foreign exchange will need to be diversified to reduce reliance on workers' remittances. 
Figure 8.22: Departures for Foreign Employment, 2002-2013

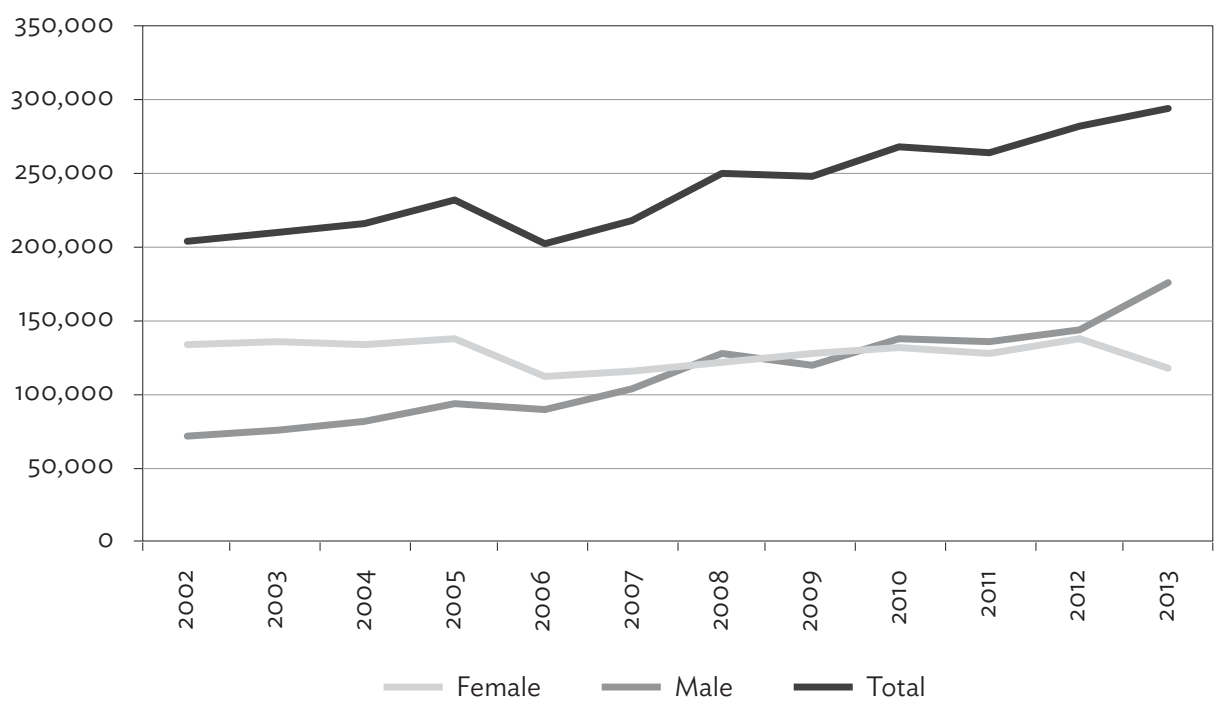

Notes: The graph shows gross departures. Department of Immigration and Emigration data show that the net departures for any purpose from the country have been just below 50,000, on average, from 2009 to 2013. Source: Arunatilake (forthcoming).

\subsection{Conclusions and Policy Suggestions}

The medium-term economic development policy envisages reorienting the economy toward a private-sector driven, competitive, sophisticated, and modern knowledge-based economy in the global market. To achieve this aspiration, the country needs a steady supply of highly skilled and competitive workers. The Sri Lankan labor market is faced with several challenges in the pursuit of this goal.

The economy is experiencing structural change. The share of agriculture has been declining, replaced by manufacturing and services. At the same time, employers are requiring more job-specific skills for their workers. The education system, especially the higher education system, is not necessarily accommodating the changing labor demand.

Sri Lanka is facing slower growth of the working-age population and an increasing dependency ratio due to population aging. Furthermore, a large share of workers is abroad. Mitigating or reversing the decline in labor force growth means finding additional sources of labor. The three possible avenues for increasing the volume of labor available for economic activity are (1) increasing labor force participation; (2) decreasing unemployment; and (3) increasing net immigration, where this is taken to include the return of migrant workers from abroad. 
The largest possible source of additional labor to counter the slow growth of the labor force would be increasing its female participation. Raising the female LFPR to the average level in high-income countries would increase the overall labor force by $17 \%{ }^{8}$ Such an increase would be adequate to replace decades of labor force reductions brought on by population aging; however, as long as women remain the principle caregivers for the elderly, the aging population will present a barrier to female labor force participation.

A number of approaches are known to be useful in encouraging female labor force participation. One is to create policies that encourage employers to hire workers on a part-time and flexible basis. Another is to promote nontraditional roles for women, which can help to break barriers in gendered economic spheres. General programs to encourage gender equality will also help. Women's roles as caregivers can also be a barrier to their full participation in the world of work. Encouraging provision of childcare by employers and providing subsidized childcare may make it easier for women to work. Sri Lanka does not have full legal equality for women in the workplace. Legal reform that guarantees women's equality in the workplace increases female labor force participation (Gonzales et al. 2015). In addition, equal wages need to be granted for male and female unskilled workers who are doing the same jobs.

Despite the gradually decreasing labor force growth, governments have been encouraging foreign employment to bring in foreign exchange. Promoting labor migration in the face of slowing labor force growth is not sustainable. Remittances abroad discourage females from entering the labor market. Instead, measures should be taken to make jobs more attractive for workers to remain in the country. The government could look into other means of earning foreign currency, to minimize the pressure to promote foreign employment.

To move toward a knowledge-based economy, Sri Lanka needs to increase the proportion of science and technology workers. The proportion of such workers remains low because the private sector is restricted from participating in the provision of tertiary education. The government could look into policies and procedures to mitigate the adverse effects of the restriction. Furthermore, real monthly earnings have declined for all types of workers, while real hourly earnings have increased. The increase in hourly wages is highest for lowerskilled workers, indicating greater competition for such workers. This could indicate a lack of demand for high-skilled occupations. Even people who are

8 Calculated based on figures from DCS (2015b). 
in science and technology occupations are not educated at the tertiary level, indicating that they are not trained to do the jobs that they do. Further, many people with tertiary education are in occupations that do not need that level of education or are not in the labor market at all. This could be because graduates do not have the skills demanded by the market, or because the jobs offered by the market are not attractive to graduates, for remuneration or other reasons. Improving the proportion of properly trained science and technology workers is key for moving Sri Lanka toward a knowledge-based economy. 


\section{References}

Asian Development Bank (ADB). 2007. Sri Lanka Country Assistance Program Evaluation: Education Sector. Mandaluyong City: ADB.

Arunatilake, N. 2016. Integrating Migrant Workers to the Labour Market Statistics of Sri Lanka. Colombo: Institute of Policy Studies. Unpublished.

forthcoming. The Sri Lankan Labor Market: Recent Trends. Mandaluyong City: ADB.

Athukorala, P. 2016. Manufacturing Exports from Sri Lanka: Opportunities, Achievements and Policy Options. Canberra. Unpublished.

Bloom, D., D. Canning, and J. Finlay. 2010. The Economic Consequences of Demographic Change in East Asia. NBER-EASE Volume 19. Chicago: University of Chicago Press.

Bloom, D., and J. Finlay. 2009. Demographic Change and Economic Growth in Asia. Asian Economic Policy Review. 4(1): 45-64.

Central Bank of Sri Lanka (CBSL). 2016. Annual Report 2015. Colombo: CBSL.

Department of Census and Statistics (DCS). 2015a. Census of Population and Housing 2012 - Final Report. Colombo: DCS.

2015b. Sri Lanka Labour Force Survey Annual Report 2014. Colombo: DCS. 2016. Sri Lanka Labour Force Survey Annual Report 2015. Colombo: DCS.

Dundar, H. et al. 2014. Building the Skills for Economic Growth and Competitiveness in Sri Lanka. Washington D.C.: World Bank.

Gonzales, C., S. Jain-Chandra, K. Kochhar, and M. Newiak. 2015. Fair Play: More Equal Laws Boost Female Labor Force Participation. IMF Working Paper. Washington D.C.: International Monetary Fund.

Gunatilaka, R. 2013. Women's Participation in Sri Lanka's Labour Force: Trends, Drivers and Constraints. Colombo: International Labour Organization.

International Labour Organization (ILO). 2016. ILOSTAT. http://www.ilo.org/ ilostat/

Majid, N., and R. Gunatilaka. forthcoming. The Welfare Dimensions of Employment Change in Sri Lanka. Asian Development Bank.

Miller, R., and S. Chan. forthcoming. The Aging Population and the Labor Market. Mandaluyong City: ADB.

Ministry of Education (MOE). 2013. Education First. Colombo: MOE.

National Education Commission. 2009. National Policy Framework on Higher Education and Technical and Vocational Education. Colombo: National Education Commission.

National Human Resource Development Council (NHRDC). 2013. Recruitment of Graduates into the Public Service, and their Contribution to Productivity vis-a-vis their Job Satisfaction. Colombo: NHRDC.

Sri Lanka Bureau of Foreign Employment (SLBFE). 2010. Annual Statistical Report of Foreign Employment 2009. Colombo: SLBFE. 
United Nations Development Programme(UNDP).2015. Millennium Development Goals Country Report 2014-Sri Lanka. Colombo: UNDP.

United Nations Population Fund (UNFPA). 2012. Sex Imbalances at Birth: Current Trends, Consequences, and Policy Implications. Bangkok: UNFPA.

World Bank. 2008. Sri Lanka: Addressing the Needs of an Aging Population. Washington, D.C.: World Bank.

2012. Sri Lanka-Demographic Transition: Facing the Challenges of an Aging Population with Few Resources. Washington, D.C.: World Bank. . various years. World Development Indicators (WDI). Washington, DC.

World Health Organization (WHO). Countries. Sri Lanka. www.who.int/ countries/lka/en/ 


\title{
Chapter 9.
}

\section{Key Policy}

\section{Recommendations}

\section{Prema-chandra Athukorala, Edimon Ginting, and Hal Hill}

\begin{abstract}
he final chapter briefly recapitulates the study's key policy recommendations. The book has been prepared during a critical juncture in Sri Lanka's move forward-after a quarter of a century of internal struggle, peace has finally been achieved, paving the way for strong economic growth and significant poverty reduction. However, challenges of the global economic slowdown and Sri Lanka's slower economic growth and fiscal imbalances need to be overcome. The discussions in the book and its recommendations aim to help clarify the way forward.
\end{abstract}

It is important to emphasize the integrated and interactive nature of these recommendations. That is, the recommended policies will have greater impact if they are implemented in a comprehensive manner. Partial and incomplete reforms will be less effective and could even be counterproductive.

At the outset, four general sets of policy reform are central to the objective of accelerated development.

- First, significant macroeconomic reform is needed.

- Second, there is a strong case for renewing the emphasis on trade and commercial policy liberalization.

- Third, Sri Lanka can achieve macroeconomic and trade reform without compromising its historic strengths in education and health.

- Fourth, reforms will be more effective if they are accompanied by greater investments in infrastructure, combined with a regulatory environment that encourages public and private investment and ensures that the increased investment addresses both efficiency and equity objectives. 
The summary is organized by chapters, each of which provides the supporting background and detail.

\subsection{Macroeconomic Management}

There is a broad consensus on the need for fiscal consolidation, creating fiscal space by boosting revenues to address the fiscal risks and expenditure pressures ahead. This will require the introduction of robust tax measures, sustained improvement of tax administration, and other institutional changes.

Cutting Unproductive Expenditure. The progress in cutting unproductive expenditure also needs to continue considering the requirement for more infrastructure spending and the potential fiscal pressure arising from the country's aging population in the long term. Increased private participation in financing viable urban infrastructure could potentially create fiscal space for other productive spending in the medium term. Improvement in the overall performance of state-owned enterprises (SOEs) would reduce the fiscal burden and the government's contingent liabilities.

Adjusting Monetary Policy. The deterioration of Sri Lanka's international competitiveness, as reflected in the persistent appreciation in the real exchange rate, has been an important factor behind Sri Lanka's indifferent performance in manufacturing exports. Therefore, macroeconomic adjustments are needed to restore international competitiveness by depreciating the real exchange rate. This will, of course, require a substantial nominal depreciation of the rupee. However, given the massive build-up of foreign currency-denominated government debt, exchange rate depreciation alone may worsen the budgetary problems. Therefore, a comprehensive policy package is needed, encompassing greater exchange rate flexibility and fiscal consolidation through both rationalization of expenditure and a widening of the revenue base.

Fiscal Consolidation and Inflation. Successful fiscal consolidation is the key to managing inflation. But with an increased proportion of government debt coming from the market and interest payment being the largest item of government spending, lower domestic inflation will also directly benefit the government budget through declining interest payments. Reducing inflation is also the key for attracting the significant amount of private investment needed to support higher growth. Empirical evidence has identified a negative relationship between the inflation level and its volatility with the growth of gross domestic product. One important channel is through a higher cost of capital. 


\subsection{Services and Logistics}

Three key policy priorities for services pertain to

- liberalizing trade further,

- liberalizing the regulatory environment for the services sector, and

- reducing government involvement in service provision.

Liberalizing Services. First, continue the overall trade liberalization. The reforms of the late 1970s need to be extended and intensified, as discussed in Chapter 4. In turn, an internationally oriented goods sector requires an efficient services sector, so that its service links costs are competitive.

Second, liberalize the services sector further. Loosen regulatory barriers and strengthen regulatory arrangements, particularly those that ensure competitive and efficient services. Unlike trade barriers, tradable services are typically subject to regulatory barriers both at and behind the borders. This constrains the tradable services' global integration and competition. Moreover, there are often discriminatory regulations between domestic and foreign investments in the same services, affecting their costs and market structures.

Third, reduce government involvement in the economy by scaling back public ownership in competitive industries and by reforming SOEs more generally. For the private sector to flourish, it needs to face fewer regulatory constraints. Government involvement in service supply increases the market risks of, and imposes additional costs on, the private sector, discouraging both domestic private and foreign investment. Often, government service providers are inefficient, thus imposing additional costs on the private sector. The government role needs to shift from service supplier to facilitator, enabling the private sector to play a more effective role in service supply.

Coordinating Logistics. The key challenges for logistics include uncoordinated development of transport infrastructure, lack of synergy between city and port development, bureaucratic red tape, failure to attract global third party logistics firms, and a lack of a unified and holistic policy approach. Developing a master plan and establishing a national committee on logistics is important to address issues arising from weaker coordination and communication, while greater use of information and communication technology will help cut red tape. In addition, reforms that aim to introduce better regulation, encourage greater private-sector participation, and enhance competition will help the country improve the performance of its logistics sector and unlock its location potential. 
The current Sri Lankan logistics regulatory arrangements lack harmonization. Policies affecting the logistics subsector's performance are set by several government agencies that are separately responsible for transport, investment, commerce, industry, and customs and border management. The lack of a unified approach to logistics policy can lead to inefficiencies, duplication, and inconsistencies.

Exporters of perishable goods maintain that the process of checking for regulatory and security compliance is time consuming and inefficient. Other grievances include inadequate training of agency officials on how to handle perishable cargo, frequent pilferage of items packed for export, lack of surveillance cameras in inspection areas, and lack of temperature controlled areas for inspecting perishable items. Respondents also complained about the slow progress in introducing paperless trade and the Single Window facility.

Specifically, the following recommendations are offered:

- Devise a master plan and a strategy to develop the logistics subsector.

- Establish a national-level committee on logistics.

- Ensure that objectives of city development are integrated into logistics development.

- Introduce a central data exchange to facilitate seamless flow of information.

- Introduce regulations to ensure fair competition and standards for service quality.

- Facilitate greater participation of global leading third-party logistics providers.

- Increase the focus of transport infrastructure development plans on the logistics subsector's needs.

- Fast-track implementation of logistics infrastructure.

- Implement far-reaching SOE reform.

\subsection{Manufacturing Exports}

The Sri Lankan experience supports the view that trade-cum-investment policy reforms can set the stage for new exporting firms to emerge. The findings make a strong case for redressing backsliding in policy, continuing the marketoriented reforms agenda that was left incomplete in the late 1990s, and setting up institutional safeguards to avert further backsliding. 
Tariffs and Duties. Unification of para tariffs and the standard customs duties and rationalization of the resultant tariff structure with the aim of achieving greater uniformity of rates is an important policy goal. In addition to economic efficiency gains, this would help to improve the efficiency of customs administration. Customs revenue could increase under a more uniform tariff structure, through achieving greater transparency of the tariff administration and reducing incentives for smuggling.

Role of the Board of Investment. Restoring the role of the Board of Investment (BOI) to its original status as the apex institute for promoting foreign direct investment (FDI) is vital for linking the economy to rapidly evolving global production networks. This requires repealing, or superseding by new legislation, the Revival of Underperforming Enterprise and Underutilized Assets Act and the Strategic Development Project Act, and a firm commitment at the highest political level to promote FDI.

There is also a strong case for rationalizing the fiscal incentives offered by the BOI. The very objective of giving incentives for promoting FDI is nullified if they are not made strictly time-bound and transparent. However, whether the government should go ahead with abolishing or phasing out tax incentives for export-oriented foreign firms is highly debatable. Characterizing the current BOI regime as an "enclave arrangement" is not consistent with facts. Many other countries have implemented export-processing zone schemes as a an appendage to a highly restrictive trade regime, whereas in Sri Lanka BOI privileges are available to foreign and local investors that meet the approval criteria (the prime criterion being "export orientation"), and BOI-approved firms can operate anywhere in the country.

Exchange Rate and Fiscal Consolidation. Restoring the international competitiveness of the economy by depreciating the real exchange rate is essential for sustaining robust exporting. This requires a substantial nominal depreciation of the rupee. The Central Bank of Sri Lanka's recent move to achieve greater flexibility in determining the exchange rate is therefore a step in the right direction. However, under the current economic conditions, relying on nominal exchange rate depreciation alone for restoring international competitiveness could be counterproductive. As noted above, given the massive build-up of foreign-currency-denominated government debt, exchange rate depreciation naturally worsens budgetary woes. And given the increased exposure of the economy to global capital markets, a large abrupt change in the exchange rate could shatter investor confidence, triggering capital outflows. 
Therefore, an improvement in Sri Lanka's overall investment climate requires (1) a comprehensive policy package encompassing greater exchange rate flexibility and fiscal consolidation (which requires both rationalization of expenditure and widening of the revenue base) to achieve a durable reduction in the public debt; and (2) complementary measures, including trade and investment policy reforms.

Labor. The labor shortages reported, which have received much emphasis in recent policy debates, seem to be at least partly due to structural impediments that hinder the operation of free market incentives. Providing facilities and incentives for firms to locate factories where labor is available and requiring them to provide workers with dormitories (as is widely done in many other successful exporting countries) as part of the BOI investment approval and monitoring procedures and infrastructure development could redress these structural impediments to labor mobility. There is also a clear need for reforms to achieve labor market flexibility: repealing restrictions set by the Industrial Dispute Act and the Termination of Employment of Workers Act on retrenchment of workers for economic reasons, and a shifting from centralized wage fixing toward work-place bargaining.

\subsection{Agriculture}

With regard to policy priorities, successive governments have implemented several programs aimed at achieving multiple objectives, including selfsufficiency, poverty alleviation, safe and nutritious food, and enhanced export competitiveness. However, a focused and consolidated effort with clear policy directives is required to speed up the modernization of agriculture. Modernization should help producers acquire economies of scale; encourage private investment in food processing (by minimizing policy uncertainties); increase productivity (through reforms in mechanization policy, seed and planting material policy, and land policy); increase investments in public goods such as agricultural research, extension, and irrigation (by diverting resources from public procurement and price subsidies); improve access to agricultural insurance and finance; and promote entrepreneurship.

Specifically, there are five major policy recommendations to overcome critical constraints to the agriculture sector, and six recommendations to increase public investment. 
The policy recommendations are:

(1) Focus on providing incentives to a limited number of commodities with export potential and on commercializing agriculture.

(2) Speed up the land titling program and enhance opportunities for land consolidation.

(3) Continue to promote appropriate technologies and enhance mechanization (e.g., drip irrigation and greenhouse technologies).

(4) Improve inefficiencies in the seed market and take measures to increase the availability of seeds of high-yielding varieties.

(5) Gradually withdraw price and marketing interventions. Divert the expenditures to provision of agricultural extension, agricultural finances, irrigation infrastructure, and research and development.

Recommendations to enhance returns from public investment are:

(1) Increase government expenditure on productivity-enhancing infrastructure such as irrigation and rural roads.

(2) Increase allocations for agricultural research.

(3) Establish linkages to connect smallholders to global value chains.

(4) Encourage FDI and public-private partnerships in agro-processing.

(5) Improve coordination across government agencies involved in designing and implementing policy pertaining to agriculture.

\subsection{State-Owned Enterprises}

The key guiding reform principles for SOEs are based on the principal-agent framework and management dynamic, including governance aspects such as information, visibility, answerability, and internal operational (efficiency) aspects such as performance incentives and competition. Two reform options that work on these principles and that are likely to have considerable potential in Sri Lanka are (1) performance contracts, and (2) the government holding company model.

Performance Contracts. The essence of performance contracts is to institutionalize effective incentive structures and processes that reward managers and employees for improvements in efficiency, productivity, and consumer service. This approach is particularly useful when ownership change is not a workable option. A typical performance contract sets out clear, transparent, and measurable targets and indicators, with a focus on three key areas: performance evaluation, performance information, and performance 
incentives. Performance evaluation deals with issues such as the selection of entities responsible for designing, implementing, monitoring, and evaluating a contract and the technical procedure pertaining to evaluation. Performance incentives link the performance of the stakeholders to rewards and penalties, based on the outcome of the evaluation exercise.

Government Holding Company Model. Sri Lankan policy makers could well study Singapore's "Temasek model." Temasek is a state-owned holding company that owns and manages state assets in a wide range of sectors on behalf of the Singapore government. Temasek also takes investment decisions on behalf of the government, including on listing, divestment, and acquisition of shares. To implement the Temasek model requires certain political economy conditions such as a strong regulatory governance framework, accountability processes that are not muddied by political patronage, and access to an adequate pool of technocrats and professional civil servants.

Some elements of the Temasek approach-specifically, listing shares of commercial SOEs on the stock exchange and institutionalizing performance contracts-could be considered in the Sri Lankan context. The precise structure and scope of Sri Lanka's version of this Temasek model-the Public Enterprises Board (PEB)-has not been made public. However, interviews with key persons provided some details. The legislation governing the PEB is currently at the Attorney General's department and is expected to be enacted in 2017. The PEB membership will likely be appointed by the Constitutional Council.

Management Contracts. The management contract modality is also useful for addressing issues pertaining to SOE management inadequacies and is a form of public-private partnership. Empirical evidence from around the world indicates that this modality is effective at infusing competition and improving productivity and the quality of service in situations where divestiture is not feasible. Similar to performance contracts, this modality can also be used as a step toward eventual privatization.

Sri Lanka's experience with management contracts points to some crucial ingredients that need to be in place to produce efficient and socially beneficial outcomes:

- First, management contracts must be drafted transparently, with all stakeholders able to access the content of the contracts.

- Second, management companies must be selected on a competitive basis using open bidding procedures. 
- Third, the basis and calculation of management fees must be clearly set out in the contract.

- Fourth, conditions such as investment requirements and environmental and social obligations must be specifically delineated in the contract.

- Fifth, exit and termination clauses should be clearly laid out.

- Sixth, service standards and default triggers should be clearly defined.

- Finally, private management partners must have sufficient autonomy to respond to market forces and take decisions in line with principles of competition.

\subsection{Urban Finance}

Mobilizing financial resources is critical to ensuring sustainable urbanization. Financing instruments are needed to raise the upfront costs to build urban infrastructure, and the underlying funding instruments are critical to provide (1) the stream of revenues needed to deliver current urban services, and (2) the funding leverage needed to mobilize the required upfront infrastructure financing while protecting environmental amenities. Mobilizing these funding and financing resources requires a coordinated approach involving central and local-level governments, development partners, and the private sector.

The major recommendations are to better realign functions and finance, link spatial and sector planning, and improve options for private participation.

Realigning Functions and Finance. The intergovernmental context for urban service delivery and the enabling urban finance framework need to be reviewed to determine how functions and finance can best be reassigned across central, provincial, and local levels. This will require clear assignment of roles and responsibilities across the three levels within a broader intergovernmental fiscal framework analysis. Functional assignment across government levels in Sri Lanka has been largely reactive, incremental, and not based on the principal of subsidiarity. The result has been contradictory assignment and/or duplication of responsibilities, leading to confusion, the provision of inadequate or excess public services, and/or inefficient use of scarce public resources.

Linking Spatial and Sector Planning. An enabling urban framework must effectively link sector and spatial planning within and between urban areas. The responsibility for physical and sector planning is fragmented across agencies 
and departments, with very little interaction and coordination within individual urban areas and across the urban spatial systems. This fragmentation and lack of coordination creates major challenges to coordinating and implementing an effective urban financial framework.

Improving Options for Private Participation. To date, urban development in Sri Lanka has been approached as a purely public sector issue, with urban planning being implemented by the government on behalf of the public. Mobilizing private sector capital flow, either directly from private equity financing or through public-private partnerships, is now critical to meeting the investment requirements for the Megapolis project and other future urban infrastructure projects. Creating a legal and regulatory environment to enable private sector involvement is a first step.

Setting up an Urban Financial Framework. The three foregoing objectives in turn indicate that a framework for urban finance in Sri Lanka needs to be established. Key elements include resetting the intergovernmental fiscal framework, operationalizing a spatial planning and coordination framework, and institutionalizing a governance framework for urbanization.

\subsection{Labor and Education}

The Sri Lankan economy is experiencing structural change. The share of agriculture has been declining, replaced by manufacturing and services. At the same time, employers are requiring more job-specific skills for their workers. The education system, especially the higher education system, is not necessarily accommodating the changing labor demand. Sri Lanka is also facing slower growth of the working age population and an increasing dependency ratio due to population aging. Furthermore, a large share of workers is abroad. Mitigating or reversing the decline in labor force growth means finding additional sources of labor. The three possible avenues for increasing the volume of labor available for economic activity are (1) increasing labor force participation; (2) decreasing unemployment; and (3) increasing net immigration, where this is taken to include the return of migrant workers from abroad.

Increasing Women in the Labor Force. The largest possible source of additional labor to counter the slow growth of the labor force would be increasing its female participation. Raising the female labor force participation rate to the average level in high-income countries would increase the overall labor force 
by $17 \%$. Such an increase would be adequate to replace decades of labor force reductions brought on by population aging; however, as long as women remain the principal caregivers for the elderly, the aging population will present a barrier to female labor force participation.

A number of approaches are known to be useful in encouraging female labor force participation. One is to create policies that encourage employers to hire workers on a part-time and flexible basis. Another is to promote nontraditional roles for women, which can help to break barriers in gendered economic spheres. General programs to encourage gender equality will also help. Women's roles as caregivers can also be a barrier to their full participation in the world of work. Encouraging provision of childcare by employers and providing subsidized childcare may make it easier for women to work. In addition, equal wages need to be granted for male and female unskilled workers who are doing the same jobs.

Considering Foreign Employment. Despite the gradually decreasing labor force growth, governments have been encouraging foreign employment to bring in foreign exchange. Promoting labor migration in the face of slowing labor force growth is not sustainable. Remittances abroad discourage females from entering the labor market. Instead, measures should be taken to make jobs more attractive for workers to remain in the country.

Growing the Knowledge Base. To move toward a knowledge-based economy, Sri Lanka needs to increase the proportion of science and technology workers. The proportion of such workers remains low because the private sector is restricted from participating in the provision of tertiary education. The government could look into policies and procedures to mitigate the adverse effects of the restriction. Even people who are in science and technology occupations are not educated at the tertiary level, indicating that they are not trained to do the jobs that they do. Further, many people with tertiary education are in occupations that do not need that level of education or are not in the labor market at all. This could be because graduates do not have the skills demanded by the market, or because the jobs offered by the market are not attractive to graduates, for remuneration or other reasons. 


\section{Index}

Figures, notes, and tables are indicated by $f, n$, and $t$ following the page number.

A

Abernathy, F., 122n5

Abeyratne, Sirimal, 39, 81

Abeysekera, S., 161

Abeysekera, T., 161

Abeysinghe, Subhashini, 39, 81

Agrarian Development Act (2000), 172

Agriculture sector, 41, 147-81. See also

Plantations

coconut value chains, $162-63$, $163 f$

context for, 148

credit policy for, 174-76

dairy value chains, $159-60,160 f$

decline of, 268-71, 270-71f

employment in, 41, 147, 151-52,

$151 t, 166$

exports from, 149, 154, 154t,

163-64, 169-70, 177

fertilizers, $168,170-71$

fish value chains, $166-68,168 f$

food consumption patterns,

153-54, 153-54t

GDP, contributions to, 22, 150,

150t, 268-69

gender and, 41, 152

Green Revolution and, 170, 176

history of, 148-50

international comparisons,

$$
155-57,155-56 t
$$

irrigation, 149, 157, 173

labor force participation rates,

$151-52,151 t$ land policy, 172-73, $172 t$

land-use patterns, 152, $152 t$

marketing, 170

mechanization and, 168, 177

modernization of, 41, 147-48, 304-5

organic produce, 164

policy framework and

instruments, 168

policy history, 7

recommendations for, 177-78, 304-5

research and extension, 41, 176

rice value chains, $158-59,158 f$

seed and planting material, 176

spice value chains, $163-65,165 f$

tariffs for, 10

tea value chains, $165-66,166 f$

trade in, 27-28, 27-28f, 154, 154t, $169-70,170 f$

value chains, $157-68$

vegetable value chains, $160-62$,

$162 f$

Airline privatization, 191-93, $199 f$

Airports, 93-95

Apparel industry

buyer-driven production

networks for, 115, 117, 123

competition in, 121-22

domestic availability of inputs

for, 124

ethical trade norms for, 18 
exports, increases of, 28-29, 28f,

29n22, 32

gender and, 125-26, 126n8

history of, 121-23

labor scarcity in, 136-37

resilience of, 40

social responsibility in, 125

tariffs on, 9

top 20 products in, $122,123 t$

ASEAN (Association of Southeast

Asian Nations), 1, 36

Asia. See also International

comparisons; specific countries

electronics industry in, 29

financial crisis (1997-1998), 21,

36

gender imbalance in, 281

revenue ratio comparisons, 54 ,

$54 f$

Asian Development Bank, 182, 184n8

Asian financial crisis (1997-1998), 21, 36

Association of Southeast Asian

Nations (ASEAN), 1, 36

Athukorala, Prema-chandra, 1, 38,

$40-41,51,111$

Authoritarianism, 6, 191

B

Bandaranaike Kumaratunga,

Chandrika, 182n1, 194

Banking sector, 188, 202n21, 318. See

also Central Bank of Sri Lanka

(CBSL)

Beetsma, R., 67

Bhalla, S., 33

Birth rates, 279

Board of Investment (BOI)

approval process of, 15

on foreign direct investment,

129-30

incentives of, 12, 12n13, 16 job bank of, 136

recommendations for, 303

unified policy framework of, 15

Bonds spread, 59, $60 f$

Buddhist centers of learning, 278

Budget deficit

exchange rate adjustments, $70-72$

growth, support of, 52

inflation resulting from, 5, 19, 38

as percentage of GDP, $38,52,53 f$

Burgher ethnic group, $3 n 3$

Buses, 187, 198, $198 f$

Buyer-driven production networks,

$115,117,119 t, 123$

C

Canada, property taxes in, 252

Cellular telephones, 85

Central Bank of Sri Lanka (CBSL)

agricultural credit policy, 174-75

budget financing, 67-69, 68f, $68 n 6$

Business Outlook Survey of, 134-35

exchange rate adjustments, 19-20, 70-72, 303

Centre for the Promotion of Imports

from Developing Countries, 164

Ceylon Burgher ethnic group, $3 n 3$

Ceylon Electricity Board (CEB), 184,

185f, 198, 199f, 220-21

Ceylon Petroleum Corporation (CPC), $199 f$

Cham, Maria Rowena, 42, 182

Chang, Ha-Joon, 210

Children

demographic changes, 285-87,

286f, 308-9

education rates, 275

employment of, 18, 137 
China, People's Republic of (PRC)

corporate SOE forms in, 206-7, $210,211 b$

economic growth in, 1

fertility rates in, $281,282 f$

gender imbalance in, 281

joint development projects in, 254

life expectancy in, 281, $282 f$

SOE reforms in, $211 b$

Civil war (1983-2009)

demographics, effect on, 280

economy, effect on, $7-8,10,19,53$, $70-71$

end of, 73

foreign direct investment, effect on, 126,129

Coconut production

for export, 154, $154 t$

land-use patterns for, 152, $152 t$

value chain for, 162-63, $163 f$

Colombo Gas Company, 193b

Colombo Metropolitan Region (CMR), 231

Colonialism, 2-4, 235

Commercial Hub Regulation No. 1 (2013), 100

Commercialization, 208

Committee on Public Enterprises, $183 n 2$

Competitiveness. See International competitiveness

Compulsory Education Policy (1998), 275

Constitution

on government powers, 235, 238-39

on nationalization of foreign assets, $8,14-15$

reforms to, 3

on urban finance, 255
Consumer price index (CPI), 24-25, $25 n 20$

Conversion of Government Owned Business Undertakings into Public Corporations (1989), 191

Conversion of Public Corporations or Government Owned Business Undertakings into Public Companies (1987), 191

Co-operative Credit Societies Ordinance (1911), 174

Cooperative Wholesale Establishment, 170

Corporate restructuring, 208

Corruption, 37, 37t, 191-92, $192 b$

CPC (Ceylon Petroleum Corporation), $199 f$

CPI (consumer price index), 24-25, $25 n 20$

Currency. See Monetary and exchange rate policy

Customs Ordinance (1869), 100

Customs regulation. See also Logistics clearance procedures for, 135 import duties, 168, $169 f$ recommendations for, 137, 303 Single Window facilities for, 101 , 102, 104, 302

D

Dairy production, 159-60, $160 f$

Danquah, M., 67, 75, 77

Davoodi, H., 56

Debrun, X., 67

Defense expenditures, 5

Demographic changes, 279-87

aging population, $44,63,269$,

271, 279-80, 283-85, 295 dependency ratio, 44, 285-87,

$286 f, 294$

economic effects of, 279-80

fertility rates, 281, 282f, 285 
forecasts for, $280,280 f, 283-84$, $283 f, 285 f$

labor force trends, 287-92, 288-89f, 290t, 291-93f

life expectancy, 281-82, $282 f$

Demographic dividend, 279, 285-86

Dependency ratio, 44, 285-87, 286f, 294

Developer-related charges, 248, 249t, 253

Development rights, sale of, 248, 250t, 254

Diet. See Food consumption patterns

Doing Business Index, 98t, 99

\section{E}

Ease of Doing Business ranking, 37, $37 t$

EBI (export bias index), 12, 12n10

Economic development. See also Liberalization processes; Macroeconomic management; Policy history; Policy recommendations

comparative dimensions of, 35-38, 35-37t

development changes and, 279-80

economic growth, 20-22, $21 f$

export promotion, 13-14

export structure, 27-32, 27-28f, 30-32f

foreign investment policy, 14-16 inflation and underemployment, $24-27$

job creation and, 289, $290 f$

overview of, $2-6$

poverty and inequality, 33-34

savings and investment, 23-24, $24 f$

structural changes, 22-23,

$22-23 t, 294$

stylized facts on, 5-6 trade policy and, 9-13, 11t

urbanization and, 232

Economic Policy Statement, 81, 186-87

EDB (Export Development Board),

13-14

Education

apparel sector employment and, 125

equality in, 6

gender and, 44, 275, $276 f$

graduate recruitment processes,

272

issues with, 277-79

labor demand and, 269, 294

manufacturing sector

employment and, 125, 135

as percentage of GDP, 62, 62f,

279

public vs. private, 269, 277-79,

295

rates of, $273-75,274 f, 276 f$

recommendations for, $45,308-9$

regional comparisons in, $36,37 t$

spending pressures in, 61

unemployment and, 86

universities, 6n5, 277-79

Effective rate of protection (ERP),

9-13, 10n9, $11 t$

Egalitarianism, 6, 33

Elderly population, 44, 63, 279-80, 283-85, 309

Electronic commerce (e-commerce), 89-90

Electronics industry

case study on, 220-21

civil war, effect on, 29, 129,

$129 n 10$

foreign-invested enterprises for,

$118,119 t$

lack of participation in, 29

producer-driven production in,

115 
Elkaduwa Plantations Limited (EPL), 218-19

Employment. See also Foreign employment; Labor force participation rate (LFPR); Labor market and human capital in agriculture sector, $41,147,151-52$, $151 t, 166$ child labor, 18, 137 ethics and, 125 foreign direct investment and, 118, 275

in free trade zones, 17-18, 135-36 job creation, 81, 271-72, $273 f$ labor shortages, 40-41, 135-37, 139, 275,304

in manufacturing sector, 125,135 , 275

in public sector, $6,26,58,272$ recruitment for, 136 in science and technology, 44, 295-96, 309

by sector, $23,23 t, 270,271 f$ in service sector, $82,83 f, 86$ skills for, 271-76, 273-74f, 273n, $276 f, 279,295$

in state-owned enterprises, 197 , $197 f, 203$

termination policies for, 17, 139

in transport sector, 93

unemployment rates, 26-27, 26f, $86,289,290 f$

Empowered Sri Lanka, 268

English language skills, 279

Entrepot trade, 101-2

Entrepreneurship, 41, 272

Environment Programme of UN, 167 EPL (Elkaduwa Plantations Limited), 218-19
ERP (effective rate of protection), 9-13, 10n9, 11t

Estates. See Plantations

Ethics, employment practices and, 125

Ethnic groups. See also Civil war conflict among, 3, 6, 8, 8n7 origins of, $3 n 3$ political representation of, 3 European Union (EU)

Centre for the Promotion of Imports from Developing Countries, 164 concessions for apparel, 121, $121 n 4$

Exchange Control Act (1953), 100 Exchange rate policy. See Monetary and exchange rate policy Export bias index (EBI), 12, 12n10 Export Development Board (EDB), 13-14

Exports. See also Apparel industry; International competitiveness; Manufacturing exports agricultural, 149, 154, 154t, 163-64, 169-70, 177 development record and, 27-32, 27-28f, 30-32f diversification of, 29, 41, 52, 154 of fish products, 167 history of, 13-14 international comparisons of, 29, $30-32 f, 32$ liberalization processes, effect of, 27-29, 111, 137 perishable goods, 102, 302 promotion of, 13-14 of services, 86 taxes on, 9-13, 9n8, 11t, 134 


\section{$\mathbf{F}$}

Family budget surveys, 25

Fashion apparel, 122, 122n5

Fenochietto, R., 77

Fertility rates, 281, 282f, 285

Fertilizers, 168, 170-71

Field survey evidence, for manufacturing exports, 134-37

Finance Commission, 238-39

Fiscal policy, 52-67 aging population, effect on, 63 bonds spread, $59,60 f$ expenditure ratios, 57-61, 58f, 60f, 64-67, $65 t$ government spending, 52-53, $53 f$ health and education spending, $62,62 f$

interest payments, $59,59 f$

recommendations for, 63-67, 65t, $300,303-4$

revenue ratios, 52-56, 54-55f, $54 n 2,64-67,65 t$

spending pressures, 61-62 state-owned enterprises, burden

$$
\text { of, 62-63 }
$$

tax productivity, $56-57,57 f$

for urbanization, 238-39

Fiscal Responsibility Management Act (2013), 66

Fish production, 166-68, $167 f$

Food consumption patterns, 153-54,

153-54t

Footwear manufacturing, export

diversification, 29

Foreign debt

debt-to-GDP ratio, 52, 53f, 59, $59 f$

exchange rate depreciation for, 300, 303

IMF stand-by agreement resulting from, 71, 195

reduction of, 73
Foreign direct investment (FDI)

employment and, 118, 275

history of, 14-16, 126, 126n9, 127t incentives for, 138, 303 industry composition, 126, $128 \mathrm{f}$ international comparisons on, 37-38

labor market disputes, 18 liberalization of, 8, 28-29 manufacturing export expansion and, 40, 126-30, 127-28f, 127t, $129 t$

nationalization of foreign assets and, 8, 14-16, 192 original design and brand manufacturers, 123-24 taxes and, 16, 169

Foreign employment. See also

Remittances from foreign employment

in apparel industry, 125

benefits of, 136-37

census measures and, 280-81, $281 n 2$

gender and, 136

increasing trend of, 293-94, $294 f$ promotion of, 295, 308

rural population participation in, 41,275

in skilled vs. unskilled workers, 86-87, $87 f$

Foreign exchange. See also

Remittances from foreign

employment

fish exports and, 167

foreign direct investment and, 15

monetary and exchange rate policy on, 19, 67-68, 70, 72

reserves of, 3

restrictions on, 9, 13

Foreign Investment Advisory

Committee, 15 
Free trade zones (FTZs)

employment in, 17-18, 135-36

history of, $14 n 14$

as incentive for FDI, 8, 14-15

labor shortages in, 275

poverty reduction from, 34

Fruit production, 152, 152t, 155, 155t.

See also Coconut production

\section{G}

Garment industry. See Apparel industry

"Garment without Guilt" campaign, 125

Gas sector, 191-93, 193b

GCEC (Greater Colombo Economic

Commission), 14-15, 17, 129

GDP. See Gross domestic product

Gender

agriculture sector employment and, 41,152

apparel industry employment and, 125-26, 126n8

demographic pyramid for, $280 f$, 281

education rates, $44,275,276 f$

equality of, 6

foreign employment and, 136

labor force participation rates,

44, 269, 287-92, 288-91f, 290t, 295, 307-8

life expectancy rates, $281-82$

nontraditional employment and, 295

unemployment rates, 26

wage differences and, 291-92, 293f, 295

Gini ratio, 33

Ginting, Edimon, 1, 38, 51

Glewwe, P., 33

Global Competitive Index, 93
Global Competitiveness Report, 134-35

Global financial crisis (2007-2008), 21,36

Global production networks (GPNs)

benefits of, 114-15

buyer-driven production

networks and, 115, 117, 119t, 123

data on, 141-42

expansion of, 113

export performance for, 116-20,

116-17f, 118-19t

export structure

characterizations of, $114 n 2$, 116

foreign direct investment and, 118

human capital constraints on, 120

producer-driven production

networks and, 115, $119 t$

shift toward, 40, 131

Government holding company model,

$42,213,305-6$

Great Britain

colonialism of, 2-4, 235

property taxes in, 252

Greater Colombo Economic

Commission (GCEC), 14-15, 17, 129

Green Revolution, 170, 176

Gross domestic product (GDP)

agriculture sector contributions

to, $22,150,150 t, 268-69,270 f$

budget deficit as percentage of,

$38,52,53 f$

cost of logistics as percentage of, 91

debt ratio to, $52,53 f, 59,59 f$

education as percentage of, 62 ,

$62 f, 279$

external shocks, effect on, 20-21,

$2 \ln 18$ 
forecasts for, 284

government-expenditure ratio,

57-61, 58f, $60 f$

government services as

percentage of, 33,85

growth of, 20-22, $21 f$

health and education spending as percentage of, $62,62 f$

interest payments as percentage of, $59,59 f$

property taxes as percentage of, 252

revenue ratio to, $52-56,54-55 f$,

$54 n 2$

service sector contributions to,

$82,83 f, 83 t, 269-70,270 f$

SOBE revenue as percentage of, 197

SOEs, effect on, 7, 63, 199n20

trade ratio to, 51

transport sector as percentage of, 93

Gunaruwan, T. L., 211

Gunatilaka, R., 291

Gunawardena, Asoka S., 42, 229

Guruge, Aneesha, 42, 182

H

Habitat III summit (2016), 229

Highly skilled workers, 273-74, 273n, $274 f$

Hill, Hal, 1

History. See also Civil war; Policy history

of agriculture sector, $148-50$

of apparel industry, 121-23

of exports, 13-14

of foreign direct investment

(FDI), 14-16, 126, 126n9, $127 t$

of free trade zones (FTZs), 14n14

independence, 2-4, 149 of labor market and human capital, 16-18

of macroeconomic management, 19-20

of state-owned enterprises, 7 , $189-95,193-94 b$

of unions, $16-18$

Human capital. See Labor market and human capital

Human Development Index, 232

IMF. See International Monetary Fund Imports

EU apparel concessions, 121, $121 n 4$

food products, 149, 153-54, $154 t$

restrictions on, 7, 9

seeds, regulation of, 176

substitution policies, 7, 29, 120, 149,169

tariffs on, 9-13, 11t, 99, 303

taxes and customs duties on, 168, $169 f$

Income. See Wages and income India

economic growth in, 1

property taxes in, 252

Indian Ocean Tsunami (2004), 21

Indonesia

property taxes in, 252

transport SOE, $209 b$

Industrial Dispute Act (1950), 17, 139,

304

Inflation

budget deficit as cause of, 5, 19, 38

CPI for measurement of, 25 , $25 n 20$

flexible, 68

monetary and exchange rate policy and, 24-25, 24n19, 25f, 71-72 
rate of, $69,69 f$

reform recommendations for, 73 , 301

Informal employment, 272

Information and communications

technology

employment skills in, 279, 295

Internet use, 85, 89-90

logistics and, 100-101

telecommunications sector, 85 ,

188, 191-93, 193b

Infrastructure. See also State-owned

enterprises (SOEs)

for coconut production, 162

debt financed, 19, 21-23

logistics and, 91

reform recommendations, 46

spending pressures for, 61

trade costs related to, 135

for transport, 94-97

urbanization and, 248, 249t, 256

Institutional record, 6

Interest payments, 59

International comparisons

of agriculture sector, $155-57$, $155-56 t$

of economic development,

35-38, 35-37t

exchange rate policy and, 19

of exports, 29, 30-32f, 32

gender and, 281

of labor force participation rate, 291, $291 f$

of logistics, 38, 91-93, 92-93t,

97-99, $98 t$

of property taxes, 252

of state-owned enterprise

reforms, 206-7

International competitiveness

apparel exports and, 121-22 liberalization program for, 19

logistics companies and, 39,

88-89, 104

macroeconomic management and, $24,45,74$

manufacturing exports and, 40,

$112,121-22,130,134$

monetary and exchange rate

policy, 38-39, 139, 300, 303

International Labour Convention, 17

International Labour Organization, 18

International Monetary Fund (IMF)

Article VIII Status from, 9, 13

deficit targets for, 64,66

Extended Fund Facility

arrangement of, 183, 195-96, $196 b$

floating exchange rates and, 70

public opinion on, $183 n 3$

stand-by agreement with, 71, 194

tax potential estimates of, 76

International schools, 277-78

International Standard Industrial

Classification (ISIC), $93 \mathrm{n} 3$

Internet use, 85, 89-90

Investment. See Savings and

investment

Irrigation, 149, 157, 173

J

Janatha Estates Development Board

(JEDB), 185f, 199f, 203, 218-19

Janatha Vimukthi Peramuna, 183n2,

205, $212 n 25$

Japan, joint development projects in, 254

Jobs. See Employment

Joint Apparel Association Forum, 125

Joint development, 254

Just-in-time delivery, 29n22 
Kelly, Roy, 42, 229

Khatri, Yougesh, 38, 51, 66

Khazana SOE model of Malaysia, 42, 213

Kikuchi, M., 173

Knight, Malathy, 42, 182

Knight-John, M., 212n25

Knowledge-based economy, 295-96, 309

Kochhar, K., 66

Kodithuwakku, S., 161

Korea, Republic of, 3, 35, 91, 97, 104, 291

Kumar, Utsav, 1

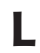

Labor force participation rate (LFPR) age and, 287-89, 288-89f, 291 decline of, 287, 288f, 291 gender and, 44, 269, 287-92, 288-91f, 290t, 295, 307-8 international comparisons of, 291, $291 f$ projections for, $287,288 f$

Labor market and human capital, 4344, 268-98. See also Employment; Foreign employment demographic changes, effect on, 279-87, 280f, 282-83f, 285-86f education rates and, $275,276 f$ education system issues and, 277-79

history of, 16-18 job growth and skills requirements for, 271-76, 273-74f, $276 f$

labor force trends and participation, 287-92, 28893f, 290t, 308-9

labor shortages, 40-41, 135-37, 139, 275, 304 recommendations for, 294-96, 308-9

sectoral composition shifts in, 269-71, 270-71f

working abroad, 293-94, $294 f$

Labor unions. See Unions

Land. See also Agriculture sector government policy on, 168,

172-73

land-use patterns, $152,152 t$ productivity comparisons, 155-57, 155-56t reform of, 149, 173 tenure system for, 172-73, 172t

Land Development Ordinance (1935), 172

Land Reform Act (1972), 7

Land transport, 94-95

Land value capture mechanisms, 248 , $250 t, 253$

Lanka Marine Services, 192b, 211

Lankaputhra Development bank, 203b

Lee Kuan Yew, 3-4

LFPR. See Labor force participation rate

Liberalization processes agriculture and, 149, 170, 174 back-sliding from, 8-9, 40, 51, 111-12, 302 exchange rate policy and, 70 exports, effect on, 27-29, 111, 137 foreign direct investment and, 126 instigators of, 7-8 labor market flexibility and, 17 macroeconomic policy and, 19 poverty, effect on, 33 recommendations for, 45 second wave of, 8, 9, 19 service sector and, 87-88 SOE reform process, 189-95 
textiles and garments industry, improvements to, 121

trade policy, 9-13, 11t

Liberation Tigers of Tamil Eelam, 70

Life expectancy rates, 279, 281-82

Logistics, 39, 88-105. See also Service sector

apparel industry and, 124

defined, 81,88

government role in, 97-101, $98 t$

impediments to, 101-3, 302

overview, 88-90

recommendations for, 103-5,

301-2

regional comparisons in, 38 ,

92-93, 92-93t, 97-99, $98 t$

subsectors of, 90-93

supermarkets and, 161

technological innovation and, 89-90

third-party providers of, 104 transport infrastructure, 94-97,

135

Logistics Performance Index, 37, 37t, 92

\section{M}

Macroeconomic management, 38-39,

51-80. See also Fiscal policy

civil war and, 70-71

history of, 19-20

improvements in, 73

monetary and exchange rate

policy, 5, 38-39, 67-72, 68-69f,

$71 f$

recommendations for, $45,73-74$, 300

record of, 5

revenue potential estimates,

75-77, 76f, $78 f$

SOEs, costs of, 190, 190n14

Mahapola Higher Education

Scholarship Trust Fund, 277
Mahinda Chintana 2010, 81

Malaysia

economic comparisons with, $35-36,35-37 t$

Khazana SOE model of, 42, 213

logistics comparisons, 92-93t, 93

product space map of, 29, 30-31f

Management contracts

for plantations, 190-91

as public-private partnership,

215

recommendations for, 306-7

requirements for, 216

Manufacturing exports, 40-41, 111-46.

See also Apparel industry

analytical framework for, 113-16

data sources on, 112

determinants of, 130-37

development record and, 27-32, 27-28f

econometrics for, 130-34, 133t,

$135 t$

employment and, 125, 135, 275

export performance, 116-26,

116-17f, 118-19t

field survey evidence, 134-37

foreign direct investment and

expansion of, 126-30, 127-28f,

$127 t, 129 t$

GDP contributions, 22

growth of, 51, 269

recommendations for, 137-40,

302-4

trade data compilation, 141-42

Marketing, agricultural, 170

MCC (multicountry consolidation) for

logistics services, 102

Megapolis Master Plan, 43, 95-96, 230-31, 257-58, 308

MFA (Multi Fiber Agreement) quota, $121-22$ 
Microfinance, 174

Migrant workers. See Foreign employment

Mihin Lanka, $199 f$

Millennium Development Goals, 277

Mineral exports, 27, 27f, 114

Ministry of Public Enterprise

Development, 184, 184n5, 204

Mobile telephones, 85

Monetary and exchange rate policy

Dutch Disease effect, 23

inflation rate and, 24-25, $24 n 19$, 25f, 71-72

international competition and, 139, 300, 303

liberalization of, 19-20

macroeconomic management and, 5, 38-39, 67-72, 68-69f, $71 f$

manufacturing exports and, 130-34, 139

recommendations for, 45,73 , 300, 303-4

Monetary Law Act (1949), 67-68

Moody's rating scale, 202

Multicountry consolidation (MCC) for logistics services, 102

Multi Fiber Agreement (MFA) quota, $40,121-22$

Municipal Council Ordinance (1947), 237

Muslim people, $3 n 3$

\section{$\mathbf{N}$}

National Agenda Committee on

Logistics and Transport, 97

National Human Resource

Development Council, 272

Nationalization of foreign assets, 8 ,

14-16, 192

National Workers Charter (1995), 18

New Urban Agenda, 229
Oil industry, 198, $199 f$

Operating Instructions of the New

Comprehensive Rural Credit

Scheme, 175

Organic produce, 164

Original design and brand manufacturers, 123-24

Osei-Assibey, E., 67, 75, 77

Own-source revenues (OSRs), 239-42, 240-43t, 247

P

Paddy Lands Act (1958), 172

Paddy Marketing Board (PMB), 7, 158, $158 n 1,168,170$

Performance contracts for

privatization, 42, 213, 305-6

Pessino, C., 77

Plantations

case study on, 218-19

education rates of children, 275

history of, 148-50

labor force participation rates, $151,151 t, 289$

management contracts for, 190-91

as SOEs, 184, 202-3, 216, 218-19

tea production on, 165-66

Plant Protection Ordinance, 176

Policy history, 6-20

exports, 13-14

foreign investments, 14-16

labor market, 16-18

macroeconomics, 19-20

trade policy regime, 9-13

Policy recommendations, 299-309

for agriculture sector, 177-78,

304-5

for education, 278, 308-9

for fiscal policy, 63-66, 65t 
for labor market and human

capital, 294-96, 308-9

for logistics and services, 103-5,

301-2

for macroeconomic management, $45,73-74,300$

for manufacturing exports,

137-40, 302-4

overview, 44-46

for services sector reform, $87-88$

for state-owned enterprise

reforms, 210-17, 305-7

for tax reform, $252-53$

for urban finance, 247-48, 259-62, 307-8

Poverty and inequality

agricultural employment and, 41, 151,174

decline of, 51

development record and, 33-34, $34 f$

microfinance and, 174

war-related employment and, 34, $34 n 23$

Pradeshiya Sabhas Act (1987), 237

PRC. See People's Republic of China

Premadasa, Ranasinghe, 190-91

Privatization

corruption and, $192 b$

defined, 210

key conditions for, 210

performance contracts for, 213

urbanization and, 257-59, 300,

308

Producer-driven production networks,

$115,119 t$

Property taxes

decrease in, 242

as percentage of GDP, 252

from provincial councils, 241, 246 as source of own-source

revenues, 240-42

for urbanization funding, 248 ,

249t, 251-54

Protectionist policy. See Effective rate of protection (ERP)

Provincial councils (pradeshiya sabhas)

census policy urban definition and, 234

local authority expenditures, 243-46

property taxes from, 241, 246

revenue grants for, 241

urban services responsibilities

for, 237-38

PSO (public service obligations), 187

Public Enterprise Board (PEB), 195, 214-15, 306

Public health expenditures

as percentage of GDP, $62,62 f$

reform recommendations, 45

spending pressures in, 61

Public Investment Programme

(2017-2020), 61

Public-private partnerships (PPPs)

management contracts as, 215

public perception of, 212, 212n25

SOE reform and, 208

for urbanization, 236, 254, $257-59,262$

Public sector employment, 6, 26, 58, 272

Public service obligations (PSO), 187

Public Utilities Commission of Sri

Lanka (PUCSL), 194

$\mathbf{R}$

Railways, 95, 96

Rajapakse, Mahinda, 194

Regaining Sri Lanka

(Wickremesinghe), 194 
Remittances from foreign employment commercial opportunities from, 23

foreign exchange rates and, 32, 293, 295, 309

growth in, 87

labor force participation rates of women and, 291

poverty reduction from, 34

Resource endowments, 27, 27f, 114

Retirement age, 284, 287

Revenue grants, 239-42, 240-42t

Revenue potential, 75-77, 76f, $78 f$

Revival of Underperforming Enterprises

and Underutilized Assets Act (2011),

16,303

Rice production

land-use patterns, 152, $152 t$

productivity comparisons of, 155 , $155 t$

seed for, 176

self-sufficiency in, 149, 177

value chain, $158-59,158 f$

Right to Information legislation,

$212 n 26$

Roads, 95-97, 99

Robinson, Joan, 16-17

Rondinelli, D., 206-7

Rubber-based product manufacture, 120

Rural population. See also Provincial councils

agricultural employment of, 41,

$147,149,151,171$

credit for, 174-76, $175 t$

education of, 275, 276f, 277

foreign employment

participation of, 41, 275

labor force participation rates,

287, 289, $289 f$

manufacturing employment of,

$125,126 n 8,136,275$

military participation of, $34 n 23$ as percentage of total, 41

poverty and, 151

property taxes from, 241, 246

transport options for, 187

urbanization rate of, 234

\section{$\mathbf{S}$}

Sarvananthan, M., 26

Savings and investment, 23-24, 24f, $197,197 f$

Scheme of Industrialization (1957), 7

Science and technology occupations,

44, 295-96, 309

Seaports

case study on, 221-22

congestion in, 96

customs clearance procedures, 135

logistics and, 90-91, 91f, 91t

regulation of, 99-100

transport infrastructure for, 94

Seed Act (2003), 176

Self-employment, 41, 272

Self-sufficiency in food production, 41,

149, 169, 177

Senanayake, D. S., $3 n 2$

Service delivery, 255-57

Service link costs, 82

Service sector, 39, 82-88. See also

Logistics

defined, 81

economic structural changes,

22-23, 82-84, 83-84f, 83t

employment in, $82,83 f, 86$

government role in, 88

growth of, 268-70, 270-71f

recommendations for, 301

regional comparisons in, 38

subsectors of, $84-87,85 t, 86 f$

Shops and Office Employees Act

(1954), 18 
Singapore

economic comparisons, 35-36, $36-37 t$

logistics comparison, 92-93t, 93

Temasek SOE model of, 42, 213-14, 306

Single Window facilities, 101, 102, 104, 302

Sinhalese ethnic group, 3 , 3n3

Skills for employment, 271-76, 273-

$74 f, 273 n, 276 f, 279,295$. See also

Education

SLA (Sri Lanka Airlines), $199 f$

SLFP. See Sri Lanka Freedom Party

SLPA (Sri Lanka Port Authority), 100-101, 185f, 221-22

SLSPC (Sri Lanka State Plantations

Corporation), 218-19

SLT (Sri Lanka Telecom), 193b

SLTB. See Sri Lanka Transport Board Smallholder Plantation

Entrepreneurship Development

Programme, 174

SOBEs. See State-owned business

enterprises

Social welfare services

citizen expectation of, 186-87

education, 277

income status of recipients, 6

as percentage of GDP, 33,85

SOE employment as, 197, 197f, 203

SOEs. See State-owned enterprises

Spice production, 154, 154t, 163-65, $165 f$

Sri Lanka. See also specific topics

Asian financial crisis, effect of, 21, 36

development policy of, 268

economic overview of, 2-6

geographic location and development outcomes, 5, 39

independence of, 2-4, 149

policy history, 6-20

stability in, 1-3

stylized facts on, 4-6

Sri Lanka Airlines (SLA), $199 f$

Sri Lanka Development Policy Review 2004, 111

Sri Lanka Freedom Party (SLFP), 182n1, 183n2, 187, 191

Sri Lanka Insurance Corporation, 192b, 211

Sri Lanka Port Authority (SLPA), 100-101, 185f, 221-22

Sri Lanka State Plantations

Corporation (SLSPC), 185f, 199f, 218-19

Sri Lanka Telecom (SLT), 193b

Sri Lanka Transport Board (SLTB), 185f, 187, 198, 198-99f, 222-23

State Industrial Corporation Act (1957), 7

State-owned business enterprises (SOBEs)

case studies on, 218-23

defined, 184-85, $185 f$

investment and employment in, $197,197 f$

losses and profits of, 200, $201 f$

net losses of, 198-99, $199 f$

reform initiatives for, 204-5,

204-5f

revenue as percentage of GDP, 197

State-owned enterprises (SOEs), 42, $182-228$

analysis of, $183-85,183 n 4,185 f$ classification of, $185,185 f$ competition in, 186-88, 186n9, 188nn11-12 current context of, 195-205, 197-203f, 204-5b 
defined, 184-85

employment in, 197, 197f, 203

fiscal burden of, 62-63

history of, 7, 189-95, 193-94b

international experience in, 206-7, 206f, 209b, $211 b$

issues with, 212

numbers of, 184, 184nn7-8

recommendations for, 210-17, 305-7

reform types, 207-10

in services and logistics, 82, 105

spending pressures in, 61

State Resource Management

Corporation, 195

Strategic Development Projects Act (2008), 15, 303

Strategic Enterprise Management

Agency, 194-95

Supply chain management. See

Logistics

Sustainable Development Goals of UN, 229

\section{$\mathbf{T}$}

Tamil ethnic group, 3, 3n3

Taniguchi, Kiyoshi, 43, 268

Tanzi, V., 56

Tariffs on imports, 9-13, 11t, 99, 303

Taxes. See also Property taxes administration issues, $56-57,57 f$

aging population, effect on, 63 on agricultural machinery, 177

buoyancy of, 56

for export-oriented firms, 134

on exports, 9-13, 9b8, 11t, 134

foreign direct investment and, 16, 169

on imports, $168,169 f$

productivity of, $56,56 n 3$

reform recommendations for, $64-67,65 t, 252-53$ for urban financing, 239-42, 248, $249 t$

Tax gap, 75-77, $78 f$

Tax holidays, 12, 12n13, 16

Tea production

for export, 28, 28f, 154, 154t

land-use patterns, 152, $152 t$

productivity comparisons of, 155 ,

$155 t$

value chain, 165-66, $166 f$

Technological innovation, logistics and, 89

Technology and science occupations, 44, 295-96, 309

Telecommunications sector, 85, 188, 191-93, 193b. See also Information and communications technology

Temasek model for SOEs, 42, 213-14, 306

Termination of Employment of

Workmen Act (1953), 17, 139, 304

Textiles. See Apparel industry

Thailand

economic comparisons with, 35-36, 35-37t

product space map of, 29, 30-31f

Tourism, 32, 85-86, 95

Trade Facilitation Agreement (2016), 99, 169

Trade policy. See also Exports; Imports development outcomes and, 5 liberalization of, 9-13, 11t post-independence, 7 reform recommendations, 45 , 301

Trade unions. See Unions

Transparency International, 37

Transport infrastructure, 94-97. See also Seaports airports, 93-95 bus routes, 187, 198, $198 f$ case study on, 222-23 
employment and, 93

GDP contributions of, 93

impediments to, 96-97

in Indonesia, $209 b$

recommendations for, 105

roads, 95-96, 99

\section{$\mathbf{U}$}

Unemployment, 26-27, 26f, 86, 289, $290 f$

Unions

in apparel industry, 125-26

history of, 16-18

privatization of SOEs, resistance to, $193 b$

SOE reform and, 39, 82

United Kingdom

colonialism of, 2-4, 235

property taxes in, 252

United National Party (UNP), 183n2, 187, 189-92, 194

United Nations (UN)

Environment Programme, 167

Sustainable Development Goals, 229

United People's Freedom Alliance, 194 United States

African Growth Opportunity Act, 121

aid from, 14-15

apparel market in, 121

property taxes in, 252

Universal Free Education Policy

(1945), 275

Universities, 6n5, 277-79

UNP (United National Party), 183n2,

187, 189-92, 194

Urbanization, 42-43, 229-67. See also

Infrastructure

current context of, 231-37 evolution, form, and structure of,

$232-34,233 t$

finance and funding options for,

237-38, 248-54, 249-50t

income growth and, 54

institutional roles and functions of,

$235-37,236 t, 262$

intergovernmental fiscal

framework for, 238-39, 260-61

local authority expenditures on,

243-46, 244-46t

local government revenues for,

239-43, 240-43t

population rate and, 232-34, 233t, 246

private participation in, $257-59$,

300, 308

property taxes and charges for,

251-54

recommendations for, 247, 259-62, 307-8

service delivery and, $255-57$

spatial and sector planning for, 257 , $261,307-8$

urban sprawl, 231, 234

user charges for, 248, 249t, 251
Value-added tax (VAT), 56-57, 64

Vegetable production land-use patterns, $152,152 t$ productivity comparisons of, 155 , $155 t$ value chain, $160-62,162 f$

Vernooij, A., 159

Viet Nam, property taxes in, 252

Voting rights, 3

Vulnerable employment, 272 


\section{W}

Wages and income

in agriculture sector, 171

in apparel industry, 122

gender and, 291-92, 293f, 295

increases in, 295

minimum wages, 18, 291

reform in, 64

regional comparisons for, 35-36, $35-36 t$

urbanization and, 54

Wages Board Ordinance (1941), 18
Weerahewa, Jeevika, 41, 147, 158n1, 161

Western Region Megapolis Master

Plan, 43, 230-31

Wickremesinghe, Ranil, 81, 186-87, 194

Women. See Gender

World Bank

agriculture income, 171

Doing Business Index, 98t, 99

Ease of Doing Business, 37, 37t

Logistics Performance Index, 92

World Trade Organization (WTO), 99, 169 


\section{The Sri Lankan Economy}

\section{Charting A New Course}

This is a pivotal period in Sri Lanka's economic development. The end of conflict opens a door for accelerated economic growth and poverty reduction. Reform is needed to regain momentum because fiscal imbalances and rising public debt could jeopardize macroeconomic stability. The economy would benefit from significant trade and commercial policy reform. The labor market suffers from sluggish growth of formal sector employment and from skills mismatches, which can be addressed by changes in education policy and systems. The book analyzes these and related critical constraints on the Sri Lankan economy, and proposes a set of policy reforms that would lay the foundations for more rapid and inclusive development.

\section{About the Asian Development Bank}

ADB's vision is an Asia and Pacific region free of poverty. Its mission is to help its developing member countries reduce poverty and improve the quality of life of their people. Despite the region's many successes, it remains home to a large share of the world's poor. ADB is committed to reducing poverty through inclusive economic growth, environmentally sustainable growth, and regional integration.

Based in Manila, ADB is owned by 67 members, including 48 from the region. Its main instruments for helping its developing member countries are policy dialogue, loans, equity investments, guarantees, grants, and technical assistance. 